Ewa Szafrańska

Wielkie osiedla mieszkaniowe w mieście postsocjalistycznym

Geneza, rozwój, przemiany, percepcja
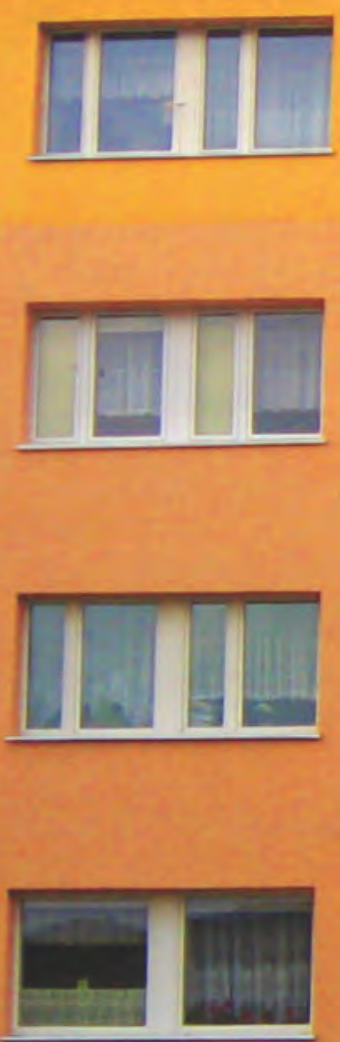

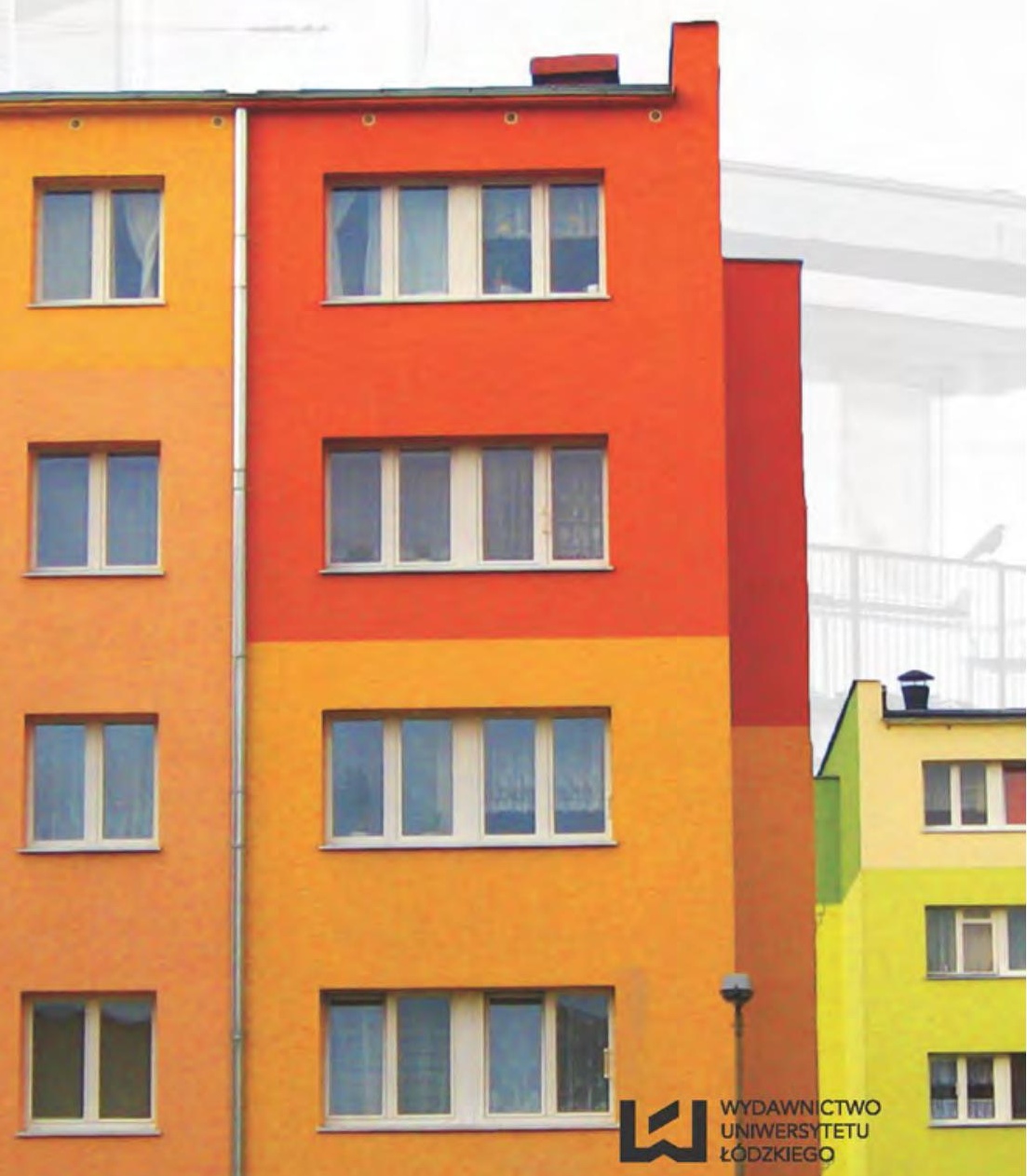


Wielkie osiedla mieszkaniowe w mieście postsocjalistycznym 


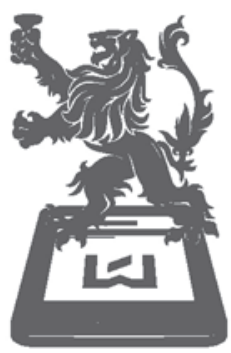

WYDAWNICTWO

UNIWERSYTETU
EODZKKEGO 
Ewa Szafrańska

Wielkie osiedla mieszkaniowe

w mieście postsocjalistycznym

Geneza, rozwój, przemiany, percepcja
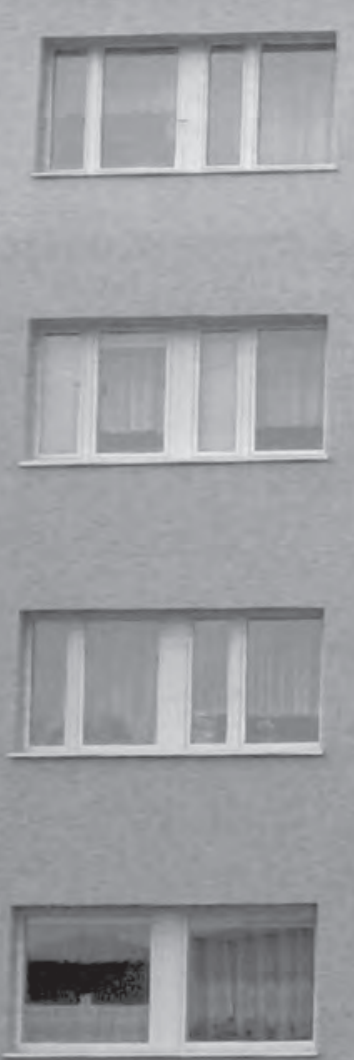

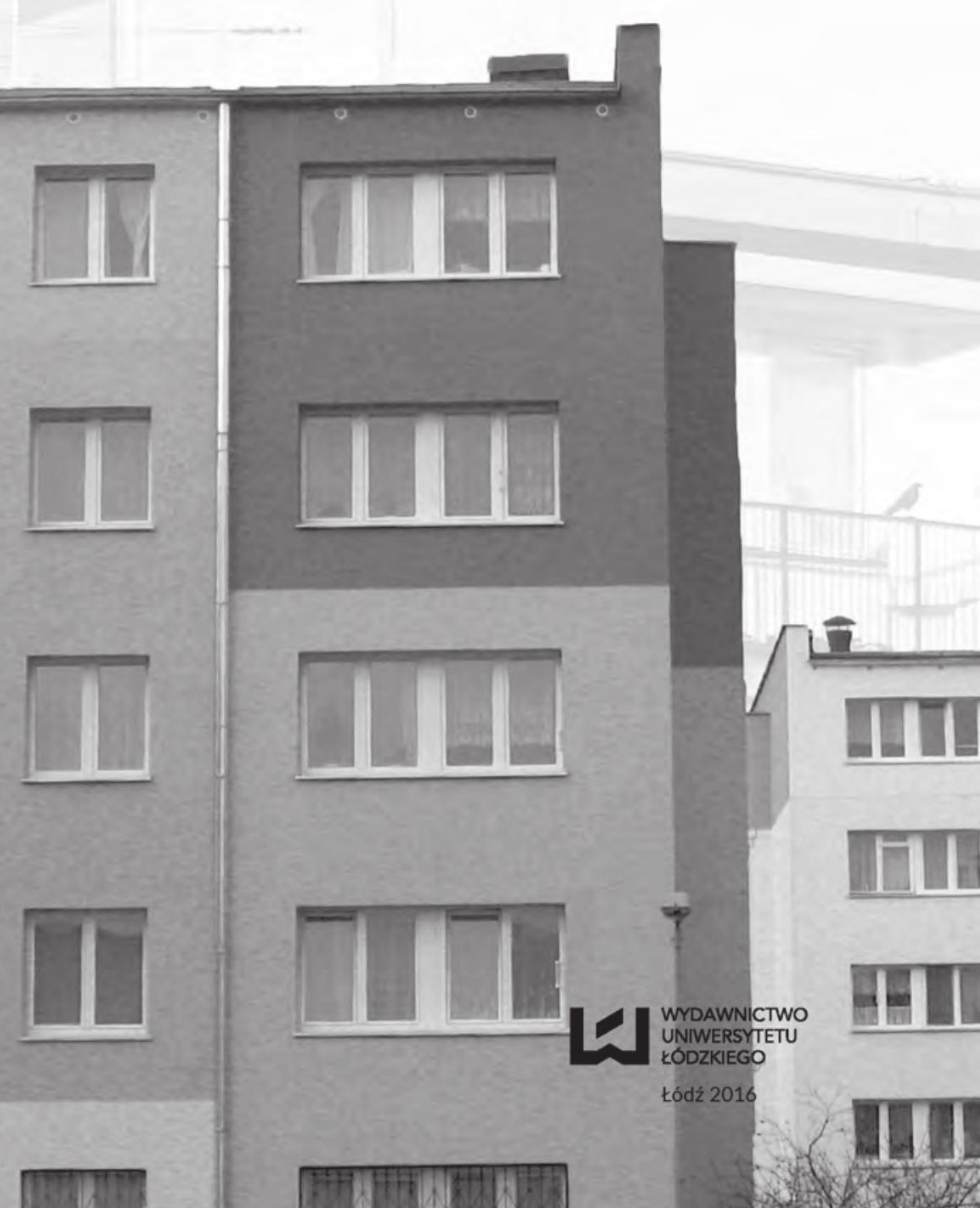


Ewa Szafrańska - Uniwersytet Łódzki, Wydział Nauk Geograficznych Instytut Geografii Miast i Turyzmu, ul. Kopcińskiego 31, 90-142 Łódź

\title{
RECENZENT
}

Jacek Kotus

\section{REDAKTOR INICJUJĄCY}

Damian Rusek

\section{ADIUSTACJA, REDAKCJA TECHNICZNA I SKŁAD KOMPUTEROWY Elżbieta Paradowska}

\author{
MAPY I RYSUNKI \\ Anna Wosiak
}

\section{PROJEKT OKŁADKI}

Katarzyna Turkowska

Zdjęcie wykorzystane na okładce: (C) Depositphotos.com/susha

Wydrukowano z gotowych materiałów dostarczonych do Wydawnictwa UŁ

(C) Copyright by Ewa Szafrańska, Łódź 2016

(C) Copyright for this edition by Uniwersytet Łódzki, Łódź 2016

\section{Wydane przez Wydawnictwo Uniwersytetu Łódzkiego \\ Wydanie I. W.07011.15.0.M}

Ark. druk. 22,0

ISBN 978-83-8088-210-2

e-ISBN 978-83-8088-211-9

https://doi.org/10.18778/8088-210-2

Wydawnictwo Uniwersytetu Łódzkiego

90-131 Łódź, ul. Lindleya 8

www.wydawnictwo.uni.lodz.pl

e-mail: ksiegarnia@uni.lodz.pl

tel. (42) 6655863 


\section{SPIS TREŚCI}

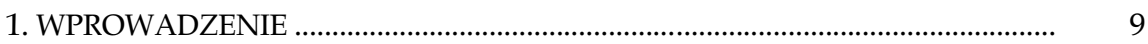

1.1. Problem badawczy .......................................................................................... $\quad 10$

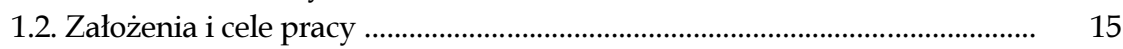

1.3. Podstawy teoretyczne pracy ……………..................................................... 18

1.4. Metody badań i materiały źródłowe .......................................................... 21

2. KONTEKST TEORETYCZNY PRACY …………................................................... 27

2.1. Mieszkalnictwo jako przedmiot badań naukowych .................................... 27

2.2. Wielkie osiedle mieszkaniowe jako forma urbanistyczna i społeczna ..... $\quad 32$

2.3. Podejścia teoretyczne $w$ badaniach osiedli mieszkaniowych .................... $\quad 37$

2.4. Wielkie osiedla mieszkaniowe $\mathrm{w}$ badaniach naukowych ........................... 41

2.5. Koncepcje wyjaśniające przemiany osiedli mieszkaniowych ...................... 47

3. GENEZA I UWARUNKOWANIA ROZWOJU WIELKICH OSIEDLI MIESZKA-

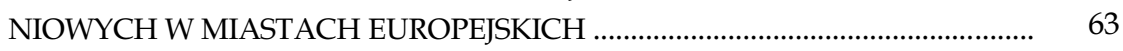

3.1. Koncepcje urbanistyczno-architektoniczne z XIX i z I połowy XX wieku 64

3.2. Pierwsze realizacje wielkoskalowych modernistycznych założeń osiedlowych w miastach europejskich .................................................................. 77

3.3. Uwarunkowania rozwoju wielkich osiedli mieszkaniowych w powojennej Europie .......................................................................................... 82

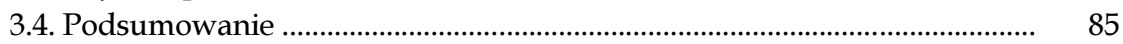

4. ROZWÓJ I EWOLUCJA WIELKICH OSIEDLI MIESZKANIOWYCH W MIEŚCIE SOCJALISTYCZNYM ............................................................................................. 89

4.1. Miasto socjalistyczne jako idea i byt realny ................................................... 89

4.2. Czynniki kształtujące strukturę rezydencjalną w mieście socjalistycznym 91

4.3. Uwarunkowania rozwoju wielkich osiedli mieszkaniowych w mieście socjalistycznym

4.4. Od osiedla społecznego do wielkiego osiedla mieszkaniowego - ewolucja wielorodzinnej zabudowy osiedlowej w powojennej Polsce ......

4.5. Wielkie osiedla mieszkaniowe $\mathrm{w}$ mieście socjalistycznym u progu transformacji

4.6. Podsumowanie 
5. PRZEMIANY WIELKICH OSIEDLI MIESZKANIOWYCH W MIEŚCIE POSTSOCJALISTYCZNYM

5.1. Miasto postsocjalistyczne - główne cechy

5.2. Procesy kształtujące strukturę rezydencjalną w mieście postsocjalistycznym

5.3. Przemiany wielkich osiedli mieszkaniowych w miastach postsocjalistycznych - wybrane przykłady

5.3.1. Przemiany w strukturze demograficznej i statusie społecznym mieszkańców

5.3.2. Przemiany w strukturze funkcjonalno-przestrzennej i morfologii ..

5.3.3. Przemiany fizjonomiczne

6. PERCEPCJA I WALORYZACJA WIELKICH OSIEDLI MIESZKANIOWYCH W MIEŚCIE POSTSOCJALISTYCZNYM

6.1. Teoretyczne podstawy badań percepcji i waloryzacji środowiska mieszkaniowego

6.2. Uwarunkowania percepcji i waloryzacji środowiska mieszkaniowego ...

6.3. Percepcja i waloryzacja wielkich osiedli mieszkaniowych w mieście postsocjalistycznym - wybrane przykłady

6.3.1. Satysfakcja mieszkaniowa, poczucie więzi z miejscem zamieszkania i preferencje migracyjne

6.3.2. Ocena wybranych aspektów zagospodarowania i wyposażenia osiedli oraz ich walorów architektoniczno-urbanistycznych i estetycznych

6.3.3. Relacje społeczne i więzi mieszkańców

6.3.4. Poczucie bezpieczeństwa w osiedlach

\section{WIELKIE OSIEDLA MIESZKANIOWE ŁODZI - STUDIUM PRZYPADKU}

7.1. Ewolucja struktury społeczno-przestrzennej miasta

7.2. Wielkie osiedla mieszkaniowe Łodzi - rozwój przestrzenny i charakterystyka

7.3. Przemiany wielkich osiedli mieszkaniowych Łodzi po 1990 roku

7.3.1. Przemiany w strukturze demograficznej i statusie społecznym mieszkańców

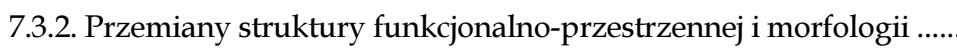

7.3.3. Przemiany fizjonomiczne

7.4. Percepcja i waloryzacja wielkich osiedli mieszkaniowych Łodzi wybrane aspekty

7.5. Podsumowanie 
Bibliografia 



\section{WPROWADZENIE}

Rewolucja przemysłowa zapoczątkowana $\mathrm{w}$ Europie na przełomie XVIII i XIX wieku zaburzyła naturalne procesy ewolucji miejskich struktur przestrzennych i stworzyła potrzebę zweryfikowania dotychczasowych modeli rozwoju miast oraz sformułowania nowych doktryn urbanistycznych (Ostrowski 1975). Powstałe wówczas duże zapotrzebowanie na siłę roboczą w miastach wywołało masowy napływ ludności ze wsi i dynamiczny rozwój urbanizacji. Żywiołowe przemiany przestrzenne prowadziły do powstawania obszarów chaotycznej zabudowy i przemieszania terenów przemysłowych $z$ terenami mieszkaniowymi oraz innymi funkcjami miejskimi. Dążenie do coraz bardziej intensywnego wykorzystania terenu powodowało większe zagęszczenie zabudowy i koncentrację ludności. Tempo rozwoju miast było tak intensywne, że budownictwo i tworzące się systemy infrastruktury technicznej nie były w stanie zaspokoić potrzeb mieszkańców (Chmielewski 2001, Słodczyk 2012).

Chaos przestrzenny oraz ciągłe pogarszanie się warunków egzystencji mieszkańców sprawily, że od początku XIX do I połowy XX wieku pojawiło się wiele idei i koncepcji urbanistyczno-architektonicznych oraz społecznych proponujących poprawę tego stanu przez zmiany w organizacji mieszkalnictwa (Ostrowski 1975, Benevolo 1995). Wiele z tych koncepcji wywarło bezpośredni bądź pośredni wpływ na kształtowanie się powojennego środowiska mieszkaniowego w Europie, w tym w szczególności na rozwój wielorodzinnego budownictwa osiedlowego. Do najważniejszych z nich należą: utopijne idee przestrzennej organizacji społeczeństwa europejskich socjalistów (głównie Ch. Fouriera i R. Owena), prace środowiska architektów skupionych wokół Międzynarodowego Kongresu Architektury Nowoczesnej $(\text { CIAM })^{1}$ i niemieckiej szkoły Bauhausu (w tym przede wszystkim Le Corbusiera i W. Gropiusa), amerykańska idea jednostki sąsiedzkiej (Perry 1939) oraz koncepcja osiedla społecznego, rozwijana w polskiej myśli urbanistycz-

${ }^{1}$ Congrès Internationaux d'Architecture Moderne to międzynarodowa organizacja architektów modernistycznych utworzona w celu konsolidacji i wzajemnej konsultacji środowiska propagującego rozwój architektury współczesnej. Powstała w 1928 r. na znak manifestu nowego trendu w architekturze i sztuce, jakim był modernizm. W ramach jej działalności zorganizowano 10 zjazdów, które odbywały się nieregularnie do 1956 r. 
nej (Brukalska 1948, Syrkus 1976). Autorzy tych koncepcji, uważani za twórców i prekursorów nowoczesnej urbanistyki, dążyli do takiego zaplanowania miasta, które stanowiąc jednocześnie miejsce pracy i zamieszkania zapewniałoby wyższy standard życia mieszkańców i funkcjonalność całego układu. Najważniejszą przesłanką ich powstawania była bowiem poprawa warunków życia w przeludnionych i nieharmonijnie rozwijających się miastach przemysłowych.

$\mathrm{Na}$ historyczne kształtowanie się idei organizacji przestrzeni mieszkaniowej w poszczególnych krajach europejskich, w tym koncepcji osiedli wielorodzinnych, wpływ miała sytuacja społeczno-polityczna i ekonomiczna, $\mathrm{w}$ jakich idee te powstawały ${ }^{2}$. $\mathrm{Z}$ jednej strony miały one bowiem charakter ideologiczny związany z kształtowaniem nowych wzorów życia, z drugiej zaś pragmatyczny, wynikający z konieczności bardziej intensywnego wykorzystania terenu $\mathrm{w}$ miastach poprzez budowanie wzwyż, a także z potrzeby zapewnienia jak największej liczby tanich i szeroko dostępnych mieszkań. Najbardziej pragmatyczny charakter, motywowany przede wszystkim czynnikami ekonomicznymi i koniecznością zaspokojenia drastycznego głodu mieszkaniowego, miały koncepcje osiedlowe formułowane $\mathrm{w}$ Niemczech okresu Republiki Weimarskiej, gdzie narodziła się idea "der soziale Siedlungsbau" - masowej budowy małych, tanich, zuniformizowanych mieszkań spełniających minimum egzystencjalne ${ }^{3}$ (Goldzamt 1971, Rembarz 2010). Tam też w latach 20. XX wieku powstały pierwsze osiedla mieszkaniowe zabudowane powtarzalnymi $\mathrm{w}$ formie, standaryzowanymi budynkami utrzymanymi w duchu modernizmu i funkcjonalnego strefowania miasta. Stały się one pierwowzorem początkowo niewielkich, a z czasem coraz większych założeń osiedlowych, budowanych masowo od Atlantyku po Władywostok po II wojnie światowej, których geneza, rozwój, przemiany i percepcja są zasadniczym przedmiotem niniejszej pracy.

\subsection{Problem badawczy}

Idea wielkich osiedli mieszkaniowych o zabudowie blokowej, w języku potocznym i w literaturze naukowej określanych też "blokowiskami" (Borowik 2003, 2007) lub „osiedlami z wielkiej płyty” (Rembarz 2010), jakkolwiek

\footnotetext{
${ }^{2}$ W literaturze dotyczącej historii rozwoju miast (np. Goldzamt 1971) podkreśla się szczególnie odmienność uwarunkowań panujących w krajach anglosaskich i w Europie kontynentalnej, które miały wpływ na kształt omawianych koncepcji.

${ }^{3}$ Osiedla takie powstawały w tym czasie także w Austrii (w Wiedniu), Holandii (w Amsterdamie i Rotterdamie) oraz w Polsce (m.in. w Warszawie i Łodzi), lecz na największą skalę budowano je w Niemczech.
} 
w swej genezie sięga koncepcji architektoniczno-urbanistycznych i planistycznych powstających już od początku XIX wieku, najpełniej miała szanse zmaterializować się dopiero $\mathrm{w}$ warunkach zniszczeń, jakie w miastach europejskich spowodowała II wojna światowa. Szczególnie dogodne warunki do ich powstawania pojawily się $\mathrm{w}$ krajach realnego socjalizmu, gdzie ich budowa na masową skalę niemającą sobie równych w krajach zachodniej Europy ${ }^{4} \mathrm{w}$ dużej mierze była związana ze specyfiką tego ustroju i podyktowana wymogami tzw. socjalistycznej urbanizacji podporządkowanej forsownej industrializacji (Jałowiecki 1995, Sagan 2000a). Okres rozwoju wielkich osiedli mieszkaniowych, budowanych powszechnie w Europie od konca lat 50. XX wieku, w krajach socjalistycznych trwał do przełomu lat 80. i 90., czyli do końca trwania tego ustroju, podczas gdy w krajach zachodnioeuropejskich już od lat 70. rezygnowano z tej formy zabudowy, dostrzegając $\mathrm{w}$ niej obszary problemowe ${ }^{5}$ (Turkington $\mathrm{i}$ in., red. 2004). W efekcie, jak podają szacunki, w krajach całej Europy (z wyłączeniem byłego ZSRR), w wielkich osiedlach o zabudowie blokowej, liczących ponad 2,5 tys. mieszkań w początkach lat 90. zamieszkiwało ponad $40 \mathrm{mln}$ mieszkańców, z czego ponad $34 \mathrm{mln}$ stanowiła ludność krajów Europy Centralnej i Wschodniej (Knorr-Siedow 1997).

$\mathrm{W}$ osiedlach tych oferowano ujednolicone pod względem standardu, teoretycznie dostępne dla każdego, oraz dobrze wyposażone i nowoczesne jak na owe czasy mieszkania, co sprawiło, że w krajach socjalistycznych stały się one wręcz wizytówką socjalizmu i materialną emanacją przyjętej $\mathrm{w}$ tym ustroju ideologii egalitaryzmu ${ }^{6}$. Równocześnie zamieszkiwanie $\mathrm{w}$ nich, poprzedzone długim (zazwyczaj kilkunastoletnim) okresem oczekiwania na "przydział", przywiązywało ludzi do miejsca i podporządkowywało władzy, która poprzez realizację tzw. normatywu mieszkaniowego oraz centralnie sterowane rozdzielnictwo, ignorujące indywidualne preferencje lokalizacyjne i jakościowe, decydowała, kto, jak i gdzie ma mieszkać (Woroniecka 2007, Jarosz 2010). Osiedla te charakteryzowały: wielka skala urbanistyczna i demograficzna (największe $\mathrm{z}$ nich zamieszkiwane były przez kilkadziesiąt, a niektóre nawet przez ponad 100 tys. mieszkańców),

${ }^{4}$ W niektórych krajach Europy Zachodniej (np. Francja, Holandia, Szwecja) wielkie osiedla mieszkaniowe osiągały skalę porównywalną z osiedlami budowanymi w krajach socjalistycznych, jednak ich udział w całych zasobach mieszkaniowych był znacznie mniejszy.

${ }^{5}$ Krajem europejskim, w którym najwcześniej (na przełomie lat 60. i 70 XX w.) wycofano się ze wznoszenia wielkich osiedli o zabudowie blokowej, była Wielka Brytania. W pozostałych krajach zachodniej i północnej Europy osiedla wznoszono jeszcze do około połowy lat 70., natomiast w krajach Europy Południowej jeszcze w latach 80. XX w.

${ }^{6} \mathrm{~W}$ krajach socjalistycznych, szczególnie w początkowej fazie tego ustroju, polityka przydziału mieszkań oparta była na celowym przemieszaniu mieszkańców, tak aby tworzyli zróżnicowaną statusowo zbiorowość, co w założeniu miało tworzyć solidarność nowego społeczeństwa (Czepczyński 1999). 
monotonna architektura zabudowy, którą tworzyły jednolite, powtarzalne w formie, szare budynki wielorodzinne określane blokami, niska jakość wykonania i niewielkie powierzchnie mieszkań, a także brak zróżnicowania funkcjonalnego i niedostateczne wyposażenie $\mathrm{w}$ infrastrukturę społeczną i usługową. Chaotyczna i bezładna struktura przestrzenna tych osiedli, w tym przede wszystkim brak archetypicznego dla miasta uliczno-pierzejowego układu zabudowy i wyraźnie wyodrębnionych przestrzeni publicznych, a także rozległe niezagospodarowane przestrzenie międzyblokowe (w efekcie tworzące "przestrzenie niczyje") pozbawione walorów "miejsca" (w rozumieniu Y.F. Tuana 1987) sprawiły, że nie bez powodu osiedla te zyskały miano „blokowisk”, ,szarych betonowych pustyni” lub „miejskich sypialni" (Coudroy de Lille 2000). Ich peryferyjne położenie i na ogół niewystarczające $\mathrm{w}$ stosunku do potrzeb połączenia komunikacyjne $\mathrm{z}$ centrum miasta, ubogie wyposażenie infrastrukturalne i monofunkcyjność oraz heterogeniczna i przypadkowa struktura społeczna, na którą w dużej mierze składali się napływający do pracy w przemyśle mieszkańcy wsi bez uprzednich doświadczeń życia miejskiego (Węcławowicz 2007) sprawiały, że osiedla te, zwłaszcza w początkowym okresie po oddaniu do użytku, będąc częścią miast miały niemiejski charakter i $\mathrm{w}$ istocie stanowiły - parafrazując metaforę „,nie-miejsc" M. Augé7 - „nie-miasto”.

Mimo to $\mathrm{w}$ krajach realnego socjalizmu zamieszkanie $\mathrm{w}$ takim osiedlu stwarzało niemal jedyną możliwość poprawy złych warunków życia (Węcławowicz 2007). Dotyczyło to zwłaszcza ludności migrującej ze wsi oraz mieszkańców przedwojennej substandardowej zabudowy miejskiej. W Polsce, podobnie jak w innych krajach socjalistycznych, silny strukturalny deficyt na rynku mieszkaniowym (,głód mieszkań”) powstały na skutek dynamicznej urbanizacji, postępująca degradacja przejętych przez państwo przedwojennych zasobów mieszkaniowych oraz ograniczenia dla budownictwa indywidualnego, a także niskie (spłaszczone na skutek polityki egalitaryzmu społecznego) dochody ludności i związane z tym relatywnie niskie aspiracje mieszkaniowe, tworzyły warunki, w których - jak podaje M. Lewicka (2004, s. 311): „mieszkanie w bloku stanowiło obiekt marzeń większości obywateli, niezależnie od ich statusu społecznego". Wielkie osiedla

7 „Nie-miejsca” (fr. non-lieux), zgodnie z koncepcją zaproponowaną w 1992 r. przez antropologa kultury Marca Augé, stanowią opozycję do tzw. miejsc antropologicznych, historycznie zdefiniowanych, określonych $\mathrm{w}$ danym miejscu i czasie. Nie-miejsca według tego autora powstają $\mathrm{w}$ czasach supernowoczesności w wyniku krzyżowania się ze sobą ludzi i informacji z odległych od siebie miejsc i środowisk. M. Augé pisząc o nie-miejscach miał na myśli nie tylko nie-miejsca $w$ rozumieniu przestrzennym, ale też społecznym (relacji osób przebywających w takich miejscach) - zarówno w stosunku do siebie nawzajem, jak i w odniesieniu do tych miejsc. Nie-miejsca są "wszędzie takie same” i pozbawione swoistego, lokalnego kolorytu (Augé 2010). 
blokowe w krajach tego ustroju były obszarem zamieszkiwania nie tylko ludności robotniczej, ale także „socjalistycznej klasy średniej”, a nawet przedstawicieli socjalistycznych elit (Kovács, Herfert 2012, Erőss 2013).

Sytuacja ta zmieniła się na przełomie lat 80. i 90. XX wieku. Zapoczątkowane wówczas przemiany ustrojowe, którym towarzyszył znaczny wzrost zróżnicowania społecznego, a w konsekwencji możliwości nabywczych i aspiracji mieszkaniowych całych grup mieszkańców miast socjalistycznych, sprawily, że zamieszkiwanie w osiedlu blokowym straciło na atrakcyjności. Można nawet twierdzić, że w wielu środowiskach społecznych, w szczególności obejmujących grupy, które stały się beneficjentami procesu transformacji ustrojowej, zostało napiętnowane jako „zły adres”. Osiedla blokowe w krajach postsocjalistycznych, choć zróżnicowane pomiędzy poszczególnymi krajami oraz miastami, wielu badaczy już w pierwszych latach transformacji zdiagnozowało jako obszary problemowe (lub potencjalnie problemowe), zagrożone "slamsowieniem”, obszary "ucieczkowe”, fizycznie i społecznie zdegradowane, a także pozbawione więzi wspólnotowych i związków z terytorium (por. Szelényi 1996, Jałowiecki 1995, Czepczyński 1999, Rykiel 1999, Gaczek, Rykiel 1999). Na zły wizerunek i niski prestiż tego typu zabudowy, który w latach 90. minionego stulecia funkcjonował nie tylko w świadomości potocznej i w literaturze naukowej, ale także w dyskursie publicznym i medialnym, wpływ miało zapewne przekonanie, że wielkie osiedla mieszkaniowe po zmianie ustroju wejdą w kolejną fazę cyklu rozwoju zaobserwowaną w krajach zachodnioeuropejskich już od końca lat 70. XX wieku, określaną w literaturze jako „syndrom wielkiego osiedla” (Knorr-Siedow 1997) lub "spirala upadku” (Prak, Priemus 1986) ${ }^{8}$. W ich wyniku wiele osiedli blokowych w krajach zachodniej Europy (głównie we Francji, w Holandii i krajach skandynawskich) stało się obszarami wykluczenia społecznego, gettami, terenami zamieszkałymi przez imigrantów oraz ludność o niskim statusie społeczno-ekonomicznym.

W krajach postsocjalistycznych ten negatywny wizerunek blokowisk jako środowisk mieszkaniowych o niskich walorach społecznych, urbanistyczno-architektonicznych, estetycznych i symbolicznych w większości nie znalazł jednak potwierdzenia w badaniach empirycznych. Wyniki prac badawczych dowodzą, że wiele osiedli o zabudowie blokowej w krajach Europy Środkowo-Wschodniej charakteryzuje się relatywnie wysokimi udziałami osób z wyższym wykształceniem, aktywnych zawodowo i społecznie (Turkington i in., red. 2004, Zborowski 2005, Csaba 2006, Węcławowicz i in. 2003, Węcławowicz 2007, Szafrańska 2008, Kovács, Herfert 2012, Kabisch, Grossmann 2013). Powszechność tego habitatu sprawia, że zamieszkiwanie w blokowisku nie jest postrzegane jako społecznie degradujące, a miesz-

${ }^{8}$ Por. rozdział 2.3. 
kańcy tych osiedli na ogół deklarują wysoką satysfakcję z zamieszkiwania w nich i niską skłonność do migracji (Borowik 2003, 2007, Węcławowicz i in. 2005, Szafrańska 2009, Wiest 2011, Kovács, Herfert 2012, Andráško i in. 2013). Również badania dotyczące warunków mieszkaniowych dowodzą, że osiedla o zabudowie blokowej wciąż charakteryzują relatywnie dobre warunki zamieszkania, zwłaszcza $w$ miastach o względnie dużym udziale starych, substandardowych i zaniedbanych zasobów mieszkaniowych (Kaczmarek 1996, Dzieciuchowicz 2002, 2011, Marcińczak 2009). Podobnych wniosków dostarczają badania preferowanych miejsc zamieszkania, które wysoko sytuują osiedla blokowe w strukturze miasta (Groeger 2004, Wiest 2011, Kovács, Herfert 2012, Andráško i in. 2013). Także status społeczny mieszkańców blokowisk, mimo odpływu ludności najzamożniejszej o wysokich aspiracjach mieszkaniowych, nie obniża się (Szafrańska 2012, Zborowski 2005). A wciąż utrzymująca się, choć upłynęło ponad 20 lat od początku transformacji, relatywnie wysoka pozycja tych osiedli w strukturze społeczno-przestrzennej większości miast postsocjalistycznych (Musterd, van Kempen 2005, Węcławowicz 2007, Zborowski 2005, Marcińczak 2009) przeczy przewidywanej w początkach lat 90. XX wieku ich społecznej i fizycznej degradacji zapowiadanej jako nieuchronne następstwo transformacji ustrojowej (por. Jałowiecki 1995, Szelényi 1996).

Warto także odnotować, że po 1990 roku w wielu osiedlach mieszkaniowych o zabudowie blokowej zachodzą przemiany, które zmieniają ich strukturę społeczną, przestrzenną, funkcjonalną oraz fizjonomię. Przemiany te $\mathrm{z}$ jednej strony mają charakter planowy zmierzający do poprawy warunków zamieszkania, które w literaturze w zależności od podejścia określane są jako modernizacja (Chmielewski, Mirecka 2001, Kozłowski 2005, Tokajuk 2007), humanizacja (Borowik 2003, 2007, Kozłowski 2010), rewitalizacja (Gorczyca 2009, Ostańska 2009), rehabilitacja (Rębowska 1999, 2000, Rębowska i in. 2006), restrukturyzacja (Węcławowicz 2003) czy też reurbanizacja (Rembarz 2010, Gzell i in. 2009). Z drugiej zaś strony mają charakter spontaniczny związany z transformacją ustrojową, czyli przekształcaniem się miast socjalistycznych $w$ miasta postsocjalistyczne $i$ ich powrotem na ścieżki rozwojowe typowe dla miast $\mathrm{w}$ krajach wolnego rynku. Należą do nich prywatyzacja, komercjalizacja, sakralizacja, segregacja i separacja (por. Matlovič, Sedlakova 2007). Równocześnie, na przemiany zachodzące w wielkich osiedlach mieszkaniowych w skali lokalnej oraz krajowej, nakładają się procesy ogólnoświatowe, takie jak globalizacja, rozwój technologii i usług, liberalizacja polityki społecznej, polityczna i gospodarcza integracja, a także przemiany społeczno-kulturowe oraz demograficzne (Zborowski 2000).

Geneza, rozwój, przemiany oraz percepcja wielkich osiedli mieszkaniowych w mieście postsocjalistycznym, których analiza jest głównym przedmiotem niniejszej pracy, choć były już podejmowane w pracach empirycz- 
nych i studiach teoretycznych na gruncie nie tylko geografii, ale także architektury i urbanistyki oraz socjologii, wciąż nie są zjawiskami dobrze rozpoznanymi. A duża dynamika przemian zachodzących w tych osiedlach, nie mniejsza niż na innych obszarach miejskich, sprawia, że stanowią one bardzo interesujący "poligon badawczy”, a równocześnie swoiste laboratorium przemian miasta socjalistycznego $\mathrm{w}$ miasto postsocjalistyczne.

Problem badawczy pracy koncentruje się zatem wokól dwóch zasadniczych pytań. Po pierwsze, jak zmieniają się wielkie socjalistyczne osiedla mieszkaniowe $\mathrm{w}$ mieście postsocjalistycznym i w jaki sposób ich przemiany wpisują się w przekształcania ustrojowe. Po drugie zaś, jaka jest percepcja i społeczna akceptacja środowisk mieszkaniowych tworzonych przez tę formę zabudowy we współczesnym mieście postsocjalistycznym; środowisk, których idea narodziła się w okresie rewolucji przemysłowej, głównie w celu zapewnienia minimum dla najuboższych, a które w II połowie XX wieku $\mathrm{w}$ krajach realnego socjalizmu stały się standardem mieszkaniowym dla milionów, niezależnie od ich statusu społecznego i zamożności.

\subsection{Założenia i cele pracy}

Podjęcie refleksji zarówno teoretycznej, jak i empirycznej dotyczącej wielkich osiedli mieszkaniowych uznano za ważne z następujących powodów:

- są to obszary stanowiące najbardziej widoczne i najbardziej rozległe przestrzennie dziedzictwo socjalizmu we współczesnych miastach postsocjalistycznych, będące bardzo istotnym elementem struktury społeczno-przestrzennej tych miast;

- obserwacje oraz różne badania empiryczne pokazują, że są to tereny, na których po 1990 roku zachodzą znaczące przemiany zarówno społeczno-demograficzne, przestrzenne, jak i funkcjonalne; zmienia się też ich fizjonomia i społeczna percepcja - stają się bardziej przyjaznym i akceptowanym środowiskiem mieszkaniowym;

- obszary te są wciąż stosunkowo mało poznane, postrzegane przez pryzmat wielu stereotypów, które należy weryfikować w badaniach w różnych skalach przestrzennych i przy użyciu różnych metod;

- przemiany zachodzące $\mathrm{w}$ wielkich osiedlach mieszkaniowych $\mathrm{w}$ miastach postsocjalistycznych, ich społeczna percepcja oraz pozycja $\mathrm{w}$ strukturze społeczno-przestrzennej miast są niezwykle ważne z punktu widzenia przyszłości tej formy zabudowy, a w konsekwencji ze względu na jej rozmiary i udział w zasobach mieszkaniowych dla przyszłości tych miast. 
Najważniejszym jednak impulsem do napisania tej pracy była chęć wpisania się $\mathrm{w}$ dyskusję naukową dotyczącą przekształcania się miasta socjalistycznego $\mathrm{w}$ miasto postsocjalistyczne i wplywu tego procesu na przemiany wielkich osiedli mieszkaniowych. Analiza literatury polskiej, jak i zagranicznej pozwoliła bowiem stwierdzić, że wraz z transformacją ustrojową i powrotem miast socjalistycznych na ścieżkę rozwoju typową dla miast wolnego rynku, nie bacząc na obarczenie ich dziedzictwem poprzedniego ustroju, w refleksji teoretycznej przyjęto a priori, że miasta te szybko zaczną powielać ścieżki przekształceń miast zachodnioeuropejskich, a znajdujące się $\mathrm{w}$ nich osiedla wejdą w fazę rozwojową określaną jako spirala upadku. Założenie to, podzielane przez wielu badaczy, oparte było na przekonaniu, że lata 1945-1990 były w miastach realnego socjalizmu okresem, w którym tylko odroczone zostały uniwersalne stadia rozwoju miejskiego (por. van den Berg i in. 1982), toteż po 1990 roku nastąpią w nich te same fazy, które w miastach zachodnioeuropejskich i amerykańskich obserwowano kilka dekad wcześniej (por. Enyedi 1996, Tosics 2005). I choć współcześnie wielu badaczy jest zgodnych co do specyfiki miast postsocjalistycznych, to wciąż mimo upływu ponad ćwierć wieku od początku transformacji ustrojowej, nadal trwa dyskusja naukowa na temat podobieństw i różnic pomiędzy ścieżkami przekształceń miast zachodnioeuropejskich i postsocjalistycznych.

Odnosząc się do tej dyskusji, jako główną tezę pracy przyjęto zdanie bliższe obecnemu w literaturze podejściu historycznemu (por. Szelényi 1996, Tosics 2005), że ścieżki rozwojowe wielkich osiedli mieszkaniowych oraz ich społeczna percepcja w miastach postsocjalistycznych wykazują daleko idącą specyfikę, która jest konsekwencją wytworzenia się w krajach Europy Centralnej i Wschodniej w II połowie XX wieku szczególnego typu miasta niemającego odpowiednika $w$ innych warunkach ustrojowych. A obserwowane $\mathrm{w}$ nich obecnie, $\mathrm{w}$ XXI wieku, procesy nie tylko nie powielają procesów zachodzących w osiedlach zachodnioeuropejskich, lecz przebiegają według własnego wzorca, który uwarunkowany jest zarówno dziedzictwem okresu realnego socjalizmu, jak i przebiegiem procesów transformacyjnych, na które nakładają się procesy zachodzące w skali europejskiej oraz globalnej.

W pracy przyjęto cztery główne cele badawcze o charakterze poznawczym, wyjaśniającym i aplikacyjnym. W warstwie poznawczej w wymiarze empirycznym były to: po pierwsze identyfikacja i analiza przemian społecznych, przestrzennych, funkcjonalnych i fizjonomicznych zachodzących w wielkich osiedlach mieszkaniowych oraz rozpoznanie determinant tych przemian; po drugie określenie percepcji i poziomu społecznej akceptacji wielkich osiedli mieszkaniowych oraz czynników, które je determinują. W wymiarze teoretycznym za cel przyjęto ustalenie, czy istnieje jeden wspólny (uniwersalny) wzorzec przekształceń wielkich osiedli mieszkaniowych w miastach postsocjalistycznych i w jakim stopniu ścieżki przekształ- 
ceń tych osiedli wpisują się $\mathrm{w}$ modele przemian tych środowisk mieszkaniowych sformułowane dla miast zachodnioeuropejskich. W warstwie aplikacyjnej natomiast praca miała być głosem w toczącej się obecnie dyskusji na temat przyszłości wielkich osiedli w miastach po socjalizmie. Aby jednak zbadać i zrozumieć fenomen wielkich osiedli mieszkaniowych we współczesnych miastach, prześledzono genezę tej formy zabudowy oraz jej rozwój w okresie realnego socjalizmu, co znacznie rozszerzyło zakres czasowy pracy poza okres miasta postsocjalistycznego.

Realizacja tak postawionych celów pracy wymagała sformułowania następujących pytań badawczych:

1. Jaka była geneza wielkich osiedli mieszkaniowych w miastach europejskich?

2. Dlaczego wielkie osiedla mieszkaniowe na największą skalę rozwinęły się w miastach socjalistycznych?

3. Jakie były trajektorie rozwoju wielkich osiedli mieszkaniowych w miastach socjalistycznych, co je determinowało i czym różniły się od trajektorii rozwoju tej formy zabudowy w miastach krajów zachodnioeuropejskich?

4. Jakie przemiany nastąpily po 1990 roku w strukturze społecznej, przestrzennej i funkcjonalnej oraz fizjonomii wielkich osiedli mieszkaniowych w mieście postsocjalistycznym?

5. Jaki jest kierunek, tempo, natężenie, determinanty i efekty przemian zachodzących w wielkich osiedlach mieszkaniowych? Kto jest głównym aktorem tych przemian?

6. W jaki sposób przemiany wielkich osiedli mieszkaniowych wpisują się $\mathrm{w}$ przemiany ustrojowe (specyficzne dla przechodzenia od socjalizmu do postsocjalizmu) oraz $\mathrm{w}$ szerzej rozumiane przemiany cywilizacyjne zachodzące we współczesnym świecie, które nakładają się na procesy transformacji ustrojowej?

7. Jaka jest percepcja i społeczna akceptacja środowisk mieszkaniowych tworzonych przez tę formę zabudowy we współczesnym mieście postsocjalistycznym i co je determinuje?

8. Jakie jest miejsce (pozycja) wielkich osiedli mieszkaniowych w strukturze społeczno-przestrzennej miasta postsocjalistycznego?

9. Czy istnieje jeden wspólny, uniwersalny wzorzec rozwoju i przemian wielkich osiedli mieszkaniowych w miastach postsocjalistycznych?

10. Czy osiedla te powielają ścieżki przekształceń wielkich osiedli w miastach zachodnioeuropejskich, czy też przekształcają się w sposób swoisty, specyficzny dla miast po socjalizmie?

11. Jakie czynniki będą decydowały o przyszłości wielkich osiedli mieszkaniowych w mieście postsocjalistycznym i jakie są ich perspektywy? 


\subsection{Podstawy teoretyczne pracy}

Podstawy teoretyczne pracy oparto na założeniu, że wielkie osiedla mieszkaniowe są szczególnym rodzajem przestrzeni mieszkaniowej, ta zaś jest jedną z form przestrzeni społecznej. Przyjęcie takiego założenia lokuje pracę w naukach społecznych, a ściślej - na pograniczu co najmniej kilku nauk i ich subdyscyplin, które zajmują się miastem i przestrzenią miejską (geografii społecznej miast, socjologii miasta, psychologii środowiskowej), oraz implikuje przyjęcie określonych założeń teoretyczno-metodologicznych dotyczących zarówno natury badanych zjawisk, jak i sposobów ich wyjaśniania. Założenie to wymaga zdefiniowania pojęcia "przestrzeń społeczna”, które podobnie jak termin "przestrzen” ma wiele znaczeń i różnie jest konceptualizowane na gruncie różnych dyscyplin naukowych (por. Lisowski 2003, Rykiel 2008, Majer 2010). Nie wnikając jednakże w tym miejscu w szczegółową dyskusję pojęciową, która jest przedmiotem wielu odrębnych prac (np. Maik, Stachowski 1995, Lisowski 2003), na podstawie przeglądu literatury zarówno geograficznej, jak i socjologicznej (Buttimer 1969, Gołdyka 1976, Wallis 1990, Maik, Stachowski 1995, Lisowski 2003, Jałowiecki, Szczepański 2006, Węcławowicz 2007, Rykiel 2008, Majer 2010) za podstawę badań przyjęto dwa ujęcia przestrzeni społecznej9:

- ekologiczne, w ramach którego przestrzeń społeczna to obszar o określonych cechach fizycznych zamieszkiwany i/lub użytkowany przez zbiorowość o określonych cechach społecznych; w ujęciu tym cechy tej zbiorowości współwystępują z cechami fizycznymi tej przestrzeni;

- kulturalistyczne (świadomościowe), określane też jako kulturowe i/lub symboliczne, w którym przestrzeń społeczna to przestrzeń (obszar, terytorium, miejsce), której jednostki i zbiorowości nadają określone znaczenie, wartość, którą naznaczają.

Pierwsze $\mathrm{z}$ proponowanych ujęć ma źródło $\mathrm{w}$ tradycji szkoły chicagowskiej (w klasycznej ekologii społecznej) R. Parka, E. Burgessa i R. Mc Kenzie'ego oraz wypracowanych $w$ jej ramach koncepcji obszarów naturalnych i będących jej twórczym rozwinięciem koncepcji analizy obszarów

9 Wymienione ujęcia przestrzeni społecznej nawiązują do wyróżnionych przez $\mathrm{Ch}$. de Lauwe w 1952 r. (cyt. za: Lisowski 2003) dwóch warstw przestrzeni ekologiczno-społecznej: obiektywnej oraz subiektywnej, czyli postrzeganej przez określonych użytkowników przestrzeni. Subiektywna interpretacja przestrzeni obiektywnej powstaje w świadomości człowieka i może mieć charakter racjonalny lub emocjonalny. Aspekty racjonalne związane są z traktowaniem przestrzeni jako wartości użytkowej związanej z zaspokajaniem potrzeb bytowych. Z kolei aspekty emocjonalne traktują przestrzeń jako źródło wrażeń, przeżyć estetycznych, intelektualnych (ibid., s. 138). 
społecznych E. Shevky'ego, W. Bella i M. Williamsa $(1949,1955)^{10}$. W ujęciach tych przestrzeń miejska jest przedmiotem rywalizacji zbiorowości ludzkich, a kształt miasta jest wynikiem procesów koncentracji, centralizacji, segregacji, inwazji i sukcesji, a także zmian w podziale pracy, $\mathrm{w}$ funkcjonowaniu gospodarstw domowych oraz rozmieszczeniu ludności.

Drugie natomiast ujęcie przestrzeni społecznej przyjęte $\mathrm{w}$ pracy odwołuje się do kulturalizmu i pierwszej zwartej koncepcji wyjaśniającej relacje przestrzeń-społeczeństwo na gruncie nauk społecznych, której autorem był F. Znaniecki (1938), a kontynuatorem A. Wallis (1977, 1990). Współcześnie ujęcie to mieści się $\mathrm{w}$ ramach szkół humanistycznych i wraz z orientacją behawioralną tworzy teoretyczno-metodologiczne ramy badań geografii społecznej miast, których problematyka dotyczy percepcji i waloryzacji przestrzeni ( Lisowski 2008). W ramach tej grupy podejść przestrzeń społeczna pełna jest znaczeń i symboli, jest doświadczana, waloryzowana i naznaczana przez ludzi, którzy ją tworzą i użytkują. Tym samym nawiązując do koncepcji Y.F. Tuana (1987) nabiera cech miejsca. W przypadku badania przestrzeni zamieszkania podejście kulturalistyczne wydaje się być niezbędne, ponieważ "mieszkanie jest tym podstawowym miejscem $\mathrm{w}$ przestrzeni, do którego człowiek osiadły odnosi swoje różnorodne powiązania z otaczającym go światem i w którym - na odwrót - otoczenie określa jego miejsce w przestrzeni (Goryński 1973, s. 7). Jako dobro niezbędne każdej rodzinie dom (nawet jeśli jest to tylko niewielkie mieszkanie) jest miejscem zaspokajania wszystkich najważniejszych potrzeb człowieka, zarówno podstawowych jak i wyższego rzędu. W ujęciach humanistycznych dom to nasz orbis inetrior, centrum wszechświata, mikrokosmos, miejsce będące synonimem bezpieczeństwa, pewności i ładu (Sulima 2010), miejsce, w którym jesteśmy „u siebie”, do którego „wracamy po aktywności w świecie [...] i zbieramy siły do ponownego wkroczenia w świat" (Woroniecka 2007, s. 13).

Wielkie osiedle mieszkaniowe $\mathrm{w}$ niniejszej pracy rozpatrywane jest także jako jeden z hierarchicznych poziomów środowiska mieszkaniowego. Środowisko mieszkaniowe, w literaturze określane też jako środowisko mieszkalne (Turowski 1979) lub habitat (Bać 1987) jest różnie definiowane (por. Suliborski 1976, Turowski 1979, Schneider-Skalska 2005, Dzieciuchowicz 2011, Groeger 2013). W klasycznej geografii miast, według A. Suliborskiego (1976), środowisko mieszkaniowe tworzą cztery strefy będące częściami przestrzeni miejskiej: mieszkanie, budynek, nieruchomość (działka)

10 Na gruncie socjologii miasta (Czekaj 2007, Majer 2010) podaje się, że E. Shevky oraz W. Bell (twórcy analizy obszarów społecznych) są przedstawicielami nurtu neoekologicznego, którego cechą było zakładanie znacznie większego, niż w klasycznej szkole chicagowskiej, udziału świadomości $w$ podejmowaniu decyzji przestrzennych oraz większy udział czynników kulturowych $\mathrm{w}$ procesach kształtowania przestrzeni. Tym samym neoekologia zrywała z naturalizmem wczesnej szkoły chicagowskiej. 
oraz obszar (czyli przestrzeń położona poza granicami nieruchomości mieszkalnej), które tworzą dwie różne pod względem jakościowym i funkcjonalnym podprzestrzenie, nazywane przez tego autora wewnętrznym i zewnętrznym środowiskiem mieszkaniowym. Na użytek niniejszej pracy przyjęto definicję środowiska mieszkaniowego zaproponowaną $\mathrm{w}$ pracach z zakresu socjologii mieszkalnictwa (por. Turowski 1979, Siemiński 1985, Bać 1987), według której jest to całość elementów fizykoprzestrzennych, społecznych i kulturowych współkształtujących obszar codziennych działań, aktywności i ruchliwości przestrzennej człowieka oraz determinujących jego postawy jako użytkownika tego obszaru (Borowik 2003, s. 80). Według typologii J. Turowskiego (1979), teoretyka i badacza osiedli, pojęcie środowiska mieszkaniowego (określanego przez tego autora jako środowisko mieszkalne) ma charakter hierarchiczny i może być ujmowane jako: mikrośrodowisko mieszkalne, czyli mieszkanie, dom oraz najbliższe otoczenie przestrzenno-społeczne, szersze środowisko mieszkalne (mezośrodowisko), które obejmuje zespół domów (bloków) stanowiących osiedle lub dzielnicę, oraz makrośrodowisko mieszkalne, czyli miasto wraz z całą strefą podmiejską.

Z punktu widzenia niniejszej pracy ważna jest jakość tak rozumianego środowiska mieszkaniowego (habitatu), której wybrane elementy mają aspekt fizyczny, kwantyfikowalny (np. lokalizacja i dostępność komunikacyjna osiedla, wielkość mieszkań, wyposażenie w obiekty infrastruktury) i można je oceniać w ujęciu obiektywnym. Inne zaś mają wymiar jedynie subiektywny (np. poczucie bezpieczeństwa, więź sąsiedzka, zadowolenie z zamieszkiwania) i można je badać wyłącznie z punktu widzenia użytkownika środowiska mieszkaniowego. Dlatego też niezbędne jest podejście integrujące obiektywne i subiektywne perspektywy badawcze i odwołanie się do badań z zakresu percepcji.

Perspektywa teoretyczna przyjęta w badaniach odwołuje się również do koncepcji glokalizacji (Robertson 1995, Bauman 1997), zgodnie z którą jedną z ważnych dróg analizy trendów zachodzących na poziomie globalnym (makro) jest perspektywa lokalna (mikro). Według A. Giddensa (1990), globalizacja nie jest zjawiskiem występującym "tam, na zewnątrz", odnoszącym się do systemów światowych, ale dzieje się również "tutaj, wewnątrz", dotykając naszej codzienności, ponieważ dokonuje swoistej „inwazji w lokalność". Zgodnie z tymi rozważaniami procesy dokonujące się na poziomie światowym (europejskim) czy krajowym mają znaczący wplyw na procesy zachodzące $w$ skali miast i pojedynczych osiedli, ale aby je zrozumieć należy je analizować przez pryzmat lokalny. Tym samym wszelkie rozważania na temat przemian wielkich osiedli mieszkaniowych w skali europejskiej (w skali bloku państw postsocjalistycznych) powinny odbywać się w oparciu o analizy empiryczne poszczególnych miast i poszczególnych osiedli. 
Aby zatem uwzględnić w pracy kontekst lokalny zdecydowano, że jej część empiryczna poświęcona zastanie studium przypadku jednego z miast postsocjalistycznych, jakim jest współczesna Łódź. Nie wnikając w tym miejscu, jak dalece Łódź jest typowym miastem postsocjalistycznym, nie ma wątpliwości, że jest miastem, które w latach 1945-1990 funkcjonowało $\mathrm{w}$ ustroju realnego socjalizmu i podlegało ideologii oraz prawom tego ustroju, toteż zgodnie z definicją miasta postsocjalistycznego S. Liszewskiego z 2001 roku (omówioną szerzej w rozdziale 2 niniejszej pracy) spełnia to kryterium. I mimo że przedwojenny rozwój Łodzi daleki był od typowej ścieżki rozwojowej miast europejskich (por. Liszewski 2009), to w okresie powojennym miasto to rozwijało się jako typowe miasto socjalistyczne i poddane było takim samym wpływom ustrojowym jak inne wielkie miasta w Polsce. Były to: pełna zależność od władz centralnych, podporządkowywanie rozwoju społecznego i przestrzennego priorytetom ideologicznym, brak rynku, forsowna industrializacja, silna migracja ze wsi, głód mieszkaniowy oraz budowa wielkich osiedli mieszkaniowych. Specyfiką Łodzi $\mathrm{w}$ porównaniu do innych wielkich miast w Polsce jest uniknięcie zniszczeń w okresie II wojny światowej, zatem nie wystąpił tu po 1945 roku problem zburzonej substancji mieszkaniowej. Istniał jednak (i istnieje nadal) nie mniej poważny problem substancji mieszkaniowej o bardzo niskim standardzie, który jest skutkiem historycznych uwarunkowań i niespotykanego nigdzie indziej szybkiego tempa rozwoju Łodzi w II połowie XIX wieku jako wielkiego ośrodka przemysłowego.

Wybór jednego miasta jako obszaru szczegółowych studiów empirycznych wynikał także z przekonania, że określony poziom szczegółowości badań wymaga ograniczenia ich zasięgu przestrzennego, tak aby uzyskane wnioski były w pełni potwierdzone. Uzasadnienie metodologiczne takiego wyboru jest także konsekwencją decyzji o zastosowaniu w pracy metod jakościowych (obserwacja i wywiad swobodny), które wymagają bezpośredniego oglądu badanych zjawisk, aby zgodnie z proponowanym przez F. Znanieckiego „współczynnikiem humanistycznym”, określanym przez S. Ossowskiego (1962) „empatią badacza”, lepiej je zrozumieć.

\subsection{Metody badań i materiały źródłowe}

Złożoność problematyki badawczej dotyczącej zarówno społecznych, jak i fizycznych aspektów przestrzeni miejskiej tworzących środowisko mieszkaniowe oraz przekonanie, że poznanie badanych zjawisk powinno być możliwie wszechstronne, wymaga podejść zintegrowanych czerpiących $\mathrm{z}$ dorobku różnych orientacji teoretyczno-metodologicznych stosowanych 
we współczesnej geografii społecznej miast. Przyjęcie takiego założenia wynika z przekonania, że każdy z paradygmatów stosowanych $\mathrm{w}$ badaniach miast i każda $z$ orientacji teoretyczno-metodologicznych odczytuje i interpretuje tylko pewne aspekty badanych zjawisk (por. Węcławowicz 2007, Maik, Stachowski 1995, Maik 2012). A jak podaje W. Maik (2012), ze względu na pluralistyczny i polimorficzny charakter geografii miast, metodologia badań geograficznych nie tylko może, ale nawet „powinna tworzyć mozaikę ujęć teoretyczno-metodologicznych, które dają różny ogląd badanej rzeczywistości. W warstwie metodologicznej może to być łączenie różnych ujęć ilościowych i jakościowych, obiektywnych i subiektywnych, aksjologicznych i neutralnych wobec wartości" (Maik 2012, s. 136).

Przyjmując zatem, że każda z perspektyw teoretyczno-metodologicznych pozwala dojrzeć inne strony rzeczywistości społecznej i poznać inne jej aspekty $\mathrm{w}$ pracy przyjęto postawę racjonalnego eklektyzmu (Jałowiecki, Szczepański 2006), która zakłada konieczność integralnej interpretacji świata społecznego poprzez poszukiwanie najbardziej wartościowych cech istniejących nurtów i eliminacji ich słabości ${ }^{11}$. Podejście takie zgodne jest $\mathrm{z}$ emergentystyczną koncepcją miasta określaną też koncepcją komplementarności (Maik 2012, s. 64), która zakłada, że badana rzeczywistość nie jest homogeniczna, a proces kształtowania miasta rozgrywa się na wielu płaszczyznach (poziomach), które należy uwzględnić w badaniach. Przyjęte w pracy podejście metodologiczne jest zatem podejściem zintegrowanym, które łączy ujęcia ilościowe i jakościowe, podejścia scjentystyczne z podejściem humanistycznym oraz holizm szkoły chicagowskiej (ale nie naturalizm, charakterystyczny dla jej wczesnej fazy) i szkół makrostrukturalnych (strukturalno-funkcjonalnych) z indywidualizmem szkół kulturalistycznych. Zastosowana w pracy procedura łączenia różnych metodologii w literaturze z zakresu nauk społecznych określana bywa też jako triangulacja (Denzin 2006).

Przyjęcie określonych założeń, a także specyfika i złożoność przedmiotu badań, który stanowią procesy zachodzące $\mathrm{w}$ wielkich osiedlach mieszkaniowych, ich niemal powszechne występowanie oraz, mimo istotnych podobieństw, zróżnicowanie istniejące zarówno w skali europejskiej, krajowej, regionalnej, jak i w skali poszczególnych miast, wymaga zastosowania trzech przestrzennych skal badawczych: makro, mezo i mikro. Są to:

11 Indywidualizm metodologiczny i poznawczy wpisany w szkoły kulturalistyczne, humanistyczne i różne nurty określane jako postmodernistyczne eliminuje podstawową słabość perspektywy holistycznej, czyli brak odwołań do świata odczuć pojedynczego człowieka. A równocześnie tylko podejścia całościowe, w postaci ujęć strukturalistycznych (makrostrukturalnych), pozwalają dostrzec grupy i całości społeczne (klasy, warstwy, kategorie), zinterpretować ich różne położenie, interesy oraz ewentualne między nimi konflikty i umieścić je w szerszym kontekście zarówno społecznym, jak i przestrzennym (miejskim, krajowym, globalnym) (por. Jałowiecki, Szczepański 2006, Węcławowicz 2007). 
- skala europejska i krajowa (makroskala) - wielkie osiedla mieszkaniowe w krajach postsocjalistycznych;

- skala pojedynczego miasta (mezoskala) - wielkie osiedla mieszkaniowe $\mathrm{w}$ wybranych miastach postsocjalistycznych, $\mathrm{w}$ Polsce $\mathrm{i}$ innych krajach europejskich jako kontekst dla szczegółowych badań empirycznych prowadzonych w skali wybranego miasta, jakim jest Łódź;

- skala pojedynczego osiedla (mikroskala) - studium przypadku Łodzi oraz studia przypadków wybranych wielkich osiedli mieszkaniowych spełniające kryteria definicyjne przyjęte w badaniu.

W pracy przyjęto, że obrazy uzyskane w każdej z perspektyw badawczych (skal przestrzennych) wzajemnie się uzupełniają i weryfikują. Każda z tych skal przestrzennych (perspektyw) implikuje także przyjęcie określonych, właściwych dla niej podejść badawczych oraz zastosowania odpowiednich metod i skorzystania $z$ innych źródeł danych, obejmujących zarówno źródła pierwotne, tworzone na użytek niniejszej pracy, jak i źródła wtórne (zastane) - (tab. 1).

Tab. 1. Źródła danych i metody zastosowane w pracy

\begin{tabular}{|c|c|c|c|c|}
\hline \multirow[b]{2}{*}{ Skala analizy } & \multicolumn{4}{|c|}{ Płaszczyzny badawcze wielkich osiedli mieszkaniowych } \\
\hline & geneza & \begin{tabular}{|c|} 
rozwój \\
i struktura
\end{tabular} & przemiany & percepcja \\
\hline $\begin{array}{l}\text { Makro (skala euro- } \\
\text { pejska i krajowa) }\end{array}$ & \multirow{3}{*}{$\begin{array}{l}\text { kwerenda } \\
\text { literatury }\end{array}$} & \multicolumn{3}{|c|}{ analiza źródeł zastanych (desk research) } \\
\hline Mezo (skala miasta) & & \multirow{2}{*}{$\begin{array}{l}\text { analiza źródeł } \\
\text { zastanych, } \\
\text { inwentaryza- } \\
\text { cja urbani- } \\
\text { styczna }\end{array}$} & \multirow{2}{*}{$\begin{array}{l}\text { inwentary- } \\
\text { zacja urba- } \\
\text { nistyczna, } \\
\text { obserwacja }\end{array}$} & $\begin{array}{l}\text { ilościowa metoda kwestiona- } \\
\text { riuszowa - standaryzowany } \\
\text { wywiad kwestionariuszowy }\end{array}$ \\
\hline $\begin{array}{l}\text { Mikro (skala poje- } \\
\text { dynczego osiedla) }\end{array}$ & & & & $\begin{array}{l}\text { jakościowa metoda kwestio- } \\
\text { nariuszowa - wywiad swo- } \\
\text { bodny (pogłębiony) }\end{array}$ \\
\hline
\end{tabular}

Źródło: opracowanie własne.

Wykorzystane $\mathrm{w}$ pracy materiały źródłowe o charakterze wtórnym to, obok danych z literatury polskiej i zagranicznej, dane z Urzędów Statystycznych, Urzędu Miasta Łodzi, Miejskiego Ośrodka Pomocy Społecznej w Łodzi, Miejskiej Komendy Policji, biur obrotu nieruchomościami oraz informacje pozyskane $\mathrm{w}$ spółdzielniach mieszkaniowych. Dane pierwotne natomiast to pozyskane $\mathrm{w}$ toku własnych badań terenowych wyniki obserwacji i inwentaryzacji oraz badań kwestionariuszowych zarówno ilościowych (wywiady ustrukturyzowane), jak i jakościowych (wywiady swobodne ze standaryzowaną listą poszukiwanych informacji) przeprowadzonych w wielkich osiedlach mieszkaniowych Łodzi. 
Szeroki zakres merytoryczny i interdyscyplinarność pracy sprawia, że jej zakres czasowy obejmuje - w części teoretycznej - okres od pierwszych koncepcji osiedla jako jednostki urbanistycznej i społecznej, natomiast w części empirycznej - okres miasta socjalistycznego (lata 1945-1989) oraz okres posocjalistyczny (po 1990 r.). Konieczność analizy opartej na wykorzystaniu danych statystycznych pochodzących ze spisów powszechnych oraz ich ograniczona dostępność dla jednostek przestrzennych mniejszych niż miasto sprawia, że analizy statystyczne dotyczą tylko lat, dla których dostępne są odpowiednie dane.

Zakres przestrzenny pracy obejmuje postsocjalistyczną część Europy, a w szczególności te kraje, które w literaturze (Hamilton i in., red. 2005, s. 6) określa się jako Europę Centralną, a ściślej Środkowo-Wschodnią (East Central Europe) - subregion Europy Centralnej i Wschodniej, który wyodrębnił się po zmianie ustroju, czyli Polskę, Czechy, Słowację, Węgry, Słowenię i b. NRD. Zakres pracy rozpatrywać można także $w$ trzech skalach odpowiadających trzem przyjętym w pracy poziomom analizy: w skali makro obejmuje wybrane kraje postsocjalistyczne Europy Środkowo-Wschodniej, w skali mezo - wybrane miasta postsocjalistyczne, a w skali mikro - wybrane osiedla.

Praca składa się z ośmiu rozdziałów. Pierwszy z nich to wprowadzenie, w którym sformułowano główną tezę pracy, przedstawiono jej cele i założenia oraz podstawy teoretyczne. Rozdział drugi przedstawia teoretyczno-metodologiczny kontekst badań nad wielkimi osiedlami mieszkaniowymi, pokazuje wielowymiarowość tego fenomenu i stanowi przegląd podejść badawczych i definicji tej formy zabudowy. W rozdziale trzecim skupiono się na genezie i uwarunkowaniach rozwoju wielkoskalowych założeń osiedlowych, poprzez omówienie najważniejszych koncepcji urbanistycznych i architektonicznych XIX i XX wieku, które miały największy wpływ na kształtowanie się współczesnej urbanistyki, w tym na rozwój budownictwa osiedlowego $\mathrm{w}$ miastach europejskich. Koncepcje te omówiono z uwzględnieniem kontekstu i uwarunkowań społeczno-politycznych, w jakich powstawały oraz przez pryzmat wpływu, jaki wywarły na kształt powojennych wielkich osieli mieszkaniowych będących przedmiotem niniejszej pracy.

Kolejny, czwarty rozdział przedstawia rozwój i cechy wielkich osiedli mieszkaniowych w mieście socjalistycznym, stanowiąc niezbędne tło analizy tych osiedli w okresie miasta postsocjalistycznego, po 1990 roku. W rozdziale piątym analizowano przemiany, jakie zaszły w strukturze społecznej i przestrzennej wielkich osiedli mieszkaniowych w miastach postsocjalistycznych. W szóstym omówiono teoretyczno-metodologiczne aspekty badań nad percepcją środowiska mieszkaniowego oraz przedstawiono wybrane aspekty percepcji tej formy urbanistycznej w oparciu o publikowane wyniki badań empirycznych przeprowadzonych w krajach postsocjalistycz- 
nych. Rozdziały te oparte są na szerokim przeglądzie prac literatury polskiej i zagranicznej. W rozdziale siódmym zaprezentowane zostały wyniki własnych badań empirycznych przeprowadzonych w dziewięciu wielkich osiedlach mieszkaniowych Łodzi spełniających kryteria definicyjne przyjęte $\mathrm{w}$ pracy. Rozdział ten zawiera zagadnienia dotyczące rozwoju budownictwa osiedlowego w Łodzi, przemian jakim po 1990 roku podlegają te osiedla, a także wybranych aspektów ich percepcji, które z jednej strony pokzują, jaka jest jakość zamieszkiwania $\mathrm{w}$ tych osiedlach, $\mathrm{z}$ drugiej zaś stanowią źródło, w oparciu o które prognozować można ich perspektywy oraz podejmować działania zmierzające do modernizacji tych środowisk mieszkaniowych. Pracę kończy rozdział ósmy, który stanowi podsumowanie przeprowadzonych analiz i przedstawia najważniejsze wnioski.

Struktura pracy odzwierciedla poszczególne etapy postępowania badawczego (rys. 1).

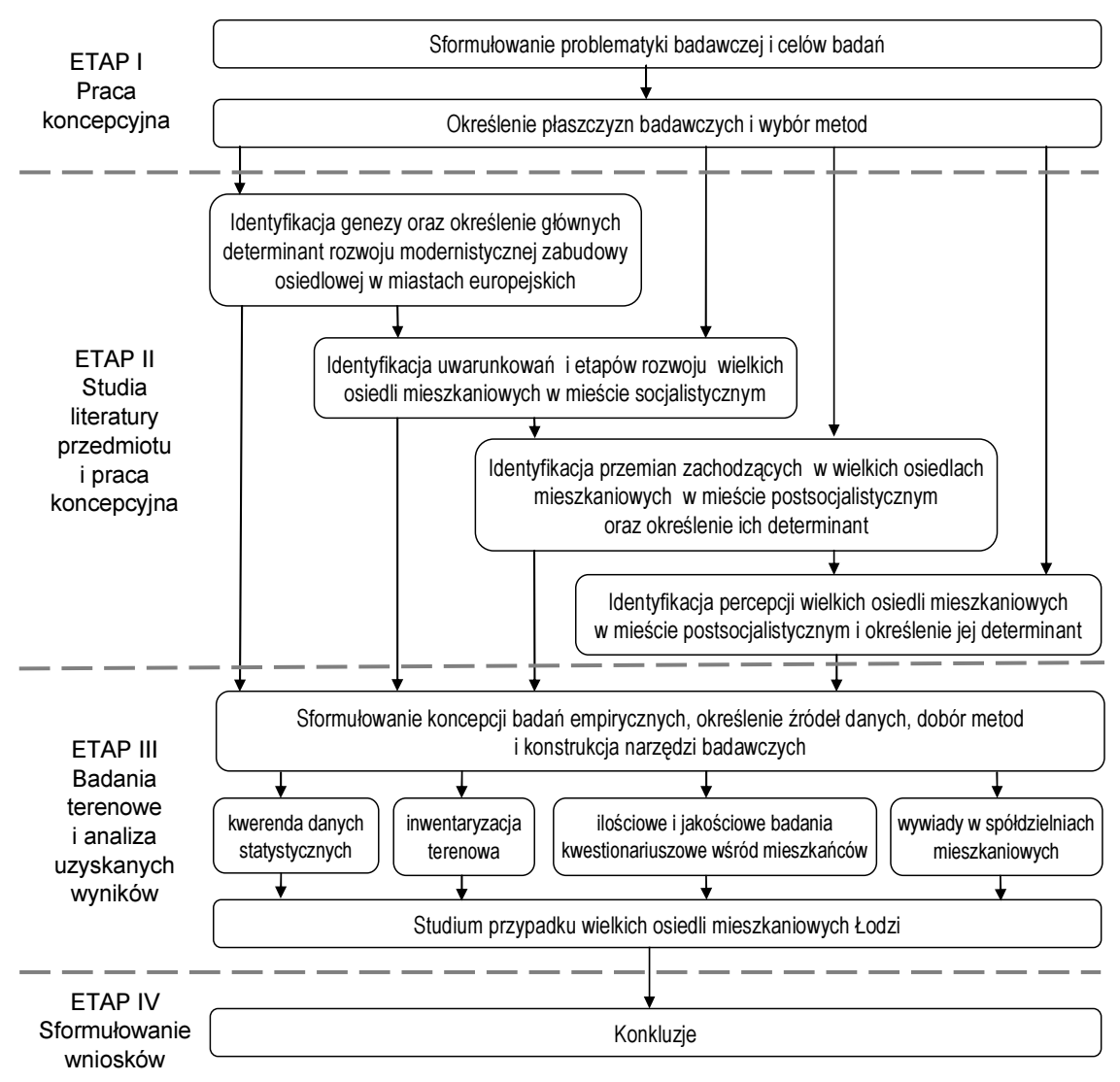

Rys. 1. Etapy postępowania badawczego

Źródło: opracowanie własne 


\section{KONTEKST TEORETYCZNY PRACY}

\subsection{Mieszkalnictwo jako przedmiot badań naukowych}

Badania zagadnień związanych z szeroko rozumianym mieszkalnictwem w literaturze określane wspólną nazwą studiów mieszkaniowych realizowane są na gruncie różnych nauk. Interdyscyplinarny charakter tych badań $\mathrm{i}$ ich szeroki zakres tematyczny sprawia, że pozostają w kręgu zainteresowań geografów, ekonomistów, socjologów, urbanistów i architektów, planistów, przedstawicieli nauk politycznych i prawnych, historyków, a także antropologów społecznych i psychologów środowiskowych (Jewdokimow 2011).

Według D. Claphama (2002), jednego z głównych teoretyków tej dziedziny, cztery najważniejsze obszary badawcze studiów mieszkaniowych (housing studies) to opis i analiza polityki mieszkaniowej państwa, badanie aspektów ekonomicznych mieszkalnictwa, analiza geograficzna zmierzająca do wyjaśnienia czynników wpływających na przestrzenną dystrybucję mieszkań (w tym także decyzje mieszkaniowe gospodarstw domowych, procesy mobilności itp.) oraz analiza nierówności w dostępie do zasobów mieszkaniowych ${ }^{12}$. Współcześnie, według geografów A. Blunt i R. Dowlinga (2006), studia mieszkaniowe oprócz wymienionych obejmują także stosunkowo nową dziedzinę badań związanych z doświadczaniem oraz odkrywaniem sensu i znaczenia domu (mieszkania), określaną jako "geografia domu" (home geography), która - jak twierdzą ci autorzy - obecnie staje się coraz

$12 \mathrm{~W}$ powojennej Polsce instytucjonalną ramę badań nad mieszkalnictwem tworzyły: Instytut Budownictwa Mieszkaniowego, od 1968 r. Instytut Gospodarki Mieszkaniowej, a po 1990 r. Zakład Mieszkalnictwa Instytutu Rozwoju Miast (Cesarski 2007). Jak podaje ten autor, prace badawcze realizowane $\mathrm{w}$ ramach tych instytucji obejmowały głównie analizy dotyczące zmian warunków mieszkaniowych ludności oraz poziomu zaspokajania potrzeb mieszkaniowych w kontekście sytuacji demograficznej kraju i prowadzone były głównie w oparciu o wyniki kolejnych spisów ludności i mieszkań, a po 1990 roku także o badania reprezentacyjne (ibid.). Do autorów, którzy w największym stopniu przyczynili się do rozwoju badań nad mieszkalnictwem w powojennej Polsce należą m.in. A. Andrzejewski, W. Czeczerda, J. Goryński, W. Lieterer-Merwege oraz W. Nieciuński (ibid.). 
ważniejszym obszarem badawczym. Obecność w ramach housing studies nowych nurtów badań związanych $\mathrm{z}$ podejściem humanistycznym nie zmienia jednak faktu, że w ich obrębie wciąż dominuje paradygmat pozytywistyczny, korzeniami sięgający badań warunków mieszkaniowych prowadzonych na przełomie XIX i XX wieku w miastach przemysłowych Europy i USA ${ }^{13}$ oraz wyrosłej z nich tradycji szkoły chicagowskiej (Clapham 2002, Jewdokimow 2011). Mimo szerokiego i stale rozszerzającego się zakresu przedmiotowego studiów mieszkaniowych nie wyczerpują one całego spektrum badań nad mieszkalnictwem prowadzonych $\mathrm{w}$ poszczególnych dyscyplinach naukowych. Niektóre z nich wyodrębniły nawet własne subdyscypliny związane $\mathrm{z}$ badaniami mieszkaniowymi (np. socjologia, w ramach której istnieje subdyscyplina określana socjologią mieszkalnictwa - por. E. Kaltenberg-Kwiatkowska 1982) ${ }^{14}$.

We współczesnej geografii polskiej studia nad mieszkalnictwem nie stanowią odrębnej subdyscypliny badawczej, lecz mieszczą się w różnych jej subdyscyplinach $\mathrm{w}$ zależności od zakresu przedmiotowego, jakiego dotyczą i przyjmowanych założeń teoretyczno-metodologicznych. Studia z zakresu mieszkalnictwa $\mathrm{w}$ miastach tradycyjnie prowadzone były $\mathrm{w}$ postaci badań zagospodarowania i użytkowania przestrzeni w ramach geografii osadnictwa i geografii ludności (por. Liszewski 2008b, s. 172), a współcześnie prowadzone są $\mathrm{w}$ ramach geografii społecznej miast - subdyscypliny lokującej się na pograniczu geografii miast i geografii społecznej. Studia te, poza nielicznymi (np. Dzieciuchowicz i in. 1972, Suliborski 1976, Dziewoński 1990, Kaczmarek 1996, Kotus 2006, 2007, Dzieciuchowicz 2011, Groeger 2013), w większości mają charakter empiryczny i na ogól nie obejmują wątków teoretycznych, ponieważ - jak podaje A. Lisowski (2008, s. 202-204) - poja-

${ }^{13}$ Badania te w początkowym okresie stanowiły jeden z aspektów badań warunków życia w miastach, ale ponieważ koncentrowały się na najuboższych grupach ludności (głównie robotnikach i imigrantach), a ich wyniki rozważano w perspektywie czynników przyczyniających się do integracji bądź dezintegracji społecznej, stały się „matrycą politycznego myślenia o zamieszkiwaniu" (Jewdokimow 2011, s. 18) Także współcześnie, jak podaje ten autor na podstawie przeglądu prac zamieszczonych $\mathrm{w}$ dwóch głównych periodykach reprezentujących ten nurt badawczy („Housing Studies” oraz „Housing Theory and Society”), badania nad mieszkalnictwem „nie są wolne od uwikłania w politykę społeczną", ponieważ poruszana w nich problematyka podporządkowana bywa bieżącym problemom (ibid., s. 16).

${ }_{14}$ W ramach socjologii mieszkalnictwa E. Kaltenberg-Kwiatkowska (1982, s. 30-37) wyróżnia pięć podstawowych obszarów badawczych. Pierwszy z nich to potrzeby mieszkaniowe oraz poziom i sposób ich zaspokojenia, drugi to badania dostępu do mieszkań, trzeci obejmuje ich społeczno-przestrzenne zróżnicowanie, czwarty to badania wpływu różnych rozwiązań architektoniczno-urbanistycznych na życie mieszkańców oraz ich zadowolenie z zagospodarowania i wyposażenia osiedli, piąty natomiast, nazywany przez tę autorkę "socjologia mieszkania", obejmuje wzory użytkowania mieszkań. 
wiły się i wciąż funkcjonują jako próba weryfikacji efektów działań w zagospodarowaniu przestrzeni ${ }^{15}$. Znacznie większy dorobek teoretyczny mają natomiast geografowie $\mathrm{w}$ dziedzinie badań warunków życia (ujmowanych niekiedy jako poziom życia lub jakość życia), w ramach których potrzeby mieszkaniowe i poziom ich zaspokojenia (w postaci warunków mieszkaniowych i bytowych) traktowane są jako jedna $z$ ważnych składowych szeroko rozumianych potrzeb społecznych (obok potrzeb w zakresie bezpieczeństwa, zdrowia, pracy i wypoczynku oraz innych). Teoretyczno-metodologicznymi aspektami badań warunków życia i rolą geografii w tych badaniach najszerzej zajmowali się S. Liszewski $(1988,1995,2004)$ oraz A. Zborowski (2004) ${ }^{16}$. Definiowanie pojęcia warunków mieszkaniowych na gruncie geografii i określenie zakresu ich badań w tej dyscyplinie było natomiast przedmiotem współautorskiego studium J. Dzieciuchowicza, B. Stolarczyka i A. Suliborskiego (1972). W ujęciu tym warunki mieszkaniowe, czyli wielkość, stan, wyposażenie i zaludnienie substancji mieszkaniowej, dzielą się na tzw. warunki wewnętrzne oraz zewnętrzne. Wewnętrzne obejmują zużycie, wyposażenie, wielkość i zaludnienie zabudowy mieszkaniowej, zaś zewnętrzne gęstość zaludnienia, koncentrację zabudowy mieszkaniowej oraz skupienie usług (ibid.). Blisko ćwierć wieku później S. Kaczmarek (1996) w ramach badań tej sfery warunków życia człowieka w mieście wyodrębniła pojęcie warunków zamieszkania, na które składają się kolejno: standard mieszkania, standard budynku, w którym mieszkanie się znajduje oraz standard otoczenia, w którym usytuowany jest budynek (ibid., s. 9). Do analizy przestrzennego zróżnicowania tak rozumianych warunków zamieszkania autorka wprowadziła element percepcji i subiektywnego ich wartościowania przez mieszkańców.

Specyfika geografii sprawia, że ważną kategorią badawczą w tej dziedzinie jest - w zależności od ujęcia - środowisko mieszkaniowe lub przestrzeń mieszkaniowa. Pojęcia te, definiowane także na gruncie architektury, urbanistyki i socjologii17, w polskiej literaturze geograficznej po raz pierwszy zdefiniowane zostały przez A. Suliborskiego (1976), a następnie J. Dzieciuchowicza (2011) oraz L. Groeger (2013). Środowisko mieszkaniowe, zgod-

${ }^{15}$ Mimo że geografia społeczna odeszła od tradycyjnego determinizmu środowiskowego, jak podaje A. Lisowski (2008), w geografii „wyjaśnianie różnic w sytuacji społecznej częściej odwołuje się do [...] zewnętrznych przeszkód i ułatwień w działaniach na danym terytorium niż istniejących oddziaływań społecznych, czyli relacji ekonomicznych, politycznych i kulturowych" oraz że "podejście takie jest zrozumiałe, ponieważ nawiązuje do istotnego znaczenia samego podłoża terytorialnego dla wyjaśniania różnic $\mathrm{w}$ atrybutach i działaniach jednostek i zbiorowości terytorialnych, co wynika z tradycji badań geograficznych" (ibid. s. 202-204).

${ }_{16}$ Do prac zbiorowych dotyczących badań warunków życia w miastach na gruncie geografii należą prace pod red. T. Czyż (1991) oraz I. Jażdżewskiej (2004).

${ }^{17}$ Por. G. Schneider-Skalska (2004), I. Borowik (2003). 
nie z definicją A. Suliborskiego (1976), to zbiór miejsc zamieszkania zidentyfikowany za pomocą zbioru istotnych dla człowieka elementów społeczo-ekonomiczno-przyrodniczych oraz relacji zachodzących pomiędzy nimi. Środowisko mieszkaniowe według tego autora - jak wspomniano w rozdziale 1.3 - tworzą cztery strefy będące częściami przestrzeni miejskiej: mieszkanie, budynek, nieruchomość stanowiąca bezpośrednie otoczenie budynku oraz obszar położony poza granicami nieruchomości, z którym człowiek pozostaje $\mathrm{w}$ bezpośrednim kontakcie, a jego granice są płynne w zależności od rodzaju zabudowy oraz aktywności mieszkańców. Strefy te tworzą dwie różne pod względem jakościowym i funkcjonalnym podprzestrzenie, nazwane wewnętrznym i zewnętrznym środowiskiem mieszkaniowym. Znacznie szerszej pojęcie to definiuje natomiast J. Dzieciuchowicz (2011, s. 13), według którego środowisko mieszkaniowe to "tereny i zabudowa mieszkaniowa wraz z towarzyszącą im infrastrukturą społeczną i techniczną oraz budownictwo mieszkaniowe i gospodarka mieszkaniowa, a także użytkownicy lokali mieszkalnych określonych jednostek terytorialnych". Relacją pomiędzy przestrzenią mieszkaniową a środowiskiem mieszkaniowym oraz miejscem zamieszkania zajmowała się także L. Groeger, według której (2013, s. 51) środowisko mieszkaniowe jest pojęciem szerszym niż przestrzeń mieszkaniowa i stanowi część przestrzeni geograficznej pełniącą realnie lub potencjalnie funkcje mieszkaniowe, zagospodarowaną na cele mieszkaniowe, postrzeganą i wartościowaną przez ludność jako miejsce zamieszkania.

Współcześnie, po 2000 roku, do głównych zagadnień badawczych realizowanych $\mathrm{w}$ geografii polskiej $\mathrm{w}$ ramach studiów nad mieszkalnictwem w miastach należą:

- analiza zasobów mieszkaniowych w miastach - ich rozwój, rozmieszczenie przestrzenne, wielkość, stan oraz struktura (Dzieciuchowicz 2002, 2005, 2011, Ilnicki 2001, 2003, 2006, Masica, Milewska 2003, Marszał, red. 2003, Marszal, Stawasz 2006, Milewska, Ogrodowczyk 2006, Miszewska 2000, 2001, 2006, Milewska-Osiecka 2010, Groeger 2013, Stępniak 2014);

- badania warunków zamieszkania (warunków mieszkaniowych) w miastach - ich poziom, zróżnicowanie przestrzenne i ocena (Marcińczak 2004);

- badania warunków życia $\mathrm{w}$ miastach $\mathrm{w}$ powiązaniu z warunkami mieszkaniowymi (warunkami zamieszkania) (Parysek 2004, Śleszyński 2004b, Winiarczyk-Raźniak 2004, Szmytkowska 2004, Lisowski 2004, Marcińczak 2006, Liszewski 2004, 2009);

- badania percepcji i waloryzacji przestrzeni mieszkaniowej (Groeger 2004, 2013, Jaroszewska-Brudnicka 2004, Szkurłat 2004, Marcińczak 
2004, 2007, Rydz, Szymańska 2007, Górczyńska 2008, Radwańska 2007, Szafrańska 2009, Janiszewska i in. 2010, 2011);

- badania struktur społeczno-przestrzennych miast i procesów kształtujących te struktury, które analizowane są w powiązaniu ze strukturą rezydencjalną miasta (Jaroszewska-Brudnicka 2004, Zborowski 2005, Szmytkowska 2004, 2008, Jadach-Sepioło 2009, Marcińczak 2009, 2013, Jakóbczyk-Gryszkiewicz, red. 2012, 2013, Jakóbczyk-Gryszkiewicz 2013, Górczyńska 2014);

- badania relacji pomiedzy popytem i podażą na rynku mieszkaniowym w miastach (Śleszyński 2004a, 2005, 2007);

- inne badania, głównie o charakterze jakościowym, jak geografia domu (Klima 2012, 2013), krajobraz mieszkaniowy jako element krajobrazu kulturowego miasta (Czepczyński 2006).

Osobną grupę badań w geografii społecznej miast, które mają pośredni związek z mieszkalnictwem stanowią studia dotyczące różnych aspektów życia miejskiego, gdzie cechy zamieszkiwanego obszaru wyodrębnione przez rodzaj zabudowy mieszkaniowej przyjmowane są jako grupa zmiennych niezależnych, wyjaśniających różne zjawiska o charakterze społecznym (społeczno-przestrzennym). Do takich badań należą np. studia nad typami i rodzajami sąsiedztwa w różnych typach zabudowy miejskiej (Kotus 2007), studia nad przestępczością w przestrzeni miejskiej (Guzik 2000a, b, Mordwa 2013), badania więzi z miejscem zamieszkania w zależności od układu zabudowy (Fuhrmann 2009a, b), badania poziomu kapitału ludzkiego i społecznego $\mathrm{w}$ mieście $\mathrm{w}$ powiązaniu $\mathrm{z}$ jego strukturą rezydencjalną (Szafrańska 2008).

Wymienione prace dotyczą różnych skal przestrzennych, od skali jednego osiedla mieszkaniowego aż do skali krajowej, ale głównie obejmują skalę pojedynczego miasta. Odwołują się one najczęściej, podobnie jak większość prac z zakresu interdyscyplinarnych housing studies, do neopozytywistycznego (scjentystycznego) i behawioralnego wzorca wyjaśniania, sporadycznie sięgając do orientacji humanistycznych. Klasyczne podejście humanistyczne stosowane jest w geografii mieszkalnictwa właściwie tylko w obrębie nurtu badawczego określanego jako geografia domu. Badania percepcji i waloryzacji, które co prawda korzystają z podejść humanistycznych, a według A. Lisowskiego (2008, s. 204) integrują podejścia humanistyczne i behawioralne, najczęściej mieszczą się w nurcie geografii człowieka, stosując podejścia behawioralne i neobehawioralne. 


\subsection{Wielkie osiedle mieszkaniowe jako forma urbanistyczna i społeczna}

Badanie wielkich osiedli mieszkaniowych wymaga ich zdefiniowania. Punktem wyjścia do definiowania wielkiego osiedla mieszkaniowego jest definicja osiedla, które jako pojęcie urbanistyczne i potoczne zarazem ma wiele znaczeń18 ${ }^{18}$ Różni badacze przypisują osiedlu różne treści i wartości (Węcławowicz 2007, s. 189). Może być ono „zarówno pojęciem opisowym, kategorią przestrzenną i społeczną, jak i ideologiczną zwierającą explicite określony model organizacji życia społecznego" (Jałowiecki, Szczepański 2006, s. 388). Wiele definicji osiedla zawiera postulaty dotyczące sposobu jego organizacji, w tym organizacji życia społecznego, które nie mają jednak odzwierciedlenia $\mathrm{w}$ rzeczywistości i są $\mathrm{w}$ istocie pewnymi typami idealnymi - niezrealizowanymi bądź niedającymi się zrealizować postulatami urbanistycznymi jak np. koncepcja jednostki sąsiedzkiej C.A. Perry'ego (1939) ${ }^{19}$, czy też osiedle społeczne B. Brukalskiej (1948) ${ }^{20}$. Obie te idee traktowały osiedle jako obszar nawiązywania licznych i intensywnych kontaktów społecznych, które prowadzą do silnych więzi pomiędzy mieszkańcami, a zatem jako twór urbanistyczny i społeczny zarazem, co nie znajduje odzwierciedlenia w podejściach współczesnych.

Współcześnie w urbanistyce - jak podaje Leksykon architektoniczno-budowlany (Skowroński 2008, s. 84) - osiedle definiuje się jako "gęsto zabudowane tereny mieszkalne $\mathrm{w}$ mieście stanowiące zgrupowanie budynków wielorodzinnych wraz ze związanymi z obsługą mieszkańców obiektami usługowymi oraz terenami zielonymi". Definicja ta wprost nawiązuje do używanego w polskim planowaniu urbanistycznym od 1974 roku $^{21}$, toż-

18 W niniejszym opracowaniu rozumienie pojęcia „osiedle” ograniczone zostało do jednostki struktury przestrzennej miasta i dotyczy zabudowy wielorodzinnej (pomijając tym samym znacznie szersze znaczenie tego pojęcia wykraczające poza zakres pracy, występujące w osadnictwie i w urbanistyce, gdzie osiedlem jest każde zgrupowanie domów mieszkalnych, np. osiedle domów jednorodzinnych, osiedle podmiejskie, osiedle wiejskie) - por. D. Sokołowski (1999).

19 Koncepcja jednostki sąsiedzkiej (neighbourhood unit) sformułowana przez C.A. Perry'ego w 1923 r. po raz pierwszy została opublikowana w 1929 r., jednak pełnego zdefiniowania i określenia doczekała się dopiero w 1939 r. w pracy pt. Housing for the machine age (Perry 1939).

${ }^{20}$ Koncepcje te zostały szerzej omówione $\mathrm{w}$ rozdziale 3 niniejszej pracy.

${ }^{21}$ Jak podaje G. Wojtkun (2008 s. 186), w normatywie urbanistycznym wprowadzonym w Polsce w 1974 r. po raz pierwszy od zakończenia II wojny światowej usankcjonowano klasyfikację urbanistyczną zespołów zabudowy mieszkaniowej, a także ich znaczenie w skali miasta, „starając się w ten sposób powstrzymać postępujący w poprzednich dziesięcioleciach proces atomizacji miasta polegający na powstawaniu luźnych konglomeratów niezależnych osiedli". Jednocześnie zrezygnowano wówczas z podziału na ośmio- i dziesięciotysięczne modelo- 
samego z pojęciem „osiedle” określenia „strukturalna jednostka mieszkaniowa" (SJM), którą tworzy wydzielony pod względem funkcjonalnym i przestrzennym układ wielorodzinnej zabudowy mieszkaniowej wraz z odpowiadającym jej programem podstawowych urządzeń usług, wypoczynku i komunikacji rozmieszczonych w zasięgu dojścia pieszego do 500 metrów (por. Czarnecki 2002, s. 38, Wojtkun 2008, s. 186). Zdefiniowane w ten sposób sąsiadujące ze sobą strukturalne jednostki mieszkaniowe (SJM) miały tworzyć zespoły (ZSJM) równoważne dzielnicy mieszkaniowej (ibid.).

W literaturze spoza kręgu urbanistyki osiedle definiowane jest bardzo ogólnie i niejednoznacznie. Jak podają B. Jałowiecki i M. Szczepański (2006): "osiedle to zespół mieszkaniowy nieokreślonej wielkości od kilku do kilkudziesięciu tysięcy mieszkańców, składający się z luźno stojących domów wielorodzinnych oddzielonych od siebie pustymi przestrzeniami" (ibid., s. 387), przy czym dalej w tej samej pracy czytamy, że jest to „przestrzeń kameralna na ogół dość wyraźnie ograniczona, w której na skutek niewielkiej liczby mieszkańców nawiązują się dość liczne kontakty społeczne" (ibid., s. 389), co potwierdza niejednoznaczność tego pojęcia.

Wyprowadzone wprost z pojęcia osiedla zasadnicze dla niniejszej pracy określenie „wielkie osiedle mieszkaniowe” w literaturze przedmiotu także ma różne definicje i używane jest zamiennie $\mathrm{z}$ wieloma innymi terminami (tab. 2). Warto jednak dodać, że większość autorów nie definiuje tego pojęcia, przyjmując zapewne milczące założenie, że jego desygnaty przestrzenne jako powszechnie znane nie wymagają uprzedniego zdefiniowania.

Przyjęte na użytek niniejszej pracy pojęcie wielkich osiedli mieszkaniowych jest odpowiednikiem występujących w literaturze anglojęzycznej terminów large housing estates oraz large scale housing estates (Power 1997, s. 20), jak i niemieckojęzycznego Großsiedlung (Knorr-Siedow 1996). W literaturze polskiej wielkie osiedla mieszkaniowe najczęściej definiuje się zgodnie z definicją sformułowaną na użytek paneuropejskiego programu RESTATE (Restructuring Large Housing Estates in European Cities)22 jako wyodrębnione przestrzennie grupy budynków liczące ponad 2 tys. mieszkań powstałe w II połowie XX wieku, budowane przez państwo lub z udziałem państwa. Definicja ta odnosi się wprost do definicji brytyjskiej badaczki A. Power i używana jest $\mathrm{w}$ wielu krajach europejskich (por. Wassenberg 2013). Ta sama definicja funkcjonuje także $\mathrm{w}$ wersji nieco zmodyfikowanej, gdzie jako kryterium wyodrębniania wielkich osiedli przyjmuje się liczbę mieszkań

we jednostki mieszkaniowe, a liczbę mieszkańców w osiedlach oparto na wskaźnikach intensywności zabudowy.

22 Program RESTATE zrealizowany w 2005 r. obejmował badania 29 wielkich osiedli mieszkaniowych zlokalizowanych w 10 krajach europejskich: Polska, Niemcy, Słowenia, Węgry, Francja, Hiszpania, Holandia, Wielka Brytania, Szwecja i Włochy. 
wynoszącą co najmniej 2,5 tys. oraz użycie w ich budowie prefabrykowanych technologii (Knorr-Siedow 1996, 1997). Niektórzy autorzy na użytek badań zawężają tę definicję do osiedli liczących co najmniej 6 tys. mieszkań i usytuowanych w budynkach liczących co najmniej pięć kondygnacji (por. Wiest 2011, Kovács, Herfert 2012). Modyfikacją terminu large housing estates jest termin high-rise housing estates, zastosowany przez R. Turkingtona, F. Wassenberga i R. van Kempena (red. 2004), który oprócz innych wymienionych wcześniej cech definiujących osiedla także odnosi się do wysokości ich zabudowy, liczącej co najmniej pięć kondygnacji.

Tab. 2. Pojęcia określające wielkie osiedla mieszkaniowe o zabudowie blokowej używane w literaturze polskiej

\begin{tabular}{|c|c|}
\hline Określenie & Autor i rok wydania pracy \\
\hline Wielkie osiedla mieszkaniowe & $\begin{array}{l}\text { G. Węcławowicz (2003, 2007), G. Rembarz (2005), } \\
\text { A. Zborowski (2005), M. Fuhrmann (2008), K. Gorczyca } \\
\text { (2009), S. Rzyski, K. Mędrzycka (2010), E. Szafrańska (2010, } \\
\text { 2012), A. Warchalska-Troll (2012) }\end{array}$ \\
\hline Wielkie zespoły mieszkaniowe & $\begin{array}{l}\text { W. Misiak (1988), B. Jałowiecki (1994, 1995, 2010), I. Sagan } \\
\text { (1997), L. Coudroy de Lille (2000), I. Borowik (2003), } \\
\text { B. Jałowiecki, M.S. Szczepański (2006) }\end{array}$ \\
\hline Blokowiska & $\begin{array}{l}\text { M.S. Szczepański (1991), B. Jałowiecki (1991), A. Basista } \\
\text { (1999), W. Gaczek, Z. Rykiel (1999), Z. Rykiel (1999), } \\
\text { K. Rębowska (2000), M. Motak (2003), I. Borowik (2003, } \\
\text { 2007), A. Rębowska i in. (2006), E. Szafrańska (2009), } \\
\text { B. Miszewska, D. Sikorski (2010), L. Coudroy de Lille } \\
\text { (2000, 2010), M. Niezabitowski (2010), A. Janiszewska i in. } \\
\text { (2010), J. Trybuś (2011), G. Wojtkun (2012a) }\end{array}$ \\
\hline Osiedla blokowe ${ }^{a}$ & $\begin{array}{l}\text { M. Czepczyński (1999), S. Liszewski (2001b), I. Jażdżewska } \\
\text { (red. 2010), M. Radwańska (2010), S. Rzyski, K. Mędrzycka } \\
\text { (2010), J. Słodczyk (2010), W. Szymańska (2010) }\end{array}$ \\
\hline $\begin{array}{l}\text { Powojenne wielorodzinne } \\
\text { zespoły mieszkaniowe }\end{array}$ & J. Dzieciuchowicz (2002) \\
\hline $\begin{array}{l}\text { Osiedla wielkoblokowe, wielko- } \\
\text { blokowe osiedla mieszkaniowe }\end{array}$ & I. Sagan (2000a), K. Pawłowska (1996) \\
\hline $\begin{array}{l}\text { Wielkoblokowe zespoły } \\
\text { mieszkaniowe }\end{array}$ & A. Rębowska (1999) \\
\hline $\begin{array}{l}\text { Zespoły mieszkaniowe z wiel- } \\
\text { kiej płyty, osiedla z wielkiej } \\
\text { płyty }\end{array}$ & B. Gronostajska (2010a, 2010b) \\
\hline Osiedla wielkopłytowe & G. Rembarz (2010) \\
\hline
\end{tabular}

a Określenie osiedli blokowych może obejmować też osiedla małe i być szersze w stosunku do pojęcia wielkich osiedli, toteż $\mathrm{w}$ tabeli przywołano tylko te prace, których autorzy piszą o wielkich osiedlach mieszkaniowych.

Źródło: opracowanie własne. 
Innym pojęciem często używanym zamiennie $\mathrm{z}$ określeniem wielkich osiedli jest termin „wielkie zespoły mieszkaniowe”, który z kolei pochodzi z Francji (les grand ensembles d'habitation), gdzie po raz pierwszy użyty został w 1935 roku (Coudroy de Lille 2000). Jak podaje autorka, do końca lat 50. $\mathrm{XX} \mathrm{w}$. grand ensembles były $\mathrm{w}$ istocie niewielkimi zespołami liczącymi do 1500 mieszkań w budynkach czteropiętrowych, a dopiero w późniejszym okresie przybrały formę znaną współcześnie z wielu postsocjalistycznych miast europejskich.

W polskiej literaturze naukowej wielkie zespoły mieszkaniowe definiowane były także na gruncie socjologii. Do najbardziej ogólnych i pojemnych znaczeniowo definicji wielkich zespołów mieszkaniowych należy definicja W. Misiaka (1988, s. 125), według którego są to „kompleksowo zaprojektowane obszary miejskie na wyznaczonej przestrzeni miast, w których dominują funkcje mieszkaniowe nad innymi, a budownictwo blokowe wykonane jest najczęściej technologiami przemysłowymi". Do bardziej szczegółowych i bliżej charakteryzujących tę formę urbanistyczną należy definicja B. Jałowieckiego (1980, s. 77), który przyjmuje, że wielkie zespoły mieszkaniowe to „zgrupowania dużych bloków mieszkalnych, lepiej lub gorzej wyposażonych $\mathrm{w}$ podstawowe jedynie usługi, pozbawione $\mathrm{w}$ zasadzie miejsc pracy, strukturalnie słabo powiązane $\mathrm{z}$ dotychczasowym obszarem ścisłego zainwestowania miejskiego i pełniące głównie sypialne funkcje". W literaturze powstałej w okresie późniejszym, po 1990 roku, można spotkać definicje wielkich zespołów mieszkaniowych formułowane w oparciu o charakterystykę tego obszaru z okresu ich budowy, które nie uwzględniają dokonujących się w nich przemian i mają charakter wartościujący. Do takich definicji należy np. definicja I. Borowik (2003, s. 83), według której „wielki zespół mieszkaniowy to monofunkcyjna przestrzeń miasta, zabudowana wykonanymi w technologii przemysłowej budynkami mieszkalnymi, tworzącymi wielkoskalowe urbanistycznie i demograficznie środowisko mieszkaniowe o ubogim programie infrastrukturalnym i społecznym, szczątkowej zieleni i nijakim wyrazie estetycznym". W bardziej radykalnych stwierdzeniach wielkie zespoły mieszkaniowe to obszary, które „nie zawierają żadnych treści społecznych, powodują rozpad miasta i powstawanie bezpostaciowych przestrzeni zurbanizowanych, które są dla ich mieszkańców obce i słabo przyswojone" (Jałowiecki, Szczepański 2006, s. 389).

Innym często używanym określeniem omawianej formy zabudowy jest „blokowisko". Termin ten nie ma definicji w literaturze naukowej, lecz jest w niej bardzo rozpowszechniony głównie na skutek funkcjonowania w świadomości potocznej i dyskursie publicznym oraz medialnym. Współcześnie wśród autorów polskich pojęcie blokowisko używa się często zamiennie z określeniem wielkich osiedli mieszkaniowych i wielkich zespołów mieszkaniowych, nie rozróżniając w żaden sposób tych terminów (por. Borowik 
2003, 2007, Gaczek, Rykiel 1999, Rykiel 1999). Negatywna konotacja tego pojęcia sprawia, że częściej bywa używane w pracach, które krytycznie odnoszą się do tej formy zabudowy we współczesnych miastach. Według G. Węcławowicza (2007) określenie blokowisko wskazuje na „klęskę pierwotnych koncepcji związanych z ideą osiedla, która zarówno w swojej treści społecznej, jak i formie architektonicznej miała stanowić postęp w stosunku do organizacji przestrzennej zamieszkiwania $\mathrm{w}$ mieście wczesnoprzemysłowym" (ibid., s. 192).

W literaturze z dziedziny architektury wielkie osiedla często określane są poprzez technologię ich budowy jako "osiedla z wielkiej płyty" (Gronostajska 2010a, b), czy też "osiedla wielkopłytowe" (Rembarz 2010). W tym jednak przypadku osiedla, które rozbudowywane były przez dziesięciolecia i w związku z tym wykonane zostały w różnej technologii (np. Nowa Huta w Krakowie, w której najstarsze bloki z lat 50. wybudowano z materiałów tradycyjnych oraz stosując zabudowę obrzeżną) tylko w części swego obszaru spełniają te kryteria.

W niektórych krajach europejskich (np. Francja, Niemcy) definicja wielkiego osiedla mieszkaniowego stanowi odrębną kategorię prawną, wprowadzoną $\mathrm{w}$ celu ułatwienia realizacji specjalnej polityki przestrzennej nastawionej na transformację tych obszarów, aby nie dopuścić do powstania w nich (lub pogłębiania się) negatywnych zjawisk (tzw. syndromu wielkiego osiedla lub spirali upadku). W zachodnich landach Niemiec przed rokiem 1994 do kategorii prawnej Großsiedlung, czyli wielkie osiedle, ustawowo zaliczano powojenne struktury mieszkaniowe liczące powyżej 500 mieszkań. Obecnie, od czasu reunifikacji, kategoria ta obejmuje osiedla liczące minimum 2,5 tys. mieszkań, uznając dotychczasową definicję za odrębną kategorię, tzw. małych wielkich osiedli. We Francji natomiast status Grand Ensemble przysługuje obszarom mieszkaniowym powyżej 2 tys. mieszkań w obrębie Wielkiego Paryża i powyżej 1 tys. mieszkań na prowincji (Rembarz 2010). W większości jednak krajów europejskich ta forma zabudowy nie ma jednej ogólnie przyjętej definicji, co bardzo utrudnia szacunki dotyczące jej rzeczywistej skali oraz relacji do ogółu zasobów mieszkaniowych w miastach.

Nie rozstrzygając $\mathrm{w}$ tym miejscu, czy bardziej precyzyjny i lepiej oddający istotę rzeczy jest termin "wielkie osiedle”, „wielki zespół” czy „blokowisko", na podstawie przeglądu dostępnej literatury, na użytek niniejszej pracy przyjęto pojęcie wielkich osiedli mieszkaniowych, które następnie zdefiniowano z uwzględnieniem specyfiki miast, które w latach 1945-1989 funkcjonowały $\mathrm{w}$ warunkach realnego socjalizmu. W definicji tej przyjęto, że wielkie osiedla mieszkaniowe to wyodrębnione przestrzennie obszary zunifikowanej zabudowy wielorodzinnej wykonanej w prefabrykowanej technologii, liczące ponad 5 tys. mieszkań, powstałe w II połowie XX wieku, 
których budowa finansowana była ze środków publicznych. Przyjęcie jako kryterium liczby 5 tys. mieszkań wynika ze specyfiki krajów Europy Środkowo-Wschodniej, w których wiele osiedli znacznie przekracza przyjmowaną dotychczas $\mathrm{w}$ badaniach paneuropejskich skalę 2,5 tys. (por. Węcławowicz 2003).

Jako zasadnicze dystynkcje wielkich osiedli mieszkaniowych przyjęto zatem:

- wielką skalę;

- jednorodność zabudowy i technologie jej wykonania;

- wyraźne wydzielenie przestrzenne;

- okres budowy;

- publiczne źródło finansowania.

Przyjęcie takiej definicji oznacza, że poza obszarem zainteresowań niniejszej pracy znalazły się, znane $\mathrm{z}$ wielu miast, relatywnie niewielkie osiedla mieszkaniowe oraz zespoły bloków wkomponowane w inną zabudowę mieszkaniową, a niekiedy $\mathrm{z}$ tą zabudową przemieszane. Osiedla te bowiem, mimo że podobne $\mathrm{w}$ fizjonomii do osiedli wielkich, to ze względu na niedużą skalę i/lub brak wyraźnego wydzielenia przestrzennego, wymagają odmiennego traktowania, ponieważ nie podzielają wielu problemów specyficznych dla wielkich osiedli wynikających z ich ogromnej skali, monotonii i monofukcyjności. Ważnym kryterium definicyjnym jest również okres powstawania omawianych osiedli, ponieważ ich socjalistyczna proweniencja sprawia, że stanowią one twór specyficzny nie tylko przestrzennie, ale także społecznie poprzez heterogeniczną, silnie zróżnicowaną statusowo strukturę mieszkańców, która była wynikiem sposobu ich zasiedlania. Tym samym poza zakresem pracy znalazły się nie tylko modernistyczne osiedla przedwojenne, lecz również nowe osiedla powstałe po 1990 roku (tzw. deweloperskie), które we współczesnych miastach postsocjalistycznych ze względu na strukturę przestrzenną i skalę zaczynają przybierać formę urbanistyczną zbliżoną do wielkich osiedli z okresu socjalizmu, lecz są zupełnie inne ze względu na sposób zasiedlania i skład społeczny mieszkańców.

\subsection{Podejścia teoretyczne $w$ badaniach osiedli mieszkaniowych}

Podejścia teoretyczne $\mathrm{w}$ badaniach osiedli mieszkaniowych $\mathrm{w}$ literaturze geograficznej ewoluowały wraz $\mathrm{z}$ rozwojem tej nauki. W tradycyjnej geografii miast w badaniach o charakterze krajobrazowym i użytkowania ziemi osiedle mieszkaniowe traktowano jako jedną z jednostek strukturalnych 
charakteryzujących miasto, obok takich jednostek, jak parki i tereny zielone, tereny produkcyjne, tereny usługowe (Węcławowicz 2007, s. 189). Osiedla mieszkaniowe $\mathrm{w}$ tym ujęciu były częścią terenów zurbanizowanych pełniących funkcje mieszkaniowe.

Od lat 70. XX wieku badania osiedli mieszkaniowych jako wydzielonej przestrzennie i społecznie jednostki analitycznej związane są najczęściej z nurtem badań wewnątrzmiejskich dotyczących analiz i wyjaśnień struktury przestrzennej całego miasta. Zmiana ta, jak podaje G. Węcławowicz (2007), wiązała się ze stopniowym „wchodzeniem” w ostatnich dekadach XX wieku geografii miast w skalę wewnątrzmiejską i zwracaniem coraz większej uwagi na poszczególne składniki struktury miasta. Źródłem inspiracji w tym podejściu stał się dorobek klasycznej szkoły chicagowskiej (klasycznej ekologii społecznej) R. Parka, E. Burgessa i R. Mc Kenzie'ego (1925) oraz wypracowanych w jej ramach koncepcji obszarów naturalnych. Jej twórczym rozwinięciem była analiza obszarów społecznych E. Shevky'ego, W. Bella i M. Williamsa $(1949,1955)$ oraz nurty neoekologiczne, a w późniejszym okresie także ekologia czynnikowa. $W$ ujęciach tych, jak już powiedziano, przestrzeń rezydencjalna miasta jest przedmiotem rywalizacji zamieszkujących je grup ludzkich, a jej kształt jest wynikiem w klasycznej ekologii społecznej - procesów koncentracji, centralizacji, segregacji, inwazji i sukcesji, a w analizie obszarów społecznych - zmian w podziale pracy, $\mathrm{w}$ funkcjonowaniu gospodarstw domowych oraz rozmieszczeniu ludności. Efektem tych procesów jest struktura społeczno-przestrzenna miasta (struktura rezydencjalna), a poszczególne osiedla mieszkaniowe rozpatrywane są jako elementy tak rozumianej struktury lub jako jedna z jej stref i zajmują w niej określone pozycje.

Nieco inaczej zagadnienie to ujmowane jest w należącej do orientacji strukturalistycznych marksistowskiej perspektywie teoretycznej, określanej też jako radykalna, która wywarła duży wpływ na geografię miast w latach 70. i 80. minionego wieku. W podejściu tym osiedla mieszkaniowe, podobnie jak cała sfera mieszkalnictwa w miastach, rozpatrywane były jako obszar reprodukcji siły roboczej i stosunków produkcji zgodnie z interesem ekonomicznym kapitalizmu (por. Harvey 1973, Castells 1977). Głównym założeniem orientacji radykalnej było wyjaśnianie zróżnicowań społeczno-przestrzennych w miastach za pomocą analizy ograniczeń politycznych i ekonomicznych, jakie nakładane są na działalność człowieka w mieście, a tezą wyjaśniającą twierdzenie, że wszelkie działania człowieka, w tym także te, które prowadzą do zróżnicowań mieszkaniowych w miastach, podporządkowane są logice kapitalizmu i przyczyniają się do stabilizacji tego systemu poprzez stałe odtwarzanie (reprodukcję) nierówności społecznych (Harvey 1975). Zróżnicowanie warunków mieszkaniowych w tym ujęciu nie jest bowiem wynikiem indywidualnych preferencji i wolnego wyboru ludzi, 
lecz jedynie ich reakcją w ramach istniejących możliwości (Harvey 1973). W warunkach krajów socjalistycznych perspektywa ta również pozwala traktować przestrzeń mieszkaniową jako przestrzeń reprodukcji siły roboczej, tyle że służącą interesom ekonomicznym innego ustroju ${ }^{23}$.

W szeroko wykorzystywanej na gruncie geografii koncepcji społecznego wytwarzania przestrzeni B. Jałowieckiego (1988, 2010), która jest twórczym rozwinięciem myśli strukturalistów H. Lefebvre'a (1974) oraz M. Castellsa $(1977,1982)$, przestrzeń mieszkaniowa stanowi jedną z pięciu form przestrzennych $\mathrm{w}$ miastach (obok przestrzeni produkcji, władzy, symboliki i wymiany) i należy do przestrzeni konsumpcji. Jak podaje B. Jałowiecki (2010), przestrzeń konsumpcji związaną z prostą reprodukcją siły roboczej, stanowią mieszkania wraz $\mathrm{z}$ minimalnym wyposażeniem materialnym w postaci infrastruktury technicznej. Natomiast przestrzeń konsumpcji związaną $\mathrm{z}$ rozszerzoną reprodukcją sily roboczej, stanowią tereny ochrony zdrowia, tereny zielone i rekreacyjne oraz przestrzenie systemów instytucjonalnych (np. szkolnictwo i instytucje społeczno-kulturalne) (ibid., s. 38). Przestrzeń ta zgodnie z marksowską wizją historii jest wytwarzana na każdym etapie historycznego rozwoju miast przez różnych aktorów dla różnych użytkowników. W mieście socjalistycznym, jak podaje ten autor (ibid., s. 190), przestrzeń obejmująca mieszkania wraz z podstawowym wyposażeniem usługowym zaspokajającym potrzeby życia codziennego $\mathrm{w}$ postaci wielkich osiedli mieszkaniowych wytwarzana była głównie w celu obsługi nowo powstających i rozbudowywanych zakładów przemysłowych. Wytwarzaniem oraz dystrybucją tak rozumianej przestrzeni konsumpcji zajmowały się władze polityczne, które realizując sterowaną politykę mieszkaniową próbowały godzić przyjęte przez siebie ideologiczne zasady sprawiedliwości społecznej z realizacją doraźnych potrzeb, czyli rekrutacją i stabilizacją siły roboczej (Jałowiecki 2010).

Kolejna z orientacji wyjaśniających tworzenie się i zróżnicowanie struktury rezydencjalnej miasta przyjmowanych $\mathrm{w}$ geografii to orientacja behawioralna. Podejście to, sięgając do metod zaczerpniętych głównie z psychologii środowiskowej i socjologii, skupia się na analizie potrzeb ludzkich, a za cel przyjmuje zrozumienie motywacji jakimi człowiek kieruje się w swych decyzjach i zachowaniach (Walmsley, Lewis 1997, s. 15). W ujęciu tym kon-

${ }^{23}$ I tak np. w ustroju kapitalistycznym pracownicy obciążeni koniecznością spłaty kredytu mieszkaniowego są mniej skłonni do strajku, a zatem własność mieszkań wśród klasy robotniczej jest środkiem włączania jej w świat kapitalistycznych wartości oraz zmniejszania jej rewolucyjnych skłonności (Blunt, Willis 2000). Posiadanie mieszkania (domu) na własność ma zatem zachęcać do większego zaangażowania w pracę i identyfikacji ze światem wartości kapitalistycznych (ibid.). W ustroju socjalistycznym natomiast stabilizacja siły roboczej nie polegała na prawie własności zamieszkiwanej nieruchomości, lecz na prawie jej użytkowania (na zasadzie przydziału) (Jałowiecki 2010). 
cepcja homo oeconomicus zastąpiona została koncepcją homo psychologicus człowieka wartościującego, który nie zawsze w sposób racjonalny podejmuje decyzje i wybiera spośród różnych alternatyw, w zależności od zasobu informacji, jakie posiada (Węcławowicz 2007, s. 23). Orientacja behawioralna obejmuje szerokie spektrum tematyki badawczej, a do problemów badawczych bezpośrednio związanych z zamieszkiwaniem człowieka w mieście należą badania preferencji mieszkaniowych i migracyjnych, badania zachowań przestrzennych i decyzji dotyczących wyboru miejsca realizacji różnych potrzeb, a także znajdujące się na pograniczu geografii behawioralnej i geografii humanistycznej (por. Bartnicka 1989, s. 12) badania percepcji i waloryzacji zamieszkiwanego środowiska. $W$ podejściu behawioralnym akcentuje się wzajemny związek między człowiekiem i otaczającym go środowiskiem, w którym człowiek kształtuje to środowisko i jednocześnie sam jest przez nie kształtowany (Gold 1980, s. 4).

Innym podejściem mieszczącym się blisko orientacji behawioralnej, które rozwinęło się w opozycji do stosowanej w tym nurcie metodologii pozytywistycznej, jest orientacja humanistyczna (por. Walmsley, Lewis 1997, Pacione 2001). Orientacja ta, nieczęsto stosowana w geografii „w czystej formie", częściej jako inspiracja, oparta jest na założeniu, że społeczną rzeczywistość miasta należy rozpatrywać z punktu widzenia człowieka traktowanego jako podmiot a nie przedmiot (Jędrzejczyk 2004). Podmiot, który ma swój własny świat i patrzy na środowisko przez pryzmat własnego doświadczenia (Walmsley, Lewis 1997) i który z jednej strony jest ograniczony przestrzenią $\mathrm{w}$ sensie fizycznym, $\mathrm{z}$ drugiej zaś przekracza tę przestrzeń i tworzy własne indywidualne "przestrzenie" (określane jako społeczne lub kulturowe) wychodzące poza aspekt fizyczny. W podejściu tym, czerpiącym teoretyczne inspiracje z prac Y.F. Tuana (1987) oraz E. Relpha (1976), a w geografii polskiej z założeń kulturalizmu F. Znanieckiego oraz jego kontynuatora A. Wallisa, naczelną kategorią analityczną jest miejsce. Przedmiotem analiz $\mathrm{w}$ tym nurcie są percepcja, interpretacja i wartościowanie środowiska (przestrzeni, miejsca) oraz odkrywanie jego sensu i znaczenia (sense of place), jednak - odmiennie niż w geografii behawioralnej - ujmowane wyłącznie subiektywnie (Bartnicka 1989, s. 11). Przestrzeń mieszkaniowa $\mathrm{w}$ tym indywidualistycznym podejściu analizowana jest $\mathrm{z}$ punktu widzenia użytkujących ją jednostek, czyli jako miejsce zamieszkania - miejsce znaczące, szczególne, określone przez rozmaite (indywidualne i grupowe) wyobrażenia, symbole i postawy (Wallis 1990). Współcześnie w ramach geografii humanistycznej wyodrębnił się nowy nurt badań określany jako geografia domu (Blunt, Wills 2000, Blunt, Dowling 2006), traktująca dom nie tylko jako budynek lub schronienie, ale jako miejsce szczególne, „niezastąpione centrum znaczenia” (Relph 1976, s. 39), miejsce „do którego się wy- 
cofujemy i z którego idziemy naprzód" (Tuan 1971, s. 189)24. Dom (i miejsce zamieszkania) w tym ujęciu, niezależnie od tego, czy jest to rodzinne, wielopokoleniowe siedlisko, czy małe mieszkanie w bloku, to centrum wszechświata, miejsce szczególne, do którego człowiek jest mniej lub bardziej przywiązany i które zawsze, niezależnie od swych obiektywnych walorów, jest dla człowieka jednym $\mathrm{z}$ najważniejszych miejsc, jakich doświadcza w swoim życiu (por. Blunt, Wills 2000, Blunt, Dowling 2006). Ujęcie to odwołuje się także do zagadnień filozoficznych związanych z istotą zamieszkiwania, o czym pisał m.in. M. Heidegger (1977), według którego zamieszkiwanie jest budowaniem więzi, związków między człowiekiem i miejscem, a poprzez miejsce $z$ przestrzenią.

\subsection{Wielkie osiedla mieszkaniowe $w$ badaniach naukowych}

Interdyscyplinarny charakter problematyki badawczej związanej z szeroko rozumianym mieszkalnictwem, zarówno $\mathrm{w}$ sferze społecznej, jak i przestrzennej sprawia, że wielkie osiedla mieszkaniowe, podobnie jak cała sfera mieszkalnictwa $\mathrm{w}$ miastach, są domeną zainteresowań geografów, socjologów, urbanistów, architektów, a także przedstawicieli innych nauk zajmujących się miastem jako obszarem zamieszkiwania człowieka, czyli psychologii środowiskowej i antropologii społecznej.

Wielość nauk zajmujących się tematyką osiedli oraz różnorodność sposobów jej ujmowania wymaga pewnych zabiegów porządkujących. Jako główne kryteria podziału badań wielkich osiedli mieszkaniowych prezentowanych w dostępnej literaturze zarówno polskiej, jak i zagranicznej (anglojęzycznej) przyjęto:

- reprezentowaną dyscyplinę badawcza, przy czym dominują tu badania urbanistów i architektów, geografów oraz socjologów, a w mniejszości występują opracowania z innych dziedzin - antropologii społecznej i psychologii środowiskowej;

- zakres przedmiotowy pracy, często będący pochodną reprezentowanej dziedziny nauki, ze względu na który wyróżnić można publikacje dotyczące morfologii osiedli, ich rozwoju przestrzennego, układów zabudowy, struktury przestrzenno-funkcjonalnej, warunków życia w osiedlach (warunków zamieszkania lub jakości życia), struk-

${ }^{24}$ Zgoła inaczej dom bywa postrzegany przez pryzmat nowej orientacji badawczej określanej jako feministyczna, która jest jedną z perspektyw przyjmowanych we współczesnej geografii miast (Maik 2012). Jak podają bowiem geografowie A. Blunt i R. Dowling (2006), dom z tej perspektywy może być również miejscem dyskryminacji, cierpienia, bólu i przemocy. 
tury społecznej i demograficznej osiedli, percepcji osiedli, więzi społecznych i terytorialnych $\mathrm{w}$ osiedlach, przekształceń osiedli, przy czym wiele opracowań ma charakter kompleksowy obejmujący szeroki zakres przedmiotowy;

- zakres podmiotowy i przestrzenny pracy, ze względu na który wyróżnić można publikacje dotyczące jednego osiedla oraz o charakterze komparatystycznym obejmujące więcej osiedli w jednym, kilku, a nawet $\mathrm{w}$ kilkunastu miastach lub krajach;

- stosowane podejścia teoretyczno-metodologiczne, które często (lecz nie zawsze) są pochodną reprezentowanej dziedziny nauki oraz podejmowanej tematyki - od podejść scjentystycznych poprzez klasyczne aż do podejść humanistycznych;

- zakres czasowy badań, z uwagi na który wyróżnić można badania o charakterze statycznym oraz badania dynamiczne rejestrujące zmiany zachodzące w osiedlach;

- czas i miejsce prowadzonych badań, w podziale na miasta socjalistyczne/postsocjalistyczne oraz miasta zachodnioeuropejskie, co ma znaczenie ze względu na odmienne uwarunkowania powstawania, rozwoju i funkcjonowania osiedli, a także możliwości dokonania obiektywnej oceny (w tym krytycznej) tej formy zabudowy.

W grupie opracowań z dziedziny urbanistyki i architektury w literaturze polskiej najważniejsze pozycje w całości poświęcone wielkim osiedlom mieszkaniowym, które ujmują ich problematykę w sposób zaproponowany w niniejszej pracy, ukazały się po 1990 roku. Wśród nich wyróżnić można prace, których przedmiotem są współczesne procesy przekształcania wielkich osiedli w zależności od ujęcia określane jako modernizacja (Chmielewski, Mirecka 2001, Tokajuk 2007) lub rehabilitacja (Mirecka 1995, Rębowska 1999, 2000, Rębowska i in. 2006). Osobną grupę stanowią prace omawiające genezę tej formy zabudowy (Wojtkun 2008, Sołoducha 2007, Motak 2003, 2012) oraz jej rozwój przestrzenny i współczesne przekształcenia na przykładzie wybranych miast: Szczecina (Wojtkun 2004), Białegostoku (Tokajuk 2007) oraz Katowic i Lipska (Komar 2012, 2014). Przedmiotem studiów architektów i urbanistów są także prawne, społeczne oraz techniczne możliwości przekształceń tej formy zabudowy (Basista 1999, Gzell i in. 2009, Rembarz 2010).

Odmiennie niż w urbanistyce i architekturze, w socjologii większość prac z bogatej literatury dotyczącej osiedli powstała przed 1990 rokiem. Omawianie dorobku z tej dziedziny wymaga zatem sięgnięcia do lat 60 . XX wieku, kiedy powstały liczne opracowania, które w efekcie stworzyły polską tzw. socjologię osiedlową i na kolejne lata stały się klasyką dla innych publikacji tego typu. Były to przede wszystkim prace J. Turowskiego (1976, 
red. 1979), J. Ziółkowskiego (1965), B. Jałowieckiego (1968), W. Siemińskiego (1980, 1982a, b, 1985), P. Kryczki (1981), S. Nurka (1982) oraz G. Misiaka (1988). Głównym obszarem zainteresowania socjologów od początku były i są obecnie społeczne aspekty zamieszkiwania $w$ wielkich osiedlach ze szczególnym uwzględnieniem istniejących tam więzi społecznych, w tym przede wszystkim więzi sąsiedzkich, a także stylu życia mieszkańców, ich preferencji mieszkaniowych i migracyjnych oraz percepcji i waloryzacji różnych aspektów zamieszkiwania $\mathrm{w}$ osiedlach, najczęściej związanych z jego wyposażeniem, estetyką, dostępnością komunikacyjną, prestiżem itp. Opracowania te w dużej mierze oparte były na badaniach kwestionariuszowych przeprowadzanych wśród mieszkańców, ale miały też wymiar teoretyczny, np. typologia osiedli zaproponowana przez B. Jałowieckiego w 1968 roku (tab. 3) oraz typologia sąsiedztwa P. Kryczki (1981). Ze studiów socjologicznych powstałych po 1990 roku dotyczących wielkich osiedli najbardziej kompleksowy charakter miały: opracowanie M. Szczepańskiego (1991), które dotyczy szerszych zagadnień funkcjonowania miasta socjalistycznego, a jako jego materialną egzemplifikację traktuje blokowiska w Tychach, oraz praca I. Borowik (2003) obejmująca zagadnienia związane zarówno z genezą tej formy zabudowy, jak i jej współczesną percepcją analizowaną na przykładzie osiedli wrocławskich. Do współczesnych opracowań z pogranicza socjologii oraz antropologii społecznej należy między innymi publikacja J. Gądeckiego (2012) dotycząca procesów gentryfikacji w osiedlu Nowa Huta w Krakowie.

Geografia, w obszarze badawczym której mieści się niniejsza praca, jest dyscypliną najbardziej zróżnicowaną pod względem tematyki i zakresu przedmiotowego publikacji dotyczących wielkich osiedli mieszkaniowych. Wynika to zapewne z szerokości tej dziedziny oraz dużej różnorodności zainteresowań geografów: od studiów morfologicznych, poprzez studia struktury przestrzennej i społecznej, aż po badania percepcji zamieszkiwanej przestrzeni i więzi społecznych, które kształtują się w oparciu o zamieszkiwane terytorium. Równocześnie w dyscyplinie tej odnaleźć można całe spektrum podejść teoretyczno-metodologicznych obecnych $\mathrm{w}$ badaniach przestrzeni rezydencjalnej miast - od scjentystycznych (np. Dzieciuchowicz 2011) do humanistycznych (np. Szkurłat 2004, Klima 2013), a także podejścia zintegrowane łączące wybrane orientacje metodologiczne (np. Kaczmarek 1996, Kotus 2007, Marcińczak 2009), przy czym - jak już powiedziano podobnie jak $\mathrm{w}$ innych dziedzinach nauki zajmujących się osiedlami mieszkaniowymi, tak i w geografii dominują podejścia pozytywistyczne (neopozytywistyczne) oraz behawioralne (noeobehawioralne).

Biorąc pod uwagę literaturę geograficzną powstałą w Polsce przed 1989 rokiem można stwierdzić, że wielkie osiedla o zabudowie blokowej najczęściej badano jako jedną ze stref miasta (jeden z rodzajów zabudowy), nie 
traktując ich jako zasadniczy obszar badań. W latach 90. XX wieku, w pierwszej dekadzie transformacji, osiedla te również nie budzily szerokiego zainteresowania badaczy, którzy skupiali się bądź na badaniu całych miast, bądź ich strefy wewnętrznej (centralnej) i/lub strefy podmiejskiej. Strefę osiedli, jako podlegającą mniej intensywnym przemianom transformacyjnym (por. Liszewski 2001b), pozostawiali poza głównym nurtem swoich badań. Do nielicznych powstałych $\mathrm{w}$ tym okresie publikacji poświęconych w całości tej formie urbanistycznej należą między innymi opracowania I. Sagan (1997), M. Czepczyńskiego (1999) oraz W. Gaczek i Z. Rykla (1999).

Tab. 3. Typologia osiedli mieszkaniowych

\begin{tabular}{|c|c|}
\hline Kryterium typologii & Typy osiedli i ich najważniejsze cechy \\
\hline \multirow{4}{*}{$\begin{array}{l}\text { Relacja, w jakiej } \\
\text { pozostają zasadnicze } \\
\text { funkcje osiedla, czyli } \\
\text { mieszkanie, usługi } \\
\text { i praca }\end{array}$} & $\begin{array}{l}\text { - osiedla, w których miejsca zamieszkania, usług i pracy skupione na } \\
\text { stosunkowo niewielkiej przestrzeni nie wymagającej korzystania } \\
\text { ze środków transportu; }\end{array}$ \\
\hline & $\begin{array}{l}\text { - osiedla, w których miejsca zamieszkania znajdują się w pobliżu } \\
\text { miejsc pracy, ale oddzielone są od usług; }\end{array}$ \\
\hline & $\begin{array}{l}\text { - osiedla, w których miejsca zamieszkania wyposażone są w usługi, ale } \\
\text { oddzielone od miejsc pracy; }\end{array}$ \\
\hline & $\begin{array}{l}\text { - osiedla, w których miejsca zamieszkania oddzielone są od usług } \\
\text { i miejsc pracy. }\end{array}$ \\
\hline \multirow[t]{3}{*}{$\begin{array}{l}\text { Koncepcja organi- } \\
\text { zacji życia społecz- } \\
\text { nego w osiedlu }\end{array}$} & $\begin{array}{l}\text { - kolektywistyczne, w których istotnie ograniczona jest indywidualna } \\
\text { sfera życia człowieka (w tym np. funkcja opiekuncza i wychowawcza } \\
\text { rodziny, a także funkcja rodziny jako gospodarstwa domowego). } \\
\text { Koncepcja osiedli kolektywistycznych wiązała się z rozwojem idei } \\
\text { zbiorowych form zaspokajania różnych potrzeb życiowych oraz } \\
\text { z wymiarem praktycznym (bliskość miejsc zamieszkania i miejsc } \\
\text { pracy), co miało wpływ na silniejsze powiązanie pracowników } \\
\text { z miejscem pracy (aż do ich uzależnienia od pracodawcy); }\end{array}$ \\
\hline & $\begin{array}{l}\text { - indywidualistyczne, zakładające taką realizację osiedla, która pozwa- } \\
\text { la na optymalne w danych warunkach indywidualne zaspokajanie } \\
\text { potrzeb zamieszkującej w nim zróżnicowanej społeczności; }\end{array}$ \\
\hline & $\begin{array}{l}\text { - paternalistycznea, wywiedzione z XIX-wiecznego paternalizmu kapi- } \\
\text { talistycznego, którego efektem działania była budowa osiedli tzw. } \\
\text { patronalnych (patronackich) wznoszonych przez właścicieli fabryk } \\
\text { w celu zapewnienia mieszkań zatrudnionym w nich robotnikom, co } \\
\text { podobnie jak w przypadku osiedli kolektywistycznych, oprócz wy- } \\
\text { miaru praktycznego (bliskość miejsc zamieszkania i miejsc pracy), } \\
\text { miało wpływ na silniejsze powiązanie załogi z miejscem pracy (aż do } \\
\text { ich uzależnienia od pracodawcy). }\end{array}$ \\
\hline
\end{tabular}

a Osiedla takie, współcześnie określane jako robotnicze, przyzakładowe (zakładowe), budowane były także w XX wieku, przy czym w krajach kapitalistycznych głównie do II wojny światowej, a krajach socjalistycznych aż do lat 80 . XX wieku.

Źródło: opracowanie własne na podstawie B. Jałowiecki (1968). 
Zainteresowanie problematyką wielkich osiedli w geografii polskiej znacznie wzrosło po 2000 roku. Pojawiło się wówczas wiele prac, głównie o charakterze empirycznym, których zarówno tematyka, jak i zakres są bardzo zróżnicowane. Przedmiotem studiów, które ukazały się w tym czasie były przekształcenia $\mathrm{w}$ zagospodarowaniu i w strukturze społecznej, przestrzennej, przestrzenno-funkcjonalnej lub morfologicznej wielkich osiedli mieszkaniowych zachodzące $\mathrm{w}$ okresie transformacji omówione na przykładzie wybranych osiedli Łodzi (Masica, Milewska 2003, Milewska 2003, Adamus 2011, Wojtkiewicz 2010, Szafrańska 2010, 2014), Poznania (Ciesiółka 2010), Lublina (Rodzoś, Flaga 2010), Torunia (Radwańska 2010), Katowic (Warchalska-Troll 2012), Warszawy (Kozłowski 2005, 2006, 2010, Węcławowicz i in. 2003) oraz Sankt Petersburga (Jażdżewska 2010), a także innych, mniejszych miast Polski (np. Gorczyca 2010, Miszewska, Szmytkie 2010, Szymańska 2010).

Kolejny nurt prac empirycznych obejmujących problematykę wielkich osiedli mieszkaniowych, który rozwinął się po 2000 roku na gruncie geografii polskiej obejmował studia $\mathrm{z}$ zakresu percepcji i waloryzacji tej formy zabudowy przez jej mieszkańców oraz ich więzi społecznych i terytorialnych. Są wśród nich opracowania, które dotyczą zarówno pojedynczych osiedli, np. w Łodzi (Szafrańska 2009) i Lublinie (Rodzoś, Flaga 2010), jak i prace komparatystyczne analizujące większą liczbę osiedli w jednym mieście, np. w Gdańsku (Rzyski, Mędrzycka 2010), Łodzi (Janiszewska i in. 2010, 2011), Warszawie (Węcławowicz i in. 2005, Kozłowski 2005, 2010, Fuhrmann 2009a, 2009b, Górczyńska 2008) oraz Katowicach (Warchalska-Troll 2012). Do studiów geograficznych zawierających wątki teoretyczne oraz zagadnienia dotyczące genezy tej formy zabudowy, uwarunkowań jej rozwoju i możliwości przekształceń oraz perspektyw należą prace: L. Coudroy de Lille (2000), Z. Rykla (2000), G. Węcławowicza i in. (2004), S. Kozłowskiego (2005, 2010), K. Gorczycy (2009), J. Słodczyka (2010) oraz E. Szafrańskiej (2013). Zagadnieniu temu poświęcony jest także jeden z rozdziałów książki Geografia społeczna miast G. Węcławowicza (2007).

Biorąc zaś pod uwagę obecność tematyki wielkich osiedli w ogólnopolskich czasopismach geograficznych można stwierdzić, że jest ona reprezentowana bardzo skromnie. Kwerenda numerów dwóch najstarszych periodyków, czyli "Czasopisma Geograficznego" oraz „Przeglądu Geograficznego" z lat 1990-2014 dowiodła, że tematyka ta poruszana była tylko dwukrotnie w „Przeglądzie Geograficznym” przez G. Węcławowicza (2003) oraz M. Górczyńską (2008). Nieco więcej natomiast publikacji na temat budownictwa osiedlowego pojawiło się $\mathrm{w}$ wydawanych w Polsce czasopismach anglojęzycznych („Miscellanea Geographica” oraz "Geographia Polonica”). W pierwszym z nich po 1990 roku opublikowano dwa artykuły (Fuhrmann 2010, Pieniążek 2010) dotyczące osiedli w Warszawie oraz Berlinie, w dru- 
gim natomiast cztery, z których dwa dotyczyły osiedla Nowa Huta w Krakowie (Stenning 2005, Stenning $\mathrm{i}$ in. 2007), oraz po jednym osiedli $\mathrm{w}$ miastach czeskich (Maier 2005) i osiedli w Łodzi (Szafrańska 2014). Do wydawnictw ciągłych, które w całości poświęcone zostało wielkim osiedlom, należy natomiast XXIII tom serii „Konwersatorium Wiedzy o Mieście” z 2010 roku, zatytułowany Osiedla blokowe w strukturze przestrzennej miast.

Osobną grupą są opracowania, których przedmiotem nie są wyłącznie osiedla, lecz całe miasta, a osiedla traktowane są w nich jako jedna ze stref miejskich, czy też jedna z form zabudowy miejskiej. Do takich prac należą np. wymieniane już studia z zakresu struktur społeczno-przestrzennych miast podejmowane głównie na gruncie geografii społecznej, których wynikiem jest zazwyczaj określenie pozycji (miejsca), jakie zajmują wielkie osiedla w strukturze społeczno-przestrzennej poszczególnych miast (różnych typów miast). Do takich studiów należą publikacje dotyczące Poznania (Gaczek 1979), Warszawy (Węcławowicz 1988), Torunia (Jaroszewska-Brudnicka 2004), Krakowa (Zborowski 2005), Gdyni (Szmytkowska 2008) oraz Łodzi (Rykiel 1999, Marcińczak 2009).

Prace dotyczące wielkich osiedli mieszkaniowych $\mathrm{w}$ innych krajach postsocjalistycznych ${ }^{25}$ powstałe po 1990 roku koncentrowały się, podobnie jak opracowania autorów polskich, na przemianach spolecznych, przestrzennych i funkcjonalnych zachodzących w tych osiedlach oraz ich percepcji i waloryzacji przez mieszkańców. Do takich publikacji należą m.in. międzynarodowe studia o charakterze porównawczym (Dekker, van Kempen 2005, Musterd, van Kempen 2005, Dekker i in. 2011), omawiające wyniki badań przeprowadzonych $w$ ramach cytowanego już projektu RESTATE, realizowanego w 2005 roku w 10 krajach europejskich, w tym w czterech postsocjalistycznych, w których badaniami objęto osiedla w Warszawie, Budapeszcie, Berlinie oraz Lubljanie i Koprze ${ }^{26}$, również praca zbiorowa pod redakcją R. Turkingtona, R. van Kempena i F. Wassenberga (2004) omawiająca rozwój i przemiany wielkich osiedli w 15 krajach europejskich, w tym w sześciu postocjalistycznych (Polska, Ukraina, NRD, Słowacja, Węgry i Słowenia), opracowania porównujące ścieżki rozwojowe osiedli w czterech krajach na przykładzie wybranych osiedli w Lipsku, Budapeszcie, Wilnie i Sofii (Kovács, Herfert 2012, Wiest 2011) oraz publikacja, w której po-

${ }^{25}$ Ze względu na ograniczoną dostępność do publikacji o charakterze lokalnym w niniejszej pracy omówiono i wykorzystano tylko pozycje anglojęzyczne i takie, które ukazały się $\mathrm{w}$ postaci zwartych wydawnictw książkowych lub opublikowane zostały w czasopismach naukowych o zasięgu międzynarodowym.

${ }^{26} \mathrm{~W}$ projekcie RESTATE uwzględniono 29 osiedli, z których siedem to osiedla w miastach postsocjalistycznych: Wrzeciono i Ursynów Płn. w Warszawie, Havanna w Budapeszcie, Nyíregyháza w węgierskim mieście Jósavdros, Nove Fužine w Ljublianie, Žusterna-Semelda w Koprze oraz Marzahn Hellersdorf we wschodniej części Berlina. 
równywane są wybrane osiedla w Polsce i Słowacji (Nowa Huta w Krakowie i Petržalka w Bratysławie) - (Stenning i in. 2010).

Do pozycji obejmujących mniejszą skalę terytorialną (krajową lub miejską) należą między innymi: prace omawiające rozwój i współczesne przemiany wielkich osiedli: w Czechach (Temelová i in. 2011), Słowacji (Divinsky 2004), Rumunii (Constantin 2007, Pasztor, Peter 2009), na Ukrainie (Durmanov, Dubbeling 2004), w Słowenii (Dimitrovska Andrews, Černič Mali 2004) oraz na Węgrzech (Egedy 2000, Kovács, Douglas 2004), a także studia przypadków pojedynczych osiedli w Berlinie (Knorr-Siedow 2004, KnorrSiedow, Droste 2005), Ljubljanie i Koprze (Černič Mali i in. 2005), Budapeszcie (Tosics i in. 2005), Tallinie (Kähirik, Tammaru 2010), Rydze (Treija 2010) oraz w Lipsku (Kabisch, Grossmann 2013).

\subsection{Koncepcje wyjaśniające przemiany osiedli mieszkaniowych}

W analizie i wyjaśnianiu przemian struktury społecznej oraz fizycznej miejskich środowisk mieszkaniowych (w tym także wielkich osiedli), a w konsekwencji zmian w ich pozycji i prestiżu w strukturze rezydencjalnej miasta, w literaturze światowej stosuje się co najmniej trzy zasadnicze podejścia teoretyczne określane przez E. van Beckhoven i in. $(2009$, s. 5) jako tradycyjne. Pierwsze $\mathrm{z}$ nich to podejście ekologiczne (human ecology approach) rozwinięte na gruncie ekologii społecznej zaproponowanej przez badaczy szkoły chicagowskiej, które oparte jest na mechanizmach konkurencji ekonomicznej różnych grup społecznych o przestrzeń miejską. Drugie to podejście kulturowe (subcultural approach) skupiające się na znaczeniu więzi społecznych istniejących $\mathrm{w}$ ramach poszczególnych środowisk mieszkaniowych, które mogą łagodzić lub nasilać zmiany wynikające $\mathrm{z}$ działania różnych sił zewnętrznych (np. ekonomicznych). Trzecim jest podejście na gruncie ekonomii politycznej (political economy approach), w którym przemiany zachodzące w poszczególnych dzielnicach (osiedlach) mieszkaniowych wyjaśnia się przez czynniki zewnętrzne o charakterze społeczno-ekonomicznym i politycznym. Nieco inaczej podejścia te grupują P. Somerville i in. (2009), którzy wyróżniają: podejścia ekologiczne oparte na dorobku szkoły chicagowskiej, podejścia behawioralne podkreślające $\mathrm{w}$ procesie przemian rolę kwestii kulturowych, $\mathrm{w}$ tym sieci powiązań pomiędzy mieszkańcami oraz podejścia instytucjonalne, zgodnie z którymi główną determinantą przemian środowisk mieszkaniowych jest sposób zarządzania nimi.

W ramach wymienionych podejść powstało wiele teorii i modeli przemian wykorzystywanych przez różnych autorów w analizie przemian wiel- 
kich osiedli mieszkaniowych, wśród których wyróżnić można dwie zasadnicze grupy: 1) teorie i modele o charakterze uniwersalnym, głównie amerykańskie, wyjaśniające przemiany $\mathrm{w}$ różnych typach środowisk mieszkaniowych, które z pewnymi ograniczeniami stosuje się do ich analizy w wielkich osiedlach o zabudowie blokowej, 2) teorie i modele skupione na wyjaśnianiu kryzysu wielkich osiedli mieszkaniowych, powstałe $\mathrm{w}$ krajach zachodnioeuropejskich, gdzie kryzys ten rozpoczął się już w latach 70. XX wieku.

Wśród podejść o charakterze uniwersalnym największe znaczenie ma powstała w Stanach Zjednoczonych blisko 100 lat temu, lecz wciąż inspirująca wielu badaczy, przywoływana już w niniejszej pracy chicagowska szkoła ekologii społecznej R. Parka, E. Burgessa, i R.D. McKenzie'ego (1925), która wychodzi od koncepcji miasta jako obszaru bezosobowej konkurencji (impersonal competition) między jednostkami i grupami o zdobycie pożądanych lokalizacji. Konkurencja ta odbywa się za pośrednictwem wolnego rynku i wyraża w zróżnicowaniu renty gruntowej, a różne możliwości nabywcze poszczególnych grup powodują ich segregację $\mathrm{w}$ przestrzeni miejskiej oraz wytwarzanie się jednorodnych obszarów wyróżniających się z otoczenia pod względem fizycznym, ekonomicznym i kulturowym, określanych jako naturalne (natural areas). W związku z tym jednak, że atrakcyjność poszczególnych obszarów naturalnych w mieście i zdolności nabywcze poszczególnych grup z upływem czasu zmieniają się, następują procesy przemieszczeń określane jako inwazja oraz sukcesja, związane z zajmowaniem coraz to nowych i lepszych lokalizacji oraz wypieraniem dotychczas zamieszkujących tam społeczności. Identyfikacja tych procesów posłużyła E. Burgessowi w 1925 roku do konstrukcji szeroko opisywanego w literaturze koncentrycznego modelu rozwoju miasta, przedstawiającego rozmieszczenie poszczególnych grup społecznych w przestrzeni miejskiej. Podejście to $z$ jednej strony wyjaśnia procesy przemian związane z migracjami poszczególnych grup ludności i zajmowaniem przez nie coraz lepszych lokalizacji, z drugiej zaś $\mathrm{w}$ postaci statycznych modeli struktury społeczno-przestrzennej miasta - model Burgessa oraz będące jego twórczym rozwinięciem modele ekonomisty H. Hoyta (1939) oraz geografów Ch. Harisa i E. Ullmana (1945) - ukazuje konsekwencje tych procesów.

Inną teorią o charakterze uniwersalnym, która w swoim rodowodzie sięga dorobku intelektualnego szkoły chicagowskiej, zwłaszcza cytowanych już prac E. Burgessa i H. Hoyta, jest ekonomiczna teoria filtracji mieszkaniowej (ang. housing filtering), która po raz pierwszy pojawiła się w literaturze na przełomie lat 50. i 60. minionego stulecia (Lowry 1960, Clark 2010). Teoria ta, rozwijana między innymi przez amerykańskiego ekonomistę W. Grigsby'ego (1963), zakłada, że przemiany obszarów mieszkaniowych powodowane są przez ich naturalne starzenie się (i zużywanie) oraz poja- 
wianie się $\mathrm{w}$ przestrzeni miejskiej nowej, bardziej atrakcyjnej zabudowy mieszkaniowej o wyższym standardzie i/lub lepszej lokalizacji. W myśl tej koncepcji pojawianie się na rynku nieruchomości nowych mieszkań (domów), do których przeprowadzają się przedstawiciele zamożniejszych kategorii społecznych, uruchamia cały "łańcuch przeprowadzek" (ang. chain of moves). Zamożni wyprowadzając się zwalniają swoje dotychczasowe mieszkania dla mniej zamożnych, którzy wchodząc na ich miejsce zwalniają tym samym swoje tańsze mieszkania dla jeszcze mniej zamożnych itd. Proces filtracji sprawia, że każdy nowy dom (mieszkanie) o wyższym standardzie "filtruje w dól" istniejące już zasoby mieszkaniowe, które sukcesywnie są zajmowane przez coraz uboższe warstwy społeczeństwa ${ }^{27}$. Jeśli budowa nowych mieszkań/domów nie jest wystarczająca dla zaspakajania potrzeb ludzi o wysokich dochodach, proces ten jest stłumiony (Baer, Williamson 1988). Proces filtracji jest przeciwieństwem procesu gentryfikacji, ponieważ wiąże się z utratą wartości mieszkań znajdujących się na obszarach "filtrowanych" oraz ze stopniowym obniżaniem się ich statusu społecznego (Clark 2010). Z teorią filtracji mieszkaniowej ściśle powiązany jest model W. Grigsby'ego z 1987 roku (Grigsby i in. 1987), który wpisując się w podejście ekologiczne zakłada, że procesy sukcesji są stałym czynnikiem rozwoju miast i głównym mechanizmem przemian terenów mieszkaniowych, a ich występowanie jest kombinacją czynników wewnętrznych stanowiących o charakterystyce obszaru, jak i zewnętrznych działających na poziomie makro, obejmujących czynniki społeczno-demograficzne, ekonomiczne oraz polityczne (van Beckhoven i in. 2009).

Kolejną teorią należącą do grupy uniwersalnych jest nawiązujący do podejścia kulturowego model tkanki społecznej czy też struktury społecznej (social fabric) K. Temkina i W. Rohe z 1996 roku (Temkin, Rohe 1996). Przemiany środowisk mieszkaniowych są według tych autorów kombinacją sił zewnętrznych o charakterze społecznym, ekonomicznym oraz politycznym, a także społecznych, ekonomicznych i fizycznych cech tego środowiska, ale na ostateczny efekt przemian wpływ mają sami mieszkańcy - ich struktura oraz siła i intensywność relacji pomiędzy nimi, określana jako sieci społeczne (van Beckhoven i in. 2009).

Wśród teorii o rodowodzie europejskim wyjaśniających przemiany zachodzące $\mathrm{w}$ wielkich osiedlach mieszkaniowych, a w szczególności procesy

${ }^{27} \mathrm{~W}$ warunkach amerykańskich uważano, że pozytywnym efektem tego procesu w skali całego rynku jest poprawa warunków mieszkaniowych wszystkich kategorii ludności, w tym także najuboższych, którzy stanowią ostatnie ogniwo tego łańcucha (Marullo 1983). Dlatego też od lat 60. XX w. koncepcja ta używana była w odniesieniu do działań podejmowanych $\mathrm{w}$ ramach polityki mieszkaniowej w USA, nastawionej na poprawę warunków mieszkaniowych uboższych grup ludności, poprzez pośrednie subsydiowanie powstawania nowej zabudowy, z której korzystają warstwy zamożniejsze (Smith-Heimer 1985). 
ich deterioracji, najważniejszą rolę odgrywa model spirali upadku (spirals of decline) N. Praka i H. Priemusa opublikowany w 1986 roku (Prak, Priemus 1986), oparty na analizie problemów osiedli holenderskich stanowiących ważną część sektora mieszkalnictwa socjalnego w tym kraju. Model ten, pierwszy $\mathrm{z}$ opracowanych $\mathrm{w}$ odniesieniu do przemian zachodzących $\mathrm{w}$ tej formie zabudowy, oparto na założeniu, że jej współczesna zła kondycja jest rezultatem trzech wzajemnie wzmacniających się spirali degradacji (określanych też jako spirale upadku): społecznej, ekonomicznej oraz technicznej (Prak, Priemus 1986). Zgodnie z tym modelem degradacja osiedli rozpoczyna się od zmian w ich strukturze społecznej, które są następstwem spadku atrakcyjności osiedla i zwiększania się mobilności przestrzennej mieszkańców oraz wzrostu liczby gospodarstw domowych o niskich dochodach. Zmianom tym towarzyszyć może odpływ gospodarstw zamożniejszych. W konsekwencji zmniejsza się zakres kontroli społecznej w osiedlu, następuje wzrost liczby aktów wandalizmu i tworzą się warunki do rozwoju przestępczości. To zaś dalej obniża atrakcyjność mieszkaniową osiedla, która zapoczątkowała te procesy. Powiązana z degradacją społeczną osiedla jego degradacja techniczna jest konsekwencją wzrostu tempa wymiany mieszkańców, który może prowadzić do pojawiania się pustostanów, a także nasilania się wandalizmu na skutek niskiej kontroli społecznej otoczenia. Pogarszająca się jakość techniczna osiedla prowadzi do dalszego odpływu mieszkańców i postępującej jego degradacji, która jednakże uzależniona jest od wyjściowej jakości zasobów mieszkaniowych - im są gorsze, tym szybciej ulegają degradacji. Konsekwencją spadku ich atrakcyjności i wartości w dwóch wymienionych wymiarach jest degradacja ekonomiczna osiedla. Wzrastają koszty jego utrzymania, a zwiększanie się liczby mniej zamożnych gospodarstw domowych oraz obecność pustych lokali zmniejszają dochody z najmu mieszkań i powodują wzrost kosztów eksploatacji. Zarządzający osiedlem zaczyna ograniczać inwestycje związane z jego utrzymaniem. Konsekwencją jest napływ coraz słabszych ekonomicznie gospodarstw domowych, który pogłębia omówione procesy (Prak, Priemus 1986). Wartość tego modelu, mimo że nie wprowadza nowych, nieznanych wcześniej zmiennych do ogólnych procesów degradacji obszaru, dostrzeżonych i omówionych już przez badaczy szkoły chicagowskiej, polega na odniesieniu się do powojennych wielkich osiedli, które jako sektor mieszkalnictwa socjalnego miały szczególną pozycję na rynku mieszkaniowym wielu krajów Europy Zachodniej, a równocześnie bardzo szybko od lat 70. XX wieku zaczęły ulegać procesom deterioracji.

W literaturze zachodnioniemieckiej ( $w$ b. RFN), obejmującej problematykę przemian wielkich osiedli mieszkaniowych, gdzie kwestie przeciwdziałania pojawiającym się $\mathrm{w}$ nich negatywnym zjawiskom uznano za ważne, podobnie jak w innych krajach zachodnioeuropejskich, już w latach 70 . 
XX wieku podobną sekwencję zdarzeń opisuje schemat reakcji łańcuchowej O. Gibbinsa (Chmielewski, Mirecka 2001). Zgodnie z tym schematem w cyklu życia osiedla wyróżnić można cztery następujące po sobie fazy, przy czym o ile trzy pierwsze są kolejnymi etapami zmierzającymi do degradacji osiedla, ostatnia obejmuje działania naprawcze (rys. 2), których podjęcie pozwala uniknąć dalszej degradacji społecznej oraz technicznej osiedla i zminimalizować skutki zjawiska, określanego w literaturze niemieckiej (KnorrSiedow 1997) jako „syndrom wielkiego osiedla”. Syndrom ten definiuje się jako zespół uwarunkowań przestrzenno-społecznych wpływający na negatywny wizerunek osiedla i przyspieszający tempo spirali upadku oraz wymiany silniejszych na słabszych kulturowo mieszkańców, co wywołuje wzrost liczby pustostanów oraz rozwój strukturalnych problemów społecznych pogłębiających degradację i dewastację przestrzenną osiedla (Rembarz 2010, s. 151).

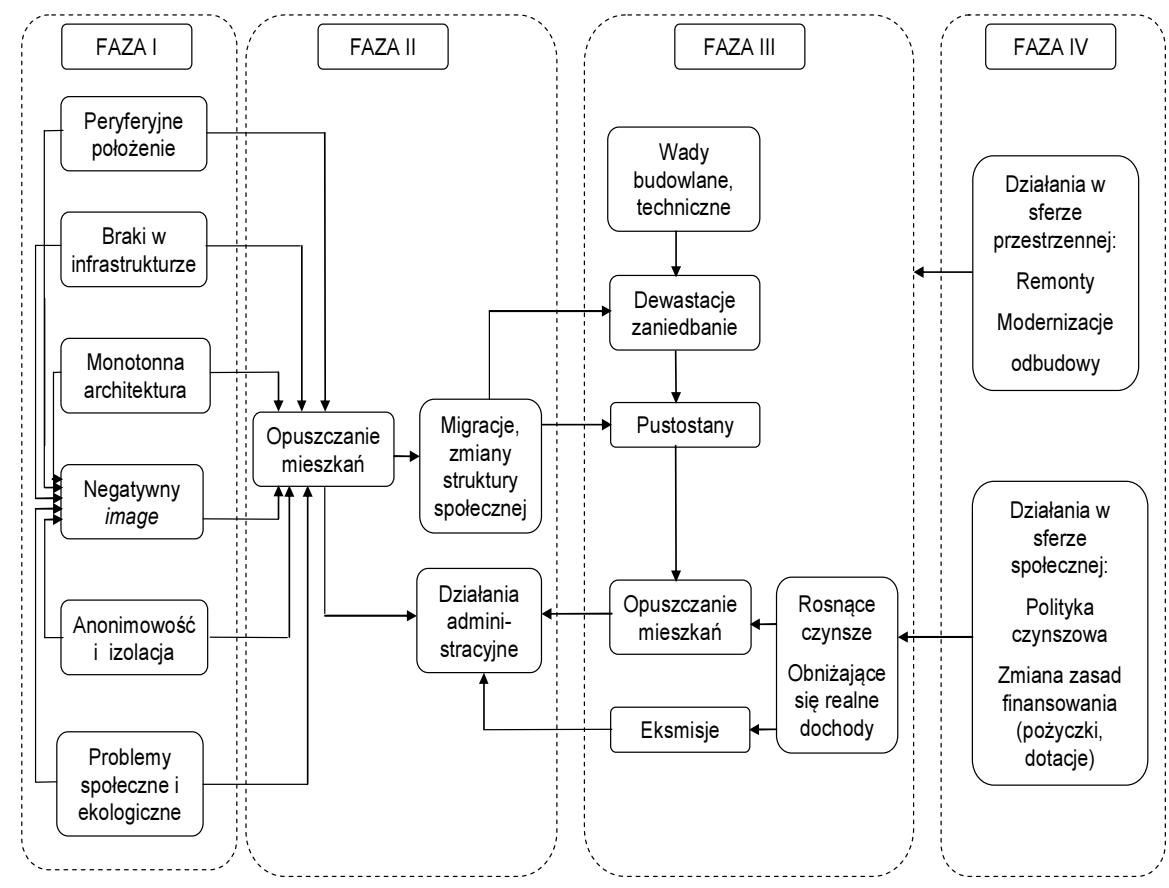

Rys. 2. Schemat reakcji łańcuchowej zachodzącej w poszczególnych fazach rozwoju wielkich osiedli mieszkaniowych

Źródło: J.M. Chmielewski, M. Mirecka 2001, s. 63 (cyt. za: Gibbins 1986)

Kolejną z teorii dostarcza praca brytyjskiej badaczki A. Power z 1997 roku, która zwraca uwagę na kwestie zarządzania osiedlami mieszkaniowymi jako na jedną z najważniejszych determinant ich kondycji zarówno społecz- 
nej, jak i fizycznej. Model ten w największym stopniu nawiązuje do podejść rozwijanych na gruncie ekonomii politycznej, bo jakkolwiek nie podkreśla $\mathrm{w}$ takim stopniu roli czynników makroekonomicznych i makrospołecznych, to bardzo dużą wagę przywiązuje do kwestii politycznych związanych z zarządzaniem, które mają kluczowe znaczenie dla aktualnej sytuacji osiedli mieszkaniowych oraz dla ich przyszłości. A. Power w przeciwieństwie do wielu innych badaczy (w tym np. do N. Praka i H. Priemusa), którzy degradację fizyczną osiedli traktują jako skutek ich degradacji społecznej a nie jako przyczynę, bardzo dużą rolę w zachowaniu dobrej struktury społecznej osiedli upatruje $\mathrm{w}$ dobrym zagospodarowaniu ich przestrzeni. Obejmuje ono organizację i utrzymanie osiedlowych przestrzeni publicznych oraz kompozycję i jakość zabudowy, które według tej autorki mają ogromny wpływ na odbiór społeczny osiedli zarówno wewnętrzny (wśród mieszkańców), jak i zewnętrzny. Dobrze zaplanowana, zorganizowana oraz starannie utrzymana przestrzeń publiczna w osiedlach odgrywa jej zdaniem kluczową rolę w jakości warunków mieszkaniowych i może przyczynić się do wzrostu poczucia tożsamości oraz większej integracji społecznej mieszkańców. Jeśli zaś jest odwrotnie, w osiedlach mogą powstawać i nasilać się różnego rodzaju problemy charakterystyczne dla wielkich osiedli mieszkaniowych o zabudowie blokowej. Duże znaczenie w procesie utrzymania osiedli w dobrej kondycji społecznej ma także stan zasobów mieszkaniowych, a szczególnie tej ich części, która jest użytkowana wspólnie przez mieszkańców, czyli wind, klatek schodowych, korytarzy itp. Te - jej zdaniem powinny być zadbane najbardziej, ponieważ ich stan silnie wpływa na postawy mieszkańców i jeśli jest dobry, powstrzymuje ich przed opuszczeniem osiedla, a jeśli zły - przyjmuje charakter czynnika wypychającego, co w konsekwencji powoduje ich degradację społeczną (Power 1997, van Beckhoven $i$ in. 2005).

Kolejny z modeli, który opracowany został $\mathrm{w}$ odniesieniu do wielkich osiedli mieszkaniowych o zabudowie blokowej, ale znajduje zastosowanie $\mathrm{w}$ analizie także innych form zabudowy o charakterze socjalnym jest autorstwa H.S. Andersena (2002). Zdaniem tego autora, analizującego sytuację $\mathrm{w}$ miastach duńskich, degradacja wielkich osiedli mieszkaniowych następuje na skutek procesów kształtowanych przez trzy współzależne elementy. Pierwszy z nich stanowią okoliczności dane (given circumstances), które obejmują warunki na lokalnym rynku mieszkaniowym, koszty utrzymania mieszkań oraz wygląd i wyposażenie osiedli. Drugi to obserwowane problemy (observed problems), do których zalicza bierność i niskie zaangażowanie mieszkańców, problemy społeczne i zachowania patologiczne, problemy związane z napływem imigrantów oraz złą reputację osiedli. Trzecim natomiast są przemiany rezydencjalne (residential changes), które obejmują skład społeczny zarówno obecnych, jak i napływających mieszkańców, a także 
wskaźnik mobilności różnych grup społecznych zamieszkujących osiedle (Andersen 2002).

Osobną grupą teorii służących wyjaśnianiu negatywnych zjawisk zachodzących w wielkich osiedlach o zabudowie blokowej są teorie o charakterze deterministycznym (głównie architektonicznym lub urbanistycznym), które akcentują negatywny wpływ architektury oraz układów przestrzennych stosowanych w wielkich modernistycznych osiedlach mieszkaniowych na zachowania ludzi. Do teorii takich należy między innymi skrajnie deterministyczna teoria brytyjskiej geograf A. Coleman, opublikowana w roku 1985 w pracy Utopia on trial, w której autorka wręcz oskarża architektów o wadliwe projektowanie urbanistyczne i architektoniczne osiedli blokowych, będące jej zdaniem przyczyną większości pojawiających się w nich problemów (Coleman 1985, Wassenberg 2013). Teoria ta jako skrajna wzbudziła w środowisku naukowym duży sprzeciw oraz mnożenie przykładów osiedli, które mimo podobnej struktury przestrzennej i rozwiązań architektonicznych nie uległy procesom degradacji lub uległy im w bardzo niewielkim stopniu (Wojtkun 2004, Wsssenberg 2013). Krytycy A. Coleman skupili się na pokazywaniu, że negatywne procesy zachodzące w osiedlach są kombinacją czynników zewnętrznych oraz wewnętrznych, a struktura przestrzenna osiedli jest tylko jednym $\mathrm{z}$ nich, który $\mathrm{w}$ zależności od szerszego kontekstu społecznego, ekonomicznego oraz politycznego może być mniej lub bardziej ważnym powodem degradacji (Adriaanse 2011, Wassenberg 2013).

Kolejną teorią, którą ze względu na jej determinizm urbanistyczny często stawia się w jednym rzędzie z koncepcją A. Coleman, choć $\mathrm{w}$ istocie jej charakter mieści się na pograniczu teorii urbanistycznych oraz społecznych, jest kryminologiczna teoria "przestrzeni obronnej” (defensible space) ${ }^{28}$ amerykańskiego architekta i planisty O. Newmana z 1972 roku. Była ona twórczym rozwinięciem opublikowanej ponad dekadę wcześniej koncepcji amerykańskiej planistki J. Jacobs ${ }^{29}$. Newmanowska teoria przestrzeni obronnej często przytaczana jest $\mathrm{w}$ analizie przemian wielkich osiedli mieszkaniowych, przede wszystkim na gruncie urbanistyki i architektury (por. Gronostajska 2010a, b, Wassenberg 2013), w szczególności przez badaczy, którzy głównej determinanty nasilenia zachowań przestępczych w tych osiedlach

28 Termin ten w jęz. polskim tłumaczony jest także jako „przestrzeń bezpieczna” lub „przestrzeń broniona" (Jasiński 2013, s. 159).

${ }^{29}$ Jane Jacobs, w głośnej pracy z 1961 roku pt. The Death and LIfe of Great American Cities, analizując przyczyny upadku i poszukując możliwości odradzania się miast amerykańskich, za istotny czynnik wpływający na poprawę bezpieczeństwa uznała powrót ludzi na ulice. Autorka ta, przypominając o roli wspólnoty sąsiedzkiej, pisała o tzw. "oczach na ulicy" sugerując jednocześnie, że ludzie obserwujący innych z okien swoich domów są najlepszą ochroną mieszkańców (Kwiatkowski, Racoń-Leja 2005). 
upatrują $\mathrm{w}$ wadliwym sposobie ich zaprojektowania ${ }^{30}$. Zgodnie $\mathrm{z}$ koncepcją O. Newmana bezpieczeństwo na terenach mieszkaniowych uzależnione jest przede wszystkim od poczucia terytorialności oraz naturalnej kontroli społecznej użytkowanego terenu, związanej z poczuciem odpowiedzialności za określony fragment przestrzeni. Biorąc zaś pod uwagę to, że głównym problemem $\mathrm{w}$ osiedlach mieszkaniowych jest brak wyraźnego wyodrębnienia przestrzeni publicznej, półpublicznej, pólprywatnej oraz prywatnej ${ }^{31} \mathrm{w}$ osiedlach tych niemożliwy jest odpowiedni nadzór społeczny i przestępczość rośnie ${ }^{32}$. Warunkiem skutecznego nadzoru jest według tego autora nie tylko wyraźne wyodrębnienie określonych rodzajów przestrzeni, ale też wyraźny podział odpowiedzialności za każdą z nich. Mieszkańcy odpowiadać powinni za przestrzeń prywatną i półprywatną, właściciele nieruchomości za przestrzenie pólpubliczne oraz częściowo pólprywatne, a władze lokalne (samorząd) za przestrzenie publiczne (Newman 1972). Koncepcja defensible spcae zatem, podobnie jak teoria J. Jacobs, opowiada się za konkretnymi rozwiązaniami planistycznymi i architektonicznymi, które pozwolą na tworzenie $\mathrm{w}$ ramach dużych osiedli małych jednostek sąsiedzkich umożliwia-

${ }^{30}$ Teoria O. Newmana wpisuje się w popularną w środowisku architektów i urbanistów koncepcję zapobiegania przestępczości przez odpowiednie kształtowanie przestrzeni, w literaturze określaną jako CPTED (ang. Crime Prevention Through Environmental Design), która narodziła się w USA na przełomie lat 60. i 70. XX wieku jako koncepcja kryminologiczna zajmująca się sposobami zapobiegania przestępczości przez kombinację czynników związanych z fizycznym zagospodarowaniem przestrzeni oraz czynników psychologicznych związanych z kontrolą społeczną (Czapska, red. 2012). O. Newman (1972) jako architekt w większym stopniu niż inni autorzy zajmujący się zagadnieniami bezpieczeństwa $\mathrm{w}$ miastach skupiał się na konkretnych rozwiązaniach projektowych i architektonicznych zapobiegających przestępczości, co przyniosło jego koncepcji ogromną popularność.

${ }^{31}$ O. Newman wyróżnił cztery rodzaje przestrzeni przyjmując jako kryterium sposób jej wykorzystania: 1) publiczna, która obejmuje miejsca i otwarte i dostępne dla wszystkich, czyli drogi, ulice, place, parki, ogrody, 2) półpubliczna, obejmująca wszystkie przestrzenie przeznaczone do ogólnego użytku znajdujące się pod kontrolą administracyjną, czyli np. budynki administracji publicznej, sklepy, a w osiedlach przestrzeń wokół budynków, otwarte korytarze, windy, klatki schodowe itp. 3) półprywatna, należąca do określonych grup, dzielona $\mathrm{z}$ innymi mieszkańcami, ale wydzielona do użytkowania przez te grupy, w osiedlach są to np. ogródki przydomowe, wspólne wydzielone korytarze, strychy itp., oraz 4) prywatna, właściwa dla jednostki (lub rodziny), obejmująca mieszkania, wnętrza domów i inne miejsca dostępne tylko ich mieszkańcom.

32 Teoria ta w praktyce zweryfikowana została przez F. Wassenberga, autora wieloletnich studiów prowadzonych $\mathrm{w}$ osiedlach mieszkaniowych, $\mathrm{w}$ jednym $\mathrm{z}$ największych osiedli europejskich - Bijlmermeer w Amsterdamie, które doświadcza licznych problemów charakterystycznych dla spirali upadku. W wyniku swoich badań autor ten stwierdził, że największym problemem osiedli jest niezdefiniowana odpowiedzialność za przestrzenie półpubliczne oraz przestrzenie wspólne, użytkowane przez zbyt duże grupy mieszkańców, z którymi nikt się nie utożsamia. Przestrzenie te - między własnym mieszkaniem a ulicą - tym samym stają się przestrzeniami niczyimi (Wassenberg 2013). 
jących społeczny nadzór nad miejscem zamieszkania poprzez uczynienie ludzi odpowiedzialnymi za środowisko, w którym żyją.

Inną teorią, która podobnie jak koncepcja O. Newmanna stosowana jest głównie w kryminologii, lecz służy także wyjaśnianiu czynników wpływających na procesy deterioracji osiedli mieszkaniowych, jest powstała na gruncie socjologii miasta teoria "rozbitych okien” (broken windows) J.Q. Wilsona oraz G.L. Kellinga z 1982 roku (Wilson, Kelling 1982). Koncepcja ta w Polsce znana też jako teoria „wybitych szyb” (Kelling, Coles 2000), w bardzo dużym stopniu, podobnie jak koncepcja A. Power, uwzględnia kwestie związane z zarządzaniem osiedlami, opiera się bowiem na założeniu, że każdy przejaw wandalizmu $\mathrm{w}$ przestrzeni ( $\mathrm{w}$ tym $\mathrm{np}$. tytułowe rozbite okna, ale także nielegalne graffiti, śmiecenie, niszczenie mienia itp.), jeśli nie zostanie $\mathrm{w}$ porę naprawiony lub usunięty, powoduje eskalację dalszych negatywnych zachowań i skutkuje kolejnymi takimi aktami, a w konsekwencji prowadzi do poważniejszych przestępstw. Podstawą sformułowania tej teorii jest założenie zweryfikowane na gruncie psychologii społecznej mówiące o tendencji do lamania norm społecznych w otoczeniu, w którym istnieje tolerancja dla z pozoru drobnych i początkowo niegroźnych negatywnych zachowań.

Jednym z najnowszych oraz najbardziej kompleksowych modeli wyjaśniających przemiany zachodzące $w$ europejskich wielkich osiedlach mieszkaniowych i determinujących ich pozycję we współczesnych miastach jest model podażowo-popytowy, który uwzględnia wpływ bardzo wielu czynników, zaproponowany przez F. Wassenberga, R. Turkingtona i R. van Kempena w zbiorowej pracy z 2004 roku pt. High-rise Housing in Europe: Current Trends and Future Prospects. Według tych autorów do głównych czynników, które mają obecnie i będą miały w przyszłości wpływ na przemiany, a w konsekwencji na pozycję wielkich osiedli mieszkaniowych w krajach europejskich, należą: na poziomie mikro - popyt i podaż na lokalnym/regionalnym/krajowym rynku mieszkaniowym, a na poziomie makro - trendy globalne oraz polityka publiczna odnosząca się do tej formy zabudowy.

W grupie czynników kształtujących popyt na mieszkania w wielkich osiedlach w poszczególnych miastach, regionach i krajach znajdują się: po pierwsze - liczba i struktura gospodarstw domowych (ich wielkość, skład i struktura wieku), będące pochodną przemian demograficznych oraz zmian kulturowych i stylu życia, po drugie - preferencje i aspiracje mieszkaniowe gospodarstw domowych będące konsekwencją zmian stylu życia, indywidualizacji oraz zachwiania typowego dla tradycyjnych społeczeństw cyklu życia rodziny, a także zmian $\mathrm{w}$ organizacji czasu, w tym w sposobach spędzania czasu wolnego. Preferencje te mogą być wysoce zindywidualizowane, ale mogą też podlegać różnym modom, formować się pod wpływem mediów, stereotypów i innych elementów kształtujących świadomość spo- 
łeczną. Trzecim czynnikiem kształtującym popyt na mieszkania w wielkich osiedlach są ograniczenia gospodarstw domowych dotyczące ich zasobów finansowych, ale także zasobów wiedzy, w tym wykształcenia, umiejętności, wiedzy na temat rynku mieszkaniowego, jak również zasobów politycznych i społecznych, czyli sieci i zakresu kontaktów ułatwiających poruszanie się na rynku mieszkaniowym (Wassenberg $\mathrm{i}$ in. 2004).

Do czynników kształtujących podaż mieszkań w wielkich osiedlach należą natomiast według wspomnianych autorów: warunki zamieszkania oferowane $\mathrm{w}$ poszczególnych osiedlach (lokalizacja osiedli, stan ich zagospodarowania i wyposażenia, organizacja przestrzeni publicznych, a także wielkość i struktura zasobów mieszkaniowych, jakość materiałów użytych do ich budowy oraz wykonawstwo, projekt urbanistyczno-architektoniczny osiedla, wysokość zabudowy itp.), które mimo uniformizacji różnią się pomiędzy sobą. Nie mniej istotne znaczenie $\mathrm{w}$ podaży ma także reputacja poszczególnych osiedli oraz tej formy zabudowy „w ogóle" (Wassenberg i in. 2004). Ta zaś, jak pokazują liczne badania percepcji (por. rozdział 6 pracy), tylko w części jest wynikiem obiektywnej oceny walorów wielkich osiedli, $\mathrm{w}$ dużej mierze natomiast jest efektem procesów ich stereotypizacji i stygmatyzacji. Po stronie podażowej, związanej z warunkami oferowanymi przez tę formę zabudowy, znajdują się także, jak w pracy A. Power (1997), jakość zarządzania poszczególnymi osiedlami, która w istotny sposób przyczyniać się może do podnoszenia i obniżania zarówno ich walorów, jak i reputacji.

Wśród megatrendów, czyli trendów działających na poziomie globalnym, europejskim oraz krajowym F. Wassenberg i in. (2004) wymieniają: 1) trendy technologiczne, przyczyniające się do "kurczenia się świata”, do których należą rozwój społeczeństwa informacyjnego i nowych form komunikacji oraz wzrost mobilności przestrzennej33, 2) trendy ekonomiczne związane z globalizacją, zmierzające do integracji i unifikacji europejskiej oraz wzrostu zamożności społeczeństw, 3) trendy polityczne związane z ograniczaniem roli państwa, obejmujące ograniczenie interwencjonizmu państwowego, wzrost roli rynku, a także transformację ustrojową w krajach wschodniej i centralnej Europy, skutkujące ograniczeniem roli państwa w gospodarce, ograniczeniem jego roli opiekunczej, wzrostem roli rynku, upadkiem idei egalitaryzmu oraz zwiększeniem się indywidualnej odpowiedzialności, 4) trendy demograficzne, które obejmują starzenie się ludności i masową, często nielegalną, ekonomiczną oraz polityczną imigrację, 5) trendy społeczno-kulturowe obejmujące wzrost indywidualizmu i zmiany stylu życia oraz tradycyjnego systemu norm i wartości, emancypację kobiet oraz większą

${ }^{33}$ Wzrost mobilności przestrzennej uznany $\mathrm{w}$ tym modelu za efekt działania czynników technologicznych jest również wyrazem czynników społeczno-kulturowych, ekonomicznych, politycznych i innych. 
różnorodność społeczno-kulturową społeczeństw, a także 6) trendy środowiskowe, do których należą wzrost poziomu zagrożenia, obniżenie się poczucia bezpieczeństwa oraz konieczność respektowania wymogów środowiska naturalnego. Ostatnim, odrębnie rozpatrywanym czynnikiem działającym na poziomie makro, determinowanym przez wymienione trendy jest, według tych autorów, polityka mieszkaniowa. Obejmuje ona zarówno politykę generalną, czyli np. kwestie fiskalne, zagadnienia określające strukturę własności, jak i politykę specjalną skupioną na rozwiązywaniu problemów powstałych $\mathrm{w}$ tej formie zabudowy. Może ona działać na poziomie europejskim, krajowym, regionalnym oraz lokalnym, co w praktyce wiąże się ze źródłami jej finansowania (Wassenberg i in. 2004).

Omawiając literaturę, której przedmiotem zainteresowania jest wyjaśnianie przemian zachodzących $\mathrm{w}$ wielkich osiedlach mieszkaniowych, nie można pominąć grupy pozycji traktujących o specjalnej polityce skupionej na rozwiązywaniu problemów powstających w tej formie zabudowy. Elementami owej polityki, niezależnie od jej poziomu (europejski, krajowy, lokalny), są celowe działania zmierzające do przekształceń wielkich osiedli. $\mathrm{W}$ literaturze polskiej działania te, w zależności od stosowanego podejścia, określane są jako modernizacja (Chmielewski, Mirecka 2001, Kozłowski 2005), rewitalizacja (Gorczyca 2009), rehabilitacja (Rębowska 2000, Rębowska i in. 2006), reurbanizacja (Gzell i in. 2009, Gzell 2010, Rembarz 2010), restrukturyzacja (Węcławowicz 2003) lub humanizacja (Misiak 1993, Borowik 2003, 2007, Kozłowski 2010).

Pierwsze z wymienionych pojęć, czyli „modernizacja”, akcentuje przede wszystkim materialny aspekt przekształceń środowiska mieszkaniowego. Według A. Tokajuka (2007) w odniesieniu do osiedli mieszkaniowych postulat modernizacji skupia się na podniesieniu ich walorów użytkowych i dotyczyć może zarówno całych osiedli, jak i pojedynczych budynków, a nawet mieszkań. Określenie to bywa także rozumiane szerzej, jak w pracy J. Chmielewskiego i M. Mireckiej pt. Modernizacja osiedli mieszkaniowych, gdzie definiowane jest jako „dostosowanie osiedla do współczesnych wymogów użytkowych, standardów przyjmowanych dla aktualnie wznoszonych zespołów mieszkaniowych, a przez te działania uzyskiwanie środowiska zamieszkania odpowiadającego współczesnej kulturze" (Chmielewski, Mirecka 2001, s. 11). Według I. Borowik (2003, s. 59) natomiast modernizacja środowiska mieszkaniowego to jego unowocześnianie, udoskonalanie techniczne, architektoniczne i ekonomiczne z uwzględnieniem zwiększenia standardu mieszkań, jak również podniesienia jakości przestrzeni publicznej i półpublicznej. Pojęcie modernizacji w odniesieniu do osiedli, ze względu na jego techniczny i urbanistyczno-architektoniczny wymiar, częściej używane jest przez architektów i urbanistów niż przez geografów i socjologów. Dwa kolejne terminy używane w odniesieniu do celowych prze- 
kształceń osiedli mieszkaniowych to rehabilitacja i rewitalizacja. Określenia te, jak podaje G. Rembarz (2010), mają zbliżone zakresy znaczeniowe i dotyczą działań służących odnowie środowiska mieszkaniowego, przy czym ich zakres według tej autorki jest szerszy niż odnowa techniczna, którą akcentuje się w przypadku działań modernizacyjnych. Według K. Rębowskiej (i in. 2006) termin "rewitalizacja” powinien być zastrzeżony dla starych dzielnic o wartości zabytkowej, a w stosunku do osiedli blokowych powinno się używać pojęcia rehabilitacji. Inni autorzy natomiast (Gzell i in. 2009, Gzell 2010, Rembarz 2010) w analizie celowych przekształceń realizowanych w wielkich osiedlach mieszkaniowych używają określenia „reurbanizacja”, której celem - jak podaje G. Rembarz (2010, s. 144) - jest ",stworzenie krajobrazu miejskiego o cechach katalizujących wzrost poziomu społeczno-kulturalnego, nie zaś ulepszanie osiedla”. Jest to „działanie w celu spowolnienia lub wręcz niedopuszczenia do ich społeczno-kulturowej degradacji, $\mathrm{w}$ wyjątkowych przypadkach dające efekt trwałego zainicjowania samorozwoju dzielnicy" (ibid., s. 144). Reurbanizacja wielkich osiedli mieszkaniowych rozumiana jest jako nadanie tym obszarom cech miejskości utożsamianych z tradycyjną tkanką miejską. Jest procesem, który koncentruje się na kwestii jakości przestrzeni publicznych wielkich osiedli i przywracania im miejskości w warstwie zarówno przestrzennej, jak i społeczno-kulturowej (ibid., s. 143) Do działań podejmowanych w ramach tak rozumianej reurbanizacji należą (Ziobrowski 1998):

- intensyfikowanie użytkowania przestrzeni miejskiej;

- uzupełnianie struktur zmierzające do koncentracji zabudowy;

- różnicowanie wprowadzanych funkcji;

- podwyższanie standardu obiektów i urządzeń;

- kształtowanie krajobrazu miejskiego poprzez aranżację i wzbogacanie form architektonicznych elementami śródmiejskiej scenografii.

Ostatnie $\mathrm{z}$ wymienionych pojęć używanych w literaturze $\mathrm{w}$ odniesieniu do przekształceń wielkich osiedli mieszkaniowych, to pojęcie humanizacji, które ma najszerszy zakres znaczeniowy. Termin ten, jako wywiedziony z humanizmu, czyli postawy moralnej i intelektualnej zakładającej, że człowiek jest najwyższą wartością i źródłem innych wartości, według Słownika języka polskiego PWN oznacza dostosowanie czegoś do potrzeb i możliwości człowieka. W literaturze naukowej teoretyczne aspekty humanizacji wielkich osiedli oraz praktyczny wymiar tego procesu najszerzej omawia I. Borowik w pracy Blokowiska - miejski habitat w ogladzie socjologicznym z 2003 ro$\mathrm{ku}$. Według tej autorki humanizacja oznacza „proces przekształcania habitatu $\mathrm{w}$ celu zapewnienia jego mieszkańcom takich warunków zamieszkiwania, które w pełni zaspokajałyby całokształt ich potrzeb" $(2003$, s. 50). W odniesieniu do miejskiego środowiska mieszkaniowego, jakim jest wielkie 
osiedle o zabudowie blokowej, humanizacja ma oznaczać restytucję indywidualizmu i ludzkiej skali, a także takich wartości humanistycznych, jak: spokój, intymność, swojskość, bezpieczeństwo, estetyka oraz harmonia budowli i krajobrazu (ibid., s. 51). Ma zatem być tworzeniem Tuanowskiego „miejsca". Postulatywny charakter tego procesu sprawia, że humanizacja często pozostaje ideą, celem, dążeniem, ponieważ, jak zauważa ta autorka - „nie jest stanem, który można będzie kiedykolwiek osiągnąć i przyjąć z zadowoleniem" (ibid., s. 51). Teoretyczne rozważania nad humanizacją wielkich osiedli pozwoliły wyróżnić sześć aspektów tego procesu, do których należą: psychospołeczny, urbanistyczny, architektoniczny, estetyczny, techniczny oraz ekologiczny (tab. 4).

Tab. 4. Aspekty humanizacji osiedli mieszkaniowych

\begin{tabular}{|l|l|}
\hline \multicolumn{1}{|c|}{ Aspekt } & \multicolumn{1}{|c|}{ Szczegółowe działania zmierzające do humanizacji osiedla } \\
\hline Psychospołeczny & $\begin{array}{l}\text { Podniesienie poczucia świadomości i doświadczania środowiska mieszka- } \\
\text { niowego jako „miejsca" - mojego, naszego, wspólnego, upodmiotowienie } \\
\text { użytkowników przekształcanego habitatu, pobudzenie ich współodpo- } \\
\text { wiedzialności za swój habitat, a także budowanie bądź intensyfikacja } \\
\text { więzi sąsiedzkich i integracja społeczna mieszkańców. }\end{array}$ \\
\hline Urbanistyczny & $\begin{array}{l}\text { Wprowadzanie nowych rozwiązań w układzie przestrzennym osiedla i je- } \\
\text { go relacjach z otoczeniem, nowe zakomponowanie tras komunikacyjnych, } \\
\text { zieleni i małej architektury, przywrócenie archetypu ulicy, środka, odejś- } \\
\text { cie od monofunkcyjności przestrzeni mieszkaniowych. }\end{array}$ \\
\hline Architektoniczny & $\begin{array}{l}\text { Zewnętrzne przekształcanie budynków, różnicowanie ich form, kształtów } \\
\text { i wysokości, wprowadzenie lub zintensyfikowanie małej architektury, } \\
\text { detalu architektonicznego, archetypu przodu i tyłu budynków, wewnętrz- } \\
\text { ne przekształcenia budynków polegające na poprawie jakości półprywat- } \\
\text { nej/półpublicznej przestrzeni klatek schodowych i wewnętrznych koryta- } \\
\text { rzy oraz mieszkań, przystosowanie półprywatnej/ półpublicznej prze- } \\
\text { strzeni do potrzeb osób starszych i niepełnosprawnych. }\end{array}$ \\
\hline Estetyczny & $\begin{array}{l}\text { Nadanie lub przywrócenie utraconych walorów estetycznych: piękna har- } \\
\text { monii, kolorystyki, dbałości o detal, gry form i barw w elewacjach budyn- } \\
\text { ków. }\end{array}$ \\
\hline Poprawa stanu budynków od strony technicznej i budowlanej. \\
\hline Techniczny & $\begin{array}{l}\text { Wprowadzenie zieleni lub zintensyfikowanie jej ilości, równoważenie re- } \\
\text { lacji człowiek-przestrzeń oraz habitat-krajobraz naturalny, dbałość o śro- } \\
\text { dowisko naturalne, zwiększenie i poprawa jakości miejsc przeznaczonych } \\
\text { na wypoczynek i zabawę na świeżym powietrzu. }\end{array}$ \\
\hline Ekologiczny & \\
\hline
\end{tabular}

Źródło: opracowanie własne na podstawie Z. Bać (1994) oraz I. Borowik (2003).

Omówione powyżej koncepcje wyjaśniające przemiany zachodzące $\mathrm{w}$ osiedlach mieszkaniowych odwołują się do dwóch zasadniczych grup czynników wyróżnionych za E. van Beckohoven i in. (2005), które te prze- 
miany determinują. Pierwsza z nich to czynniki endogeniczne, działające na poziomie mikro, analizowane $\mathrm{w}$ odniesieniu do pojedynczych osiedli lub ich grup i uwarunkowane sytuacją w tych osiedlach, druga zaś to czynniki egzogeniczne funkcjonujące na poziomie mezo i makro, zewnętrzne w stosunku do osiedli (tab. 5).

Tab. 5. Determinanty przemian środowisk mieszkaniowych wyodrębnione $\mathrm{w}$ literaturze światowej stosowane w odniesieniu do wielkich osiedli

\begin{tabular}{|c|c|}
\hline Determinanty & $\begin{array}{l}\text { Autorzy podkreślający szczególną rolę } \\
\text { wymienionych determinant }\end{array}$ \\
\hline [1] & {$[2]$} \\
\hline \multicolumn{2}{|c|}{$\begin{array}{l}\text { Endogeniczne, działające na poziomie mikro } \\
\text { (w skali pojedynczych osiedli lub ich grup) }\end{array}$} \\
\hline $\begin{array}{l}\text { Wyjściowa jakość zasobu } \\
\text { mieszkaniowego }\end{array}$ & $\begin{array}{l}\text { N.L. Prak, H. Priemus (1986), A. Power (1997), } \\
\text { F. Wassenberg i in. (2004) }\end{array}$ \\
\hline $\begin{array}{l}\text { Obecne warunki zamieszkania } \\
\text { w osiedlu }\end{array}$ & $\begin{array}{l}\text { N.L. Prak, H. Priemus (1986), W. Grigsby i in. (1987), } \\
\text { A. Power (1997), H.S. Andersen (2002), } \\
\text { F. Wassenberg i in. (2004) }\end{array}$ \\
\hline $\begin{array}{l}\text { Nasycenie infrastrukturą społeczną } \\
\text { i usługowo-handlową }\end{array}$ & $\begin{array}{l}\text { N.L. Prak, H. Priemus (1986), A. Power (1997) } \\
\text { H.S. Andersen (2002), F. Wassenberg i in. (2004) }\end{array}$ \\
\hline $\begin{array}{l}\text { Architektura i zastosowane układy } \\
\text { zabudowy }\end{array}$ & $\begin{array}{l}\text { O. Newman (1972), A. Coleman (1985), N.L. Prak, } \\
\text { H. Priemus (1986), A. Power (1997), H.S. Andersen } \\
(2002)\end{array}$ \\
\hline Zarządzanie osiedlem & $\begin{array}{l}\text { J.Q. Wilson, G.L. Kelling (1982), N.L. Prak, } \\
\text { H. Priemus (1986), W. Grigsby i in. (1987), } \\
\text { K. Temkin, W.M. Rohe (1996), A. Power (1997), } \\
\text { F. Wassenberg i in. (2004) }\end{array}$ \\
\hline $\begin{array}{l}\text { Stan utrzymania przestrzeni } \\
\text { publicznych }\end{array}$ & $\begin{array}{l}\text { J.Q. Wilson, G.L. Kelling (1982), A. Power (1997), } \\
\text { H.S. Andersen (2002), F. Wassenberg i in. (2004) }\end{array}$ \\
\hline $\begin{array}{l}\text { Stan utrzymania zasobów } \\
\text { mieszkaniowych }\end{array}$ & $\begin{array}{l}\text { N.L. Prak, H. Priemus (1986), W. Grigsby i in. (1987), } \\
\text { A. Power (1997), H.S. Andersen (2002), F. Wassen- } \\
\text { berg i in. (2004) }\end{array}$ \\
\hline Lokalizacja osiedla & $\begin{array}{l}\text { N.L. Prak, H. Priemus (1986), W. Grigsby i in. (1987), } \\
\text { H.S. Andersen (2002), F. Wassenberg i in. (2004) }\end{array}$ \\
\hline Struktura własności mieszkań & $\begin{array}{l}\text { N.L. Prak, H. Priemus (1986), H.S. Andersen (2002), } \\
\text { F. Wassenberg i in. (2004) }\end{array}$ \\
\hline $\begin{array}{l}\text { Poziom zamożności i źródła docho- } \\
\text { dów mieszkańców (w tym relacja } \\
\text { kosztów utrzymania mieszkań } \\
\text { i dochodów) }\end{array}$ & $\begin{array}{l}\text { N.L. Prak, H. Priemus (1986), W. Grigsby i in. (1987), } \\
\text { H.S. Andersen (2002), F. Wassenberg i in. (2004) }\end{array}$ \\
\hline $\begin{array}{l}\text { Więzi społeczne łączące mieszkań- } \\
\text { ców i poczucie przywiązania do } \\
\text { miejsca zamieszkania }\end{array}$ & $\begin{array}{l}\text { N.L. Prak, H. Priemus (1986), K. Temkin, W.M. Rohe } \\
\text { (1996), A. Power (1997), H. S. Andersen (2002) }\end{array}$ \\
\hline $\begin{array}{l}\text { Struktura społeczno-demograficzna } \\
\text { i status społeczny mieszkańców }\end{array}$ & N.L. Prak, Premius (1986), F. Wassenberg i in. (2004) \\
\hline
\end{tabular}




\begin{tabular}{|c|c|}
\hline [1] & [2] \\
\hline \multicolumn{2}{|c|}{$\begin{array}{l}\text { Egzogeniczne, działające na poziomie } \\
\text { mezo i makro: }\end{array}$} \\
\hline \multicolumn{2}{|r|}{ w skali lokalnej } \\
\hline $\begin{array}{l}\text { Warunki zamieszkania w osiedlu } \\
\text { w relacji do innych zasobów } \\
\text { dostępnych na lokalnym rynku } \\
\text { mieszkaniowym }\end{array}$ & $\begin{array}{l}\text { N.L. Prak H. Priemus (1986), W. Grigsby i in. (1987), } \\
\text { H.S. Andersen (2002), F. Wassenberg i in. (2004) }\end{array}$ \\
\hline $\begin{array}{l}\text { Lokalny rynek pracy i możliwości } \\
\text { ekonomiczne mieszkańców miasta }\end{array}$ & F. Wassenberg $\mathrm{i}$ in. (2004) \\
\hline $\begin{array}{l}\text { Struktura społeczna i demograficzna } \\
\text { mieszkańców miasta (w tym liczba } \\
\text { i struktura gospodarstw domowych) } \\
\end{array}$ & F. Wassenberg i in. (2004) \\
\hline $\begin{array}{l}\text { Reputacja i prestiż osiedla na } \\
\text { lokalnym runku mieszkaniowym }\end{array}$ & $\begin{array}{l}\text { N.L. Prak, H. Priemus (1986), W. Grigsby i in. (1987), } \\
\text { H.S. Andersen (2002), F. Wassenberg i in. (2004) }\end{array}$ \\
\hline \multicolumn{2}{|c|}{$\begin{array}{c}\text { w skali ponadlokalnej } \\
\text { (krajowej i międzynarodowej) }\end{array}$} \\
\hline Przemiany ekonomiczne & $\begin{array}{l}\text { K. Temkin, W.M. Rohe (1996), W. Grigsby i in. } \\
\text { (1987), N.L. Prak, H. Priemus (1986), H.S. Andersen } \\
\text { (2002), F. Wassenberg i in. (2004) }\end{array}$ \\
\hline $\begin{array}{l}\text { Przemiany społeczno-demograficz- } \\
\text { ne w tym w liczbie i strukturze gos- } \\
\text { podarstw domowych }\end{array}$ & W. Grigsby $i$ in. (1987), F. Wassenberg $i$ in. (2004) \\
\hline $\begin{array}{l}\text { Przemiany technologiczne, w szcze- } \\
\text { gólności związane z rozwojem trans- } \\
\text { portu i nowych form komunikacji }\end{array}$ & W. Grigsby $i$ in. (1987), F. Wassenberg $i$ in. (2004) \\
\hline $\begin{array}{l}\text { Polityka mieszkaniowa, społeczna } \\
\text { i fiskalna państwa }\end{array}$ & $\begin{array}{l}\text { N.L. Prak, H. Priemus (1986), W. Grigsby i in. (1987), } \\
\text { F. Wassenberg i in. (2004) }\end{array}$ \\
\hline $\begin{array}{l}\text { Reputacja i prestiż zabudowy } \\
\text { blokowej „w ogóle” }\end{array}$ & $\begin{array}{l}\text { N.L. Prak, H. Priemus (1986), K. Temkin, W.M. Rohe } \\
\text { (1996), A. Power (1997), H.S. Andersen (2002), } \\
\text { Wassenberg i in. (2004) }\end{array}$ \\
\hline $\begin{array}{l}\text { Przemiany stylu życia i wzorów ro- } \\
\text { dziny oraz związane z tym przemia- } \\
\text { ny aspiracji mieszkaniowych }\end{array}$ & W. Grigsby $i$ in. (1987), F. Wassenberg $i$ in. (2004) \\
\hline
\end{tabular}

Źródło: opracowanie własne.

Koncepcje te, jakkolwiek często przytaczane $\mathrm{w}$ analizie przemian zachodzących $\mathrm{w}$ osiedlach mieszkaniowych miast zachodnich, nie dadzą się wprost zastosować do przemian osiedli w mieście postsocjalistycznym. Wyjaśnianie przemian środowisk mieszkaniowych $\mathrm{w}$ miastach wymaga bowiem uwzględnienia kontekstu historycznego i uwarunkowań społecznych, ekonomicznych oraz politycznych, w jakich środowiska te powstawały, przez wiele lat funkcjonowały i wciąż funkcjonują. Przyjęty w pracy na podstawie literatury (por. van Beckhoven i in. 2009), podział tych koncepcji na amerykańskie i europejskie wynika nie tylko różnic w miejscu ich pow- 
stania, ale przede wszystkim z różnych uwarunkowań społeczno-ekonomicznych i politycznych, w jakich powstawały, a w konsekwencji różnych problemów jakich dotyczą. Modele amerykańskie (zarówno z lat 20. XX wieku jak i z okresu powojennego) odwoływały się do rynku mieszkaniowego oraz działania renty gruntowej i mechanizmów cenowych, mają zatem charakter uniwersalny i odnoszą się do różnych środowisk mieszkaniowych ( $w$ tym także do wielkich osiedli). Koncepcje europejskie natomiast (poza nielicznymi) koncentrowały się przede wszystkim na mieszkalnictwie socjalnym, które w znacznie większym stopniu jest uzależnione od modelu polityki mieszkaniowej przyjętej $\mathrm{w}$ danym kraju. Ich powstawanie było reakcją na poważne problemy, które na określonym etapie rozwoju pojawily się w osiedlach krajów zachodnich, a ich głównym celem było dostarczenie wiedzy, która pomogłaby te problemy choć częściowo rozwiązać lub zapobiec ich dalszemu rozwojowi. Uwzględniały one jednak przede wszystkim problemy powstające $\mathrm{w}$ zasobach mieszkaniowych sektora publicznego, który był dominującym sektorem w strukturze własności zasobów w wielkich osiedlach tych krajów.

Warunki, w jakich funkcjonują osiedla w miastach krajów Europy Środkowo-Wschodniej, mimo że na skutek transformacji ustrojowej i liberalizacji rynku mieszkaniowego w znacznej mierze upodobniły się warunków $\mathrm{w}$ miastach zachodnioeuropejskich i amerykańskich, to jednak wciąż charakteryzują się daleko idącą specyfiką. Specyfika ta wynika po pierwsze $\mathrm{z}$ ich socjalistycznej przeszłości, kiedy zachowując formę przestrzenną i sposób dystrybucji mieszkań charakterystyczny dla budownictwa socjalnego (duża koncentracja niewielkich mieszkań, dystrybuowanych w formie przydziału i dostępnych "dla każdego"), miały heterogeniczną strukturę społeczną reprezentującą wszystkie kategorie statusowe (także te najwyższe), po drugie zaś z ich bardzo znaczącego udziału w strukturze zasobów mieszkaniowych w miastach oraz daleko idącej prywatyzacji po 1990 roku.

Jakakolwiek jednak wymienione teorie i modele są wyrazem czasu i miejsca, w którym powstały, to ustalenia ich autorów w wielu przypadkach prowadzą do podobnych wniosków. A każda z tych koncepcji, które traktować można także jako komplementarne, wyjaśniające przemiany z różnych punktów widzenia lub kładące nacisk na inne aspekty tego samego zjawiska, zawiera wiele elementów, które z pewnymi ograniczeniami można zastosować do przemian zachodzących $\mathrm{w}$ osiedlach miast postsocjalistycznych, które są przedmiotem analiz zawartych w dalszej części pracy. 


\section{GENEZA I UWARUNKOWANIA ROZWOJU WIELKICH OSIEDLI MIESZKANIOWYCH W MIASTACH EUROPEJSKICH}

Na przestrzeni wieków powstawało wiele idei urbanistycznych i społecznych zarazem, które dążyły do stworzenia uniwersalnego, idealnego środowiska mieszkaniowego, np. koncepcja platońskiej „Atlantydy” czy też „Miasta Słońca" Tomasza Campanelli ${ }^{34}$. Największy rozwój takich koncepcji nastąpił na przełomie XVIII i XIX wieku wraz z początkiem rewolucji przemysłowej, czyli w momencie narodzenia się współczesnej urbanistyki, która według W. Ostrowskiego (1975, s. 12) „mogła narodzić się dopiero po pojawieniu się nowoczesnego miasta - wytworu cywilizacji przemysłowej".

Koncepcje te podzielić można na dwie zasadnicze grupy (Słodczyk 2012, s. 340). Pierwsze $\mathrm{z}$ nich związane były z ideą tzw. ville sociale (miasta społecznego) i obejmowały projekty osiedli robotniczych, których forma przestrzenna $\mathrm{w}$ harmonijny sposób miała połączyć pracę $\mathrm{w}$ przemyśle $\mathrm{z}$ odpowiednimi warunkami życia pod względem sanitarnym i środowiskowym. Należą do nich projekt miasta idealnego Chaux ${ }^{35}$, który stworzył dla robotników kopalni soli w końcu XVIII wieku we Francji C.N. Ledoux wizjonerski architekt uważany za prekursora nowoczesnej architektury, a także oparte na kolektywizacji życia mieszkańców projekty socjalistów utopijnych: myśliciela Ch. Fouriera, autora koncepcji Falansteru oraz

${ }^{34} \mathrm{~W}$ literaturze z zakresu historii urbanistyki omówionych jest wiele koncepcji tzw. miast idealnych i miast utopijnych począwszy od projektu starożytnego miasta chińskiego pochodzącego z końca II tysiąclecia p.n.e. i starożytnego indyjskiego miasta idealnego, poprzez koncepcje renesansowe aż do projektów współczesnych (por. Benevolo 1995, Ostrowski 1975, 2001, Chmielewski 2001, Czarnecki 2002, Wojtkun 2004, Słodczyk 2012).

35 Projekt ten wzorowany na projekcie pałacu w Wersalu uwzględniał centralną pozycję pałacu dyrektora, co symbolizowało istniejąca hierarchię społeczną i centralizację władzy, ale jego otoczenie w postaci budynków produkcyjnych, usługowych i mieszkaniowych wyrażało nową koncepcję stosunków społecznych. Osiedle to miało być wyposażone w liczne urządzenia uwzględniające zarówno techniczne wymogi produkcji, jak i różnorodne potrzeby bytowe mieszkańców (sklepy, szpital, łaźnia, szkoła, dom kultury, kościół, biblioteka) i było wyrazem wiary, że poprzez odpowiednio zorganizowaną przestrzeń oraz architekturę można oddziaływać na poprawę stosunków międzyludzkich i ograniczać sprzeczności społeczne (Jałowiecki, Szczepański 2006). 
przedsiębiorcy R. Owena, prekursora ruchu spółdzielczego, twórcy modeli tzw. wsi przemysłowych i osiedla-komuny dla robotników przędzalni New Lenark w Szkocji.

Druga grupa koncepcji, powstałych na przełomie XIX i XX wieku oraz w okresie międzywojennym, wymaga szerszego omówienia, ponieważ należą do niej projekty, które wywarly znacznie większy wpływ na kształtowanie się osiedli mieszkaniowych $\mathrm{w}$ powojennej Europie. W większości $\mathrm{z}$ nich dążono do ograniczenia koncentracji i rozluźnienia zabudowy, zwiększenia roli terenów zielonych $\mathrm{w}$ przestrzeni miasta, szczególnie w pobliżu zabudowy mieszkaniowej, oraz oddzielenia terenów przemysłowych od mieszkalnictwa (Słodczyk 2012). Do koncepcji tych należą: koncepcja miast ogrodów E. Howarda, która próbowała łączyć zalety życia w mieście i na wsi, minimalizując niedogodności obu tych środowisk mieszkaniowych, koncepcja "miasta przemysłowego" T. Garniera z funkcjonalnym podziałem przestrzeni miejskiej, pasmowo-liniowe koncepcje osadnictwa A. Soria y Mata i N. Milutina, projekt jednostki sąsiedzkiej C.A. Perry'ego, koncepcje Le Corbusiera i domów-komun w ZSRR oraz idea miasta funkcjonalnego zaproponowana w Karcie Urbanistyki uchwalonej na IV Międzynarodowym Kongresie Architektury Nowoczesnej (CIAM) w 1933 roku, znanej jako Karta Ateńska. Na szczególną uwagę zasługuje także powstała w latach 20. minionego stulecia w Niemczech koncepcja "osiedla społecznego", rozwijana od lat 30. w polskiej myśli urbanistycznej, której głównymi przedstawicielami byli uczestnicy polskiej grupy CIAM - B. i S. Brukalscy oraz H. i Sz. Syrkusowie.

\subsection{Koncepcje urbanistyczno-architektoniczne z XIX i z I połowy XX wieku}

Jedną z pierwszych XIX-wiecznych koncepcji urbanistycznych, odznaczającą się na tyle dużą dojrzałością, że mimo swego utopijnego charakteru miała szanse z pewnymi ograniczeniami zaistnieć $\mathrm{w}$ praktyce ${ }^{36}$, jest wzorowany na Wersalu projekt Falansteru francuskiego filozofa Charlesa Fouriera z 1830 roku, który polegał na tworzeniu wspólnot łączących kolektywną pracę $\mathrm{w}$ przemyśle i rolnictwie. Zaprojektowana w tej koncepcji wspólnota, określana jako Falanga licząca 1620 osób, miała składać się z ludzi wolnych i równych, którzy sami mieli zarządzać miastem, pracą i życiem codzien-

36 Utopijną z założenia koncepcję Falansteru udało się częściowo zrealizować francuskiemu przedsiębiorcy J.B. Godine'owi założycielowi kompleksu produkcyjno-mieszkaniowego określanego jako Familister (Chmielewski 2001). 
nym zorganizowanym w duchu skrajnego kolektywizmu (Kania 2010). Największy gmach wspólnoty, centralny pałac zwany Falansterem, miał być wyposażony w obiekty nazywane dzisiaj obiektami użyteczności publicznej, które przeznaczone były do realizacji czynności zbiorowych. Budynki miały być ustawione $\mathrm{w}$ formie kwadratu $\mathrm{z}$ centralnie położonym dziedzińcem honorowym usytuowanym przed pałacem (Chmielewski 2001).

Autorem kolejnego projektu, którego idea jako skrajnie utopijna nie mogła jednak zaistnieć w praktyce, był Robert Owen, który idealną organizację struktury przestrzennej osiedla widział $\mathrm{w}$ formie budowli opartych na planie czworoboku, gdzie okalające budynki przeznaczone były na funkcje mieszkalne i usługowe, natomiast we wnętrzu mieścily się budynki do użytku całej społeczności. Liczba mieszkańców miała wynosić od 300 do 1200. Wizja R. Owena, podobnie jak koncepcja Ch. Fouriera, oparta była na krytyce ustroju kapitalistycznego oraz przekonaniu, że zorganizowana forma zbiorowego gospodarowania (kolektywizm) jest podstawą zaistnienia społeczeństwa idealnego (Wojtkun 2004). Owenowskie tzw. wsie przemysłowe miały łączyć walory życia wiejskiego z funkcjami przemysłowymi, co miało stanowić alternatywę dla ówczesnych niezdrowych miast (Ostrowski 1975).

Wymienione modele miast tworzone przez socjalistów utopijnych, mimo że niedoskonałe i nierealne ${ }^{37}$, stanowiły inspirację dla późniejszych kierunków rozwoju planowania urbanistycznego. Według Ch. Jencksa (1987) i L. Benevolo (1995) istnieje wyraźny związek Falansteru Ch. Fouriera z jednostką mieszkaniową Le Corbusiera poprzez z góry określoną liczbę mieszkańców, scentralizowane usługi i odpowiednie wyposażenie dziedzińca. Przemyślenia pierwszych socjalistów znalazły wyraz również w koncepcji miast ogrodów E. Howarda (Słodczyk 2012). Jak zauważa natomiast B. Jałowiecki, mimo że te skrajnie kolektywistyczne wizje nie miały bezpośredniego wpływu na rzeczywiste procesy wytwarzania przestrzeni, to jednak odegrały istotną rolę w późniejszym kształtowaniu się doktryn urbanistycznych, ponieważ ich echa odnaleźć można w radzieckich projektach domów komun z lat 20. XX w., w koncepcjach Le Corbusiera oraz planach "osiedla społecznego" rozwijanych przez lewicowe środowisko polskich architektów w okresie międzywojennym (Jałowiecki, Szczepański 2006).

Kolejną ważną koncepcją urbanistyczną, która wywarła istotny wpływ na kształtowanie się zasad planowania miast w XX wieku był model miasta ogrodu opracowany przez brytyjskiego stenografa Ebenezera Howarda.

37 O ile utopijną koncepcję Falansteru udało się częściowo zrealizować w praktyce, to projekty R. Owena próbowano realizować co najmniej kilkakrotnie (m.in. w Szkocji - częściowa realizacja projektu komuny dla robotników przędzalni New Lenark oraz w USA - próba realizacji gminy "New Harmony”), lecz wszystkie próby zakończone były fiaskiem (Jałowiecki, Szczepański 2006). 
Autor ten w pracy z 1898 roku pt. To-morrow, która w kolejnym wydaniu (1902) została zatytułowana Garden Cities of To-morrow, w reakcji na żywiołowy rozrost aglomeracji londyńskiej i gwałtowne pogorszenie warunków życia mieszkańców przedstawił koncepcję miasta ogrodu (Howard 1902). Koncepcja ta była próbą połączenia dwóch odmiennych sposobów organizacji przestrzeni i życia społecznego charakterystycznych dla miasta oraz dla wsi (Jałowiecki, Szczepański 2006). Miasta ogrody przewidziane dla 32 tys. mieszkańców miały być samowystarczalnymi strukturami osiedleńczymi opartymi na rzucie okręgu, z radialnym podziałem przestrzeni, gdzie każdy z sześciu planowanych pierścieni przeznaczony był na inne funkcje. $\mathrm{W}$ centralnym punkcie E. Howard przewidywał park $\mathrm{z}$ otaczającymi go usługami społeczno-kulturalnymi, natomiast strefa mieszkaniowa, składająca się z dwóch pierścieni zabudowy, przedzielona była pasmem zieleni parkowej, w którym planowano lokalizację szkól, kościołów oraz placów zabaw dla dzieci (Kania 2010). W myśli E. Howarda dostrzega się pierwsze próby podziału miasta na strefy funkcjonalne i oddzielenie miejsc zamieszkania od miejsc pracy i usług, które stały się podstawą późniejszych koncepcji strefowania miasta (m.in. w pracach Le Corbusiera oraz funkcjonalistów Karty Ateńskiej). Główną ideą E. Howarda było zapewnienie mieszkańcom odpowiednich warunków życia. Miało to polegać nie tylko na wprowadzeniu odpowiedniej ilości terenów zielonych, właściwym wyposażeniu $\mathrm{w}$ usługi wraz z kształtowaniem miejsc centralnych, będących zalążkiem przestrzeni integralnych danych społeczności, ale również na odpowiednim stosunku liczby mieszkańców do liczby miejsc pracy i właściwym rozwiązaniu kwestii komunikacyjnych (Ostrowski 2010).

Inną koncepcją, która $\mathrm{w}$ znacznie większym stopniu rozwinęła ideę funkcjonalnego strefowania przestrzeni był projekt miasta przemysłowego (cite industrielle), francuskiego architekta Tony'ego Garniera opublikowany w 1917 roku. Autor ten, uważany za pioniera współczesnej urbanistyki (Pawłowski 1972), podobnie jak E. Howard, chciał stworzyć koncepcję ośrodka, który łączy możliwość pracy w przemyśle $\mathrm{z}$ dobrymi warunkami życia. W jego koncepcji teren miasta został podzielony na trzy strefy: produkcyjno-przemysłową, mieszkaniową oraz tzw. strefę higieniczną, w której miały być zlokalizowane obiekty infrastruktury technicznej oraz tereny rekreacyjne (Słodczyk 2012). Miasto miało być podzielone na długie, wąskie parcele o wymiarach 150 na $30 \mathrm{~m}$ biegnące ze wschodu na zachód w celu właściwej orientacji pomieszczeń w budynkach. Domy mieszkalne miały być otoczone zielenią i zlokalizowane na dobrze nasłonecznionym terenie. Odseparowane strefy o różnych funkcjach miały być połączone sprawnie działającą komunikacją, która zapewniała łatwy dojazd do miejsc pracy. T. Garnier przewidywał segregację ruchu pieszego i kołowego, a także wy- 
odrębnienie ulic ruchu szybkiego i wolnego. Liczba mieszkańców miasta miała wynosić ok. 35 tys. (Garnier 1917, cyt. za: Wiebenson 1969).

Oba omówione projekty, miast ogrodów oraz miasta przemysłowego, łączy idea funkcjonalnego strefowania przestrzeni miejskiej, która stała się podstawą planowania urbanistycznego w II połowie XX wieku. Lecz zarówno E. Howard jak i T. Garnier operowali w swych koncepcjach podobną, niewielką skalą wielkości miasta (ok. 35 tys.), co nie jest bez znaczenia, bowiem jak uważa B. Jałowiecki i M.S. Szczepański (2006, s. 124) jej przekroczenie, które obserwuje się $\mathrm{w}$ miastach współczesnych, pozbawia plan segregacji funkcji społecznego i ekonomicznego sensu.

Omawiając koncepcje, które miały istotny wpływ na tworzenie przestrzeni mieszkaniowych w II połowie $X X$ wieku wiele uwagi należy poświęcić koncepcjom jednego z najbardziej wpływowych architektów i urbanistów tego stulecia, jakim był Charles Édouard Jeanneret znany jako Le Corbusier - jeden z prekursorów zunifikowanego, kolektywnego budownictwa, które na masową skalę rozwinęło się $\mathrm{w}$ powojennych miastach europejskich. Dzięki jego pracom upowszechniła się nowa forma budynku mieszkalnego, a także nowa, odmienna od dotychczasowych, koncepcja rozmieszczenia budynków w przestrzeni. $W$ jego projektach zabudowa mieszkaniowa przybiera postać zespołu wielkich luźno rozmieszczonych brył, co oznaczało odejście od zasady obrzeżnej zabudowy ulic (Chmielewski 2001). Le Corbusier już w latach 20 . XX wieku proponował uprzemysłowione formy budownictwa (w fabrykach domów) i wznoszenie ich z gotowych elementów montowanych na miejscu (Ostrowski 2001). Jedną z jego idei społecznych było "pogodzenie dwóch pojęć tak całkowicie przeciwstawnych, jakimi są jednostka i zbiorowość" (Jencks 1982, s. 79). Wśród licznych wizji tego architekta, opracowanych w okresie przed IV CIAM, na uwagę zasługują przede wszystkim futurystyczna koncepcja znana pod nazwą "miasto współczesne", a w nim bloki-wille, projekt domów w Pessac oraz koncepcja "miasto promienne".

Koncepcja miasta współczesnego (la ville contemporaine) opracowana przez Le Corbusiera w 1922 roku przewidziana była dla 3 mln mieszkańców. Przy jej projektowaniu autor uwzględnił podstawowe założenia wzorowane na koncepcji T. Garniera: zmniejszenie zatłoczenia centrum, wzrost gęstości zabudowy mieszkaniowej, poprawę komunikacji (poprzez rozdzielenie ruchu pieszego i kołowego), zwiększenie ilości zieleni w mieście (,miasto $\mathrm{w}$ parku”) oraz rozdzielenie funkcjonalne przestrzeni miejskiej ${ }^{38}$

${ }^{38} \mathrm{~W}$ projekcie miasta współczesnego obecna była idea, z której Le Corbusier zrezygnował $\mathrm{w}$ późniejszych pracach, a mianowicie strefowanie miasta $\mathrm{w}$ zależności od statusu społecznego mieszkańców: $w$ centrum miały znajdować się domy przeznaczone dla elity biznesu i klasy średniej, na obrzeżach zaś domy dla robotników. Z czasem główną cechą projektów 
(Jencks 1982, von Moos 2009). Charakterystycznymi elementami tego projektu były 24 sześćdziesięciopiętrowe wieżowce w centrum miasta oraz tzw. bloki-wille (immeubles villas), które stanowily istotny krok na drodze rozwoju nowoczesnego budownictwa osiedlowego (Misiak 1993). Projektowane bloki-wille (stanowiące formę pośrednią między budownictwem jednoi wielorodzinnym) Le Corbusier planował wyposażyć w liczne wspólne dla wszystkich mieszkań urządzenia usługowe, które miały uwolnić gospodynie domowe od uciążliwych zajęć. Idea ta, określana jako „przedłużanie domu" (Ostrowski 2001) znalazła naśladowców w ówczesnym Związku Radzieckim, gdzie bloki-wille (choć projektowane $\mathrm{w}$ innych realiach ustrojowych) stały się wzorcem kolektywnego budownictwa mieszkaniowego w formie tzw. domów-komun ze wspólnymi dla wszystkich mieszkańców urządzeniami społecznymi typu stołówka, sala gimnastyczna, biblioteka i inne ${ }^{39}$ (Jencks 1982).

Następnym krokiem w historii rozwoju standaryzowanej architektury osiedlowej była budowa zaprojektowanego przez Le Corbusiera w 1925 ro$\mathrm{ku}$ osiedla domów robotniczych $\mathrm{w}$ Pessac na przedmieściach Bordeaux (Jencks 1982). Osiedle przeznaczone dla robotników cukrowni miało być nowością nie tylko w dziedzinie mieszkalnictwa, ale i stylu życia (Misiak 1993), laboratorium doświadczalnym $\mathrm{w}$ dziedzinie standaryzacji i produkcji masowej w budownictwie wielorodzinnym (Borowik 2003). Osiedle tworzyło 51 dwukondygnacyjnych domów zatopionych w zieleni (idea „miasta w parku") zaprojektowanych tak, by nie tworzyć wnętrz urbanistycznych. Zbudowano je z szablonowych elementów konstrukcyjnych, które jak klocki ułożone w zróżnicowane formy, zachowywały powtarzalność głównego, jednakowego dla wszystkich modułu. Domy w Pessac zasiedlone zostały w 1929 roku, lecz niedługo potem ich mieszkańcy zaczęli nadawać swoim najbliższym przestrzeniom indywidualność. Zamurowywali okna, obudowywali tarasy, dzielili wnętrza mieszkań według własnego uznania, swobodnie zmieniali kolorystykę i dobudowywali pomieszczenia gospodarcze (Jencks 1982, Syrkus 1976). Niszczyli tym samym zunifikowany charakter idealnej corbusierowskiej architektury. Jak podaje Ch. Jenks (1982, s. 79), sam twórca skomentował to mówiąc: "życie ma zawsze rację, a architektura

\footnotetext{
tego autora stał się egalitaryzm, który znalazł swój wyraz w nieco późniejszym projekcie miasta promiennego (la ville radieuse) z 1930 roku (Słodczyk 2012).

${ }^{39}$ Mimo że radzieccy projektanci traktowali projekty domów-willi jako prototyp budownictwa kolektywnego, trzeba pamiętać o innych uwarunkowania politycznychch, jakie panowały we Francji tego okresu i w ZSRR. Wille Le Corbusiera miały np. pomieszczenia dla służby, a projektowane $\mathrm{w}$ nich mieszkania-apartamenty miały być dwupoziomowe. Jak podaje Ch. Jencks (1982), projekt francuskiego architekta oparty był częściowo na ideałach społecznej utopii i komunizmu, częściowo na zasadach kapitalizmu, a częściowo na pragmatycznej idei oszczędności skali (Jencks 1982, s. 43).
} 
się myli", przyznając tym samym, że potrzeby mieszkaniowe są zindywidualizowane i nie da się zaspokoić ich jednym uniwersalnym modułem.

Kolejną, ważną z punktu widzenia rozwoju koncepcji modernistycznej zabudowy mieszkaniowej na masową skalę, była idea "miasta promiennego" (la ville radieuse) Le Corbusiera z 1930 roku. Projekt ten w sensie społecznym był bardziej egalitarny niż poprzednie, nie przewidywał bowiem przestrzennej segregacji mieszkańców ze względu na charakter ich pracy (Słodczyk 2012). Inspirowany liniowym modelem miasta rozwijanym przez N. Milutina w ZSRR, proponował pasmowy, równoległy układ terenów mieszkaniowych i przemysłowych. Funkcję mieszkaniową w mieście miały pełnić swobodnie rozmieszczone bloki mieszkalne budowane z elementów prefabrykowanych, które tworzyć miały jednostki mieszkalne (osiedla). Między blokami przewidziano duże powierzchnie zieleni. Mieszkania miały być dostępne dla wszystkich oraz dopasowane do wielkości i potrzeb poszczególnych rodzin. W projekcie zwrócono uwagę na zapewnienie odpowiedniej ilości światła słonecznego. Na dachach domów przewidziano ogrody. Pojedynczy blok mieszkalny przeznaczony był dla około 2,7 tys. osób (na każdego mieszkańca przeznaczono ok. $14 \mathrm{~m}^{2}$ ), a ich ustawienie na filarach (5 $\mathrm{m}$ nad powierzchnią ziemi) miało służyć zwiększeniu wolnej przestrzeni (ibid., s. 388) ${ }^{40}$.

Niejako niezależnie od koncepcji Le Corbusiera i niemal w tym samym czasie, w 1929 roku ${ }^{41}$, w Stanach Zjednoczonych opublikowana została jedna $\mathrm{z}$ najważniejszych $\mathrm{w}$ historii rozwoju planowania osiedli mieszkaniowych koncepcja jednostki sąsiedzkiej (Neighbourhood unit) opracowana przez amerykańskiego planistę Clarence'a A. Perry'ego. Koncepcja ta oddawała pragnienie miasta opartego na poczuciu wspólnoty (Borowik 2003). Jednym z celów jej stworzenia była bowiem chęć stymulowania identyfikacji mieszkańców ze społecznością sąsiedzką, a tym samym odtworzenia tradycyjnych, wspólnotowych więzi społecznych utraconych w toku życia w mieście. Wielkość jednostki wynikała z zasięgu szkoły podstawowej przeznaczonej dla 1 tys. dzieci, a liczba mieszkańców wynosić miała 5-6 tys. Neighbourhood unit charakteryzować miały: odrębność terytorialna i określona powierzchnia (65 ha), oddzielenie ruchu pieszego i kołowego (ulice wewnętrzne wyłączone z ruchu kołowego, a trasy szybkiego ruchu zlokalizowane na zewnątrz), skupienie punktów usługowych i handlowych w centrum zespołu oraz na jego obrzeżach w okolicach przystanków komunikacji miejskiej, duża ilość terenów zielonych oraz miejsc do rekreacji i spędzania wol-

${ }^{40}$ Idea ta po pewnych modyfikacjach została przekształcona przez Le Corbusiera w zrealizowaną po II wojnie światowej koncepcję Unité d'habitation - jednobryłowych jednostek mieszkaniowych, szerzej omówioną w dalszej części pracy.

${ }^{41}$ Koncepcja ta po raz pierwszy w formie częściowej opublikowana została w 1929 r., a w formie pełnej dopiero w $1939 \mathrm{r}$. 
nego czasu, które miały spełniać funkcję integracyjną (Perry 1939). W centrum osiedla miały znajdować się obiekty związane z kulturą, jednostki oświatowo-wychowawcze oraz kościoły. Niewielka liczba mieszkańców oraz rozmieszczenie budynków mieszkalnych i usług miały sprzyjać codziennym kontaktom i wytworzeniu się $\mathrm{w}$ tej zbiorowości silnej więzi społecznej (Jałowiecki, Szczepański 2006). Ich umacnianiu miały służyć liczne urządzenia wspólne, czyli stołówki, pralnie, czytelnie, kluby, które tym samym uzupełniały funkcje mieszkania oraz proponowały wspólnotowy model życia mieszkańców. Proponowany przez Perry'ego model miał zatem, jak podają B. Jałowiecki i M. Szczepański (2006), wyraźny sens ideologiczny, bowiem "urbanista występował tu w charakterze organizatora życia społecznego, narzucając użytkownikom z góry zaprogramowane sposoby zachowań i nie pozostawiając im większego wyboru" (ibid., s. 387). W polskiej myśli urbanistycznej echa tej koncepcji odnaleźć można w idei „osiedla społecznego" (Goldzamt 1971).

Na rozwój idei modernistycznego budownictwa osiedlowego w powojennej Europie wywarła ogromny wpływ również niemiecka myśl urbanistyczno-architektoniczna z I połowy XX wieku. Jej źródeł upatruje się w działalności stowarzyszenia Werkbund ${ }^{42}$, organizacji powołanej w $1907 \mathrm{r}$. głoszącej zasady funkcjonalizmu i prostoty (Wojtkun 2004). Nie mniej ważnym wydarzeniem $w$ rozwoju nowoczesnej architektury było powołanie w 1919 roku przez Waltera Gropiusa w Weimarze uczelni architektonicznej Bauhaus, której program zakładał tworzenie nowoczesnej, funkcjonalnej architektury integralnie związanej z innymi dziedzinami sztuki oraz dążenie do estetycznej i technicznej jedności dzieł. Jednym ze źródeł inspiracji dla twórców skupionych wokół szkoły Bauhausu oraz propagowanego przez nich modernizmu (ruchu nowoczesnego w architekturze) była działalność artystyczna holenderskiej grupy De Stijl (czyli styl), której głównymi przedstawicielami byli T. van Doesburg, P. Mondrian i J.J. Oud, architekci zaangażowani w projektowanie jednych z pierwszych modernistycznych osiedli mieszkaniowych w Holandii (Wojtkun 2004).

Wśród koncepcji niemieckich architektów, które wywarly wpływ na kształtowanie nowoczesnych form zabudowy mieszkaniowej (osiedlowej), były utopijne projekty Waltera Gropiusa i Bruno Tauta z 1918 roku (Wojtkun 2004). Zgodnie $\mathrm{z}$ zasadami przyjętymi $\mathrm{w}$ niemieckim budownictwie mieszkaniowym w tym okresie proponowano: w odniesieniu do mieszkań aby wielkość ich powierzchni użytkowej spełniała warunek minimum egzystencji (i w związku z tym zapewniała niewysoki koszt utrzymania miesz-

42 Działalność Werkbundu polegała m.in. na organizacji wystaw, które były przeglądem najnowszych trendów w architekturze tamtych czasów oraz propagowanie tzw. nowej architektury. 
kania), w odniesieniu do budynków - typizację, standaryzację i uniformizację, co znacznie obniża koszty ich wznoszenia, w odniesieniu do systemów zabudowy - stosowanie tzw. układu linijkowego, czyli sytuowanie budynków mieszkalnych prostopadle do ulic, polepszające ich nasłonecznienie i warunki higieniczno-sanitarne $\mathrm{w}$ mieszkaniach, a równocześnie obniżające koszty ich budowy. Ta ostania zasada, często wykorzystywana w powojennej zabudowie osiedlowej (współcześnie określana także jako zabudowa grzebieniowa - Chmielewski, Mirecka 2001), miała umożliwić liwidację zamkniętych podwórzy i „ulic-korytarzy” oraz korzystną lokalizację domów w stosunku do stron świata (z wystawą wschodnią lub zachodnią), ochronę przed uciążliwościami ruchu kołowego oraz możliwość wprowadzenia zieleni pomiędzy budynki mieszkalne ${ }^{43}$. Jakkolwiek proponowany w tych ideach "maszynistyczny" sposób formowania środowiska życia człowieka był wówczas - w okresie walki o światło i higienę - postrzegany jako bardzo postępowy (Wojtkun 2004), to rygorystyczne przestrzeganie zasad orientowania zabudowy mieszkaniowej według kierunków stron świata, jak pisze W. Ostrowski (1975), raziło skrajnym schematyzmem, a powstałe w ten sposób rozwiązania były monotonne i pozbawione czytelności.

Wśród koncepcji dotyczących kolektywnego budownictwa mieszkaniowego, które - jak podaje E. Goldzamt (1971) - miały wpływ na powojenne budownictwo osiedlowe $\mathrm{w}$ miastach socjalistycznych należy wymienić także projekty domów-komun i miast-komun $\mathrm{z}$ okresu międzywojennego w ZSRR. Powstawały one pod wpływem zachodnioeuropejskiej myśli urbanistycznej, szły jednak znacznie dalej w idei kolektywizacji. Jeden $\mathrm{z}$ takich projektów, autorstwa L. Sabsowicza z końca lat 20. XX wieku, zakładał budowę miasta dla 50-60 tys. mieszkańców, w którym podstawową jednostką miały być domy-komuny dla 1-2 tys. osób z daleko posuniętą kolektywizacją życia mieszkańców, likwidacją rodziny, gospodarstwa domowego, skolektywizowanym wychowywaniem dzieci i ścisłą regulacją dnia mieszkańców (Słodczyk 2012). Pomieszczenia mieszkalne miały pełnić jedynie funkcje sypialne ${ }^{44}$, ponieważ - jak osobliwie pisał w 1930 r. L. Sobsowicz: „socjalistyczna organizacja życia powinna zapewnić maksymalną swobodę rozwoju indywidualności każdego mieszkańca. Rozwój indywidualności

${ }^{43}$ Oparty na tych zasadach teoretyczny projekt miasta dla $2 \mathrm{mln}$ mieszkańców, opracowany w 1924 r. przez niemieckiego architekta L. Hilberseimera, stanowił "totalną" kompozycję złożoną z identycznych sekcji mieszkalnych usytuowanych wzdłuż osi północ-południe, która zrywała z pojęciami wnętrza, skalą ludzką i kierunkami w kompozycji (Wisłocka 1971).

${ }^{44}$ Twórcy omawianych rozwiązań dążyli do maksymalnego ograniczenia indywidualnej powierzchni mieszkalnej na rzecz rozbudowanego programu usług zbiorowych. W skrajnych koncepcjach domów-koumun funkcja mieszkalna miała być realizowana $\mathrm{w}$ indywidualnych kabinach sypialnych o powierzchni $4,0 \mathrm{~m}^{2}$ na osobę, zestawionych $\mathrm{w}$ układzie korytarzowym (Wojtkun 2004, s. 276). 
będzie jednak osiągnięty nie drogą odosobnienia $\mathrm{w}$ osobnych pokojach, a właśnie w kolektywie, bo tylko w obcowaniu z innymi człowiek ma możliwość rozwoju własnej indywidualności" (Jałowiecki 1994). Projekty domów-komun i miast-komun w mniejszym stopniu miały charakter urbanistyczny, w większym zaś społeczny i były wyrazem koncepcji nowej organizacji życia społecznego, która powstała i ewoluowała w porewolucyjnej Rosji. Głównym założeniem tej koncepcji była przebudowa od podstaw tkanki społecznej, a organizacja jednostek mieszkaniowych opartych na wspólnym korzystaniu z rozbudowanych usług społecznych temu celowi miała służyć (Goldzamt 1971). Wkrótce jednak, na początku lat 30., odstąpiono od tych koncepcji, uznając je za zbyt radykalne (Goldzamt 1971, Słodczyk 2012).

Ukoronowaniem wielu idei i koncepcji urbanistyczno-architektonicznych okresu międzywojennego była Karta Urbanistyki uchwalona jako podsumowanie IV Międzynarodowego Kongresu Nowoczesnej Architektury (CIAM - Congrès Internationaux de l'Architecture Moderne ${ }^{45}$ ) zorganizowanego w 1933 roku w Atenach, która do historii przeszła pod nazwą Karty Ateńskiej. Jednym z członków i założycieli CIAM oraz aktywnych jej działaczy był Le Corbusier, którego idee odcisnęły znaczące piętno na postulatach zawartych w dokumencie.

Karta Ateńska była spisem licznych wad, jakimi charakteryzowały się miasta początku XX wieku oraz postulatów i wymagań, którymi powinni kierować się architekci i urbaniści przy planowaniu i projektowaniu obszarów miejskich. Zawierała otwartą krytykę i postulaty naprawy dotyczące kolejno: warunków mieszkaniowych w miastach, warunków pracy, wypoczynku i organizacji ruchu miejskiego, a jej główną ideą był postulat „,miasta funkcjonalnego". W dokumencie tym krytykowano przede wszystkim ${ }^{46}$ :

- nadmierne zagęszczenie ludności w centralnych dzielnicach miast;

- nadmierne zagęszczenie osób w mieszkaniach (niedostateczną powierzchnię mieszkaniową przypadającą na osobę);

- złe warunki sanitarne;

- brak odpowiedniego nasłonecznienia mieszkań;

- niedostatek wolnych przestrzeni i terenów zielonych w miastach;

- zróżnicowanie przestrzeni mieszkaniowej według zamożności mieszkańców;

- uciążliwości wynikające z rozwoju ruchu kołowego i ich negatywny wpływ na warunki zamieszkania (hałas, kurz i spaliny);

45 Organizacja powstała w 1928 r. na znak manifestu nowego trendu w architekturze i sztuce, jakim był modernizm. Zorganizowano 10 zjazdów, które odbywały się nieregularnie do 1956 r.

${ }^{46}$ Opracowano na podstawie Le Corbusier (1973). 
- braki w wyposażeniu terenów mieszkaniowych w urządzenia usługowe i użyteczności publicznej i ich źle przemyślana lokalizacja.

Aby zmienić ten stan rzeczy w Karcie Ateńskiej postulowano m.in.:

- przeznaczanie pod zabudowę mieszkaniową terenów najkorzystniejszych ze względów zarówno zdrowotnych, jak i przyrodniczych;

- zmniejszenie nadmiernego zagęszczenia ludności ${ }^{47}$, czemu służyć miało zwiększanie wysokości budynków mieszkalnych wykorzystujące rozwój możliwości nowych technologii budowlanych (wysokie budynki powinny stać $\mathrm{w}$ odpowiednio szerokich odstępach, tak by między nimi znajdowało się jak najwięcej obszarów zielonych);

- zapewnienie terenom mieszkaniowym odpowiedniego nasłonecznienia;

- wyburzenie zniszczonej tkanki mieszkaniowej stanowiącej zagrożenie zdrowotne dla mieszkańców;

- poprawę lokalizacji usług publicznych (np. w przypadku szkół lokalizowanie ich możliwie jak najbliżej miejsc zamieszkania i możliwie daleko od dróg szybkiej komunikacji miejskiej, ze względu na zapewnienie warunków bezpiecznego docierania dzieci i młodzieży do szkoły);

- oddzielenie terenów mieszkaniowych od arterii komunikacyjnych, które przenikałyby się tylko w najbardziej koniecznych miejscach, zakaz lokalizacji linii zabudowy wzdłuż tras komunikacyjnych;

- zwiększenie powierzchni terenów zielonych w mieście i wprowadzaniu do niego „elementu przyrody”, czyli właściwej proporcji słońca, wolnej przestrzeni i zieleni;

- oddzielenie terenów mieszkaniowych od terenów przemysłowych pasami zieleni i takie ich rozmieszczenie, aby redukować do minimum odległości między miejscem zamieszkania i miejscem pracy;

- oddzielenie ruchu pieszego od samochodowego i rozróżnienie ulic zależnie od ich przeznaczenia (osiedlowe, spacerowe, tranzytowe, główne arterie).

Zgodnie z Kartą Ateńską najważniejszą funkcją miast jest funkcja mieszkaniowa, która stanowi program sam w sobie. Tereny mieszkaniowe powinny być bezwzględnie zaopatrzone $w$ funkcje, które zaspokajają wszystkie potrzeby związane z codziennym życiem człowieka, ponieważ „poza

47 Proponowano m.in. ustalenie norm liczby osób, które miałyby zasiedlać dany teren oraz określoną liczbę mieszkań, ale nie umieszczono żadnych dokładnych wytycznych, według których budowniczowie miast mieliby postępować (proporcji, udziału procentowego elementu przyrody do powierzchni miasta czy jego stosunku do wysokości zabudowy, nie zaproponowano również powierzchni mieszkania, jaka powinna przypadać np. na jednego mieszkańca). 
mieszkaniem rodzina wymaga istnienia $\mathrm{w}$ sąsiedztwie urządzeń wspólnych, które są prawdziwym przedłużeniem funkcji mieszkania" (Karta Ateńska 1933). Do takich urządzeń zaliczono ośrodki zaopatrzenia w żywność, ośrodki pomocy lekarskiej, żłobki, przedszkola, szkoły, a ponadto urządzenia służące rozwojowi kulturalnemu oraz tereny rekreacji.

Karta Ateńska, według M. Szczepańskiego (1991, s. 34-51), proponując rewolucję miejską wprowadzała $\mathrm{w}$ istocie rewolucję społeczną, a kluczowe w niej funkcje przypisywała nowej "sofokracji” - urbanistom, architektom i planistom. Jednakże, jak pisze K. Pawłowska (1996, s. 120) „psychosocjologiczne kompetencje architektów były niewystarczające i wiele ich koncepcji skonstruowanych na szlachetnych przesłankach społecznych w praktyce niosło zbyt dużo uproszczeń nie uwzględniających złożoności życia społecznego". Mimo to Karta Ateńska odegrała bardzo istotną rolę w ustaleniu standardów i wymagań $\mathrm{w}$ zakresie projektowania miast w następnych kilkudziesięciu latach. Najpełniejszym materialnym wyrazem przestrzennym tego dokumentu stały się wielkie osiedla mieszkaniowe budowane po II wojnie światowej niemal w całej Europie, przede wszystkim w krajach realnego socjalizmu.

Ważną rolę $\mathrm{w}$ rozwoju idei powojennego budownictwa osiedlowego miała koncepcja osiedla społecznego, która krystalizowała się Polsce w latach 30. i 40. XX wieku. Koncepcja ta narodziła się w okresie fascynacji modernizmem $\mathrm{w}$ architekturze $\mathrm{i}$ urbanistyce oraz rozkwitu prospołecznych ideologii zamieszkiwania, jak również z konieczności poszukiwania nowych rozwiązań w budownictwie mieszkaniowym w związku z panującym kryzysem ekonomicznym. Jej źródeł upatruje się w idei "miast ogrodów” E. Howarda, ,jednostki sąsiedzkiej” C.A. Perry'ego, a także postulatach architektury i urbanistyki wyłożonych w programach szkoły Bauhaus i projektach produkowania mieszkań na masową skalę W. Gropiusa oraz w pracach środowiska CIAM (Borowik 2003).

Głównymi teoretykami koncepcji osiedla społecznego byli architekci Helena i Szymon Syrkusowie oraz Barbara Brukalska48, autorka wydanej w 1948 roku pracy pt. Zasady spotecznego projektowania osiedli mieszkaniowych. Koncepcja ta opierała się na dwóch zasadniczych wzajemnie ze sobą powiązanych ideach: ekonomicznej, polegającej na poszukiwaniu taniego sposobu zwiększenia zasobów mieszkaniowych, oraz społecznej związanej z wyznaczaniem ram przestrzennego współżycia zbiorowego mieszkańców jednost-

48 Pomiędzy poglądami B. Brukalskiej a H. Syrkus istniały pewne różnice w proponowanym sposobie zaspokajania różnych potrzeb mieszkańców (od kolektywizmu do indywidualizmu). O ile bowiem H. Syrkus szukała uśrednionej formy zaspokajania potrzeb i mówiła o tzw. wypośrodkowanej potrzebie masowej, to B. Brukalska nawoływała do pozostawiania mieszkańcom jak największej przestrzeni prywatnej, intymności i swobody oraz zachowania równowagi pomiędzy zaspokajaniem potrzeb zbiorowych i jednostkowych (Borowik 2003). 
ki osiedlowej (Misiak 1993). Jej autorzy podobnie jak w koncepcjach niemieckich zakładali budowę "mieszkań społecznie najpotrzebniejszych" (inaczej „mieszkań minimalnych”), czyli mieszkań spełniających podstawowe standardy powierzchniowo-instalacyjne, a równocześnie możliwych do utrzymania przez nisko uposażoną ludność robotnicząa9 (Goldzamt 1971). Tym co odróżniało polskie koncepcje osiedla społecznego od ich niemieckich wzorców była niechęć do sztywnych i schematycznych rozwiązań przestrzennych w postaci zabudowy linijkowej. Stosując się do wytycznych Karty Ateńskiej polscy architekci poszukiwali takiej formy zabudowy, która umożliwiłaby indywidualizowanie poszczególnych sekcji osiedla.

Minimalizacja powierzchni mieszkań i redukcja niektórych ich funkcji, pozwalające na obniżenie czynszów, miały być rekompensowane przez rozbudowę obiektów usługowych nazywanych urządzeniami społecznymi. Jako przykład takich urządzeń kompensujących braki mieszkania wymieniano świetlice, biblioteki, jadłodajnie (Brukalska 1948). Równocześnie rozwinięta sfera usług zbiorowych miała przyczynić się do wytwarzania więzi społecznych w środowisku zamieszkania. Jak podaje E. Goldzamt (1971), realizacja niektórych funkcji mieszkania $\mathrm{w}$ sferze usług zbiorowych była jednak podyktowana głównie wymogami ekonomicznymi, a w mniejszym stopniu przekonaniem o wyższości życia kolektywnego nad indywidualnym. Ten ostatni pogląd natomiast, który przyświecał koncepcjom rozwijanym $\mathrm{w}$ tym okresie $\mathrm{w}$ radzieckiej myśli urbanistycznej, znalazł wyraz w opracowaniu H. i S. Syrkusów z 1940 roku pt. Obsługa społeczna jako czynnik kształtujący osiedle, $\mathrm{w}$ którym podkreślano m.in. anachronizm pracy kobiety $\mathrm{w}$ indywidualnym gospodarstwie domowym i konieczność zapewnienia w miejscu zamieszkania takich urządzeń społecznych, które tę pracę pozwolą zminimalizować (Goldzamt 1971).

Według B. Brukalskiej (1948) miasto powinno tworzyć układ hierarchiczny wywodzący się z hierarchii określonych potrzeb mieszkańców i składać z następujących jednostek: a) mieszkanie rodzinne, b) dom zbiorowy dla 100-150 osób, c) kolonia tworzona przez 200-250 mieszkań i zamieszkiwana przez około 800 osób, d) osiedle (ok. 5 tys. osób) składające się z 5-6 kolonii, e) dzielnica mieszkaniowa (25-40 tys. osób) ${ }^{50}$. Kolonie miały charakteryzować się silną więzią społeczną między najbliższymi sąsiadami, ale podstawowym terenem życia sąsiedzkiego miało być osiedle.

49 Wielkość tych mieszkań miała się zmieniać w czasie i być uzależniona od aktualnej kondycji ekonomicznej grup będących adresatami tego typu zabudowy.

${ }^{50} \mathrm{~W}$ okresie powojennym wielkości strukturalnych jednostek oparte na zasadach opracowanych przez B. Brukalską określano ogólnokrajowymi normami projektowania i modyfikowano w zależności od potrzeb oraz od skali określonego przedsięwzięcia (osiedle np. mogło liczyć nawet 20 tys. mieszkańców) - G. Wojtkun (2012a). 
W związku z tym, że głównym adresatem tej koncepcji była ludność robotnicza, której nie stać było na samodzielne finansowanie tak wyposażonego lokum, idei osiedla społecznego towarzyszył rozwój stosunkowo mało popularnej jeszcze spółdzielczości mieszkaniowej51. Do postulatów zawartych $\mathrm{w}$ dorobku polskich architektów, które przesądziły o charakterze polskiej spółdzielczości mieszkaniowej w tym okresie, należały: postulat finansowego i organizacyjnego uczestnictwa państwa w rozwoju mieszkalnictwa dla uboższych warstw społecznych, przekonanie, że mieszkania nie należy traktować jako towaru, ponieważ zaspokaja ono jedną z podstawowych potrzeb człowieka, postulat, że miasta powinny być rozbudowywane planowo, że powinny $\mathrm{w}$ nich powstawać samowystarczalne kolonie osiedlowe $\mathrm{z}$ odpowiednią ilością zieleni oraz że $\mathrm{w}$ budowie domów powinny być zastosowane możliwie wysokie standardy higieny (co, ciepła woda, węzeł sanitarny w mieszkaniu). W celu zapewnienia maksymalnie dużej liczby mieszkań po przystępnych cenach określono kategorię mieszkania społecznie najpotrzebniejszego przyjmując, że jest to lokum o powierzchni $28-45 \mathrm{~m}^{2}$ dla rodziny 3-5-osobowej. Uważano także, że osiedla powinny być wyposażone we wszystkie urządzenia użyteczności publicznej, umożliwiające realizację potrzeb i służące integracji mieszkańców. Właścicielem gruntów, na których budowane są osiedla, powinno być państwo lub władze miejskie (Peisert 2009).

Proponowana przez polskich architektów koncepcja „osiedla społecznego", obok koncepcji jednostki sąsiedzkiej C.A. Perry'ego oraz niemieckiej idei masowej budowy mieszkań najmniejszych utrzymanych w duchu minimum egzystencjalnego stała się według E. Goldzamta (1971) jednym z najważniejszych źródeł inspiracji dla powojennego budownictwa mieszkaniowego w Polsce oraz w innych krajach socjalistycznych.

51 Za właściwego twórcę ideologicznych podstaw spółdzielczości uważa się utopijnego socjalistę Roberta Owena, który uważał, że drogą do naprawy społeczeństwa jest likwidacja kategorii zysku, która jest przyczyną kryzysu kapitalizmu, ale też niesprawiedliwością samą w sobie (Peisert 2009). Pierwsze spółdzielnie mieszkaniowe powstały w Anglii na początku XIX w. Tam też powstała pierwsza w świecie Ustawa o spółdzielniach budowlanych, której celem była poprawa warunków życia ubogiej ludności miejskiej, w szczególności robotniczej, żyjącej w skrajnie złych warunkach higienicznych, poprzez zapewnienie jej mieszkań spełniających minimalne wymogi higieny i pozwalające na zdrowe życie. Od początku XIX w. spółdzielnie powstawały także w Niemczech, w Austrii i na ziemiach polskich (Księga polskiej spótdzielczości za: A. Peisert 2009). 


\subsection{Pierwsze realizacje wielkoskalowych modernistycznych założeń osiedlowych $\mathrm{w}$ miastach europejskich}

W okresie po I wojnie światowej duży popyt na mieszkania i chęć poprawy niskiego standardu mieszkalnictwa $\mathrm{w}$ dzielnicach robotniczych spowodowały realizacje pierwszych dużych projektów masowego budownictwa mieszkaniowego inicjowanych przez władze publiczne. Był to równocześnie wyraz coraz powszechniejszego przekonania, że państwo odpowiada za warunki życia mieszkańców (Słodczyk 2012, s. 389). Budownictwo takie w okresie międzywojennym na największą skalę realizowane było w Niemczech (m.in. we Frankfurcie nad Menem oraz w Berlinie), w Austrii (w Wiedniu), w Holandii (w Amsterdamie i Rotterdamie), ale jego przykłady na znacznie mniejszą skalę odnaleźć można także w Polsce, np. osiedle Warszawskiej Spółdzielni Mieszkaniowej w Warszawie, czy osiedle im. J. Monwiłła-Mireckiego w Łodzi.

Pierwsze osiedla projektowane $\mathrm{w}$ duchu funkcjonalizmu, które $\mathrm{z}$ dzisiejszego punktu widzenia stanowią pierwowzór wielkich osiedli mieszkaniowych powstawały w Niemczech już w latach 20. XX wieku (Rembarz 2010). Przeznaczone były dla osób niezamożnych (głównie ludności robotniczej), a ich budowa wynikała z potrzeby zaspokojenia drastycznego głodu mieszkaniowego, który dotknął Niemcy po I wojnie światowej. Mieszkania te, zwane "mieszkaniami najmniejszymi" (Minimalwohnunug), budowane były w duchu Existenzminimum, czyli mieszkań spełniających minimum egzystencjalne, tak aby były tanie i dostępne dla niezamożnej ludności robotniczej, co osiągano dzięki udziałowi w ich budowie środków publicznych (Goldzamt 1971), głównie socjaldemokratycznych zarządów miast. Do osiedli takich należały m.in. wybudowane w II połowie lat 20. Romerstadt we Frankufurcie nad Menem, pochodzące $\mathrm{z}$ tego samego okresu osiedla Torten II w Dessau i Siemenstadt pod Berlinem, osiedle Dammerstock w Karlsruhe (wszystkie projektu W. Gropiusa) oraz osiedle Berliner-Zehlendorf w Berlinie autorstwa Bruno Tauta (Jałowiecki, Szczepański 2006, s. 133). Najbardziej znanym osiedlem tego okresu'52, które już w czasie budowy określano wielkim osiedlem mieszkaniowym, jest modernistyczny zespół mieszkaniowy wzniesiony w latach 1925-1930 w Britz pod Berlinem (niem. Grossiedlung Britz) zaprojektowany m.in. przez B. Tauta. Osiedle to

52 W 2008 r. osiedle Britz wraz z pięcioma innymi modernistycznymi zespołami mieszkaniowymi Berlina zostało wpisane na listę dziedzictwa kulturowego UNESCO. Unikatowość osiedla oraz duża ilość zieleni i terenów rekreacyjnych sprawiają, że współcześnie, mimo relatywnie małych powierzchni (średnio $49 \mathrm{~m}^{2}$ ), mieszkania w Britz cieszą się w Berlinie powodzeniem (,Rzeczpospolita”, 12.08.2008 r.). 
zwane także osiedlem Podkowy (od głównego budynku mieszkalnego w tym kształcie) liczy blisko 2000 mieszkań, które w większości powstały w czterokondygnacyjnych budynkach wielorodzinnych w zabudowie „linijkowej". Częściowe zróżnicowanie zabudowy osiedla i zastosowana przez B. Tauta bogata kolorystyka pozwoliły uniknąć monotonii i schematyczności charakterystycznej dla tego typu układów (Wojtkun 2004).

Kolejnym przykładem realizacji budownictwa mieszkań komunalnych na masową skalę był tzw. „Czerwony Wiedeń" - program budowy modernistycznych osiedli mieszkaniowych dla rodzin robotniczych realizowany przez socjaldemokratyczne władze stolicy Austrii w latach 1919-1933. W ramach tego programu powstało 72 tys. mieszkań zlokalizowanych w ogromnych (długich na $1 \mathrm{~km}$ ) blokach mieszkalnych z pełną infrastrukturą społeczną (na którą składały się m.in. łaźnie, obiekty sportowe, szpitale, placówki edukacyjne, kulturalne, domy opieki i wiele innych). Do największych i najbardziej znanych architektoniczno-urbanistycznych realizacji tego programu należy modernistyczny Karl-Marx-Hof, jeden z najdłuższych budynków w Europie, o długości 1100 m, wybudowany w latach 1927-1930, w którym zaprojektowano 1382 mieszkania.

Program masowego komunalnego budownictwa mieszkaniowego rozwijano również w Amsterdamie i Rotterdamie, gdzie już w latach 20. XX wie$\mathrm{ku}$ powiązano prowadzone przez władze publiczne programy budownictwa mieszkaniowego z modernistyczną architekturą i formą budynków, co stanowiło ważny krok w procesie kształtowania się idei współczesnego osiedla blokowego (Słodczyk 2012).

W Polsce interesującym przykładem przedwojennej zabudowy osiedlowej, na bazie której wykrystalizowała się powojenna idea mieszkalnictwa społecznego, były osiedla realizowane przez powstałą w 1921 roku Warszawską Spółdzielnię Mieszkaniową (WSM). Skupione wokół WSM środowisko lewicowych architektów i urbanistów w realizacjach taniego spółdzielczego budownictwa mieszkaniowego dla robotników upatrywało możliwość spełniania nie tylko ambitnych planów architektoniczno-urbanistycznych, ale także wychowawczych i społecznych (Peisert 2009). Środowisko to starało się czerpać ze sprawdzonych wzorów budownictwa spóldzielczego, głównie w Wiedniu i Frankfurcie nad Menem. Widziano w nich wzorzec osiedli mieszkaniowych proponujących tanie i higieniczne budownictwo, zapewniające godne i minimalnie komfortowe warunki życia dla robotników ${ }^{53}$. Realizacją WSM było osiedle „Pionier” na Żoliborzu (Kolonie

${ }^{53} \mathrm{~W}$ istocie mieszkania te dla robotników okazały się zbyt drogie do utrzymania. Ich wadą było także nieprzystosowanie do wzorów życia rodziny robotniczej - mała kuchnia uniemożliwiała gromadzenie się całej rodziny i traktowanie jej jako izby jadalnej, co stanowiło jeden z wzorców życia ówczesnych rodzin robotniczych (Peisert 2009). Znaczący odpływ robotników, 
na Żoliborzu i Rakowcu) autorstwa B. i S. Brukalskich budowane od roku 1928, w którym w różnych okresach zamieszkiwało od 4 do 6 tys. mieszkańców. Zabudowę osiedla tworzyły wielorodzinne budynki mieszkalne, usytuowane $\mathrm{w}$ formie zabudowy obrzeżnej, nieuwzględniającej postulatów niemieckich funkcjonalistów zalecających jak najkorzystniejszą lokalizację budynków względem stron świata. Do wybuchu II wojny światowej WSM zrealizowała 1345 mieszkań na Żoliborzu i 293 na Rakowcu (Ostrowski 1971).

Innym przykładem modernistycznej zabudowy osiedlowej w miastach polskich jest osiedle im J. Monwiłła-Mireckiego w Łodzi powstałe z inicjatywy socjaldemokratycznych władz miasta w latach 1928-1931. Osiedle zbudowane zostało zgodnie $\mathrm{z}$ wymogami funkcjonalizmu i modernizmu $\mathrm{w}$ nowoczesnej w owym czasie zabudowie linijkowej prostopadłej do ulic oraz $\mathrm{w}$ nawiązaniu do idei miasta ogrodu (otoczone jest rozległymi terenami zieleni). Na osiedle składa się 21 trzypiętrowych bloków z cegły, w których znajduje się 1026 mieszkań, zamieszkanych obecnie przez około 2,1 tys. osób. Wysokość mieszkań w tym osiedlu jest relatywnie duża jak na budownictwo tego typu, wynosi bowiem około 2,9 m. Lokale mieszkalne mają powierzchnię od 40 do $60 \mathrm{~m}^{2}$. Mieszkania posiadały wysoki jak na owe czasy standard - elektryczność, bieżącą wodę i kanalizację, co stanowiło rzadkość w przedwojennej Łodzi. W zamyśle osiedle miało stanowić obszar zamieszkiwania łódzkich robotników, jednak $\mathrm{w}$ rzeczywistości $\mathrm{w}$ obliczu kryzysu gospodarczego $z$ lat 30. czynsze w nowoczesnych blokach okazały się zbyt wysokie dla ludności robotniczej i zamieszkiwała w nim głównie inteligencja - lekarze, urzędnicy, artyści (Baranowski 1996), tak jak stało się również w przypadku osiedla "Pionier" w Warszawie (zob. Peisert 2009).

Modernistyczna idea wznoszenia budynków mieszkalnych o wielkiej kubaturze oraz lokowania ich w odseparowaniu od siebie i wśród zieleni, zamiast w zwartej zabudowie miejskiej, bezpośrednio po II wojnie światowej zaowocowała projektami pojedynczych autonomicznych jednostek mieszkaniowych - unites d'habitation. Prekursorskim przykładem tej formy architektonicznej, która według B. Jałowieckiego „wpisuje się w historyczny ciąg utopijnych rozwiązań organizacji ludzkiego habitatu" (Jałowiecki, Szczepański 2006, s. 132), była jednostka mieszkaniowa zaprojektowana przez Le Corbusiera wybudowana w latach 1947-1952 na przedmieściach Marsylii, od miejsca swej lokalizacji określana ,jednostką marsylską". Projekt ten, określany przez historyków architektury „marsylskim szaleństwem" (von Moos 2009, s. 171), od początku budził duże zainteresowanie,

którzy pierwotnie stanowili około 3/4 mieszkańców osiedla WSM, nastąpił po $1929 \mathrm{r}$. w wyniku wielkiego kryzysu. W przededniu wojny już ${ }^{3 / 4}$ mieszkańców stanowiła inteligencja (ibid.). 
ale i wiele kontrowersji54. Przeznaczony dla 1,6 tys. osób, wyposażony w zlokalizowane wewnątrz budynku (na dwóch środkowych kondygnacjach) liczne placówki handlowe oraz $\mathrm{w}$ całe zaplecze infrastrukturalne (m.in. piekarnię, przedszkole, salon fryzjerski, pocztę, restaurację, kluby młodzieżowe, salę gimnastyczną, basen, salę zabaw dla dzieci) ${ }^{55}$, był materializacją wieloletnich przemyśleń architekta i koncepcji budowy wielkiej samowystarczalnej „maszyny do mieszkania”. Jednostka marsylska zaprojektowana właściwie dla mniej zamożnych lokatorów, na skutek relatywnie drogich mieszkań oraz "uroku nowości", początkowo zasiedlona została przez ludzi zamożnych, którzy jednak z czasem ją opuszczali (Jałowiecki, Szczepański 2006). Spowodowało to stopniową degradację, najpierw w sferze wspólnych usług, a następnie mieszkań. Z biegiem czasu okazało się, że zaprojektowany przez Le Corbusiera kolektywistyczny sposób życia oparty na wspólnych urządzeniach usługowych nie przyjął sięc5 (Ostrowski 2001). Mało funkcjonalne okazały się również same mieszkania. Mimo że część z nich była dwupoziomowa (na wzór immeubles villas), a ich projekty teoretycznie uwzględniały zróżnicowanie potrzeb mieszkańców (Jencks 1987), wiele mieszkań nie odpowiadało ich potrzebom (np. z powodu przejściowych pokoi, braku dostatecznej liczby oddzielnych sypialni, miniaturowych kuchni) i było przebudowywanych (Ostrowski 2001).

Unite d'habitation według projektu Le Corbusiera pojawiła się jeszcze tylko w kilku miastach ${ }^{57}$, przy czym nigdzie nie spełniła pokładanych w niej oczekiwań zapewnienia idealnego środowiska mieszkaniowego. Do najbardziej dramatycznych należą losy jednostki w Briey, wybudowanej w roku 1963 dla górników lotaryńskiego zagłębia rud żelaza, która po 20 latach powolnej degradacji została niemal całkowicie opuszczona przez mieszkań-

${ }^{54}$ W 1952 r. La Société pour l’Estétique de la France wytoczyła proces domagając się rozebrania budynku (Ostrowski 1975), równocześnie zaś miejscowe biuro podróży organizowało zwiedzanie jednostki, ponieważ tak wiele osób nawet $\mathrm{z}$ odległych krajów chciało zobaczyć dzieła architekta, o którym mówiono, że „pokazał jak powinno się mieszkać w drugiej połowie XX wieku" (Ostrowski 2001, s. 154).

${ }^{55}$ Jak podaje W. Ostrowski (2001), wyposażenie jednostki w placówki usługowe w okresie jej budowy zostało znacznie okrojone $w$ stosunku do tego, co przewidywał projekt. Zrezygnowano $\mathrm{z}$ wielu usług, $\mathrm{w}$ tym $\mathrm{np}$. $\mathrm{z}$ umieszczenia $\mathrm{w}$ budynku ośrodka zdrowia wraz z pokojami dla chorych, które według projektu Le Corbusiera zajmować miały niemal całą najwyższą kondygnację jednostki.

${ }^{56}$ W. Ostrowski (2001) tak opisał sposób życia w jednostce marsylskiej: „gospodynie domowe przygotowywały posiłki w mieszkaniu, nie korzystając z usług miejscowej restauracji [...], dokonywały zakupów raz na tydzień w wielkich ośrodkach zapewniających większy wybór niż małe sklepy w jednostce [...], dzięki pralkom domowym zanoszenie bielizny do prania w lokalnym ośrodku stało się niepotrzebne" (s. 154).

${ }^{57}$ Kolejne unites d'habitation wybudowano w następnych latach jeszcze w kilku miastach m.in. w Nantes (w 1955 r.), Berlinie (w 1957 r.), Briey (w 1963 r.) oraz Firminy (w 1965 r.) (Ostrowski 2001). 
ców58 (Ostrowski 2001). Jakkolwiek główną przyczyną tego stanu był upadek górnictwa i zamykanie kopaln, które nastąpiło w kilka lat po oddaniu jednostki do użytku, niebagatelne znaczenie miał także duże zróżnicowanie społeczne, etniczne i obyczajowe mieszkańców powodujące konflikty, a także fakt, że wielu z nich pochodziło wprost ze wsi i unite d'habitation nie stwarzała warunków zamieszkania odpowiadających ich potrzebom ${ }^{59}$. Nie sprawdziło się również to, co miało być jednym z walorów tej formy zabudowy, czyli lokalizacja jednostki w znacznym oddaleniu od zwartej zabudowy miejskiej, ponieważ wielu mieszkańców chciało swoje potrzeby zaspokajać korzystając z bardziej zróżnicowanej oferty dostępnej w mieście. Mylne przekonanie twórcy unite d'habitation, że istnieje jeden uniwersalny, odpowiadający wszędzie i wszystkim, idealny model sposobu życia i zamieszkiwania nie po raz pierwszy okazał się utopią (Ostrowski 2001).

Stanowiąca jedną z głównych zasad projektów Le Corbusiera kolektywistyczna idea "przedłużania mieszkań" poprzez wyposażenie budynku (lub kompleksu budynków) we wspólne usługi i liczne miejsca, w których mieszkańcy swe indywidualne potrzeby będą realizować we wspólnocie, obecna była już w XIX-wiecznych koncepcjach miast utopijnych Ch. Fouriera oraz R. Owena, w koncepcji jednostki sąsiedzkiej C. Perry'ego i osiedla społecznego H. i Sz. Syrkusów, a także w projektach domów-komun w ZSRR. W tych ostatnich jednak tak dalece szła w kierunku kolektywizacji, że - jak podaje Jałowiecki (2006): „przeraziła nawet samych autorów”, dzięki czemu dość szybko z niej zrezygnowano. Idea ta z jednej strony miała kreować więzi pomiędzy mieszkańcami, a po drugie czynić ich życie znacznie łatwiejszym. Dotyczyć to miało głównie kobiet, które prowadząc gospodarstwa domowe dzięki rozbudowanym usługom mogłyby zostać jak wówczas twierdzono - „wyzwolone z uciążliwych zajęć domowych" (Goldzamt 1971). I tak, np. bardzo małe kuchnie w jednostce marsylskiej (znane z polskich osiedli socjalistycznych okresu gomułkowskiego) nie miały być miejscem przygotowywania posiłków, ponieważ rozwinięte funkcje zbiorowego żywienia teoretycznie umożliwiały realizację tej potrzeby poza domem. Założenia te jednak nie spełniły się, mieszkańcy chcieli bowiem zaspokajać swoje potrzeby $\mathrm{w}$ przestrzeni indywidualnej. Podobne fiasko dotyczyło idei kreowania więzi społecznych poprzez wspólne zamieszkiwanie, ponieważ - jak pisał W. Ostrowski (2001, s. 158): „mieszkanie pod wspólnym dachem oraz korzystanie ze wspólnych usług nie zapewnia inte-

${ }^{58}$ W 1984 r., po eksmitowaniu ostatnich lokatorów, niszczejący budynek z blisko 400 opustoszałymi mieszkaniami, otoczono parkanem i zamknięto (Ostrowski 2001, s. 156).

${ }^{59}$ Jak podaje W. Ostrowski (2001, s. 155), imigrantom z terenów wiejskich nie wystarczała zieleń za oknem i wiszące ogrody w loggiach, ponieważ woleli mieć własne ogródki, w których mogliby uprawiać warzywa, a wielu z nich w mieszkaniach hodowało nawet drobny inwentarz. 
gracji społecznej tam gdzie natrafia ona na opory w postaci antagonizmów politycznych, klasowych, etnicznych i innych". Mimo to, jak stwierdził ten autor, nie jest powiedziane, że koncepcja ta nie znalazła nigdzie warunków dogodnych do realizacji (podając przykład osiedli w Sztokholmie ${ }^{60}$ ), nie ma jednak charakteru uniwersalnego i nie jest możliwa do urzeczywistnienia, jeśli nie spotka się z akceptacją mieszkańców.

\subsection{Uwarunkowania rozwoju wielkich osiedli mieszkaniowych w powojennej Europie}

W wyniku II wojny światowej w Europie nastąpiły istotne zmiany społeczne, gospodarcze i polityczne. Ogromne straty wojenne, zarówno ludnościowe jak i materialne, a także masowe wędrówki ludności (i krajowe związane ze zniszczeniami wojennymi, i międzynarodowe będące konsekwencją m.in. przesunięć granic państwowych) stworzyły uwarunkowania wymagające nowych rozwiązań. Dziedziną, która wymagała szczególnej uwagi było mieszkalnictwo. Zniszczona w wyniku działań wojennych (niekiedy niemal doszczętnie, jak w przypadku Warszawy, Mińska, Drezna) substancja mieszkaniowa w miastach, a także niski standard i zły stan techniczny większości przedwojennych zasobów mieszkaniowych spowodowały, że popyt na mieszkania był znacznie wyższy niż ich podaż, a potrzeby mieszkaniowe znacząco przewyższały możliwości ich zaspokojenia. Sytuację tę pogłębiał rosnący napływ ludności do miast, związany głównie z rynkiem pracy, a także powojenny wyż demograficzny, w wyniku którego presja na potrzebę mieszkania w miastach jeszcze wzrosła. W niektórych krajach, tak jak Wielka Brytania i Francja, nastąpił wówczas także znaczący napływ migrantów z byłych kolonii ${ }^{6}$.

W obliczu tej sytuacji rządy wielu państw europejskich przyjęły na siebie większą lub mniejszą odpowiedzialność, uzależnioną od krajowych

${ }^{60}$ Szwecja jest krajem, w którym idea kolektywnego zamieszkiwania znalazła pozytywny odzew wśród mieszkańców i gdzie modernistyczne osiedla mieszkaniowe wyposażone we wspólne urządzenia usługowe $\mathrm{w}$ początkowym okresie swego powstawania na przełomie lat 60. i 70. XX wieku cieszyły się dużą popularnością. Przykładem takiej zabudowy jest grupa osiedli zlokalizowanych w strefie zewnętrznej Sztokholmu ( $\mathrm{m}$ in. Vallingby, Farsta, Husby), połączonych z centrum miasta transportem szynowym, liczących po kilkadziesiąt tysięcy mieszkańców, w których zaplanowano funkcjonowanie wielu urządzeń wspólnych (Adamczewska-Wejchert 1985). Obecnie jednak osiedla te są obszarem zamieszkiwania imigrantów (lub ich potomków), głównie z Turcji, Libanu, Syrii, Iraku i Somalii, którzy stanowią zdecydowaną większość mieszkańców (w osiedlu Husby ponad 80\%) - Musterd, van Kempen (2005).

${ }^{61}$ Jak podają M. Blanc i J. Stébé (2004), do Francji po wojnie algierskiej w 1962 r. napłynęło ok. 1,2 mln migrantów z tego kraju. 
uwarunkowań politycznych, społecznych i gospodarczych, za rozwiązanie lub przynajmniej złagodzenie istniejących wówczas problemów mieszkaniowych. Modernistyczna idea masowego i funkcjonalnego budownictwa mieszkaniowego spod znaku Karty Ateńskiej wydawała się wprost stworzona do realizacji tego celu. Było nim uzyskanie w stosunkowo krótkim czasie i w ekonomiczny sposób dużej liczby nowych mieszkań zapewniających podstawowy, a w relacji $\mathrm{z}$ wieloma istniejącymi zasobami, względnie wysoki standard zamieszkiwania.

Jako główne przyczyny budowania wielkich osiedli mieszkaniowych w powojennej Europie w skali całego kontynentu, bez uwzględnienia specyfiki krajów socjalistycznych (które omówione zostały w rozdziale 4 tej pracy), w literaturze wymienia się (Turkington, van Kempen, Wassenberg 2004, Musterd, van Kempen 2005):

- konieczność rozwiązania problemów mieszkaniowych powstałych po II wojnie światowej jako konsekwencja zniszczeń wojennych oraz znacznego wzrostu liczby urodzeń;

- masowe migracje ze wsi do miast w poszukiwaniu pracy;

- rozwój innowacyjnych technologii $\mathrm{w}$ budownictwie umożliwiających stosowanie prefabrykatów;

- przekonanie, że zastosowanie modernizmu w architekturze pozwoli zbliżyć się do ideałów sprawiedliwości społecznej;

- chęć ochrony terenów wiejskich przed presją ze strony inwestorów;

- zapotrzebowanie na podniesienie standardu życia;

- znaczna degradacja i zły stan techniczny starej substancji mieszkaniowej;

- konkurencja pomiędzy gminami w celu zapewnienia nowoczesnego mieszkalnictwa;

- wsparcie rządów w rozwiązywaniu problemów mieszkaniowych.

Udział państwa $\mathrm{w}$ finansowaniu i organizacji budownictwa mieszkaniowego, choć miał miejsce w niemal wszystkich krajach europejskich, różnił się znacznie swym zakresem w skali kontynentu. Szczególna pod tym względem sytuacja, która występowała w krajach socjalistycznych - gdzie udział państwa w gospodarce, $\mathrm{w}$ tym także $\mathrm{w}$ budownictwie, miał charakter hegemonii i właściwie pozbawiony był alternatywy - niewątpliwie przyczyniła się do znacznie większego rozwoju tej formy zabudowy w krajach realnego socjalizmu niż $\mathrm{w}$ krajach Europy Zachodniej. Jednak również wśród tych ostatnich wymienione uwarunkowania sprawiły, że już w pierwszych latach po II wojnie światowej zaczęly powstawać początkowo niewielkie, a z czasem coraz bardziej rozległe obszary zabudowy blokowej wznoszone w duchu Karty Ateńskiej. 
Ich budowa na masową skalę była możliwa dzięki użyciu nowych technologii budowlanych. Pojawiła się możliwość wznoszenia budynków przy użyciu wysokich dźwigów budowlanych (żurawi) oraz nowe materiały, takie jak stal, beton i będący ich połączeniem żelbet (Motak 2012). Budownictwo uprzemysłowione na pierwszym etapie opierało się na konstrukcji tzw. wielkiego bloku (technologia wielkoblokowa), a dopiero w okresie późniejszym (od lat 60. w Europie Zachodniej, od lat 70. XX w. w Polsce) na konstrukcji zwanej wielką płytą (budownictwo wielkopłytowe) (Basista 2001, Motak 2012).

Pierwsze powojenne modernistyczne osiedla blokowe na dużą skalę powstawały w Europie już od lat 50., ale początek ery masowego budownictwa blokowego datuje się na wczesne lata 60. minionego stulecia. Kraje, w których era ta zaczęła się najwcześniej to Dania, Szwecja, Holandia oraz Wielka Brytania (Wassenberg i in. 2004). Osiedla takie powstawały w całej Europie, lecz ich skala i wielkość w poszczególnych krajach uzależniona była od krajowych uwarunkowań społeczno-kulturowych, gospodarczych i politycznych, które były silnie zróżnicowane. Wśród krajów Europy Zachodniej największą skalę ta forma budownictwa osiągnęła we Francji, Szwecji oraz Holandii. We Francji, gdzie wielkie osiedla mieszkaniowe budowano do połowy lat 70. XX wieku, odnotowano także najszybszą dynamikę przyrostu liczby mieszkań w tych osiedlach (Blanc, Stébé 2004). $\mathrm{W}$ rezultacie $\mathrm{w}$ wielkich osiedlach mieszkaniowych tego kraju (tylko w zasobach HLM, czyli sektorze budownictwa społecznego) z tego okresu znajdowało się ponad 2,6 mln mieszkań (Coudroy de Lille 2000).

Za symboliczny koniec epoki budowy wielkich osiedli na świecie uważa się natomiast rok 1972, kiedy w Saint Louis w stanie Missouri w USA wysadzono $\mathrm{w}$ powietrze pierwszy budynek osiedla blokowego Pruitt-Igoe, składającego się z kompleksu 14-piętrowych bloków, powstałych w latach 1954-1956, które ze względu na brak chętnych do zamieszkania z czasem stało się ośrodkiem przestępczości. Wydarzenie to uznane zastało przez krytyka architektury Ch. Jencksa (1987) za śmierć architektury modernistycznej. Jednak jak zauważa M. Motak (2012) opinia ta, choć szeroko rozpowszechniona, uznana została za nieco przedwczesną, ponieważ budowa wielkich osiedli była kontynuowana. W wielu krajach Europy Zachodniej do końca lat 70., w krajach Europy Południowej (m.in. Włochy i Hiszpania) do połowy lat 80., a w krajach Europy Środkowo-Wschodniej, na skutek uwarunkowań ustrojowych, do początku lat 90. XX wieku. W większości krajów zachodnioeuropejskich jednak druga połowa lat 70. oznaczała schyłkową fazę tej formy zabudowy. 


\subsection{Podsumowanie}

Celem rozważań przedstawionych $\mathrm{w}$ niniejszym rozdziale była prezentacja najważniejszych koncepcji urbanistycznych i architektonicznych XIX i XX wieku, które miały decydujący wpływ na kształtowanie się współczesnej urbanistyki, w tym na rozwój wielkoskalowego budownictwa osiedlowego wznoszonego po II wojnie światowej w miastach europejskich, a w szczególności w krajach socjalistycznych. Przedstawienie tych koncepcji uznano za ważne, ponieważ idee, które inspirowały architektów i urbanistów II połowy XX wieku narodziły się wraz z pojawieniem się w miastach przemysłu, głównie jako reakcja na panujące w nich złe warunki mieszkaniowe.

Pierwszą z nich była idea kolektywnego zamieszkiwania, ktora poprzez nową organizację przestrzeni miejskiej wpływać miała na kształtowanie się nowych form życia społecznego zaproponowana między innymi w utopijnych koncepcjach Ch. Fouriera i R. Owena. Jej źródłem była krytyka panujących wówczas stosunków społecznych i potrzeba zapewnienia higienicznych warunków życia ludności robotniczej. Jedną z dróg osiągnięcia tego celu miała być kolektywizacja życia społecznego realizowanego w precyzyjnie zaprojektowanej i ograniczonej przestrzeni mieszkaniowej. Koncepcja ta inspirowała wielu późniejszych architektów i urbanistów, ale przede wszystkim swą obecność zaznaczyła w radzieckiej myśli urbanistycznej, której była bliska ze względów ideowych. Tam też została rozwinięta w postaci idei domów-komun i doprowadzona w końcu lat 20. XX w. do skrajnej formy zakładającej taką organizację mieszkalnictwa, która niemal całkowicie eliminowała indywidualizm z życia społecznego. I mimo że już w latach 30. ubiegłego stulecia oficjalnie zarzucono budowę domów-komun w ZSRR, to jednak echa idei kolektywizmu mieszkaniowego w mniej skrajnej formie można odnaleźć także $\mathrm{w}$ pracach Le Corbusiera i w założeniach jednostki sasiedzkiej C.A. Perry'ego, które powstały w zgoła innych warunkach ustrojowych. Pokłosiem tej idei w powojennych miastach socjalistycznych była niewątpliwie struktura i wielkość wznoszonych w nich mieszkań związana z przekonaniem, że życie społeczne mieszkańców miast socjalistycznych ma toczyć się w kolektywie, nie zaś w indywidualnej przestrzeni mieszkaniowej pozbawionej kontroli zewnętrznej.

Druga grupa idei obejmuje te, które wpłynęły na kształt przestrzenny i urbanistyczny powojennych wielkich osiedli mieszkaniowych i które w większości wyłożone zostały w Karcie Ateńskiej uznanej za dokument programowy tej formy zabudowy. Realizacja tych idei miała sprawić, że warunki mieszkaniowe $\mathrm{w}$ miastach poprawią się, a miasto stanie się bardziej przyjazne, zdrowsze i bardziej higieniczne dla mieszkańców, dzięki innej niż dotychczas organizacji przestrzeni mieszkaniowej. 
Pierwszą z tych idei, która stała się fundamentem powojennego planowania miejskiego, $\mathrm{w}$ tym także budowy wielkich osiedli było funkcjonalne strefowanie przestrzeni miejskiej. I choć jej głównym manifestem stała się Karta Ateńska, była ona jedną z zasad kształtowania wcześniejszej koncepcji "miasta przemysłowego" T. Garniera oraz koncepcji miasta linearnego A. Sorii y Mata, a także projektów Le Corbusiera z lat 20. XX wieku. A jej prekursorskie próby odnaleźć można już w koncepcji miast ogrodów E. Howarda, który proponował oddzielenie miejsc zamieszkania od miejsc pracy i usług oraz "zatopienie” mieszkań w otaczającej zieleni, łącząc w ten sposób zalety życia $\mathrm{w}$ mieście i na wsi. Rozdział funkcji miejskich proponowany przez tych autorów dla stosunkowo niewielkich miast i osiedli, realizowany w wielkich osiedlach budowanych po II wojnie światowej, stał się jedną z podstawowych ułomności tej formy zabudowy.

Kolejną ideą, która miała istotny wpływ na kształtowanie się struktury przestrzennej współczesnych osiedli był modernistyczny postulat zerwania z tradycyjnym układem kwartałowej zabudowy miejskiej i XIX-wiecznej ulicy. Wprowadzanie do projektowania osiedli zasad, które nastawione były na tworzenie warunków sprzyjających zdrowiu mieszkańców, powodowało, że znacznie większą wagę przywiązywano do doświetlenia mieszkań światłem słonecznym oraz do przewietrzania układu urbanistycznego. Ich wyrazem przestrzennym było sytuowanie budynków uwzględniające ich optymalną orientację w stosunku do stron świata, lokalizację w odpowiedniej odległości od siebie, otaczanie zielenią oraz stosowanie takich układów zabudowy, najczęściej równoległych, które umożliwiały realizację tych zasad. Do modernistycznych postulatów, których głównym celem było szybkie zaspokojenie rosnących potrzeb mieszkaniowych w sposób zapewniający mieszkańcom podstawowy standard, należały także: typizacja i uniformizacja zabudowy, korzystanie w budowie mieszkań z prefabrykatów umożliwiających jak najszybsze ich wznoszenie i obniżenie kosztów budowy (co w osiedlach powojennych realizowano przez wykorzystanie technologii wielkopłytowych) oraz funkcjonalną prostotę formy architektonicznej, pozbawionej zbędnych detali. Postulaty te, zanim skodyfikowano je w Karcie Ateńskiej, były realizowane $w$ osiedlach projektowanych przez modernistów związanych z niemiecką szkołą Bauhausu już w latach 20. XX wieku oraz w projektach Le Corbusiera. Szybkiemu zaspokojeniu potrzeb mieszkaniowych służyć miało również wznoszenie budynków wielkoskalowych (wielokondygnacyjnych i wieloklatkowych), które sprzyjać miało bardziej efektywnemu wykorzystaniu przestrzeni.

Idee te, podobnie jak idea rozdziału funkcji miejskich, realizowane na wielką skalę w powojennych osiedlach mieszkaniowych, wprowadzily daleko idący schematyzm i monotonię zabudowy, pozbawily ją czytelności 
i zdehumanizowały, co sprawiło, że z czasem stały się jednym z głównych mankamentów przestrzeni osiedlowej.

Konkludując, na kształtowanie się koncepcji organizacji przestrzeni mieszkaniowej, które ucieleśniły się $\mathrm{w}$ postaci osiedli znanych $\mathrm{z}$ powojennych miast socjalistycznych wpływ miała zła sytuacja mieszkaniowa we wczesnych miastach przemysłowych. Lewicowy i socjalny rodowód tych koncepcji sprawil, że znalazły dogodne warunki do realizacji w krajach Europy Środkowo-Wschodniej, gdzie na skutek panujących w nich warunków ustrojowych na wiele powojennych dziesięcioleci stały się standardem mieszkaniowym dla milionów, niezależnie od ich statusu społecznego i zamożności. 



\section{ROZWÓJ I EWOLUCJA WIELKICH OSIEDLI MIESZKANIOWYCH W MIEŚCIE SOCJALISTYCZNYM}

\subsection{Miasto socjalistyczne jako idea i byt realny}

„Miasto socjalistyczne”, mimo że szeroko opisane w literaturze, nie jest pojęciem jednoznacznym (Enyedi 1996, Szelényi 1996, Węcławowicz 1988, 1999, 2000, 2007, Szczepański 1991, Jałowiecki 1994, 1995, Tosics 2005, Jałowiecki, Szczepański 2006). Jak podaje G. Węcławowicz (1999, s. 35), definicje i opisy tego pojęcia reprezentują dwa podejścia. Pierwsze $\mathrm{z}$ nich obejmuje plany i projekty zawierające stwierdzenia, jak miasto powinno być zorganizowane, drugie zaś analityczne badania określające specyficzne cechy powojennego rozwoju miast i urbanizacji. Podobnie uważa B. Jałowiecki (1994, 1995, Jałowiecki, Szczepański 2006), według którego miasto socjalistyczne można rozumieć po pierwsze jako urbanistyczno-architektoniczną doktrynę $X X$ wieku - utopijny projekt organizacji przestrzeni i społeczeństwa, nigdy w pełni nie zrealizowany, po wtóre jako wytwór urbanistyki „realnego socjalizmu" - formacji politycznej i gospodarczej istniejącej w Polsce i w innych państwach dawnego bloku socjalistycznego.

Mówiąc o miastach socjalistycznych należy mieć świadomość, że odmienne uwarunkowania historyczne, społeczne i gospodarcze, istniejące przed II wojną światową w krajach europejskich poddanych wpływom tego ustroju, sprawiły, że pomiędzy poszczególnymi krajami, a nawet miastami tych krajów występowały dość znaczne różnice. Jednak specyfika odgórnych reguł kształtujących te miasta w latach 1945-1989 sprawiła, że pomiędzy nimi było wiele podobieństw, a nawet cech wspólnych, które różniły je od miast Europy Zachodniej funkcjonujących w tym okresie w warunkach gospodarki rynkowej (por. Węcławowicz 1999, 2007, Sagan 2000a, Musil 2005, Tosics 2005).

W odniesieniu do pytania, czym jest miasto socjalistyczne i w jaki sposób jego przemiany wpisują się $\mathrm{w}$ uniwersalny model przekształceń miejskich obserwowany $\mathrm{w}$ miastach zachodnioeuropejskich i amerykańskich, w literaturze spotkać można dwa przeciwstawne podejścia (Tosics 2005, s. 46). Zgodnie z pierwszym z nich, nazywanym ekologicznym, powojenny rozwój miast centralnej $\mathrm{i}$ wschodniej Europy wpisuje się $\mathrm{w}$ uniwersalny 
światowy model rozwoju miejskiego i powtarza wszystkie jego fazy (urbanizacja, suburbanizacja, dezurbanizacja i reurbanizacja), przy czym na skutek czynników ustrojowych są one tylko odroczone w czasie (Enyedi 1996). Drugie podejście natomiast, określane jako historyczne, zakłada że społeczeństwa rozwijające się w różnych warunkach wytwarzają jakościowo odmienne warunki rozwoju miast, na skutek czego te same fazy rozwoju miejskiego $\mathrm{w}$ różnych miastach mogą zachodzić w różnej kolejności $\mathrm{w}$ zależności od istniejących w nich uwarunkowań społeczno-ekonomicznych $^{62}$ (Szelényi 1996).

Nie wnikając jednakże w tym miejscu w dyskusję na temat tego, czy miasto socjalistyczne w ogóle istnieje (por. French, Hamilton 1979) i czy istnieje socjalistyczna urbanizacja tworząca odrębny typ miasta charakterystyczny dla tego ustroju (por. Enyedi 1996, Szelényi 1996, Węclawowicz 1999, Tosics 2005), w dalszych rozważaniach przyjęto za G. Węcławowiczem (2000), że koncepcja miasta socjalistycznego należy do kategorii miasta jako produktu określonej formacji społeczno-ekonomicznej. I choć - jak podaje ten autor (Węcławowicz 2000, s. 25) - według niektórych badaczy socjalizm był zbyt krótkim okresem, aby zmienić system osadniczy w krajach tej formacji, przyjmuje się niemal powszechnie, że istotnie zmienił strukturę wewnętrzną miast (Sagan 2000a, Zborowski 2000, Liszewski 2001b, Jałowiecki, Szczepański 2006, Parysek 2005, Węcławowicz 2007). Tym samym pojęcie "miasto socjalistyczne" można traktować zamiennie z pojęciem "miasto realnego socjalizmu".

Przyjęta w pracy koncepcja miasta socjalistycznego jako realnego bytu i produktu określonego ustroju odnosi się do dwóch kategorii miast. Z jednej strony jest to niewielka grupa miast powstałych w okresie socjalizmu na tzw. surowym korzeniu, zaplanowanych i od początku swego powstania kształtowanych zgodnie z ideologią socjalistyczną (np. polskie Nowe Miasto Tychy, Nowa Huta, Jastrzębie, niemieckie Halle Neustadt lub radzieckie socgorody), w literaturze określanych niekiedy jako „typowe miasta socjalistyczne" (Szczepański 1991, Węcławowicz 2007). Z drugiej zaś są to miasta, które definiować można przez analogię do definicji miast postsocjalistycznych sformułowanej przez S. Liszewskiego (2001), że wszystkie miasta, które niezależnie od tego, kiedy powstały, w okresie realnego socjalizmu poddawane były ideologii i prawom tego ustroju. Ponieważ jednak zakres wpływu ideologii realnego socjalizmu na strukturę przestrzenną, społeczną i funkcjonalną poszczególnych miast był różny (uzależniony głównie od wielkości i stopnia uprzemysłowienia), dlatego miastami socjalistycznymi

62 Podejście to zakłada, że ścieżki rozwojowe miast Europy Środkowo-Wschodniej i Zachodniej mogą przebiegać odmiennie i kraje postsocjalistyczne wcale nie muszą powielać faz rozwojowych miast zachodnich. 
w tym drugim znaczeniu określa się głównie miasta wielkie oraz miasta przemysłowe, czyli takie, w których wpływ ten był najsilniejszy. Aby jednak nie prowokować w tym miejscu osobnej dyskusji dotyczącej zakresu wpływu socjalizmu na przestrzeń i społeczeństwo poszczególnych miast, w niniejszej pracy miasto socjalistyczne traktowane jest jako miasto, które w latach 1945-1989 poddawane było wpływom ustroju, niezależnie od tego jak dalece wpływ ten zmienił jego strukturę społeczną i przestrzenną. A ponieważ przedmiotem pracy są wielkie osiedla mieszkaniowe powstałe w okresie socjalizmu uznano, że decyzja taka na użytek niniejszej pracy jest uprawniona.

\subsection{Czynniki kształtujące strukturę rezydencjalną w mieście socjalistycznym}

Specyfika miasta socjalistycznego i socjalistycznej urbanizacji wynikała z fak$\mathrm{tu}$, że przebiegała ona w społeczeństwach uprzemysławianych, pozbawionych prywatnej własności środków produkcji na rzecz monopolu państwowego oraz posiadających centralnie planowane systemy gospodarcze (Sagan 2000a). Rozwój miast w tym ustroju podporządkowany był priorytetom ideologicznym i politycznym, podczas gdy wartości techniczne, ekonomiczne i społeczne stawiane były przez ówczesne władze na dalekim planie (Węclawowicz 1988).

Największe znaczenie w kształtowaniu i organizacji przestrzeni miasta socjalistycznego miało uprzemysłowienie, spełniające nie tylko funkcje gospodarcze, ale przede wszystkim polityczne i ideologiczne (Węcławowicz 1999). Proces ten, określany jako "narzucona industrializacja” (Węcławowicz 1999) ze względu na swój forsowny charakter, powodował opóźnienie procesu urbanizacji w stosunku do procesu uprzemysłowienia, w literaturze nazwane "podurbanizacją" (underurbnization) (Konrad, Szelényi 1974). Głównym czynnikiem miastotwórczym była odgórnie narzucona lokalizacja i rozwój zakładów przemysłowych, a przestrzeń i funkcje miasta podporządkowywano potrzebom produkcji (Jałowiecki 1995). Z powodu opóźniania bądź braku realizacji innych inwestycji, rozwój miejski był tożsamy z rozwojem przemysłu, a "machinę wzrostu miasta kapitalistycznego" zastąpiła "machina wzrostu przedsiębiorstwa przemysłowego" (Sagan 2000a). Brak renty gruntowej sprawial, że nie respektowano przy tym wartości lokalizacyjnej ziemi, która w warunkach gospodarki rynkowej jest jednym z najważniejszych mechanizmów kształtowania przestrzeni (Rykiel 1999). Gwałtowna industrializacja, podobnie jak w okresie XIX-wiecznej rewolucji przemysłowej, powodowała duże zapotrzebowanie na siłę roboczą. Skutko- 
wało to masowymi migracjami ze wsi do miast (wspieranymi przez władze jako element socjalistycznej modernizacji społecznej) i ich szybkim wzrostem ludnościowym ${ }^{63}$ przyczyniającym się do narastającego niedoboru mieszkań. Niedobór ten, ze względu na swój drastyczny charakter, określany "głodem mieszkaniowym", próbowano zaspokoić budując wielkie osiedla mieszkaniowe, których rozwój utożsamiono z rozwojem miasta socjalistycznego. Ignorowano przy tym potrzebę remontów i odbudowy starych dzielnic (Węcławowicz 2000).

Jedną z zasadniczych cech krajów socjalistycznych była gruntowna, niemal rewolucyjna przebudowa społeczeństwa ${ }^{64}$, dokonująca się przez cały okres panowania tego ustroju, której główne zasady określono już w pierwszych latach. Struktura społeczna miast na skutek ich forsownej industrializacji zdominowana została przez ludność robotniczą oraz napływających do pracy w przemyśle mieszkańców wsi, bez uprzednich doświadczeń życia miejskiego (Węcławowicz 2007). Znikły klasy konstytuowane przez rynek, powstały nowe osie podziału społecznego związane $z$ wykonywanym zawodem, instytucją lub dziedziną gospodarki, w której podejmowano pracę oraz udziałem we władzy (Hamilton, Hirszowicz 1995). Jedną z najważniejszych zasad kształtowania struktury społecznej i przestrzennej przyjętych w mieście socjalistycznym był egalitaryzm. Pogląd ten w swym źródłowym znaczeniu dotyczy równości społecznej (fr. égalite), ale jest różnie rozumiany w różnych podejściach (np. równość wobec Boga w chrześcijaństwie, równość szans w doktrynie liberalnej itp.). W ustroju socjalistycznym idea ta, pojmowana była bardzo swoiście, nie jako równość wobec prawa, będąca podstawą każdego demokratycznego ustroju ${ }^{65}$, lecz jako równość warunków zgodnie z zasadą: „każdemu według potrzeb”, przy czym za-

${ }^{63}$ Według B. Jałowieckiego (2010) o skali tych przekształceń świadczy odnotowany kilkunasto- lub nawet kilkudziesięciokrotny wzrost liczby ludności w miastach, w których lokalizowano nowe zakłady przemysłowe. Wzrost ten w latach 1950-1975 wynosił np. w Jastrzębiu 51 razy, w Polkowicach 19 razy, w Tychach 14 razy (ibid., s. 236).

${ }^{64} \mathrm{~W}$ mieście socjalistycznym nastąpił proces dekompozycji tradycyjnych wymiarów wyznaczających pozycje jednostki w strukturze społecznej, takich jak pochodzenie, poziom dochodów, wykształcenie, styl życia. Dominującym sposobem postrzegania rozmytej i mało czytelnej struktury społecznej stał się trójpodział: inteligencja, robotnicy i chłopi (Domański 2002). W rzeczywistości jednak, o czym nie mówiły oficjalne badania, w krajach realnego socjalizmu wyodrębniła się nowa klasa elit politycznych, która była faktyczną „klasą rządzącą”. Grupa ta, wywodząca się z partyjnej nomenklatury i politycznej biurokracji, w bezklasowym - w założeniu - społeczeństwie, posiadała kontrolę nad produkcją dóbr i autorytarnie decydowała o ich dystrybucji (Domański 1997).

65 Jak napisał P. Czarnek (2009), ,,zasada równości gwarantowanej w ustroju państwa powinna się odnosić jedynie do sytuacji prawnej obywatela, a nie do zróżnicowań socjalno-ekonomicznych [...]. Dlatego też równość nie może być utożsamiana ze zwulgaryzowaną wizją egalitaryzmu i państwa socjalnego, w którym [...] zamiast dystrybucji dobrobytu dochodziło do podziału wspólnej biedy". 
równo poziom tych potrzeb, jak i sposób ich zaspokajania, nie był wynikiem konsensusu społecznego lecz określony był odgórnie. Według teoretyków ustroju realizacja politycznej idei egalitaryzmu z czasem doprowadzić miała do zaniku jakichkolwiek różnic społecznych (por. French, Hamilton 1979, Demko, Regulska 1987, Smith 1996). W kształtowaniu przestrzeni miast socjalistycznych idea ta obejmowała wyrównywanie warunków życiowych zarówno $\mathrm{w}$ ramach całej sieci osadniczej, jak i w obrębie jednej jednostki (Sagan 2000a) ${ }^{66}$. Do egalitarnych założeń kształtowania miasta socjalistycznego (Demko, Regulska 1987, s. 290) należały: likwidacja prywatnej własności, odrzucenie uprzywilejowanych klas społecznych, wprowadzenie w życie zasad równości, przyjęcie zasady, że żadna z grup społecznych ani zawodowych nie może mieć lepszych ani lepiej zlokalizowanych obszarów rezydencjalnych, równomierne rozmieszczenie usług publicznych, które powinny być jednakowo dostępne i jednakowej jakości, zminimalizowanie dojazdów do pracy lub taka ich organizacja, aby żadna z grup społecznych nie była nimi pokrzywdzona, oraz jednakowa dostępność czystego środowiska naturalnego i terenów rekreacyjnych.

Jakkolwiek struktura wewnętrzna miast socjalistycznych na skutek kształtujących ją procesów politycznych i przemieszania różnych grup społecznych w przestrzeni, miała charakter mozaikowy i mało czytelny (Węcławowicz 1988, Sagan 2000a), to jednak można było w niej wyróżnić strefy nawiązujące do modeli struktury społeczno-przestrzennej wypracowanych na gruncie szkoły chicagowskiej. Według R.F. Frencha i F.E.I. Hamiltona (1979) w miastach Europy Centralnej i Wschodniej, przemieszczając się od centrum w kierunku peryferii, można było wyróżnić następujące strefy: 1) historyczny rdzeń miasta, 2) wewnątrzmiejskie tereny o mieszanych funkcjach z okresu kapitalistycznego, 3) socjalistyczną strefę przejściową o mieszanej zabudowie, 4) tereny socjalistycznej zabudowy z lat 50. XX wieku, 5) osiedla bloków z wielkiej płyty z lat 60. i 70., 6) tereny otwarte, 7) tereny przemysłowe i przemysłowo-składowe, 8) peryferyjne tereny rekreacyjne. Według I. Szelényi'ego (1983) natomiast, w mieście socjalistycznym można było wydzielić sześć stref: 1) wielofunkcyjne centrum, 2) pierwsza strefa przejściowa o dobrych warunkach mieszkaniowych, 3) druga strefa przejściowa o funkcjach przemysłowo-mieszkaniowych i niskim standardzie, 4) strefa mieszkaniowo-przemysłowa $z$ zabudową przedwojenną oraz osiedlami mieszkaniowymi z lat 50.,5) nowe dzielnice mieszkaniowe, 6) strefa

${ }^{66} \mathrm{~W}$ Polsce ideę tę $\mathrm{w}$ sferze mieszkaniowej próbowano realizować $\mathrm{w}$ pierwszych latach powojennych (do 1956 r.) np. poprzez rozdział mieszkań w MDM Warszawie, tak aby reprezentowane w niej były wszystkie kategorie społeczne (Jewdokimow 2011). Idea ta z czasem, w praktyce realnego socjalizmu, ulegała stopniowej dezawuacji, aby w końcowej jego fazie pozostać już tylko pustym hasłem (Sagan 2000b). 
podmiejska o zabudowie typu wiejskiego o niskim standardzie i zabudowie willowej dobrze wyposażonej w media. W podziale tym strefa nowych dzielnic mieszkaniowych, czyli osiedli z wielkiej płyty, obok strefy centralnej i pierwszej strefy przejściowej, była obszarem charakteryzującym się najlepszymi warunkami mieszkaniowymi w mieście socjalistycznym. W większości krajów socjalistycznych, szczególnie w największych miastach, były to obszary zamieszkiwania nie tylko robotników, ale też wyższych kategorii społecznych, co decydowało o relatywnie wysokiej pozycji tych osiedli w strukturze społeczno-przestrzennej miasta, znacznie wyższej niż w miastach zachodnioeuropejskich i amerykańskich (Szelényi 1983) - rys. 3.

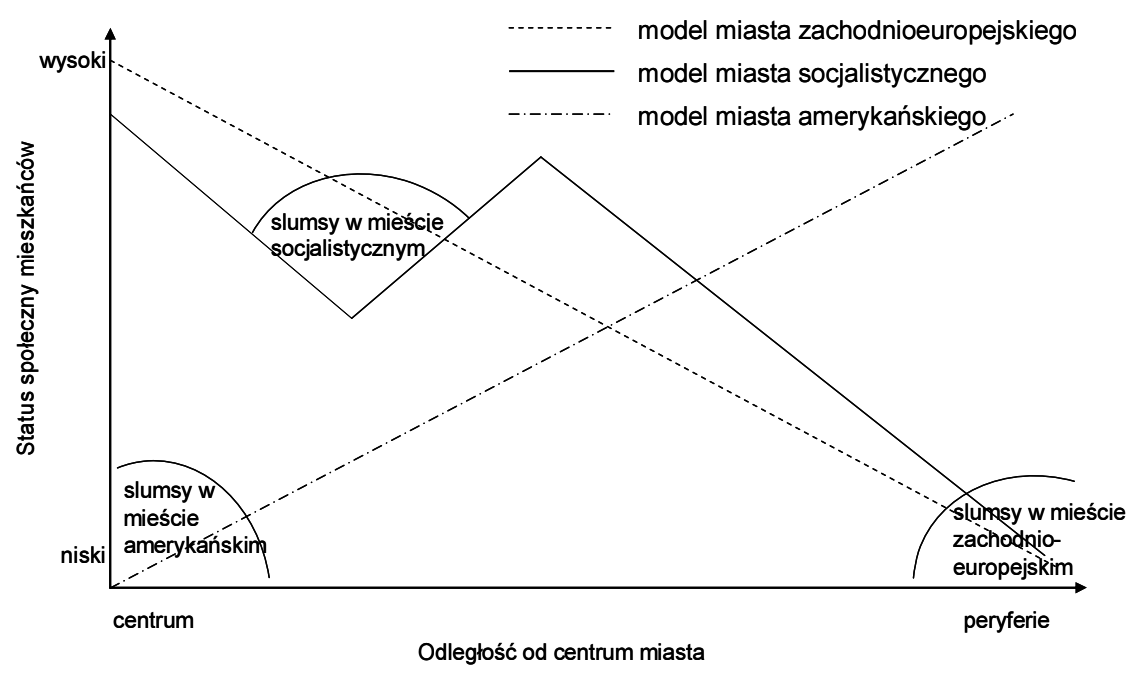

Rys. 3. Status społeczny mieszkańców a odległość od centrum w mieście socjalistycznym, zachodnioeuropejskim i amerykańskim Źródło: I. Szelényi (1983, s. 148)

Rozwój wielkich osiedli na masową skalę wpisywał się w egalitarne postulaty kształtowania miasta socjalistycznego, których jednak w praktyce realnego socjalizmu nie udało się zrealizować (Sagan 2000a). Ich budowa, paradoksalnie, mimo że wyrównywała warunki zamieszkania $w$ jednym obszarze, pogłębiała ich zróżnicowanie w skali całego miasta. Nowe osiedla oferując znacznie lepsze wyposażenie infrastrukturalne mieszkań niż stara zabudowa przyciągały mieszkańców, dla których przeprowadzka do nowych bloków często stanowiła jedyną możliwość poprawy warunków zamieszkania. Przedwojenna, w większości pozbawiona prawowitych właścicieli i nieremontowana zabudowa kamieniczna, na utrzymanie której drastycznie ograniczano nakłady inwestycyjne, podlegała dalszej dekapitalizacji 
i systematycznie traciła mieszkańców o wyższym statusie, co pogłębiało dysproporcje społeczno-przestrzenne i nasilało ucieczkę do nowych osiedli.

W miastach socjalistycznych nie istniało pojęcie rynku mieszkaniowego. Jego odpowiednikiem była polityka mieszkaniowa rozumiana jako system przepisów prawnych oraz formalnych i nieformalnych decyzji władz administracyjnych określających dostęp poszczególnych grup społecznych do mieszkań o określonej strukturze i lokalizacji (Węcławowicz 2007, s. 181). Jak podaje I. Tosics (2005, s. 48), do najważniejszych czynników determinujących politykę mieszkaniową w krajach Europy Centralnej i Wschodniej w okresie socjalizmu należały:

- znaczący udział państwa w strukturze własnościowej zasobów mieszkaniowych i gruntów w miastach (szczególnie w ich obszarach centralnych), jako konsekwencja procesów konfiskaty i nacjonalizacji67;

- silna i bezpośrednia kontrola państwa nad zagospodarowaniem i użytkowaniem terenów miejskich i podporządkowanie ich specyficznym potrzebom socjalistycznego państwa;

- administracyjne ograniczenie konsumpcji mieszkaniowej (możliwość posiadania przez rodzinę tylko jednego mieszkania);

- znaczący udział państwa $\mathrm{w}$ procesie finansowania oraz budowy i rozdzielnictwa nowych mieszkań;

- kontrola nad ograniczonym do minimum prywatnym rynkiem mieszkaniowym i prywatnym budownictwem;

- administracyjne ograniczenia $\mathrm{w}$ wielkości oraz tempie rozwoju miast (limity w napływie migracyjnym i zakazy meldunkowe w największych miastach).

W systemie tym, który charakteryzował się wysokim bezpieczeństwem zatrudnienia i kontrolowanym przez państwo niskim poziomem oraz małym zróżnicowaniem dochodów obywateli, większość najważniejszych usług zabezpieczenia społecznego (edukacja, ochrona zdrowia) realizowana była w sektorze publicznym i dostarczana bezpłatnie lub za symboliczną odpłatnością, bez uwzględnienia ich kosztów rynkowych (Tosics 2005). Podobnie było z mieszkalnictwem, które w krajach socjalistycznych było jedną z form usługi społecznej (por. Hegedús, Tosics 1996). Powszechne zabezpieczenie dostępu do tych usług, w tym do mieszkań, było głównym celem politycz-

${ }^{67}$ W Polsce w latach 1945-1994, zgodnie z kolejnymi aktami prawnymi zawierającymi przepisy mieszkaniowe, jedną z głównych form ograniczania praw właścicieli nieruchomości w miastach była tzw. publiczna gospodarka lokalami, od 1974 r. określana przez ustawodawcę jako "szczególny tryb najmu”. W myśl tych przepisów nawiązywanie stosunku najmu w budynkach należących do prywatnych właścicieli odbywało się na podstawie decyzji administracyjnych. Towarzyszyła temu rygorystyczna ochrona trwałości stosunku najmu oraz obowiązywanie urzędowych, bardzo niskich stawek czynszu, które nie pokrywały kosztów utrzymania budynków. Sytuacja ta pozbawiała właścicieli faktycznego władztwa nad nieruchomością. 
nym socjalizmu, zaś kontrola nad tym procesem była jednym $\mathrm{z}$ narzędzi realizacji tego celu. Usługi społeczne, $\mathrm{w}$ tym także związane $\mathrm{z}$ zapewnieniem mieszkań, niemal $\mathrm{w}$ całości realizowane były ze środków budżetowych i charakteryzowały się dość niskim standardem. Ich wyższy standard dostępny był jedynie dla grup o wyższym statusie społecznym ${ }^{68}$ lub dla grup mających nieformalny dostęp do dóbr i usług poprzez sieć kontaktów personalnych, która w systemie tym odgrywała bardzo istotną rolę (por. Tosics 2005, s. 47).

J. Hegedús i I. Tosics (1996) w opracowanym przez siebie modelu socjalistycznego mieszkalnictwa (East European Housing Model) jako główne elementy systemu mieszkaniowego $\mathrm{w}$ krajach tego ustroju wskazywali: polityczną kontrolę nad mieszkalnictwem, podrzędną rolę mechanizmów rynkowych, brak konkurencji pomiędzy podmiotami działającymi w tym sektorze, szeroką kontrolę nad systemem rozdziału mieszkań. Istotnymi elementami tego modelu były także: powszechne prawo do mieszkania, niskie - istotnie subsydiowane - koszty utrzymania mieszkań nieadekwatne do kosztów faktycznych, najczęściej nieprzekraczające 5\% dochodów, coraz dłuższy, w kolejnych dekadach, czas oczekiwania na przydział mieszkania oraz rosnąca dominacja niskiej jakości wielkopłytowego budownictwa mieszkaniowego (Stenning $i$ in. 2010). Model ten nigdy nie był realizowany w czystej formie, a w jego ramach można było wyróżnić kilka submodeli uwzględniających krajowe uwarunkowania ${ }^{69}$.

Wymienione uwarunkowania, jakkolwiek różniące się w poszczególnych krajach, miały wiele cech wspólnych, które kształtowały sferę zamieszkiwania w mieście socjalistycznym. Zasadniczą jego cechą była „przymusowość" wyrażająca się brakiem możliwości decydowania przez jednostki o miejscu zamieszkania (Bojar 1991). Cecha ta miała charakter systemowy,

${ }^{68}$ Jak podaje I. Toscis (2005), selektywny dostęp do usług publicznych o standardzie wyższym niż przeciętny miał na swój sposób charakter merytokratyczny (zgodnie z zasadą: „,każdemu według zasług"), co stanowiło istotny wyłom w idei egalitaryzmu i zasadzie „każdemu według potrzeb" (ibid., s. 48). Merytokracja ta jednak była ułomna, ponieważ opierała się na swoiście rozumianych "zasługach" istotnych z punktu widzenia socjalistycznego ustroju (ibid.).

${ }^{69}$ Różnice pomiędzy krajami bloku wschodniego w zakresie restrykcyjności kontroli państwa nad rynkiem mieszkaniowym podkreślał m.in. także G.S. Lowe (1994), pisząc o Węgrzech, gdzie kolejne reformy polityki mieszkaniowej spowodowały, że rynek mieszkaniowy działał względnie niezależnie, a ustawodawstwo z 1983 r. de facto zezwalało na jawną możliwość handlu i wynajmowania mieszkań bez pośrednictwa państwa. Prawna akceptacja tego stanu oznaczała nie tylko pogodzenie się z utratą kontroli nad systemem mieszkaniowym, lecz również nad nierównościami $\mathrm{w}$ dostępie do mieszkań, których zlikwidowanie stanowiło zasadniczy element ideologii socjalistycznej (Jewdokimow 2011). Odwrotnie natomiast było w Rumunii, gdzie w okresie socjalizmu stale intensyfikowano kontrolę państwa nad sektorem mieszkaniowym i zwalczano wszelkie przejawy jego urynkowienia (Lowe 1994). W Polsce natomiast istniały pewne formy prywatnej własności w mieszkalnictwie i dość wąski, ale najszerszy spośród krajów socjalistycznych zakres budownictwa realizowanego poza systemem. 
ponieważ była następstwem reguł określających zarówno dominujący tryb zdobywania nowych mieszkań, jak i warunki obrotu mieszkaniami będącymi już w posiadaniu (użytkowaniu) poszczególnych gospodarstw domowych. Lokalizacja nowych mieszkań uzależniona była przede wszystkim od rozmieszczenia terenów budowlanych przydzielonych spółdzielni w drodze decyzji administracyjnych, na które członkowie spółdzielni nie mieli żadnego wpływu. Znacznie utrudniony (a często niemożliwy) był także obrót mieszkaniami. W Polsce w przypadku mieszkań spółdzielczych i komunalnych, które stanowily zdecydowaną większość zasobu w miastach, możliwa była tylko ich zamiana, ale i ona obwarowana była wieloma ograniczeniami. W przypadku mieszkań własnościowych ${ }^{70}$ procedura ta była łatwiejsza, ale dotyczyła nielicznej grupy osób o znacznie wyższym niż przeciętny statusie materialnym (Bojar 1991). W praktyce realnego socjalizmu oznaczało to "przypisanie do mieszkania” (rys. 4), które blokowało potencjalne decyzje migracyjne związane np. ze zmianami w cyklu życia rodziny, zmianami w poziomie zamożności czy w preferencjach mieszkaniowych,

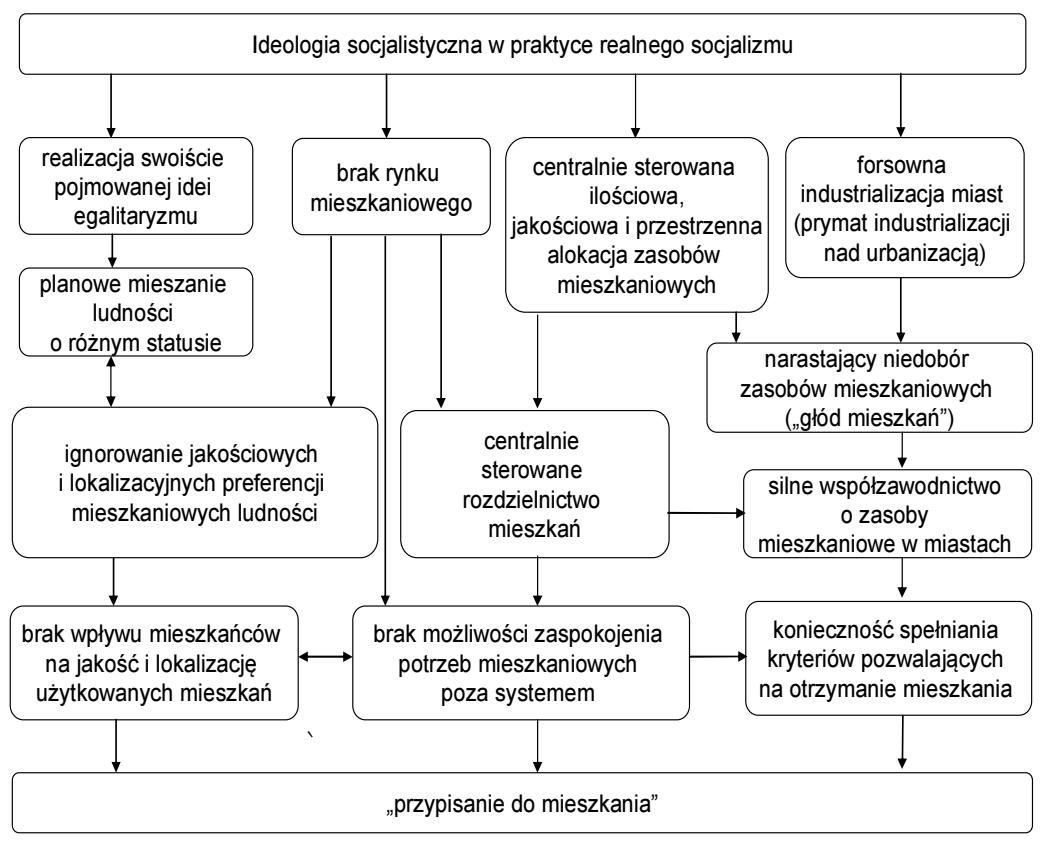

Rys. 4. Czynniki decydujące o „przypisaniu do mieszkania” w mieście socjalistycznym Źródło: opracowanie własne

${ }^{70} \mathrm{~W}$ Polsce w spółdzielczym zasobie wielorodzinnym istniało tzw. spółdzielcze własnościowe prawo do lokalu. Od 2007 r. nie ma już możliwości ustanawiania tego prawa i obecnie przysługuje ono tylko osobom, na rzecz których zostało ustanowione przed $2007 \mathrm{r}$. 
które w miastach kapitalistycznych były zasadniczymi czynnikami migracji i mechanizmami kształtującymi strukturę rezydencjalną miast.

Trudno dostępne i długo oczekiwane mieszkanie stawało się "dobrem, którego nie zmienia się przez bardzo długie lata, praktycznie [...] całe życie” (Kotus 2007, s. 104). Powiększało to znacznie wartość posiadanego, a częściej tylko użytkowanego mieszkania, które było dobrem nie tylko materialnym, ale ze względu na trudność jego „zdobycia”, stanowiło wartość autoteliczną, często wyabstrahowaną z otoczenia (Borowik 2007) i dobro niemal bezcenne. Omówiona sytuacja silnie ograniczała aspiracje mieszkaniowe ludności miast socjalistycznych. E. Kaltenberg-Kwiatkowska (2005), która zajmowała się ich badaniem wśród Polaków dowiodła, że były one „skromne, niewiele wykraczające poza stan posiadania, krojone na miarę rzeczywistości mieszkaniowej i możliwości jej zmiany" (ibid., s. 154). W realnym socjalizmie, jak zauważa dalej ta autorka, opinie Polaków o własnych warunkach mieszkaniowych były bardzo powściągliwe i często mniej krytyczne niż wynikałoby to z zastosowania obiektywnych, fachowych miar i wskaźników. Podobna sytuacja miała miejsce $\mathrm{w}$ innych krajach socjalistycznych (por. Tosics 2005).

Era miasta socjalistycznego w Europie Środkowo-Wschodniej trwała do 1989 roku i nie była jednorodna. Systemowa dominacja państwa w decyzjach dotyczących finansowania, budowy oraz rozdzielnictwa mieszkań w tym okresie ewoluowała w kolejnych dekadach tego ustroju. Według I. Szelényi'ego (1996) wyróżnić można w niej dwie fazy: pierwszą - od końca lat 40 . do połowy lat 70. XX wieku, która charakteryzowała się pełną kontrolą państwa nad sektorem mieszkalnictwa, oraz drugą trwającą od połowy lat 70. do początków lat 90. minionego stulecia, w której następowało stopniowe urynkowienie systemu $\mathrm{u}^{71}$.

Analiza ilościowego i jakościowego wymiaru sytuacji mieszkaniowej $\mathrm{w}$ miastach socjalistycznych (szczegółowo omówiona $\mathrm{w}$ pracach m.in. M. Cesarskiego 2007 i D. Jarosza 2010), pokazuje, że w okresie od początku lat 60. do upadku ustroju socjalistycznego nastąpił znaczący przyrost liczby mieszkań oraz istotnie poprawił się ich standard (głównie w zakresie wyposażenia infrastrukturalnego) - tab. 6.

Równocześnie mimo poprawy wielu wskaźników, wobec gwałtownego przyrostu liczby ludności, głównie na skutek masowej migracji ze wsi oraz relatywnie dużego przyrostu naturalnego i zwiększania się długości życia, rozmiary budownictwa mieszkaniowego w miastach socjalistycznych wciąż

${ }^{71} \mathrm{~W}$ warunkach polskich potwierdza to przykład Łodzi, gdzie wybudowane w II połowie lat 70., nowoczesne jak na owe czasy sięgające ponad 20 pięter bloki (zwane łódzkim Manhattanem), w atrakcyjnej lokalizacji ( $w$ bezpośrednim sąsiedztwie centrum) miały pulę mieszkań, które sprzedawane były na wolnym rynku za dewizy. 
były niewystarczające $\mathrm{w}$ stosunku do potrzeb. W Polsce wielkość deficytu mieszkaniowego (liczonego jako różnica pomiędzy liczbą mieszkań a liczbą gospodarstw domowych) wynosiła na koniec poszczególnych dekad odpowiednio: w 1960 roku - 1,22 mln, w 1970 roku - 1,25 mln, w 1978 - 1,61 mln, a w $1988-1,3 \mathrm{mln}, \mathrm{w}$ tym 0,8 mln w miastach (Cesarski 2007, s. 113, Jarosz 2010, s. 102) 72 .

Tab. 6. Wybrane wskaźniki sytuacji mieszkaniowej w miastach polskich w latach 1960-1988

\begin{tabular}{|l|r|r|r|c|}
\hline \multirow{2}{*}{ Wyszczególnienie } & \multicolumn{4}{c|}{ Rok } \\
\cline { 2 - 5 } & 1960 & 1970 & 1978 & 1988 \\
\hline Ludność w mln & 14,1 & 17,0 & 20,1 & 23,2 \\
\hline Mieszkania w mln & 3,5 & 4,5 & 5,7 & 7,1 \\
\hline Izby w mln & 8,6 & 12,5 & 17,6 & 23,1 \\
\hline Liczba mieszkań na 1000 osób & 248 & 265 & 283 & 306 \\
\hline Liczba gospodarstw domowych na 100 mieszkań & 122 & 120 & 118 & 111 \\
\hline Odsetek mieszkań 1-2-izbowych & 54,2 & 42,9 & 31,9 & 24,3 \\
\hline Średnia powierzchnia użytkowa mieszkania w m ${ }^{2}$ & 43,5 & 46,8 & 49,2 & 53,8 \\
\hline Średnia powierzchnia użytkowa mieszkania na 1 osobę & 11,4 & 12,8 & 14,6 & 16,8 \\
\hline Liczba izb w mieszkaniu & 2,50 & 2,77 & 3,07 & 3,29 \\
\hline Liczba osób na izbę & 1,53 & 1,32 & 1,10 & 0,97 \\
\hline Liczba osób na mieszkanie & 3,83 & 3,64 & 3,37 & 3,20 \\
\hline Udział mieszkań wyposażonych w: & & & & \\
$\quad$ - wodociąg & 55,4 & 75,2 & 87,2 & 94,8 \\
$\quad$ - łazienkę & 26,0 & 48,4 & 68,3 & 82,3 \\
$\quad$ - ustęp spłukiwany & 35,6 & 55,5 & 72,6 & 84,9 \\
$\quad$ - instalację c.o. & 13,2 & 36,2 & 56,9 & 72,7 \\
\hline
\end{tabular}

Źródło: opracowanie własne na podstawie danych z GUS (NSP 1960, 1970, 1978, 1988).

Podobnie było w innych krajach socjalistycznych, które przez cały okres trwania tego ustroju pozostawały $\mathrm{w}$ znacznym dysparytecie mieszkaniowym w stosunku do krajów europejskich, które w powojennym 45-leciu nie doświadczyły socjalistycznej urbanizacji (por. Tsenkova 1996, Jarosz 2010). Znaczny deficyt mieszkaniowy, z jakim większość krajów realnego socjalizmu wkroczyła w okres transformacji ustrojowej, na kolejne dziesięciolecia zdeterminował sytuację bytową ludności w tych krajach oraz istotnie wpłynął na pozycję wielkich osiedli mieszkaniowych $w$ miastach postsocjalistycznych po zmianie ustrojowej, która jest przedmiotem analiz w dalszej części pracy.

72 Równocześnie w Europie Zachodniej, już od początku lat 70. kraje najbardziej rozwinięte, a od lat 80 . niemal wszystkie, osiągnęły statystyczną nadwyżkę liczby mieszkań nad liczbą gospodarstw domowych (Cesarski 2007). 


\subsection{Uwarunkowania rozwoju wielkich osiedli mieszkaniowych $w$ mieście socjalistycznym}

Wielkie osiedla mieszkaniowe - jak już powiedziano - powstawały w niemal wszystkich krajach europejskich, ale na największą skalę rozwinęły się w krajach socjalistycznych. Złożyło się na to wiele przyczyn, głównie o charakterze politycznym i ideologicznym, wynikających ze specyfiki tego ustroju, ale decydowały o tym także czynniki pragmatyczne, niespecyficzne dla socjalizmu, głównie o charakterze ekonomicznym, działające w skali całej Europy. Wśród tych czynników zasadnicze znaczenie miały duże zniszczenia wojenne i wzrost liczby ludności w miastach, powodowany czynnikami demograficznymi i migracjami, oraz potrzeba zaspokojenia stale rosnących potrzeb mieszkaniowych poprzez budowę jak największej liczby mieszkań w możliwie najbardziej efektywny ekonomicznie i najszybszy sposób (Sagan 2000a, Węclawowicz 2007, Turkington i in. 2004, Musterd, van Kempen 2005). Ważną rolę w rozwoju wielkich osiedli mieszkaniowych w skali całej Europy odegrały również czynniki technologiczne, umożliwiające produkcję mieszkań na masową skalę poprzez stosowanie w budownictwie prefabrykatów, w szczególności tzw. wielkiej płyty (por. Wojtkun 2004). Specyfika krajów socjalistycznych sprawiła jednak, że bardzo istotną rolę odegrały czynniki polityczne i ideologiczne (rys. 5).

W warstwie politycznej i ideologicznej do czynników decydujących o rozwoju wielkich osiedli mieszkaniowych $\mathrm{w}$ miastach socjalistycznych należały (por. Węcławowicz 1999, 2007, Gaczek, Rykiel 1999, Sagan 2000a, Wojtkun 2008, Sýkora 2009):

- narzucona przez władze forsowna industrializacja gospodarki ${ }^{73} \mathrm{i}$ jej prymat nad urbanizacją („,podurbanizacja”), która powodowała duże zapotrzebowanie na siłę roboczą i masowe migracje ze wsi, a w konsekwencji gwałtowny wzrost ludnościowy miast i znaczny niedobór mieszkaniowy ze względu na swój drastyczny charakter określany jako "głód mieszkan";

- podporządkowane celom politycznym i scentralizowane planowanie przestrzenne, nieograniczone mechanizmami rynkowymi, prawem prywatnej własności ani działaniem renty gruntowej;

- nielimitowany dostęp do wolnych terenów;

- przyjęcie po 1956 roku zasady strefowania funkcjonalnego jako głównej doktryny urbanistyczno-architektonicznej w rozwoju przestrzennym miast;

${ }^{73}$ Forsowna powojenna industrializacja miała cechy spóźnionej rewolucji przemysłowej, ponieważ gospodarki większości krajów, w których po 1945 r. wprowadzono socjalizm, przed II wojną światową oparte były na rolnictwie (Musil 2005). 
- możliwość realizacji swoiście pojmowanej idei egalitaryzmu i wyrównywania warunków zamieszkania w przestrzeni miejskiej;

- przekonanie, że dostarczony standard mieszkaniowy jest $\mathrm{w}$ stanie $\mathrm{w}$ pełni zaspokoić potrzeby mieszkaniowe $\mathrm{w}$ miastach - nie uwzględniono bowiem ich ewolucji ani indywidualnego charakteru;

- przekonanie o ekonomicznej racjonalności budowy wielkich osiedli, które de facto okazało się nieprawdziwe (Basista 2001, Wojtkun 2004).

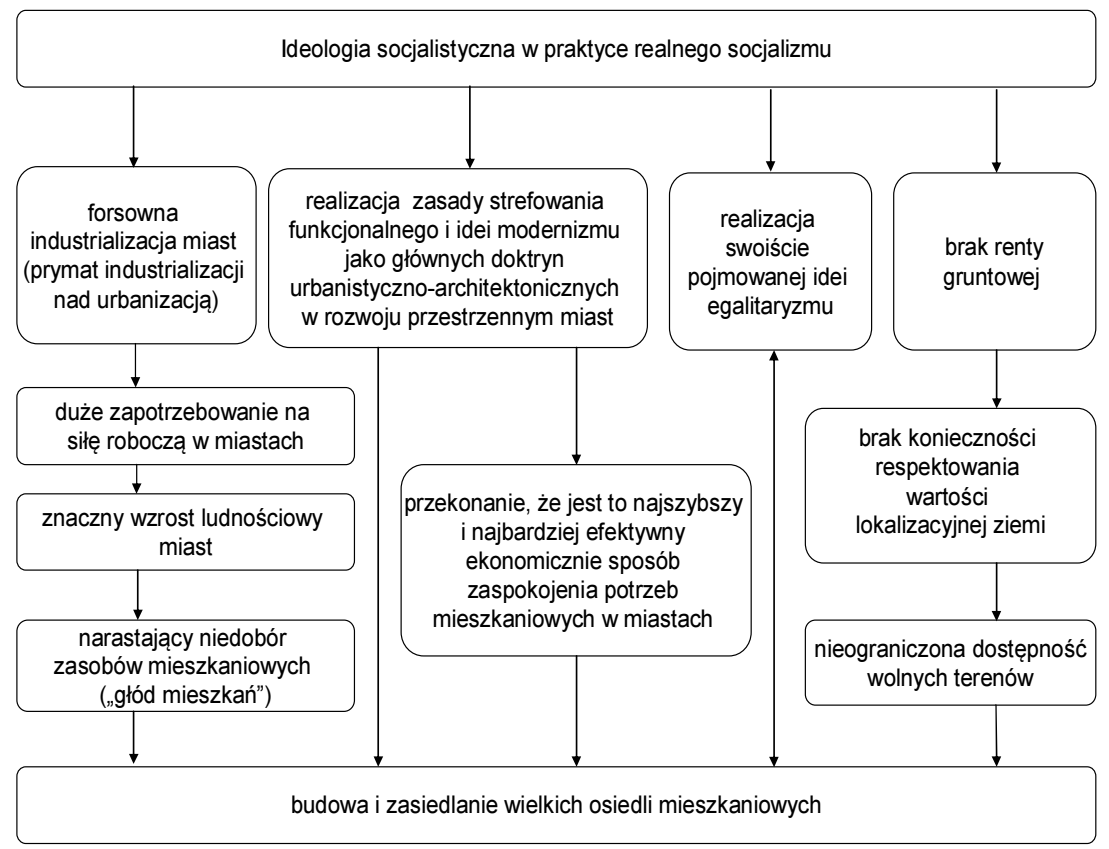

Rys. 5. Najważniejsze czynniki polityczno-ideologiczne decydujące o powstawaniu wielkich osiedli mieszkaniowych w miastach socjalistycznych

Źródło: opracowanie własne

Tym, co istotnie wpłynęło na kształt urbanistyczny wielkich osiedli mieszkaniowych $\mathrm{w}$ mieście socjalistycznym, był powrót do narodzonej w latach międzywojennych idei modernizmu ${ }^{74}$, która według wielu autorów (np. Pawłowska 1996, Knorr-Siedow 2004) miała liczne cechy wspólne z so-

${ }^{74}$ Termin „modernizm” używany zarówno w historii sztuki, jak i w historii architektury, w celu uniknięcia nieporozumień w niniejszej pracy używany jest za K. Pawłowską (1996) jako tożsamy z pojeciem „ruch nowoczesny w architekturze”; zaproponowanym przez Ch. Jencksa w pracy pt. Le Corbusier. Tragizm wspótczesnej architektury z 1973 r. (wyd. polskie - 1982). Podstawową cechą modernizmu w architekturze jest prostota formy, a głównym założeniem ,form follows function", czyli forma podąża za funkcją, która zakłada, że o pięknie budynku stanowi głównie jego funkcjonalność. 
cjalizmem. W warunkach urbanizacji socjalistycznej, w których bardzo mocno akcentowano społeczne funkcje architektury, utrzymana w duchu modernizmu idea masowego budownictwa mieszkaniowego oparta na zasadach wypracowanych przez twórców Karty Ateńskiej, wydawała się wprost idealna do urzeczywistnienia. I mimo że - jak pisał M. Szczepański (1991, s. 34): „trudno nie uznać za paradoksalne, że dokument opracowany z myślą o zupełnie innym ustroju i uwzględniający jego istotę wykorzystany został przy budowie miasta socjalistycznego", to według K. Pawłowskiej (1996) modernizm i socjalizm miały wspólne podstawy ideowe, którymi były egalitaryzm oraz internacjonalizm.

Zgodnie z bliską modernizmowi polityczną ideą egalitaryzmu naczelną zasadą kształtowania przestrzeni miasta - jak już powiedziano - miała być równość warunków życiowych. Ponieważ jednak nie było to możliwe do osiągnięcia w przedwojennej, historycznie wytworzonej i silnie zróżnicowanej substancji mieszkaniowej uznano, że należy zbudować miasto od nowa. Ujednolicone, zuniformizowane i pozbawione indywidualności nowe osiedla mieszkaniowe oferujące wszystkim mieszkańcom jednakowe warunki zamieszkania (teoretycznie uzależnione wyłącznie od wielkości gospodarstwa domowego, choć w praktyce także od innych czynników $)^{75}$ stały się materialną egzemplifikacją tej idei, określanej jako „masowe budownictwo dla bezklasowego społeczeństwa" (Knorr-Siedow 2004, s. 172).

Modernistyczne idee znacznie lepiej przystawały do socjalistycznego niż kapitalistycznego społeczeństwa, także ze względu na ich internacjonalizm. Ideolodzy i twórcy modernizmu głosili bowiem hasła „architektury międzynarodowej" sprzecznej z zasady z odrębnością terytorialną, której zanik traktowali jako automatyczne, nieuniknione i korzystne następstwo postępu (Pawłowska 1996, Knorr-Siedow 2004). Jednakże, jak pisze K. Pawłowska (1996, s. 120), "głoszone przez ideologów modernizmu przekonanie, że na drodze naukowej da się wypracować wzory uniwersalne - dobre zawsze i wszędzie, charakterystyczne także dla ideologów socjalizmu, okazało się utopią".

Bliskie modernizmowi i przyswojone przez ideologów powojennego socjalizmu przekonanie o możliwości kształtowania prawidłowych relacji międzyludzkich i osiągania ideału sprawiedliwości społecznej za pośrednictwem formy urbanistycznej nie było niczym nowym w historii myśli urba-

${ }^{75}$ Na przykład w Polsce w przyznawaniu nowych mieszkań poza kolejnością w różnych okresach PRL preferowano różne grupy, do których przede wszystkim należeli przedstawiciele władzy, służb mundurowych, robotnicy wielkoprzemysłowi, ale także nauczyciele (w tym akademiccy) oraz krótkookresowo małe liczebnie grupy wyodrębniane w oparciu o inne kryteria (np. w latach 1980-1981 absolwenci studiów wyższych, którzy ukończyli je z wyróżnieniem). Szerzej traktuje o tym praca Mieszkanie się należy... Studium z peerelowskich praktyk społecznych D. Jarosza (2010). 
nistycznej, ponieważ głosili je już w wieku XVIII twórcy miast idealnych pozostający pod wpływem socjalizmu utopijnego (por. rozdział 3). Przekonanie takie było obecne także $\mathrm{w}$ tradycji anglosaskiej ujawniając się $\mathrm{w}$ koncepcji jednostki sąsiedzkiej C.A. Perry'ego, której gorącymi zwolennikami w Polsce byli m.in. H. i Sz. Syrkusowie oraz B. Brukalska. Nigdy jednak wcześniej $\mathrm{w}$ historii ta utopijna idea nie znalazła możliwości realizacji na taką skalę jak w powojennych miastach socjalistycznych. Jak pisze E. Rewers: "po II wojnie światowej wiele miast [...] stało się niemal idealnymi miejscami realizacji socjalistycznej utopii. Były już zburzone, wyludnione, znacznemu zniszczeniu uległ także ich wymiar symboliczny. Stare przestrzenie miejskie czekały na nowy program, gotowe do przyjęcia utopii społecznej" (ibid., s. 267). Podobnie uważał B. Jałowiecki (1989, cyt. za Szczepański 1991), który pisal, że „środowiska lewicowych architektów i urbanistów z nadzieją przyjęly nowy ustrój, ponieważ stwarzał on znakomite warunki realizacji koncepcji nowoczesnej urbanistyki. Urbaniści zyskali swobodę, ponieważ nie krępowała ich już cena ziemi, powstały szanse na realizację wielkich założeń przestrzennych $\mathrm{w}$ skali miasta - a co najmniej dużych dzielnic, pojawiły się możliwości budownictwa metodami prefabrykowanymi, na podobieństwo produkcji fabrycznej, co od dawna było także postulatem modernistów" (ibid., s. 36).

Osobną sprawą pozostawała kwestia pełnej realizacji koncepcji nowoczesnej urbanistyki i założeń miasta funkcjonalnego $\mathrm{w}$ praktyce realnego socjalizmu. Niska efektywność ekonomiczna systemu socjalistycznego oraz stale rosnący głód mieszkaniowy i konieczność wznoszenia osiedli w coraz szybszym tempie i na coraz bardziej masową skalę powodowało, że z postulatów Karty Ateńskiej wybierano tylko elementy najbardziej ekonomiczne i najprostsze w realizacji. Realizacja obiektów usługowych, parkingów, terenów i obiektów sportowo-rekreacyjnych oraz kulturalnych odkładana była w czasie (i opóźniana) lub całkowicie zaniechana. To sprawiło, że urzeczywistnianie idei modernistycznych $\mathrm{w}$ urbanistyczno-architektonicznej praktyce realnego socjalizmu określone zostało w literaturze jako "socmodernizm" (Jenkcs 1982), a nawet „bieda-modernizm” (Borowik 2003, Tokajuk 2010).

\subsection{Od osiedla społecznego do wielkiego osiedla mieszkaniowego - ewolucja wielorodzinnej zabudowy osiedlowej w powojennej Polsce}

W powojennej Polsce, podobnie jak w innych krajach Europy Środkowo-Wschodniej, era budowy modernistycznych osiedli mieszkaniowych o zunifikowanej zabudowie blokowej, rozpoczęła się w końcu lat 50. i trwała do 
końca panowania ustroju socjalistycznego, czyli do początku lat 90. Wcześniej, bezpośrednio po II wojnie światowej, rozwój myśli urbanistycznej i architektonicznej $\mathrm{w}$ Polsce opierał się na dokonaniach i doświadczeniach architektów działających w okresie międzywojennym i opracowanej przez nich idei osiedla społecznego (Tokajuk 2007). Idea ta, zaproponowana $w$ innych warunkach ustrojowych dobrze wpisywała się w zasady powojennego egalitaryzmu, ponieważ - jak pisał A. Grudziński (1999, s. 45): „ujednolicony standard zabudowy i zasiedlanie nowych zespołów przez rodziny należące do różnych środowisk miały doprowadzić do przełamania barier istniejących między poszczególnymi grupami społecznymi a tym samym do integracji społeczeństwa". Mimo to już na przełomie lat 40. i 50. idea osiedla społecznego została politycznie zanegowana ${ }^{76}$ na rzecz socrealizmu (realizmu socjalistycznego) 77 , który w latach 1949-1956 stał się nie tylko w Polsce, lecz we wszystkich krajach socjalistycznych obowiązująca doktryną urbanistyczno-architektoniczną ${ }^{78}$.

Powrót do idei budownictwa osiedlowego, który nastąpił w II połowie lat 50. XX wieku wraz z odrzuceniem doktryny socrealizmu, był wynikiem $\mathrm{z}$ jednej strony nawiązania do przedwojennej polskiej myśli urbanistycznej, z drugiej zaś zainteresowania architekturą zachodnioeuropejską, w której modernizm osiągał w tym okresie szczyt rozwoju (Motak 2012). Najważniejszym jednak czynnikiem była niska efektywność ekonomiczna systemu budownictwa socjalistycznego oraz potrzeba budowania mieszkań w szybszym niż dotychczas tempie i w sposób bardziej oszczędny. Okazało się, że charakterystyczny dla socrealizmu bogaty wystrój architektoniczny budynków, a w szczególności ich artystyczna fasadowość, okazały się być nadmiernym obciążeniem dla socjalistycznej gospodarki (Basista 2001). Decydujący wpływ na podjęcie decyzji o uprzemysłowieniu metod produkcji i wykonawstwa $\mathrm{w}$ wielorodzinnym budownictwie mieszkaniowym wywarly niezadowalające rezultaty w zakresie przyrostu nowej zabudowy mieszkaniowej (Wojtkun 2008). Odrzucając doktrynę socrealizmu ${ }^{79}$ wprowadzono

${ }^{76}$ Głównym zarzutem pod adresem projektantów osiedli społecznych w Warszawie było „bezkrytyczne przenoszenie na grunt warszawski izolacjonistycznych koncepcji anglosaskiej jednostki sąsiedzkiej" (Syrkus 1976).

77 Socrealizm (realizm socjalistyczny) jako styl w architekturze obowiązywał w ZSRR od 1934 r., a w pozostałych krajach socjalistycznych od lat 40. XX wieku. Architektura socrealizmu, zgodnie z naczelnym hasłem głoszonym $\mathrm{w}$ oficjalnej propagandzie przez twórców tej doktryny, miała być „socjalistyczna w treści i narodowa w formie” (Pawłowska 1996).

${ }^{78} \mathrm{~W}$ Polsce do największych zespołów urbanistycznych wybudowanych w tym okresie należą projektowane jako samodzielne "miasta socjalistyczne" Nowa Huta (Osiedla A, B, C, D) oraz Nowe Tychy (osiedla A i B), a także Marszałkowska Dzielnica Mieszkaniowa w Warszawie (Basista 2001).

79 Po okresie stalinizmu architektura socrealizmu została potępiona. Obecnie jednak, jak pisze Basista (2001, s. 27): „oceniamy ją nieco lagodniej, ponieważ [...] pod kilkoma względami 
tym samym przyjęte $\mathrm{w}$ nowoczesnej urbanistyce zasady funkcjonalnego strefowania miasta, którego jednym z ważnych elementów funkcjonalnych miało stać się miejskie osiedle mieszkaniowe o budowie wewnętrznej zachowującej prawidłowości jednostki sąsiedzkiej (Kotarbiński 1967, s. 80).

Wówczas, w końcu lat 50. XX wieku, rozpoczął się Polsce trwający blisko 40 lat okres wznoszenia początkowo niewielkich, a z czasem coraz większych osiedli mieszkaniowych, w którym wyróżnić można kilka zasadniczych etapów rozwoju tej formy zabudowy (Kiciński 2004, Tokajuk 2007, Wojtkun 2008) $)^{80}$. I mimo że poszczególne osiedla powstające na tych etapach różniły się miedzy sobą, to centralne planowanie oraz odgórnie narzucane normatywy sprawiały, że miały wiele cech wspólnych. W całym tym okresie na skutek czynników ustrojowych wielorodzinne budownictwo mieszkaniowe pozostawało wyłączną domeną sektora publicznego. Od 1956 roku $^{81}$ jego realizacja pozostawała w gestii trzech inwestorów: rad narodowych (budownictwo tzw. kwaterunkowe), zakładów pracy i reaktywowanych wówczas spółdzielni mieszkaniowych, które z czasem stały się największym „,budowniczym” osiedli mieszkaniowych. Reaktywacja spółdzielczości mieszkaniowej, której tradycje sięgały lat przedwojennych była jednak pozorna, ponieważ tak jak cały ruch spółdzielczy, tak i spółdzielnie mieszkaniowe były w gruncie rzeczy ciałem publicznym - jak podaje A. Basista (2001, s. 66) - „parapaństwowym”, podległym odgórnym decyzjom i centralnie sterowanej polityce mieszkaniowej.

Głównym instrumentem polityki mieszkaniowej w Polsce okresu realnego socjalizmu były tzw. normatywy mieszkaniowe, szczegółowe zasady dotyczące wielkości i struktury mieszkań projektowanych w budynkach wielorodzinnych. Pierwszy powojenny normatyw określony został przez Ustawe o normach $i$ standardach budowlanych wprowadzoną w życie w 1947 roku (Wilczek 2010). Ustawa ta, jak podaje A. Basista (2001, s. 31), określając "minimalny i maksymalny poziom zaspokojenia potrzeb w zakresie przestrzeni mieszkalnej i użytkowej [...] miała chronić nie tylko interesy oby-

osiedla i budynki pochodzące z wczesnych lat 50. przewyższają efekty późniejszej działalności budowlanej [...]. Po pierwsze był to ostatni okres, w którym preferowano zabudowę obrzeżną, dzięki którym ulica pozostawała wciąż ulicą a zespoły budynków tworzyły zamknięte wnętrza [...], po drugie nie było jeszcze nacisków, by budynki bezwindowe posiadały aż pięć kondygnacji [...]. Po trzecie niższą zabudowę wieńczono spadzistymi dachami [...], po czwarte, były to lata lepszej jakości rzemiosła i tradycyjnych materiałów budowlanych [...], po piąte, pierwsze osiedla projektowano i budowano wraz z pełną infrastrukturą społeczną: szkołami, przedszkolami, żłobkami, zakładano sklepy i kina".

${ }^{80} \mathrm{~W}$ literaturze przedmiotu spotyka się różną periodyzację rozwoju wielorodzinnego budownictwa osiedlowego w Polsce (por. Kiciński 2004, Tokajuk 2007, Wojtkun 2008).

${ }^{81} \mathrm{~W}$ latach 1949-1956 jedynym inwestorem w wielorodzinnym budownictwie mieszkaniowym był Zakład Osiedli Robotniczych z tzw. dyrekcjami terenowymi i branżowymi, które w 1956 r. podporządkowane zostały radom narodowym (Basista 2001). 
wateli poprzez zagwarantowanie im minimum powierzchni mieszkaniowej, lecz również, poprzez określenie maksimum, interes państwa, które było stroną bezpośrednio zaangażowaną w proces budowy mieszkań". Normatywy te do końca obowiązywania (uchylono je w 1988 r.) kilkakrotnie ulegały modyfikacjom w zależności od sytuacji gospodarczej i polityki mieszkaniowej państwa (por. Wilczek 2010). Zasady określone w normatywie zawierały kilka typów mieszkań przeznaczonych dla rodzin o określonej strukturze i liczbie osób w gospodarstwie domowym (tab. 7). Ich projektowanie zostało oparte na przeciętnym standardzie określonym powierzchnią mieszkalną i powierzchnią użytkową przeznaczoną dla jednej osoby. W 1947 roku wielkości te wynosiły odpowiednio 7 i $11 \mathrm{~m}^{2}$, co - biorąc pod uwagę ówczesną bardzo złą sytuację mieszkaniową w Polsce - stanowiło relatywnie wysoki standard mieszkaniowy ${ }^{82}$ (por. Tokajuk 2007, Wojtkun 2008).

Tab. 7. Normatywne wielkości mieszkań w Polsce latach 1947-1988 a

\begin{tabular}{|c|c|c|c|c|c|c|c|c|}
\hline \multirow{3}{*}{\begin{tabular}{|c|} 
Liczba \\
osób \\
w gospo- \\
darstwie \\
domowym
\end{tabular}} & \multicolumn{8}{|c|}{ Rok } \\
\hline & \multicolumn{2}{|c|}{1947} & \multicolumn{2}{|c|}{1951} & \multicolumn{2}{|c|}{1959} & \multicolumn{2}{|c|}{1974} \\
\hline & $\begin{array}{c}\text { liczba } \\
\text { izb }\end{array}$ & $\begin{array}{l}\text { p.u. } \\
\text { w } \mathbf{m}^{2}\end{array}$ & $\begin{array}{c}\text { typ } \\
\text { lokalu }\end{array}$ & $\begin{array}{l}\text { p.u. } \\
\text { w m }{ }^{2}\end{array}$ & $\begin{array}{c}\text { typ } \\
\text { lokalu }\end{array}$ & $\begin{array}{l}\text { p.u. } \\
\text { w m }{ }^{2}\end{array}$ & $\begin{array}{c}\text { typ } \\
\text { lokalu }\end{array}$ & $\begin{array}{l}\text { p.u. } \\
\text { w m }{ }^{2}\end{array}$ \\
\hline 1 & \multirow{2}{*}{$1-1,5$} & \multirow{2}{*}{22} & $P$ & $16-21$ & M1 & $17-20$ & M1 & $25-28$ \\
\hline 2 & & & PK & $24-30$ & M2 & $24-30$ & M2 & $30-35 / 36$ \\
\hline 3 & 2 & 35 & $2 \mathrm{PK}$ & $30,5-39$ & M3 & $33-38$ & M3 & $444-48 / 52$ \\
\hline 4 & $2,5-3$ & 41 & $2 \mathrm{PK}$ & $41-50$ & M4 & $42-48$ & M4 & $56-61 / 63$ \\
\hline 5 & $3-3,5$ & 48 & 3PK & $50,5-56,5$ & M5 & $51-57$ & M5 & $65-70 / 73$ \\
\hline 6 & \multirow[b]{3}{*}{4} & \multirow{3}{*}{58} & $3 \mathrm{PK} / 4 \mathrm{PK}$ & $59-69$ & M6 & $59-65$ & \multirow{3}{*}{ M6/7 } & \multirow{3}{*}{$75-85$} \\
\hline 7 & & & & & & & & \\
\hline 8 & & & 4PK/5PK & $70-80$ & M7 & $67-71$ & & \\
\hline
\end{tabular}

a Ostatni normatyw uchwalony w 1974 r. obowiązywał aż do 1988 r.

p.u. - powierzchnia użytkowa.

Źródło: M. Wilczek (2010).

Równolegle z ewolucją normatywu mieszkaniowego zmianom ulegały także tzw. normatywy urbanistyczne, czyli przepisy określające zasady projektowania zespołów mieszkaniowych, które determinowały sposób ich zabudowy i wykorzystania terenu, a także wymagany program usług towarzyszących (Tokajuk 2007).

82 Realizowane wówczas budownictwo wielorodzinne miało uwzględniać następujące postulaty: każda rodzina ma zajmować samodzielne mieszkanie, kuchnia nie może pełnić funkcji sypialnych, $\mathrm{w}$ jednym pokoju powinny być ulokowane maksymalnie dwa miejsca do spania, lokal mieszkalny nie może być zlokalizowany w suterenie, każde mieszkanie ma być wyposażone w urządzenia sanitarne (Wojtkun 2008, s. 178). 


\section{Lata 1956-1970}

Osiedla budowane $\mathrm{w}$ pierwszym okresie rozwoju tej formy zabudowy w Polsce, czyli w końcu lat 50. i na początku lat 60. XX wieku, charakteryzowały się niewielką w stosunku do budowanych w kolejnych latach, skalą urbanistyczną. $\mathrm{W}$ ich projektowaniu nawiązywano do koncepcji jednostki sąsiedzkiej oraz miast ogrodów, a także do rozwiązań architektoniczno-urbanistycznych przyjętych w tym czasie w Szwecji i Wielkiej Brytanii (Kiciński 2004). Wiele z budowanych wówczas osiedli charakteryzowała kameralna skala wnętrz i umiarkowana wysokość zabudowy (Kaczmarek 1996, Trybuś 2011). Do początku lat 60 . budynki w osiedlach wznoszone były w technologii mieszanej - z użyciem materiałów tradycyjnych (cegła) i z niewielkim udziałem elementów prefabrykowanych. W rozwiązaniach budynków najczęściej spotykany był tzw. układ punktowy (Tokajuk 2007). Osiedla te często lokalizowane były $\mathrm{w}$ bliskim sąsiedztwie zwartej zabudowy śródmiejskiej. Ich dobre wyposażenie $\mathrm{w}$ usługi podstawowe $\mathrm{i}$ tereny zieleni sprawiło, że zapewniały one mieszkańcom wysoki jak na owe czasy standard warunków zamieszkania. Jak podaje J. Trubuś (2011) wiele osiedli w Warszawie, których budowę rozpoczęto w tym okresie (i kontynuowano w początkach lat 60.) np. Bielany, Rakowiec, Sady Żoliborskie, Zatrasie, uważane było za "dobry adres". Co więcej, wiele z nich projektowanych było wówczas z uwzględnieniem kontekstu przestrzennego. Przykładem takiego dobrego wkomponowania $\mathrm{w}$ zastane otoczenie jest projektowana w końcu lat 1950. budowana od 1960 roku najstarsza część osiedla Sady Żoliborskie ${ }^{83}$ w Warszawie. Do innych wiodących rozwiązań tego okresu, w których odzwierciedlenie znalazły skandynawskie pryncypia architektoniczne, należą Wzgórza Krzesławickie w Krakowie oraz Wzgórza Redłowskie w Gdyni (Wojkun 2008, s. 179). Dobrym przykładem osiedla z tego okresu jest także Osiedle im. A. Mickiewicza w Lublinie.

Począwszy od lat 60. minionego stulecia, na skutek wdrożenia polityki oszczędności ${ }^{84}$, warunki zamieszkiwania oferowane w nowo budowanych osiedlach stopniowo zaczęły ulegać pogorszeniu. Było to wynikiem nasilenia działań mających na celu radykalne potanienie mieszkalnictwa, a jednocześnie zwiększenie liczby oddawanych do użytku mieszkań, ponieważ dynamika ich przyrostu w Polsce do 1960 roku nie zaspokajała istniejących potrzeb mieszkaniowych, a ponadto była niższa niż w innych krajach socjalistycznych (Wojtkun 2008, s. 179). W 1961 roku po raz pierwszy (nieza-

83 Osiedle Sady Żoliborskie budowane było w okresie kilkunastu lat (1960-1975) i stopniowo wraz z budową kolejnych kolonii, zatracało swój pierwotny unikatowy charakter urbanistyczno-architektoniczny.

${ }^{84}$ A. Basista (2001, s. 37) stwierdzil, że politykę oszczędności często traktowano jako hasło i cel sam w sobie, co niekiedy doprowadzało do absurdu, ponieważ $\mathrm{w}$ imię pozornych oszczędności często de facto budowano drożej i zwiększano koszty eksploatacji budynków. 
leżnie od obowiązującego wówczas normatywu) ograniczono normę powierzchni mieszkaniowej do $5-7 \mathrm{~m}^{2}$ na osobęe 85 , co stanowiło wyraźny regres w stosunku do lat ubiegłych (Basista 2001). Wplyw idei modernizmu na zasady projektowania osiedli $\mathrm{w}$ tym okresie wyrażał się (zgodnie $\mathrm{z}$ normatywem urbanistycznym z 1961 r.) w ograniczaniu powierzchni mieszkań przy zachowaniu relatywnie dużej ilości terenów wolnych od zabudowy. Jak pisała w owym czasie B. Brukalska (1962, s. 148): „zwiększamy zagęszczenie na 1 ha, czym zapewniamy większej liczbie mieszkańców możliwość korzystania z usług miejskich, nie pozbawiając ich przy tym tego, co Le Corbusier nazywał szczęściem: słońca, powietrza i zieleni". W związku z niedostatkiem terenów uzbrojonych pod zabudowę mieszkaniową w normatywie urbanistycznym z 1961 roku zakazano wznoszenia budynków niskich oraz ograniczono zakres programu usługowego (Wojtkun 2008, s. 180).

Od połowy lat 60 . ubiegłego wieku, kiedy zaczęto oddawać do użytku osiedla tzw. oszczędnościowe ${ }^{86}$ (Basista 2001), w budownictwie osiedlowym nastąpiło odczuwalne pogorszenie standardu. W 1964 roku, chcąc obniżyć koszty budowy mieszkań, dokonano nowelizacji normatywu urbanistycznego, podwyższając wskaźniki wykorzystania terenu (Tokajuk 2007). Zwiększono zarówno poziomą, jak i pionową intensywność zabudowy. Wzrosła liczba budynków wysokich (najczęściej jedenastokondygnacyjnych) i szerokich, a w celu ograniczenia kosztów budowy związanych z instalacją wind i konstrukcją klatek schodowych, wprowadzono budynki tzw. korytarzowe z mieszkaniami zorientowanymi na jedną stronę, co istotnie pogarszało ich walory użytkowe. W mieszkaniach obniżono stropy (co spowodowało zmniejszenie objętości powietrza, a tym samym pogorszenie ich standardu) oraz zlikwidowano wentylację pokoi. Masowo zaczęto stosować ściany betonowe, $\mathrm{w}$ związku z czym nastąpiło pogorszenie izolacji termicznej i akustycznej mieszkań (Tokajuk 2007). Zmniejszano „zbędne” powierzchnie, do minimum ograniczano początkowe wyposażenie kuchni i łazienek, parkiety zastępowano płytkami PCV (Basista 2001). Ograniczano do minimum lub nawet rezygnowano z budowy balkonów oraz loggii (Wojtkun 2008). Wycofano się z przestrzegania zasady rozkładowości mieszkań (stosując rozwiązania amfiladowe) oraz zachowania właściwych proporcji pomieszczeń. Zasada oszczędności sprawiła, że zaczęto budować mieszka-

85 Zaostrzenie to obejmowało tzw. normę kwaterunkową określającą zasady przydziału mieszkań i przyjęte było jako rozwiązanie tymczasowe, lecz w praktyce obowiązywało aż do 1971 r. Zasady te pozwalały na możliwość wprowadzania do mieszkań kategorii M2 trzech osób, do mieszkania M3 czterech lub nawet pięciu osób, a do M4 nawet sześciu (Tokajuk 2007), czym znacznie przekraczano formalnie obwiązujący wówczas normatyw mieszkaniowy.

86 Przykładem najbardziej drastycznych oszczędności w wielorodzinnym budownictwie mieszkaniowym z tego okresu było opracowanie projektu uwzględniającego usytuowanie pomieszczeń sanitarnych poza mieszkaniami, który zaproponowano m.in. w Trójmieście. 
nia z tzw. ślepymi kuchniami bez doświetlenia dziennego, z czego jednak, na skutek zdecydowanego oporu społecznego, szybko zrezygnowano (por. Basista 2001, Wojtkun 2008). Coraz bardziej powszechne od połowy lat 60 . stosowanie prefabrykatów powodowało unifikację i zanik indywidualności budynków w poszczególnych osiedlach oraz całych osiedli. Obowiązujące wówczas przepisy zabraniały $\mathrm{w}$ nowo wznoszonych osiedlach stosowania indywidualnych projektów oraz wznoszenia na terenach uzbrojonych budynków o wysokości niższej niż pięć lub jedenaście kondygnacji wymaganych przez władze jako najbardziej ekonomiczne ${ }^{87}$ (Basista 2001). Proporcje budynków niskich i wysokich ulegały zmianie w poszczególnych dekadach, lecz zasada dominacji tych dwóch wysokości budynków w budownictwie uspołecznionym została zachowana przez cały okres socjalizmu.

Powszechne w II połowie lat 60. XX wieku sytuowanie budynków $\mathrm{w}$ układzie równoległym (w literaturze określanym jako grzebieniowy - por. Chmielewski, Mirecka 2001) powodowało utratę kameralności wnętrz urbanistycznych, co dotychczas było ważnym walorem zabudowy osiedlowej. $\mathrm{W}$ osiedlach $\mathrm{z}$ tego okresu normą stały się ograniczenia i opóźnienia w realizacji urządzeń i obiektów usługowych, rekreacyjnych, sportowych i parkingów. $Z$ reguły także $w$ projektach tych osiedli nie rezerwowano terenów pod ich rozbudowę skupiając się głównie na budowie mieszkań. Nie brano także pod uwagę możliwości zwiększenia liczby samochodów. Sytuacja ta uległa niewielkiej poprawie w końcu lat 60., kiedy nieco obniżono wskaźniki intensywności zabudowy oraz skorygowano zasady projektowania terenów osiedlowych. W wyniku tych zmian, w nieznacznie większym, choć wciąż niewystarczającym stopniu, uwzględniono realizację programu usług podstawowych, terenów zieleni i miejsc parkingowych (Tokajuk 2007) ${ }^{88}$.

Projektowane wówczas założenia osiedlowe lokowane były $\mathrm{w}$ coraz większym oddaleniu od historycznej tkanki miejskiej i obejmowały coraz bardziej rozległe tereny. Jak podaje A. Tokajuk (2007, s. 46), wśród projektów zespołów mieszkaniowych realizowanych w Polsce w latach 1964-1968, połowę stanowiły duże zespoły przeznaczone dla ponad 5,5 tys. osób (z czego ok. $30 \%$ dla 5,5-10 tys., a ok. $20 \%$ dla ponad 10 tys.). W projektach tych dominowały, stanowiąc ponad 3/4 ogółu, mieszkania M-3 i M-4, o minimalnej możliwej powierzchni użytkowej od 33 do $48 \mathrm{~m}^{2}$.

87 Pięć kondygnacji w budynku stanowiło najtańsze rozwiązanie niewymagające stosowania dźwigów windowych, jedenaście natomiast było najtańszym rozwiązaniem z wykorzystaniem dźwigów, ponieważ nie wymagało dodatkowych kosztownych urządzeń technicznych.

${ }^{88}$ A. Tokajuk (2007, s. 49) pisał, że projektowana gęstość zaludnienia w terenach osiedlowych latach 1961, 1965 oraz 1968 wynosiła odpowiednio 570, 730 oraz 650 osób/ha, a średnia powierzchnia osiedla przypadająca na jednego mieszkańca w tych latach to 25,20 i $24 \mathrm{~m}^{2}$. 
Okres ten (1956-1970) przyniósł wiele nowych inwestycji mieszkaniowych, które jednakże wobec dorastania pokolenia powojennego wyżu demograficznego oraz masowej migracji ludności ze wsi do miast, wciąż były niewystarczające $w$ stosunku do potrzeb. Na terenie całego kraju rozpoczęto wówczas realizację blisko 340 osiedli o zabudowie wielorodzinnej oraz ich zespołów (Wojtkun 2008, s. 181), jednak dynamika przyrostu nowych mieszkań w Polsce $\mathrm{w}$ tym okresie wciąż była niedostateczna i niższa niż $\mathrm{w}$ innych krajach socjalistycznych. Sytuacja w polskim mieszkalnictwie na przełomie lat 60 i 70. nie dorównywała jego poziomowi w krajach zachodnioeuropejskich, od których dzielił Polskę blisko dwudziestoletni dystans biorąc pod uwagę wielkość powierzchni i rodzaj wyposażenia mieszkań oraz towarzyszący im program użytkowy (Wojtkun 2008). W 1970 roku wskaźnik liczby nowych mieszkań oddanych do użytku wynosił w Polsce 5,9 na 1000 osób i był jednym z najniższych w Europie (ibid.). Także efekty tego przyrostu, czyli liczba mieszkań na 1000 osób w Polsce wciąż odstawała od innych krajów socjalistycznych (rys. 6).

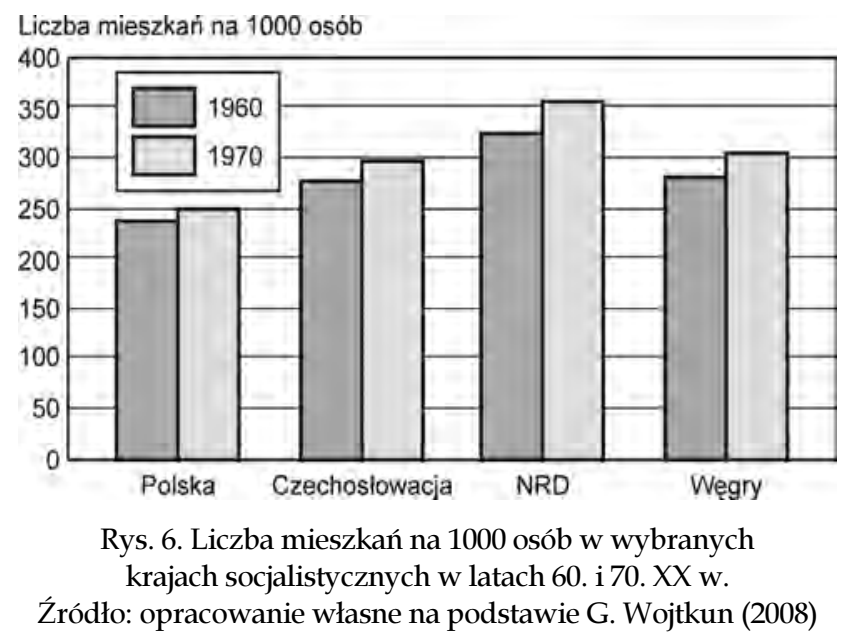

Największymi założeniami, których budowę rozpoczęto w tym okresie w polskich miastach były osiedla: Tysiąclecia w Katowicach (w 1961 r.), Za Żelazną Bramą (w 1965 r.) i Kępa Gocławska (1968 r.) w Warszawie, Żubardź (w 1958 r.), Dąbrowa (w 1960 r.) i Teofilów (w 1963 r.) w Łodzi, Rataje (w 1966 r.), Słowiańskie (w 1966 r.) i Winogrady (w 1969 r.) w Poznaniu, Grunwaldzkie we Wrocławiu (1968 r.) oraz Krowodrza w Krakowie (1968 r.). Największym i najbardziej spektakularnym budynkiem tego czasu jest wzorowana na jednostce marsylskiej (zarówno architektonicznie, jak 
i ideologicznie $)^{89}$ tzw. Superjednostka, osiemnastokondygnacyjny budynek powstały w Katowicach w latach 1967-1970, w którym znajdują się 762 mieszkania o łącznej powierzchni użytkowej 37,3 tys. $\mathrm{m}^{2}$.

\section{Lata 1971-1989}

Kolejny etap w rozwoju budownictwa osiedlowego w Polsce rozpocząl się w 1971 roku. Jego nadejście związane było ze zmianą władzy w kraju (odejściem W. Gomułki z funkcji I sekretarza PZPR i początkiem dekady E. Gierka) oraz przyjęciem nowych założeń polityki społeczno-gospodarczej, której istotnym elementem stała się poprawa warunków mieszkaniowych Polaków ${ }^{90}$. Przepisy normatywne, które formalnie uległy zmianie dopiero $\mathrm{w}$ roku 1974, już wcześniej (od początku lat 70.) podlegały pewnym korektom (por. Tokajuk 2007). Zgodnie z nowym normatywem znacznie wzrosła przeciętna wielkość mieszkań oddawanych do użytku, poprawiła się ich struktura funkcjonalno-przestrzenna (m.in. w większych mieszkaniach możliwość przewietrzania na przestrzał, oddzielenie łazienki od WC, obowiązkowe wyposażenie mieszkań w balkony lub loggie). Poprawiła się rozkładowość mieszkań i proporcje pomieszczeń, przy czym $\mathrm{w}$ dalszym ciągu utrzymano zasadę projektowania pokoju dziennego z miejscem do spania, co wciąż pozostawiało ten standard daleko poza obowiązującymi wówczas $\mathrm{w}$ większości krajów europejskich, postulatami Karty Kolońskiej ${ }^{91}$. W zakresie rozwiązań urbanistycznych normatyw z 1974 roku przyniósł zmiany podnoszące standardy w wyposażeniu osiedla. Przewidziano zwiększenie minimalnej powierzchni zieleni oraz terenów wypoczynkowych na 1 mieszkańca (odpowiednio 8 oraz $5,5 \mathrm{~m}^{2}$ ), zwiększono liczbę miejsc parkingowych i zaplanowano

89 Początkowo w Superjednostce planowano umieścić usługi dla mieszkańców, a mieszkania pozbawić kuchni na wzór kolektywnych radzieckich jednostek mieszkaniowych. Ostatecznie zaniechano tego pomysłu i zdecydowano o budowie kuchni, które jednak były bardzo małe i pozbawione światła dziennego.

${ }^{90} \mathrm{~W} 1972$ r. na V plenarnym posiedzeniu KC PZPR przyjęto „Perspektywiczny program mieszkaniowy”, w którym zaplanowano „pełne zaspokojenie potrzeb mieszkaniowych socjalistycznego społeczeństwa", a w szczególności uzyskanie przez każdą polską rodzinę samodzielnego mieszkania w ciągu niespełna 20 lat (do 1990 r.). Miało to zostać osiągnięte przez oddanie do użytku ponad $7 \mathrm{mln}$ nowych mieszkań - blisko $3 \mathrm{mln}$ w pierwszym okresie (19711980) oraz 4,5 w drugim (1981-1990) (Wojtkun 2008, s. 181).

91. Karta Kolońska to dokument sformułowany w 1957 r. a następnie zmodyfikowany w 1971 r. przez międzynarodowe stowarzyszenia i instytucje, w tym: Komisję Mieszkania Rodzinnego Unii Organizacji Rodzinnych, Komitetu Mieszkalnictwa ONZ, Międzynarodową Unię Architektów, określający minimalne wymagane powierzchnie mieszkań, stosownie do wielkości rodziny przyjęte $\mathrm{w}$ wielu krajach zachodnioeuropejskich. Według zaleceń tego dokumentu standardy powierzchni mieszkań wynosiły dla jednej osoby $-35,5 \mathrm{~m}^{2}$, dla dwóch $51,0 \mathrm{~m}^{2}$, dla trzech - $64,5 \mathrm{~m}^{2}$, dla czterech - od $69,9 \mathrm{~m}^{2}$ do $74,5 \mathrm{~m}^{2}$, dla pięciu osób - od $92,0 \mathrm{~m}^{2}$ i dla sześciu osób - 102-107 m². Zgodnie ze standardami zawartymi w Karcie pokój dzienny nie powinien pełnić funkcji sypialnych, a pokoje sypialne miały być przeznaczone maksymalnie dla dwóch osób. 
wzrost powierzchni usługowej o 50\%. Wzrosła norma nasłonecznienia mieszkań oraz dopuszczono możliwość stosowania zabudowy o bardziej zróżnicowanych gabarytach (3-16 kondygnacji), przy czym w praktyce nadal najczęściej wznoszono budynki 5- i 11-kondygnacyjne (Basista 2001).

Cechą charakterystyczną tego okresu, który trwał do przełomu lat 80. i 90. XX wieku, jest dominacja budownictwa wielkopłytowego ${ }^{92}$, którego udział w zasobach mieszkaniowych stale wzrastał (w końcu lat 60 . wynosił około $16 \%$ powierzchni użytkowej mieszkań w zabudowie wielorodzinnej w miastach, a 1980 r. już blisko 85\%). Konstrukcje wznoszone przy użyciu wielkiej płyty ${ }^{93}$ charakteryzowały się jeszcze większą niż dotychczasowe unifikacją i standaryzacją, zarówno mieszkań jak i budynków, znacznie mniejszą elastycznością rozwiązań i możliwością dostosowania ich do indywidualnych potrzeb mieszkańców, a także licznymi wadami powstającymi na etapie ich produkcji (w fabrykach domów), transportu na miejsce budowy oraz montażu ${ }^{94}$, co istotnie obniżało początkową jakość oddawanych do użytku mieszkań (Rębowska i in. 2006).

Pierwsza dekada tego okresu, lata 70. charakteryzowała się najbardziej dynamicznym po II wojnie światowej przyrostem zasobów mieszkaniowych $\mathrm{w}$ budynkach wielorodzinnych zlokalizowanych $\mathrm{w}$ wielkich osiedlach. Liczba wybudowanych mieszkań na 1000 osób wzrosła wówczas z 5,8 (1971 r.) do najwyższej wartości w okresie PRL - 8,1 (w 1978 r.). Powstające wtedy wielkie osiedla (a właściwie zespoły osiedli) projektowane były na kilkadziesiąt, a nawet na ponad 100 tys. mieszkańców (np. warszawski Ursynów). Ich wielka skala urbanistyczna i demograficzna na trwale zmieniła strukturę społeczno-przestrzenną miast w sposób charakterystyczny nie tylko dla miast polskich, ale większości miast socjalistycznych w Europie. Lokalizowane na terenach oddalonych od zwartej zabudowy śródmiejskiej stały się wielkimi monofunkcyjnymi „megasypialniami” miast socjalistycznych. W okresie tym rozpoczęto budowę m.in. największych łódzkich osied-

$92 \mathrm{~W}$ Polsce prefabrykacja pojawiła się już we wczesnych latach powojennych, lecz początkowo dotyczyła tylko najbardziej podstawowych elementów konstrukcji i wyposażenia budynków - stropów, schodów, kanałów wentylacyjnych, a także drzwi i okien (Basista 2001). Dopiero później, od II poł. lat 60. zaczęto stosować technologie, które przyjęło się określać jako wielkopłytowe. Ich skrajnym przejawem były fabryki domów, w których wytwarzano tzw. wielką płytę - elementy ścian odpowiadające wielkości pomieszczeń i wysokości stropów (niekiedy nawet z osadzoną już stolarką okienną i drzwiową), gotowe do montażu na placu budowy (Motak 2003).

${ }^{93} \mathrm{~W}$ Polsce w całym okresie rozwoju budownictwa wielkopłytowego stosowano co najmniej kilkanaście systemów prefabrykacji, które szczegółowo omówione są w licznych pracach (por. Wojtkun 2008, Rębowska i in. 2006, Słodczyk 2010, 2012).

94 Szczegółowa charakterystyka problemów powstających na poszczególnych etapach procesu konstrukcyjnego i montażowego wielkiej płyty przedstawiona została w pracy G. Wojtkuna (2008). 
li - Retkini (w 1971 r.) i Widzewa-Wschód (1973 r.), wrocławskiego osiedla Gaj (1979 r.), warszawskich osiedli - Stegny (1971 r.), Targówek (1974 r.), Chomiczówka (1974 r.), Ursynów Płn. (1975 r.), Ursynów Płd. (1977 r.), Tarchomin (1977 r.), Targówek (1977 r.) oraz Bemowo (1977 r.), krakowskich osiedli - Prądnik Czerwony (1974 r.) i Prokocim (1976 r.), wrocławskiego osiedla Kozanów (1977 r.), gdańskiej Zaspy (1972 r.), poznańskiego Piątkowa (1977 r.) oraz osiedla Rubinkowo (1974 r.) w Toruniu. Charakterystyczna dla tego okresu fascynacja możliwościami technologicznymi oraz gigantomania zaowocowała także powstaniem największych pojedynczych budynków w formie modernistycznych bloków mieszkalnych, do których należą tzw. Falowce na Przymorzu w Gdańsku, spośród których największy, wybudowany w latach 1970-1973, liczy 1792 mieszkania oraz tzw. Jamnik jeden z najdłuższych budynków w Polsce (o długości $508 \mathrm{~m}$ ), wzniesiony w Warszawie w latach 1971-1973, w którym znajdują się 43 klatki schodowe i 430 mieszkań na pięciu kondygnacjach.

Tab. 8. Budownictwo mieszkaniowe w Polsce w latach 1956-1990

\begin{tabular}{|l|c|c|c|c|c|c|c|}
\hline \multirow{2}{*}{ Wyszczególnienie } & \multicolumn{7}{|c|}{ Lata } \\
\cline { 2 - 8 } & $\begin{array}{l}1956- \\
1960\end{array}$ & $\begin{array}{c}1961- \\
1965\end{array}$ & $\begin{array}{l}1966- \\
1970\end{array}$ & $\begin{array}{c}1971- \\
1975\end{array}$ & $\begin{array}{c}1976- \\
1980\end{array}$ & $\begin{array}{c}1981- \\
1985\end{array}$ & $\begin{array}{c}1986- \\
1990\end{array}$ \\
\hline $\begin{array}{l}\text { Liczba wybudowanych mieszkań } \\
\text { ogółem (w tys.) }\end{array}$ & 621,9 & 754,2 & 942,1 & 1121,1 & 1308,5 & 954,4 & 850,3 \\
\hline $\begin{array}{l}\text { Udział mieszkań wybudowanych } \\
\text { w miastach jako \% ogółu mieszkań }\end{array}$ & 59,5 & 74,2 & 74,3 & 76,0 & 79,0 & 75,8 & 73,2 \\
\hline $\begin{array}{l}\text { Liczba mieszkań wybudowanych } \\
\text { w miastach na 1000 osób }\end{array}$ & 5,5 & 7,4 & 8,5 & 9,5 & 10,3 & 6,6 & 5,4 \\
\hline
\end{tabular}

Źródło: opracowanie własne na podstawie J. Jarosz (2010).

Od początku lat 80. minionego wieku na skutek kryzysu gospodarczego skala realizowanych inwestycji mieszkaniowych zaczęła spadać (tab. 8). Liczba wybudowanych mieszkań na 1000 osób w latach 1986-1990 była prawie dwukrotnie niższa niż w rekordowym okresie 1976-1980. Do połowy lat 80 . na skutek szukania oszczędności pogorszeniu ulegało wyposażenie osiedli w obiekty infrastruktury usługowej i tereny zieleni, a także standard budowanych mieszkań. W II połowie lat 80., w końcowym okresie PRL, sytuacja ta uległa niewielkiej poprawie. W oddawanych wówczas osiedlach zaczął pojawiać się skromny detal architektoniczny w postaci np. bardziej urozmaiconych wejść do klatek schodowych, urozmaiconych balkonów, niewielkich spadzistych zadaszeń itp. Częściej także różnicowano zabudowę pod względem wysokości, a w projektowaniu uwzględniano potrzebę kreowania przestrzeni publicznych w osiedlach (por. Nowakowski 
2013). Przeciętna wielkość mieszkań oddawanych do użytku wzrosła, a uwzględnianie $\mathrm{w}$ większym stopniu niż dotychczas potrzeb przyszłych mieszkańców sprawiło, że osiedla z tego okresu do dziś uchodzą za najbardziej atrakcyjne w polskich miastach (Kiciński 2004).

W 1989 roku wraz z początkiem transformacji ustrojowej nastąpiło wycofanie się państwa $\mathrm{z}$ bezpośredniej ingerencji w budownictwo mieszkaniowe, co spowodowało zaniechanie budowy wielkich osiedli. Proces ten wygasał jeszcze w początkach lat 90., kiedy kończono już rozpoczęte inwestycje osiedlowe ${ }^{95}$. W sumie w okresie od końca II wojny światowej do połowy lat 90. w miastach polskich oddano do użytku 5,7 mln lokali, z czego ponad $3,5 \mathrm{mln}$ stanowity mieszkania wykonane $\mathrm{w}$ technologii prefabrykowanej, charakterystycznej dla wielkich osiedli (tab. 9)96 (Rębowska i in. 2006).

Odejście państwa od subsydiowania budownictwa mieszkaniowego oraz przesunięcie go $\mathrm{w}$ sferę wolnego rynku, które ostatecznie nastąpiło w połowie lat 90. XX wieku, spowodowało gwałtowny spadek liczby budowanych mieszkań, a nowe stały się dostępne tylko dla najzamożniejszych grup społecznych. Tym samym, zgodne z polityką mieszkaniową okresu PRL, założenie, że „mieszkanie się należy"97 (Jarosz 2010), zostało zweryfikowane przez reguły wolnego rynku i rozwój gospodarki neoliberalnej.

Tab. 9. Zasoby mieszkaniowe w miastach polskich wybudowane w latach 1945-1995

\begin{tabular}{|c|c|c|c|c|c|}
\hline \multirow{2}{*}{ Wyszczególnienie } & \multirow{2}{*}{ Ogółem } & \multicolumn{4}{|c|}{ W tym wybudowane w latach } \\
\hline & & 1945-1970 & 1971-1978 & 1979-1988 & 1989-1995 \\
\hline $\begin{array}{l}\text { Liczba mieszkań (w tys.) } \\
\text { w tym } \\
\text { - wykonanych w technolo- } \\
\text { giach prefabfabrkowanych }\end{array}$ & $\begin{array}{l}5718,1 \\
3573,1\end{array}$ & $\begin{array}{r}2012,4 \\
461,1\end{array}$ & $\begin{array}{l}1566,7 \\
1262,8\end{array}$ & $\begin{array}{l}1585,5 \\
1445,4\end{array}$ & $\begin{array}{l}553,5 \\
403,8\end{array}$ \\
\hline $\begin{array}{l}\text { Powierzchnia użytkowa } \\
\left.\text { mieszkań (w mln } \mathrm{m}^{2}\right) \\
\text { w tym } \\
\text { - w technologiach } \\
\text { prefabrykowanych }\end{array}$ & $\begin{array}{l}334,9 \\
218,2\end{array}$ & $\begin{array}{r}102,8 \\
23,6\end{array}$ & $\begin{array}{l}85,6 \\
69,0\end{array}$ & $\begin{array}{r}104,1 \\
94,9\end{array}$ & $\begin{array}{l}42,4 \\
30,8\end{array}$ \\
\hline
\end{tabular}

Źródło: opracowanie własne na podstawie szacunków dokonanych w pracy A. Rębowskiej $\mathrm{i}$ in. (2006).

${ }_{95} \mathrm{~W}$ trakcie kończenia już rozpoczętych inwestycji mieszkaniowych spółdzielnie, nie mogąc uzyskać kredytów, niejednokrotnie wymagały od przyszłych lokatorów znaczącej partycypacji w kosztach budowy mieszkań, co w wielu przypadkach nie było możliwe.

${ }^{96}$ Nie wszystkie mieszkania $\mathrm{z}$ wielkiej płyty powstawały $\mathrm{w}$ wielkich osiedlach, ale poza nimi można było to zjawisko obserwować na bardzo niewielką skalę.

${ }^{97}$ D. Jarosz w pracy pt. Mieszkanie się należy... Studium z peerelowskich praktyk spotecznych zanalizował różne sposoby wchodzenia w użytkowanie mieszkań w ustroju socjalistycznym. 
Przedstawione powyżej etapy rozwoju osiedli w polskim mieście socjalistycznym, mimo pewnych różnic, przebiegały podobnie także $\mathrm{w}$ innych krajach realnego socjalizmu (Turkington i in. 2004). Analiza tego procesu zawarta w literaturze pozwoliła na wyodrębnienie uniwersalnego schematu przedstawiającego poszczególne etapy rozwoju osiedla, które w większości miast socjalistycznych miały zbliżony przebieg (por. rys. 7).

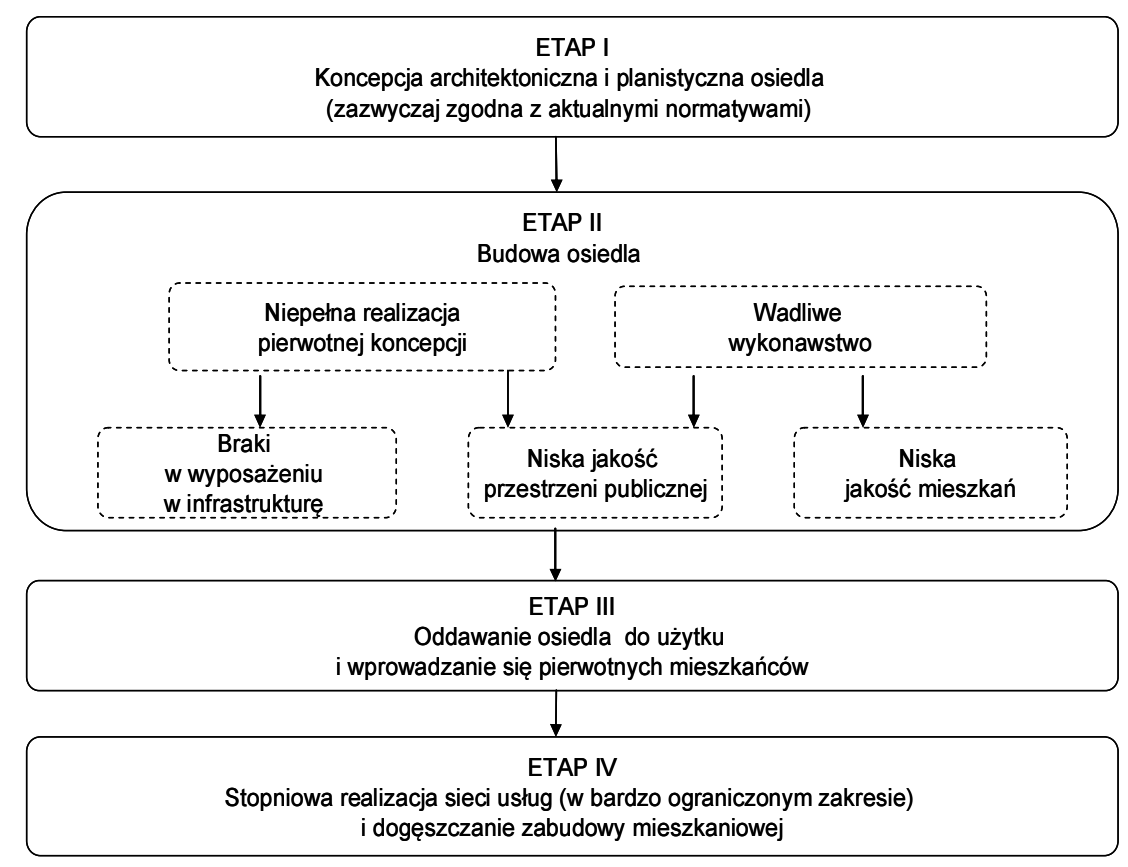

Rys. 7. Etapy rozwoju wielkiego osiedla mieszkaniowego w mieście socjalistycznym Źródło: opracowanie własne na podstawie G. Węcławowicza (2007)

\subsection{Wielkie osiedla mieszkaniowe w mieście socjalistycznym u progu transformacji}

Wielkie osiedla mieszkaniowe, jak już powiedziano, powstawały po II wojnie światowej $\mathrm{w}$ wielu miastach świata i w niemal wszystkich dużych miastach europejskich. Specyfika miasta socjalistycznego i socjalistycznej urbanizacji sprawiła jednak, że budowane w Europie Środkowo-Wschodniej, mimo wielu podobieństw, różniły się od wielkich osiedli w krajach zachodnioeuropejskich. Wśród podobieństw wymienić można: w pierwszej fazie rozwoju tej formy zabudowy, czyli w okresie od początku lat 60. do połowy 
lat 70. podobną skalę i dynamikę ich wznoszenia, rzędu kilkudziesięciu tysięcy mieszkań rocznie ${ }^{98}$, publiczne źródło finansowania, używanie do ich budowy prefabrykatów produkowanych w fabrykach domów, na skutek czego osiedla te miały podobną fizjonomię, peryferyjne położenie większości tych osiedli w przestrzeni miast (głównie późniejszych, budowanych od połowy lat 60. XX w.), a także wytwarzanie $\mathrm{w}$ nich przestrzeni wspólnych, przy założeniu, że będą one odgrywały ważną rolę w kreowaniu więzi pomiędzy mieszkańcami oraz że mieszkańcy będą wspólnie dbać o ich utrzymanie (Wassenberg i in. 2004, Dekker, van Kempen 2005).

Wśród najważniejszych różnic pomiędzy wielkimi osiedlami w krajach socjalistycznych i krajach Europy Zachodniej podkreślić należy m.in. czas ich najbardziej dynamicznego rozwoju, skalę demograficzną i urbanistyczną, funkcję, jaką pełniły w lokalnych oraz krajowych zasobach mieszkaniowych, strukturę demograficzną i status społeczny mieszkańców, a także percepcję i prestiż określające miejsce tych osiedli w strukturze społeczno-przestrzennej miast (Coudroy de Lille 2000, Wassenberg i in. 2004, Musterd, van Kempen 2005).

\section{Czas rozwoju i skala wielkich osiedli mieszkaniowych}

Pierwszą zasadniczą różnicą jest czas najbardziej dynamicznego rozwoju wielkich osiedli o zabudowie blokowej. W krajach zachodnioeuropejskich szczytowy okres ich rozwoju nastąpił w II połowie lat 60. XX wieku, a w krajach socjalistycznych przypadł na II połowę lat 70. i początek lat 80 ., kiedy w Europie Zachodniej wycofano się z ich budowy (rys. 8).

Różna była również skala tych osiedli i ich rola w zasobach mieszkaniowych miast. W krajach Europy Środkowo-Wschodniej udział mieszkań $\mathrm{w}$ wielkich osiedlach mieszkaniowych $\mathrm{w}$ końcu okresu socjalistycznego średnio przekraczał 30\% w stosunku do ich ogółu, a w krajach Europy Zachodniej szacowany był na około 3-7\% (Kovács 1999). We wschodnich landach Niemiec w połowie lat 90 . XX stulecia mieszkał w nich co czwarty obywatel, a w landach zachodnich - co 60. (Rembarz 2010). Jak podaje T. Knorr-Siedow (2004), spośród 20 największych osiedli mieszkaniowych w tym kraju, które liczą od około 20 tys. do blisko 60 tys. mieszkań, 17 znajduje się na terenie byłego $\mathrm{NRD}^{99}$ (głównie we wschodniej części Berlina), a tylko

98 W Holandii np. w latach 1965-1974 rocznie powstawało od 50 do 70. tys. mieszkań socjalnych, spośród których większość stanowiły mieszkania w wielkich osiedlach mieszkaniowych (Wassenberg, van Kempen 2004, s. 135). Podobnie było w Szwecji, gdzie przyjęty na lata 1964-1974 program „Milion mieszkań” (z którego w efekcie zrealizowano ok. 70\%, czyli blisko 700 tys.) także w zdecydowanej większości oparty był na rozwoju wielkich osiedli (Wassenberg $i$ in. 2004).

${ }^{99} \mathrm{Z}$ grupy 17 największych osiedli b. NRD sześć zlokalizowanych jest w Berlinie Wschodnim, po dwa w Halle i Magdeburgu, a po jednym w Rostocku, Lipsku, Chemnitz i w kilku innych mniejszych miastach. 
trzy $\mathrm{w}$ byłych landach zachodnich (w Berlinie oraz w Monachium). Największe $\mathrm{z}$ nich to położone po wschodniej części muru berlińskie osiedla Marzahn i Hellersdorf, liczące w sumie ponad 100 tys. mieszkań (Knorr-Siedow 2004, s. 168). W krajach zachodnioeuropejskich, największe osiedla podobne w skali do osiedli socjalistycznych, budowano we Francji (np. osiedle Sarcelle pod Paryżem z przełomu lat 50. i 60. liczące 13 tys. mieszkań) i Holandii (np. osiedle Bijlmermeer z lat 1968-1975 w Amsterdamie, które liczy ponad 13 tys. mieszkań). Fakt, że w krajach zachodnich odpowiednio wcześnie wycofano się z budowania wielkich osiedli, sprawil, iż nie zdążyły one zdominować przestrzeni mieszkaniowej miast tak jak stało się to w miastach socjalistycznych, gdzie wznoszono je niemal cztery dekady.

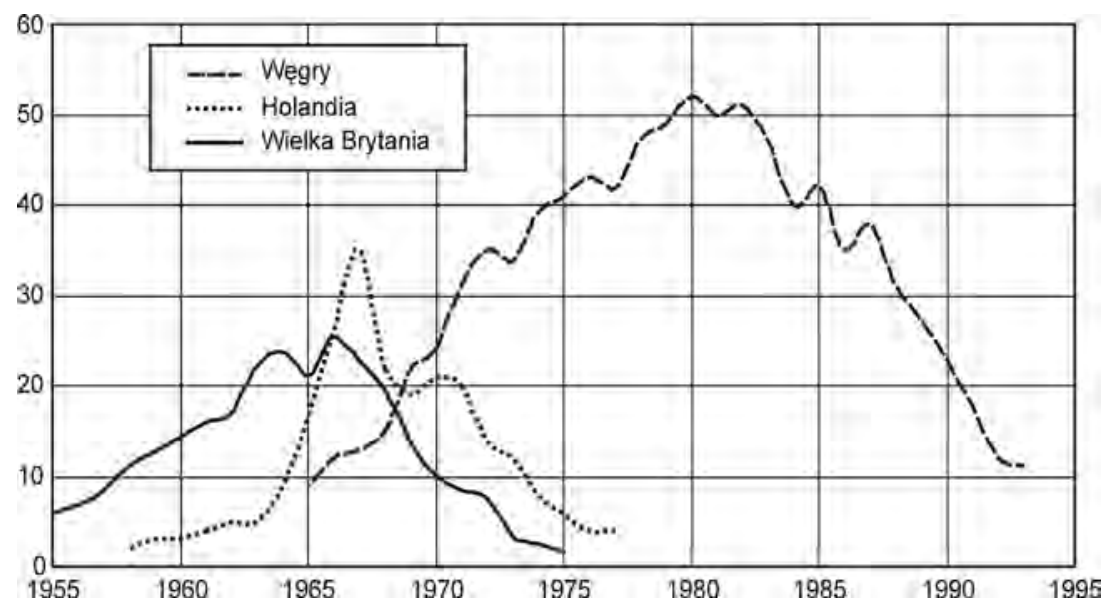

Rys. 8. Udział mieszkań budowanych w wielkich osiedlach mieszkaniowych w ogólnej liczbie mieszkań oddawanych do użytku w wybranych krajach europejskich w latach 1955-1995

Źródło: opracowanie własne na podstawie F. Wassenberg i in. (2004)

Precyzyjne określenie skali wielkich osiedli mieszkaniowych w poszczególnych krajach i miastach socjalistycznych nie jest możliwe ze względu na brak danych mówiących o tym, jaka część mieszkań wybudowanych w okresie powojennym $\mathrm{w}$ sektorze publicznym wzniesiona została $\mathrm{w}$ zabudowie osiedlowej. Wszystkie zatem wartości dotyczące liczby mieszkań w wielkich osiedlach mieszkaniowych opierają się na szacunkach, które nie są łatwe do przeprowadzenia ze względu na brak powszechnie przyjętej i jednoznacznej definicji tej formy zabudowy. Według bardzo ogólnych szacunków Institute for Regional Development and Structural Planning, w początkach lat 90. ubiegłego wieku wielkie osiedla mieszkaniowe liczące ponad 2,5 tys. 
mieszkań stanowiły $29 \%$ zasobu mieszkaniowego krajów socjalistycznych, a zamieszkiwało w nich około $170 \mathrm{mln}$ osób (w 53 mln mieszkań), wyłączając zaś kraje b. ZSRR - około 34 mln osób (w 11 mln mieszkań) (Knorr-Siedow 1997).

W Polsce za punkt wyjścia do takich szacunków przyjmuje się liczbę mieszkań powstałych w latach 1951-1988 w gospodarce uspołecznionej, która wynosi blisko $5 \mathrm{mln}$ (Chmielewski, Mirecka 2001). Nie wszystkie z nich jednak wchodziły w skład wielkich osiedli, zatem inni autorzy (Rębowska i in. 2006) proponują, aby szacunki te oprzeć na liczbie mieszkań wykonanych w latach 1945-1995 w prefabrykowanej technologii, która wynosi około 3,6 $\mathrm{mln}^{100}$ (por. tab. 9). Na postawie innych szacunków stwierdza się, że we współczesnej Polsce $\mathrm{w}$ wielkich osiedlach mieszkaniowych mieszka od 7 do 8 mln (Słodczyk 2012), a nawet ponad 8 mln mieszkańców (Węcławowicz 2007), a osiedla te koncentrują ponad połowę ludności miejskiej (Rębowska 1999) i około 56\% gospodarstw domowych (Rembarz 2010).

Według innych szacunków, przeprowadzonych dla wybranych krajów Europy Środkowo-Wschodniej, udział mieszkań w wielkich osiedlach mieszkaniowych w stosunku do liczby lokali wybudowanych w latach 1960-1990 i w stosunku do ich ogółu, najwyższy był w b. Czechosłowacji, gdzie wynosił $66 \%$ i $36 \%$, a najniższy w b. NRD (48\% i $18 \%)$ - rys. 9. W Polsce wartości te wynosily odpowiednio 61\% i 35\% (Knorr-Siedow 1996).

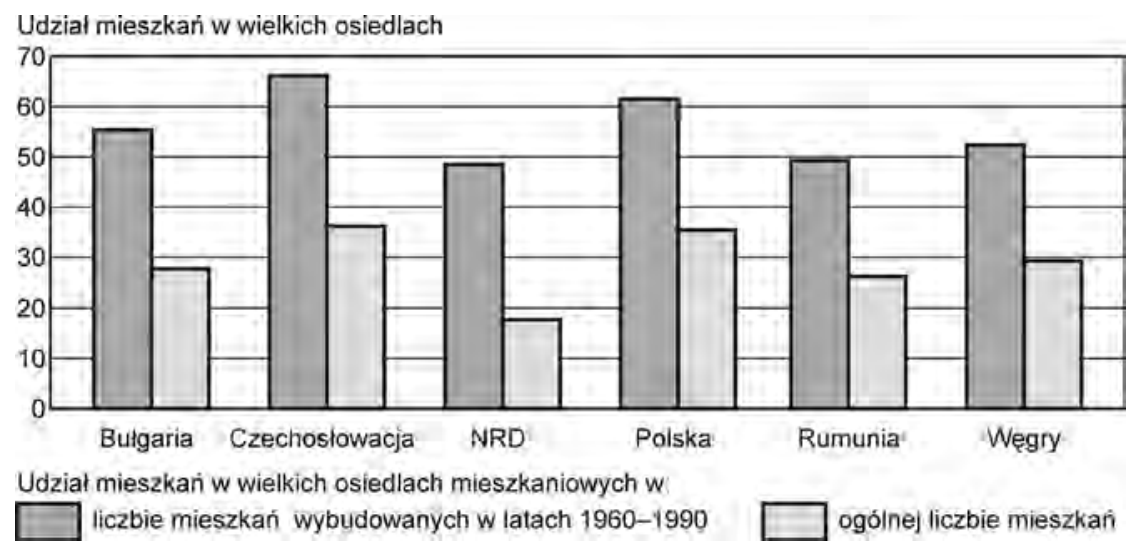

Rys. 9. Udział mieszkań w wielkich osiedlach mieszkaniowych w stosunku do ich ogółu w wybranych krajach Europy Środkowo-Wschodniej w początku lat 90 . XX wieku Źródło: opracowanie własne na podstawie T. Knorr-Siedow (1996)

100 Autorzy tej pracy jako cezurę czasową końca budowy wielkich osiedli przyjęli 1995 r., ze względu na kończenie w pierwszych latach 90. już rozpoczętych inwestycji osiedlowych. 


\section{Struktura demograficzna i status społeczny mieszkańców wielkich osiedli}

Różnice dotyczą także tego, dla kogo budowano wielkie osiedla. W krajach bloku wschodniego mieszkania w osiedlach blokowych przeznaczone były dla uśrednionej pod względem potrzeb i anonimowej grupy odbiorców (określonej jedynie pod względem demograficznym - głównie rodzin $\mathrm{z}$ dziećmi). I mimo że $\mathrm{w}$ różnych okresach premiowano $\mathrm{w}$ dostępie do mieszkań różne grupy i kategorie społeczne (najczęściej robotników wielkoprzemysłowych, przedstawicieli władzy, członków partii, przedstawicieli tzw. inteligencji pracującej), nigdy nie miały one (poza nielicznymi wyjątkami np. w Czechach i na Węgrzech) charakteru budownictwa socjalnego, przeznaczonego dla warstw społecznych o niższych dochodach. Socjalny charakter osiedli blokowych w większości krajów Europy Zachodniej101 doprowadził do tego, że wiele z nich (głównie we Francji, Holandii, Szwecji, Wlk. Brytanii) już od lat 70. XX w. stopniowo stawało się obszarami koncentracji mniejszości etnicznych, wysokiego bezrobocia, ludności o niskich dochodach oraz dużego zagrożenia przestępczością, na skutek czego ich reputacja stopniowo (najpierw powoli, a później coraz szybciej) obniżała się ${ }^{102}$ (Wassenberg i in. 2004, Musterd, van Kempen 2005, Kovács, Herfert 2008). W krajach socjalistycznych na skutek przyjętej w tym ustroju ideologii egalitaryzmu osiedla te miały bardziej zróżnicowaną strukturę społeczną, a jako powszechna forma zamieszkiwania, nie tylko nie podlegały procesom stygmatyzacji, ale przeciwnie - cieszyły wysokim prestiżem mieszkaniowym w porównaniu z innymi obszarami miast (Szelényi 1983, Turkington i in. 2004, Sýkora 2009) - rys. 10. Mieszkańcy tych osiedli różnili się wykształceniem, obyczajami, zamożnością, pochodzeniem, zawodem i stylem życia (Tyszka 1982). Mozaika społeczna w wielkich osiedlach sprawiała, że „kierowca mieszkał obok profesora uniwersytetu, a reżyser był sąsiadem robotnika budowlanego" (Węcławowicz i in. 2003, s. 49). Znamienne było także to, że dla wielu nowych mieszkańców, bez wcześniejszych doświadczeń życia miejskiego, przeprowadzka do osiedla odrywając ludzi od ich korzeni i wprowadzając ich w obce, wyalienowane formy modernistycznych osiedli, wiązała się z niemal całkowitą zmianą stylu życia (Racon-Leja 2010).

101 W Holandii osiedla blokowe początkowo planowane były dla gospodarstw domowych o przeciętnych zarobkach, lecz nie znalazły wśród nich uznania. W 1974 kiedy wprowadzono subsydia mieszkaniowe dla najuboższych, w osiedlach tych zaczęła następować wymiana mieszkańców na mniej zamożnych, dla których wcześniej były one ekonomicznie niedostępne (Wassenberg, van Kempen 2004, s. 129).

102 Nazwa największego podparyskiego osiedla Sarcelle, budowanego w latach 50. i 60. XX w., które w końcu lat 70. zamieszkiwane było przez 60 tys. mieszkańców, we francuskiej literaturze urbanistycznej stała się synonimem „choroby przedmieść" polegającej na budowaniu olbrzymich, nieludzkich osiedli i symbolem patogennego środowiska mieszkaniowego (Coudroy de Lille 2000; Jałowiecki, Szczepański 2006). 


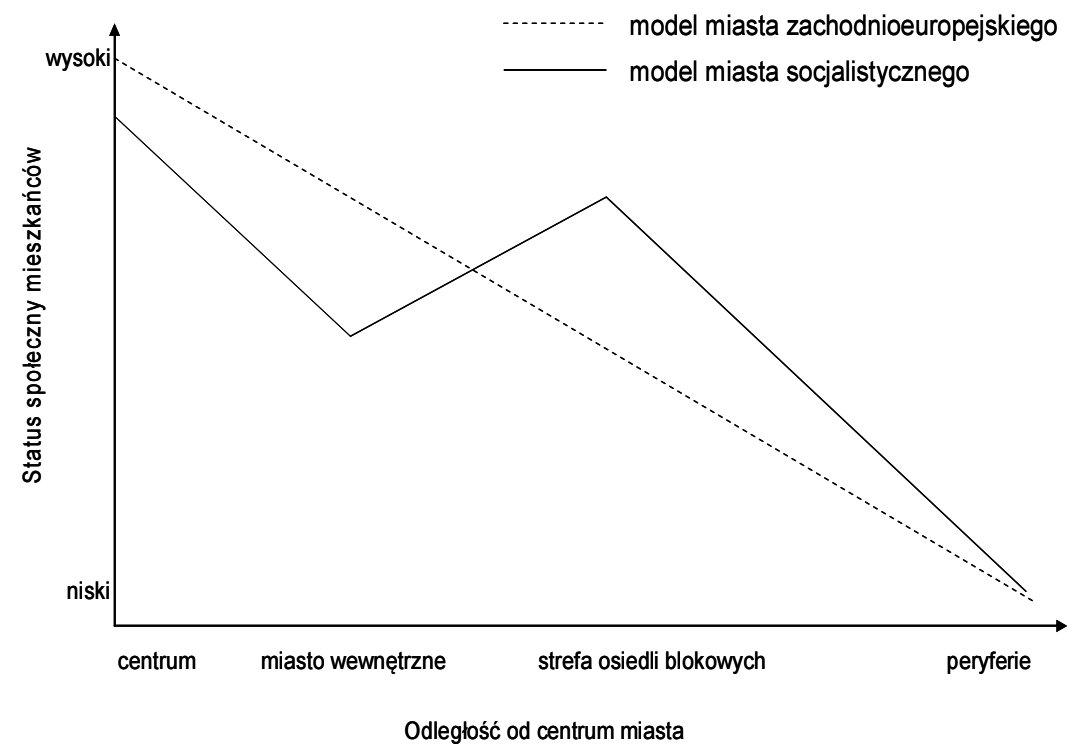

Rys. 10. Status społeczny mieszkańców strefy wielkich osiedli mieszkaniowych w mieście socjalistycznym i zachodnioeuropejskim Źródło: opracowanie własne na podstawie I. Szelenyi (1983, s. 148),

L. Sykora (2009, s. 390)

Zróżnicowaniu statusowemu mieszkańców towarzyszyła ich względna jednorodność demograficzna wynikająca z preferencji przyznawanych na etapie zasiedlania mieszkań rodzinom z dziećmi. Wydłużony czas oczekiwania na mieszkanie, charakterystyczny dla niemal wszystkich krajów socjalistycznych (poza b. NRD), sprawiał, że była to grupa reprezentująca tę samą lub podobną fazę cyklu życia rodziny, która wyznaczała określone potrzeby gospodarstw domowych (obejmujące głównie dostępność przedszkoli i szkół podstawowych) oraz że osiedla te miały relatywnie młodą strukturę wieku. Jednak na skutek dużej stabilizacji mieszkaniowej pierwszych mieszkańców oraz tego, że osiedla powstawały w okresie czterech kolejnych dekad trwania socjalizmu, najstarsze $\mathrm{z}$ nich (powstałe od końca lat 50. do początków lat 70.) u progu transformacji należały do obszarów intensywnego demograficznego starzenia się.

W większości krajów realnego socjalizmu osiedla te, szczególnie w największych miastach ${ }^{103}$, ze względu na oferowane wówczas relatywnie dobre warunki mieszkaniowe, stanowily obszary zamieszkiwania inteligencji oraz

103 Sytuacja ta uzależniona była od wielkości miasta. W ośrodkach mniejszych przedstawiciele wyższych kategorii społecznych zamieszkiwali raczej wolnostojącą zabudowę jednorodzinną (Knorr-Siedow 2004). 
socjalistycznych elit104 (Szelényi 1983, Sagan 2000b, Zborowski 2005, Erőss 2013). W niektórych krajach jednakże, np. na Węgrzech, status społeczny mieszkańców nowo powstających osiedli zmieniał się wraz ze zmieniającą się w kolejnych dekadach polityką alokacji mieszkaniowej, na skutek czego był bardziej homogeniczny i silniej uzależniony od okresu budowy osiedla. Jak podają I. Szelényi (1983) oraz Z. Kovács i M. Douglas (2004), od końca lat 50 . do polowy lat 60 . minionego stulecia nowe mieszkania $w$ osiedlach przyznawano przede wszystkim przedstawicielom klasy "niebieskich kolnierzyków", silnie demonstrując przy tym ich robotniczy charakter. Od połowy lat 60 . w nowych osiedlach pojawiło się relatywnie wielu przedstawicieli klasy urzędniczej, intelektualistów i elit powiązanych z władzą, zaś w latach 70., zgodnie z obowiązującą wówczas polityką mieszkaniową nastawioną na silny egalitaryzm, lokowano $\mathrm{w}$ nich ludność uboższą, niewykwalifikwaną, rodziny wielodzietne oraz ludność romską. Lata 80 . przyniosły natomiast $\mathrm{w}$ tym kraju zmiany polegające na znacznym zmniejszeniu skali budowanych osiedli i wprowadzaniu do systemu dystrybucji mieszkań elementów rynkowych, co sprawiło, że nowe mieszkania blokowe stały się dostępne tylko dla zamożniejszych, w związku z czym zasiedlały je głównie rodziny młodych profesjonalistów z dziećmi, dla których mieszkanie takie stanowiło pierwszy krok w dalszym łańcuchu przeprowadzek (Kovács, Douglas 2004, s. 238). Polityka alokacji mieszkaniowej realizowana w innych krajach socjalistycznych nie była aż tak jednoznaczna, ale w każdym z tych krajów w różnych okresach premiowano $\mathrm{w}$ dostępie do mieszkań wybrane kategorie i grupy społeczne (Sagan 2000a, Jarosz 2010), co jednak nie zapobiegło ich mozaikowej strukturze społecznej, która na lata stała się jedną z cech charakterystycznych tej formy zabudowy.

Wymienione przyczyny spowodowały, że status społeczny wielkich osiedli mieszkaniowych $\mathrm{u}$ progu transformacji był nie tylko heterogeniczny, ale także zróżnicowany zarówno w skali poszczególnych miast i krajów, jak i w skali wewnątrzmiejskiej (pojedynczych osiedli), np. w zależności od okresu ich budowy. Wraz z ewolucją polityki mieszkaniowej w końcu lat 80. w takich krajach, jak Węgry, Polska, b. Czechosłowacja, kiedy wciąż jeszcze powstawały nowe osiedla, $\mathrm{w}$ starszych zainicjowany został, na początku na bardzo niewielką skalę, wspomniany już proces określany jako filtracja, związany z odpływem zamożniejszych i lepiej wykształconych mieszkańców do innych lokalizacji, głównie do jednorodzinnej zabudowy mieszka-

104 Ze szczegółowej analizy składu społecznego warszawskiego Ursynowa (Węcławowicz i in. 2003) wynika, że wiele nowych mieszkań w tym osiedlu przyznane zostało wysokim działaczom partyjnym, urzędnikom ministerialnym, a także profesjonalistom i twórcom kultury, wśród których było wielu dziennikarzy, reżyserów, aktorów, muzyków, pisarzy, naukowców itp. W efekcie w początkowym okresie rozwoju osiedla, czyli we wczesnych latach 80., ok. 33\% mieszkańców miało wyższe wykształcenie (ibid., s. 48-49). 
niowej (Kovács, Douglas 2004, Zborowski 2005, Temelová i in. 2011). W Polsce dotyczyło to głównie tzw. oszczędnościowych osiedli z okresu gomułkowskiego, które oferowały najmniej atrakcyjne warunki zamieszkania (Kiciński 2004), a na Węgrzech i b. Czechosłowacji (głównie w dzisiejszych Czechach), osiedli z lat 70., w których nadreprezentowana była ludność uboga i romska (Kovács, Douglas 2004, Temelová i in. 2011). Generalnie jednak proces ten odbywał się na niewielką skalę i nie wpłynął znacząco na obniżenie statusu społecznego wielkich osiedli, który do początku lat 90. XX wieku pozostał relatywnie wysoki.

\section{Struktura funkcjonalna i rozmieszczenie wielkich osiedli}

Zasadniczą cechą wielkich osiedli mieszkaniowych, która stanowiła jedną z najważniejszych ułomności tej formy urbanistycznej była jej monofunkcyjność. Zdecydowana dominacja funkcji mieszkaniowej oraz niedorozwój innych funkcji miejskich, w tym przede wszystkim funkcji usługowej, wynikał z niepełnej realizacji pierwotnych założeń architektoniczno-urbanistycznych osiedli, które uwzględniały wyposażenie ich $\mathrm{w}$ infrastrukturę społeczną i usługową. Jeśli przyjąć, że główną cechą miasta jest jego wielofunkcyjność (Liszewski 2008a), to brak zróżnicowania funkcjonalnego był jedną z przyczyn niemiejskiego charakteru wielkich osiedli. Niewystarczająca liczba placówek handlowych i usługowych, ośrodków zdrowia, szkół i przedszkoli wymuszała specyficzną organizację życia codziennego mieszkańców osiedli i zmiany w strukturze ich dziennego czasu oraz organizacji zadań domowych. Uwzględniając istniejące $\mathrm{w}$ tamtym okresie trudności komunikacyjne można twierdzić, że dla wielu mieszkańców powrót z pracy na osiedle był jak wyjazd $\mathrm{z}$ miasta, ponieważ wiązał się z nie tylko $\mathrm{z}$ dużą odległością od centrum, ale też brakiem możliwości realizacji potrzeb innych niż mieszkaniowe. Powodowało to, że styl życia w osiedlach miał charakter niemiejski, a na pewno niewielkomiejski, choć osiedla były częścią wielkich miast.

Rozmieszczenie wielkich osiedli mieszkaniowych w strukturze przestrzennej miast uzależnione jest od okresu ich budowy. Początkowo, w pierwszej powojennej dekadzie, osiedla te wypełniały wolne tereny między dzielnicami podstawowymi i wkraczały $\mathrm{w}$ miejsce starych domów w centrach niektórych miast (Rykiel 1999). Począwszy od II połowy lat 60., ze względu na ich znacznie większą skalę, osiedla lokowano głównie na terenach wolnych, odseparowanych przestrzennie od zwartej zabudowy śródmiejskiej, a często w dużym oddaleniu od niej. Jak zauważa I. Sagan (2000a), powodowało to specyficzny rozkład gęstości zaludnienia miast socjalistycznych, która nie tylko nie malała wraz z odległością od centrum, lecz często wzrastała - od relatywnie niskiej zabudowy śródmiejskiej ku wysokim budynkom wielorodzinnym (wieżowcom) na peryferiach. Strefa wielkich 
osiedli często miała charakter koncentryczny, w postaci pierścienia otaczającego miasto centralne i jego strefę przejściową, co pokazuje m.in. przykład Budapesztu (rys. 11) oraz Warszawy (rys. 12).

Wiele z nich lokowano „na zielonym polu” (Gaczek, Rykiel 1999), czyli na terenach inkorporowanych do miast $\mathrm{w} X X$ w., obejmujących mniej lub bardziej zagospodarowane tereny wiejskie i rolnicze. Znajdowało to niekiedy wyraz $\mathrm{w}$ nazewnictwie nowych osiedli zapożyczonych od byłych wsi (np. Retkinia, Widzew, Rataje, Służew, Tarchomin oraz wiele innych).

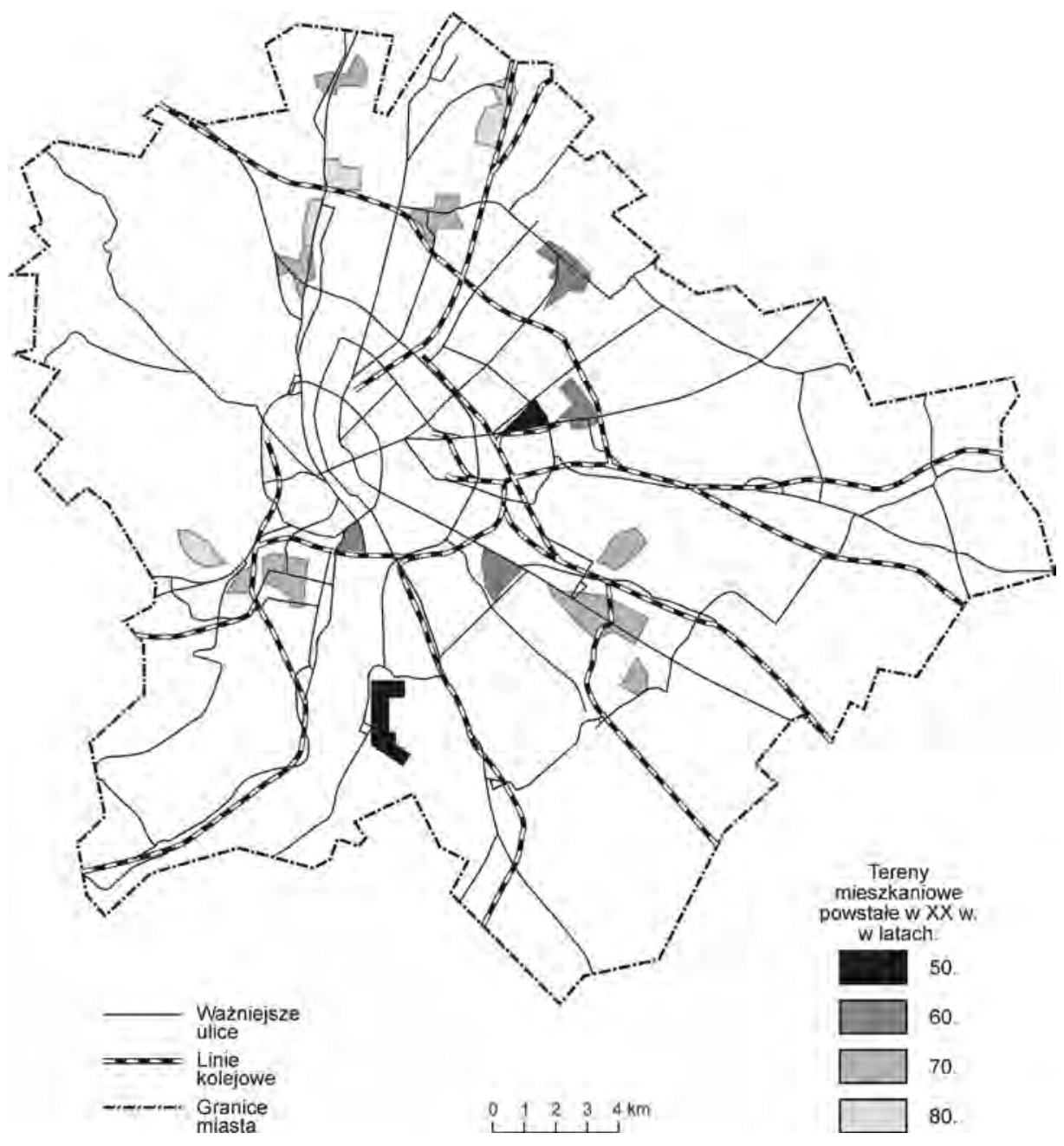

Rys. 11. Rozmieszczenie wielkich osiedli mieszkaniowych w Budapeszcie i okres ich budowy

Źródło: opracowanie własne na podstawie T. Csaba (2006, s. 6-8) 


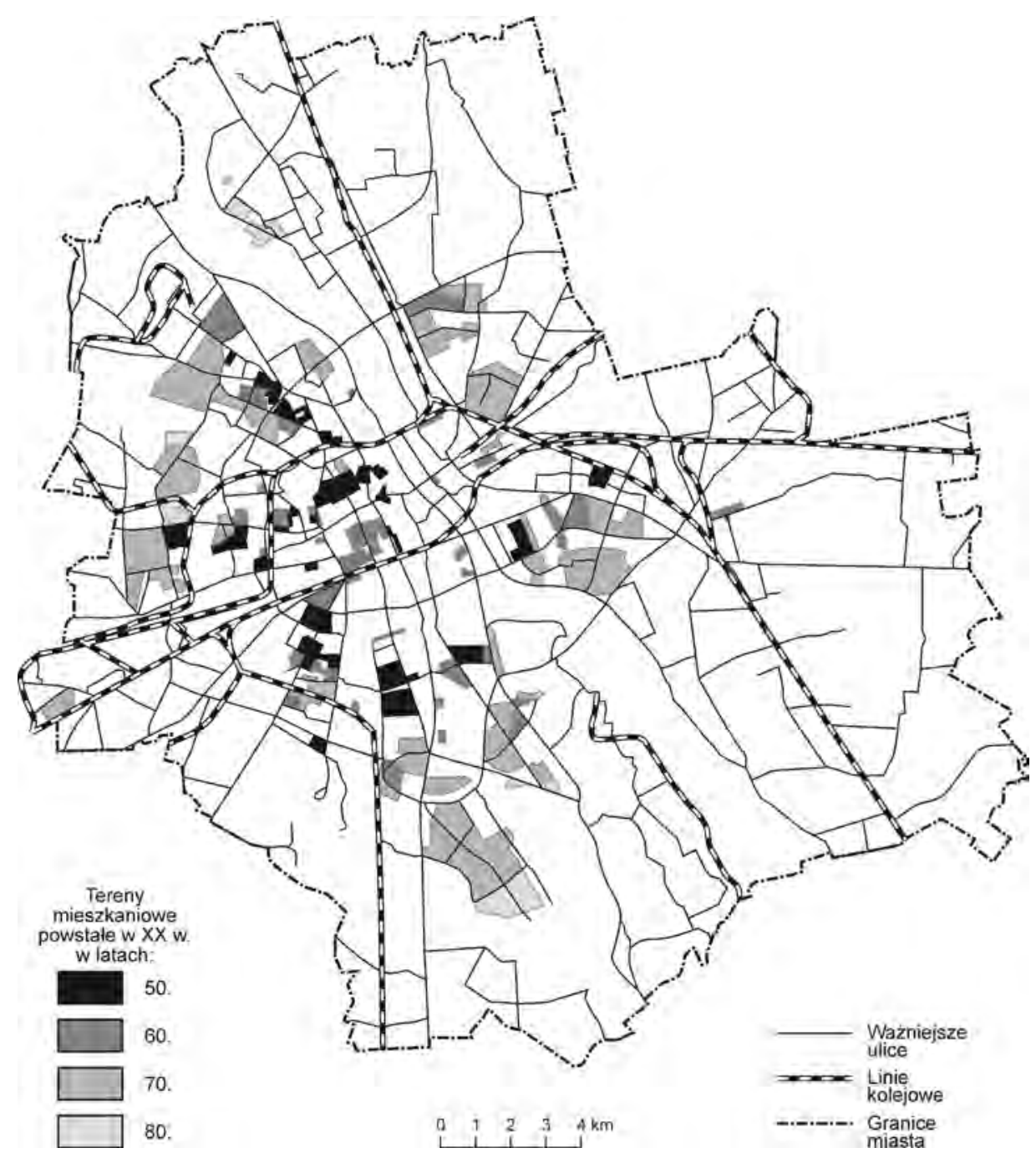

Rys. 12. Tereny mieszkaniowe o zabudowie blokowej w Warszawie i okres ich budowy Źródło: opracowanie własne na podstawie Atlasu Warszawy (Stępniak i in. 2009)

Według M. Gaczek i Z Rykla (1999) przestrzenne odseparowanie tych osiedli od tradycyjnej tkanki miejskiej i miejsc pracy, a równocześnie ich wielka skala przestrzenna i demograficzna, monofunkcyjność sypialni miejskich oraz nierozwiązane do końca problemy komunikacyjne stwarzały złe warunki życia mieszkańców w tych osiedlach. Z czasem jednak, wraz ze stale postępującymi procesami rozwoju przestrzennego miast socjalistycznych, które odbywały się poprzez inkorporację dalszych terenów podmiejskich, a także wraz z rozwojem sieci dróg i poprawą dostępności komunika- 
cyjnej osiedli wiele $\mathrm{z}$ nich, budowanych jako peryferyjne, w końcu okresu realnego socjalizmu silniej zostało powiązanych z tkanką miejską. Również bardzo powolne i wciąż niepełne $\mathrm{w}$ stosunku do pierwotnych założeń uzupełnianie $w$ osiedlach funkcji innych niż mieszkaniowe wiązało się z niewielką poprawą warunków życia w poszczególnych osiedlach w stosunku do sytuacji, jaka miała w nich miejsce w pierwszych latach użytkowania.

\section{Morfologia i fizjonomia wielkich osiedli}

$\mathrm{W}$ osiedlach mieszkaniowych budowanych w krajach socjalistycznych wyróżnić można kilka powtarzających się układów zabudowy: grzebieniowy, blokowy, gniazdowy, liniowy oraz meandrowy (Chmielewski, Mirecka 2001) - rys. 13. Układ gniazdowy tworzą budynki punktowe, liniowy - długie pojedyncze budynki usytuowane wzdłuż linii prostej, meandrowy - ciągi budynków przełamywanych pod kątem prostym, a blokowy - budynki wyodrębniające wnętrza urbanistyczne. Układ blokowy - najkorzystniejszy z punktu widzenia kształtowania się więzi sąsiedzkich w osiedlach, stosowany był stosunkowo rzadko - częściej w osiedlach nowszych, powstałych po 1980 roku. Najmniej korzystne pod tym względem były stosowane najczęściej układy grzebieniowy oraz liniowy.

1.

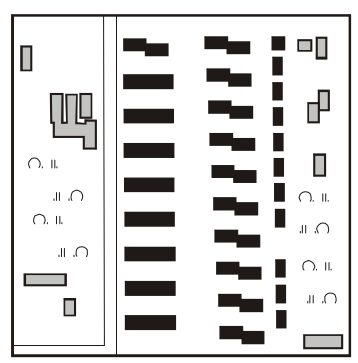

4.

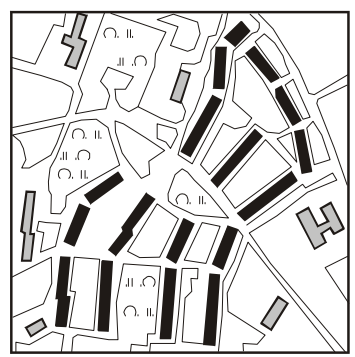

2.

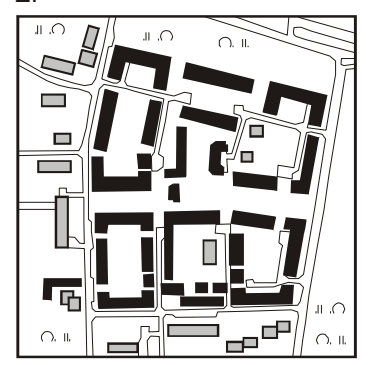

5.

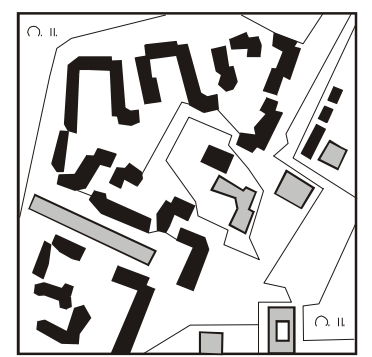

3.

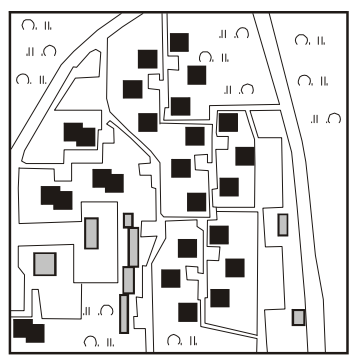

LEGENDA: audynki mieszkalne

inne budynki

tereny zielone

ciągi komunikacyjne

Rys. 13. Układy zabudowy stosowane w osiedlach mieszkaniowych 1 - układ grzebieniowy, 2 - układ blokowy, 3 - układ gniazdowy, 4 - układ liniowy, 5 - układ meandrowy Źródło: J.M. Chmielewski, M. Mirecka (2001, s. 23) 
Charakterystyczną cechą fizjonomii wielkich osiedli powstających w okresie socjalizmu była ich unifikacja i anonimowość. Anonimowość ta, jak podaje A. Basista (2001), miała trzy wymiary: mieszkań w budynku, budynków $\mathrm{w}$ osiedlu oraz osiedli $\mathrm{w}$ miastach. Zunifikowane materiały oraz technologie ich wznoszenia sprawiały, że osiedla budowane w tym samym okresie niemal nie różniły się między sobą, niezależnie od tego, w jakiej dzielnicy czy mieście powstawały. Unifikacja ta miała charakter także międzynarodowy, choć istniały pewne zróżnicowania, zwłaszcza pomiędzy Europą Wschodnią i Zachodnią, gdzie budynki były nieco bardziej zróżnicowane i charakteryzowały się wyższym standardem wykonania.

Kolejną cechą charakterystyczną dla zabudowy blokowej w wielkich osiedlach była jej monotonna kolorystyka ograniczona do różnych odcieni szarości, czyli koloru betonu, który był głównym materiałem używanym do ich budowy. Większość budynków wzniesionych w technologii wielkiej płyty nie była otynkowana, a widoczne gołym okiem spojenia płyt i struktura betonu sprawiały nie tylko złe wrażenia estetyczne, ale też poczucie, że budynki te są "niedokończone". Dominacji szarości w krajobrazie osiedla te zawdzięczały miano pobawionych wyrazu, ",szarych, betonowych pustyni".

Inną cechą osiedli blokowych powstających w okresie socjalizmu, która miała wpływ na ich fizjonomię było niskiej jakości wykonawstwo, zarówno mieszkań jak całych budynków: „Sufity i ściany są popękane. Tynki odpadają, klepki parkietu można bez trudu wyjmować. Wypadają kontakty ze ścian [...] ruszają się źle zamocowane kaloryfery i zlewozmywaki [...] prawie wszystkie drzwi w mieszkaniach nie domykają się [...]". Cytowany fragment pochodzi z opisu osiedla spółdzielczego w Szczecinie, w kilkanaście miesięcy po ukończeniu jego budowy, który ukazał się w 1963 roku w czasopiśmie „Fundamenty" 105 i choć dotyczy jednego osiedla, wydaje się oddawać panujące wówczas podejście do wykonawstwa w sektorze publicznym w ogóle. Według A. Basisty (2001) zła jakość wykonanych wtedy budynków była wynikiem niewydolności całego systemu, na który składały się kłopoty z siłą roboczą, brak odpowiedniego nadzoru, kradzieże, konieczność pośpiechu w wykonaniu planów, niska jakość dostarczanych prefabrykatów, ich podatność na uszkodzenia, a także marnotrawstwo i brak racjonalności. Do istotnych wad zabudowy wielkopłytowej należały też zła izolacja termiczna ścian zewnętrznych oraz zła akustyka mieszkań, które istotnie obniżały komfort zamieszkiwania.

105 Cytat za A. Basistą (2001), który pisał, że po kilku latach publikowania materiałów piętnujących patologie $\mathrm{w}$ budownictwie mieszkaniowym (przykładowe tytuły artykułów na ten temat z lat 1960-1963: Partactwo, Patologia budownictwa, Brakoróbstwo nie ujdzie bezkarnie, Pomnik brakoróbstwa, Skandal) zaprzestano je publikować ze względu na niepoprawny politycznie charakter tego typu informacji. 


\section{Przestrzenie publiczne wielkich osiedli mieszkaniowych}

Pojęcie przestrzeni publicznej w geografii ma bardzo wiele definicji (Maik 2011) i zazwyczaj utożsamiane jest $z$ przestrzenią centralną miast. W wielkich osiedlach mieszkaniowych przestrzeń publiczną zdefiniować można, przyjmując za punkt wyjścia jej morfologię i funkcje, jako wszystkie wspólne elementy znajdujące się na terenie osiedla, które nie są przestrzenią prywatną poszczególnych mieszkańców ani ich przestrzenią grupową (pólprywatną/sąsiedzką/środowiskową). Są to zatem tereny zielone, rekreacyjno-sportowe, miejsca wypoczynku na świeżym powietrzu (ławki, skwery, place zabaw, mała architektura), ciągi piesze (chodniki, alejki i drogi wewnętrzne wyłączone z ruchu kołowego), a także ogólnodostępne przestrzenie handlowe i usługowe.

Budowa wielkich osiedli mieszkaniowych uwolniła rozległe tereny pod potencjalne przestrzenie publiczne. Realizacja i zagospodarowanie wielu z nich, ze względu na pośpiech w budowie osiedli oraz brak środków finansowych, odraczane było w czasie, a często zaniechane. Jakość tych, które zostały zrealizowane, pomimo niekiedy dobrych intencji projektantów, bardzo często pozostawiała wiele do życzenia (Racoń-Leja 2010). W efekcie - jak podają autorzy zajmujący się tym zagadnieniem (Chmielewski, Mirecka 2001, Borowik 2003, 2007, Węclawowicz i in. 2003, 2004, Rębowska i in. 2006, Rembarz 2010, Tokajuk 2007, Wojtkun 2004, 2008, Racon-Leja 2010) - stwierdzić można, że przestrzenie publiczne wielkich osiedli mieszkaniowych budowanych w Polsce do końca 80. XX w., charakteryzowały:

- amorficzność, chaos i brak czytelności;

- brak wyraźnego wyodrębnienia przestrzeni półpublicznych (grupowych) i prywatnych;

- pozostawienie rozległych, niezagospodarowanych przestrzeni otwartych, które nabierały charakteru "przestrzeni niczyich";

- niedostatek i zły stan zieleni (przypadkowe nasadzenia, brak dbałości);

- niefunkcjonalne ciągi piesze (formalnie określane jako pieszo-jezdne), często wyznaczone w sposób nieodpowiadający strumieniom ruchu, co powodowało ich nieużyteczność;

- niedostatek terenów o charakterze rekreacyjnym oraz sportowo-rekreacyjnym: boisk, ścieżek rowerowych, parków, alejek spacerowych;

- niedostateczne oraz ubogie wyposażenie i zaniedbanie miejsc zabaw dla dzieci;

- niedostatek, a najczęściej brak, elementów małej architektury i mebli miejskich;

- brak miejsc dostosowanych do potrzeb osób starszych i niepełnosprawnych; 
- niedostateczne oświetlenie, co zwiększało poczucie braku bezpieczeństwa mieszkańców;

- ogólne zaniedbanie wynikające $\mathrm{z}$ braku faktycznego gospodarza tych terenów.

W odróżnieniu od historycznej zabudowy miejskiej w postaci kwartałów, przestrzeń blokowisk nie tworzyła zdefiniowanych wnętrz urbanistycznych, ponieważ uniemożliwiały to stosowane układy przestrzenne, w tym realizowane do lat 80 . niemal wyłącznie, a potem głównie, układy grzebieniowy i liniowy (Chmielewski, Mirecka 2001, Wojtkun 2004, Racoń-Leja 2010), które prowadziły do silnej segregacji funkcji. W krajobrazie osiedlowym czytelniejsze były podziały na strefy komunikacyjne, rekreacyjne, usługowe, mieszkaniowe, niż na przestrzenie publiczne, grupowe i prywatne (Chmielewski, Mirecka 2001).

Zbyt rozległe niezagospodarowane przestrzenie nabierały charakteru „przestrzeni niczyich”. Anonimowość przestrzeni i brak nad nimi kontroli społecznej, zgodnie z teorią $\mathrm{O}$. Newmana, przyczyniały się do obniżenia poczucia bezpieczeństwa mieszkańców, które jest bardzo istotnym walorem jakości zamieszkiwania, mimo że badania nie potwierdzily faktycznej wysokiej przestępczości w socjalistycznych osiedlach mieszkaniowych (por. Czapska, red. 2011, Mordwa 2013). Proces degradacji ubogiej i mało funkcjonalnej przestrzeni publicznej pogłębiał brak poszanowania wspólnej własności i odpowiedzialności za jej utrzymanie (Racoń-Leja 2010).

\section{Więzi społeczne i terytorialne mieszkańców wielkich osiedli}

Atrybuty zarówno społeczne, jak i przestrzenne wielkich osiedli mieszkaniowych nie sprzyjały formowaniu się $\mathrm{w}$ nich tożsamości zbiorowej, więzi i poczucia przynależności. Według A. Pawłowskiej (1996) oraz W. Gaczek i Z. Rykla (1999), wielkie osiedla mieszkaniowe w mieście socjalistycznym to przestrzeń „nieoswojona" i architektonicznie „znijaczona"106. Niedostatki swojskości w wielkich osiedlach były z jednej strony wynikiem heterogeniczności społecznej mieszkańców, z drugiej zaś cech urbanistyczno-architektonicznych tej formy zabudowy, do których należały (Pawłowska 1996):

- wysokość budynków "odrywająca” mieszkańców od bezpośredniego kontaktu z miejscem;

- swobodny, nieczytelny układ przestrzenny budynków i brak elementów charakterystycznych utrudniające orientację w przestrzeni;

106 Według K. Pawłowskiej (1996) termin „znijaczenie przestrzeni” jest opozycją do określenia "swojskość", które wprost nawiązuje do obecnego w geografii humanistycznej pojęcia miejsca jako przestrzeni oswojonej (Tuan 1987). Swojskość zaś to cecha lub zestaw cech, które sprawiają, że między człowiekiem lub grupą ludzi a miejscem oraz pomiędzy ludźmi wspólnie zamieszkującymi to miejsce mogą nawiązywać się emocjonalne związki przynależności i przywiązania (Pawłowska 1996, s. 6). 
- brak czytelnych granic osiedla uniemożliwiający identyfikację zasięgu miejsca;

- pozbawienie indywidualności miejsca przez zniszczenie w trakcie budowy osiedla zastanej specyfiki przyrodniczej i kulturowej;

- typowa, pseudouniwersalna forma budynków utrudniająca identyfikację i orientację przestrzenną;

- przekroczenie skali wielkości odpowiedniej dla samoorganizacji społecznej wspólnoty terytorialnej;

- niedorozwój, zła lokalizacja i brak indywidualnej formy centrum lokalnego, uniemożliwiające jego funkcjonowanie jako ośrodka życia wspólnoty.

Podobnego zdania dotyczącego więzi mieszkańców w wielkich osiedlach mieszkaniowych jest Z. Rykiel (2000), który uważa, że takie cechy osiedli, jak heterogeniczność, nakazowo-rozdzielczy system przyznawania mieszkań, duży udział ludności napływowej z terenów wiejskich, brak faktycznego właściciela domów, brak wyboru miejsca zamieszkania i społecznego sąsiedztwa, a także anonimowość stosunków społecznych, wpływały dezintegracyjnie na postawy mieszkańców. Przymusowość sąsiedztwa wynikająca z celowo założonej polityki integracji różnych warstw społecznych była cechą dezintegrującą społeczność sąsiedzką wielkich osiedli także według Z. Tyszki (1982). Nadmierne zróżnicowanie statusu społecznego mieszkańców preferujących często krańcowo różne wartości i style życia, nie sprzyjało wytwarzaniu silnych więzi sąsiedzkich, rodziło poczucie anonimowości i braku oparcia w najbliższym otoczeniu. Atomizacji tej towarzyszyła jednocześnie przymusowość codziennych kontaktów i „współuczestniczenie" w życiu sąsiadów wynikające z niskiej jakości standardów budowlanych (cienkie ściany i stropy, nieszczelne drzwi i okna, klatki schodowe i windy obsługujące lokatorów kilkudziesięciu mieszkań), brak intymności we własnych czterech ścianach, a do tego konieczność podporządkowania się i dostosowania do reguł życia zbiorowego, przebywając w przestrzeni prywatnej (Tyszka 1982).

Paradoksalnie jednak, jak podaje K. Pawłowska (1996), „unieruchomienie" ludzi w stosunku do miejsc zamieszkania wynikające $\mathrm{z}$ tego, że mieszkanie w mieście socjalistycznym było przydzielane, a nie wybierane, a możliwość jego zamiany silnie ograniczona, dawało czas na zadomowienie i tworzyło okoliczności sprzyjające związkom swojskości. Podobnie uważa J. Kotus (2007), według którego mieszkańców nowo powstających osiedli, zróżnicowanych pod względem poziomu wykształcenia, dochodów i pochodzenia społecznego, łączył wspólny „syndrom pionierski” zasiedlania nowej ziemi, radość ze spełnienia marzeń o posiadaniu własnego „M", najczęściej lepszy standard wyposażenia nowego mieszkania od poprzedniego 
oraz zasady życia osiedlowego wdrażane przez spółdzielnie mieszkaniowe i instytucje osiedlowe (ibid., s. 106). Dodatkowym bodźcem tworzenia związków swojskości w osiedlach była w pewnym zakresie wspólnota losu i dzielenie rosnących trudności dnia codziennego. W ówczesnym bowiem systemie, którego cechą immanentną były permanentne niedobory, największą wartość miały tzw. znajomości (Marody, red. 1991). A w miejscu zamieszkania jakim było osiedle, często oddalone od centrum miasta i źle wyposażone w podstawową infrastrukturę społeczną i usługową, możliwość wzajemnej pomocy sąsiedzkiej była nieoceniona. Podobnych wniosków dostarczają, uznane za klasykę na gruncie tzw. socjologii osiedlowej, badania prowadzone w latach 70. XX stulecia w Lublinie (Turowski 1973, Kryczka 1981), z których wynika, że w wielu zespołach osiedlowych powstawały zintegrowane społeczności sąsiedzkie i istniały silne więzi pomiędzy mieszkańcami. Ich źródłem, jak słusznie zauważa J. Kotus (2007, s. 107), po części mogły być działania propagandowe (np. tzw. czyny społeczne związane z zagospodarowywaniem osiedli) i inne odgórne akcje, niejako wymuszające nawiązywanie interakcji pomiędzy mieszkańcami. Ale kreowały je również osiedlowe instytucje: szkoły, przedszkola, domy kultury, kluby, a że większość mieszkańców nowo budowanych bloków stanowiły rodziny z dziećmi, wymienione instytucje odgrywały ważną rolę integrującą.

\subsection{Podsumowanie}

Rozważania zawarte w niniejszym rozdziale miały odpowiedzieć na dwa pytania. Po pierwsze: dlaczego wielkie osiedla mieszkaniowe wznoszone w duchu modernizmu i funkcjonalnego strefowania miasta, choć powstawały po obu stronach "żelaznej kurtyny", na znacznie większą skalę rozwinęły się w miastach socjalistycznych? Po drugie: jakie były trajektorie rozwoju tych osiedli w miastach socjalistycznych, co je determinowało i czym różniły się od trajektorii rozwoju tej formy zabudowy w miastach krajów zachodnioeuropejskich?

Przeprowadzona analiza czynników kształtujących strukturę społeczno-przestrzenną w miastach Europy Środkowo-Wschodniej, pozwoliła stwierdzić, że niespotykana nigdzie indziej masowa skala tej formy zabudowy w miastach socjalistycznych wynikała przede wszystkim ze specyfiki ustroju. I mimo że budowa wielkich modernistycznych osiedli mieszkaniowych uwarunkowana była także przez czynniki niespecyficzne dla socjalizmu, działające w skali całej Europy, takie jak duże zniszczenia wojenne i wzrost liczby ludności w miastach, który powodował potrzebę budowy jak 
największej liczby mieszkań w możliwe szybki sposób, to jednak najważniejszą rolę odegrały czynniki ideologiczne i polityczne.

Kluczowe znaczenie miał brak rynku mieszkaniowego zastąpionego przez przyjętą w tym systemie socjalistyczną politykę mieszkaniową. Realizatorzy tej polityki stosując swoisty paternalizm państwa opiekuńczego odgórnie określali najlepszy - ich zdaniem - sposób zaspokojenia potrzeb mieszkaniowych i decydowali o tym, kto, jak i gdzie ma mieszkać. Wpisująca się $\mathrm{w}$ ten model budowa wielkich osiedli była rezultatem - jak się okazało $\mathrm{w}$ praktyce - utopijnych założeń o możliwości realizacji w ten sposób swoiście pojmowanej idei egalitaryzmu i wyrównywania warunków zamieszkania w przestrzeni miejskiej. Ważną rolę odgrywało również przekonanie, że dostarczony $\mathrm{w}$ ten sposób standard jest $\mathrm{w}$ stanie zaspokoić potrzeby mieszkaniowe $\mathrm{w}$ miastach, $\mathrm{w}$ wymiarze nie tylko ilościowym - czego $\mathrm{w}$ praktyce nigdy nie udało się zrealizować, ale też jakościowym - nie uwzględniono bowiem ich ewolucji ani indywidualnego charakteru.

I mimo że przekonanie o możliwości osiągania ideału sprawiedliwości społecznej za pośrednictwem formy urbanistycznej nie było niczym nowym w historii myśli urbanistycznej, ponieważ głosili je już w XIX wieku twórcy miast idealnych pozostający pod wpływem socjalizmu utopijnego (por. rozdział 3), to jednak nigdy wcześniej w historii idea ta nie znalazła możliwości realizacji na taką skalę jak w miastach socjalistycznych. Nie było również niczym nowym, bliskie modernizmowi i przyswojone przez ideologów powojennego socjalizmu, przekonanie o możliwości kształtowania prawidłowych relacji międzyludzkich za pomocą formy urbanistycznej. Ujawniło się ono już w I połowie XX wieku w koncepcjach Le Corbusiera i w idei jednostki sąsiedzkiej C.A. Perry'ego, której gorącymi zwolennikami w Polsce byli m.in. H. i Sz. Syrkusowie oraz B. Brukalska. W krajach zachodnich jednakże dość szybko uznano je za utopię społeczną, której nie da się zrealizować.

Uwarunkowania te sprawiły, że budowa wielkich osiedli w krajach bloku wschodniego trwała aż do lat 90. XX wieku, podczas gdy w miastach Europy Zachodniej już w latach 70., po krótkim okresie fascynacji modernizmem i zaspokojeniu powojennego głodu mieszkaniowego, zaniechano ich budowy. Rozpoczęty później i znacznie dłuższy czas budowy wielkich osiedli $\mathrm{w}$ miastach socjalistycznych trwający aż do upadku ustroju oraz znacznie wyższy ich udział w stosunku do całego budownictwa mieszkaniowego (rys. 14) sprawil, że zdominowały one krajobraz miast socjalistycznych na kolejne dziesięciolecia.

Specyfika ustroju socjalistycznego zadecydowała nie tylko o skali wielkich osiedli, ale wpłynęła także na ich prestiż i pozycję w strukturze społeczno-przestrzennej miasta. W miastach zachodnioeuropejskich bowiem 


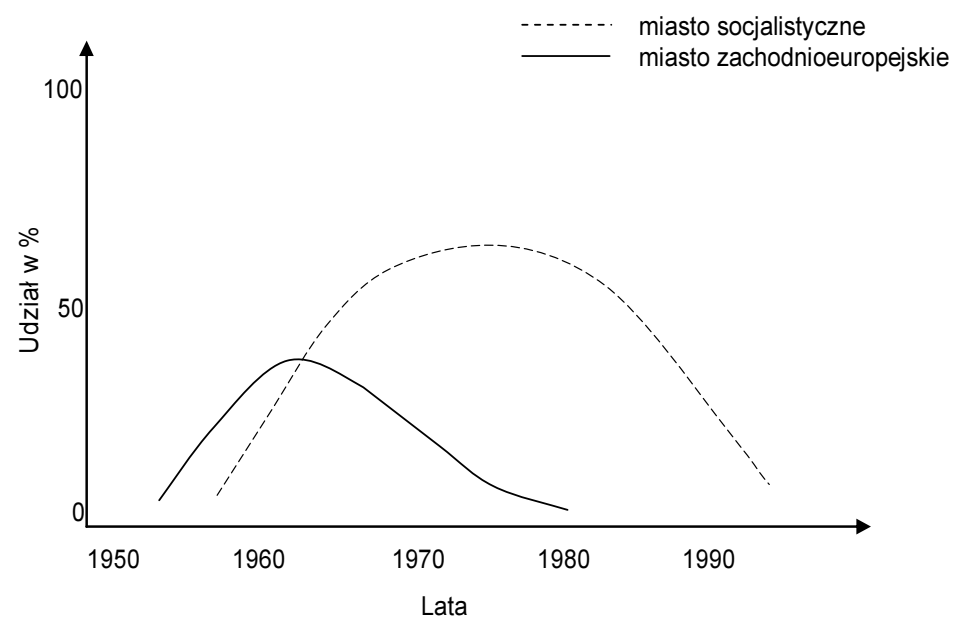

Rys. 14. Rozwój wielkich osiedli mieszkaniowych w miastach socjalistycznych i miastach zachodnioeuropejskich w latach 1955-1995 Źródło: opracowanie własne

od końca lat 70. XX wieku wraz ze wzrostem zamożności mieszkańców $\mathrm{w}$ osiedlach tych zaczęły następować procesy filtracji mieszkaniowej oraz inwazji na te obszary ludności słabszej ekonomicznie i społecznie. Doprowadzily one do znacznego obniżenia ich atrakcyjności mieszkaniowej, a w wielu przypadkach do daleko idącej deterioracji społecznej i urbanistycznej. W praktyce realnego socjalizmu natomiast, gdzie proces alokacji mieszkaniowej miał charakter polityczny, a równocześnie nie istniała (lub istniała w bardzo niewielkim zakresie), perspektywa poprawy warunków mieszkaniowych poza systemem uspołecznionego budownictwa blokowego można mówić o "przypisaniu do mieszkania”. Blokowało to potencjalne decyzje migracyjne związane np. ze zmianami w cyklu życia rodziny, zmianami w poziomie zamożności czy w preferencjach mieszkaniowych, które w miastach kapitalistycznych były zasadniczymi czynnikami migracji i mechanizmami kształtującymi strukturę rezydencjalną miast. Uwarunkowania te $\mathrm{w}$ oczywisty sposób wpływały na relatywnie wysoki status społeczny i prestiż mieszkaniowy tych osiedli, a w konsekwencji ich pozycję w strukturze społeczno-przestrzennej miast, która w miastach socjalistycznych była znacznie wyższa od obserwowanej w miastach zachodnioeuropejskich. Jego obniżenie nastąpiło natomiast dopiero po zmianie ustroju, czyli dużo później niż w miastach zachodnioeuropejskich i w znacznie mniejszym stopniu (rys. 15).

Przedstawiona $w$ rozdziale ewolucja wielorodzinnej zabudowy osiedlowej oraz analiza ich struktury społecznej i przestrzennej w wybranych mia- 
stach socjalistycznych pozwoliła także stwierdzić, że osiedla te, mimo tej samej proweniencji "osiedli socjalistycznych", nie stanowią jednak w pełni jednorodnego zbioru. Czynnikami, które najbardziej je różnicują nie są jednak uwarunkowania krajowe, bo te, mimo pewnych odmienności, były podobne w obozie krajów realnego socjalizmu, lecz okres budowy poszczególnych osiedli. Scentralizowana polityka mieszkaniowa realizowana $\mathrm{w}$ różnych krajach socjalistycznych w latach 1960-1989 wraz ze zmianami władzy modyfikowała bowiem nieco swe priorytety. W kolejnych dekadach zmieniały się również warunki techniczne budowy osiedli, do których należą np. dostępność wolnych terenów w miastach i możliwości technologiczne. Najważniejszą rolę odgrywały jednak zcentralizowane decyzje w postaci różnego rodzaju normatywów oraz szczegółowych przepisów określających gdzie, jak i dla kogo się buduje oraz komu i na jakich zasadach "należy się" mieszkanie. Różnice pomiędzy osiedlami z kolejnych dekad uwidaczniały się głównie w ich strukturze przestrzennej, wielkości i lokalizacji, ale także, choć w znacznie mniejszym stopniu, w ich strukturze społecznej. Ta ostatnia bowiem, jak już powiedziano, na skutek realizacji wspólnych dla wszystkich krajów tego ustroju zasad socjalistycznej alokacji mieszkaniowej, była dość jednorodna demograficznie i heterogeniczna statusowo.

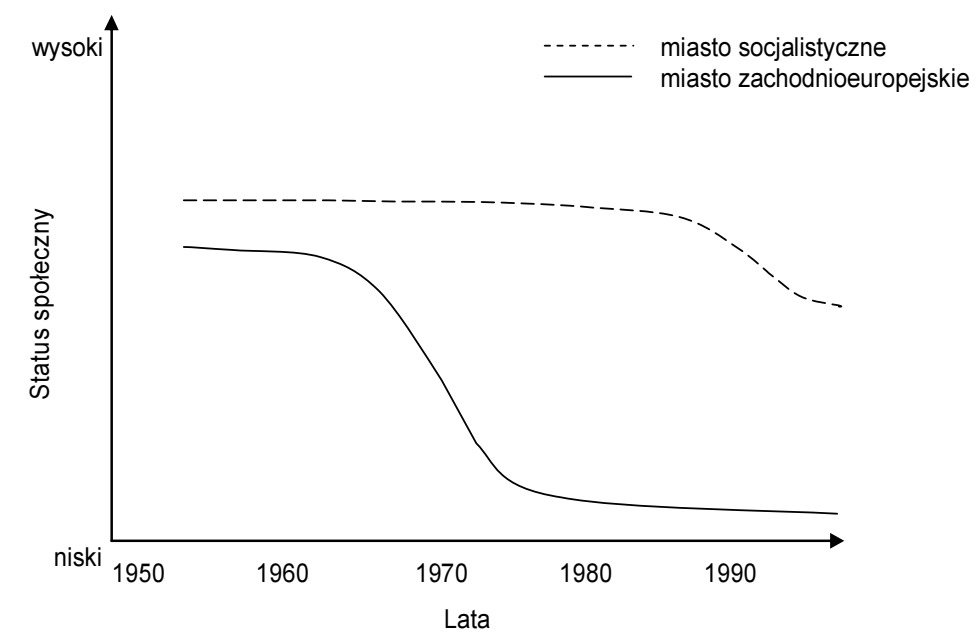

Rys. 15. Status społeczny i prestiż wielkich osiedli w miastach socjalistycznych i miastach zachodnioeuropejskich w latach 1955-1995 Źródło: opracowanie własne

Konkludując można stwierdzić, że socjalistyczny model mieszkalnictwa (por. Hegedús, Tosics 1996) i socjalistyczna polityka alokacji mieszkaniowej, swoiste dla miast tego ustroju, które mniej lub bardziej konsekwentnie - 
w zależności od krajowych uwarunkowań i od zmieniających się w poszczególnych dekadach priorytetów - realizowane były do wczesnych lat 90 . XX wieku sprawily, że u progu transformacji ustrojowej osiedla te w miastach socjalistycznych, mimo podobnej fizjonomii, stanowiły specyficzny dla tego ustroju i zupełnie inny zasób mieszkaniowy niż osiedla w krajach zachodnioeuropejskich. A specyfika ta istotnie zdeterminowała ich przemiany po zmianie ustrojowej, w okresie miasta postsocjalistycznego, które są przedmiotem analiz $w$ dalszej części pracy. 


\section{PRZEMIANY WIELKICH OSIEDLI MIESZKANIOWYCH W MIEŚCIE POSTSOCJALISTYCZNYM}

\subsection{Miasto postsocjalistyczne - główne cechy}

Proces polegający na przechodzeniu od socjalizmu do kapitalizmu, nazywany $\mathrm{w}$ literaturze transformacją ustrojową, utożsamiany jest $\mathrm{z}$ wykreowaniem się nowej formy miasta określanej mianem miasta postsocjalistycznego. Pojęcie to, choć niejednoznaczne ${ }^{107}$ i nie przez wszystkich akceptowane, najczęściej oznacza typ miasta zdefiniowany w oparciu o cezurę czasową, jaką jest przełom lat 80. i 90. XX wieku oraz typ ustroju, w jakim to miasto funkcjonowało $w$ latach 1945-1989. Zgodnie z definicją S. Liszewskiego (2001b, s. 304), którą przyjęto na użytek niniejszej pracy, miasto postsocjalistyczne to „każde miasto, które [...] funkcjonuje w nowych warunkach polityczno-gospodarczych, a wcześniej (przed 1990 r.) istniało w okresie realnego socjalizmu, niezależnie od tego, czy zostało zbudowane w tym systemie [...] podlegając przez 45 lat ideologii i prawom tego ustroju".

Przemiany zachodzące po 1989 roku w miastach postsocjalistycznych uwarunkowane są wieloma czynnikami działającymi na różnych poziomach, począwszy od globalnego, poprzez europejski, regionalny (kraje postsocjalistycznej Europy), krajowy oraz lokalny (Sýkora 2000, Węcławowicz 2000). Najważniejsze $\mathrm{z}$ nich są następstwem procesów uruchomionych przez transformację ustrojową i powrót miast socjalistycznych na ścieżki rozwojowe typowe dla miast krajów wolnego rynku. Procesy te zostały szeroko omówione w literaturze, głównie przez geografów i socjologów (m.in. Marody (red.) 1991, Musil 1993, Harloe 1996, Szelényi 1996, Enyedi 1998,

${ }^{107}$ Określenie „miasto postsocjalistyczne” jest kalką językową najczęściej używanego i funkcjonującego w jęz. angielskim post-socialist city, choć mogłoby być tłumaczone także jako "miasto posocjalistyczne". Ponadto w literaturze anglojęzycznej, funkcjonuje także określenie city after socialism (Andrusz i in., red. 1996), co tłumaczyć można jako „miasto po socjalizmie”. W literaturze anglojęzycznej funkcjonuje też, rzadziej używane, określenie post-communist city (Sýkora 1999, 2000). 
Parysek 1998, Kovács 1999, Sýkora 1999, 2000, 2009, Węclawowicz 1998, 1999, 2000, 2002, 2007, 2013, Wnuk-Lipiński 2003, Jażdżewska (red.) 2000, 2001, Matlovič 2000, Rykiel 2000, Liszewski 2001b, Zborowski 2000, 2001, 2005, Sagan 2000a, b, Matlovič i in. 2001, Kostinsky 2001, Hamilton i in. (red.) 2005, Szczepański 2005, Matlovič, Sedlakova 2007, Stanilov 2007, Stenning 2005, Stenning i in. 2007, 2010). Do najważniejszych z nich, które kształtowały miasto postsocjalistyczne jako miasto nowego typu, należały (Węcławowicz 1999, 2000, 2002, 2007):

- powrót znaczenia renty gruntowej i innych mechanizmów rynkowych $\mathrm{w}$ gospodarce oraz zmiana kryteriów alokacji przestrzennej z politycznych na ekonomiczne;

- powstanie rzeczywistych samorządów terytorialnych reprezentujących interesy społeczności lokalnych;

- decentralizacja władzy państwowej i przesunięcie kontroli nad przestrzenią z centrum do władz lokalnych;

- zmiany w strukturze własności;

- przemiany struktury społeczno-zawodowej związane ze zmniejszeniem się zatrudnienia w sektorze przemysłowym na korzyść usług;

- wzrost rozwarstwienia dochodów mieszkańców.

Mimo że w dyskursie dotyczącym przejścia miast Europy Środkowo-Wschodniej od socjalizmu do kapitalizmu dominuje perspektywa transformacji ustrojowej, to włączenie się ich po 1990 roku w obieg gospodarki światowej spowodowało, że ważną determinantą zachodzących w nich procesów stały się procesy ogólnoświatowe. Najważniejsze z nich to globalizacja, rozwój technologii i usług, liberalizacja polityki społecznej związana $\mathrm{z}$ upadkiem idei państwa dobrobytu welfare state, polityczna i gospodarcza integracja, a także przemiany społeczne i demograficzne (Zborowski 2000). Zmiany zachodzące $\mathrm{w}$ mieście postsocjalistycznym rozpatruje się często także w kontekście modernizacji, która jako przemiana o charakterze cywilizacyjnym poprzez swój wielopłaszczyznowy charakter oddziałuje na niemal wszystkie sfery życia w globalizującym się świecie (Zborowski 2005). Szeroko opisane w literaturze procesy modernizacji (Szczepański 1999, Ziółkowski 1999), jakkolwiek zachodzą już od wielu dziesięcioleci, to w Europie Środkowo-Wschodniej, wskutek transformacji nabrały znacznego przyśpieszenia. Wśród przemian modernizacyjnych, które są przedmiotem zainteresowania geografii społecznej miast, z punktu widzenia niniejszej pracy za ważne uznać należy nie tylko zmiany gospodarcze, ale także przemiany w sferze społeczno-kulturowej, które mają istotny wpływ na kształtowanie się nowej struktury rezydencjalnej w miastach postsocjalistycznych. Najważniejsze $\mathrm{z}$ nich to wzrost indywidualizmu i aspiracji życiowych jednostek, zwiększanie się otwartości na nowe doświadczenia i niezależności 
wobec autorytetów, a także zmiany w postrzeganiu tradycyjnych ról społecznych (w tym ról rodzinnych) i osłabienie więzi (Okólski 2000). Ich konsekwencją są m.in. wzrost aspiracji mieszkaniowych i zwiększenie się ruchliwości przestrzennej $w$ miastach oraz przemiany modelu rodziny. Te ostatnie, charakterystyczne dla drugiego przejścia demograficznego (teorii zaproponowanej przez D. van de Kaa i R. Lesthaegha), mają wpływ przede wszystkim na starzenie się społeczeństwa i wzrost liczby małych (jednoi dwuosobowych) gospodarstw domowych. Ich główne przyczyny związane są ze zmianami wzorów życia rodzinnego oraz płodności (na skutek między innymi spadku liczby zawieranych małżeństw, wzrostu liczby rozwodów oraz odraczania w czasie decyzji o urodzeniu pierwszego dziecka) (Okólski 2005). Procesy te, obserwowane w krajach Europy Zachodniej i Pólnocnej od lat 60., a w krajach bloku wschodniego od lat 90. XX wieku, szczególnie silnie zaznaczają się $\mathrm{w}$ dużych miastach, które przestały rosnąć ludnościowo, a wiele $\mathrm{z}$ nich dotyka ubytek ludności. Proces kurczenia się miast obserwowany w wielu krajach Europy, w krajach postsocjalistycznych jest szczególnie nasilony ze względu na zachodzące w nich połączenie postsocjalistycznego i postfordowskiego procesu transformacji (Wiechmann 2009) oraz nakładających się nań procesów globalnych. Zdaniem J. Musila (2003) współwystępowanie procesów upadku systemu socjalistycznego i globalizacji we wszystkich jej wymiarach: społecznym, ekonomicznym i politycznym, sprawia, że miasta postsocjalistyczne funkcjonują $\mathrm{w}$ warunkach dwóch jednoczesnych rewolucji, kiedy najnowsze formy globalnej gospodarki zaszczepia się $\mathrm{w}$ społeczeństwach, które przez wiele dekad funkcjonowały w warunkach odmiennych niż zachodnioeuropejskie.

W literaturze geograficznej przemiany miast postsocjalistycznych najczęściej analizuje się w odniesieniu do ich struktury wewnętrznej, odrębnie dla głównych stref wyróżnionych w oparciu o dorobek szkoły chicagowskiej108, a także w odniesieniu do ich struktury fizycznej (morfologii i fizjonomii), funkcjonalnej oraz społecznej, czym zajmowali się m.in.: R. Matlovič (2000), I. Sagan (2000a), L. Sýkora (2000), A. Zborowski (2005), S. Liszewski (2001b), R. Matlovič i in. (2001), R. Matlovič i A. Sedlakova (2007) oraz S. Marcińczak (2009). Jedno z takich ujęć przedstawia tab. 10.

108 W strukturze społeczno-przestrzennej miast postsocjalistycznych, w dużej mierze odziedziczonej po byłym ustroju i określanej jako mało czytelna, przemieszana i mozaikowa (Węcławowicz 2007, Sagan 2000a), R. Matlovič i in. (2001) wyodrębnili pięć stref pozostających w układzie koncentrycznym: 1) historyczny rdzeń miasta, 2) miasto wewnętrzne, 3) strefa zabudowy willowej, 4) strefa wielkich osiedli mieszkaniowych oraz 5) wielofunkcyjna strefa podmiejska, S. Liszewski (2001b) cztery: 1) centrum, 2) strefę wewnętrzną, 3) strefę zewnętrzną utożsamianą $\mathrm{z}$ inwestycjami okresu realnego socjalizmu, $\mathrm{w}$ tym $\mathrm{z}$ wielkimi osiedlami mieszkaniowymi, oraz 4) strefę podmiejską, a A. Zborowski (2000): 1) centrum, 2) obrzeża centrum, 3) strefę bloków oraz 4) strefę przedmiejską. 
Tab. 10. Główne procesy transformacji zachodzące w poszczególnych strefach miasta postsocjalistycznego

\begin{tabular}{|c|c|c|c|}
\hline \multirow[b]{2}{*}{ Strefa miasta } & \multicolumn{3}{|c|}{ Struktura } \\
\hline & $\begin{array}{c}\text { fizyczna } \\
\text { (morfologiczna) }\end{array}$ & $\begin{array}{c}\text { funkcjonalna } \\
\text { (funkcjonalno-przestrzenna) }\end{array}$ & $\begin{array}{l}\text { społeczna (społeczno- } \\
\text {-przestrzenna) }\end{array}$ \\
\hline $\begin{array}{l}\text { Rdzeń } \\
\text { miasta }\end{array}$ & $\begin{array}{l}\text { gentryfikacja, } \\
\text { rewitalizacja }\end{array}$ & $\begin{array}{l}\text { komercjalizacja, sakralizacja, } \\
\text { fragmentacja funkcjonalna }\end{array}$ & $\begin{array}{l}\text { gentryfikacja, } \\
\text { separacja }\end{array}$ \\
\hline $\begin{array}{l}\text { Miasto } \\
\text { wewnętrzne }\end{array}$ & $\begin{array}{l}\text { gentryfikacja, } \\
\text { rewitalizacja, } \\
\text { recesja i ugory } \\
\text { miejskie }\end{array}$ & $\begin{array}{l}\text { komercjalizacja, sakralizacja, } \\
\text { deindustrializacja } \\
\text { demilitaryzacja, } \\
\text { fragmentacja funkcjonalna }\end{array}$ & $\begin{array}{l}\text { gentryfikacja, } \\
\text { segregacja, } \\
\text { separacja }\end{array}$ \\
\hline $\begin{array}{l}\text { Obszar zabudowy } \\
\text { willowej }\end{array}$ & rewitalizacja & $\begin{array}{l}\text { komercjalizacja, } \\
\text { sakralizacja }\end{array}$ & - \\
\hline $\begin{array}{l}\text { Strefa osiedli } \\
\text { mieszkaniowych }\end{array}$ & $\begin{array}{l}\text { rewitalizacja, } \\
\text { recesja i ugory } \\
\text { miejskie }\end{array}$ & $\begin{array}{l}\text { komercjalizacja, } \\
\text { sakralizacja }\end{array}$ & $\begin{array}{l}\text { regresja statusowa, } \\
\text { segregacja }\end{array}$ \\
\hline $\begin{array}{l}\text { Miasto } \\
\text { zewnętrzne }\end{array}$ & $\begin{array}{l}\text { suburbanizacja, } \\
\text { rewitalizacja, } \\
\text { recesja i ugory } \\
\text { miejskie }\end{array}$ & $\begin{array}{l}\text { komercjalizacja, } \\
\text { sakralizacja, } \\
\text { fragmentacja funkcjonalna }\end{array}$ & $\begin{array}{l}\text { suburbanizacja, } \\
\text { segregacja, } \\
\text { separacja }\end{array}$ \\
\hline
\end{tabular}

Źródło: opracowanie własne na podstawie R. Matlovič i in. (2001, s. 18), R. Matlovič, A. Sedlakova $(2007$, s. 34).

Różne tradycje kulturowe i historyczne sprawiają, że wymienione procesy przebiegać mogą odmiennie w poszczególnych krajach postsocjalistycznych lub w ich grupach ${ }^{109}$ (Węclawowicz 2002, Musil 2005, Hamilton i in., red. 2005). Na tempo i kierunek tych przemian wpływają również czynniki lokalne (miejskie), do których należą pozycja miasta w hierarchii osadniczej kraju (w szczególności odmienna pozycja stolic), wielkość miasta, kondycja gospodarcza i lokalny rynek pracy (warunkujący zamożność gospodarstw domowych i ich możliwości nabywcze), ale także zasoby kapitału ludzkiego (poziom wykształcenia mieszkańców, ich przedsiębiorczość) i poziom kapitału społecznego (tradycje samorządności, partycypacja społeczna itp.) (Węcławowicz 2007, Misiak 2005).

W konsekwencji wymienionych procesów, które determinowane są zjawiskami zachodzącymi na wszystkich poziomach (globalnym, europejskim, regionalnym, krajowym oraz lokalnym), nastąpiły istotne przemiany we wszystkich strefach miast postsocjalistycznych, w tym także w strefie wiel-

${ }^{109}$ W literaturze (Hamilton i in., red. 2005, s. 8) na obszarze postsocjalistycznej Europy wyodrębnia się: Europę Środkowo-Wschodnią (Central-East Europe) określaną też jako Centralna, obejmującą Polskę, Czechy, Słowenię, Słowację i Węgry, a także Europę Południowo-Wschodnią (Albania, Bułgaria, Rumunia i kraje b. Jugosławii bez Słowenii), Europę Wschodnią (Białoruś, Mołdawia, Ukraina i europejska część Rosji) oraz Kraje Bałtyckie (Estonia, Litwa i Łotwa). 
kich osiedli mieszkaniowych i w ich strukturze: społecznej, morfologicznej oraz funkcjonalnej, które jako zasadniczy przedmiot niniejszej pracy, omówione zostały w dalszej jej części.

\subsection{Procesy kształtujące strukturę rezydencjalną w mieście postsocjalistycznym}

W okres transformacji ustrojowej wiele państw socjalistycznych, mimo trwającej blisko 40 lat uprzemysłowionej produkcji mieszkań na masową skalę, weszło z głębokim kryzysem mieszkaniowym i ogromnym niedoborem mieszkań (Buckley, Tsenkova 2006). Sytuacja ta w pierwszej dekadzie po zmianie ustroju nie tylko nie uległa poprawie, ale nawet pogorszyła się (Stanilov 2007). Utrzymywanie się $\mathrm{w}$ tym czasie znaczącego deficytu na rynku mieszkaniowym $w$ tej grupie krajów uwarunkowane było wieloma czynnikami. Po pierwsze, na skutek zmiany polityki mieszkaniowej państwa gwałtownie spadła liczba nowych mieszkań oddawanych do użytku. Po drugie, mimo spadku liczby ludności w miastach, liczba gospodarstw domowych nie zmniejszyła się, ponieważ znacznie wrósł udział gospodarstw jednoosobowych. Po trzecie, w okresie socjalizmu wiele gospodarstw domowych dzieliło swoje mieszkania $\mathrm{z}$ innymi (głównie z rodzicami lub innymi krewnymi), co wiązało się ze znaczną deprywacją, z pozoru zaspokojonych, potrzeb mieszkaniowych (Tsenkova 1996). Na sytuację tę nałożyła się relatywnie młoda struktura wieku w miastach postsocjalistycznych i wchodzenie w dorosłość kolejnych roczników wywierających presję na rynek mieszkaniowy (druga fala powojennego wyżu demograficznego), a także zły lub bardzo zły stan, dużej części starych, nieremontowanych zasobów mieszkaniowych (Węclawowicz $2003 \mathrm{i}$ in.). W Polsce w początkowym okresie transformacji deficyt mieszkaniowy sięgał 1,5 mln mieszkań, a liczba tych, które przeznaczone były do rozbiórki wynosiła około 800 tys. (ibid., s. 19).

Realizowana wówczas $\mathrm{w}$ krajach postsocjalistycznych polityka mieszkaniowa nastawiona była na potrzebę znalezienia możliwości poprawy sytuacji na rynku mieszkaniowym negując przy tym pryncypia byłego ustroju. Inspiracją dla tych działań stała się ideologia neoliberalna, która dominowała w dyskursie publicznym w Europie Zachodniej w latach 80. minionego stulecia. Ta ścieżka przekształceń rynku mieszkaniowego $w$ krajach postsocjalistycznych preferowana była także przez międzynarodowe instytucje finansowe, np. Bank Światowy i Międzynarodowy Fundusz Walutowy, które nadzorowały proces przekształceń $w$ tych krajach i wymagały niemal całkowitego wycofania się państwa ze wszystkich form produkcji i dystrybucji mieszkań (Stanilov 2007). 
Wycofanie się państwa z polityki mieszkaniowej charakterystycznej dla socjalistycznego modelu mieszkalnictwa ${ }^{110}$ (por. Hegedús, Tosics 1996) spowodowało gwałtowne załamanie się budownictwa mieszkaniowego, które dopiero w XXI wieku stopniowo zaczęło podnosić się z upadku (Tsenkova 1996). W pierwszej kolejności na Węgrzech, w Czechosłowacji i w Polsce w krajach, w których najwcześniej zrealizowano polityczne reformy ${ }^{111}$. Po depresji początku lat 90. minionego stulecia liczba mieszkań oddawanych do użytku w tych krajach wzrosła, przy czy w żadnym z nich w 2000 roku nie osiągnęła stanu z roku 1990112. Jednym z czynników, który miał wpływ na ożywienie budownictwa mieszkaniowego $\mathrm{w}$ krajach postsocjalistycznych było pojawienie się w połowie lat 90 . możliwości korzystania z kredytów hipotecznych, przy czym dostęp do nich w początkowym okresie transformacji był silnie ograniczony113. Wpływ na poprawę sytuacji miało także nowe wówczas zjawisko kupowania domów i mieszkań przez graczy z krajów zachodnich, których kusily relatywnie niskie ceny nieruchomości i niskie koszty życia w krajach postsocjalistycznych. Zjawisko to nasiliło się po roku 2004, po wstąpieniu ośmiu krajów postsocjalistycznych do UE. W wyniku tych zmian nastąpił ilościowy przyrost mieszkań, ale także wzrost średniej powierzchni lokali oddawanych do użytku, co nieznacznie poprawiło bardzo niskie wskaźniki standardu mieszkaniowego notowane w latach 90. (Stanilov 2007) ${ }^{114}$.

Jedną z głównych form przekształceń rynku mieszkaniowego w okresie transformacji ustrojowej była prywatyzacja istniejących zasobów mieszkaniowych. Proces ten przebiegał w poszczególnych krajach w różnym tem-

110 Proces ten, w literaturze określany dewelfaryzacją (Warzywoda-Kruszyńska 2012, s. 151), oznaczał wycofywanie się państwa z dostarczania bezpłatnie lub po niskich cenach różnych usług społecznych (edukacji, ochrony zdrowia, aktywności czasu wolnego), w tym także z mieszkalnictwa.

111 Według P. Śleszyńskiego (2005) sytuacja mieszkaniowa w Polsce w latach 1988-2002 pod względem pewnych wskaźników pogorszyła się, bo choć liczba mieszkań zamieszkanych wzrosła o 8,5\%, to wzrost liczby gospodarstw domowych wyniósł 11,4\%. Pozytywnym zjawiskiem był natomiast wyższy od przyrostu gospodarstw domowych wzrost przeciętnej powierzchni użytkowej (o 25,9\%) oraz liczby izb (o 18,5\%).

112 Średnio w 13 krajach postsocjalistycznych w latach 1990-2000 liczba nowych mieszkań oddawanych do użytku spadła ponaddwukrotnie (z 4,4 do 1,8 na 1000 mieszkańców, przy czym dla porównania w tym samym okresie w krajach Europy Zachodniej wartości te wynosiły odpowiednio 6,5 oraz 5,8). Najmniejszy spadek odnotowały Słowenia, Chorwacja oraz Polska (o prawie połowę), a największy, co najmniej czterokrotny, kraje postradzieckie (przy czym np. Łotwa ponad 10-ktrotny) oraz Bułgaria (Stanilov 2007, s. 174).

${ }_{113}$ W Czechach np. w końcu lat 90. kredyty mieszkaniowe były dostępne dla gospodarstw domowych, których średni dochód wynosił co najmniej trzykrotność średniej krajowej (Stanilov 2007).

${ }^{114} \mathrm{~W}$ końcu lat 90 . w krajach tych średnio na jedną osobę przypadało $20 \mathrm{~m}^{2}$ powierzchni użytkowej mieszkania, podczas gdy w krajach Europy Zachodniej - $36 \mathrm{~m}^{2}$ (Stanilov 2007, s. 176). 
pie, co wynikało $\mathrm{z}$ faktu, że już $\mathrm{u}$ progu transformacji istniały pomiędzy nimi znaczące różnice $w$ strukturze własności zasobów mieszkaniowych ${ }^{115}$. Polityka ich prywatyzacji opierała się na dwóch mechanizmach: sprzedaży mieszkań obecnym lokatorom oraz na restytucji nieruchomości byłym właścicielom. Działanie tych mechanizmów było zróżnicowane w zależności od priorytetów polityki społeczno-ekonomicznej przyjętej w poszczególnych krajach. W niektórych krajach kładziono większy nacisk na restytucję mienia, w innych na prywatyzację publicznych zasobów mieszkaniowych, dzięki czemu wielu dotychczasowych lokatorów stawało się właścicielami dotychczas użytkowanych mieszkań. W większości krajów bałkańskich, na Litwie i Węgrzech proces prywatyzacji został zakończony już w połowie lat 90., a we wschodnich Niemczech, Czechach, Słowacji i Polsce przebiegał wolniej i z większym naciskiem na restytucję własności. Szczególnie było to widoczne w Czechach i wschodnich Niemczech, gdzie wielkie programy reprywatyzacyjne znacznie opóźniały prywatyzację pozostałych zasobów, na skutek czego w obu tych krajach w końcu lat 90. istniał relatywnie duży zasób publiczny (Stanilov 2007). W innych natomiast udział właścicieli mieszkań znacznie wzrósł, sięgając w krajach bałtyckich oraz w Bułgarii, rekordowych w skali całej Europy, wartości powyżej 90\% (Tsenkova 2003). W niektórych krajach, aby przyspieszyć ten proces oferowano bardzo korzystne warunki wykupu mieszkań. Na przykład na Węgrzech sprzedawano mieszkania za mniej niż 10\% ich wartości rynkowej116 (Hegedús, Tosics 1998), dzięki czemu w Budapeszcie w latach 1990-2006 udział publicznych zasobów mieszkaniowych skurczył się z 51 do 8\% (Kovács, Herfert 2012). Podobnie korzystne warunki prywatyzacji mieszkań stworzono na Litwie, na skutek czego w Wilnie w latach 1991-2001 udział publicznych zasobów mieszkaniowych spadł z 82 do niecałych $2 \%$ (ibid.). W wyniku przesunięcia produkcji, dystrybucji i własności mieszkań z sektora publicznego do prywatnego, w 2002 roku średni udział mieszkań stanowiących prywatną własność w miastach krajów postsocjalistycznych przekroczył $60 \%$, podczas gdy w Europie Zachodniej wynosił średnio 40\% (Stanilov 2007).

Przywrócenie rynkowych reguł obrotu nieruchomościami oraz powrót renty gruntowej zmieniły kryteria alokacji przestrzennej z politycznej na ekonomiczną. Głównym kryterium rywalizacji na rynku mieszkaniowym stała się siła ekonomiczna gospodarstw domowych, co z jednej strony uwolniło sytuację $\mathrm{w}$ mocno kontrolowanej dotychczas i scentralizowanej przez państwo sferze życia, jaką było mieszkalnictwo, z drugiej jednak, w warun-

115 W 1989 r. własność prywatną stanowiło blisko 70\% mieszkań na Węgrzech i w Słowenii i po ok. 40\% w Czechosłowacji i Polsce (Stanilov 2007, s. 176).

116 Lokatorzy mieszkań mogli nabywać je za około 15\% wartości rynkowej, od której jeszcze można było uzyskać $40 \%$ upustu za płatność gotówką (Hegedús, Tosics 1998). 
kach gwałtownej liberalizacji gospodarki, powiększyło obszar deprywacji mieszkaniowej, a wielu grupom uniemożliwiło lub bardzo ograniczyło dostęp do mieszkań.

Istotnym czynnikiem $\mathrm{w}$ kształtowaniu się nowej sytuacji na rynku mieszkaniowym były przemiany w strukturze społecznej, którym towarzyszyło silne rozwarstwienie ekonomiczne, ograniczane ze względów ideologicznych $\mathrm{w}$ okresie realnego socjalizmu. Wraz z rozwarstwieniem dochodów nastąpiło znacznie silniejsze powiązanie ich z poziomem wykształcenia oraz pozycją społeczno-zawodową ludności (Domański 2002). Grupy osób najlepiej wykształconych i zajmujących stanowiska kierownicze, które istotnie zyskały ekonomicznie i w największym stopniu stały się beneficjentami przemian ustrojowych, zyskały swobodę poruszania się na nowym, postsocjalistycznym rynku mieszkaniowym, podczas gdy osoby o niskich kwalifikacjach, niedostosowane do nowoczesnych wymogów gospodarki, które stały się przegranymi transformacji, znalazły się na jego marginesie. Związany z transformacją ustrojową proces rozwarstwienia ekonomicznego społeczeństwa, a w konsekwencji znacznego ubożenia dużej jego części obserwowany był w latach 90 . we wszystkich krajach objętych przemianami ustrojowymi (por. Szelényi 2001, Domański 2002, Csizmady 2003, Zborowski 2005). Jak podaje A. Csizmady (2003), proces ten był mniej odczuwalny w państwach, które relatywnie szybko ukończyły neoliberalne reformy (np. Polska i Węgry), znacznie bardziej zaś dotkliwy w krajach, w których system określić można było jako neopatrymonialny (np. Bułgaria i Rumunia) ${ }^{117}$. Podział społeczeństwa na wygranych (winners) oraz przegranych (loosers) procesu transformacji (por. Domański 2004) w literaturze socjologicznej określony został jako "pęknięcie” struktury społecznej (Słomczyński, Janicka 2005), ponieważ nie towarzyszyło mu wykształcenie się silnej klasy średniej, która jest podstawowym elementem prawidłowo uformowanej stratyfikacji społecznej. Według socjologów, zgodnie z teorią akumulacji przewag zwanej też efektem św. Mateusza ${ }^{118}$, rozwarstwienie to będzie się pogłębiało (ibid., s. 133).

117 Jak podaje H. Domański (2002), na podstawie badań porównawczych pt. Ethnicity, Poverty and Gender in Transitional Societes przeprowadzonych w $2000 \mathrm{r}$. w siedmiu krajach postsocjalistycznych, odsetek osób odnotowujących spadek poziomu życia w latach 1988-2000 wynosił w: Bułgarii 86,6\%, Rosji - 77,7, Rumunii - 77,3, Słowacji - 60,2, w Polsce - 52,6 i na Węgrzech $-51,5 \%$.

118 Pojęcie efektu św. Mateusza (ang. Mathew effect) do socjologii wprowadził w 1968 r. R. Merton, aby opisać zjawisko kumulacji nagród w nauce. $W$ kolejnych latach termin ten stosowany był w innych dyscyplinach (psychologii, pedagogice), a do analizy struktury społecznej po raz pierwszy zastosowano go w USA w latach 80. XX w. (Słomczyński, Janicka 2005). Pojęcie to odwołuje się do słów z Ewangelii św. Mateusza „Każdemu bowiem, kto ma, będzie dodane, tak że nadmiar mieć będzie. Temu zaś, kto nie ma, zabiorą nawet to, co ma" (Mt, 25, 30, Przypowieść o talentach). 
Silne rozwarstwienie ekonomiczne i związany z tym wzrost aspiracji mieszkaniowych w grupach, które zyskały w wyniku transformacji ustrojowej przyczyniły się do znacznego zróżnicowania oferty na rynku mieszkaniowym (Kovács, Herfert 2012). Pojawiły się nowe obszary rezydencjalne o wysokim prestiżu mieszkaniowym $\mathrm{w}$ postaci nieobecnych $\mathrm{w}$ mieście socjalistycznym rozległych suburbiów, luksusowych apartamentowców i parków mieszkaniowych, osiedli zamkniętych, a także rewitalizowanych terenów zabudowy śródmiejskiej. $W$ konsekwencji wymienionych przemian $\mathrm{w}$ miastach postsocjalistycznych nastąpił wzrost rezydencjalnej mobilności, pojawiły się obszary atrakcyjne i „obszary ucieczkowe”, fizycznie i społecznie zdegradowane (Sagan 2000b). Ludność zamożna zaczęła się koncentrować $\mathrm{w}$ przestrzennie odizolowanych enklawach wysokiego standardu mieszkaniowego, a ludność biedna na terenach starego zdekapitalizowanego budownictwa (Węcławowicz 2007). Procesy te przyczyniły się do wzrostu segregacji społeczno-przestrzennej, która wprawdzie - jak podaje S. Marcińczak (2013, s. 104) - mieści się w europejskiej średniej i wciąż jest znacznie niższa niż w miastach amerykańskich, to jednak w relacji do okresu sprzed 1990 roku pogłębiła się. Zjawiska te wiązały się także z pojawieniem się w mieście postsocjalistycznym procesów separacji, czyli oddzielania się przestrzennego określonych grup mieszkańców o wysokim statusie od pozostałej, większej części (Matlovič i in. 2001). Rosnąca na skutek wzrostu zróżnicowania ekonomicznego potrzeba zapewnienia bezpieczeństwa sprawiła, że wiele nowych mieszkań w miastach budowanych jest w zamkniętych i strzeżonych osiedlach (gated communities). Przyczynia się to do procesu fragmentacji przestrzeni miejskiej (Matlovič i in. 2001) oraz pojawiania się w miastach obszarów mieszkaniowych niedostępnych dla pewnych grup społecznych, nie tylko fizycznie, ale także kulturowo i symbolicznie (Gądecki 2007).

Zmiana ustroju spowodowała pojawienie się na rynku mieszkaniowym nowych aktorów społecznego wytwarzania przestrzeni. W Polsce są nimi władze lokalne, samorządy pomocnicze, inwestorzy (deweloperzy), spółdzielnie mieszkaniowe (które po zmianie ustroju zyskały znacznie większą autonomię), wspólnoty mieszkaniowe oraz różne kategorie mieszkańców. Ci ostatni jednak, jak pisał J. Kotus (2007, s. 109), mimo decentralizacji władzy i silnej polityki prosamorządowej nierzadko byli na końcu listy aktorów sceny miejskiej, ponieważ ich głos często nie był brany pod uwagę. I mimo że w ostatnich latach sytuacja ta zmieniła się na korzyść mieszkańców poprzez działanie takich instrumentów partycypacji społecznej, jak np. budżet obywatelski, to jednak wciąż głównym decydentem w procesach zagospodarowania i użytkowania przestrzeni miasta jest ten, kto posiada większy kapitał (Jałowiecki i in. 2009).

Szczególną rolę w kształtowaniu przestrzeni rezydencjalnej miast posocjalistycznych odgrywają celowe działania zmierzające do poprawy jakości 
istniejących zasobów mieszkaniowych. Są one elementem polityki mieszkaniowej realizowanej najczęściej na poziomie lokalnym, ale także krajowym, co w praktyce wiąże się ze źródłami ich finansowania. W literaturze polskiej działania te, jak już powiedziano, mają bardzo wiele określeń, do których należą modernizacja (Chmielewski, Mirecka 2001, Kozłowski 2005), rewitalizacja (Gorczyca 2009), rehabilitacja (Rębowska 1999, 2000, Rębowska i in. 2006), reurbanizacja (Gzell i in. 2009, Rembarz 2010), restrukturyzacja (Węcławowicz 2003) lub humanizacja (Misiak 1993, Borowik 2003, 2007). Liczne przykłady takich działań, realizowanych $\mathrm{w}$ wielkich osiedlach mieszkaniowych $\mathrm{w}$ Polsce i w innych krajach postsocjalistycznych, obejmujących zarówno całe osiedla, jak i poszczególne ich fragmenty, są szeroko omówione w literaturze (Rębowska 1999, 2000, Rębowska i in. 2006, Wojtkun 2004, Turkington i in., red. 2004, Kozłowski 2005, Chmielewski, Mirecka 2001, Constantin 2007, Tokajuk 2007, Łodziński 2009, Ostańska 2009, Rembarz 2010, Kabisch, Grossmann 2013, Wassenberg 2013). W Polsce działania te podejmowane są zarówno przez podmioty zarządzające zasobami mieszkaniowymi (głównie spółdzielnie mieszkaniowe, ale także wspólnoty mieszkańców), jak i władze miejskie, władze krajowe natomiast dofinansowują je częściowo i tylko w wybranych aspektach (tzw. ustawy termomodernizacyjne z 1998 i 2008 r.) ${ }^{119}$. Obejmują one głównie działania związane z techniczną modernizacją dotychczasowej zabudowy oraz poprawą jakości przestrzeni publicznych. Przyczyniają się do polepszenia warunków zamieszkania w osiedlach oraz do poprawy ich wizerunku wśród mieszkańców (por. Szafrańska 2009, Kozłowski 2010, Temelová i in. 2011), lecz ich słabość w miastach postsocjalistycznych polega na tym, że są one wciąż fragmentaryczne i napotykają wiele barier. Wśród najważniejszych wymienia się brak skoordynowanej polityki przyszłego rozwoju tych osiedli, która wymaga zaangażowania różnych stron: począwszy od władz państwowych, poprzez władze miejskie, władze dzielnic/osiedli, właścicieli znajdujących się tam zasobów mieszkaniowych, inwestorów zainteresowanych potencjałem rozwojowym obszaru i last but not least samych mieszkańców. Drugim utrudnieniem jest bariera finansowa, ponieważ proces ten, jeśli ma spełnić swoje zadanie (a nie polegać tylko na odświeżaniu elewacji budynków), wymaga dużych nakładów (Stanilov 2007). W Polsce zwraca się także uwagę na brak pełnego uporządkowania kwestii własności gruntów i brak faktycznego gospodarza tych terenów, ponieważ po części jest nim miasto, po części spółdzielnie mieszkaniowe, a po części sami mieszkańcy (Rembarz

119 Wprowadzona w 1998 r. Ustawa o wspieraniu przedsięwzięć termomodernizacyjnych pozwalała wspierać z budżetu państwa remonty budynków mające na celu zmniejszenie ich zapotrzebowania na energię cieplną, ale $w$ efekcie jej działania znacząco zmieniła się fizjonomia budynków w wielkich osiedlach. Obecnie proces ten wspomagany jest przez Ustawę o wspieraniu termomodernizacji i remontów z $2008 \mathrm{r}$. 
2010). Do barier tych należą także ograniczone stosowanie idei partnerstwa publiczno-prywatnego, niedoskonałość i niespójność prawa w zakresie zagospodarowania przestrzeni, które powodują liczne konflikty o charakterze społeczno-przestrzennym, brak współpracy samorządów lokalnych z zarządami osiedli, brak rezerwy mieszkań, która pozwalałaby na wyburzenia i zmniejszanie kubatury budynków oraz prawne ograniczanie możliwości działania spółdzielni mieszkaniowych i ich duże rozdrobnienie, które utrudnia skuteczne działanie. S. Kozłowski (2010) wśród przeszkód wymienia również brak finansowego wsparcia dla badań naukowych o charakterze aplikacyjnym, które pozwoliłyby monitorować ewentualne problemy wielkich osiedli mieszkaniowych, a w przyszłości służyć ich rozwiązywaniu. Barierą na drodze modrnizacji osiedli są niekiedy postawy samych mieszkańców protestujących przeciwko zmianom, co wynika zarówno z ogólnej niechęci do zmian, z braku wiedzy o tym, czemu (i komu) takie zmiany mają służyć, braku komunikacji pomiędzy mieszkańcami a podmiotami realizującymi działania modernizacyjne, a wreszcie $\mathrm{z}$ obaw przed koniecznością partycypacji finansowej $\mathrm{w}$ tych działaniach oraz przed ewentualnym wzrostem czynszu (Borowik 2003, Kozłowski 2010). Duży poziom prywatyzacji mieszkań $\mathrm{w}$ osiedlach $\mathrm{z}$ jednej strony opóźnia procesy ich degradacji zarówno społecznej, jak i fizycznej, z drugiej jednak umożliwia mieszkańcom blokowanie niektórych działań modernizacyjnych.

Paradoksalnie tym, co hamuje ewentualne działania modernizacyjne podejmowane $\mathrm{w}$ osiedlach polskich, jest wciąż relatywnie dobry standard zasobów mieszkaniowych i wciąż stosunkowo dobre warunki życia, które są w nich oferowane (zwłaszcza w relacji do rozległych obszarów starej zabudowy mieszkaniowej zdekapitalizowanej i zdegradowanej fizycznie oraz społecznie w okresie socjalizmu), a także ich wciąż relatywnie dobra reputacja, która sprawia, że nie dostrzega się potencjalnych zagrożeń, jakie obszary te mogą generować w przyszłości (Kozłowski 2010, Rembarz 2010). $\mathrm{W}$ Polsce tylko $\mathrm{w}$ niektórych miastach, rozumiejąc potencjalne zagrożenia, wielkie osiedla wpisuje się do lokalnych dokumentów planistycznych jako obszary wymagające działań naprawczych (Gorczyca 2009).

Wymienionych problemów związanych $\mathrm{z}$ małym zaawansowaniem działań modernizacyjnych doświadczają także inne kraje postsocjalistyczne (Divinsky 2004, Dimitrovska Andrews, Černič Mali 2004, Kovács, Douglas 2004, Constantin 2007), z jednym wyjątkiem, jakim są wschodnie landy Niemiec, w których programy modernizacji wielkich osiedli rozpoczęto już $\mathrm{w}$ latach 90. XX wieku angażując $w$ ten proces ogromne środki finansowe ${ }^{120}$.

${ }^{120}$ W latach 1990-1999 w Niemczech na realizację programu modernizacji wielkopłytowych zasobów mieszkaniowych wydano ok. 70 mld marek, a w latach 2000-2008 rząd fede- 
Bezpośrednim impulsem do rozpoczęcia tych działań była reunifikacja Niemiec w 1991 roku, która unaoczniła drastyczne różnice w standardzie zasobów mieszkaniowych $\mathrm{w}$ miastach landów wschodnich i zachodnich oraz spowodowała, że modernizacja i rewitalizacja wielkich osiedli $w$ b. NRD stała się jednym z podstawowych priorytetów władz ${ }^{121}$ (Rembarz 2010). Zakres przestrzenny i koszty tego procesu były ogromne, ponieważ bezpośrednio po zjednoczeniu w wielkich osiedlach blokowych mieszkal co czwarty obywatel b. NRD, podczas gdy w landach zachodnich - co sześćdziesiąty (ibid., s. 146). W niemal wszystkich wielkich miastach wdrożono wówczas programy naprawcze oparte na bogatych doświadczeniach krajów zachodnich (głównie Francji, Holandii, Szwecji i Wlk. Brytanii), a także doświadczeniach własnych $\mathrm{z}$ b. RFN, lecz największe środki finansowe przeznaczono na ten cel $\mathrm{w}$ osiedlach Berlina Wschodniego, w którym blisko 2/3 populacji mieszkało w wielkich osiedlach (Tosics 2004). W 1992 roku rozpoczęto w tym mieście realizację wszechstronnego 10-letniego planu odnowy wielkich osiedli, skierowanego na poprawę jakości mieszkań i architektury budynków oraz przekształcenia przestrzenne ${ }^{122}$. Nakłady na realizację tego programu ponoszone były głównie przez władze centralne, ale także przez najemców, zarządców nieruchomości i władze miejskie (Knorr-Siedow 2004, Tosics 2004). Ich prowadzenie na taką skalę możliwe było w Niemczech z trzech powodów. Po pierwsze dzięki finansowaniu ich z rządu federalnego, po drugie dzięki specyficznej na tle innych miast postsocjalistycznych i zbliżonej do krajów zachodnioeuropejskich strukturze własności zasobów mieszkaniowych w wielkich osiedlach, których po zmianie ustroju nie prywatyzowano (w połowie lat 90 . własność prywatna nie przekraczała 5\% tych zasobów mieszkaniowych - K. Wiest 2011), po trzecie dzięki znaczącemu odpływowi mieszkańców z landów wschodnich do zachodniej części kraju, w wyniku którego około 30\% zasobów mieszkaniowych w miastach wschodnich Niemiec opustoszało (Stanilov 2007, s. 184, za: Hanneman 2004). W żadnym z krajów postsocjalistycznych, poza b. NRD, takie warunki nie

ralny wyłożył kolejne 17 mld na dopłaty do preferencyjnych kredytów przeznaczonych na ten cel (Czado 2012).

${ }^{121} \mathrm{Za}$ nie mniej ważne uznano rewitalizację zasobów mieszkaniowych z przełomu XIX i XX w., która również pochłonęła znaczące nakłady finansowe (Rembarz 2010).

122 Działania te obejmowały: podwyższanie standardu technicznego, funkcjonalności i walorów użytkowych poszczególnych budynków i mieszkań, urozmaicanie architektury budynków, przekształcenia przestrzeni publicznych oraz wyburzenia i zmniejszania kubatury największych budynków (Łodziński 2009, Rembarz 2010). Ich realizacja doprowadziła w ciągu 10 kolejnych lat do renowacji blisko $90 \%$ budynków i mieszkań (ponad $60 \%$ poddano renowacji kompletnej, a ponad 25\% - częściowej). Koszt renowacji jednego mieszkania wynosił średnio 20 tys. euro, co było tylko częścią kosztów całej operacji wyburzeń i przekształceń przestrzennych dokonanych w tych osiedlach (Knorr-Siedow 2004). 
zaistniały, toteż programy odnowy wielkich osiedli, jeśli w ogóle były w nich realizowane, to na znacznie bardziej ograniczoną skalę.

Wymienione procesy zachodzące $\mathrm{w}$ strukturze rezydencjalnej miast postsocjalistycznych zarówno planowe, jak i żywiołowe, działające na różnych poziomach oraz w różnych skalach: począwszy od globalnej, poprzez europejską, krajową i regionalną, na lokalnej kończąc, niejednokrotnie trudno oddzielić ze względu na współwystępowanie i wzajemne oddziaływanie. Ich efektem są przekształcenia struktury wielkich osiedli we wszystkich jej płaszczyznach: społecznej, funkcjonalno-przestrzennej, morfologicznej oraz fizjonomicznej, które omówione zostały w kolejnej części pracy.

\subsection{Przemiany wielkich osiedli mieszkaniowych w miastach postsocjalistycznych - wybrane przykłady}

Prace geograficzne dotyczące przemian zachodzących w wielkich osiedlach mieszkaniowych po 1990 roku obejmują dwie zasadnicze grupy opracowań. Pierwsza to prace teoretyczno-empiryczne zmierzające do ujęć modelowych, w których analizuje się wielkie osiedla jako jedną ze szczególnych form przestrzeni rezydencjalnej lub jedną ze stref miasta postsocjalistycznego (Enyedi 1998, Czepczyński 1999, Gaczek, Rykiel 1999, Coudroy de Lille 2001, Rykiel 1999, 2000, Zborowski 2000, 2005, Liszewski 2001b, Hamilton i in., red. 2005, Sagan 2000a, b, Węcławowicz 1999, 2000, 2013, Matlovič i in. 2001, Matlovič, Sedlakova 2007, Marcińczak 2009, Stenning i in. 2010). Druga natomiast to ujęcia empiryczne, które skupiają się na szczegółowej analizie przekształceń zachodzących $\mathrm{w}$ poszczególnych osiedlach. Zasięg przestrzenny tych opracowań ograniczony jest dostępnością danych i/lub możliwością przeprowadzenia badań terenowych, toteż nie mają one charakteru całościowego, lecz obejmują wybrane jednostki (dwie lub więcej), najczęściej zlokalizowane w jednym mieście (Borowik 2003, Węcławowicz i in. 2003, 2005, Wojtkun 2004, Kozłowski 2005, 2006, 2010, Szafrańska 2010, 2014, Kährik, Tammaru 2010, Rzyski, Mędrzycka 2010, Warchalska-Troll 2012, Komar 2013). Istnieje też grupa prac pokazujących przemiany osiedli w kilku miastach jednego kraju (Kallabova 2000, Dimitrovska Andrews, Černič Mali 2004, Knorr-Siedow 2004, Kovács, Douglas 2004, Černič Mali i in. 2005, Egedy 2000, Temelová i in. 2011,) lub nawet w kilku krajach (Chmielewski, Mirecka 2001, Turkington i in., red. 2004, van Kempen i in. 2005, Rowlands i in., red. 2010, Dekker i in. 2011, Jażdżewska, red. 2010, Wiest 2011, Kovács, Herfert 2012). Wiele opracowań realizowanych jest także w formie studiów przypadków, w których analizowane są procesy zachodzące w pojedyn- 
czych osiedlach (np. Masica, Milewska 2003, Szafrańska 2009, Ciesiółka 2010, Rodzoś, Flaga 2010, Gorczyca 2010, Radwańska 2010, Kabisch, Grossmann 2013). Walorem prac empirycznych jest dostarczanie danych, które $\mathrm{z}$ jednej strony pozwalają weryfikować różnego rodzaju sądy dotyczące wielkich osiedli, w tym także o charakterze stereotypu (np. stereotyp o ich szybkiej degradacji społecznej), z drugiej zaś dokonywać pewnych (z konieczności, niestety, ograniczonych) porównań oraz identyfikować czynniki, które różnicują te przemiany w poszczególnych krajach, miastach, a także $\mathrm{w}$ różnych osiedlach tego samego miasta.

Przemiany wielkich socjalistycznych osiedli mieszkaniowych w niniejszym rozdziale omówione zostały w oparciu o istniejącą literaturę. Analizie poddane zostały przekształcenia ich struktury społecznej $\mathrm{w}$ wymiarze zarówno hierarchicznym (struktura społeczno-zawodowa mieszkańców, ich status ekonomiczny, wykształcenie), jak i niehierarchicznym (płeć, wiek, struktura etniczna), przemiany ich struktury morfologicznej (obejmujących kształt i rozplanowanie zabudowy), struktury funkcjonalnej (funkcjonalno-przestrzennej), a także fizjonomii, obejmujące fizjonomię zabudowy oraz innych elementów krajobrazu osiedli (tereny zielone, rekreacyjne). Osobna grupa zagadnień omówionych $\mathrm{w}$ niniejszym rozdziale dotyczyła przemian przestrzeni publicznych wielkich osiedli, które integrują zmiany dokonujące się na wszystkich wymienionych płaszczyznach (głównie morfologicznej i funkcjonalnej).

\subsubsection{Przemiany w strukturze demograficznej i statusie społecznym mieszkańców}

Jednym z najważniejszych procesów zachodzących w strukturze społecznej $\mathrm{w}$ wielkich osiedlach mieszkaniowych $\mathrm{w}$ miastach postsocjalistycznych jest starzenie się ich mieszkańców (Zborowski 2000). Proces ten zachodzi we wszystkich wielkich osiedlach powstałych w okresie socjalizmu. Jego cechą charakterystyczną jest synchronizacja z okresem budowy poszczególnych osiedli, co wynika ze specyficznego sposobu ich zasiedlania - ludnością jednorodną pod względem statusu rodzinnego (głównie rodziny z dziećmi) oraz wieku (najczęściej pokolenie ówczesnych 30-latków). Czynnikiem, który przez lata pogłębiał starzenie się osiedli była mała wymiana migracyjna związana ze stabilizacją mieszkaniową ich pierwotnych mieszkańców oraz stopniowe wchodzenie tworzonych przez nie gospodarstw domowych w fazę cyklu życia rodziny określaną jako "faza opuszczonego gniazda", związaną z odpływem dorosłych dzieci (Matlovič i in. 2001, Zborowski 2005, Kovács, Herfert 2012, Temelová i in. 2011). Proces ten występował już 
w okresie socjalizmu ${ }^{123}$, wówczas jednak był silnie ograniczony głębokim deficytem na rynku mieszkaniowym, toteż w latach 90. objawił się z dużym natężeniem wynikającym z jego opóźnienia. Fala odpływu objęła bowiem nie tylko osoby młode, ale także te, które odraczały wyprowadzkę i zamieszkiwały wspólnie ze starzejącymi się rodzicami tworząc gospodarstwa trzypokoleniowe i użytkując wspólnie małe, nieprzystosowane do tego mieszkania. Wpływ na demograficzne starzenie się wielkich osiedli mają także procesy niespecyficzne dla tej formy zabudowy, obserwowane w niemal wszystkich dużych miastach europejskich, związane $z$ drugim przejściem demograficznym (Zborowski 2000, Węcławowicz i in. 2003).

Bliższa analiza zmian $\mathrm{w}$ strukturze wieku mieszkańców wybranych osiedli w miastach różnych krajów (Budapeszcie, Lipsku, Pradze, Łodzi, Warszawie) pokazuje, że proces ich demograficznego starzenia się, jakkolwiek w latach 90. XX wieku oraz na początku XXI wieku przebiegał w szybkim tempie, to począwszy od połowy pierwszej dekady XXI wieku zaobserwować można jego spowolnienie (por. Geróházi, Szemzó 2005, Musterd, van Kempen 2005, Bernt 2007, Temelová i in. 2011, Szafrańska 2013, Węcławowicz i in. 2003). Co więcej, w osiedlach najstarszych, z przełomu lat 50. i 60. minionego stulecia następuje obecnie intensywna wymiana pokoleniowa. Proces ten jest skutkiem z jednej strony ubytku naturalnego wśród osób, które jako pierwsze zasiedlały mieszkania, a obecnie należą do kohorty wiekowej 70- oraz 80-latków, z drugiej zaś dziedziczenia mieszkań i zajmowania ich przez pokolenie wnuków pierwotnych mieszkańców - obecnie należących do pokolenia 20- i 30-latków. Ważnym czynnikiem, który generuje napływ do osiedli osób w tych grupach wiekowych jest także relatywnie duży obrót sprywatyzowanymi lokalami na wtórnym rynku mieszkaniowym. Mieszkanie w prefabrykowanym osiedlu w wielu miastach postsocjalistycznych jest bowiem często pierwszym etapem biografii mieszkaniowej młodych osób wchodzących na rynek pracy, zwłaszcza w miastach o dobrej kondycji gospodarczej, czyli przede wszystkim w miastach największych oraz stołecznych (por. Węcławowicz 2003 i in., Kovásc, Douglas 2004, Musterd, van Kempen, 2007, Temelová i in. 2011, Kovács, Herfert 2012). Atrakcyjność tych mieszkań dla ludzi młodych wynika z korzystnej relacji ich ceny do jakości. Osiedla te oferują bowiem relatywnie dobre warunki mieszkaniowe $\mathrm{i}$ wyposażenie $\mathrm{w}$ infrastrukturę techniczną oraz społeczno-usługową, często także są korzystnie położone w przestrzeni miasta i mają dobrą dostępność komunikacyjną.

123 Jak podają Z. Kovács i M. Douglas (2004) we wszystkich budapesztańskich osiedlach mieszkaniowych (obejmujących w 1990 r. 33,2 tys. mieszkań), udział osób w wieku 60 lat i więcej w 20-leciu 1970-1990 wzrósł niemal trzykrotnie (z 11 do 31,2\%). 
Demograficzne „odmładzanie” osiedli jest również wynikiem napływu studentów, którzy na czas studiów wynajmują, a niekiedy nawet nabywają mieszkania. Proces ten, określany jako "studentyfikacja” lub „beanizacja” (Zborowski 2005, s. 416), obejmuje głównie miasta akademickie, a w nich przede wszystkim osiedla o dogodnej lokalizacji w stosunku do uczelni. Beanizacja wielkich osiedli $w$ miastach polskich odnotowana została dotychczas m.in. w Krakowie (Zborowski 2005, Jerschina i in. 2012), Warszawie (Węcławowicz i in. 2003), Lublinie (Rodzoś, Flaga 2010), Poznaniu (Kotus 2007, Ciesiółka 2010), Łodzi (Jakóbczyk-Gryszkiewicz i in. 2014)124. I mimo że proces ten nie zmienia struktury mieszkańców w sposób trwały, ponieważ obejmuje pobyty czasowe, często nierejestrowane i niedające się uchwycić w żadnych statystykach, to jednak w widoczny sposób zmienia krajobraz społeczny osiedli. Nie zawsze zmiana ta jest korzystna, ponieważ, jak podaje A. Zborowski (2005), proces beanizacji jest niekorzystny dla rozwoju miasta zarówno w krótkiej, jak i długiej perspektywie, a według badacza sąsiedztw J. Kotusa (2007, s. 110), studenckie użytkowanie mieszkań, ze względu na swój „niesąsiedzki” charakter, przyczynia się do znacznego ograniczenia, a nawet zaniku kontaktów sąsiedzkich.

Napływ studentów oraz omówiony już napływ osób tworzących młode gospodarstwa domowe (w wyniku dziedziczenia lub nabywania mieszkań) powoduje, że struktura wiekowa niektórych osiedli ulega polaryzacji, ponieważ rosnącemu udziałowi osób starszych oraz osób młodych do 35. roku życia towarzyszy zmniejszanie się udziału osób w średnich grupach wiekowych (40- i 50-latków) (Kabisch, Grossmann 2013). Zjawisko to obserwuje się także w Polsce, ponieważ, jak podają J. Rodzoś i M. Flaga (2010), na podstawie analizy struktury wieku mieszkańców największego osiedla w Lublinie z lat 60. minionego stulecia, można zaryzykować twierdzenie, że jego obecna struktura społeczna ma charakter "emerycko-studencki”.

Wymienione procesy związane ze sprzedażą czy wynajmem mieszkań blokowych powodujące napływ młodszych grup mieszkańców są obserwowane szczególnie w krajach, w których mieszkania te po 1990 roku zostały w znaczącej części sprywatyzowane, czyli Polska, Węgry, Czechy, Słowacja, Bułgaria. W krajach tych mieszkanie wciąż jest dobrem cennym i wręcz deficytowym, przy czym nie na skutek fizycznego ich braku, jak w poprzednim ustroju, ale głównie na skutek bariery w ich dostępności ekonomicznej (Temelová i in. 2011, Kovács, Herfert 2012). Zupełnie inaczej natomiast

124 Szczegółowe badania dotyczące lokalizacji miejsc zamieszkania studentów zamiejscowych studiujących na uczelniach łódzkich i niekorzystających z akademika pokazały, że ponad $80 \%$ z nich wynajmuje mieszkania w zabudowie blokowej, najczęściej zlokalizowanej w wielkich osiedlach. Główną przyczyną tak dużej popularności tej formy zabudowy wśród studentów, jak wynika z ich deklaracji, jest dostępność cenowa oraz dobra relacja jakości do ceny (Jakóbczyk-Gryszkiewicz i in. 2014, s. 100). 
wygląda sytuacja demograficzna wielkich osiedli w b. NRD, gdzie po 1990 roku odnotowano masowe migracje ludności do landów zachodnich i gwaltowną depopulację miast. Przykład jednego z największych osiedli mieszkaniowych $b$. NRD - osiedla Grünau w Lipsku (przykład 1) pokazuje bezprecedensowe, nienotowane $\mathrm{w}$ żadnym $\mathrm{z}$ pozostałych krajów postsocjalistycznych zmniejszenie się w ciągu ostatnich 20 lat liczby mieszkańców osiedla o niemal połowę (z 85 tys. w 1989 r. do mniej niż 44 tys. w 2009 r.) oraz wciąż postępujące i szybkie tempo ich starzenia się (Kabisch, Grossmann 2013).

\section{Przykład 1: osiedle Grünau, Lipsk (Niemcy)a}

Osiedle Grünau wzniesione w latach 1976-1987, zlokalizowane jest w zachodniej części Lipska, w odległości $6 \mathrm{~km}$ od centrum miasta i w bliskim sąsiedztwie popularnych terenów rekreacyjnych. Osiedle zajmuje 870 ha i składa się z ośmiu kompleksów mieszkalnych oddawanych do użytku średnio co dwa lata. Liczba mieszkań w 1990 roku wynosiła tam ponad 30 tys. Od 2003 roku osiedle objęte zostało federalnym programem modernizacji oraz wzmocnienia partycypacji mieszkańców. W okresie od 2002 do 2005 roku w wyburzono w nim ponad 3800 mieszkań, a do 2009 roku w sumie blisko 6 tys. Większość pozostałych $\mathrm{w}$ osiedlu budynków została zmodernizowana. Niemal wszystkie mieszkania (96\%) są własnością podmiotów publicznych, które zajmują się ich wynajmem i administracją. Zaledwie $4 \%$ mieszkań zostało sprywatyzowanych.

Od początku lat 90. XX wieku osiedle ulegało gwałtownemu wyludnianiu się oraz starzeniu mieszkańców, przy czym masowy ich odpływ (rzędu 2,5 tys. mieszkańców rocznie), odnotowany głównie w latach 1995-2004, znacząco osłabił tempo po 2004 roku (rys. 16).

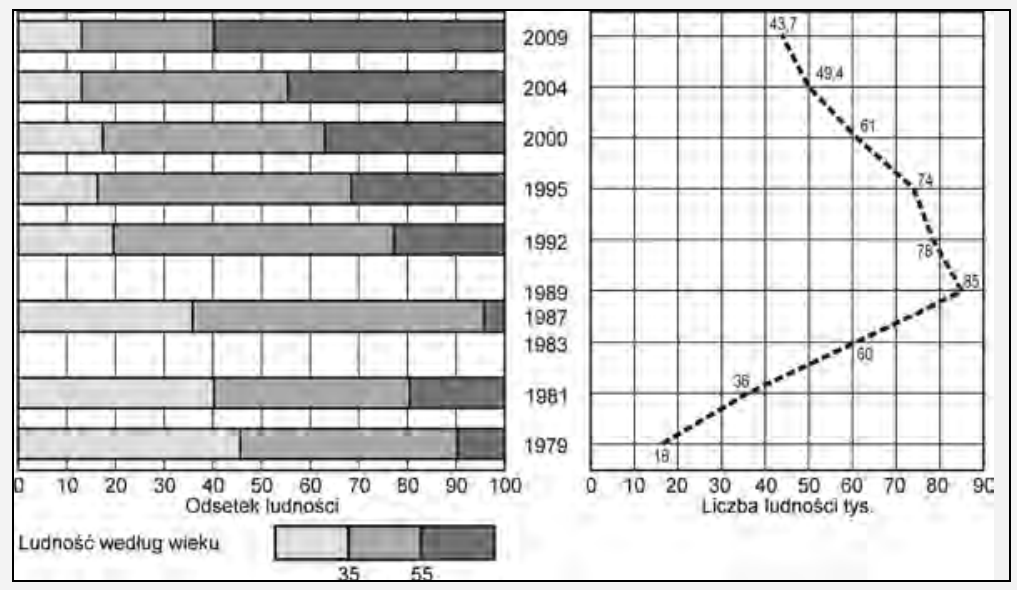

Rys. 16. Zmiany w liczbie ludności i strukturze wieku osiedla Grünau w Lipsku w latach 1979-2009 


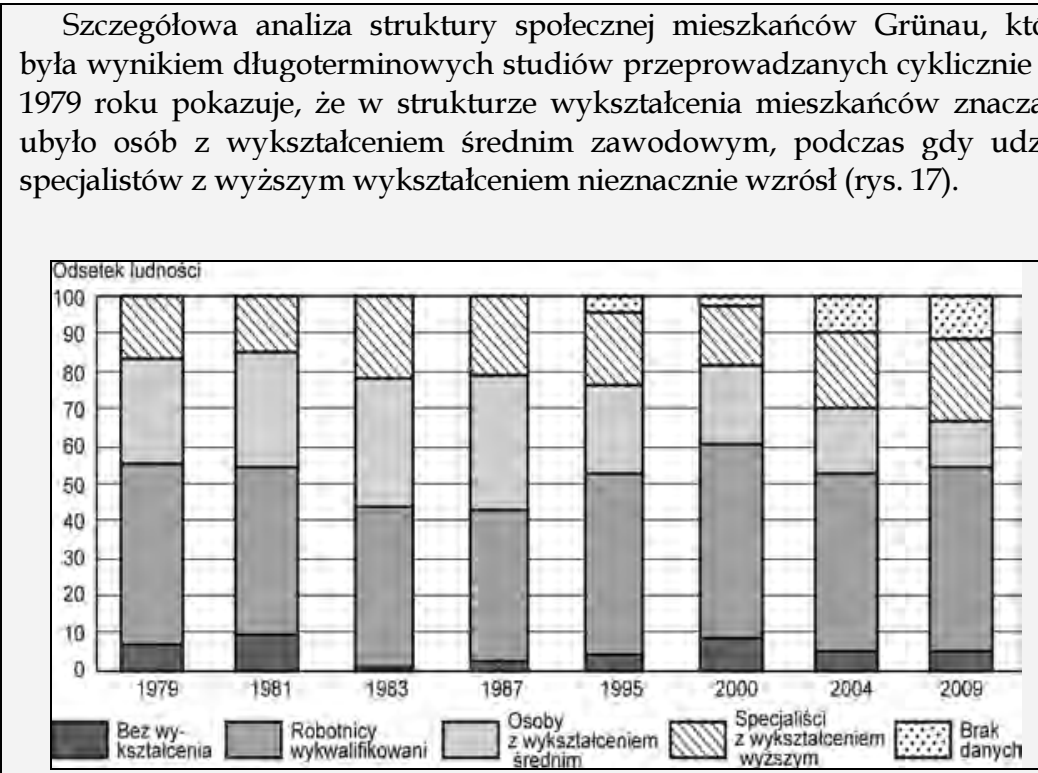

Rys. 17. Struktura wykształcenia mieszkańców osiedla Grünau w Lipsku w latach 1979-2009

Struktura gospodarstw domowych pokazuje znaczący wzrost udziału gospodarstw jedno- i dwuosobowych, które w 2009 roku stanowiły ponad 3/4 ogółu (rys. 18).

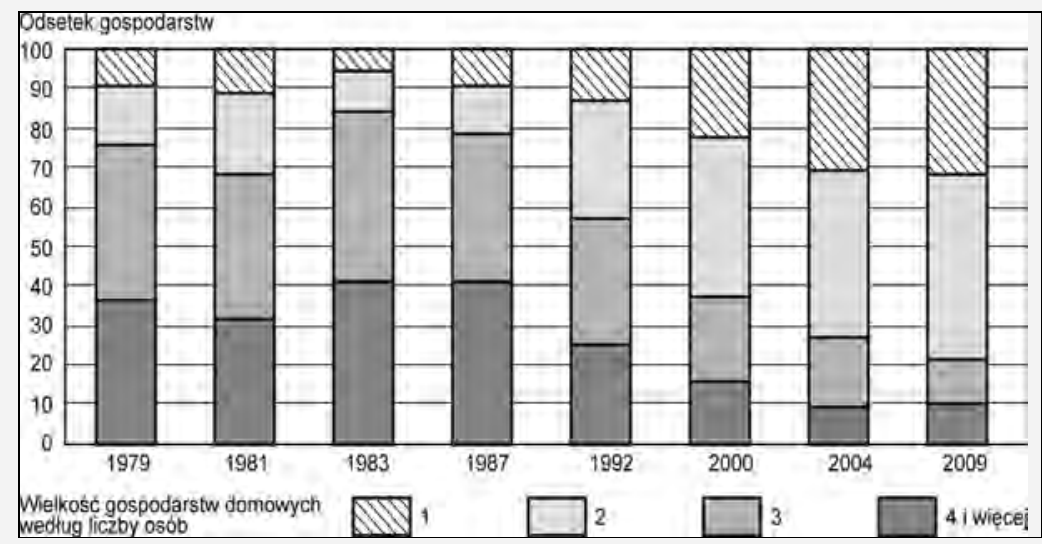

Rys. 18. Struktura gospodarstw domowych osiedla Grünau w Lipsku w latach 1979-2009

a Opracowano na podstawie literatury (Wiest 2011, Kovács, Herfert 2012, Kabisch, Grossmann 2013). 
Masowy odpływ z osiedla nie jest jednak przejawem jego degradacji, dotyczy bowiem w takim samym stopniu całego Lipska, które od lat 90. wyludnia się i starzeje demograficznie i w którym w latach 90 XX wieku ponad $30 \%$ mieszkań, nawet o dobrym standardzie, opustoszało (Kabisch, Grossmann 2013). Następująca w tym osiedlu polaryzacja wiekowa (poprzez wyhamowanie odpływu, a nawet napływ ludzi młodych) częściowo jest zasługą polityki mieszkaniowej prowadzonej wobec wielkich osiedli $w \mathrm{~b}$. NRD, zmierzającej nie tylko do ich fizycznej odnowy, ale także do wykreowania ich image'u jako środowiska mieszkaniowego idealnego dla osób młodych zakładających swoje pierwsze gospodarstwa domowe oraz dla osób starszych (Remarz 2010, Kabisch, Grossmann 2013).

Kolejnym procesem zidentyfikowanym $\mathrm{w}$ strukturze społecznej wielkich osiedli mieszkaniowych jest zmiana w składzie mieszkańców pod względem ich statusu spolecznego ${ }^{125}$. Status ten $\mathrm{w}$ okresie socjalizmu był przemieszany, ale relatywnie wysoki, a wielu z nich (np. Ursynów w Warszawie, Prądnik Czerwony w Krakowie, Radogoszcz-Wschód w Łodzi) nawet dużo wyższy niż $\mathrm{w}$ innych obszarach miasta. $\mathrm{W}$ mieście postsocjalistycznym natomiast, w warunkach wzrostu aspiracji mieszkaniowych i sily nabywczej wielu gospodarstw domowych oraz pojawienia się nowych obszarów o dużej atrakcyjności rezydencjalnej (nowe apartamentowce, osiedla grodzone, rozległe suburbia, zrewitalizowane centra miast), a w konsekwencji wzrostu mobilności przestrzennej, miał według wielu autorów ulec gwałtownemu obniżeniu (por. Jałowiecki 1995, Szelényi 1996, Enyedi 1998, Rykiel 1999, Sagan 2000b) (tab. 11).

Na skutek tych procesów według Z. Kovácsa i G. Herferta (2012) po 1990 roku zmianie ulec miała pozycja wielkich osiedli mieszkaniowych w strukturze społeczno-przestrzennej miasta postsocjalistycznego, która w poprzednim ustroju plasowała je wysoko, wyżej niż obszary sąsiadujące $\mathrm{z}$ centrum. Kierunek przewidywanych zmian w statusie społecznym mieszkańców tej strefy po 1990 roku obrazuje rys. 19. Jest to jednak, jak pokazują cytowane badania, kwestia dyskusyjna i wciąż otwarta.

I mimo że status ten obniżył się $\mathrm{w}$ relacji do okresu socjalizmu można stwierdzić, że powszechne niemal przekonanie obecne w dyskursie zarówno

${ }^{125} \mathrm{~W}$ warunkach europejskich wobec braku lub ograniczonego dostępu do danych statystycznych status społeczny mieszkańców osiedli najczęściej mierzony jest za pomocą wykształcenia, rzadziej pozycji społeczno-zawodowej a wyjątkowo sytuacji ekonomicznej. Te ostatnie dane, jeśli już są brane pod uwagę, pochodzą z badań częściowych o charakterze ankietowym, gdzie badani sami deklarują swój status ekonomiczny. W Polsce niestety ostatni spis powszechny z 2011 r. nie dostarczył danych nawet o wykształceniu mieszkańców osiedli, ponieważ najmniejszymi jednostkami agregacji danych spisowych były miejscowości. 
Tab. 11. Przewidywania dotyczące obniżania się statusu społecznego mieszkańców wielkich osiedli w mieście postsocjalistycznym

\begin{tabular}{|l|l|}
\hline \multicolumn{1}{|c|}{$\begin{array}{c}\text { Autor, rok } \\
\text { wydania }\end{array}$} & \multicolumn{1}{c|}{ Przewidywany przebieg procesu } \\
\hline $\begin{array}{l}\text { B. Jałowiecki } \\
\text { (1995, s. 43) }\end{array}$ & $\begin{array}{l}\text { "w najbliższym czasie nastąpi [...] szybki proces degradacji istniejących } \\
\text { wielkich zespołów mieszkaniowych. Spora częśc mieszkańców [...] nie bę- } \\
\text { dzie w stanie ponosić ciężarów finansowych utrzymania mieszkań. Z kolei } \\
\text { dysponent lub właściciel nie będzie miał środków na konserwację i remonty } \\
\text { tandetnie wykończonych budynków. Stopniowo przestaną funkcjonować } \\
\text { windy, mnożyć się będą awarie instalacji, których nikt nie będzie naprawiał, } \\
\text { przeciekać będą dachy i rynny. Stopniowo wielkie bloki w zespołach miesz- } \\
\text { kaniowych będą zamieniać się w slumsy. Z budynków tych zaczną uciekác } \\
\text { bardziej zamożni mieszkańcy, co pogłębi jeszcze społeczną degradację tych } \\
\text { zespołów." }\end{array}$ \\
\hline $\begin{array}{l}\text { I. Szelényi } \\
\text { (1996, s. 315) }\end{array}$ & $\begin{array}{l}\text { "this low quality housing, located in undesirable neighbourhoods, [...] Those who work } \\
\text { can afford are beginning to escape from them, leaving the poor and ethnic minorities } \\
\text { to concentrate in them (a process of residualization familiar in the similar estates on } \\
\text { the periphery of many Western European cities). As a result, the whole belt of 'new } \\
\text { housing estates' is likely to become the slums of the early twenty-first century." }\end{array}$ \\
\hline $\begin{array}{l}\text { G. Enyedi } \\
\text { (1998, s. 33) }\end{array}$ & $\begin{array}{l}\text { "the rapid decline of housing estates into slums represents the 'time bomb' of urban } \\
\text { development, a possible source of a grave urban crisis". }\end{array}$ \\
\hline
\end{tabular}

Źródło: opracowanie własne.

naukowym, jak i medialnym ${ }^{126} \mathrm{w}$ szczególności w latach 90 . oraz na początku XXI wieku, że wielkie osiedla po 1990 roku, na wzór osiedli w krajach zachodnioeuropejskich, zamienią się $\mathrm{w}$ krótkim czasie $\mathrm{w}$ obszary problemowe i staną się postsocjalistycznymi slamsami, nie znalazło potwierdzenia $\mathrm{w}$ badaniach empirycznych. Co więcej, doświadczenia ponad dwóch dekad transformacji pokazały, że zapowiadana $\mathrm{w}$ początkowym okresie transformacji masowa ucieczka mieszkańców reprezentujących wyższe kategorie statusowe ze strefy wielkich osiedli do stref bardziej atrakcyjnych mieszkaniowo i obszarów stanowiących "dobry adres", która skutkować miała ich degradacją społeczną, nastąpiła $\mathrm{w}$ dużo mniejszym stopniu niż przewidywano (por. Zborowski 2005, Marcińczak 2009, Temelová i in. 2011, Kovács, Herfert 2012, Kabisch, Grossmann 2013, Szafrańska 2014). A skala tego procesu jest zindywidualizowana i w znacznym stopniu uzależniona od czyn-

${ }^{126}$ Na przykład film fabularny w reżyserii R. Glińskiego pt. Cześć Tereska, zrealizowany w osiedlu Ostrobramska na warszawskiej Pradze w 2001 r., który interpretowany był jako oskarżenie ponurego blokowiska $\mathrm{w}$ wielkim mieście o rozwój patologii wśród młodzieży. Także medialna popularność terminu „blokersi”, wymyślonego pod koniec lat 90. XX wieku, określającego sfrustrowanych, często nieuczących się i niepracujących młodych ludzi, zamieszkujących wielkomiejskie osiedla z wielkiej płyty, uważających się (i uważanych) za pozbawionych perspektyw, dla których stojąca przed blokiem lawka jest centrum życia towarzyskiego, często nadużywających alkoholu i narkotyków (por. Frustraci z wielkiej ptyty, "Wprost”, 37/2000, Skocz do góry, „Polityka”, 10/2001). 
ników o charakterze lokalnym, wśród których akcentuje się różnice pomiędzy poszczególnymi krajami, regionami kraju i miastami, a nawet czynniki działające w skali pojedynczego osiedla (takie jak czas jego budowy, wielkość, lokalizacja, wyposażenie, warunki mieszkaniowe, struktura własnościowa, dotychczasowa reputacja i skład społeczny mieszkańców itp.) (por. Egedy 2000, Ruoppila, Kährik 2003, Dekker i in. 2005, Musterd, van Kempen 2005, 2007, Tosics i in. 2005, Zborowski 2005, Węcławowicz 2003, 2007, Sýkora 2009, Temelová i in. 2011).

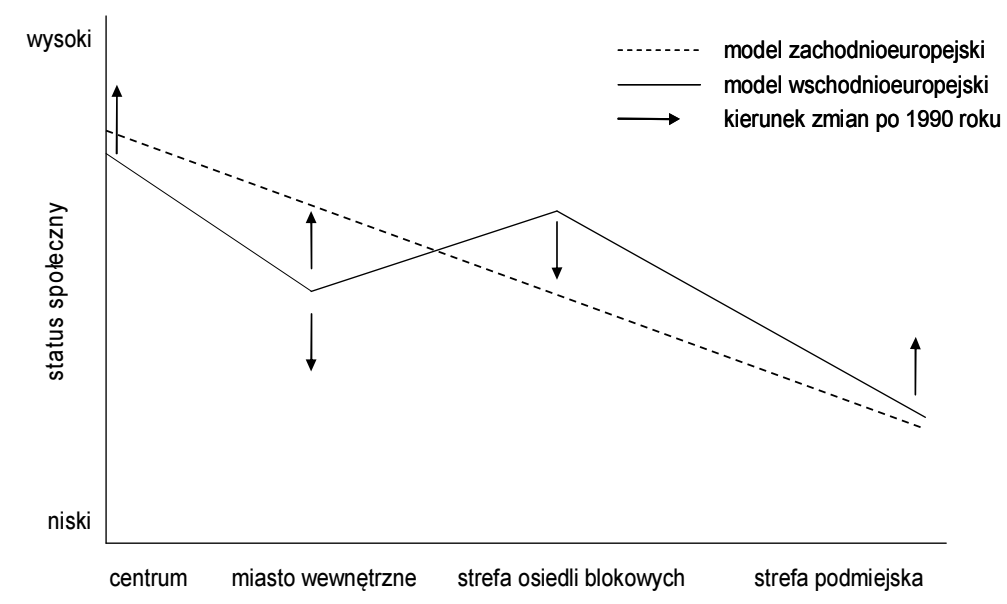

Rys. 19. Kierunek przewidywanych zmian w statusie społecznym mieszkańców poszczególnych stref miasta po 1990 roku Źródło: opracowanie własne na podstawie

Z. Kovács, G. Herfert (2012, s. 326), L. Sýkora (2009, s. 390)

Większość autorów zajmujących się przemianami struktury społecznej strefy wielkich osiedli mieszkaniowych w mieście postsocjalistycznym przedstawia je jako „normalne” obszary miejskie o zdrowej strukturze społecznej, niepodlegające żadnym szczególnym procesom wyróżniającym je na tle innych obszarów (por. Kovács, Herfert 2012). Co więcej, jak podają ci autorzy (ibid.), wielu badaczy stwierdza, że status społeczny osiedli nie obniżył się znacząco, ponieważ wciąż są one atrakcyjne dla przedstawicieli klasy średniej oraz klasy niższej średniej. Atrakcyjność mieszkaniową wielkich osiedli dla przedstawicieli tych klas zauważa m.in. T. Knorr-Siedov (2004) w miastach b. NRD, zwłaszcza w Berlinie i w innych dużych miastach o dobrej kondycji ekonomicznej. Obecni mieszkańcy tych osiedli, jak podaje przywołany autor, to głównie zasiedziali starzejący się pierwsi lokatorzy oraz młodzi miejscy profesjonaliści (przedstawiciele grupy Yuppies), którzy w przestrzeni miasta poszukują dobrze zlokalizowanych i dobrze utrzymanych 
środowisk mieszkaniowych, zapewniających im anonimowość (ibid., s. 179). A na podstawie cytowanych już badań przeprowadzonych w osiedlu Grünau w Lipsku (Kabisch, Grossmann 2013) stwierdzono, że przeciętny status społeczny jego mieszkańców wciąż jest wyższy niż średnia dla miasta. Mimo bowiem dużego odpływu $\mathrm{z}$ tego osiedla, który dokonał się na przełomie $\mathrm{XX}$ i XXI wieku (por. przykład 1), relatywnie duży udział osób z wyższym wykształceniem w tym osiedlu nie tylko utrzymał się, ale nawet wzrósł.

Podobne rezultaty odnotowali A. Kährik i T. Tammaru (2010), którzy na podstawie badań osiedli w Tallinie stwierdzili, że po 1990 roku osiedla te zachowały relatywnie dobry image i zróżnicowany skład społeczny mieszkańców oraz brak wyraźnych oznak obniżania się ich statusu społecznego. Również w osiedlach blokowych Pragi czeskiej status społeczny mieszkańców nie obniżył się, a barierą były tu relatywnie wysokie ceny mieszkań w tych osiedlach, uwarunkowane dobrą kondycją ekonomiczną miasta i równocześnie dużą presją na rynku mieszkaniowym (Temelová i in. 2011). Ze szczegółowej analizy procesów migracyjnych zachodzących w latach 1995-2003 w osiedlach blokowych stolicy Czech ${ }^{127}$ wynika, że wśród mieszkańców, którzy tam napływają są głównie osoby młode i dobrze wykształcone, co oznacza, że zróżnicowany, ale wciąż relatywnie dobry status społeczny wielkich osiedli, w najbliższych latach utrzyma się (ibid.). Wśród cech, które różnicują atrakcyjność mieszkaniową poszczególnych osiedli w Pradze i wpływają na zachodzące w nich procesy migracyjne J. Temelová i in. (2011) wymieniają: okres budowy osiedli, dotychczasowy wiek i skład społeczny mieszkańców, obecność w nich nowej zabudowy, dostępność komunikacyjną osiedli, strukturę własnościową zasobów oraz warunki zamieszkania.

Podobnie jest na Węgrzech, gdzie szybka i niemal pełna prywatyzacja mieszkań (sięgająca ponad 90\% zasobów w osiedlach prefabrykowanych) we wczesnych latach 90. doprowadziła do znacznego zróżnicowania poszczególnych osiedli pod względem ich atrakcyjności mieszkaniowej i prestiżu. W Budapeszcie na skutek wysokich kosztów utrzymania sprywatyzowanych mieszkań $\mathrm{z}$ większości osiedli wyemigrowały najmniej zamożne gospodarstwa domowe, które przeniosły się do lokali o niższym standardzie, zazwyczaj położonych na obrzeżach miasta (Geróhazi, Szemző 2005, Csaba 2006). Dobrym przykładem obrazującym sposób, w jaki prywatyzacja pozytywnie wpłynęła na skład społeczny mieszkańców jest jedno z większych budapesztańskich osiedli blokowych Havanna, gdzie w latach 1994-

127 W Pradze, jak podaje J. Temelová, i in. (2011) jest ponad 50 osiedli blokowych w sumie liczących ponad 200 tys. mieszkań zamieszkiwanych przez ok. pół mln mieszkańców (tj. 42\% ludności Pragi). Analiza liczby i struktury migrantów oparta została na próbie reprezentatywnej dla prawie połowy mieszkańców tych osiedli, czyli ok. 24\% mieszkańców całego miasta. 
2004 w wyniku prywatyzacji oraz odpływu mniej zamożnych gospodarstw domowych odnotowano poprawę składu społecznego mieszkańców (Geróhazi, Szemző 2005) (przykład 2).

\section{Przykład 2: osiedle Havanna, Budapeszt (Węgry) ${ }^{\mathrm{b}}$}

Osiedle Havanna w Budapeszcie, nazwane tak na cześć zwycięstwa kubańskiej rewolucji socjalistycznej, powstało w latach 1977-1985. Obecnie (w 2011 r.) w osiedlu znajduje się 6,6 tys. mieszkań, które zamieszkuje ponad 17 tys. mieszkańców. W wyniku szybkiej prywatyzacji zasobów mieszkaniowych we wczesnych latach 90 . blisko $90 \%$ mieszkań w osiedlu zostało sprywatyzowanych. Możliwość ich wykupu na własność za ok. 10-15\% wartości rynkowej oraz sprzedaży bez żadnych ograniczeń na wolnym rynku spowodowała dużą wymianę migracyjną na tym obszarze. Wymiana ta nastąpiła głównie na skutek dużego odpływu mieszkańców o niższym statusie społeczno-ekonomicznym oraz napływu na ich miejsce osób młodych (głównie rodzin z dziećmi) reprezentujących klasę niższą średnią. Pozbywanie się mieszkań, które często następowało niemal natychmiast po ich wykupie, dotyczyło głównie osób najuboższych i wynikało z jednej strony z chęci zarobku na różnicy cen, z drugiej zaś z faktu, że mieszkańców tych nie było stać na ich utrzymanie po prywatyzacji, głównie ze względu na bardzo wysokie koszty ogrzewania.

Problemem osiedla Havanna jest jego nie najlepsza reputacja, sięgająca okresu sprzed 1990 roku, kiedy lokowano w nim osoby o niskim statusie społecznym przesiedlane $\mathrm{z}$ budynków substandardowych podlegających rozbiórkom. Duża podaż mieszkań w osiedlu oraz jego reputacja sprawia, że ich ceny są relatywnie niskie $\mathrm{w}$ porównaniu $\mathrm{z}$ innymi dzielnicami Budapesztu, choć koszty utrzymania dość wysokie. Korzystna relacja cen do warunków życia (dobre wyposażenie w szkoły, instytucje opieki medycznej i inne usługi społeczne na wysokim poziomie, dobra dostępność komunikacyjna) skutkuje napływem do osiedla kategorii wiekowych i statusowych, które poprawiają jego strukturę społeczną.

b Opracowano na podstawie literatury (Kovács, Douglas 2004, Musterd, van Kempen 2004, Gerőhőzi, Szemző 2005, Csaba 2006, Kovács, Herfert 2012).

Z badań osiedli blokowych prowadzonych w Słowacji (Divinský 2004) również wynika, że wciąż są one obszarami heterogenicznymi społecznie i nie można jednoznacznie stwierdzić, że ta forma zabudowy związana jest ze szczególnym natężeniem problemów społecznych. Jak podaje ten autor, przedstawiciele wąskiej grupy najwyższych kategorii społecznych już w okresie socjalizmu częściej niż w osiedlach blokowych mieszkali w domach jednorodzinnych, toteż po 1990 roku nie notowano tam masowego odpływu tej kategorii społecznej. Po 2000 roku odpływ był również relatywnie niewielki, a ograniczały go z jednej strony mała skłonność Słowaków 
do ruchliwości przestrzennej, z drugiej zaś niezwykle częste, zwłaszcza w Bratysławie i innych dużych miastach, posiadanie przez nich drugich domów na obszarach wiejskich (ibid.). Zjawisko to, zaspokajając potrzebę „bycia u siebie" i zamieszkiwania w domu jednorodzinnym, w Słowacji jest jedną z głównych przyczyn powstrzymujących odpływ z osiedli blokowych na suburbia, które $\mathrm{w}$ innych krajach postsocjalistycznych stanowią istotny kierunek migracji z tych osiedli. Posiadanie drugich domów na wsi, jakkolwiek częste wśród mieszkańców wszystkich form zabudowy w dużych słowackich miastach, wśród mieszkańców wielkich osiedli jest niemal powszechne, ponieważ w dużej mierze stanowią oni ludność napływową o korzeniach wiejskich (często $\mathrm{w}$ pierwszym pokoleniu) i wciąż silnych związkach rodzinnych z wsią (Divinský 2004).

Podobnie jest $\mathrm{w}$ Polsce, gdzie empiryczne studia osiedli w wielu miastach np. w Warszawie (Węcławowicz i in. 2003), Lublinie (Rodzoś, Flaga, 2010), Poznaniu (Ciesiółka 2010), Łodzi (Szafrańska 2014), Krakowie (Jerschina i in. 2012) pokazują, że mimo pewnych symptomów filtracji mieszkaniowej i odpływu osób najzamożniejszych i o najwyższych aspiracjach mieszkaniowych degradacja społeczna osiedli zapowiadana w latach 90. nie nastąpiła. Przeciwnie, w wielu miastach polskich osiedla te są obszarami zamieszkiwanymi przez kategorie o co najmniej średnim statusie społecznym, lokującymi się relatywnie wysoko w strukturze społeczno-przestrzennej miast (Marcińczak 2009, Zborowski 2005). Niektóre osiedla, np. Prądnik Czerwony w Krakowie czy Ursynów w Warszawie, które w okresie poprzedniego ustroju miały nieformalny charakter osiedli inteligenckich ${ }^{128}$, wciąż mają bardzo dobrą reputację w mieście i dobrą strukturę społeczną (Jerschina i in. 2012, Węcławowicz i in. 2003, 2005).

O dobrej strukturze społecznej wielu osiedli w Polsce świadczą też inne niż wykształcenie miary statusu opisujące skład społeczny mieszkańców, czyli np. udział osób bezrobotnych czy korzystających z pomocy społecznej na tle innych obszarów miast, które - jak pokazują badania - są znacznie niższe niż na obszarach określanych jako problemowe, a nawet niż średnie w tych miastach (por. badania w Łodzi - E. Szafrańska 2008, w Lublinie - J. Rodzoś, M. Flaga 2010, w Poznaniu - P. Ciesiółka 2010). Z przeprowadzonych $\mathrm{w}$ miastach polskich badań wynika również (podobnie jak na Węgrzech i w Czechach - por. J. Temelova i in. 2011, I. Tosics i in. 2005), że status społeczny osiedli blokowych często, choć nie zawsze, związany jest z ich wiekiem. Osiedla nowsze, wybudowane później, charakteryzują się

${ }^{128}$ W osiedlu Ursynów w latach 80. ponad 30\% mieszkańców miało wyższe wykształcenie (Węcławowicz i in. 2003). Podobnie wysoki status w minionym ustroju miało krakowskie osiedle Prądnik Czerwony, a z ostatnich jego badań wynika, że status ten został utrzymany, ponieważ w 2006 r. udział mieszkańców z wyższym wykształceniem sięgał tam ok. 40\% (Jerschina $\mathrm{i}$ in 2012). 
z reguły wyższym statusem społecznym mieszkańców niż osiedla starsze. Przy czym nie jest to wyłącznie pochodna struktury wieku mieszkańców tych osiedli, lecz także wynik reguł socjalistycznej alokacji mieszkaniowej, która $\mathrm{w}$ różnych dekadach preferowała określone kategorie społeczne $\mathrm{w}$ rozdzielnictwie mieszkań. Relatywnie wysoki status społeczny mieszkańców strefy wielkich osiedli mieszkaniowych w początku XXI wieku, wyższy niż w ubiegłych dekadach, a także wpływ okresu budowy na ich aktualną pozycję statusową ukazują badania A. Zborowskiego (2005), których ilustracją jest model zróżnicowania społeczno-przestrzennego Krakowa zidentyfikowany dla lat 50 . i 60 ., dla lat $70 . X X$ wieku oraz dla okresu z początku XXI stulecia (rys. 20).

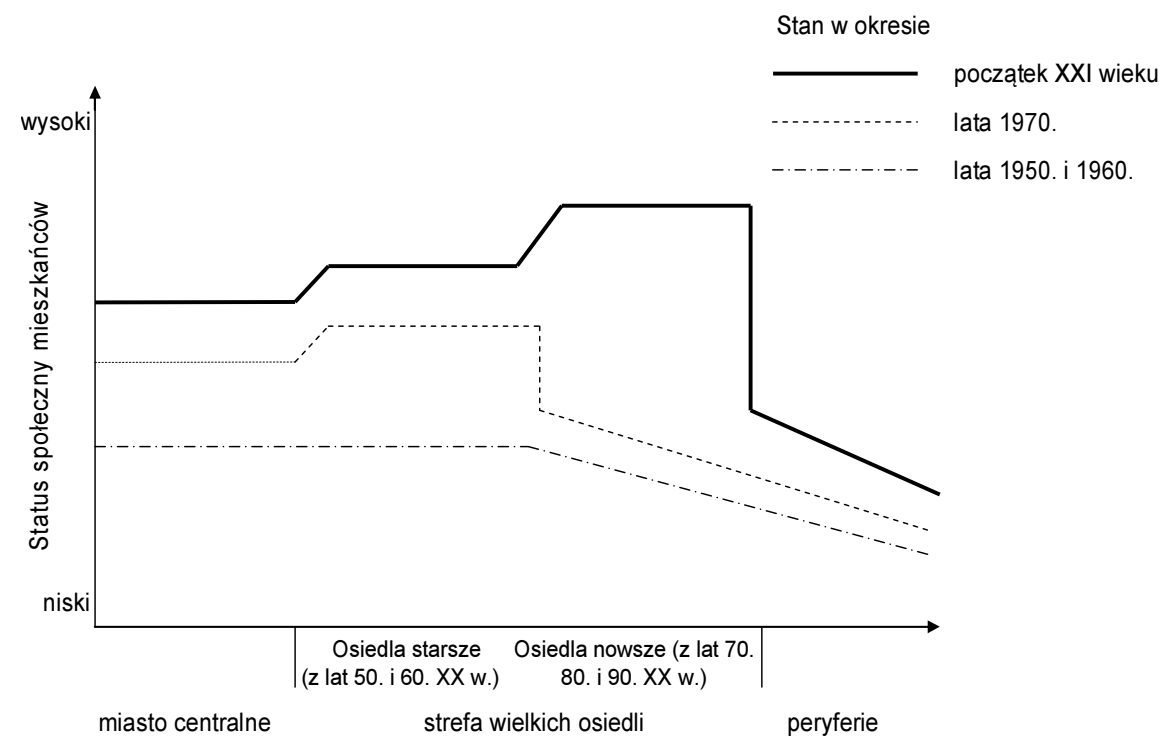

Rys. 20. Profil przemian statusu społecznego w mieście polskim od lat

30. XX wieku do początków XXI wieku (na przykładzie Krakowa)

Źródło: opracowanie własne na podstawie A. Zborowski (2005, s. 425)

Wymienione pozytywne przykłady nie świadczą jednak o tym, że we wszystkich miastach i we wszystkich postsocjalistycznych osiedlach blokowych status społeczny mieszkańców nie obniża się. Skrajnym przykładem takiego osiedla, które uległo zarówno społecznej jak i fizycznej degradacji jest niewielkie osiedle blokowe Chanov w czeskim Moście zamieszkiwane głównie przez ludność romską, a także osoby bezrobotne, biedne, zadłużone, korzystające z pomocy społecznej, popadające w konflikt z prawem (Temelová i in. 2011). Procesy wykluczenia społecznego w tym osiedlu, jak zauważają autorzy, rozpoczęly się jednak już w okresie socjalizmu na skutek 
lokowania tam ludności romskiej oraz biednej. Wymiana mieszkańców (inaczej niż w innych socjalistycznych osiedlach mieszkaniowych) następowała tam już przed 1990 rokiem, ponieważ ludność zamożniejsza i lepiej wykształcona, w tym także zamożniejsi Romowie, opuszczała to osiedle (Temelová i in. 2011). Innym przykładem osiedla degradującego się, choć znacznie mniej drastycznie niż wyżej opisane, jest Kóbánya-Újhegy w Budapeszcie (Kovács, Douglas 2004), które również już od momentu powstania przeznaczone było dla ludności reprezentującej niższe kategorie społeczne na skutek czego po 1990 roku, odmiennie niż pozostałe osiedla w tym mieście, stało się obszarem, na którym występuje wiele negatywnych zjawisk społecznych (przykład 3).

\section{Przykład 3: osiedle Kóbánya-Újhegy, Budapeszt (Węgry)c}

Osiedle Kóbánya-Újhegy w Budapeszcie wybudowane zostało w latach 70. w sąsiedztwie dzielnicy przemysłowej i zajmuje 27,4 ha. W $2006 \mathrm{r}$. zamieszkiwane było przez ponad 20 tys. mieszkańców. Zabudowa osiedla składa się głównie z ogromnych, długich na kilkaset metrów wieżowców, tworzących najmniej przyjazną dla człowieka równoległą zabudowę, zorientowaną w jednym kierunku, która nie wytwarza wnętrz urbanistycznych. Osiedle od początku przeznaczone było dla niewykwalifikowanych oraz słabo wykwalifikowanych robotników przemysłowych, a także ludności romskiej. Tym samym już pierwotni mieszkańcy osiedla, inaczej niż w większości osiedli socjalistycznych, stanowili grupę względnie homogeniczną o niskim statusie społecznym. W latach 90. skład społeczny mieszkańców tego osiedla stanowił ograniczenie dla procesu prywatyzacji, ponieważ mieszkańcy nie byli w stanie wykupić mieszkań nawet na preferencyjnych warunkach oferowanych we wszystkich węgierskich osiedlach mieszkaniowych. W konsekwencji zablokowało to możliwość wymiany mieszkańców na wyższe kategorie statusowe i utrwaliło niski status społeczny osiedla.

c Opracowano na podstawie literatury (Kovács, Douglas 2004, Csaba 2006).

Analizując problem potencjalnej degradacji społecznej osiedli blokowych można stwierdzić, że poza nielicznymi wyjątkami dotyka on niewielkich fragmentów osiedli, a nawet ma charakter punktowy. Dzieje się tak, gdyż w okresie socjalizmu z różnych powodów określone kategorie ludności o niższym statusie społecznym koncentrowano w pojedynczych budynkach lub w ich niewielkich zespołach tworząc w ten sposób socjalistyczne quasi-slamsy. Obecnie, po transformacji ustrojowej problem ten utrwalił się i w ramach osiedli blokowych o względnie dobrej i zróżnicowanej strukturze społecznej tworzy enklawy biedy i wykluczenia. Ze zjawiskiem tym mamy do czynienia np. w osiedlu Josavaros na Węgrzech $z$ lat 70. minionego wieku, gdzie jeden z budynków, w którym mieści się blisko 200 małych mieszkań komunalnych, koncentruje ludność o niskim statusie spo- 
łecznym, przy czym generalnie osiedle zamieszkiwane jest przez klasę średnią oraz klasę niższą średnią (Musterd, van Kempen 2005, s. 112). W Polsce podobna sytuacja występuje np. w szczecińskim osiedlu Książąt Pomorskich $\mathrm{z}$ lat 70. XX wieku, gdzie $\mathrm{w}$ początkach lat 80. ulokowano dwa 11-kondygnacyjne hotele robotnicze $\mathrm{z}$ przewagą mieszkań $\mathrm{M}-1$, których mieszkańcy - nie identyfikując się z zastanym otoczeniem - wielokrotnie naruszali zasady współżycia społecznego (kradzieże, rozboje, włamania, akty wandalizmu), co bardzo niekorzystnie wpłynęło na bezpośrednie sąsiedztwo tych budynków (Wojtkun 2004, s. 124). Inny przykład takiej niewielkiej enklawy wynikającej z lokalizacji wewnątrz osiedla hotelu robotniczego można znaleźć w warszawskim Ursynowie (Węcławowicz i in. 2003). Hotel ten po zakończeniu budowy osiedla zasiedlony został przez osoby starsze oraz niepełnosprawne, a obecnie po 1990 roku zamieszkują w nim głównie osoby mało zamożne, które wynajmują mieszczące się tam małe i relatywnie tanie lokale, tworząc w ten sposób swoistą punktową ",enklawę biedy" w tym osiedlu (ibid., s. 55).

W przypadku Węgier, Czech i Słowacji, a zatem krajów, w których występuje relatywnie duży udział ludności romskiej w miastach, obecność tej grupy jest jedną z cech współtowarzyszących niższej pozycji statusowej poszczególnych osiedli, przy czym według A. Csizmady (2003), nie jest jej główną przyczyną. Zjawisko to bowiem ze względu na swoją skalę nie nosi znamion segregacji etnicznej znanej z osiedli Europy Zachodniej, ponieważ udziały ludności romskiej w wielkich osiedlach dużych miast nie przekraczają kilku procent (ibid.), a jej rozmieszczenie ma charakter wyspowy (obejmujący od jednego do kilku budynków). Przykładem osiedla o silnym zróżnicowaniu wewnętrznym $\mathrm{z}$ "enklawami biedy" jest też osiedle Kročehlavy w czeskim mieście Kladno położonym niedaleko Pragi (przykład 4).

Wymienione przykłady pokazują, że z segregacją zarówno statusową, jak i etniczną wielkich osiedli $\mathrm{w}$ miastach postsocjalistycznych mamy do czynienia raczej $\mathrm{w}$ mikroskali, na obszarach subosiedlowych, poprzez wyodrębnianie się w przestrzeni wewnątrzosiedlowej obszarów lepszych i gorszych. Segregacja społeczna i etniczna całych osiedli ma natomiast charakter wyjątkowy i dotyczy raczej niewielkich osiedli mieszkaniowych.

Inny ważny wniosek, który sformułować można na podstawie analizy omówionych w literaturze przykładów osiedli (lub ich enklaw) najsilniej degradujących się dowodzi, że zachodzące $\mathrm{w}$ nich współcześnie procesy są przede wszystkim konsekwencją socjalistycznej alokacji mieszkaniowej i koncentracji osób pozostających na marginesie społeczeństwa już w okresie socjalizmu, a w mniejszej mierze przemian transformacyjnych, które jedynie to zjawisko pogłębiły i wydaje się, że także utrwaliły. 


\section{Przykład 4: osiedle Kročehlavy, Kladno (Czechy) ${ }^{\mathrm{d}}$}

Osiedle Kročehlavy, zlokalizowane jest w mieście Kladno położnym 20 km od Pragi. W 2010 r. osiedle to liczyło 27 tys. mieszkańców i koncentrowało około $40 \%$ zasobu mieszkaniowego miasta.

W wyniku przemian zachodzących po 1990 roku obecna struktura społeczno-przestrzenna tego osiedla jest silnie zróżnicowana. Są w nim obszary o bardzo zawansowanych procesach demograficznego starzenia się i relatywnie młode, a także będące w złej kondycji zarówno społecznej, jak i fizycznej, gdzie poziom bezrobocia przekracza $20 \%$, oraz tereny zadbane, o poziomie bezrobocia poniżej 5\%, w których zamieszkuje ludność zamożniejsza. Przyczyny tak dużego zróżnicowania osiedla upatruje się $\mathrm{w}$ okresie budowy poszczególnych jego fragmentów (budowano je partiami od lat 50. do końca lat 80.), jak też proweniencji poszczególnych grup budynków. Część z nich miała bowiem charakter budownictwa zakładowego, przeznaczonego wyłącznie dla robotników lokalnych fabryk, a część (kilka największych bloków) budowano z założeniem lokowania tam ludności w trudnej sytuacji ekonomicznej. Osiedle to zatem, jakkolwiek heterogeniczne, już w okresie socjalizmu miało swoje homogeniczne strefy o podobnym składzie społecznym mieszkańców, a współczesne zróżnicowanie jego przestrzeni jest odbiciem zróżnicowania powstałego w poprzednim ustroju, będącego wynikiem socjalistycznej alokacji mieszkaniowej.

Współcześnie dzięki niewielkiej odległości od Pragi oraz niższym niż w stolicy cenom mieszkań (stanowiącym ok. $2 / 3$ przeciętnej ceny w prefabrykowanych osiedlach praskich), osiedle to (szczególnie jego fragmenty w dobrej kondycji) stało się popularne wśród młodych oraz wykształconych prażan, którzy kupują tu mieszkania i dojeżdżają do pracy w stolicy. Jakkolwiek napływ tej grupy chroni osiedle przed degradacją i prowadzi do poprawy jego struktury demograficznej oraz społecznej, to poprawa ta może nie mieć charakteru trwałego. Stabilność rezydencjalna tej grupy, jak wynika z badan, jest bowiem mała, a osiedle Kročehlavy traktowane jest przez nich jako czasowe miejsce zamieszkania i jako etap startowy do dalszego samodzielnego życia.

d Opracowano na podstawie: J. Temelová i in. (2011).

Biorąc pod uwagę porównania składu społecznego mieszkańców osiedli $\mathrm{w}$ ujęciu międzynarodowym, przeprowadzonym $\mathrm{w}$ oparciu o badania w ramach projektu RESATE, wynika, że mieszkańcy osiedli w miastach postsocjalistycznych wciąż są znacznie lepiej wykształceni, młodsi, o znacznie większej aktywności zawodowej i wyższych dochodach, niż mieszkańcy osiedli w krajach zachodnioeuropejskich (Musterd, van Kempen 2005). W zdecydowanej większości (odmiennie niż w miastach zachodnich) są także właścicielami zajmowanych mieszkań. Różnice te potwierdzają też inne porównania o charakterze międzynarodowym (Turkington i in., red. 2004). 


\subsubsection{Przemiany $w$ strukturze funkcjonalno-przestrzennej i morfologii}

Omówione powyżej przemiany w strukturze społecznej osiedli postsocjalistycznych zachodzą również na skutek procesów zmieniających ich strukturę przestrzenną poprzez przemiany morfologiczne oraz funkcjonalne, które pozostają ze sobą w ścisłym związku. Do najważniejszych wśród tych procesów należą: intensyfikacja zabudowy mieszkaniowej, komercjalizacja, sakralizacja przestrzeni i kształtowanie się nowych przestrzeni publicznych.

Pierwszy z wymenionych procesów - intensyfikacja zabudowy mieszkaniowej, która w wielkich osiedlach zaczęła dokonywać się po 1990 roku (Matlovič i in. 2001), to proces mający dwojaki charakter. Po pierwsze jest to dogęszczanie istniejącej oryginalnej substancji mieszkaniowej powstałej przed 1990 rokiem poprzez zabudowę terenów wolnych. Większość z nich to obszary pierwotnie przeznaczone na rozwój obiektów infrastruktury społecznej i usługowej, które na skutek oszczędności i pośpiechu w budowie osiedli nigdy nie zostały zrealizowane. Część zaś stanowią tereny (często dość rozległe) niezagospodarowane celowo, pozostawione jako otwarte "przestrzenie międzyblokowe". Po drugie, intensyfikacja zabudowy nastąpiła poprzez zabudowywanie obszarów położonych na obrzeżach istniejącej zabudowy, co spowodowało przesuwanie się granic osiedli. Znaczące rozmiary tego procesu wynikają z możliwości wykorzystania uzbrojenia terenu i istniejącej infrastruktury, co znacznie obniża koszty inwestycji i podnosi atrakcyjność tych terenów dla deweloperów (Stanilov 2007). Specyfika tych procesów $\mathrm{w}$ osiedlach miast postsocjalistycznych polega na tym, że zmieniają one strukturę morfologiczną osiedli $w$ kierunku przeciwnym niż działania podejmowane w krajach Europy Zachodniej, głównie we Francji i Holandii, ale także $\mathrm{w} \mathrm{b}$. NRD, które zmierzają do rozgęszczenia zabudowy poprzez wyburzenia budynków mieszkalnych, zwłaszcza tych o największej kubaturze (wysokich i długich) (por. Wassenberg 2013, Kabisch, Grossmann 2013). W krajach tych na miejsce wielkoskalowych budynków mieszkaniowych wprowadza się zabudowę niższą i o mniejszej gęstości, w innych zaś tereny te pozostawia się wolne lub przeznacza na inne funkcje (głównie rekreacyjne lub usługowe).

Nowa zabudowa mieszkaniowa najczęściej obejmuje pojedyncze budynki wielorodzinne lub ich zespoły. Ich cechą charakterystyczną jest wyższy standard i odmienna od otoczenia fizjonomia oraz estetyka (detale architektoniczne, bogatsza kolorystyka i zróżnicowane bryły budynków, elementy małej architektury). Nowe budynki często wyposażone są w podziemne garaże, a ich parterowe kondygnacje przeznaczone są na handel i usługi (Węcławowicz i in. 2003). Sposób usytuowania nowej zabudowy w przestrzeni osiedli uwarunkowany jest dostępnością wolnych terenów, toteż bywa przypadkowy. Jednakże w szczególnych przypadkach może się 
przyczynić do wykreowania nowych atrakcyjnych przestrzeni publicznych, np. poprzez zastosowanie nieobecnej dotychczas w tych osiedlach zabudowy obrzeżnej i tworzenie wielofunkcyjnych ciągów handlowo-usługowo-komunikacyjnych. Rozwiązanie takie z sukcesem zostało zastosowane np. w osiedlu Ursynów w Warszawie (por. Kozłowski 2010).

Społeczną konsekwencją pojawienia się nowej zabudowy w osiedlach jest napływ ludności o wyższym statusie społeczno-ekonomicznym niż dotychczasowa i wyodrębnienie się $\mathrm{w}$ ich przestrzeni wyspowych obszarów o lepszym statusie społecznym oraz wyższym prestiżu mieszkaniowym (Węcławowicz 2007). Barierą w nabyciu mieszkania w nowych budynkach zlokalizowanych w osiedlach blokowych są ceny, które nie należą do niskich. $\mathrm{Z}$ badań przeprowadzonych $\mathrm{w}$ osiedlu Ursynów w Warszawie wynika, że koszt $1 \mathrm{~m}^{2}$ nowego mieszkania budowanego w nim na początku XXI wieku był równy dwukrotności średniego miesięcznego wynagrodzenia w stolicy (Węcławowicz i in. 2003). Podobnie było w innych polskich miastach, gdzie proporcja ta wynosiła $\mathrm{w}$ tym okresie od 1,5 do 2 (Szafrańska 2012).

Skrajnym przypadkiem tego procesu jest powstawanie wewnątrz osiedli obszarów zamkniętych (gated communities), w literaturze polskiej określanych także jako osiedla grodzone lub osiedla „za bramą". Jakkolwiek nie wszystkie nowe budynki mieszkaniowe w osiedlach blokowych powstają jako zamknięte, proces grodzenia się i oddzielania od pozostałej większej części mieszkańców, określany jako separacja (Matlovič i in. 2001), w osiedlach miast postsocjalistycznych występuje dość często, choć jego skala jest bardzo różna. W Polsce budowa osiedli grodzonych w ogóle, w tym także wewnątrz istniejącej wcześniej zabudowy blokowej, największe rozmiary osiągnęła w Warszawie (por. Jałowiecki, Łukowski 2007). Osiedla grodzone, jak już wcześniej powiedziano, lokalizują się w centrach osiedli blokowych albo na ich obrzeżach w zależności od dostępu do wolnych terenów (rys. 21). Interesujące jest to, że na ich lokowanie w poszczególnych osiedlach nie ma dużego wpływu aktualna ich reputacja (Węclawowicz $i$ in. 2003). Jak bowiem pokazują badania prowadzone w Warszawie (ibid.), zamieszkanie $\mathrm{w}$ ogrodzonej enklawie jest równie atrakcyjne na cieszącym się dobrą opinią sięgającą minionego okresu osiedlu Ursynów, jak i mającym znacznie gorszą reputację robotniczym osiedlu Wrzeciono.

Jak podaje J. Gądecki (2007), przyczyny powstawania osiedli grodzonych mają dwa pozornie ze sobą rywalizujące wyjaśnienia. Pierwsze z nich nawiązuje do lęku o bezpieczeństwo, drugie natomiast osiedla tego typu traktuje jako rezultat zmian klasowych i potrzeby prestiżu. Osiedla grodzone według tej drugiej koncepcji stają się ucieleśnieniem utopii klasy średniej. Wielu ich mieszkańców, przedstawicieli zamozniejszych kategorii społecznych ,,$[. .$.$] poszukuje sprywatyzowanej utopii oferującej bezpieczeństwo,$ 
homogeniczną populację, niewielką skalę i możliwą do zarządzania, prywatną przestrzeń [...]" (Gądecki 2007, s. 91), a zatem atrybutów, których próżno szukać $\mathrm{w}$ anonimowych $\mathrm{i}$ heterogenicznych społecznie wielkich osiedlach. Badania przeprowadzone $\mathrm{w}$ osiedlach warszawskich $\mathrm{w}$ ramach projektu RESTATE (Bierzyński, Kozłowska 2005) pozwalają stwierdzić, że ponad $80 \%$ mieszkańców jako główną przyczynę chęci zamieszkiwania $\mathrm{w}$ takim osiedlu podaje bezpieczeństwo. $\mathrm{W}$ miastach postsocjalistycznych jednakże paradoksem budowy gated communities lokalizowanych wewnątrz istniejących osiedli blokowych jest fakt, że osiedla te często są spokojne i bezpieczne (Dymnicka 2007). Z analiz dotyczących przestępczości miejskiej wynika nawet, że należą do jednych z bezpieczniejszych obszarów w wielu miastach (por. Czapska, red. 2012, Mordwa 2013). Nie ma zatem - jak pisze M. Dymnicka (ibid.) - realnych powodów, aby w osiedlach o zróżnicowanej, ale wciąż relatywnie dobrej strukturze społecznej, odgradzać się od otoczenia i tworzyć iluzję wysp bezpieczeństwa na rzekomym oceanie przestępczości.

WRZECIONO

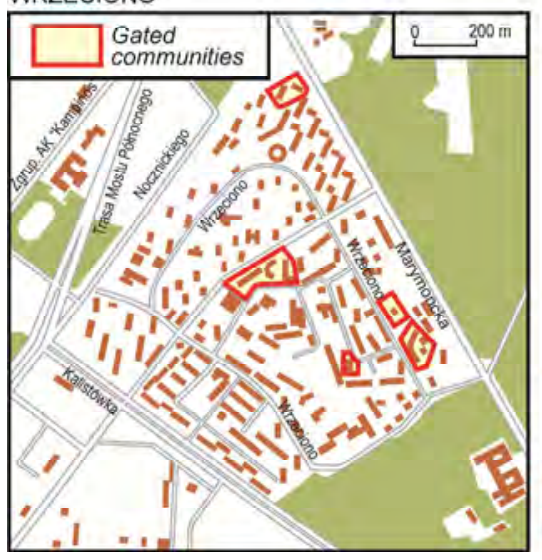

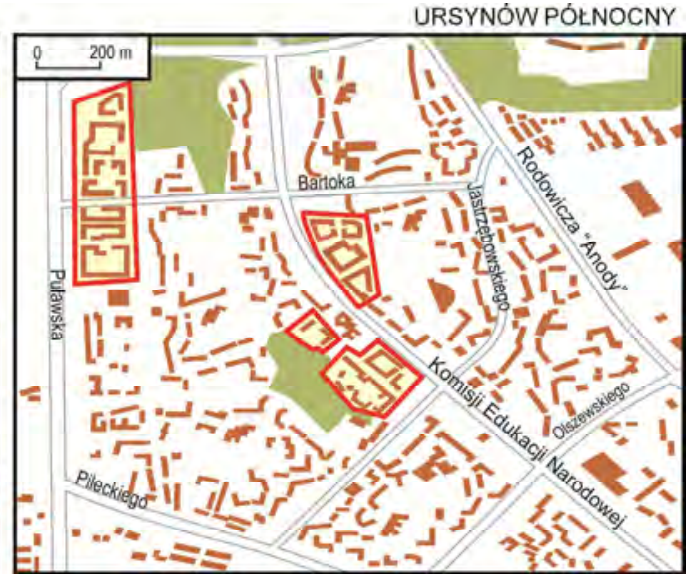

Rys. 21. Lokalizacja gated communities w osiedlach mieszkaniowych

Wrzeciono i Ursynów Północny w Warszawie w 2005 roku Źródło: opracowanie własne na podstawie A. Bierzyński, A. Kozłowska (2005)

Wśród negatywnych konsekwencji powstawania w osiedlach blokowych grodzonych enklaw mieszkaniowych najważniejszą jest zawłaszczanie osiedlowej przestrzeni publicznej oraz przerywanie jej ciągłości w wymiarze zarówno fizycznym, poprzez tworzenie barier uniemożliwiających swobodne przemieszczanie się, jak i kulturowym (symbolicznym), które wiążą się z procesami segregacji i separacji społecznej. Badania ankietowe 
przeprowadzane wśród mieszkańców osiedla Retkinia w Łodzi (Szafrańska 2009) potwierdzają także ich złą percepcję. Obecność gated community w bezpośrednim sąsiedztwie wywołuje bowiem frustrację i poczucie "gorszości" u mieszkańców spoza enklawy.

Niezależnie jednak od tego, jak ocenia się powstawanie nowych budynków mieszkaniowych w przestrzeni osiedli blokowych, zarówno w formie grodzonych, jak i niegrodzonych enklaw, niewątpliwie zjawisko to przyczynia się do napływu ludności młodszej, lepiej wykształconej oraz o wyższym statusie ekonomicznym, a w konsekwencji do poprawy struktury społecznej tych osiedli. Przyczynia się także do podniesienie ich prestiżu mieszkaniowego, ponieważ - jak słusznie zauważa W. Jarczewski (2010, s. 60): „w tym nieco chaotycznym, ale coraz powszechniejszym trendzie «dogęszczania» można jednak dostrzec szansę dla wielkich osiedli mieszkaniowych [...] i sposób na uchronienie wielu z tych obszarów przed degradacją. Nowe, udane inwestycje w osiedlach blokowych pokazują społeczności lokalnej, że to miejsce żyje. Nowi, stosunkowo zamożni mieszkańcy tych budynków, nobilitują zazwyczaj nieco biedniejszych sąsiadów w wielkiej płycie, prowokując ich do formułowania tezy: jeżeli «tacy» się tutaj sprowadzają, to ja nie będę się wyprowadzał". Zjawisko to nosi zatem znamiona innego procesu, tradycyjnie utożsamianego z obszarami centralnymi w miastach, czyli gentryfikacji129, a ściślej - jednego z jej rodzajów, jakim jest new-build gentrification (por. Davidson, Lees 2005). Obecnie w literaturze użycie tego pojęcia w odniesieniu do osiedli blokowych jest rzadko spotykane i dotychczas pojawiło się tylko w kilku pracach (np. Musterd, van Kempen 2005, Węcławowicz 2007, Szafrańska 2012), co sprawia, że wciąż ma charakter dyskusyjny. Zakładając jednak, że terminy naukowe opisujące rzeczywistość ewoluują, wydaje się, że określenie "gentryfikacja” można, z pewnymi ograniczeniami, zastosować także w tym przypadku.

Kolejny proces zmieniający strukturę przestrzenną osiedli mieszkaniowych to komercjalizacja. Proces ten definiowany jest jako stopniowe powiększanie udziału obszarów komercyjnych, zwłaszcza handlu, usług, biur oraz banków i instytucji finansowych, kosztem innych, niekomercyjnych funkcji o niższym stopniu zysku ekonomicznego, np. kultury, szkolnictwa, mieszkalnictwa (Matlovič i in. 2001). Komercjalizacja traktowana jest jako

129 W odniesieniu do osiedli blokowych pojęcie "gentryfikacja” zastosować można tylko wtedy, gdy przyjmiemy najszersze (inkluzywne) rozumienie tego procesu. Według ujęć inkluzywnych gentryfikacja obejmuje bowiem nie tylko podupadłe obszary starej zabudowy mieszkaniowej, ale również przebudowę lub modernizację dzielnic zamieszkanych przez ludzi o wysokich i średnich dochodach, dzielnic lub budynków o funkcji innej niż mieszkaniowa, a nawet zagospodarowywanie terenów dotychczas niezabudowanych, na których pojawiają się nowe, zamknięte i chronione osiedla - enklawy dla zamożnych (Grzeszczak 2010), określane jako new-build gentrification (por. Davidson, Lees 2005). 
proces zachodzący $\mathrm{w}$ strukturze funkcjonalnej miasta (por. Matlovič $\mathrm{i}$ in. 2001), ale odbywa się także przez zmiany w jego strukturze morfologicznej (por. Liszewski 2001b).

W wielkich osiedlach mieszkaniowych komercjalizacja dokonuje się przede wszystkim poprzez zmiany w morfologii, czyli wypełnianie się dotychczasowej zabudowy nową zabudową o funkcji usługowej i usługowo-handlowej, ale także, choć w mniejszym stopniu, poprzez zmiany funkcji w zabudowie istniejącej, np. poprzez adaptację parterów budynków na funkcje usługowe i handlowe (Ouředniček, Temelová 2009, Ciesiółka 2010). Proces ten wiąże się z powstawaniem w przestrzeni osiedli po 1990 roku bardzo licznych nowych placówek usługowych (oddziały banków, gabinety i przychodnie lekarskie, apteki, salony urody, stacje obsługi pojazdów i inne), a także obiektów handlowych, w tym wielkopowierzchniowych należących do wielkich sieci międzynarodowych i krajowych (Liszewski 2001b, Węcławowicz i in. 2003). W osiedlach powstają również liczne lokale gastronomiczne (restauracje, puby, kawiarnie) i nowe miejsca spędzania wolnego czasu o charakterze komercyjnym (fittnes cluby, siłownie, szkoły tańca, kina, pływalnie itp.) (Węcławowicz i in. 2003, Ouředniček, Temelová 2009, Szafrańska 2010). W efekcie uboga funkcjonalnie, a w wielu przypadkach niemal monofunkcyjna dotychczas przestrzeń osiedli (zwłaszcza tych największych, usytuowanych peryferyjnie, które powstawały najszybciej i w efekcie nie bez przyczyny zyskały miano megasypialni), wypełnia się wieloma nowymi funkcjami, w tym także funkcjami wyższego rzędu130. Znaczna poprawa wyposażenia osiedli w handel oraz usługi zwiększa ich dostępność przestrzenną i $\mathrm{w}$ istotny sposób poprawia warunki zamieszkiwania zarówno w wymiarze obiektywnym, jak i subiektywnym, o czym świadczą liczne wyniki badań ankietowych prowadzonych wśród mieszkańców osiedli (omówione w kolejnym rozdziale pracy).

Inną formą przekształceń przestrzeni wielkich osiedli mieszkaniowych, po części związaną z jej komercjalizacją, jest budowa nowych miejsc parkingowych. Kwestia ta jest ważna, ponieważ zaniedbania inwestycyjne $\mathrm{w}$ tej dziedzinie sięgają czasów budowy osiedli, kiedy nie przewidywano tak szybkiego rozwoju motoryzacji. I mimo że problem ten dotyczy osiedli we wszystkich krajach (Chmielewski, Mirecka 2001), to w krajach Europy Środkowo-Wschodniej jest szczególnie dotkliwy, ponieważ upowszechnienia się motoryzacji nie brano tu pod uwagę także z innych względów. W egalitarnych społeczeństwach socjalistycznych posiadanie samochodów osobowych, traktowane jako indywidualistyczny przejaw burżuazyjnego stylu życia,

${ }^{130}$ Na przykład w warszawskim osiedlu Ursynów funkcjonuje wiele szkół różnych poziomów nauczania o zasięgu nie tylko lokalnym, w tym np. dwie szkoły wyższe, kilka galerii handlowych i Multikino (Węcławowicz i in. 2003). 
było limitowane przez władzę i stanowiło przywilej nielicznych ${ }^{131}$. W efekcie liczba miejsc parkingowych tworzonych w nowo budowanych osiedlach socjalistycznych (nawet przy uwzględnieniu prognoz rozwoju motoryzacji) była bardzo niska. W Polsce $\mathrm{np}$. w latach 70 . minionego wieku normy w tym zakresie nie przekraczały 50 na 1000 mieszkańców (Chmielewski, Mirecka 2001), a w latach 80. wynosiły około 100-150 na 1000 mieszkańców (Wojtkun 2004). Współcześnie, wraz poprawą warunków życia, posiadanie prywatnych samochodów (nierzadko dwóch w jednym gospodarstwie domowym) na tyle się upowszechniło ${ }^{132}$, że brak miejsc do parkowania stał się poważnym problemem $\mathrm{w}$ przestrzeni osiedli. Jest to najbardziej dotkliwe w osiedlach o dużej intensywności zabudowy oraz z przewagą zabudowy wysokiej, czyli takich, gdzie udział terenów wolnych jest relatywnie mały w stosunku do gęstości zaludnienia. W efekcie niemal we wszystkich osiedlach, głównie na ich obrzeżach, ale także na obszarach tzw. międzyblokowych, powstają liczne nowe parkingi, które jednak wciąż nie zaspokajają potrzeb. Zajmują one rozległe tereny, ponieważ budowa parkingów podziemnych lub wielopoziomowych naziemnych, która rozwiązałaby ten problem, stosowana jest rzadko ze względu na wysokie koszty (por. Chmielewski, Mirecka 2001). Bardzo wiele nowych parkingów to inwestycje komercyjne (parkingi strzeżone), czego efektem jest zawłaszczanie i komercjalizacja przestrzeni publicznej.

Omówione w tej części pracy przemiany morfologiczne w osiedlach związane z intensyfikacją ich zabudowy, zarówno mieszkaniowej, jak i usługowej (usługowo-handlowej) oraz z komercjalizacją mają również negatywny wymiar. W warunkach polskich, jak podaje G. Rembarz (2010), brak pełnego uporządkowania kwestii własności gruntów i brak faktycznego gospodarza tych terenów (po części jest nim miasto, po części spółdzielnia mieszkaniowa, a po części mieszkańcy) sprawia, że władze spółdzielni mieszkaniowych (które wciąż, w bardzo wielu osiedlach, mimo przeksztalceń własnościowych, są podmiotem zarządzającym) nierzadko prowadzą dość dowolną politykę przestrzenną, ograniczoną jedynie ogólnymi dokumentami planistycznymi. Praktykowana przez nie sprzedaż działek inwestorom komercyjnym, którzy lokują nowe inwestycje często o dowolnej este-

${ }^{131} \mathrm{~W}$ krajach socjalistycznych istniał także wtórny rynek motoryzacyjny, lecz wysokie ceny transakcyjne używanych samochodów przekraczały możliwości nabywcze przeciętnie zarabiających.

132 Z danych GUS wynika, że w Polsce liczba zarejestrowanych samochodów na 1000 mieszkańców w 1970 r. wynosiła 15, w 1976 - 39, a w 1990 - 138. W 2012 r. wskaźnik ten najwyższy był w Warszawie (580). W innych dużych miastach był porównywalny (w Poznaniu 554, Opolu - 551, Wrocławiu- 540, Gdańsku - 508, Krakowie - 503). Najniższy spośród wielkich miast był w Łodzi - 448. Średnio dla Polski wskaźnik ten w latach 1990-2012 wzrósł blisko czterokrotnie. 
tyce i architekturze, nie uwzględniając przy tym lokalnej specyfiki miejsca (dotychczasowe zagospodarowanie, preferencje mieszkańców), niekiedy prowadzi do chaosu przestrzennego, a w konsekwencji obniża i tak dość niską estetykę tych osiedli, a także przyczynia się do nadmiernego zagęszczania zabudowy (ibid.). Negatywne aspekty tych przemian dostrzegają także A. Bierzyński i A. Kozłowska (2005), którzy zwracają uwagę na to, że pojawienie się $\mathrm{w}$ osiedlach obiektów o zasięgu ogólnomiejskim ( $\mathrm{w}$ tym głównie hipermarketów) nie jest korzystne, ponieważ zwiększa wewnętrzny ruch samochodowy $w$ przestrzeni wewnątrzosiedlowej, powoduje hałas i ogranicza przestrzeń publiczną, a także pogarsza warunki dla lokalnego handlu. Niekorzystny wymiar obecności wielkich sieci handlowych w osiedlach odnotowali również G. Wojtkun (2004) oraz J. Rodzoś i M. Flaga (2010), stwierdzając, że skutkuje to nie tylko znacznym ograniczeniem, ale nawet upadkiem lokalnego handlu, który intensywnie rozwijał się w osiedlach w pierwszych latach po transformacji.

Wiele negatywnych skutków ma również stałe powiększanie terenów przeznaczonych na miejsca do parkowania. Proces ten, mimo że przyczynia się do poprawy warunków życia w osiedlach, zwłaszcza z punktu widzenia mieszkańców będących właścicielami samochodów, to - jak podają A. Bierzyński i A. Kozłowska (2005) na podstawie analizy osiedli warszawskich przyczynia się do ograniczania przestrzeni rekreacyjnej, tworzenia barier przestrzennych, obniżania atrakcyjności osiedli oraz intensyfikacji wewnętrznego ruchu samochodowego, który w zamyśle projektantów tych środowisk mieszkaniowych miał pozostać na zewnątrz ${ }^{133}$.

Kolejnym niezwykle ważnym, choć nie tak powszechnym jak omówiony powyżej procesem zachodzącym $\mathrm{w}$ strukturze przestrzennej wielkich osiedli mieszkaniowych jest sakralizacja przestrzeni. Według R. Matloviča (2000, s. 123) proces ten rozumiany może być dwojako: sensu stricto oraz sensu largo. W pierwszym ujęciu sakralizacja oznacza rozszerzanie się przestrzeni sakralnej przeznaczonej tylko do zaspokajania potrzeb w zakresie kultu religijnego. W drugim natomiast jest to rozwój obszarów o dominacji funkcji religijnej obejmujących obok przestrzeni sakralnej także inne urządzenia, obiekty oraz infrastrukturę religijną (np. administrację, szkolnictwo, wydawnictwa, obiekty mieszkaniowe, gospodarcze itp.).

Proces sakralizacji przestrzeni ma charakter szczególny, ponieważ jest obecny w miastach od zawsze, jednak w okresie miasta socjalistycznego na

${ }^{133}$ W tym zakresie nie było pełnej zgodności, o czym pisze G. Wojtkun (2004, s. 136), przytaczając dość śmiałe wówczas słowa H. Adamczewskiej-Wejchert z 1978 r., współprojektantki osiedla Stella w Tychach: „wbrew zakorzenionej w kraju tendencji przyjęliśmy zasadę, że samochód jest częścią aparatury obsługującej mieszkanie, że przyjeżdża się nim pod dom i nie należy go rugować z osiedla, a jedynie neutralizować fizyczne skutki kontaktu ze spalinami i hałasem" (Stępiński 1978, cyt. za: Wojtkun 2004). 
skutek próby laicyzacji społeczeństw poddanych wpływom tego ustroju został zahamowany, a w niektórych krajach nawet cofnięty poprzez wyburzanie oraz zmiany funkcji istniejących obiektów sakralnych. W krajach socjalistycznych budowę świątyń oraz obiektów o charakterze sakralnym regulowało ustawodawstwo antyreligijne, wzorowane na radzieckim (Jażdżewska 2010, s. 153), toteż ich powstawanie w nowo budowanych osiedlach mieszkaniowych, które miały stanowić wizytówkę socjalizmu, podlegało przed 1990 rokiem bardzo silnym restrykcjom. Polska była krajem socjalistycznym, w którym sakralizacja przestrzeni osiedli mieszkaniowych rozpoczęła się najwcześniej - już w latach 60. XX w., kiedy władze partyjne wydały pozwolenie na budowę kościoła w krakowskim osiedlu Nowa Huta. Kolejne nieliczne pozwolenia wydawano także $w$ latach 70. (w tym np. dla osiedla Teofilów w Łodzi, dla osiedli Rataje i Winogrady w Poznaniu), a po strajkach robotniczych w 1980 roku i wizytach Jana Pawła II w kraju proces ten nabrał tak znacznego przyspieszenia, że rok 1981 uznano za ",koniec bitwy o kościoły" (Wróbel 2005, cyt. za: Jażdżewska 2010)134. W pozostałych krajach socjalistycznych proces ten mógł się rozpocząć dopiero po 1990 ro$\mathrm{ku}$, gdzie przebiegał $\mathrm{w}$ znacznie wolniejszym tempie i na znacznie mniejszą skalę niż w Polsce (por. Matlovič i in. 2001, Jażdżewska, red. 2010)135. Z badań przeprowadzonych przez I. Jażdżewską w Petersburgu (2010) wynika, że w Rosji proces ten rozpoczą się dopiero w końcu lat 90. XX wieku.

Współcześnie sakralizacja przestrzeni osiedli mieszkaniowych $\mathrm{w}$ miastach postsocjalistycznych zachodzi $\mathrm{w}$ różnej skali oraz $\mathrm{w}$ różnym tempie, ponieważ uwarunkowana jest poziomem religijności mieszkańców poszczególnych krajów i regionów. Z badań przemian postsocjalistycznych miast czeskich i słowackich na przykładzie Pragi, Bratysławy, Ołomunca i Preszowa (Matlovič i in. 2001) wynika, że proces ten występuje w osiedlach miast słowackich (w większym natężeniu w Preszowie), co wiąże się z relatywnie wysokim poziomem religijności Słowaków (Matlovič 2000), nie stwierdzono go natomiast $\mathrm{w}$ miastach czeskich.

134 Pozytywnym tego przykładem jest osiedle Majowe w Szczecinie, zaprojektowane w latach 1977-1979 dla 10,5 tys. mieszkańców (jako tzw. modelowa jednostka mieszkaniowa, będąca częścią większego zespołu mieszkaniowego obejmującego cztery takie osiedla), w którym już na etapie projektu uwzględniono budowę zespołu sakralnego, umieszczając go w prestiżowej lokalizacji - przy zaplanowanym na wzór tradycyjnej zabudowy miejskiej rynku - forum otoczonym budynkami o funkcji mieszkaniowo-usługowej (Wojtkun 2004). Było to wynikiem, jak podaje ten autor: „ocieplenia klimatu w stosunkach między PRL i Kościołem katolickim” (Wojtkun 2004, s. 134). Mimo to w I połowie lat 80., kiedy budowano osiedle, zaniechano tego planu, a budowę świątyni rozpoczęto dopiero w 1999 r. (po 10 latach od wzniesienia wysitkiem mieszkańców osiedlowej kaplicy).

$135 \mathrm{~W}$ latach 1990-2010 w osiedlach łódzkich (w sumie liczących około 300 tys. mieszkańców) wybudowano ponad 20 kościołów i kaplic, a w liczącym 250 tys. mieszkańców osiedlu Vesely Poselok w Petersburgu cztery cerkwie oraz dwie kaplice (Jażdżewska 2010). 
Proces sakralizacji, podobnie jak komercjalizacja, zachodzi w strukturze funkcjonalnej osiedli (Matlovič i in. 2001), jednak jego przebieg wiąże się ze zmianami w strukturze morfologicznej, poprzez wydzielanie nowych działek i wypełnianie ich zabudową, a także ze zmianami w fizjonomii osiedla, ponieważ zabudowania kościelne różnią się znacząco pod względem architektonicznym od otaczających je budynków. Proces ten wzbogaca także krajobraz osiedli poprzez wprowadzenie nowych symboli i dominant w przestrzeni osiedlowej (Jażdżewska 2010). Obecność nowych świątyń $\mathrm{w}$ osiedlach i zagospodarowanie otaczających je terenów przyczynia się również do kreowania nowych przestrzeni publicznych o bardziej zindywidualizowanej formie i funkcji (Chmielewski, Mirecka 2001).

We współczesnej Polsce proces sakralizacji osiedli blokowych wydaje się już powoli dobiegać ku końcowi, ponieważ od początku XXI wieku obserwuje się jego stagnację (Jażdżewska 2010). Zmienia się także jego charakter, który zmierza ku sakralizacji sensu largo, ponieważ w sąsiedztwie świątyń powstają inne placówki kościelne: przedszkola, domy opieki, szkoły różnych szczebli, placówki medyczne itp. (ibid.), które wzbogacają wyposażenie osiedli w infrastrukturę społeczną i usługową różnego typu.

Kolejną ważną zmianą zachodzącą $\mathrm{w}$ wielkich socjalistycznych osiedlach mieszkaniowych jest kształtowanie się nowych przestrzeni publicznych. Proces ten następuje głównie na skutek przekształceń niezagospodarowanych dotychczas terenów w obszary o różnych funkcjach właściwych dla osiedlowej przestrzeni publicznej, głównie - jak wcześniej wspomniano - funkcji rekreacyjnej oraz komunikacyjnej (w rozumieniu komunikacji wewnątrzosiedlowej). Część tych terenów do lat 90. XX stulecia była niezagospodarowana, głównie na skutek rezerwowania ich na rozwój infrastruktury społecznej i usługowej, uwzględnianej w pierwotnych założeniach architektoniczno-urbanistycznych osiedli, które nigdy nie zostały zrealizowane. Część zaś to tereny niezagospodarowane celowo, często dość rozległe, pozostawione jako otwarte "przestrzenie międzyblokowe", powstałe na skutek realizacji różnego rodzaju normatywów urbanistycznych związanych z gęstością zabudowy osiedlowej. Tereny te przez swoją rozległość oraz brak czytelnej funkcji nabierały charakteru "przestrzeni niczyich”, a ich obecność w osiedlach była ważną ułomnością tej formy zabudowy (Racoń-Leja 2010).

Prace autorów badających przemiany przestrzenne zachodzące $\mathrm{w}$ wielkich osiedlach mieszkaniowych różnych miast postsocjalistycznych: Warszawy (Chmielewski, Mirecka 2001, Węcławowicz i in. 2003, Bierzyński, Kozłowska 2005, Kozłowski 2005), Łodzi (Adamus 2011, Szafrańska 2010, 2014), Krakowa (Rębowska 1999), Poznania (Ciesiółka 2010), Szczecina (Wojtkun 2004), Katowic (Warchalska-Troll 2012, Komar 2013), Lipska (Kabisch, Grossmann 2013), Pragi (Temelová i in. 2011), Bratysławy (Divinský 
2004), pokazują, że począwszy od lat 90 . tereny te, dotychczas niezagospodarowane lub zagospodarowane w sposób bardzo ubogi, są przekształcane. $\mathrm{W}$ ich miejsce powstają parki, ogólnodostępne boiska do gier zespołowych (często w sąsiedztwie szkół), ogrodzone i nowocześnie wyposażone place zabaw, "skate parki”, skwery z zielenią. Pojawiają się także nowe elementy zagospodarowania i wyposażenia przestrzeni, takie jak fontanny, meble miejskie i inne elementy małej architektury. W miejscach dotychczasowych ciągów pieszo-jezdnych wytyczane są nowe aleje spacerowe i ścieżki rowerowe, nowo projektowane ciągi piesze często uwzględniają potrzeby osób starszych i niepełnosprawnych. Likwiduje się wysokie krawężniki, buduje pochylnie, modernizuje przejścia przez jezdnie. W celu poprawy bezpieczeństwa wprowadza się strefy ruchu uspokojonego, sygnalizację świetlną i dźwiękową, poprawia oświetlenie w miejscach publicznych, a w niektórych osiedlach montuje monitoring (ibid.).

W efekcie tych przeobrażeń zmienia się nie tylko morfologia i fizjonomia terenów, które w osiedlach blokowych stanowily dotąd zaledwie potencjalne przestrzenie publiczne, ale także ich funkcje, które dotąd były ściśle od siebie separowane. Poprawie ulegają ważne walory środowiska mieszkaniowego, decydujące o jego percepcji (por. rozdz. 6 pracy), do których należy bezpieczeństwo, czystość, estetyka, obecność zieleni. Przede wszystkim jednak proces ten przyczynia się do poprawy warunków zamieszkania w osiedlach, ponieważ pozwala na realizację niemożliwych wcześniej w tej przestrzeni sposobów spędzania wolnego czasu, a w konsekwencji sprzyja kontaktom społecznym mieszkańców i przyczynia się do wzrostu ich satysfakcji mieszkaniowej. Pisał o tym m.in. architekt i urbanista J. Gehl (2009) w pracy pt. Życie między budynkami, który na podstawie badań przeprowadzonych w osiedlach dunskich dowiódł, że wygląd i jakość oraz sposób zaplanowania i zagospodarowania przestrzeni publicznych $\mathrm{w}$ środowisku zamieszkania człowieka istotnie wpływa na wszystkie sfery życia, w tym także na jakość i częstotliwość kontaktów społecznych realizowanych w miejscu zamieszkania.

Reasumując stwierdzić można, że przekształcenia przestrzenne zachodzące w osiedlach zarówno o charakterze komercyjnym, jak i niekomercyjnym powodują stopniowe odchodzenie od segregacji funkcji, które było głównym założeniem teoretyków oraz twórców osiedli, i zastępowanie ich zasadą mieszania różnych rodzajów działalności w przestrzeni. Tym samym stwarza to choć częściową szansę na upodobnienie osiedli blokowych do tradycyjnych form organizacji przestrzennej miasta, takich jak ulica, plac, a wraz z nimi powrót do wyraźniejszego wyodrębnienia przestrzeni publicznej, która jest jednym z podstawowych elementów struktury miasta. 


\subsubsection{Przemiany fizjonomiczne}

Konsekwencją przemian morfologicznych i funkcjonalnych zachodzących $\mathrm{w}$ wielkich osiedlach mieszkaniowych są zmiany w ich fizjonomii. Dotyczą one zarówno fizjonomii zabudowy (mieszkaniowej i usługowej), jak i fizjonomii innych elementów krajobrazu, np. terenów zielonych, rekreacyjnych, komunikacyjnych oraz handlowo-usługowych (np. osiedlowych rynków i targowisk). Zmiany fizjonomiczne znacznie rzadziej są przedmiotem badań niż morfologia i funkcje osiedli mieszkaniowych, a wśród nielicznych dotyczących tego zagadnienia dominują prace architektów i urbanistów (Chmielewski, Mirecka 2001, Wojtkun 2004, Rębowska 1999, 2000, Rębowska i in. 2006, Łodziński 2009, Rembarz 2010). W literaturze geograficznej analizą przemian w fizjonomii osiedli zajmowali się m.in. S. Kozłowski (2005), A. Bierzyński, A. Kozłowska (2005), P. Ciesiółka (2010), G. Węcławowicz i in. $(2003,2004)$.

Do najważniejszych zmian w fizjonomii wielkich osiedli zidentyfikowanych w dotychczasowych badaniach należą:

- zmiany $\mathrm{w}$ wyglądzie elewacji budynków mieszkalnych, których efektem jest bogatsza kolorystyka i przełamanie szarości „betonowej pustyni";

- poprawa stanu technicznego budynków (np. poprzez wymianę okien, drzwi i remonty wejść do klatek schodowych);

- przełamanie monotonii krajobrazu i jednolitego wyglądu budynków poprzez omówione już zmiany morfologiczne i funkcjonalne związane $\mathrm{z}$ wprowadzaniem zróżnicowanej architektonicznie nowej zabudowy mieszkaniowej, sakralnej oraz handlowej i usługowej;

- wzrost wielkości powierzchni i poprawa zagospodarowania terenów rekreacyjnych (place zabaw, parki, skwery, boiska);

- zwiększenie wielkości powierzchni i poprawa stanu osiedlowej zieleni.

Ważną determinantą zmian $\mathrm{w}$ fizjonomii osiedli - jak już powiedziano są działania modernizacyjne. Dzięki takim działaniom najdalej idące przemiany fizjonomiczne dokonały się $\mathrm{w}$ wielkich osiedlach wschodnich Niemiec. Tam też wskutek możliwości zaangażowania dużych środków finansowych pochodzących z budżetu centralnego stosowano najbardziej kosztochłonne projekty, np. rozluźnianie zabudowy poprzez wyburzanie wysokich budynków mieszkalnych, obniżanie wysokości budynków 10-12-kondygnacyjnych przez wyburzanie kondygnacji wyższych niż piąta, budowa zewnętrznych szybów windowych i instalacja wind osobowych w budynkach 5-kondygnacyjnych, które dotychczas pozbawione były tego udogodnienia, przebudowa istniejących (i dobudowa nowych) tarasów 
oraz balkonów w mieszkaniach czy też poprawa wyglądu fasad budynków przez zastosowanie tzw. malarstwa iluzorycznego (fot. 1, 2) (Łodziński 2009, Czado 2012, Kabisch, Grossmann 2013). Przemiany te są szeroko opisane w literaturze jako przykład, z jednej strony działań najbardziej zaawansowanych w skali całej postsocjalistycznej Europy, z drugiej zaś działań, których rezultaty nie do końca spełniły pokładane w nich oczekiwania (Stanilov 2007, Łodziński 2009, Rembarz 2010). Odpływ mieszkańców z tych osiedli bowiem, jakkolwiek znacznie zmniejszył swoją skalę po 2000 roku, trwa nadal. Wiąże się to jednak ze specyfiką państwa zjednoczonego, którego część zachodnia wciąż charakteryzuje się lepszymi warunkami życia niż część wschodnia.

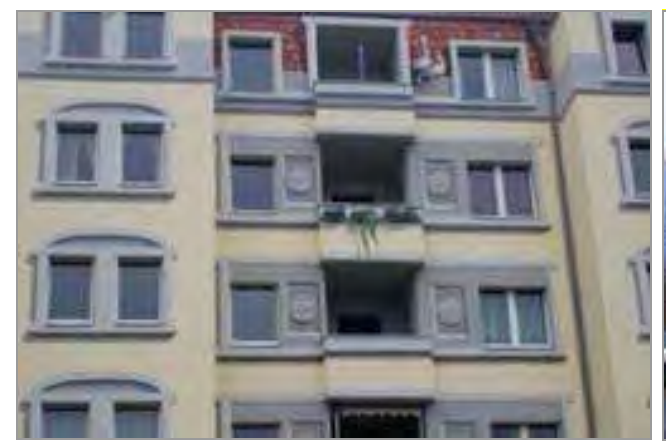

Fot. 1. Przykład zastosowania tzw. malarstwa iluzorycznego imitującego detal architektoniczny, zieleń, ptaki, dachówki itp. w celu wizualnego uatrakcyjnienia płaskiej elewacji budynku z wielkiej płyty w osiedlu Hellersdorf w Berlinie (źródło: Łodziński 2009)

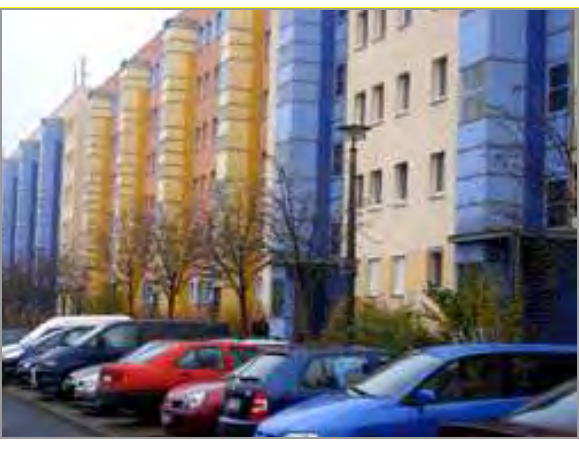

Fot. 2. Przykład modernizacji budynku w osiedlu Hellersdorf w Berlinie z odnowioną elewacją i wejściami do klatek schodowych oraz dobudowanymi przy każdym wejściu, zewnętrznymi szybami windowymi (źródło: Łodziński 2009)

Omówione powyżej zmiany w morfologii oraz fizjonomii osiedli, jeśli mają skoordynowany i planowy charakter oraz jednego inwestora (np. spółdzielnia mieszkaniowa, władze lokalne, wspólnota lub inna instytucja zarządzająca zasobem mieszkaniowym) zmieniając wygląd osiedli, czynią $\mathrm{z}$ nich bardziej przyjazne środowisko mieszkaniowe. Poprawiają ich społeczny odbiór, a wśród mieszkańców wzmacniają poczucie więzi z zamieszkiwanym obszarem. Niestety zdarza się, że zmiany te są chaotyczne i przypadkowe, a mnogość inwestorów potęguje chaos przestrzenny i architektoniczny, który nie sprzyja ani estetyzacji osiedli ani wzmacnianiu więzi mieszkańców z nimi. Niekiedy też prowadzi do nadmiernego zagęszczenia zabudowy, tym samym pozbawiając osiedla ich niewątpliwego waloru, jakim jest duża ilość terenów zielonych. 


\subsection{Podsumowanie}

Na podstawie analizy omówionych przemian zarówno społecznych, jak i przestrzennych zachodzących $\mathrm{w}$ postsocjalistycznych wielkich osiedlach mieszkaniowych stwierdzono, że przebiegają one w różnym tempie w różnych krajach, miastach, a nawet w poszczególnych osiedlach. Różnią się też częstotliwością występowania. Niektóre z nich mają charakter powszechny, inne występują często, lecz nie we wszystkich osiedlach, a niektóre są incydentalne, co jest związane ze specyfiką osiedli lub miast, w których są zlokalizowane. Systematyzacja tych procesów wymaga zatem uwzględnienia różnic w częstotliwości ich występowania.

Do najważniejszych konsekwencji zidentyfikowanych przemian zarówno tych, które już się dokonały, jak i tych, które wciąż się dokonują w wielkich osiedlach miast postsocjalistycznych, należą:

1) utrzymanie relatywnie wysokiego statusu społecznego mieszkańców, ponieważ po kilkunastu latach transformacji, mimo odpływu z tych osiedli ludności zamożniejszej i o wyższych aspiracjach mieszkaniowych, wciąż charakteryzują się one relatywnie wysokim statusem społecznym, głównie na skutek napływu nowych mieszkańców, którzy nabywają mieszkania na rynku wtórnym, jak i zasiedlania mieszkań $\mathrm{w}$ nowych budynkach nabywanych na rynku pierwotnym. Przeczy to zapowiadanej w latach 90. degradacji społecznej tych osiedli $\mathrm{i}$ jest bardzo istotne $\mathrm{z}$ punktu widzenia ich przyszłości. Wyniki badań socjologicznych mówią bowiem (por. Borowik 2007), że percepcja prestiżu mieszkaniowego określonego obszaru w mieście $\mathrm{w}$ większym stopniu uzależniona jest od składu społecznego mieszkańców, niż od jego formy architektonicznej i urbanistycznej;

2) przełamanie monofunkcyjnego charakteru wielkich osiedli mieszkaniowych, określanego w literaturze jako stan niedorozwoju funkcji miejskich, który stanowił jedną z najważniejszych ułomności tej formy urbanistycznej. W wyniku tego procesu wielkie osiedla mieszkaniowe stały się obszarami, na których zrealizowane mogą zostać wszystkie podstawowe (a nawet ponadpodstawowe) potrzeby mieszkańców i które przyciągają swą ofertą także osoby z innych obszarów miasta. Można zatem stwierdzić, że jeśli jedną z głównych cech wyróżniających przestrzeń miejską w ogólnej przestrzeni geograficznej jest jej wielofunkcyjność, to $\mathrm{w}$ okresie transformacji ustrojowej nastąpił proces, który można określić jako „umiastowienie wielkich osiedli", czyli wypełnienie tych monofunkcyjnych dotychczas terenów różnymi funkcjami miejskimi;

3) estetyzacja zabudowy i poprawa stanu zagospodarowania publicznych i półpublicznych przestrzeni międzyblokowych, poprzez 
wprowadzenie nieobecnego wcześniej koloru, detalu architektonicznego i elementów małej architektury. Proces ten anonimowej dotychczas przestrzeni osiedli blokowych nadaje wyrazistości, charakteru i znaczenia, czyli cech niezbędnych dla wytworzenia walorów miejsca. Nie jest on jeszcze zaawansowany w stopniu wystarczającym, ale jak pokazują liczne badania empiryczne prowadzone wśród mieszkańców osiedli (omówione w kolejnym, 6. rozdziale pracy) jest przez nich dostrzegany i, zmieniając społeczny odbiór tego środowiska mieszkaniowego, wzmacnia identyfikację z nim oraz podnosi jego atrakcyjność mieszkaniową, co w przyszłości zapobiec może odpływowi mieszkańców.

Analizując wymienione przemiany i odnosząc się do dorobku dotychczasowej literatury wyodrębniono $\mathrm{w}$ niniejszej pracy trzy zasadnicze grupy czynników, które je determinują. Pierwsza grupa to czynniki działające na poziomie makro, które mają swoje źródło $\mathrm{w}$ przemianach zachodzących w skali globalnej i europejskiej, w tym w szczególności w omówionych już procesach transformacji ustrojowej. Druga to czynniki działające w skali mezo, czyli w skali miejskiej, trzecia natomiast to czynniki działające na poziomie mikro, związane ze specyfiką poszczególnych osiedli. Ich działanie zilustrować można modelem zaproponowanym przez F. Wassenberga i in. (2004), który w niniejszym opracowaniu został zmodyfikowany dla miast socjalistycznych, ze szczególnym uwzględnieniem roli transformacji ustrojowej (rys. 22).

W pierwszej grupie czynników determinujących przemiany zachodzące $\mathrm{w}$ wielkich postsocjalistycznych osiedlach mieszkaniowych największe znaczenie mają procesy uruchomione $\mathrm{w}$ wyniku transformacji ustrojowej, do których należą:

- zmiana polityki mieszkaniowej państwa i niemal całkowite wycofanie się z roli "dostarczyciela" i dysponenta mieszkań, które było główną cechą socjalistycznego modelu mieszkalnictwa;

- powrót mechanizmów rynkowych $\mathrm{w}$ gospodarce, $\mathrm{w}$ tym przede wszystkim uwolnienie rynku mieszkaniowego oraz zmiana głównego kryterium alokacji przestrzennej i rywalizacji na rynku mieszkaniowym z politycznego na ekonomiczny;

- powrót znaczenia renty gruntowej i "odrodzenie" się miejsca jako dobra rynkowego;

- przekształcenia w strukturze własności, w tym prywatyzacja znacznej części zasobów mieszkaniowych;

- uruchomienie rynku kredytów hipotecznych, który pozwala na realizację aspiracji mieszkaniowych poza systemem budownictwa wznoszonego z udziałem środków publicznych; 

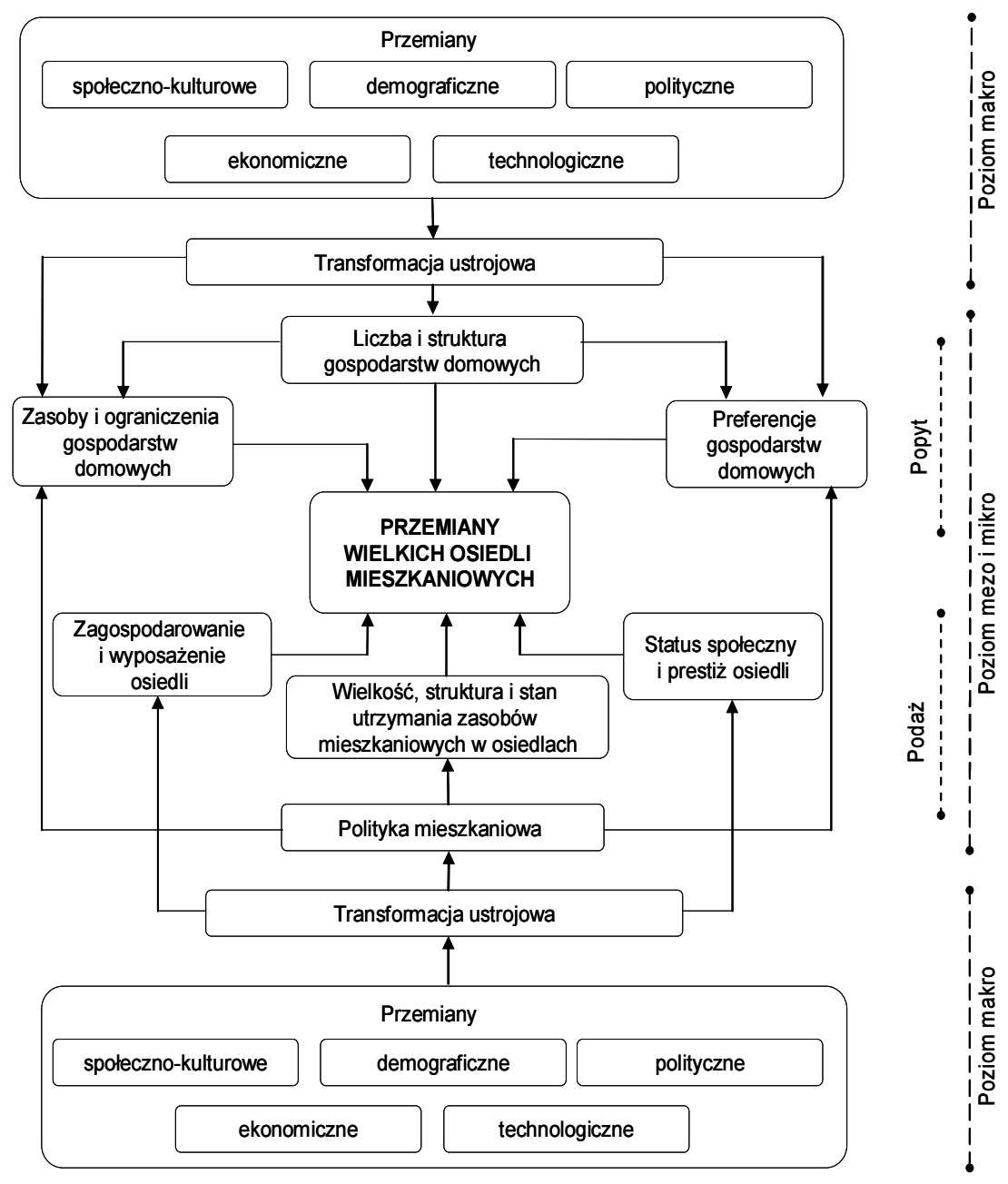

Rys. 22. Determinanty przemian wielkich osiedli mieszkaniowych w miastach postsocjalistycznych

Źródło: opracowanie własne na podstawie

F. Wassenberg $i$ in. (2004) - zmodyfikowany

- pojawienie się $\mathrm{w}$ miastach nowych obszarów rezydencjalnych o relatywnie wysokim prestiżu mieszkaniowym, przede wszystkim w wyniku suburbanizacji oraz rozwoju budownictwa tzw. deweloperskiego, a także rewitalizacji zasobów mieszkaniowych położonych w centrach miast;

- zahamowanie napływu migracyjnego do miast i wkroczenie ich w fazę kurczenia się demograficznego (depopulacji), które zmniejszyło presję na rynku mieszkaniowym w miastach; 
- przekształcenia struktury społecznej, przede wszystkim silne rozwarstwienie ekonomiczne i podział społeczeństwa na beneficjentów przemian ustrojowych oraz przegranych transformacji, który zgodnie z teorią "akumulacji przewag” będzie ulegał dalszemu pogłębieniu;

- wzrost aspiracji mieszkaniowych i zwiększenie się rezydencjalnej mobilności, które nastąpiły na skutek przemian w świadomości i wzrostu siły nabywczej gospodarstw domowych, należących do grupy beneficjentów transformacji.

Wśród czynników działających w szerszej skali, na które nakładają się wymienione procesy transformacji ustrojowej i które pośrednio bądź bezpośrednio wpływają na przemiany wielkich osiedli mieszkaniowych w miastach postsocjalistycznych, największe znaczenie mają przemiany społeczno-kulturowe i demograficzne, w tym przede wszystkim przemiany stylu życia i modelu rodziny związane $\mathrm{z}$ drugim przejściem demograficznym. Przejawiają się one w znaczącym spadku liczby urodzeń, starzeniu się społeczeństwa oraz wzroście liczby i udziału małych, jedno- i dwuosobowych, gospodarstw domowych, a w konsekwencji zmianie potrzeb mieszkaniowych zarówno w skali mikro (w zakresie wielkości i lokalizacji mieszkań), jak i w skali makro (kształtowanie się popytu na określony typ środowiska mieszkaniowego).

Do grupy determinant działających $\mathrm{w}$ skali pojedynczych miast (lub aglomeracji) należą natomiast:

a) po stronie popytowej:

- liczba i struktura społeczno-demograficzna mieszkańców miasta oraz liczba i struktura gospodarstw domowych w mieście, a także obecny stan zaspokojenia ich potrzeb mieszkaniowych,

- zasoby i ograniczenia, przede wszystkim ekonomiczne, czyli poziom zamożności i siła nabywcza (lub zdolność kredytowa) gospodarstw domowych działających na lokalnym rynku mieszkaniowym, jak też ich wiedza, umiejętności i wykształcenie związane z pozycją na lokalnym rynku pracy,

- preferencje i aspiracje mieszkaniowe gospodarstw domowych oraz ich skłonność do ruchliwości rezydencjalnej, a także preferowane przez nie wzory oraz style życia związane z zamieszkiwaniem;

b) po stronie podażowej:

- wielkość i stan zasobów mieszkaniowych w wielkich osiedlach, w szczególności w relacji do innych zasobów mieszkaniowych miasta,

- warunki zamieszkania oferowane $\mathrm{w}$ wielkich osiedlach, w tym także $\mathrm{w}$ relacji do warunków oferowanych $\mathrm{w}$ pozostałych zasobach mieszkaniowych miasta, 
- oferta lokalnego rynku nieruchomości, jej zróżnicowanie oraz dostosowanie do potrzeb i możliwości nabywczych mieszkańców,

- status społeczny i prestiż mieszkaniowy wielkich osiedli związane $\mathrm{z}$ pozycją tej formy habitatu $\mathrm{w}$ strukturze społeczno-przestrzennej miasta;

c) lokalna polityka mieszkaniowa realizowana w mieście zarówno specjalna, ukierunkowana na przemiany wielkich osiedli, jak i obejmująca inne tereny (w tym np. programy rewitalizacji obszarów centralnych, które obok suburbiów i nowych inwestycji deweloperskich stanowić mogą potencjalny obszar odpływu mieszkańców $\mathrm{z}$ wielkich osiedli).

Wzrost samodzielności miast, jaki nastąpił po zmianie ustroju powoduje, że ważną determinantą przemian zachodzących w ich strukturze wewnętrznej, w tym także w strefie wielkich osiedli, jest pozycja miasta w sieci osadniczej kraju (tu widoczne stało się uprzywilejowanie stolic oraz ich miast ościennych) oraz wielkość miasta i jego lokalizacja. Duże znaczenie mają również: kondycja ekonomiczna i rynek pracy, które niekiedy znacząco różnią się w poszczególnych ośrodkach miejskich, a także kondycja pozostałych zasobów mieszkaniowych uzależniona często od czynników historycznych, sięgających zarówno okresu rozwoju przestrzennego miasta, jak i czasów poprzedniego ustroju.

Do ostatniej z grup determinant działających $\mathrm{w}$ skali pojedynczych osiedli, które decydują o różnych ścieżkach przekształceń struktur osiedlowych w tych samych miastach i krajach, zaliczyć można:

a) determinanty urbanistyczne, do których należą:

- urbanistyczno-architektoniczne walory osiedla obejmujące zastosowane układy zabudowy, jej gęstość, wysokość i poziom zróżnicowania, a także wielkość osiedla, przy czym cechy te, ze względu na centralne planowanie najczęściej są pochodną okresu budowy osiedla,

- wyjściowa jakość mieszkań obejmująca ich strukturę i wielkość oraz jakość ich wykonawstwa, które podobnie jak projekt urbanistyczny w dużej mierze uzależnione są od okresu budowy osiedla,

- lokalizacja osiedla w przestrzeni miasta oraz jego dostępność komunikacyjna, w tym zwłaszcza w odniesieniu do publicznego transportu szynowego (takich jak: metro, szybki tramwaj miejski, kolej miejska itp.), który w ostatniej dekadzie znacznie zyskał na znaczeniu w miastach,

- nasycenie osiedla infrastrukturą społeczną i handlowo-usługową oraz jej jakość, w tym także poziom jej dostosowania do struktury społeczno-demograficznej osiedla i aktualnych potrzeb mieszkańców, 
- ilość terenów zielonych w przestrzeni osiedla i stan ich zagospodarowania,

- stan utrzymania przestrzeni publicznych i półpublicznych w osiedlu,

- stan utrzymania i fizjonomia budynków,

- struktura własności mieszkań w osiedlu,

- stan utrzymania mieszkań, który ze względu na duży udział własności prywatnej w osiedlach miast postsocjalistycznych najczęściej jest dobry lub bardzo dobry;

b) determinanty społeczne, które obejmują:

- strukturę społeczno-demograficzną i narodowościową mieszkańców, ich status społeczno-zawodowy oraz poziom zamożności i źródła dochodów;

- poziom identyfikacji z miejscem zamieszkania i skłonność do migracji, które decydują o tempie wymiany migracyjnej $\mathrm{w}$ osiedlu oraz poczuciu odpowiedzialności i dbałości mieszkańców o otaczającą przestrzeń wspólną;

c) prestiż mieszkaniowy osiedla i jego reputacja ukształtowane przez wymienione czynniki urbanistyczne oraz społeczne;

d) jakość zarządzania osiedlem oraz zakres dotychczas zrealizowanych działań modernizacyjnych mających na celu odnowę osiedla.

Odnosząc ustalenia poczynione $\mathrm{w}$ tej części pracy do obecnych w literaturze światowej koncepcji przemian środowisk mieszkaniowych wykorzystywanych $\mathrm{w}$ analizie przemian wielkich osiedli $\mathrm{w}$ miastach zachodnioeuropejskich (por. rozdział 2.3) stwierdzić można, że w wielkich osiedlach miast postsocjalistycznych nie obserwuje się lub obserwuje $\mathrm{w}$ bardzo niewielkim zakresie (tylko $\mathrm{w}$ nielicznych osiedlach lub $\mathrm{w}$ ich fragmentach) zjawisko określane jako spirala upadku lub syndrom wielkiego osiedla, czyli procesów silnej i wielopłaszczyznowej degradacji społecznej, fizycznej oraz ekonomicznej, typowych dla osiedli w miastach Europy Zachodniej.

Nie następują w nich również na tak dużą skalę, jak w krajach zachodnioeuropejskich, procesy filtracji związane z odpływem mieszkańców o wyższym statusie. Te natomiast, które zachodzą powodowane są nie tyle degradacją osiedli, lecz pojawieniem się nowych bardziej atrakcyjnych obszarów zamieszkania, nieobecnych w przestrzeni miast tej części Europy przed zmianą ustroju oraz możliwością realizacji swoich potrzeb mieszkaniowych poza systemem budownictwa subsydiowanego przez państwo (w postaci kredytów hipotecznych), która pojawiła się dopiero po zmianie ustroju. Ważną rolę $\mathrm{w}$ tym procesie miał zatem oczywisty $\mathrm{w}$ tej sytuacji wzrost silnie tłumionych $\mathrm{w}$ poprzednim ustroju aspiracji mieszkaniowych oraz naturalne zużywanie się zarówno techniczne, jak i moralne osiedlowej substancji mieszkaniowej wynikające z jej cyklu życia. A zatem dokonujące 
się $\mathrm{w}$ osiedlach procesy filtracji mają charakter ewolucyjny i całkowicie naturalny związany ze starzeniem się i zużywaniem określonej substancji mieszkaniowej, nie są zaś, jak przewidywano, masowym exodusem mieszkańców, który zamieni je szybko w obszary zdegradowane.

Nie znalazły również potwierdzenia w miastach posocjalistycznych teorie o charakterze deterministycznym, które źródła ewentualnych problemów, jakie mogą być notowane $\mathrm{w}$ wielkich osiedlach upatrują głównie $\mathrm{w}$ ich niskich walorach urbanistycznych i wadliwym planie zabudowy (por. Newman 1972, Coleman 1985). Teorie te nie potwierdziły się głównie dlatego, że - jak wynika z współczesnych ustaleń architektów i urbanistów (Wojtkun 2004) - układ przestrzenny osiedli sam w sobie nie generuje ani negatywnych ani pozytywnych zachowań społecznych (a jeśli tak się dzieje, to $\mathrm{w}$ bardzo niewielkim zakresie), a występujące $\mathrm{w}$ osiedlach zjawiska patologii społecznej mają różny charakter i wynikają z różnych przesłanek. Jak podają K. Dekker i in. (2011), pojawienie się problemów społecznych w osiedlach krajów takich, jak Francja, Holandia, Szwecja czy Dania, ma główne źródło $\mathrm{w}$ przestrzennej koncentracji tanich socjalnych mieszkań, a w konsekwencji koncentracji ludności o niskich dochodach oraz dużej rotacji mieszkańców (ibid., s. 480), czyli czynnikach, które nie występowały $\mathrm{w}$ mieście socjalistycznym i nie występują w postsocjalistycznym, gdzie osiedla te w zdecydowanej większości obejmują już prywatny zasób mieszkaniowy.

Konkludując, powyższe ustalenia pozwalają na stwierdzenie, że zarówno istniejące wcześniej uwarunkowania ustrojowe, które przy zachowaniu tej samej formy urbanistycznej decydowały o zupełnie innym składzie społecznym mieszkańców osiedli, jak i sam proces transformacji (w tym zwłaszcza szybkie tempo zachodzących zmian i równoczesne nakładanie się nań procesów o charakterze globalnym), stanowią dziedzictwo, które ma charakter unikatowy $\mathrm{i}$ istotnie determinuje procesy zachodzące $\mathrm{w}$ osiedlach miast postsocjalistycznych, a tym samym odróżnia je od procesów zachodzących w miastach zachodnioeuropejskich. 



\section{PERCEPCJA I WALORYZACJA WIELKICH OSIEDLI MIESZKANIOWYCH W MIEŚCIE POSTSOCJALISTYCZNYM}

\subsection{Teoretyczne podstawy badań percepcji i waloryzacji środowiska mieszkaniowego}

Relacje między człowiekiem a środowiskiem (w zależności od ujęcia rozumiane jako relacje człowiek-przestrzeń lub człowiek-miejsce) są jednym z głównych problemów badawczych geografii od początku istnienia tej dyscypliny (Maik 2006).

Należące do tego nurtu badań studia nad postrzeganiem i waloryzowaniem przestrzeni miejskiej, w tym także przestrzeni mieszkaniowej, współcześnie stanowią jeden z głównych problemów badawczych geografii społecznej miast (Lisowski 2008). Studia te rozwinęły się na gruncie geografii behawioralnej, wykorzystując głównie dorobek neobehawioryzmu (por. Walmsley, Lewis 1997) oraz geografii percepcji - podejść badawczych, które zajmują się analizą wyobrażeń i zachowań człowieka w celu wyjaśniania zjawisk i procesów społecznych zachodzących w przestrzeni (Lisowski 1990).

Geografia percepcji jest subdyscypliną mieszczącą się na pograniczu podejść behawioralnych i humanistycznych (Bartnicka 1989). W obu tych podejściach badacz próbuje wniknąć $w$ świadomość jednostki i jej relacje ze środowiskiem, stosując podejście rozumiejące ${ }^{136}$. I mimo że - jak podaje A. Lisowski (2007, s. 24) - współcześnie w geografii dostrzega się ambiwalentny stosunek do „percepcji”, który można nawet określić „kryzysem zau-

136 Podejście to jest pochodną zaproponowanego przez M. Webera postulatu rozumienia (Verstehen), które rozwinięte zostało przez F. Znanieckiego w postaci tzw. współczynnika humanistycznego - podejścia badawczego, zgodnie z którym, aby zrozumieć badanych trzeba umieć postawić się na ich miejscu i patrzeć na rzeczywistość, jak pisał F. Znaniecki (1938), „oczyma jej uczestników” stosując „podejście subiektywne”, nie zaś „absolutnego obserwatora" stosującego "podejście obiektywne". Proponując ten postulat F. Znaniecki jako jeden z pierwszych na świecie zastosował metodę badania dokumentów osobistych i stał się prekursorem stosowanej do dziś metody, jaką jest biografistyka, współcześnie wykorzystywanej w pracach z zakresu geografii humanistycznej (np. Kaczmarek 2005). 
fania", to jednak wciąż powstają niezliczone prace empiryczne identyfikujące wyobrażenia przestrzeni miejskiej.

Inspiracją do podejmowania studiów nad postrzeganiem i waloryzowaniem przestrzeni miejskiej w geografii była klasyczna już praca amerykańskiego urbanisty K. Lyncha Image of the City z 1960 roku, a także nieco późniejsze P.R. Goulda (1966), R.M. Downsa (1970) oraz D. Pococka i R. Hudsona (1978), zaadaptowane na polski grunt badawczy i szeroko omówione w opracowaniach m.in. B. Domańskiego i H. Libury (1986), H. Libury (1988), M. Bartnickiej (1986, 1989), G. Prawelskiej-Skrzypek (1990), Z. Rykla (1999), B. Jałowieckiego (2000), J. Słodczyka (2001), S. Mordwy (2003). Odwoływali się do niej także inni badacze, np. E. Szkurłat (2004), P. Tobiasz-Lis (2013) oraz autorzy prac zawartych $\mathrm{w}$ opracowaniach zbiorowych pod red. M. Madurowicza $(2007,2010)^{137}$.

Zaproponowana przez K. Lyncha prekursorska metoda badania wyobrażeń przy użyciu odręcznych szkiców znalazła licznych kontynuatorów i przez lata inspirowała (i wciąż inspiruje) wielu geografów (por. Knox, Pinch 2010, s. 226). Mimo jednak fundamentalnego znaczenia dla badań percepcji przestrzeni miejskiej, dorobek tego autora ma ograniczone zastosowanie w studiach dotyczących percepcji środowiska mieszkaniowego, ponieważ skupia się na odzwierciedlaniu fizycznej struktury miasta, pomijając niezwykle ważne $\mathrm{w}$ tym przypadku odczucia, postawy i preferencje mieszkańców. Ograniczenia te zaowocowały powstaniem kolejnych prac, których autorzy w znacznie większym stopniu uwzględnili aspekty wartościujące i symboliczne. Należy do nich m.in. praca P.R. Goulda z 1966 roku, dotycząca preferencji mieszkaniowych, R.M. Downsa (1970), który podjął się uporządkowania dorobku $\mathrm{w}$ dziedzinie percepcji przestrzeni geograficznej, wyróżniając trzy aspekty badań percepcyjnych: strukturalny, wartościujący i preferencyjny, oraz opracowanie D. Pococka i R. Hudsona (1978), w którym przedstawione zostało modelowe ujęcie procesu percepcji środowiska ${ }^{138}$.

137 Teoretyczno-metodologiczne aspekty percepcji są szeroko omówione w dostępnej literaturze, a ich analiza nie jest celem niniejszej pracy, toteż przedstawione zostały w sposób selektywny, jedynie w odniesieniu do zamieszkiwanego środowiska.

138 Według modelu percepcji D. Pococka i R. Hudsona (1978) percepcja jest procesem, w wyniku którego powstaje wyobrażenie. Na procesy percepcji wpływ mają trzy elementy: bieżąca informacja, bezpośrednio odbierana przez postrzegającego, wiedza zgromadzona w oparciu o wcześniejsze doświadczenie oraz kontekst przestrzenny, z którego środowisko jest postrzegane. Te trzy powiązane ze sobą rodzaje bodźców środowiskowych oddziałujących na obserwatora są przez niego odbierane i organizowane w postaci wyobrażenia przestrzennego. Wyobrażenie, które powstaje $\mathrm{w}$ wyniku percepcji jest uporządkowaną, uproszczoną reprezentacją otoczenia i schematycznym jego obrazem, a równocześnie wyrazem indywidualności postrzegającego oraz odbiciem wspólnych cech kulturowych i społecznych, które wpływają na wyobrażenia jednostek. 
Geograficzne badania percepcji odnoszą się do różnych skal przestrzennych (od lokalnej, poprzez regionalną, krajową, na światowej kończąc), a sama geografia percepcyjna jest dziedziną badań, której przedmiot jest bardzo szeroki i bardzo różnie ujmowany przez uprawiających ją badaczy ${ }^{139}$, toteż $\mathrm{w}$ niniejszym opracowaniu skupiono się na relacjach człowieka z jego środowiskiem mieszkaniowym ${ }^{140}$. Przyjmując klasyfikację badań percepcyjnych R.M. Downsa (1970) skupiono się na dwóch ich aspektach: wartościującym, związanym $z$ oceną środowiska na podstawie wyobrażeń o nim i emocjonalnymi związkami z zamieszkiwanym terytorium, oraz preferencyjnym, zawierającym preferencje przestrzenne (tu: preferencje mieszkaniowe), powstałe na podstawie wiedzy i oceny środowiska141. Przyjmując zaś rozróżnienie wyobrażeń dokonane przez D. Pococa i R. Hudsona (1978), praca opiera się na analizie ich komponentu wartościującego, który zawiera najbardziej istotne $\mathrm{z}$ punktu widzenia badania aspekty wyobrażeń: ocenę percypowanego środowiska, emocjonalne $z$ nim związki oraz postawy i predyspozycje do zachowań wobec niego. Ich efektem mogą być decyzje migracyjne $\mathrm{i}$ zachowania przestrzenne jednostek $\mathrm{w}$ użytkowanym przez nie środowisku mieszkaniowym ${ }^{142}$.

Teoretyczne inspiracje do rozważań na temat relacji człowieka z otaczającą go przestrzenią geografowie zajmujący się badaniem percepcji czerpią także z prac prekursorów geografii humanistycznej E. Relpha (1976) i Y.F. Tuana (1971) oraz z dorobku polskiej socjologii miasta, w tym głównie z prac twórcy założeń kulturalizmu F. Znanieckiego (1938) oraz jego kontynuatora A. Wallisa $(1977,1990)$. Ważnym źródłem inspiracji dla badań percepcji w geografii jest także dorobek psychologii środowiskowej, szeroko omówiony m.in. w pracach A. Bańki (2002) oraz M. Lewickiej (2012).

139 O konsekwencjach różnych sposobów rozumienia pojęcia percepcji oraz teoretycznej i metodologicznej słabości tego nurtu badań w geografii szeroko pisał A. Lisowski (2007).

140 Badania percepcji przestrzeni mieszkaniowej nie zawsze odnoszą się do zamieszkiwanego terytorium, mogą bowiem obejmować percepcję całej struktury rezydencjalnej miasta i jej społeczno-przestrzennego zróżnicowania. Na użytek niniejszej pracy skupiono się jednak na percepcji własnego środowiska mieszkaniowego.

141 Wyróżniony przez R.M. Downsa (1970) trzeci aspekt strukturalny (opisowy) koncentruje się na odzwierciedlaniu fizycznej struktury środowiska, a następnie analizowaniu zgodności tak powstałego obrazu ze stanem rzeczywistym.

142 D. Pocock i R. Hudson wyróżnili trzy komponenty wyobrażeń będących rezultatem procesu percepcji. Oprócz wartościującego, do którego odwołuje się niniejsza praca, także komponent informacyjny (opisowy), zawierający wyobrażenia dotyczące fizycznej struktury środowiska (skład, rozmieszczenie morfologia) i stanowiący podstawę do identyfikacji różnic między wyobrażeniami o nim a jego obiektywną formą. Także komponent określany jako przewidujący, który odnosi się do pożądanej struktury i wartości percypowanego środowiska i zawiera oczekiwania w zakresie zmian lub ustabilizowania stanu aktualnego (Pocock, Hudson 1978). 
Według A. Wallisa (1990) między człowiekiem i przestrzenią zachodzą cztery główne procesy: postrzeganie, wartościowanie, kształtowanie i użytkowanie. Przyjmując perspektywę tego autora przestrzeń pełna jest znaczeń i symboli, jest doświadczana i naznaczana. Analizę relacji pomiędzy człowiekiem a środowiskiem mieszkaniowym A. Wallis (1977) oparł na stworzonej przez siebie koncepcji potrzeb jednostki i rodziny realizowanych w środowisku zamieszkania. Koncepcja ta oparta jest na teorii podstawowych potrzeb, do realizacji których dążą zarówno jednostki, jak i całe społeczności. Jak podaje ten autor, najbardziej istotnymi potrzebami realizowanymi w osiedlach mieszkaniowych są: potrzeba bezpieczeństwa, oddźwięku emocjonalnego, realizacji ról społecznych i prestiżu.

Według badacza osiedli J. Turowskiego (1979), autora koncepcji badania związków jednostek i grup ze środowiskiem mieszkaniowym rozpatrywanych na gruncie założeń kulturalistycznych, między środowiskiem mieszkaniowym a świadomym podmiotem zachodzi stosunek rozpoznawania, odczytywania, przeżywania, a przede wszystkim oceniania (waloryzowania), które analizować można jako kolejne "etapy" czy też „składniki” procesu percepcji.

Według innych autorów natomiast (Bartoszek $\mathrm{i}$ in. 1997) percepcja przestrzeni jest punktem wyjścia $\mathrm{w}$ procesie jej adaptowania, przyswajania i w rezultacie kształtowania. W ich pracy czytamy, że „w szczególnym procesie przeobrażania przestrzeni ludzie przypisują swoim wytworom funkcje, sens i znaczenia. Nadawanie sensu, znaczeń i funkcji mieszkaniom i budowlom powoduje, że ich użytkownicy stale odczytują - najczęściej w sposób nie w pełni świadomy - pewne kody i szyfry. A zatem mieszkanie, dom, miasto i rozmaite ich przestrzenie stają się komunikatem znakowym dla mieszkańców [...]. Kolejne znaki są przez nich dostrzegane, klasyfikowane, porządkowane, oceniane i dopiero na tej podstawie ludzie podejmują działania codzienne" (Bartoszek i in. 1997, s. 13). Społeczny odbiór zamieszkiwanej przestrzeni jest zatem sekwencją określonych wrażeń zmysłowych i czynności intelektualnych, które w efekcie prowadzą do określonych zachowań (rys. 23).

Jak podają B. Jałowiecki i M. Szczepański (2006, s. 373), „klasyfikowanie, porządkowanie i ocenianie przestrzeni miejskiej przebiega mechanicznie, niemal bezrefleksyjnie, nie zmienia to jednak faktu, iż mieszkańcy są stałymi - krytycznymi i życzliwymi zarazem - czytelnikami poszczególnych elementów przestrzeni, która ich otacza [...], a codzienne i stałe jej odczytywanie prowadzi do powstania $\mathrm{w}$ umysłach ludzi trwałych obrazów, przekonań, stereotypów i wyobrażeń". Jednym z rezultatów procesu percepcji przestrzeni jest według tych autorów autoocena miejsca i zajmowanej w nim pozycji przestrzennej, tzw. pozycji ekologicznej, która świadomie lub nie, stale jest porównywana z miejscami przypisanymi innym jednostkom 
lub grupom. Porównywanie to prowadzi do utrwalenia stereotypów o "złych" i "dobrych" dzielnicach, "lepszych" i "gorszych" miejscach zamieszkania. Skutkiem tego może być poczucie relatywnego uprzywilejowania lub upośledzenia oraz mitologizowania pewnych miejsc i przestrzeni, co nie zawsze $w$ pełni odpowiada rzeczywistości, lecz jest wyrazem powstałych wcześniej i utrwalonych wyobrażeń czy stereotypów.

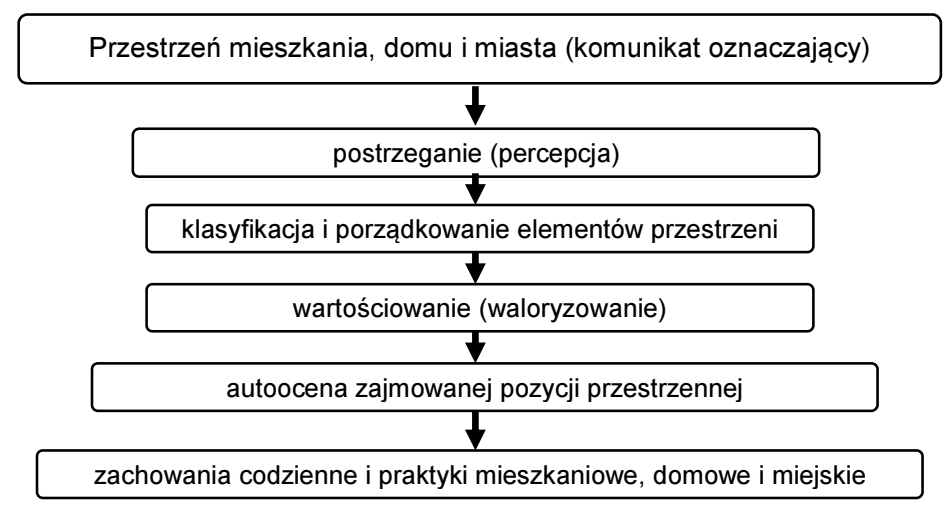

Rys. 23. Społeczny odbiór zamieszkiwanej przestrzeni Źródło: opracowanie własne na podstawie A. Bartoszek i in. (1997) oraz B. Jałowiecki i M. Szczepański (2006)

W przywołanych ujęciach waloryzacja i ocena najbliższej przestrzeni (osiedla, dzielnicy, strefy miejskiej) oraz zajmowanego miejsca i związanej z nim pozycji ekologicznej koncentruje się na pięciu podstawowych formach ładu (Bartoszek i in. 1997, s. 15):

1) ład urbanistyczno-architektoniczny, związany z kompozycyjną zawartością osiedla, kwartału czy zespołu, jego czytelnością, logiką, ulokowaniem domów, ich kształtem i wielkością, usytuowaniem terenów zielonych, sklepów, punktów usługowych, obiektów małej architektury, przebiegiem dróg i ścieżek. Ład ten w odniesieniu do miasta i osiedla wyrażać można za pomocą następujących par opozycji: zwarte - rozproszone, uporządkowane - chaotyczne, czytelne - nieczytelne, kameralne - przytłaczające, niska zabudowa - wysoka zabudowa, nasycenie małą architekturą - brak nasycenia małą architekturą;

2) ład funkcjonalny, który wiąże się z walorami użytkowymi osiedla, $\mathrm{z}$ nasyceniem w punkty usługowe, sklepy, kluby, kawiarnie, ośrodki zdrowia, żłobki, przedszkola, szkoły, place zabaw. Ład ten ujmują następujące pary opozycji: nasycenie infrastrukturą - nienasycenie 
infrastrukturą, dobre funkcjonowanie infrastruktury - złe funkcjonowanie infrastruktury;

3) ład estetyczny, czyli uroda miejsca i przestrzeni, jej czystość i schludność, barwność, symbolika ułatwiająca orientację i sprawne poruszanie się. Ład ten opisują następujące pary opozycji: ładne - brzydkie, czyste - brudne, radosne - posępne, kolorowe - szare, stylowe - bez stylu, bogata szata informacyjna - uboga szata informacyjna;

4) ład psychospołeczny oparty na sieci stosunków społecznych, wyrażających się więziach sąsiedzkich lub ich braku, we wzajemnym do siebie nastawieniu bliższych i dalszych sąsiadów, w poziomie zażyłości i identyfikacji z miejscem lub przestrzenią osiedla, w ocenie stanu bezpieczeństwa $\mathrm{w}$ osiedlu, zespole lub kwartale. Ład ten ujmują następujące pary opozycji: poczucie bycia u siebie - poczucie zagubienia i obcości, dobre stosunki sąsiedzkie - złe stosunki sąsiedzkie, dobra dzielnica (osiedle) - zła dzielnica (osiedle), bezpieczna dzielnica (osiedle) - niebezpieczna dzielnica (osiedle), spokojna dzielnica (osiedle) - hałaśliwa dzielnica (osiedle);

5) ład ekologiczny, który odnosi się do wartości środowiska naturalnego osiedla, który wyraża się w opozycjach: zdrowe otoczenie niezdrowe otoczenie, nasłonecznione - zaciemnione, zielone otoczenie - kamienna pustynia, ciche - hałaśliwe, oddalone od uciążliwego otoczenia (np. przemysł) - ulokowane w pobliżu uciążliwego otoczenia.

Najistotniejszą wartością ładu urbanistyczno-architektonicznego jest zwartość kompozycji przestrzennej, ładu funkcjonalnego - wygoda życia, ładu estetycznego - uroda miejsca i przestrzeni, ładu społecznego - więź społeczna, a także jednostkowa i zbiorowa identyfikacja z miejscem i przestrzenią, natomiast ładu ekologicznego - czyste środowisko naturalne (ibid., s. 16).

Nieco inaczej kryteria oceny zamieszkiwanej przestrzeni ujął natomiast P. Mysłek (2007), który wyodrębnił pięć grup kryteriów uwzględnianych przez mieszkańców w procesie wartościowania przestrzeni mieszkaniowej. Należą do nich (2007, s. 95):

1) kryteria użytkowe obejmujące warunki mieszkaniowe, położenie badanego obszaru w przestrzeni miasta, bliskość wolnych przestrzeni, wyposażenie $\mathrm{w}$ różnego typu usługi oraz dostępność obiektów infrastruktury społecznej i dostępność komunikacyjną, a także zarządzanie obszarem (osiedlem);

2) kryteria estetyczne - uroda okolicy, czystość, ilość terenów zielonych, atrakcyjność zabudowy;

3) kryteria bezpieczeństwa - poczucie bezpieczeństwa na danym obszarze, natężenie ruchu ulicznego i poziom hałasu; 
4) kryteria społeczne, które obejmują prestiż określonego obszaru i skład społeczny zamieszkującej je ludności, a także klimat społeczny, więzi sąsiedzkie, bliskość rodziny i znajomych;

5) kryteria sentymentalne (emocjonalne), które obejmują takie cechy, jak poziom więzi z zamieszkiwanym obszarem, poczucie jego swojskości i znajomość okolicy.

Badania socjologów (por. Turowski 1979, Szczepański 1991, Jałowiecki, Szczepański 2006) pokazują, że w przypadku poczucia deprywacji własnych potrzeb mieszkaniowych, związanych nie tylko z mieszkaniem, ale też z szerszym środowiskiem mieszkaniowym oraz braku możliwości zmiany tego stanu i realizacji potrzeb w sposób zgodny z oczekiwaniami, w umyśle człowieka może uruchamiać się psychologiczny mechanizm tzw. dysonansu poznawczego, którego redukcja prowadzi niekiedy do nieuzasadnionej, nadmiernie pozytywnej oceny zamieszkiwanego środowiska ${ }^{143}$. Zjawisko to jest tym silniejsze, im mniejsze są szanse na jego zmianę (Jałowiecki, Szczepański 2006, s. 344). Podobny mechanizm dotyczy opisanego w literaturze psychologicznej zjawiska tzw. adaptacji, która - jak podaje teoretyk i badacz jakości życia M. Rapley (2003, s. 31) - jest „problematyczną kombinacją złych warunków życia i wysokiego poziomu satysfakcji, nazywanej czasami paradoksem zadowolenia czy paradoksem niemocy".

W literaturze geograficznej pojęcie percepcji zamieszkiwanego środowiska bywa używane wymiennie z pojęciem postawy (Lisowski 2007), którą w literaturze socjologicznej definiuje się za S. Ossowskim jako ogół względnie trwałych dyspozycji do ocenienia przedmiotu, emocjonalnego nań reagowania i zachowań wobec niego (Nowak 1973, s. 23)144. Zgodnie ze strukturalną koncepcją postawy składają się na nią trzy komponenty: poznawczy, emocjonalno-oceniający (afektywny) i behawioralny. Komponent poznawczy obejmuje wiedzę, przekonania i przypuszczenia wobec przedmiotu postawy (tu: zamieszkiwanego obszaru i/lub zamieszkującej go społeczności), komponent emocjonalno-oceniający: uczucia, emocje oraz oceny, komponent behawioralny natomiast zachowania i działania (lub gotowość do nich) (ibid.). Wymienne używanie określeń "postawa” i "percepcja” w geografii wynika $\mathrm{z}$ tego, że w praktyce badawczej składnik poznawczy

143 Jak podaje M. Szczepański (1991): „Charakterystyczna jest skłonność do niedostrzegania pewnych mankamentów zajmowanego miejsca i najbliższej przestrzeni, o ile są one w jakimś przynajmniej stopniu rekompensowane przez wyimaginowane bądź rzeczywiste pozytywy. Mieszkańcy potrafią na przykład bagatelizować niektóre uciążliwości środowiska (zapylenie, hałas), jeśli mają ułatwiony dostęp do sklepów, usług, ośrodków kultury". Podobnie zauważał J. Turowski (1979), według którego mieszkańcy przejawiają znacznie większą skłonność do zadowolenia z miejsca zamieszkania niż wynikałoby to z obiektywnych jego walorów.

${ }_{144}$ Pojęcie postawy wprowadzone zostało do socjologii w $1918 \mathrm{r}$. przez W. Thomasa i F. Znanieckiego, a rozwinięte przez S. Nowaka w pracy z 1973 r. pt. Teorie postaw. 
percepcji często bywa rozszerzany i uzupełniany o aspekty ewaluatywne i emocjonalne (Lisowski 2007).

Relacje człowieka z zamieszkiwanym środowiskiem, będące ważnym składnikiem jego percepcji, bardzo często ujmowane są w kontekście więzi. Pojęcie więzi z miejscem zamieszkania jest przedmiotem badań wielu nauk (psychologii, socjologii, geografii), dlatego też w literaturze spotkać można liczne jego definicje i wiele określeń o pewnym wspólnym zakresie znaczeniowym, ale też pewnych znaczeniowych odrębnościach. W literaturze światowej wśród określeń takich wymieniane są m.in., będące domeną psychologii środowiskowej: „przywiązanie do miejsca” (place attachment), „identyfikacja z miejscem" (place identity) $\mathrm{i}$ "zadowolenie z miejsca” (place satisfaction), a także mającą swój rodowód w geografii humanistycznej Tuanowską „topofilię" (topophilia) oraz rozpatrywane głównie na gruncie socjologii „przywiązanie do społeczności lokalnej" (commmunity attachment) (Lewicka 2012, Hidalgo, Hernández 2001, Stedman 2002). Badacze więzi społecznych w osiedlach miejskich używają także pojęć „identyfikacja lokalna”, ,satysfakcja lokalna” lub „lokalny sentyment” (por. Michalska-Żyła 2010).

Jak zauważa J. Kotus (2007) - badacz tego zagadnienia na gruncie geografii - więź z miejscem zamieszkania ma dwa zasadnicze wzajemnie uzupełniające się wymiary: przestrzenny - przywiązanie do miejsca wyodrębnionego w sensie fizycznym (terytorialnym) oraz społeczny - przywiązanie do zamieszkującej to miejsce społeczności. Tak rozumiane pojecie więzi, mimo że wykracza poza klasyczne studia percepcji przestrzeni, rozpatrywanej jako proces doznań zmysłowych (głównie wzrokowych), stanowi jednak nieodłączny element wielu prac geograficznych mieszczących się $w$ tym nurcie badawczym (por. Lisowski 2007).

Bardzo ważnym atrybutem relacji człowieka ze środowiskiem mieszkaniowym w ich warstwie społecznej są więzi sąsiedzkie. Badacz i teoretyk więzi sąsiedzkich na gruncie socjologii P. Kryczka definiuje je jako „układ względnie trwałych powiązań i zależności pomiędzy osobami wynikających z bliskości zamieszkiwania, wyrażających się [...] w postaci unormowanych czynności, które zakładają określone obowiązki i uprawnienia obu stron" (Kryczka 1981, s. 116). Szczegółowa typologia stosunków sąsiedzkich w wielkomiejskim środowisku mieszkaniowym, odnosząca się do behawioralnego wymiaru zjawiska sformułowana przez tego autora, obejmuje następujące typy sąsiedztwa: (1) towarzysko-przyjacielskie, którego podstawą jest tworzenie w miejscu zamieszkania nieformalnych kręgów o charakterze koleżeńskim (lub przyjacielskim) i wspólne spędzanie czasu wolnego, (2) świadczeniowe, które polega na wymianie różnego rodzaju przysług, (3) solidarnościowe oparte na realizacji dobra wspólnego i zaangażowaniu w realizację wspólnych interesów, 4) poinformowane, które wyraża się w posiadaniu i gromadzeniu informacji o sąsiadach oraz 5) konwencjonalne, przybierające 
formę wymiany ukłonów i pozdrowień (Kryczka 1981). Nieco inną typologię zastosował natomiast J. Turowski (1976), który wyróżnił cztery formy sąsiedztwa cechujące się różnym stopniem społecznego zaangażowania. Są to: (1) sąsiedztwo towarzysko-świadczeniowe, które polega na częstych i bliskich kontaktach wkraczających w sferę życia prywatnego, (2) sąsiedztwo znajomościowo-okazjonalne, oparte na okazjonalnych stosunkach społecznych związanych z doraźną pomocą, (3) sąsiedztwo grzecznościowo-konwencjonalne ograniczone do konwencjonalnych gestów i wymiany ukłonów oraz (4) dystansowanie się wobec środowiska sąsiedzkiego, zakładające izolację społeczną.

$\mathrm{W}$ analizie relacji człowiek - środowisko mieszkaniowe w literaturze geograficznej stosowany jest także termin „satysfakcja mieszkaniowa” (residential satisfaction, housing satisfaction), który podobnie jak pojęcie postawy ma charakter zmiennej syntetycznej (wieloskładnikowej), ponieważ obejmuje zadowolenie $z$ różnych aspektów zamieszkiwania, zarówno społecznych (otoczenie społeczne, więzi, emocje), jak i fizycznych, obejmujących cechy osiedla (wygląd, wyposażenie, lokalizacja itp.) oraz cechy zajmowanego mieszkania (wielkość, stan techniczny, koszt utrzymania itp.) (por. Weidemann, Anderson 1985, Adriaanse 2007, Dekker i in. 2011). Jednym z ważnych elementów satysfakcji mieszkaniowej są preferencje migracyjne gospodarstw domowych związane $\mathrm{z}$ chęcią opuszczenia zamieszkiwanego osiedla $\mathrm{w}$ najbliższej przyszłości lub, przeciwnie, chęcią pozostania w nim (Musterd, van Kempen 2007). Potencjalna ruchliwość przestrzenna mieszkańców wielkich osiedli jest niezwykle ważną determinantą ich przyszłości, gdyż nasilony odpływ mieszkańców może być początkiem lub jednym z etapów procesów degradacji szeroko opisanych w literaturze dotyczącej przemian osiedli zachodnioeuropejskich.

Omawiane zagadnienia relacji człowiek - zamieszkiwane środowisko są także przedmiotem refleksji architektów i urbanistów, którzy jednak ujmują je nieco inaczej, głównie $\mathrm{w}$ aspekcie oddziaływania przestrzeni na człowieka poprzez dostarczane mu wrażenia sensoryczne (przede wszystkim wzrokowe), jakie wywołuje w człowieku otoczenie (Ostrowska 1991). Wrażenia te, jak podaje cytowana autorka, mogą powodować odczucia "dospołecznienia” lub „niedospołecznienia” przestrzeni. Pozytywne „dospołeczne" wrażenia wywołują obszary, które wyróżniają się posiadaniem elementów krystalizujących plan zabudowy, charakteryzują się właściwą dla człowieka skalą założeń i kameralnością rozwiązań, występowaniem cech indywidualizujących przestrzeń, a także wielofunkcyjnością oraz wykorzystaniem form naturalnych jako dopełnienie lub osnowa kompozycji, np. rzeźby terenu, istniejącej formy zieleni. $W$ opozycji do nich znajdują się cechy, które wzmacniają negatywne wrażenie "niedospołecznienia" przestrzeni związane z zachwianiem harmonii między potrzebami i możliwoś- 
ciami percepcji człowieka a cechami przestrzeni. Ich efektem jest wzbudzanie poczucia zagrożenia, wywoływanie stresu, apatii, bierności oraz sprzyjanie zjawiskom patologii społecznej, buntu, agresji i negacji, a w skrajnych sytuacjach nawet pogorszenie stanu zdrowia mieszkańców danej przestrzeni (Ostrowska 1991, s. 251-265). W wielkich osiedlach mieszkaniowych, będących szczególną formą urbanistyczno-architektoniczną kwestie związane z układem zabudowy oraz architekturą budynków często podnoszone były w literaturze (szerzej omówionej w rozdz. 2.5) jako jedna z głównych przyczyn ich niskiej atrakcyjności i źródło ich degradacji (por. Newman 1972, Coleman 1985).

\subsection{Uwarunkowania percepcji i waloryzacji środowiska mieszkaniowego}

W badaniach percepcji i waloryzacji zamieszkiwanego środowiska, a także więzi zarówno z zamieszkiwanym terytorium, jak i z współzamieszkującą je społecznością ważne jest nie tylko uzyskanie odpowiedzi na pytanie, w jaki sposób postrzegana i oceniana jest przestrzeń i jaki jest poziom zidentyfikowanych więzi, lecz także określenie uwarunkowań determinujących ten proces.

W klasycznych już badaniach osiedli mieszkaniowych J. Turowski (1979) wyróżnił trzy zasadnicze kategorie uwarunkowań więzi mieszkańców $\mathrm{z}$ osiedlem i postaw wobec niego:

1) urbanistyczne, do których należą: usytuowanie osiedla w stosunku do pozostałych obszarów miasta i warunki komunikacyjne, standard mieszkań, wyposażenie osiedla w infrastrukturę handlowo-usługową;

2) społeczne, czyli upowszechniane oceny i stereotypy, które kwalifikują osiedla jako lepsze i gorsze, struktura społeczna ludności i cechy mieszkańców, ocena stosunków międzyludzkich, wielkość jednostki mieszkaniowej oraz stopień jej wyodrębnienia w mieście;

3) osobiste, wśród których wyróżnił okres zamieszkiwania w osiedlu, osiągnięte efekty co do warunków życia oraz preferencje jednostkowe w zakresie systemu wartości i wzorów stylu życia.

Według M. Bartnickiej (1989) natomiast badania nad wartościowaniem miejskiej przestrzeni mieszkaniowej wykazały, że na ocenę atrakcyjności danego obszaru w opinii mieszkańców i na ich preferencje mieszkaniowe wpływają czynniki endogenne związane z cechami osób oceniających ${ }^{145}$

145 Według innych autorów, którzy skupili się na czynnikach endogennych, zidentyfikowanych ex post, które w największym stopniu wpływały na percepcję i waloryzację przestrzeni 
oraz egzogenne, pochodzące ze środowiska, do których należą cechy ocenianego obszaru. Przy czym, jak podaje ta autorka, o ile pierwsze z nich mają wpływ raczej na strukturę wyobrażeń, o tyle drugie kształtują przede wszystkim ich treść.

Inni autorzy (por. Jałowiecki, Szczepański 2006) w pracach nad percepcją i waloryzacją przestrzeni przyjmują trzy grupy determinant: (1) obiektywne, związane z cechami ocenianej przestrzeni, (2) subiektywne, odnoszące się do cech osób oceniających, oraz (3) związane z kontekstem przestrzennym i społeczno-kulturowym, czyli sytuacją, w której zachodzi proces percepcji i waloryzacji.

Nieco inaczej natomiast pogrupowała czynniki wpływające na percepcję i waloryzację przestrzeni E. Chądzyńska (2004), która na podstawie przeglądu różnych prac wyróżniła trzy ich grupy: (1) czynniki indywidualne - wiek, wykształcenie, wykonywany zawód, przynależność do różnego typu organizacji, miejsce zamieszkania, stan rodzinny, poziom zamożności, poziom wiedzy, stan emocjonalny, (2) czynniki przestrzenne - liczba i rodzaj elementów przestrzeni miejskiej, ich zróżnicowanie, funkcjonalność, dostępność komunikacyjna, szybkość zmian struktury miasta, (3) czynniki stanowiące źródło wiedzy o przestrzeni - własne doświadczenia, opinie innych osób, informacje pochodzące ze środków masowego przekazu.

Grupowanie czynników determinujących poziom satysfakcji mieszkaniowej w wielkich osiedlach w różnych krajach europejskich zaproponowali K. Dekker i in. (2011), którzy wyodrębnili następujące grupy determinant: (1) demograficzne, w tym głównie wielkość i strukturę gospodarstwa domowego oraz obecność w nim dzieci, a także wiek badanych, (2) socjoekonomiczne, w tym w szczególności poziom rozporządzalnych dochodów mieszkańców, ich aktywność na rynku pracy oraz poziom wykształcenia, (3) narodowościowe, przy założeniu, że imigranci inaczej postrzegają zamieszkiwane środowisko niż rdzenni mieszkańcy kraju, (4) własnościowe, wyodrębniające dwie zasadnicze kategorie mieszkańców: właścicieli i niewłaścicieli zajmowanych mieszkań, (5) cechy mieszkania (jego wielkość, stan utrzymania, liczba i układ izb) oraz (6) społeczne i urbanistyczne cechy osiedla związane ze strukturą społeczną jego mieszkańców oraz siłą ich więzi społecznych, a także $\mathrm{z}$ wyposażeniem go w różne usługi, z dostępnością komunikacyjną, bezpieczeństwem, stanem zadbania osiedla, jego lo-

mieszkaniowej, S. Nurek (1982) wskazywał na płeć i wykształcenie badanych, J. Słodczyk (2001) na kombinację wieku, wykształcenia, nabytych doświadczeń, sytuacji materialnej, lokalizacji osoby dokonującej oceny, a także jej pozycji społecznej i przynależności do określonego kręgu, a L. Groeger (2013) na poziom uzyskiwanych dochodów, wykształcenie i wiek, przy czym zmienne te znalazły się dopiero na dalszych miejscach $w$ hierarchii, po czynnikach egzogennych (obiektywnych) związanych cechami zamieszkiwanej przestrzeni. 
kalizacją $\mathrm{w}$ przestrzeni miasta oraz $\mathrm{z}$ występowaniem na jego obszarze różnych problemów i zjawisk o charakterze patologicznym.

Wymienione grupy determinant $\mathrm{w}$ praktyce badawczej mogą zostać przedstawione $\mathrm{w}$ postaci hipotez wyjaśniających, które następnie są testowane $\mathrm{w}$ badaniach empirycznych. Jako determinanty postaw wobec miejsca zamieszkania oraz więzi sąsiedzkich $w$ badaniach społecznych najczęściej przyjmuje się cztery zasadnicze grupy hipotez wyjaśniających: (1) hipoteza stratyfikacyjna, zgodnie z którą do zmiennych wyjaśniających te zjawiska należą: wykształcenie, status społeczno-zawodowy i poziom zamożności, (2) hipoteza uczestnictwa w życiu społecznym, która zakłada warunkowanie poziomu więzi z miejscem zamieszkania udziałem w różnego typu inicjatywach na rzecz lokalnej społeczności oraz lokalnego terytorium, (3) hipoteza zakorzenienia lokalnego wyrażona przez długość zamieszkiwania i częstotliwość kontaktów zewnętrznych oraz (4) hipoteza urbanizacyjna, która jako czynnik wyjaśniający relacje z miejscem zamieszkania przyjmuje jego cechy (np. wielkość miejscowości, typ zabudowy itp.) (por. Michalska-Żyła 2010).

W inny sposób do kwestii uwarunkowań relacji człowiek-przestrzeń podchodzą natomiast architekci i urbaniści. W ich pracach bowiem najważniejszą rolę $\mathrm{w}$ kształtowaniu więzi społecznych $\mathrm{w}$ środowisku mieszkaniowym przypisuje się czynnikom urbanistycznym i architektonicznym przyjmując, że "architektura, w otoczeniu której żyje człowiek, ma zdolność podtrzymywania więzi społecznych [...] utrudniając lub uniemożliwiając w ten sposób rozwój zachowań, które w odmiennych warunkach dana społeczność byłaby zdolna rozwinąć” oraz, że „wygląd przestrzeni miejskiej [...] wiąże się nie tylko z zagadnieniami estetyki, ale przede wszystkim [...] znacząco wpływa na zachowania społeczne. Przestrzenie [...] o wysokim poziomie artystycznym i estetycznym, generujące pozytywne doznania i przeżycia, jak i przestrzenie zdegradowane, w których panuje przestrzenny chaos, wywołujące negatywne odczucia - to wszystko, wpływając na samopoczucie użytkowników przestrzeni, przyczynia się do rozwijania lub utrudniania interakcji, kontaktów i więzi społecznych" (Pazder 2008, s. 164). Pogląd taki, acz niepozbawiony zupełnie słuszności, wciąż wydaje się zbyt bliski podejściu określanemu jako determinizm architektoniczny, który - jak podaje G. Wojtkun (2004, s. 13) - został ostatecznie odrzucony na początku lat 60. XX wieku.

Jednym z najważniejszych spośród wymienionych już czynnikiów, który odgrywa istotną rolę $w$ percepcji zamieszkiwanego obszaru, jest poczucie bezpieczeństwa rozumiane jako brak zagrożenia przestępczością. Według wielu badaczy (por. Jałowiecki, Szczepański 2006, Lewicka 2012) jest to bardzo istotny aspekt pozytywnych relacji człowieka z miejscem zamieszkania i pozytywnej jego waloryzacji, wiąże się bowiem z zaspokojeniem jednej 
z najważniejszych psychologicznych potrzeb człowieka - potrzeby bezpieczeństwa, której deprywacja może być bardzo dotkliwa (Zimbardo 1999). W większości ujęć poczucie bezpieczeństwa traktowane jest jako jedna $z$ determinant procesu percepcji i waloryzacji środowiska mieszkaniowego, ale równie dobrze może być rozpatrywane jako przedmiot tego procesu (w postaci badań percepcji bezpieczeństwa w miejscu zamieszkania), a nawet jako jego rezultat (np. kiedy $\mathrm{w}$ wyniku procesu percepcji określonych zjawisk w umyśle człowieka powstaje mentalna mapa miejsc bezpiecznych i niebezpiecznych). W tym przypadku w literaturze przedmiotu przyjmuje się dwie zasadnicze grupy hipotez wyjaśniających poczucie bezpieczeństwa: psychologiczno-społeczne oraz urbanistyczno-architektoniczne, przy czym znaczenie pierwszych podkreślają głównie socjologowie i psychologowie, a te drugie częściej przyjmowane są w badaniach architektów i urbanistów. W pracach geograficznych natomiast (por. Guzik 2000a, 2000b, Kotus 2007, Mordwa 2013) hipotezy te najczęściej traktuje się równorzędnie. Niezależnie jednak od tego, w jaki sposób badawczo traktuje się poczucie bezpieczeństwa, nie ulega wątpliwości, że zarówno sama przestępczość, jak i poczucie zagrożenia nią w znaczący sposób wpływają na jakość życia (Liszewski 2004). A ponieważ poczucie zagrożenia rejestrowane $\mathrm{w}$ badaniach opinii mieszkańców nie pokrywa się z obrazem przestępczości wynikającym z policyjnych danych statystycznych (por. Guzik 2000a, Frieske 2007, Mordwa 2013), to "większe znaczenie mają wyobrażenia odnośnie przestępczości i jej rozmieszczenia niż stan faktyczny" (Guzik 2000a, s. 201).

Wśród uwarunkowań procesu percepcji i waloryzacji środowiska mieszkaniowego ważą rolę odgrywają także stereotypy, o czym pisał J. Turowski już w latach 70. XX wieku (1976). Na gruncie geografii społecznej Z. Rykiel (1999) definiuje stereotyp jako funkcjonujący w świadomości społecznej, uproszczony, zniekształcony i zabarwiony wartościująco obraz rzeczywistości. Stereotypy percepcyjne dotyczące poszczególnych obszarów miasta cechuje trwałość, ponieważ raz ukonstytuowany obraz miasta podlega bardzo powolnym przemianom (Jałowiecki 2000). Jak twierdzą M. Dolata i J. Kotus (2004), o procesie stereotypizacji poszczególnych obszarów miasta można mówić, kiedy opinia o miejscu i jego użytkownikach jest wytworem sądów bazujących na dawnych faktach bądź jest opinią całkowicie nieuzasadnioną. W przypadku formy zabudowy, jaką są wielkie osiedla mieszkaniowe, proces ten jest szczególnie często obserwowany. I mimo że stereotypy te nie są zazwyczaj powielane przez samych mieszkańców, bowiem występują zwykle tam, gdzie brak jest wiedzy i informacji, to niewątpliwie są zmienną, która negatywnie wpływa na wizerunek osiedli i w konsekwencji na obniżanie satysfakcji rezydencjalnej ich mieszkańców oraz chęć migracji. Współcześnie, jak podkreśla E. Szkurłat (2004), duże znaczenie w kreowaniu i podtrzymywaniu stereotypów dotyczących przestrzeni mają 
media. O ich roli w kształtowaniu negatywnych wyobrażeń na temat poszczególnych obszarów miasta na podstawie obrazu przestępczości zawartego $\mathrm{w}$ prasie pisał m.in. R. Guzik (2000b). W przypadku wielkich osiedli mieszkaniowych media znacząco przyczyniają się do funkcjonowania negatywnego stereotypu "złych blokowisk", który mimo że nie znajduje potwierdzenia $w$ badaniach empirycznych, wciąż funkcjonuje $\mathrm{w}$ dyskursie publicznym i medialnym.

Wśród wymienionych determinant percepcji i waloryzacji środowisk mieszkaniowych nie może zabraknąć bliższego omówienia jeszcze jednej ważnej ich grupy, obejmującej kontekst przestrzenny, ponieważ - jak piszą S. Musterd i R. van Kempen (2007, s. 317): ,jednostki i gospodarstwa domowe nie działają w próżni, lecz operują w demograficznym, ekonomicznym, kulturowym i politycznym kontekście, obejmującym sąsiedztwo, miasto, region, kraj, a nawet środowisko międzynarodowe". Kontekst ten według autorów powinien uwzględniać zarówno specyfikę grupy krajów przechodzących transformację, jak i indywidualność każdego z nich, która jest konsekwencją, wprawdzie niewielkich, ale możliwych do odnotowania różnic w ścieżkach przemian od socjalizmu do gospodarki wolnorynkowej, a także różnice lokalne uwzględniające sytuację $\mathrm{w}$ poszczególnych regionach i miastach. Na ważną rolę tych różnic zwracają uwagę głównie autorzy zajmujący się porównaniami w skali międzynarodowej (np. Turkington i in. 2004, Musterd, van Kempen 2007, Dekker i in. 2011, Wiest 2011).

Kontekst przestrzenny na skutek urynkowienia mieszkalnictwa najczęściej rozpatrywany jest w związku z kondycją ekonomiczną mieszkańców miasta/regionu/kraju oraz z aktualną sytuacją na rynku nieruchomości. Te bowiem czynniki silnie determinują możliwości i bariery gospodarstw domowych działających na tym rynku, a w konsekwencji wpływają na postrzeganie poszczególnych obszarów rezydencjalnych miasta i ocenę ich atrakcyjności. Kontekst ten, jako ukształtowany w procesie historycznego rozwoju, determinuje także rolę i udział różnych form zabudowy w zasobach mieszkaniowych poszczególnych miast, które mają istotny wpływ na ich percepcję. Jeśli bowiem, jak w przypadku wielkich osiedli mieszkaniowych $\mathrm{w}$ miastach postsocjalistycznych, udział ten jest znaczący, to zamieszkiwanie $\mathrm{w}$ nich wydaje się tak powszechne $\mathrm{i}$ "zwyczajne” $\mathrm{w}$ społecznej świadomości, że nie może równocześnie stygmatyzować (por. Borowik 2003, Kaltenberg-Kwiatkowska 2005). Jak słusznie zauważa bowiem E. Kaltenberg-Kwiatkowska (2007, s. 136) nawiązując do konieczności uwzględnienia kontekstu w badaniach mieszkalnictwa, że „przywoływanie znanego porzekadła «pokaż mi swoje mieszkanie, a powiem ci kim jesteś» wymaga ostrożności - powiem dopiero wówczas, gdy będę wiedzieć co jest normą [...] w tym miejscu i w tym czasie". 


\subsection{Percepcja i waloryzacja wielkich osiedli mieszkaniowych $\mathrm{w}$ mieście postsocjalistycznym - wybrane przykłady}

Badania percepcji i waloryzacji wielkich osiedli mieszkaniowych oraz więzi społecznych i terytorialnych wśród mieszkańców tej formy zabudowy prowadzone były już w poprzednim ustroju (w Polsce głównie na gruncie socjologii, np. Jałowiecki 1968, Turowski 1976, 1979, Nurek 1982), ale w mieście postsocjalistycznym nabrały nowego wymiaru. W warunkach funkcjonowania liberalnego rynku mieszkaniowego, gdzie głównym kryterium rywalizacji na rynku mieszkaniowym jest siła ekonomiczna, i gdy pojawiły się nowe możliwości realizacji potrzeb mieszkaniowych oraz nowe obszary rezydencjalne o dużej atrakcyjności, nastąpiła istotna modyfikacja dotychczasowej percepcji różnych form zabudowy, w tym osiedli mieszkaniowych o zabudowie blokowej. Wpływ miały na to także zmiany w strukturze społecznej i w świadomości mieszkańców oraz fakt, że miejsce zamieszkania na skutek powrotu „wartości miejsca” nabrało nowego znaczenia i to nie tylko w sensie ekonomicznym czy użytkowym, ale też symbolicznym.

Zmiany uwarunkowań społecznych i ustrojowych spowodowały, że zmieniły się także same osiedla (por. rozdział 5. pracy), ale równocześnie pojawiło się, niewystępujące $\mathrm{w}$ okresie socjalizmu, widmo ich degradacji. Zaczęły funkcjonować negatywne stereotypy „blokowisk”, a ich wysoka dotychczas atrakcyjność mieszkaniowa znacząco spadła, przy czym głównie w warstwie symbolicznej, nie zaś użytkowej. Czynniki te decydują o konieczności stałego monitorowania nie tylko struktury społecznej i fizycznego stanu zachowania osiedli, ale także ich percepcji. Percepcja bowiem ma ogromne znaczenie dla ich przyszłości, zwłaszcza jeśli przyjmie się zweryfikowane już wielokrotnie założenie o wzajemnym sprzężeniu między świadomością społeczną i rzeczywistością, zgodnie z którym postrzegane zróżnicowanie przestrzeni rezydencjalnej miasta, wyzwalając określone dążenia i działania ludzkie, wpływa na decyzje lokalizacyjne i w istocie zróżnicowanie to kreuje (Kaltenberg-Kwiatkowska 1982). Dobra reputacja osiedli o zabudowie blokowej, powstrzymując dotychczasowych mieszkańców przed odpływem oraz przyciągając nowych, może uchronić je przed realną degradacją społeczną oraz urbanistyczną. Zła natomiast może uruchomić spiralę ich upadku.

Dotychczasowe badania percepcji i waloryzacji prowadzone w wielkich osiedlach mieszkaniowych w miastach postsocjalistycznych najczęściej obejmowały studia dotyczące oceny wybranych aspektów zagospodarowania i wyposażenia osiedli, w tym głównie dostępności najważniejszej infrastruktury społecznej i usługowej, a także ich satysfakcji lokalnej i zadowolenia 
z warunków mieszkaniowych, poziomu więzi społecznych i terytorialnych, $\mathrm{w}$ tym więzi sąsiedzkich, poczucia bezpieczeństwa oraz preferencji migracyjnych (określanych też jako mieszkaniowe). Były to zarówno studia przypadków pojedynczych osiedli (Szafrańska 2009, Gorczyca 2010, Niezabitowski 2010, Rodzoś, Flaga 2010, Gądecki 2012, Jerschina i in. 2012, Kabisch, Grossmann 2013), jak i komparatystyczne analizy wybranych osiedli w jednym mieście (Borowik 2003, Wojtkun 2004, Węclawowicz i in. 2005, Kotus 2007, Górczyńska 2008, Fuhrmann 2009a, b, Janiszewska i in. 2010, 2011, Warchalska-Troll 2012, Andráško i in. 2013).

Wśród porównań o charakterze międzynarodowym na uwagę zasługują prace powstałe w oparciu o wyniki programu RESTATE, których ważnym elementem (choć nie jedynym) były badania różnych aspektów percepcji i waloryzacji osiedli przez ich mieszkańców. Ich walorem jest możliwość porównania rezultatów badań przeprowadzanych przy użyciu tych samych metod i narzędzi w 29 osiedlach zlokalizowanych w 15 miastach europejskich, wśród których siedem to osiedla w miastach postsocjalistycznych. Pokłosiem tych badań są prace przeglądowe i analityczne dotyczące całego zbioru badanych osiedli (Musterd, van Kempen 2005, 2007, Dekker, van Kempen 2009, Dekker i in. 2011) oraz prace szczegółowe dotyczące osiedli polskich (Węcławowicz i in. 2005), słoweńskich (Černič Mali i in. 2005), niemieckich (Knorr-Siedow, Droste 2005) i węgierskich (Tosics i in. 2005). Inni autorzy prac zawierających międzynarodowe porównania percepcji i waloryzacji osiedli w krajach postsocjalistycznych to K. Wiest (2011) oraz Z. Kovács i G. Herfert (2012), którzy badali i porównywali wybrane osiedla w Budapeszcie, Wilnie, Lipsku oraz Sofii.

Tab. 13. Publikacje zawierające wyniki badań empirycznych dotyczących percepcji i waloryzacji wielkich osiedli mieszkaniowych wśród ich mieszkańców w polskiej literaturze naukowej po 1990 roku

\begin{tabular}{|c|c|c|c|}
\hline $\begin{array}{c}\text { Autor (autorzy) } \\
\text { oraz rok } \\
\text { wydania }\end{array}$ & Obszar badań & $\begin{array}{l}\text { Metoda i technika } \\
\text { badań }\end{array}$ & $\begin{array}{l}\text { Wielkość próby } \\
\text { (liczba respon- } \\
\text { dentów) }\end{array}$ \\
\hline$[1]$ & [2] & [3] & {$[4]$} \\
\hline \multicolumn{4}{|c|}{ Badania afiliowane w ośrodkach geograficznych } \\
\hline $\begin{array}{l}\text { G. Węcławo- } \\
\text { wicz i in. (2005) }\end{array}$ & $\begin{array}{c}\text { Warszawa (osiedla Wrzeciono } \\
\text { i Ursynów Płn.) }\end{array}$ & $\begin{array}{c}\text { Metoda ankietowa - } \\
\text { ustrukturyzowane } \\
\text { wywiady kwestio- } \\
\text { nariuszowe }\end{array}$ & 352 \\
\hline $\begin{array}{l}\text { M. Górczyńska } \\
(2008)\end{array}$ & $\overline{j w}$. & jw. & jw. \\
\hline $\begin{array}{l}\text { M. Fuhrmann } \\
(2009 a, b)\end{array}$ & $\begin{array}{c}\text { Warszawa (osiedla: Sadyba, } \\
\text { Stegny Płd., Bernardyńska, } \\
\text { Idzikowskiego) }\end{array}$ & jw. & 711 \\
\hline
\end{tabular}




\begin{tabular}{|c|c|c|c|}
\hline$[1]$ & {$[2]$} & [3] & [4] \\
\hline $\begin{array}{l}\text { E. Szafrańska } \\
\text { (2009) }\end{array}$ & Łódź (osiedle Retkinia-Północ) & jw. & 112 \\
\hline $\begin{array}{l}\text { A. Janiszewska } \\
\text { i in. }(2010,2011)\end{array}$ & $\begin{array}{c}\text { Łódź (największe osiedla miasta } \\
\text { skupione w siedmiu obszarach } \\
\text { zabudowy blokowej - } \\
\text { nieokreślone imiennie) }\end{array}$ & jw. & 1032 \\
\hline $\begin{array}{l}\text { P. Ciesiółka } \\
(2010)\end{array}$ & $\begin{array}{c}\text { Poznań (osiedle Jana III } \\
\text { Sobieskiego) }\end{array}$ & jw. & 90 \\
\hline $\begin{array}{l}\text { K. Gorczyca, } \\
\text { (2010) }\end{array}$ & $\begin{array}{c}\text { Tarnów (osiedle Pracowników } \\
\text { Zakładów Azotowych w } \\
\text { Tarnowie) }\end{array}$ & jw. & $\begin{array}{l}9,3 \% \text { gospodarstw } \\
\text { domowych }\end{array}$ \\
\hline \begin{tabular}{|l} 
J. Rodzoś, \\
M. Flaga (2010)
\end{tabular} & $\begin{array}{c}\text { Lublin (osiedle im. A. Mickie- } \\
\text { wicza) }\end{array}$ & jw. & 150 \\
\hline $\begin{array}{l}\text { A. Warchalska- } \\
\text {-Troll (2012) }\end{array}$ & $\begin{array}{c}\text { Katowice (sześć największych } \\
\text { osiedli w mieście: Tysiąclecia, } \\
\text { Witosa, Kukuczki, } \\
\text { Paderewskiego, Odrodzenia } \\
\text { i Giszowiec) }\end{array}$ & jw. & 432 \\
\hline E. Klima (2012) & Łódź - b.d. & Wywiady swobodne & 7 \\
\hline \multicolumn{4}{|c|}{ Badania afiliowane w ośrodkach socjologicznych } \\
\hline $\begin{array}{l}\text { I. Borowik } \\
(2003)\end{array}$ & $\begin{array}{l}\text { Wrocław (osiedla Gaj } \\
\text { i Sobieskiego) }\end{array}$ & $\begin{array}{c}\text { Metoda ankietowa - } \\
\text { ustrukturyzowane } \\
\text { wywiady kwestio- } \\
\text { nariuszowe }\end{array}$ & $\begin{array}{c}\text { Badania przepro- } \\
\text { wadzono dwu- } \\
\text { krotnie: } \\
\text { w } 1994 \text { r. } n=506, \\
\text { w } 2001 \text { r. } n=495 .\end{array}$ \\
\hline $\begin{array}{l}\text { M. Niezabitow- } \\
\text { ski (2010) }\end{array}$ & Katowice, blok Superjednostka & $\begin{array}{c}\text { Ustrukturyzowane } \\
\text { wywiady kwestio- } \\
\text { nariuszowe oraz } \\
\text { wywiady swobodne } \\
\end{array}$ & $\begin{array}{l}\text { Badania ilościowe } \\
\text { - 110, wywiady } \\
\text { swobodne - } 11 \\
\text { respondentów }\end{array}$ \\
\hline $\begin{array}{l}\text { J. Gądecki } \\
(2012)\end{array}$ & Kraków (osiedle Nowa Huta) & $\begin{array}{c}\text { Wywiady swobodne } \\
\text { oraz ankiety }\end{array}$ & $\begin{array}{c}\text { wywiady }-25 \\
\text { ankiety }-96\end{array}$ \\
\hline \multicolumn{4}{|c|}{ Badania afiliowane w innych ośrodkach } \\
\hline $\begin{array}{l}\text { G. Wojtkun } \\
\text { (2004) }\end{array}$ & $\begin{array}{c}\text { Szczecin (osiedla: Wzgórze } \\
\text { Hetmańskie, Arkońskie, } \\
\text { Słoneczne, Książąt Pomorskich, } \\
\text { Majowe, Bandurskiego, Bukowe) }\end{array}$ & \begin{tabular}{|c|} 
Ustrukturyzowane \\
wywiady kwestio- \\
nariuszowe oraz \\
ankiety samodziel- \\
nie wypełniane \\
przez respondentów \\
\end{tabular} & 1891 \\
\hline $\begin{array}{l}\text { J. Jerschina } i \text { in. } \\
(2012)\end{array}$ & $\begin{array}{c}\text { Kraków (osiedle Prądnik } \\
\text { Czerwony) }\end{array}$ & $\begin{array}{c}\text { Ustrukturyzowane } \\
\text { wywiady } \\
\text { kwestionariuszowe }\end{array}$ & 500 \\
\hline
\end{tabular}

Źródło: opracowanie własne.

Osobną grupę stanowią geograficzne i socjologiczne badania wybranych aspektów percepcji i waloryzacji miejskiej przestrzeni mieszkaniowej, w których wielkie osiedla są jedną ze stref miasta lub jednym z typów/ 
rodzajów zabudowy (Misiak 1993, Kaczmarek 1996, Bartoszek i in. 1997, Guzik 2000a, 2000b, Kaltenberg-Kwiatkowska 1996, 2002, 2005, Dolata, Kotus 2004, Jaroszewska-Brudnicka 2004, Groeger 2004, Lewicka 2004, Szkurłat 2004, Zborowski 2005, Kotus 2007, Mysłek 2007, Radwańska 2007, Szmytkowska 2008, Marcińczak 2007, Michalska-Żyła 2010, Bujwicka 2011, Rzyski, Mędrzycka 2010, Jerschina i in 2012, Mordwa 2013). W tego rodzaju pracach, typ zabudowy najczęściej traktowany jest jako zmienna niezależna, która w określony sposób wpływa na poziom innych zmiennych, których zróżnicowanie analizowane jest w skali miejskiej, np. poczucie bezpieczeństwa, satysfakcja mieszkaniowa, więzi społeczne i inne.

\subsubsection{Satysfakcja mieszkaniowa, poczucie więzi z miejscem zamieszkania i preferencje migracyjne}

Jednym z najbardziej powszechnych zagadnień uwzględnianych $\mathrm{w}$ badaniach percepcji i waloryzacji wielkich osiedli mieszkaniowych, jak już powiedziano, jest różnie rozumiane pojęcie satysfakcji mieszkaniowej oraz, pozostające z nim w ścisłym związku, poczucie więzi z miejscem zamieszkania i preferencje migracyjne.

Najwcześniejszą chronologicznie oraz najszerszą dotychczas pracą dotycząca tych zagadnień w polskim mieście postsocjalistycznym jest socjologiczne opracowanie I. Borowik (2003) powstałe na bazie studiów dwóch wielkich osiedli mieszkaniowych Wrocławia przeprowadzonych w latach 1994 oraz 2001. Z ustaleń tej autorki wynika, że mieszkańcy badanych osiedli w obu badanych okresach charakteryzowali się wysokim poziomem zadowolenia z zajmowanego mieszkania oraz nieco mniejszym, ale również wysokim zadowoleniem z zamieszkiwanych osiedli. Większość też nie chciała się z nich wyprowadzać. Za interesujący uznać należy wniosek tej autorki, że mimo wzrostu aspiracji mieszkaniowych i poziomu krytycyzmu wobec osiedli, zidentyfikowanego wśród respondentów w okresie siedmiu lat pomiędzy badaniami, zwiększył się odsetek zadowolonych oraz chcących pozostać w obecnym miejscu zamieszkania, a główną przyczyną tego stanu była odczuwana przez badanych poprawa warunków życia $\mathrm{w}$ osiedlu. Ważny z punktu widzenia niniejszej pracy jest także wniosek, że zmieniła się (na korzyść dla wizerunku osiedli) podawana przez respondentów główna przyczyna niechęci do wyprowadzenia się, ponieważ w 1994 r. było to przede wszystkim "przyzwyczajenie”, podczas gdy w 2001 r. „zadowolenie". Analiza zależności przeprowadzona przez autorkę pokazała także, że badane osiedla częściej chciały opuszczać osoby młodsze, lepiej wykształcone, tworzące większe gospodarstwa domowe, a także osoby zajmujące lokale niewłasnościowe. 
Podobne wnioski dotyczące zarówno poziomu satysfakcji mieszkaniowej, jak i chęci wyprowadzenia się z zamieszkiwanych osiedli uzyskała M. Górczyńska (2008), która oparła swe analizy na danych zgromadzonych $\mathrm{w}$ ramach programu RESTATE $\mathrm{w}$ dwóch osiedlach warszawskich - Wrzeciono i Ursynów Płn. Z analizy skonstruowanego przez tę autorkę wskaźnika stosunku do miejsca zamieszkania uwzględniającego zadowolenie $\mathrm{z}$ zajmowanego mieszkania oraz $\mathrm{z}$ osiedla, ocenę kontaktów $\mathrm{z}$ innymi mieszkańcami, przywiązanie do osiedla oraz plany migracyjne na najbliższe lata wynika, że mieszkańcy nowszego Ursynowa wyrażali znacznie większe zadowolenie z mieszkania i osiedla, ale równocześnie częściej deklarowali chęć wyprowadzenia się, niż mieszkańcy starszego osiedla Wrzeciono. $\mathrm{W}$ obu jednostkach odnotowano ponadto relatywnie silne przywiązanie do miejsca zamieszkania oraz dobre relacje z innymi mieszkańcami. Analiza zależności przeprowadzona przez tę autorkę pokazała: (1) większe zadowolenie z mieszkania i osiedla wśród mieszkańców będących właścicielami zajmowanych mieszkań, (2) lepszą ocenę kontaktów sąsiedzkich i większe przywiązanie wśród osób starszych oraz ambiwalencję postaw wśród osób młodych, (3) większe przywiązanie do osiedla i równocześnie mniejsze zadowolenie z zamieszkiwania w nim wśród mieszkających dłużej (4) większe zadowolenie zarówno ze swojego mieszkania, jak i z osiedla, przy czym równocześnie (co paradoksalnie nie pozostaje w sprzeczności), wyższą skłonność do migracji wśród osób o wysokich dochodach oraz (5) mniejsze zadowolenie z miejsca zamieszkania i równocześnie mniejszą chęć jego opuszczenia wśród respondentów oceniających swoje dochody jako niskie.

Duże zadowolenie $\mathrm{z}$ zamieszkiwania $\mathrm{w}$ osiedlach blokowych stwierdziła także A. Warchalska-Troll (2012), która na podstawie badań przeprowadzonych w największych osiedlach mieszkaniowych Katowic wykazała, że zdecydowana większość mieszkańców badanych osiedli (ponad 70\%) wyraziła zadowolenie z życia w nich i zadeklarowała duże do nich przywiązanie (prawie $80 \%$ raczej i bardzo przywiązanych). W największym osiedlu Lublina natomiast (Rodzoś, Flaga 2010) aż 95\% badanych mieszkańców wyraziło zadowolenie ze swego miejsca zamieszkania, z czego ponad $2 / 3$ duże zadowolenie. Równie duże zadowolenie z zamieszkiwania w osiedlu (blisko $80 \%$ ankietowanych), i to niezależnie od płci, wieku i wykształcenia, deklarowali mieszkańcy innego badanego osiedla - Prądnik Czerwony w Krakowie (Jerschina i in. 2012). Mimo wysokiego zadowolenia jednak aż $23 \%$ mieszkańców chciałoby się z niego wyprowadzić. Nie jest to jednak, jak podają autorzy tego badania (ibid, s. 245), niezadowolenie z osiedla jako miejsca zamieszkania, lecz wyraz niezadowolenia z wielkości mieszkań i z nadmiernego ich zagęszczenia. Badania te, podobnie jak badania lubelskie (Rodzoś, Flaga 2010), wykazały, że grupa osób o najsilniejszej skłonności do migracji obejmuje mieszkańców w wieku 30-49 lat, a zatem osoby 
o ustabilizowanej sytuacji rodzinnej i zawodowej, która pozwala na podejmowanie takich decyzji.

O relacjach z miejscem zamieszkania w osiedlach blokowych pisał również J. Kotus (2007) porównując je z innymi rodzajami zabudowy miejskiej. Badania tego autora przeprowadzone w Poznaniu pokazały, że osiedla blokowe z lat 60. i 70. to obszary, których mieszkańcy wykazują relatywnie silne więzi $\mathrm{z}$ miejscem zamieszkania $\mathrm{w}$ wymiarze zarówno terytorialnym (więź z terytorium), jak i społecznym (więź sąsiedzka). Blisko połowa mieszkańców badanych osiedli wykazała pełną aprobatę dla swego miejsca zamieszkania, zdecydowana większość żałowałaby gdyby była zmuszona je opuścić, a co czwarty chciałby, aby jego dzieci mieszkały w tym samym osiedlu. Ponad połowa mieszkańców badanych osiedli zadeklarowała także, że lubi przebywać $\mathrm{w}$ najbliższej okolicy zamieszkania, a prawie połowa zdecydowanie nie chciałaby się z niego wyprowadzić.

Szerszą perspektywę analizy omawianych zjawisk dają porównania o charakterze międzynarodowym. $Z$ analiz wyników najobszerniejszego z przeprowadzonych dotychczas badań zrealizowanego w 29 wielkich osiedlach europejskich $\mathrm{w}$ ramach programu RESTATE wynika, że satysfakcja mieszkaniowa w osiedlach miast postsocjalistycznych jest zbliżona do średniej satysfakcji w miastach krajów zachodnioeuropejskich (Musterd, van Kempen 2005). Biorąc zaś pod uwagę jej zmianę w ciągu ostatnich pięciu lat autorzy badań ustalili, że $\mathrm{w}$ siedmiu na osiem badanych osiedli postsocjalistycznych (poza jednym - w słoweńskim Koprze) satysfakcja ta wzrosła. Najsilniejszy jej wzrost odnotowano w warszawskim osiedlu Ursynów Płn., budapeszteńskim osiedlu Havanna i osiedlu Josavaros w mieście Nyregyhaza (na Węgrzech). Uwzględniony w tych badaniach aspekt percepcji, który ich autorzy określili jako „wiara w osiedle” (trust in the estate), oznaczający wiarę $w$ jego dobre perspektywy oraz bycie w przyszłości przyjaznym miejscem do zamieszkania, wyraziło od 35 do 55\% mieszkańców osiedli w miastach postsocjalistycznych. Największy odsetek takich osób (ponad połowę) odnotowano $\mathrm{w}$ warszawskich osiedlach Ursynów Płn. i Wrzeciono oraz w budapesztańskim osiedlu Havanna, najmniejszy zaś w osiedlach wschodniej części Berlina - Marzahn i Hellersdorf.

Do podobnych wniosków doprowadzily inne badania o charakterze komparatystycznym (Kovács, Herfert 2012), przeprowadzone w wybranych wielkich osiedlach Budapesztu (Havanna), Lipska (Grünau), Wilna (Karoliniskes) oraz Sofii (Mladost) powstałych na przełomie lat 70. oraz 80. XX wieku, z których wynika, że ich mieszkańcy wykazują dość dużą stabilizację mieszkaniową, większą niż mieszkańcy obszarów centralnych tych miast. Porównanie pomiędzy miastami dokonane przez tych autorów dowiodło, że najmniejszą chęć opuszczenia badanego osiedla w bliskiej przyszłości zadeklarowali mieszkańcy osiedla Grünau w Lipsku (tylko 12\%), które od 
połowy lat 90. poddawane jest intensywnym działaniom mającym na celu poprawę warunków zamieszkania (Kabisch, Grossmann 2013), największą zaś mieszkańcy Havanna w Budapeszcie (aż 35\%), gdzie głównym powodem chęci wyprowadzki są wysokie koszty utrzymania mieszkań (Kovács, Herfert 2012). Przyczyną dużej stabilności mieszkaniowej oraz relatywnie niskiej mobilności deklarowanej przez mieszkańców badanych osiedli jest według autorów szczególna sytuacja na rynku mieszkaniowym miast postsocjalistycznych, która sprawia, że teoretycznie duża możliwość wyboru nowego miejsca zamieszkania, która otworzyła się po zmianie ustroju, jest silnie ograniczona brakiem relatywnie dobrych, a równocześnie dostępnych ekonomicznie zasobów mieszkaniowych zlokalizowanych poza wielkimi osiedlami (Kovács, Herfert 2012). Wniosek ten potwierdza ustalenia autorów polskich powstałe $\mathrm{w}$ oparciu o badania przeprowadzone we Wrocławiu (Borowik 2003, 2007) oraz Łodzi (Szafrańska 2009).

W kontekście barier i ograniczeń, jakie mają gospodarstwa domowe działające $\mathrm{w}$ warunkach miasta postsocjalistycznego, do interesujących wniosków prowadzi, kolejna już, lecz bardziej szczegółowa, analiza satysfakcji mieszkaniowej i związanych z nią preferencji migracyjnych, przeprowadzona na podstawie projektu RESTATE, która pozwoliła na wyodrębnienie pięciu kategorii gospodarstw domowych (Musterd, van Kempen 2007). Kryterium ich wyodrębnienia była grupa zmiennych uwzględniająca różne aspekty satysfakcji mieszkaniowej. Wśród tych kategorii znalazły się: (1) wyraźnie niezadowoleni z zamieszkiwania w osiedlu, ale niewyrażający chęci (bądź niemający możliwości) wyprowadzenia się z niego, określeni jako "nieusatysfakcjonowani uwięzieni” lub, inaczej - „będący w potrzasku" (unsatisfied trapped), (2) niezadowoleni $\mathrm{z}$ zamieszkiwania $\mathrm{w}$ osiedlu, wyrażający chęć i mający poważne plany wyprowadzenia się z niego w najbliższym czasie, określani jako "nieusatysfakcjonowani, gotowi na zmianę" (unsatisfied springboard), (3) zadowoleni z zamieszkiwania $\mathrm{w}$ osiedlu, lecz także wyrażający chęć $\mathrm{i}$ poważne plany wyprowadzenia się $\mathrm{w}$ najbliższym czasie z osiedla, określeni jako "usatysfakcjonowani, gotowi na zmianę" (satisfied springboard), (4) zadowoleni z zamieszkiwania w osiedlu, którzy chcą w nim pozostać, określeni jako „usatysfakcjonowani zostający” lub ustabilizowani (satisfied stayers), (5) pozostali, niewyrażający ani silnej satysfakcji ani dyssatysfakcji z zamieszkiwania $\mathrm{w}$ osiedlu oraz bez wyraźnej chęci wyprowadzenia się z niego lub pozostania w nim (ibid, s. 312). I jakkolwiek kategoryzacja ta może budzić pewne wątpliwości, ponieważ ostatnia $\mathrm{z}$ kategorii obejmuje ponad $3 / 4$ mieszkańców wszystkich badanych osiedli, to jednak za interesujące $z$ punktu widzenia niniejszej pracy uznać należy wyodrębnienie grupy "uwięzionych", która - jak podają ci autorzy w krajach postsocjalistycznych jest znacznie wyższa niż w krajach zachodnioeuropejskich. $\mathrm{Z}$ ich ustaleń wynika, że $\mathrm{w}$ badanych osiedlach tej grupy 
krajów „uwięzieni” stanowią 14\% mieszkańców, podczas gdy w grupie osiedli z krajów zachodnioeuropejskich - średnio 6\%. "Uwięzieniu”, według tych autorów (ibid., s. 322), sprzyjają także indywidualne cechy społeczno-demograficzne badanych, takie jak: starszy wiek, długość zamieszkiwania w osiedlu, niskie dochody, a także silne więzi społeczne z współmieszkańcami. Jednak nie bez znaczenia jest ogólna sytuacja społeczno-ekonomiczna oraz sytuacja na rynku mieszkaniowym, która mieszkańcom miast postsocjalistycznych znacznie silniej ogranicza możliwości zaspokojenia swoich potrzeb mieszkaniowych $\mathrm{w}$ sposób w pełni zadowalający niż mieszkańcom krajów, które nie mają w swojej historii okresu socjalizmu.

\subsubsection{Ocena wybranych aspektów zagospodarowania i wyposażenia osiedli oraz ich walorów architektoniczno-urbanistycznych i estetycznych}

Ważnym aspektem percepcji i waloryzacji zamieszkiwanego obszaru jest ocena różnych elementów zagospodarowania i wyposażenia tego obszaru, określanych jako jego walory użytkowe (Mysłek 2007) lub jego ład funkcjonalny (Bartoszek in. 1997, Jałowiecki, Szczepański 2006). Z dotychczasowych badań przeprowadzonych w osiedlach polskich obejmujących te zagadnienia (tab. 13) wynika, że ich autorzy poddawali ocenie mieszkańców najczęściej zagospodarowanie i wyposażenie osiedli w różne obiekty infrastruktury społecznej i handlowo-usługowej (najczęściej o charakterze podstawowym), wyposażenie ich w tereny rekreacyjne oraz inne miejsca i obiekty przeznaczone do spędzania wolnego czasu, a także $\mathrm{w}$ tereny zielone. Uwzględniano również zadowolenie z wyposażenia osiedla w parkingi i sieć dróg wewnętrznych, a także oceniano jego zewnętrzną dostępność komunikacyjną i położenie $\mathrm{w}$ przestrzeni miasta. Tak rozumiane walory użytkowe osiedli badane były i analizowane odrębnie dla każdego z walorów lub w oparciu o różne wskaźniki i indeksy o charakterze grupowym, konstruowane przez poszczególnych autorów.

Z cytowanych już badań I. Borowik (2003), które umożliwiają porównanie ocen walorów użytkowych osiedli dokonanych przez mieszkańców w latach 1994-2001 wynika, że oceny te w badanym okresie poprawily się, co nie oznacza, że stały się w pełni zadowalające. Respondenci wciąż dostrzegali bowiem niedostatki wyposażenia i zagospodarowania osiedli w niemal wszystkich badanych aspektach, przy czym największa ich grupa wskazała na brak lub niedostatek terenów rekreacyjnych, parkingów i garaży oraz niewystarczająco zadbane tereny zielone i place zabaw dla dzieci. Do najbardziej niezadowolonych $z$ obecnego stanu rzeczy należały osoby młodsze oraz mieszkańcy o wyższym statusie społecznym (wyrażonym 
poprzez zamożność, wykształcenie i pozycję zawodową), co potwierdza wcześniejsze ustalenia, że osoby takie bardziej zdecydowanie formułują swoje potrzeby i są bardziej wymagające $\mathrm{w}$ stosunku do środowiska mieszkaniowego. Wysoko w tych badaniach ocenione zostało natomiast wyposażenie osiedli w handel oraz usługi.

Dostępność usług w miejscu zamieszkania i bliskość obiektów handlowych wysoko ocenili także mieszkańcy osiedli w Katowicach (Warchalska-Troll 2012), Łodzi (Janiszewska i in. 2011, Szafrańska 2009), Poznaniu (Ciesiółka 2010) oraz Lublinie (Rodzoś, Flaga 2010). Największym walorem osiedli w ich ocenie było dobre wyposażenie $w$ tereny zielone, a tym, czego brakowało najbardziej, były miejsca parkingowe. Znaczący niedostatek parkingów podnoszony był przez mieszkańców niemal wszystkich badanych osiedli $\mathrm{w}$ wymienionych miastach, przy czym najczęściej dotyczyło to osiedli najstarszych, ponieważ projektując je, uwzględniano wprawdzie rozwój motoryzacji, lecz nie przewidziano jego skali (por. Chmielewski, Mirecka 2001, Wojtkun 2004). Z analizy badań przeprowadzonych w wymienionych miastach wynika także, że we wszystkich badanych osiedlach odnotowano relatywnie dużą grupę mieszkańców, sięgającą od 20 do $30 \%$, według których aktualne wyposażenie i zagospodarowanie osiedli było na tak dobrym poziomie, że nie należałoby $\mathrm{w}$ tej dziedzinie nic zmieniać. Do grupy takiej najczęściej należały osoby najstarsze i najdłużej mieszkające w osiedlach, które z jednej strony są do nich przywiązane, z drugiej zaś, mając możliwość porównania bardzo ubogiego wyposażenia osiedli w przeszłości ze stanem współczesnym, dostrzegają ogromną jego poprawę. W drugiej grupie osób najlepiej oceniających osiedla znaleźli się mieszkańcy relatywnie młodzi, w wieku do 35 lat, którzy przeprowadzili się do osiedli niedawno (głównie kupując mieszkania), a dokonany przez nich wybór osiedla był świadomy i wynikał między innymi z dostosowania jego wyposażenia do ich aktualnych potrzeb.

$\mathrm{Z}$ analiz wyników badań zrealizowanych $\mathrm{w}$ ramach programu RESTATE pozwalających na porównania w skali międzynarodowej (Musterd, van Kempen 2005) wynika, że aspekt zamieszkiwania, jakim jest dostępność podstawowych usług, w większości osiedli oceniony został wysoko, przy czym w krajach postsocjalistycznych wyżej niż w pozostałych, ponieważ w siedmiu spośród ośmiu badanych osiedli Polski, Węgier, Słowenii i b. NRD ponad $80 \%$ mieszkańców zadeklarowała, że w ich najbliższym sąsiedztwie występują wszystkie niezbędne usługi (Musterd, van Kempen 2005).

Ewaluacja walorów funkcjonalnych osiedli nie ogranicza się do oceny ich wyposażenia, bardzo ważnym bowiem aspektem środowiska mieszkaniowego jest jego lokalizacja oraz dostępność komunikacyjna. Lokalizacja osiedli, szczególnie największych, wznoszonych w latach 70. oraz w I poło- 
wie lat $80 . \mathrm{XX}$ w., kiedy sytuowano je w znacznym oddaleniu od zwartej tkanki miejskiej, obecnie na skutek rozwoju przestrzennego miast, dokonywanego przez inkorporację terenów podmiejskich oraz zjawisko urban sprawl, nie ma już charakteru peryferyjnego. W większości miast osiedla „zrosły się" przestrzennie ze strefą zurbanizowaną, a rozwój dróg i sieci miejskiego transportu publicznego oraz upowszechnienie się samochodów osobowych znacznie poprawiły ich dostępność. Stan ten znajduje odzwierciedlenie w percepcji lokalizacji osiedli i ich dostępności komunikacyjnej, która - jak wynika z cytowanych już badań empirycznych - przez większość mieszkańców odbierana jest pozytywnie, a dla wielu z nich jest nawet głównym walorem osiedla. Odnotowano to głównie w badaniach osiedli zlokalizowanych przy najważniejszych liniach szynowego transportu publicznego, czyli metra, np. w Pradze (por. Temelova i in. 2011), Budapeszcie (Csaba 2006) i Warszawie (Węcławowicz i in. 2003), szybkiego tramwaju, np. w Poznaniu (Ciesiółka 2010), czy szybkiej kolei miejskiej, np. w Trójmieście (Rzyski, Mędrzycka 2010), gdzie mieszkańcy zawsze podkreślali ten walor osiedla.

Biorąc pod uwagę percepcję innych walorów osiedli blokowych w miastach postsocjalistycznych związanych z ich estetyką, opinie mieszkańców są bardziej zróżnicowane, a ich oceny - jak się wydaje - są bardziej powiązane $\mathrm{z}$ indywidualnym poziomem wymagań $\mathrm{w}$ tym zakresie, niż $\mathrm{z}$ obiektywnym poziomem tych walorów. $Z$ przeglądu cytowanych już badań, $w$ których analizowano te kwestie wynika między innymi, że estetyka zabudowy osiedlowej, która budzi tak wiele kontrowersji głównie wśród architektów i urbanistów (por. Jałowiecki 1994, 1995, Pawłowska 1996, Rykiel 2000), przez większość mieszkańców osiedli oceniana jest znacznie łagodniej niż przez specjalistów. Modernistyczna zabudowa osiedli nie jest negatywnie odbierana przez mieszkańców, o ile tylko budynki mają odnowione elewacje, są zadbane i prezentują względnie dobry stan techniczny. Badania przeprowadzone wśród mieszkańców osiedli w różnych miastach pozwalają stwierdzić, że bardzo rzadko kwestionują oni architektoniczny kształt zabudowy, a kwestie estetyczne najczęściej sprowadzają do stanu utrzymania budynków. Świadczyć to może o tym, że sporo racji mieli twórcy idei tej formy zabudowy twierdząc, że najważniejsza jest jej funkcjonalność. Argumentacja mieszkańców doceniających estetykę osiedli bardzo często jest wynikiem obecności na ich terenie dużej ilości zieleni, a zatem wiąże się z realizacją innego z ważnych postulatów Karty Ateńskiej oraz jej głównego teoretyka Le Corbusiera, jakim było wkomponowanie budynków mieszkalnych $\mathrm{w}$ zieleń. Wniosek ten znajduje potwierdzenie także $\mathrm{w}$ badaniach RESTATE, które pokazały, że o ile mieszkańcy krajów zachodnioeuropejskich jako główną zaletę zamieszkiwanych osiedli najczęściej wskazywali 
ich walory użytkowe, to mieszkańcy osiedli postsocjalistycznych - ilość zieleni (Mustred, van Kempen 2005).

Mieszkańców dzielą również kwestie związane z oceną dbałości o teren osiedli, przy czym tu również według większości z nich - jak wynika z cytowanych uprzednio badań (Ciesiółka 2010, Rodzoś, Flaga 2010, Janiszewska i in. 2011, Musterd, van Kempen 2005) - osiedla są zadbane. Tym, co respondenci dostrzegali przede wszystkim (głównie ci o dłuższym stażu zamieszkiwania), jest znacząca poprawa stanu zadbania osiedli w stosunku do do okresu sprzed transformacji oraz wczesnych lat 90 . XX wieku. Obecne działania służące poprawie stanu zadbania terenów osiedlowych, podejmowane $\mathrm{w}$ różnych krajach, miastach i osiedlach na różną skalę, uzależnione są, jak już powiedziano, od wielu czynników, począwszy od polityki mieszkaniowej na poziomie krajowym, a skończywszy na sprawności zarządców poszczególnych osiedli lub ich fragmentów. Lecz nawet jeśli są one skromne, to - jak pokazują badania - są przez mieszkańców dostrzegane i odnotowywane jako pozytywny kierunek zmian.

\subsubsection{Relacje społeczne i więzi mieszkańców}

Niezwykle ważnym składnikiem percepcji zamieszkiwanego obszaru - co podkreśla wielu cytowanych już autorów - jest szczególny typ więzi spolecznych wytworzonych na bazie zamieszkiwanego terytorium, który w literaturze określa się mianem więzi sąsiedzkich (por. Kryczka 1981, Kotus 2007). Jak podaje zajmująca się tym zagadnieniem E. Kaltenberg-Kwiatkowska (2002), z badań zakresu, typów i uwarunkowań wielkomiejskich kontaktów sąsiedzkich wynika, że sąsiedztwo jest nadal, mimo istotnych przekształceń zachodzących we współczesnym, globalizującym się świecie, istotną formą integracji społecznej mieszkańców wielkiego miasta, niezależnie od typu zamieszkiwanej zabudowy. W żadnym z typów zabudowy miejskiej nie jest bowiem preferowana ani realizowana spoleczna izolacja. A obserwowany współcześnie proces uniezależniania się od bezpośredniego otoczenia społecznego i brak potrzeby więzi z nim, wynikający z wzrostu ruchliwości przestrzennej i rozwoju nowych form komunikacji oraz rosnącej indywidualizacji i "prywatyzacji” życia, dotyczy przede wszystkim ludzi młodych, mobilnych, zajmujących wysokie pozycje w strukturze społecznej (Majer 2010), nie jest zatem wzorem realizowanym powszechnie ${ }^{146}$. Empi-

146 Jak podaje P. Starosta (2000) współcześnie mówi się nawet o odtwarzaniu i rozwoju wspólnot lokalnych na innych niż dotychczas zasadach i o wyłanianiu się nowych form lokalizmu. Według wprowadzonego przez R. Strassoldo (Starosta 2000, za: Strassoldo 1992) rozróżnienia na "stary i nowy lokalizm", "stary lokalizm" był pierwotny i bezrefleksyjny, minimalizował kontakty poza społecznością, utrzymując bliskość wewnątrz niej, "nowy lokalizm” 
ryczne badania więzi sąsiedzkich $\mathrm{w}$ wielkich osiedlach mieszkaniowych są o tyle ważne, że ich wyniki konfrontuje się ze stereotypem mówiącym o bardzo słabych lub niemal nieistniejących więziach tego rodzaju w zabudowie blokowej (Rykiel 2000).

Na podstawie cytowanych już socjologicznych badań I. Borowik (2003) stwierdza, że sąsiedztwo w wielkich osiedlach mieszkaniowych jest według ich mieszkańców jedną z ważnych zalet zbiorowego zamieszkiwania, docenianą przez nich i pielęgnowaną. Zdecydowana większość mieszkańców kontakty sąsiedzkie utrzymuje, choć różny jest ich zakres i motywy. Najczęściej są to "potrzeba kontaktu, wspólnoty, koleżeństwa” (ponad 40\% badanych), następnie „wzajemna pomoc” (ponad 20\%), a także „wspólnota wieku i zainteresowań" (14\%) oraz "mieszkanie obok siebie” (11\%). Ich zakres i typ w badanych osiedlach różnicują głównie wiek, płeć, poziom zamożności i czas zamieszkiwania - częściej utrzymują je ludzie starsi, kobiety, osoby mniej zamożne oraz mieszkający w nich dłużej. Żadna jednak z kategorii społeczno-demograficznych mieszkańców osiedli nie deklaruje sąsiedzkiej izolacji. Relatywnie niewielki odsetek osób przyznających się do wspólnoty zainteresowań z sąsiadami wynika zdaniem tej autorki z wciąż heterogenicznego składu społecznego mieszkańców osiedli blokowych (Borowik 2003). Trudno nie zgodzić się z tą tezą, jednak z badań niemal homogenicznych społecznie osiedli zamkniętych wynika, że relacje sąsiedzkie są w nich bardzo słabe, znacznie słabsze niż w zabudowie blokowej (Gądecki 2009), co oznacza, że zjawisko to ma bardziej złożony charakter. Potwierdza to J. Kotus (2007), który na podstawie badań różnych typów zabudowy w Poznaniu sformułował wniosek, że: „w poznańskich realiach obszary sąsiedzkie określonego typu zabudowy skategoryzować można pod względem narastającej integracji sąsiedzkiej (poczynając od najmniej zintegrowanych) w następującej kolejności: nowe zespoły mieszkaniowe z przełomu XX i XXI wieku, stare komunalne budownictwo kamieniczne, bloki miasta socjalistycznego, budownictwo jednorodzinne" (ibid., s. 235). Uzyskany przez tego autora wniosek o relatywnie silniej integracji sąsiedzkiej mieszkańców osiedli blokowych przeczy zatem opiniom, że zamieszkiwanie $\mathrm{w}$ nich nie sprzyja nawiązywaniu więzi społecznych oraz, że charakteryzują się one znacząco większą niż w innych typach zabudowy miejskiej, anonimowością społeczną.

Interesujących wniosków na temat sąsiedztwa $\mathrm{w}$ wielkich osiedlach o zabudowie blokowej potwierdzających ustalenia I. Borowik i J. Kotusa dostarczyły wyniki badań przeprowadzonych w osiedlu im. A. Mickiewicza

natomiast jest efektem świadomego wyboru, ma świadomość istnienia reszty świata i jest otwarty na relacje $\mathrm{z}$ nim. 
w Lublinie (Rodzoś Flaga 2010), gdzie stwierdzono bardzo duże i niesłabnące od lat zaangażowanie mieszkańców w relacje sąsiedzkie. Sąsiedztwo świadczeniowe utrzymywane jest tam obecnie przez ponad $80 \%$ mieszkańców, czyli niemal tyle samo ile w latach 60. oraz 70. ubiegłego wieku (co ustalili w badaniach $\mathrm{z}$ tego okresu J. Turowski oraz P. Kryczka). Zmiana, która nastąpiła $\mathrm{w}$ ciągu ostatnich kilku dekad polega jedynie na zawężeniu zakresu kontaktów sąsiedzkich poprzez ograniczenie liczby sąsiadów, z którymi są one utrzymywane (Rodzoś, Flaga 2010).

Do podobnych wniosków na temat realizowanego typu sąsiedztwa prowadzą także badania przeprowadzone w siedmiu osiedlach łódzkich (Janiszewska i in. 2010), które pokazują, że niemal wszyscy badani realizują $\mathrm{w}$ nich sąsiedztwo konwencjonalne, a większość (choć nie tak wielu jak w badaniach lubelskich) świadczy na ich rzecz różnego rodzaju przysługi (sąsiedztwo świadczeniowe). I mimo że kontakty sąsiedzkie utrzymywane przez mieszkańców tych osiedli najczęściej mają charakter konwencjonalny, to oceniane są przez nich jako dobre i przyjazne. Najmniej badanych przyznało się do zaangażowania $\mathrm{w}$ realizację wspólnych interesów i brania udziału w inicjatywach sąsiedzkich, czyli do realizacji sąsiedztwa określanego jako solidarnościowe. Nie jest to jednak cecha dystynktywna mieszkanców wielkich osiedli, a raczej wyraz charakterystycznej dla ogółu Polaków małej aktywności społecznej, wyrażającej się niskim poziomem udziału w życiu publicznym, współcześnie wzmocnionym przez rosnący indywidualizm (Czapiński, Panek 2011).

Inne badania, przeprowadzone w Łodzi przez A. Bujwicką (2011), których przedmiotem były relacje sąsiedzkie mieszkańców miasta $\mathrm{w}$ różnych typach zabudowy, dowodzą, że najczęściej spotykanym współcześnie typem sąsiedztwa w mieście, charakterystycznym także dla mieszkańców zabudowy blokowej jest sąsiedztwo o charakterze konwencjonalnym, o nieznacznym stopniu społecznego zaangażowania i preferowaniu okazjonalnego wsparcia. Nie oznacza ono dystansowania się od powiązań sąsiedzkich, ale też nie zmierza do ich zacieśniania i przenoszenia w sferę życia prywatnego. Ten typ sąsiedztwa - jak zauważa autorka, charakterystyczny jest także (niezależnie od typu zamieszkiwanej zabudowy) dla ludzi młodych oraz reprezentujących wysoki status społeczno-zawodowy, czyli osób, które w dzisiejszym zglobalizowanym świecie nie są, używając określenia zaproponowanego przez Z. Baumana (1997), „skazani na lokalność” i mają możliwość realizowania swych potrzeb społecznych w innych przestrzeniach, w tym także w przestrzeni wirtualnej, w oderwaniu od terytorium (Bujwicka 2011). Studia te pokazały, podobnie jak wcześniejsze badania E. Kaltenberg-Kwiatkowskiej (2002) i J. Kotusa (2007), że najważniejszymi predyktorami występowania poszczególnych typów sąsiedztwa są wiek, 
status społeczno-zawodowy ${ }^{147}$ oraz długość zamieszkiwania, w mniejszym zaś stopniu typ zabudowy. Wpływ typu zamieszkiwanej zabudowy (w podziale na zabudowę blokową, kamieniczną i jednorodzinną) zaczyna mieć znaczenie dopiero $w$ bardziej szczegółowych ujęciach, obejmujących wysokość tej zabudowy. Otóż bowiem, jak pokazała w swoich badaniach E. Kaltenberg-Kwiatkowska (2002), istotną determinantą nawiązywania stosunków sąsiedzkich w budynkach blokowych jest ich wysokość. Mieszkańcy zabudowy wysokiej mają, jak stwierdziła ta autorka, znacznie większe poczucie anonimowości sąsiedzkiej oraz deklarują mniejszą grupę osób, z którą utrzymują bliskie relacje sąsiedzkie, niż mieszkańcy zabudowy niskiej (w tym przypadku głównie budynków liczących pięć kondygnacji). Podobne wnioski wynikają z badań słowackich (por. Divinský 2004). Ustalenia te, jakkolwiek stwierdzone zostały w studiach nad osiedlami, to wydaje się, że mają charakter ogólny, ponieważ wpływ wysokości zabudowy (i związanego $z$ tym zagęszczenia mieszkańców oraz zatłoczenia) na różne aspekty relacji międzyludzkich podkreślany był także $\mathrm{w}$ badaniach $\mathrm{z}$ dziedziny proksemiki (por. Hall 1976).

Do podobnych ustaleń dotyczących więzi sąsiedzkich w zabudowie blokowej prowadzą porównania o charakterze międzynarodowym oparte na programie RESTATE, które pozwalają na stwierdzenie, że więzi sąsiedzkie w 29 osiedlach różnych krajów europejskich są zróżnicowane, ale relatywnie dobre (Musterd, van Kempen 2005). Odsetek mieszkańców wielkich osiedli, którzy deklarują wzajemną pomoc i sąsiedztwo świadczeniowe, najwyższy jest w osiedlach hiszpańskich i włoskich, co jednak wynikać może głównie z kwestii kulturowych oraz wieku mieszkańców i długości zamieszkiwania w nich (są to osiedla najstarsze i o największym poziomie "zasiedziałości"). W nich także zakres tych kontaktów jest największy, a ich ocena najwyższa. Z osiedli polskich uwzględnionych $\mathrm{w}$ tych badaniach podobny rezultat odnotowano w osiedlu Wrzeciono, które również charakteryzuje się dużą demograficzną starością oraz zasiedziałością mieszkańców (por. Węcławowicz i in. 2005). Zdecydowanie mniej zażyłe relacje sąsiedzkie odnotowano natomiast $\mathrm{w}$ osiedlach szwedzkich, holenderskich oraz brytyjskich, które charakteryzuje wysoka rotacja mieszkańców oraz wielokulturowość, czyli zjawiska, które nie występują w osiedlach postsocjalistycznych wcale lub występują w znacznie mniejszym zakresie. Wśród osiedli z krajów postsocjalistycznych uwzględnionych $w$ badaniu RESTATE, wyraźnie wyróżniają się osiedla polskie, czyli wspomniane już Wrzeciono oraz znacznie młodszy demograficznie i charakteryzujący się wyższym statusem spo-

$147 \mathrm{Tu}$ jako komponenty statusu przyjęto poziom wykształcenia, kategorię społeczno-zawodową, standard materialny gospodarstwa domowego i sytuację respondenta na rynku pracy (Bujwicka 2011). 
łecznym Ursynów Płn., gdzie deklaracje zarówno sąsiedztwa świadczeniowego, jak i dobrych relacji w miejscu zamieszkania osiągają wartości średnie dla całego zbioru badanych osiedli, ale są wyższe niż $\mathrm{w}$ pozostałych osiedlach z krajów postsocjalistycznych uwzględnionych w badaniu (Węgier, Słowenii oraz d. Berlina Wschodniego). Mieszkańcy osiedli z tych krajów zadeklarowali znacznie mniejsze zaangażowanie $\mathrm{w}$ kontakty sąsiedzkie i znacznie gorszą ich ocenę, porównywalną z mieszkańcami osiedli w Holandii i Wielkiej Brytanii. Przeprowadzone porównanie, jakkolwiek dostarcza pewnej wiedzy na temat różnic $\mathrm{w}$ zakresie kontaktów sąsiedzkich mieszkańców osiedli w różnych krajach, to przede wszystkim wskazuje, że główne determinanty tych różnic, czyli wiek i długość zamieszkiwania $\mathrm{w}$ osiedlu, są znacznie silniejszymi predyktorami więzi sąsiedzkiej niż typ zabudowy, który często za taki zwykło się uważać. Jak bowiem podaje J. Kotus (2007), relacje sąsiedzkie, choć bazujące na stycznościach przestrzennych uczestników, nie rozwijają się wyłącznie dzięki odniesieniom terytorialnym. Według tego autora zintegrowane wewnętrznie sąsiedztwa powstają również $\mathrm{w}$ przypadku mniej korzystnych uwarunkowań terytorialnych (np. w wysokim bloku w osiedlu z lat 70.), a mogą nie zaistnieć w sytuacji, kiedy układ przestrzenno-urbanistyczny teoretycznie sprzyja i ułatwia kontakty interpersonalne (np. ślepe uliczki w przedwojennym osiedlu willi jednorodzinnych). Zależy to bowiem od podobieństwa cech samych mieszkańców: ich wykształcenia, składu gospodarstwa domowego, długości zamieszkiwania w okolicy oraz aktywizowania lub nie sąsiedzkich relacji społecznych (Kotus 2007, s. 226).

\subsubsection{Poczucie bezpieczeństwa w osiedlach}

Ostatnim z omawianych w tym miejscu, lecz niezwykle ważnym atrybutem zamieszkiwania, który pozostaje w silnym związku zarówno z satysfakcją mieszkaniową, więzią sąsiedzką, jak i z innymi aspektami percepcji zamieszkiwanego terytorium, jest poczucie bezpieczeństwa (por. Lewicka 2012). Na poczucie bezpieczeństwa mieszkańców wielkich osiedli blokowych, tak jak i innych obszarów mieszkaniowych, wpływają trzy grupy cech, które w literaturze określa się jako: indywidualne (obejmujące społeczno-demograficzne i psychologiczne cechy jednostek), społeczno-kulturowe (do których należą np. przyjęte $\mathrm{w}$ danej grupie normy kulturowe, ogólny poziom zaufania społecznego, a także obecna w mediach „kultura przemocy"148) oraz architektoniczno-urbanistyczne, związane z typem zabu-

148 Omówione w literaturze zjawisko kultury przemocy polega na częstym i wielokrotnym pokazywaniu jej $\mathrm{w}$ mediach, tworząc tym samym nieuzasadnioną atmosferę niebezpie- 
dowy (Czapska, red. 2012). Oczywiście nie bez znaczenia jest także faktyczny poziom przestępczości, ale ten, jak pokazują badania (np. Guzik 2000a, b), często pozostaje $\mathrm{w}$ niewielkim związku z jej percepcją. Percepcja przestępczości bowiem $w$ większym stopniu opiera się na stereotypach oraz jej obrazie dostępnym w przekazach medialnych (Czapska, red. 2012). Media zaś, same kierując się stereotypami, często nadmiernie eksponują przestępczość na pewnych obszarach (w tym m.in. w osiedlach blokowych).

Analiza poczucia bezpieczeństwa mieszkańców wielkich osiedli w krajach postsocjalistycznych jest zatem zadaniem trudnym, ponieważ obecność w dyskursie publicznym i medialnym stereotypów dotyczących tej formy zabudowy, których głównym źródłem jest sytuacja w krajach zachodnioeuropejskich, sprawia, że osiedla te zwykle uważa się za obszary nasilonej przestępczości i związanego z tym niskiego poczucia bezpieczeństwa mieszkańców. Jak pokazują badania - nie zawsze jest to prawda. Jedno z takich badań, w których konfrontowano stereotyp niebezpiecznej Nowej Huty w Krakowie ze stanem faktycznym przeprowadzone zostało przez R. Guzika (2000a). Autor ten na przykładzie osiedla Nowa Huta, które od wielu lat niezmiennie cieszy się złą sławą wśród mieszkańców miasta, pokazał, jak duża jest rozbieżność pomiędzy tą opinią a stanem faktycznym, dowodząc, że rzeczywista przestępczość w osiedlu odnotowana w statystykach policyjnych należy do najniższych $w$ mieście i jest niemal dwukrotnie niższa niż w Śródmieściu Krakowa (Guzik 2000a, s. 203)149.

Zjawisko stygmatyzacji osiedli blokowych $\mathrm{w}$ miastach postsocjalistycznych, poprzez "przeniesienie” sytuacji występującej w miastach krajów zachodnioeuropejskich, bardzo dobrze ilustrują także badania K. Krajewskiego (2012). Autor ten porównywał faktyczną przestępczość w osiedlach blokowych w Amsterdamie, Berlinie (po obu stronach byłego muru), Bristolu, Budapeszcie i Krakowie ${ }^{150} \mathrm{z}$ ogólnym poziomem przestępczości $\mathrm{w}$ tych miastach, stwierdzając w konkluzji, że o ile przestępczość w osiedlach holenderskich i brytyjskich jest wyższa niż ogółem w miastach, o tyle przestępczość

czeństwa (Czapska, red. 2012, s. 38). W przypadku wielorodzinnej zabudowy blokowej, która często pokazywana jest $\mathrm{w}$ mediach $\mathrm{w}$ złym kontekście, przynosi to znaczący i często nieuzasadniony wzrost poczucia zagrożenia zarówno wśród jej mieszkańców, jak i w opiniach zewnętrznych.

149 Także w wielu innych pracach dotyczących przestrzennego zróżnicowanie poziomu przestępczości $\mathrm{w}$ miastach postsocjalistycznych stwierdzono, że rzeczywista liczba przestępstw w tych miastach jest znacznie wyższa na obszarach starej zabudowy śródmiejskiej niż w osiedlach blokowych - np. badania S. Marcińczaka i A. Siejkowskiej (2004) oraz S. Mordwy (2013) przeprowadzone w Łodzi.

${ }_{150} \mathrm{~W}$ Amsterdamie badane było osiedle Bijlmermeer, w Berlinie dwa osiedla po obu stronach byłego muru - Gropiusstadt w części zachodniej oraz Marzahn Hellersdorf i Marzahn Nord w części wschodniej, w Bristolu osiedle Hartcliffe, w Budapeszcie osiedle Békásmegyer, a w Krakowie osiedle Prądnik Czerwony (Krajewski 2012). 
w osiedlach polskich i węgierskich jest niższa od średniej dla tych miast. Sytuacja ta jak w soczewce ujawniła się także w Berlinie, ponieważ w osiedlu położonym w zachodniej części miasta przestępczość jest tak jak w Amsterdamie i Bristolu wyższa, a w osiedlach położonych we wschodniej jego części jest analogiczna do występującej w Budapeszcie i Krakowie (Krajewski 2012, s. 198). Różnice te są na tyle znaczące, że mają charakter prawidłowości, dostarczając kolejnych argumentów w dyskusji na temat roli stereotypów w postrzeganiu wielkich osiedli oraz nieuzasadnionej projekcji sytuacji w miastach zachodnioeuropejskich na miasta postsocjalistyczne.

Nie mniej ważną kwestią, jak już powiedziano, od faktycznego poziomu przestępczości w osiedlach blokowych jest jego percepcja wśród mieszkańców, która decyduje o ich poczuciu bezpieczeństwa. W tym przypadku jednak odczucia społeczne są bliższe faktom, ponieważ mieszkańcy wielkich osiedli mieszkaniowych, mimo obecnego w mediach i dyskursie publicznym stereotypu niebezpiecznych blokowisk, mają relatywnie wysokie poczucie bezpieczeństwa. Świadczą o tym badania przeprowadzone w osiedlach Wrocławia (Borowik 2003), Szczecina (Wojtkun 2004), Warszawy (Węcławowicz i in. 2005), Poznania (Kotus 2007), Krakowa (Jerschina i in. 2012), Łodzi (Szafrańska 2009, Mordwa 2010, 2013), Brna (Andráško i in. 2013), a także $\mathrm{w}$ osiedlach węgierskich, słoweńskich i niemieckich $\mathrm{w}$ ramach programu RESTATE (Tosisc i in. 2005, Černič Mali i in. 2005, Mustred, van Kempen 2005). Negatywne postrzeganie bezpieczeństwa w osiedlach blokowych jest zatem opinią o charakterze zewnętrznym, która nie jest podzielana przez ich mieszkańców. Tym bardziej, że duże znaczenie dla poczucia bezpieczeństwa w poszczególnych obszarach miejskich ma skład społeczny sąsiedztwa. A ten $w$ większości wielkich osiedli w miastach postsocjalistycznych jest heterogeniczny i wciąż, mimo pewnych symptomów selekcji negatywnej związanych z procesami filtracji mieszkaniowej, relatywnie dobry. A nawet, jak wynika z rozmieszczenia różnych kategorii statusowych ludności w przestrzeni wybranych miast polskich (Liszewski 1999, Wolaniuk 2003, Zborowski 2005, Szafrańska 2008, Szmytkowska 2008, Marcińczak 2009, Węcławowicz 2007), jest lepszy niż w innych ich rejonach.

Poczucie bezpieczeństwa, jak już powiedziano, zależy od wielu czynników, ale w literaturze najczęściej przyjmuje się dwie zasadnicze hipotezy wyjaśniające to zjawisko: psychologiczno-społeczną oraz urbanistyczno-architektoniczną, które za J. Jacobs i O. Newmanem doszukują się źródeł patologii $\mathrm{w}$ złych rozwiązaniach przestrzennych sprzyjających rozwojowi przestępczości (Czapska, red. 2012). Jakkolwiek hipotezy te rozstrzyga się w odniesieniu do różnych form zabudowy, to w przypadku wielkich osiedli mieszkaniowych wydaje się, że hipoteza urbanistyczno-architektoniczna jest nadmiernie eksponowana. A w literaturze z zakresu urbanistyki przez wie- 
lu autorów jest przyjmowana nawet a priori jako założenie, którego nie trzeba udowadniać (por. Ostrowska 1991). Z prac empirycznych analizujących wplyw rozwiązań urbanistycznych i architektonicznych zastosowanych w blokowym budownictwie osiedlowym na poczucie bezpieczeństwa mieszkańców wynika zaś, że nie jest on jednoznaczny (Wojtkun 2004, Jerschina i in. 2010). Ich autorzy uważają, że poczucie bezpieczeństwa jest pochodną zbyt wielu czynników, aby rozstrzygać o nim głównie w kontekście typu zabudowy. Również sam typ zabudowy wydaje się cechą nadmiernie zgeneralizowaną, ponieważ determinanty poczucia bezpieczeństwa mieszkańców poszczególnych osiedli często mają charakter lokalny i uzależnione są od konkretnych rozwiązań architektoniczno-urbanistycznych, np. wielkości i wysokości budynków, gęstości zabudowy, usytuowania budynków w przestrzeni osiedla, ich bezpośredniego sąsiedztwa oraz innych czynników, takich jak oświetlenie osiedli, obecność domofonów w budynkach, sposobu zagospodarowania przestrzeni publicznych itp., które są zróżnicowane $\mathrm{w}$ poszczególnych osiedlach. Tym samym teza zakładająca, że rozwiązania architektoniczne i urbanistyczne stosowane $\mathrm{w}$ zabudowie blokowej ze swej istoty sprzyjają rozwojowi przestępczości i powodują słabe poczucie bezpieczeństwa mieszkańców, nie znalazła jednoznacznego potwierdzenia w badaniach empirycznych.

\subsection{Podsumowanie}

Przedstawiona i zanalizowana w tej części pracy literatura dowodzi, że badania percepcji wielkich osiedli mieszkaniowych prowadzone są na gruncie wielu nauk, w oparciu o różne założenia teoretyczno-metodologiczne, przy użyciu różnych metod, a stosowane w nich pojęcia mogą być różnie konceptualizowane i różnie operacjonalizowane na użytek konkretnych badań. Także sposób jej wyjaśniania $\mathrm{w}$ dużej mierze zależy od istniejących w poszczególnych naukach tradycji oraz przyjmowanych w nich szerszych założeń ontologicznych i epistemologicznych. Na gruncie psychologii środowiskowej i socjologii, jako główne determinanty procesu percepcji i waloryzacji, częściej eksponuje się społeczno-demograficzne cechy badanych oraz kontekst społeczno-kulturowy, w których badane zjawiska zachodzą. Urbaniści i architekci natomiast, będąc blisko postawy, którą można określić determinizmem architektoniczno-urbanistycznym, częściej zwracają uwagę na fizyczne cechy i właściwości percypowanej przestrzeni, czyli zmienne określane jako urbanistyczne i architektoniczne. W nurcie badań geograficznych, do których należy niniejsza praca, łączy się różne podejścia i uwzględnia 
szerokie spektrum perspektyw badawczych. Podejście to wydaje się o tyle uzasadnione, że wszystkie wymienione czynniki wyjaśniające zjawiska społeczne zachodzące $\mathrm{w}$ przestrzeni mają charakter komplementarny i należy je rozpatrywać równolegle.

Wyniki uzyskane $\mathrm{w}$ badaniach percepcji wielkich osiedli mieszkaniowych w miastach postsocjalistycznych pozwalają na stwierdzenie, że ich mieszkańcy charakteryzują się relatywnie wysokim poziomem satysfakcji mieszkaniowej i więzi z zamieszkiwanym obszarem oraz słabą skłonnością do migracji. Większość z nich wykazuje duże zadowolenie $\mathrm{z}$ wyposażenia osiedli $\mathrm{w}$ infrastrukturę handlowo-usługową oraz tereny zielone, dobrze ocenia ich dostępność komunikacyjną i dostrzega zmiany zmierzające do poprawy ich zagospodarowania i estetyki. Analiza badań pozwala także na stwierdzenie, że zabudowa blokowa nie jest środowiskiem mieszkaniowym, które charakteryzuje się znacząco większą niż inne typy środowisk anonimowością w miejscu zamieszkania ani niechęcią do kontaktów sąsiedzkich czy izolacją. Relacje sąsiedzkie w wielkich osiedlach, co potwierdzają omówione badania, są zróżnicowane, ale $\mathrm{w}$ wielu $\mathrm{z}$ nich dobre, a nawet bardzo dobre, także w porównaniu $\mathrm{z}$ innymi typami współczesnej zabudowy wielkomiejskiej. Stwierdzono również, że mimo istnienia stereotypu niebezpiecznych blokowisk, większość mieszkańców czuje się w nich bezpiecznie. Wśród nielicznych negatywnych aspektów tej formy zamieszkiwania podnoszonych przez mieszkańców niemal wszystkich badanych osiedli są zbyt małe powierzchnie mieszkań, a także niedostatek miejsc służących do spędzania wolnego czasu oraz niedobór miejsc parkingowych. Mieszkańcy, którzy chcą się wyprowadzić z osiedli, najczęściej argumentują swoje decyzje potrzebą posiadania większego lokum lub realizacją marzeń o zamieszkaniu we własnym domu jednorodzinnym, często położonym poza miastem. Motywacje te nie wiążą się zatem z działaniem czynników wypychających, identyfikowanych w osiedlach krajów zachodnioeuropejskich (m.in. niski prestiż osiedla, złe otoczenie społeczne, degradacja przestrzeni czy wzrost przestępczości), a raczej z czynnikami obiektywnymi, takimi jak zmiany w cyklu życia rodziny, wzrost zamożności niektórych kategorii społecznych, a także pojawienie się po 1990 roku realnych możliwości zrealizowania indywidualnych aspiracji mieszkaniowych tłumionych $w$ okresie poprzedniego ustroju.

Co zatem sprawia, że nie najlepszej jakości środowisko mieszkaniowe, tworzone przez wielkie betonowe osiedla blokowe, jest tak dobrze postrzegane przez mieszkańców? Dotychczasowe badania wykazały, że na percepcję i wartościowanie miejskiej przestrzeni mieszkaniowej oraz na ocenę atrakcyjności obszaru w opinii mieszkańców i ich preferencje mieszkaniowe (por rozdz. 6.2) wpływają trzy grupy determinant: (1) subiektywne, okreś- 
lane też jako endogenne, do których należą związane z psychologicznymi i społeczno-demograficznymi cechami osób oceniających, a także ze stanem ich wiedzy i świadomości, (2) obiektywne, nazywane egzogennymi, a związane z cechami ocenianej przestrzeni, oraz (3) uwarunkowane kontekstem przestrzennym i społeczno-kulturowym (demograficznym, ekonomicznym, społecznym i politycznym), w którym zachodzi ten proces.

W miastach postsocjalistycznych kontekst ten, na skutek urynkowienia mieszkalnictwa po 1990 roku, najczęściej rozpatrywany jest w związku z kondycją ekonomiczną mieszkańców miasta, regionu i kraju oraz aktualną sytuacją na lokalnym, regionalnym i krajowym rynku nieruchomości. Te bowiem czynniki silnie determinują możliwości i bariery gospodarstw domowych, a w konsekwencji wpływają na postrzeganie poszczególnych obszarów rezydencjalnych miasta i ocenę ich atrakcyjności. Kontekst ten warunkuje także rolę i udział poszczególnych form zabudowy w zasobach mieszkaniowych poszczególnych miast, które również mają istotny wpływ na ich percepcję. Jeśli bowiem udział ten jest tak znaczący, jak w przypadku wielkich osiedli mieszkaniowych $\mathrm{w}$ miastach postsocjalistycznych, to zamieszkiwanie w nich wydaje się na tyle powszechne i "zwyczajne” w społecznej świadomości, że nie może równocześnie stygmatyzować (por. Borowik 2003, Kaltenberg-Kwiatkowska 2005).

Na podstawie analizy prac empirycznych dotyczących różnych aspektów percepcji i waloryzacji wielkich osiedli w miastach postsocjalistycznych stwierdzono zatem, że do głównych czynników wyjaśniających wysoki poziom satysfakcji i zadowolenia mieszkańców oraz ich słabą skłonność do migracji, należą uwarunkowania związane z kontekstem społeczno-kulturowym, ekonomicznym i politycznym, w jakim ten proces zachodzi. Kontekst ten determinuje bowiem zarówno czynniki obiektywne, czyli urbanistyczne i społeczne walory wielkich osiedli (co wyjaśniono w rozdziale 5), jak również czynniki subiektywne, czyli stan świadomości mieszkańców miast postsocjalistycznych, który wciąż, przede wszystkim wśród osób starszych, ale nie tylko, obarczony jest dziedzictwem poprzedniego ustroju.

Najważniejsze wśród nich, jak można sądzić odwołując się zarówno do wiedzy zgromadzanej w toku badań, jak i omówionej literatury, to:

1) w grupie czynników obiektywnych i związanych z kontekstem, w którym zachodzi proces persepcji:

- ogromna skala tych osiedli i ich udział w zasobach mieszkaniowych miast postsocjalistycznych, sięgający 30-40\% tych zasobów, który decyduje o ich powszechności;

- przeniesiony z czasów byłego ustroju oraz utrwalony po 1990 roku, deficyt mieszkań, obecnie nie o charakterze strukturalnym, lecz ekonomicznym; 
- daleko idąca prywatyzacja osiedlowych zasobów mieszkaniowych, w niektórych krajach sięgająca ponad 90\% mieszkań, która jest czynnikiem hamującym skłonności migracyjne i przyczynia się do silniejszej więzi zarówno z własnym mieszkaniem, jak i osiedlem, a w efekcie lepszego ich postrzegania;

- struktura dochodów mieszkańców miast postsocjalistycznych i niekorzystna relacja cen nowych mieszkań do przeciętnego wynagrodzenia, które wciąż ograniczają możliwości zaspokojenia aspiracji mieszkaniowych większości przeciętnie uposażonych gospodarstw domowych i decydują o ich większej stabilizacji przestrzennej;

- wciąż relatywnie dobre warunki mieszkaniowe oferowane $w$ tej formie zabudowy, zwłaszcza $\mathrm{w}$ porównaniu $\mathrm{z}$ istniejącą $\mathrm{w}$ wielu miastach starą substancją mieszkaniową o niskim standardzie (głównie na skutek niedoinwestowania i braku remontów obszarów centralnych miast w okresie socjalizmu);

- wciąż, mimo odpływu ludności najzamożniejszej i najlepiej wykształconej, relatywnie dobry status społeczny mieszkańców osiedli blokowych, zwłaszcza w porównaniu z obszarami starej zabudowy o niskim standardzie;

- relatywnie dobre i ulegające szybkiej poprawie w dwóch ostatnich dekadach wyposażenie osiedli w infrastrukturę handlowo-usługową oraz społeczną, duża ilość terenów zielonych szczególnie w stosunku do często pozbawionych zieleni obszarów gęstej zabudowy śródmiejskiej oraz dobra dostępność komunikacyjna wielu osiedli;

- wciąż relatywnie wysoki prestiż osiedli blokowych, mimo istnienia wielu negatywnych stereotypów na ich temat;

2) w grupie czynników subiektywnych:

- traktowanie tej formy habitatu jako "mieszkaniowej normy";

- wytworzona w czasach socjalistycznych relatywnie mała skłonność do ruchliwości przestrzennej, duża zasiedziałość i przyzwyczajenie do miejsca, a w efekcie duża stabilizacja mieszkaniowa;

- przeniesione z czasów poprzedniego ustroju i wciąż obecne w świadomości wielu mieszkańców przekonanie, że długo oczekiwane lub uzyskane kosztem wielu wyrzeczeń mieszkanie jest często jedyne na całe życie;

- traktowanie własnego mieszkania jako wartości autotelicznej, która dla większości mieszkańców miast postsocjalistycznych wciąż jest i długo jeszcze będzie dobrem trudno dostępnym, pozostającym poza zasięgiem wielu $\mathrm{z}$ nich; 
- pamięć o złych lub bardzo złych wcześniejszych warunkach mieszkaniowych, na tle których obecnie zajmowane mieszkanie blokowe ma wiele walorów;

- silnie ograniczane w okresie realnego socjalizmu i wciąż niewygórowane ambicje rezydencjalne mieszkańców miast postsocjalistycznych ${ }^{151} \mathrm{w}$ porównaniu z mieszkańcami innych krajów;

- obawy wobec zmiany dotychczasowego, oswojonego już i akceptowanego, miejsca zamieszkania, potęgowane przez niepewną, zmieniającą się $\mathbf{i}$ "płynną rzeczywistość", szeroko opisaną przez Z. Baumana (2006) w warunkach określonych przez U. Becka (2002) jako „społeczeństwo ryzyka", w tym np. realne zagrożenie bezrobociem i utratą dochodów, co ma szczególne znaczenie w krajach po socjalizmie, gdzie istnieje bardzo niski poziom świadczeń socjalnych i wciąż niewielka akumulacja prywatnego kapitału;

- zidentyfikowana w badaniach psychologicznych tendencja do nadmiernie pozytywnej waloryzacji miejsca zamieszkania na skutek między innymi adaptacji, przyzwyczajenia, ale także mechanizmu psychologicznego związanego z redukcją tzw. dysonansu poznawczego;

- poczucie braku alternatywy spowodowane ogólną sytuacją społeczno-ekonomiczną oraz sytuacją na rynku mieszkaniowym miast posocjalistycznych i niekorzystną relacją wynagrodzeń do cen mieszkań, które stwarzają barierę finansową uniemożliwiającą wielu gospodarstwom domowym zaspokojenie potrzeb mieszkaniowych w sposób bardziej satysfakcjonujący.

${ }^{151}$ Z badań ogólnopolskich E. Kaltenberg-Kwiatkowskiej (2005) wynika, że niezależnie od wielkości zajmowanego mieszkania do osiągnięcia satysfakcjonującego lokum brakuje zwykle „jednego pokoju” lub powierzchni rzędu $10 \mathrm{~m}^{2}$. Preferencje mieszkaniowe są zatem silnie ograniczane już na etapie ich formułowania. A obawy przed posiadaniem większego mieszkania wiążą się głównie z kosztami jego utrzymania, które w Polsce stanowią wciąż znaczną część budżetu gospodarstw domowych. 


\section{WIELKIE OSIEDLA MIESZKANIOWE ŁODZI - STUDIUM PRZYPADKU}

Empiryczna część pracy poświęcona została analizie rozwoju i przemian wielkich osiedli mieszkaniowych $\mathrm{w}$ wybranym mieście postsocjalistycznym, jakim jest Łódź - do niedawna drugie, a od 2007 roku trzecie co do wielkości miasto w Polsce. Jak już powiedziano we wstępie, wyboru Łodzi dokonano bez rozstrzygania tego, czy i w jakim stopniu jest ona typowym przykładem miasta postsocjalistycznego. Odwołując się jednak do definicji tego miasta przyjętej w pracy, nie ma wątpliwości, że spełnia jej kryteria, doświadczając w latach 1945-1990 wpływu ideologii socjalistycznej, której działanie pozostawiło po sobie trwałe ślady. Do dziś ślady te stanowią unikatowe w skali innych systemów politycznych dziedzictwo w postaci określonej struktury społeczno-przestrzennej, której bardzo istotnym elementem są wielkie osiedla mieszkaniowe.

Zważywszy jednak, że współczesna struktura rezydencjalna Łodzi uwarunkowana jest działaniem nie tylko ideologii socjalistycznej, ale także sięgających poprzedniego stulecia czasów „ziemi obiecanej”, do której napływały tysiące ludzi $\mathrm{w}$ poszukiwaniu pracy i lepszych warunków życia, $\mathrm{w}$ rozdziale niniejszym przedstawiony został jej rozwój od I połowy XIX wieku. Zachodzące wówczas procesy związane $\mathrm{z}$ dynamicznym rozwojem Łodzi przemysłowej istotnie wpłynęły na tkankę społeczną i urbanistyczną miasta, w tym przede wszystkim na liczbę, strukturę i przestrzenne rozmieszczenie ludności oraz standard dużej części wciąż obecnych w mieście, zasobów mieszkaniowych.

Wybór jednego miasta jako obszaru szczegółowych studiów empirycznych wynikał także z przekonania, że określony poziom szczegółowości badań wymaga ograniczenia ich zasięgu przestrzennego, tak aby uzyskane wnioski były w pełni potwierdzone. Istotne znaczenie miała również kwestia kontekstu, który na skutek urynkowienia mieszkalnictwa po 1990 roku najczęściej rozpatrywany jest $\mathrm{w}$ związku z kondycją ekonomiczną mieszkańców miasta oraz aktualną sytuacją na lokalnym rynku nieruchomości. Te bowiem czynniki, jak już powiedziano wcześniej w pracy, silnie determinują możliwości i bariery gospodarstw domowych, a w konsekwencji wpływają na pozycję poszczególnych obszarów w strukturze rezydencjalnej miasta i ocenę ich atrakcyjności. 


\subsection{Ewolucja struktury społeczno-przestrzennej miasta}

Łódź mimo posiadania praw miejskich od XV wieku jest klasycznym przykładem miasta, które powstało i rozwinęło się dzięki procesom XIX-wiecznej industrializacji. Szybki rozwój demograficzny i gospodarczy Łodzi rozpoczął się w 1820 roku, kiedy zapadła decyzja władz Królestwa Polskiego o lokalizacji tu osady rękodzielniczej i awansowaniu jej do rzędu "miast fabrycznych" (Koter 2009a). Wówczas to, w ciągu niecałych stu lat (do wybuchu I wojny światowej), z miasteczka rolniczego liczącego niespełna 800 mieszkańców ośrodek ten urósł do blisko półmilionowej metropolii, wykazując tym samym rekordowe w skali Europy tempo przyrostu demograficznego (Liszewski 2001a, s. 32). Gwałtowny przyrost ludności związany był z dynamicznym rozwojem przemysłu, głównie włókienniczego, w którym w 1913 roku zatrudnionych było ponad 100 tys. osób (ibid.). Ogromna migracja, która miała miejsce w pierwszych kilkudziesięciu latach rozwoju Łodzi przemysłowej oraz brak odpowiedniej reakcji ze strony władz przyczyniły się do chaotycznego i nieplanowego rozwoju miasta, które nie było przystosowane do wchłonięcia tak dużej liczby nowych mieszkańców. To spowodowało, że warunki mieszkaniowe w mieście charakteryzowały się wysokim stopniem zagęszczenia, przeludnieniem i brakiem podstawowej infrastruktury, przez co daleko odbiegały od warunków w innych dużych miastach (Liszewski 2009). W 1931 roku ponad połowa mieszkańców Łodzi $(58,6 \%)$ użytkowała mieszkania 1-izbowe, a tylko 8,5\% mieszkania wyposażone $\mathrm{w}$ podstawowe instalacje obejmujące elektryczność, wodociąg i kanalizację (Ginsbert 1962, s. 456). Specyfiką struktury rezydencjalnej było bezpośrednie sąsiadowanie okazałych rezydencji przemysłowców $\mathrm{z}$ przeludnionymi i pozbawionymi podstawowych instalacji sanitarnych domami robotniczymi. Najbardziej charakterystyczne elementy krajobrazu miejskiego ówczesnej Łodzi tworzyły rozległe kompleksy fabryczno-mieszkalno-rezydencjalne. $\mathrm{W}$ ich skład wchodzily budynki fabryczne oraz reprezentacyjne rezydencje właścicieli $\mathrm{w}$ formie pałaców lub willi, zespoły parkowo-ogrodowe oraz wielorodzinne domy familijne dla robotników tworzące tzw. osiedla patronackie wyposażone we własny program usługowy (w postaci np. szkoły, szpitala, sklepu, klubu dla robotników) (Koter 2009a).

Przed wybuchem II wojny światowej struktura społeczno-przestrzenna Łodzi przypominała strukturę miasta zachodniego - z pewnym uproszczeniem można twierdzić, że wykazywała podobieństwo do modelu koncentrycznego (por. Marcińczak 2009). Najlepszymi warunkami mieszkaniowymi charakteryzowała się strefa centralna, która zamieszkiwana była (z wyjątkiem części północnej, gdzie koncentrowała się biedna ludność żydowska) przez najzamożniejsze kategorie społeczne. Strefę przejściową, 
o znacznie gorszych warunkach bytowych, zamieszkiwali głównie robotnicy przemysłowi. Wyjątek $\mathrm{w}$ tej strefie stanowił obszar modernistycznej zabudowy blokowej (osiedle im. Monwiłła-Mireckiego powstałe w latach 30. XX w.) zajmowanej głównie przez urzędników i przedstawicieli inteligencji. Strefa peryferyjna, pozostająca poza granicami ówczesnej Łodzi (a przyłączona dopiero po II wojnie światowej), podobnie jak przejściowa, charakteryzowała się substandardowymi warunkami mieszkaniowymi i w większości zamieszkiwana była przez ludność najbiedniejszą, której nie stać było na lokum w granicach administracyjnych miasta (ibid., s. 71-72).

W okresie II wojny światowej Łódź poniosła duże straty ludnościowe, ale $\mathrm{w}$ relatywnie niewielkim stopniu zniszczeniu uległa jej substancja mieszkaniowa. W 1946 roku zamieszkiwało tu 430 tys. osób, czyli o około 120 tys. mniej niż w 1939 roku. Poszerzono wówczas granice miasta, powiększając jego obszar z 58,8 km² do 211,6 km² (Koter 2009b, s. 219). Łódź zyskała nowe funkcje, w tym akademicką, $\mathrm{w}$ dalszym ciągu rozwijała się też funkcja administracyjna miasta jako ośrodka władzy regionalnej, nadal jednak dominowała funkcja przemysłowa, z przewagą przemysłu włókienniczego. Dalszy powojenny rozwój przemysłu oraz nowe funkcje miasta i niewielkie zniszczenia substancji mieszkaniowej spowodowały, że liczba ludności Łodzi zaczęła szybko rosnać. W roku 1950 wynosiła już 620 tys., a jej przyrost następował aż do połowy lat 80. XX wieku, kiedy miasto zaczęło tracić mieszkańców.

Rozwój urbanistyczny Łodzi w czasach PRL zwykło się dzielić na dwa podokresy - "stalinowsko-gomułkowski" (1945-1970) oraz "gierkowski" (1971-1980, z kontynuacją do 1989 r.) (Koter 2009b). W latach 1945-1956 w dzielnicy Bałuty na terenie dawnego getta żydowskiego utworzonego przez Niemców w okresie II wojny światowej wybudowano pierwsze powojenne zespoły wielorodzinnej zabudowy mieszkaniowej. Obejmowały one nieduże osiedla, utrzymane $\mathrm{w}$ stylu socrealistycznym, wmieszane w przedwojenną zabudowę kamieniczną o niskim standardzie. Należą do nich osiedle Staromiejskie, którego wizytówką była nowa łódzka „starów$\mathrm{ka}^{\prime \prime}$, oraz większe od niego osiedle im. W. Bytomskiej budowane w tradycyjnej technologii, z charakterystyczną dla socrealizmu monumentalną obrzeżną zabudową wzdłuż ulic oraz luźniejszą zabudową wewnątrz kwartałów, która przybrała formę wolno stojących bloków (ibid.). Inne powstające wówczas budynki wielorodzinne nie tworzyły wyodrębnionych osiedli, lecz miały charakter zabudowy plombowej wypełniającej luki $\mathrm{w}$ zabudowie ulic. W okresie tym struktura przestrzenna warunków mieszkaniowych Łodzi pozostała prawie niezmieniona od czasu sprzed II wojny światowej. W dalszym ciągu Bałuty i Stare Miasto (poza niewielkimi terenami nowo wybudowanych bloków) stanowily obszar o najgorszych warunkach życia, zamieszkiwany głównie przez ludność robotniczą. Centrum 
natomiast, jako strefa o wciąż relatywnie dobrych warunkach mieszkaniowych, stanowiło obszar koncentracji przedstawicieli inteligencji zamieszkiwany między innymi przez pracowników lódzkich uczelni (Liszewski 1999).

Na przełomie lat 50. i 60. XX wieku rozpoczął się w Łodzi, podobnie jak w całej Polsce, okres budowy dużych osiedli blokowych z użyciem prefabrykowanych elementów. Rozpoczęto wówczas budowę osiedli: Doły, Koziny, Żubardź, Nowe Rokicie, Zbiorcza i Kurak. W II połowie lat 60. kontynuowano rozpoczęte inwestycje oraz przystąpiono do budowy nowych, do których należały osiedla: Teofilów, Karolew, Dąbrowa, Wielkopolska i Zarzew oraz wiele innych, mniejszych i bardziej rozproszonych w przestrzeni miasta. Powstałe wówczas zespoły budynków, z wyjątkiem Teofilowa i Karolewa, lokalizowane były na terenach położonych po wewnętrznej stronie kolei obwodowej i w układzie koncentrycznym stanowily otoczenie zasadniczego centrum miasta (Kaczmarek 1996).

Lata 70. i I połowa lat 80., podobnie jak w całej Polsce, były w Łodzi okresem najbardziej dynamicznego po II wojnie światowej rozwoju budownictwa mieszkaniowego. W roku 1972 przyjęto nowy plan zagospodarowania przestrzennego, który zakładał rozwój przestrzenny miasta w układzie promienisto-pasmowym i ustalał budowę nowych osiedli wzdłuż osi wschód-zachód. W ich bezpośrednim sąsiedztwie miały zostać utworzone nowe dzielnice magazynowo-przemysłowe (Bald 2002). Tym samym, zgodnie z zasadą funkcjonalnego strefowania miasta, miejsca zamieszkania miały być oddzielone od miejsc pracy zlokalizowanych $\mathrm{w}$ sąsiadujących $\mathrm{z}$ nimi dzielnicach przemysłowych. W budownictwie mieszkaniowym okres ten charakteryzował się dominacją systemów wielkopłytowych, wprowadzonych na masową skalę na początku lat 70. i wykorzystywanych do połowy lat 90. Wówczas to dokończono budowę osiedli Dąbrowa i Zarzew oraz wybudowano największe zespoły mieszkaniowe $\mathrm{z}$ „wielkiej płyty", liczące od kilkunastu do kilkudziesięciu tysięcy mieszkańców, czyli Retkinię, Widzew-Wschód, Chojny-Zatorze i Radogoszcz-Zachód, zlokalizowane na ówczesnych obrzeżach Łodzi. Oprócz nich powstawały także mniejsze zespoły zabudowy blokowej wkomponowane w historyczną tkankę miejską (głównie na obszarach wyburzanej substandardowej zabudowy przedwojennej), do których należały Julianowska-Inflancka, Zgierska-Stefana i Pojezierska w północnej części miasta. $Z$ tego okresu są też osiedla zlokalizowane na terenie dzielnicy Górna, położone na zachód od osiedla Dąbrowa (tzw. Dąbrowa Zachodnia), a także Czerwony Rynek i osiedle Piastów. Na przełomie lat 70. i 80. wzniesiono wysokościową Śródmiejską Dzielnicę Mieszkaniową, pierwszą i jedyną tego rodzaju w obrębie ścisłego śródmieścia, którą zlokalizowano w południowej części ulicy Piotrkowskiej. Dzielnica ta, dominując nad otoczeniem swą wysokością (od 14 do 25 kondygnacji) oraz 
modernistyczną bryłą, nazywana łódzkim Manhattanem, miała być wizytówką Łodzi i symbolem gierkowskiej nowoczesności (Koter 2009b).

W II połowie lat 80., kiedy tempo rozwoju budownictwa mieszkaniowego było już znacznie mniejsze niż w latach ubiegłych, rozpoczęto budowę położonego w północnej części Łodzi osiedla Radogoszcz-Wschód oraz zlokalizowanego na wschodnich krańcach miasta osiedla Olechów. Budowę tego ostatniego kontynuowano jeszcze w latach 90., zmieniając jednak, ze względu na zmiany ustrojowe, zasady jej finansowania ${ }^{152}$.

Największe z zagospodarowanych w okresie socjalizmu terenów mieszkaniowych, czyli Retkinia, Widzew-Wschód, Chojny-Zatorze, Radogoszcz-Wschód i Radogoszcz-Zachód, stanowiły samodzielne duże dzielnice mieszkaniowe, odrębne przestrzennie od historycznej tkanki miejskiej i znacznie od niej oddalone (Kaczmarek 1996). Ich układ przestrzenny ma charakter klinowy, rozwinięty wzdłuż dwóch głównych ciągów komunikacyjnych Łodzi, na osiach wschód-zachód (Retkinia-Widzew) oraz północ-południe (Radogoszcz-Chojny). Koncentryczno-klinowy układ przestrzenny wielorodzinnej zabudowy blokowej dopełniają osiedle Teofilów zlokalizowane w paśmie północno-zachodnim oraz osiedle Dąbrowa położone na południowy wschód od centrum miasta (rys. 24).

W całym tym okresie obejmującym lata 1950-1988, który za J. Goryńskim (1974) określić można jako okres budowy „drugiej Łodzi mieszkaniowej", liczba mieszkań w mieście niemal podwoiła się. Dobre wyposażenie nowych osiedli w podstawową infrastrukturę sprawiło, że w skali miasta nastąpiła znaczna poprawa wskaźników charakteryzujących warunki mieszkaniowe (tab. 14). Równocześnie jednak zaniedbywano remonty przedwojennej substancji mieszkaniowej, która w Łodzi stanowiła znaczącą część zasobu i w większości charakteryzowała się niskim lub bardzo niskim standardem oraz wysokim stopniem zużycia. Nakłady ponoszone na działalność remontową były $\mathrm{w}$ Łodzi niższe niż $\mathrm{w}$ innych dużych miastach Polski ${ }^{153}$, co przyczyniało się do postępującej dekapitalizacji zasobów komunalnych i powodowało, że warunki mieszkaniowe wciąż były tu mniej korzystne niż w innych ośrodkach miejskich. Wciąż charakterystyczny dla

152 Podstawą prawną do zmian w działalności inwestycyjnej spółdzielni mieszkaniowych w Polsce była Ustawa z dnia 28 grudnia 1989 r. O uporządkowaniu stosunków kredytowych. Ustawa ta zlikwidowała dotychczasową możliwość uzyskiwania przez spółdzielnie długoterminowych kredytów budowlanych na preferencyjnych warunkach (które następnie były częściowo umarzane), wprowadzając $\mathrm{w}$ ich miejsce kredyty hipoteczne udzielane osobom fizycznym. Przerzucenie ciężaru finansowego budowy mieszkań na przyszłych lokatorów przy niekorzystnych zasadach kredytowania i wysokiej inflacji spowodowało w połowie lat 90 . XX w. zapaść $\mathrm{w}$ wielorodzinnym budownictwie mieszkaniowym.

${ }^{153} \mathrm{~W}$ pierwszej połowie $1998 \mathrm{r}$. nakłady na techniczne utrzymanie komunalnych zasobów mieszkaniowych w miastach powyżej 100 tys. mieszkańców wynosiły 0,79 zl/m², w Łodzi natomiast $0,54 \mathrm{zl} / \mathrm{m}^{2}$, czyli 68\% średniej (Stan gospodarki mieszkaniowej..., s. 69). 
miasta był także znaczny deficyt mieszkaniowy, a budowa dużej liczby nowych mieszkań nie zaspokajała potrzeb rosnącej liczby ludności.

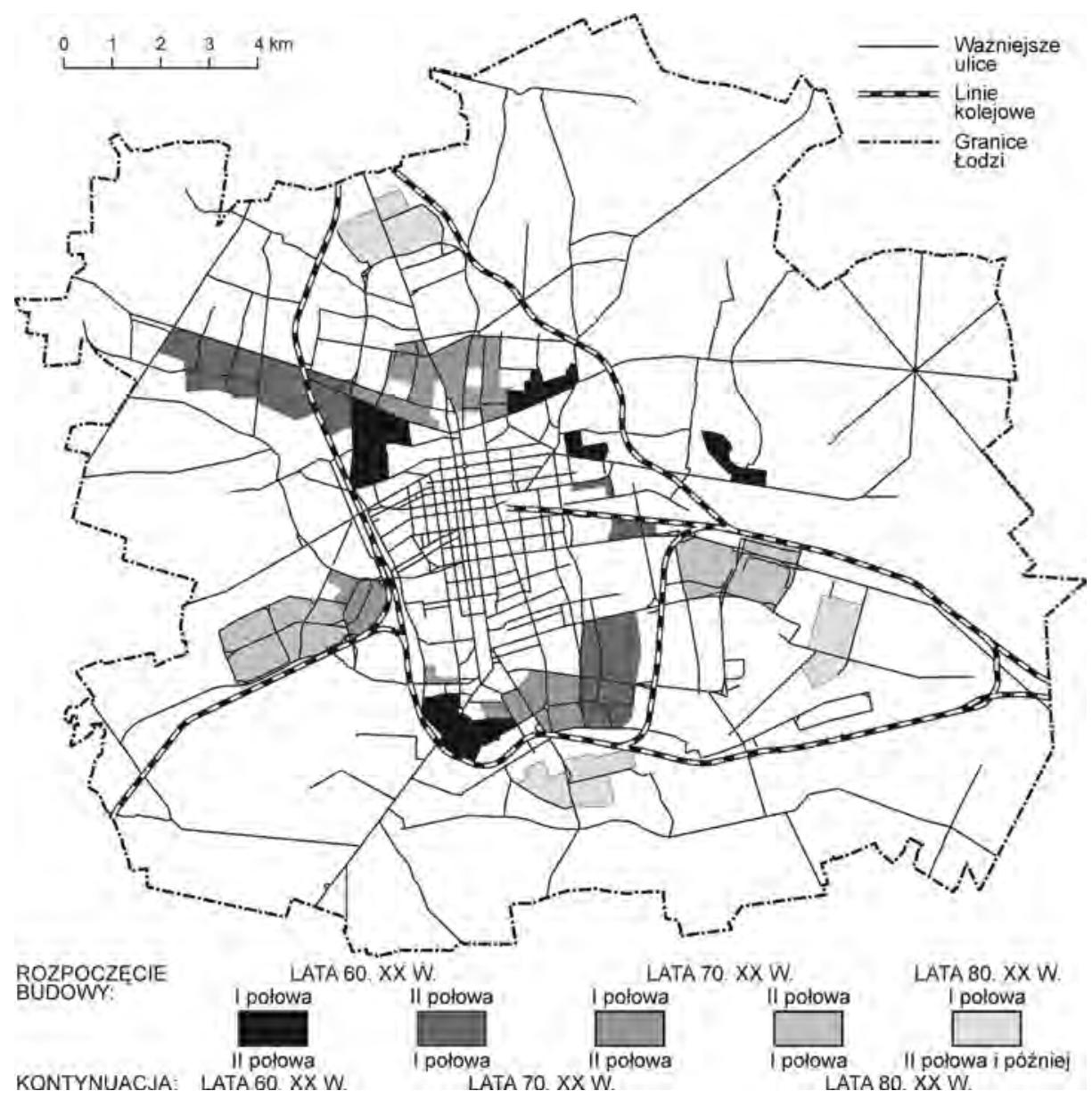

Rys. 24. Rozwój terenów wielorodzinnej zabudowy blokowej w Łodzi w latach 1960-1990 Źródło: opracowanie własne

Powstanie nowych osiedli oraz brak należytych nakładów na remonty starej substancji mieszkaniowej przyczynily się do zmian w strukturze społeczno-przestrzennej Łodzi. Począwszy od lat 60. XX wieku, centrum miasta zaczęły opuszczać osoby zamożniejsze i lepiej wykształcone (Liszewski 1999). $\mathrm{W}$ okresie tym, podobnie jak $\mathrm{w}$ innych dużych miastach Polski (por. Sagan 2000a, Zborowski 2005, Węcławowicz 2007), zaczęły następować procesy filtracji, które zapoczątkowały powolną degradację zarówno społeczną, 
Tab. 14. Zmiany wybranych wskaźników mieszkaniowych w Łodzi w latach 1950-1988

\begin{tabular}{|l|c|c|c|c|c|}
\hline \multirow{2}{*}{ Wyszczególnienie } & \multicolumn{5}{c|}{ Rok } \\
\cline { 2 - 6 } & 1950 & 1960 & 1970 & 1978 & 1988 \\
\hline Liczba ludności w tys. & 630,0 & 717,1 & 762,7 & 825,2 & 854,3 \\
\hline Liczba mieszkań zamieszkanych w tys. & 172,2 & 203,5 & 238,8 & 288,1 & 313,8 \\
\hline Przeciętna liczba osób na 1 izbę & 1,93 & 1,78 & 1,28 & 1,05 & 0,96 \\
\hline Przeciętna liczba izb w mieszkaniu & 1,8 & 1,9 & 2,4 & 2,6 & 2,9 \\
\hline Przeciętna liczba osób w mieszkaniu & 3,51 & 3,42 & 3,04 & 2,81 & 2,67 \\
\hline Udział mieszkań wyposażonych w: & & & & & \\
- wodociąg & 25,8 & 48,8 & 71,2 & 83,7 & 90,9 \\
- ustęp spłukiwany & 15,8 & 27,3 & 51,2 & 69,2 & 80,4 \\
- lazienkę & 8,7 & 17,7 & 45,0 & 65,9 & 75,6 \\
- centralne ogrzewanie & 3,0 & 12,6 & 41,2 & 60,3 & 70,7 \\
\hline
\end{tabular}

Źródło: opracowanie własne na podstawie danych NSP (1950, 1960, 1970, 1978, 1988).

jak i fizyczną wielu fragmentów centrum. Zainicjowany wówczas proces dekoncentracji miejsc zamieszkania łódzkiej inteligencji, w kolejnych dekadach wraz z rozwojem nowego budownictwa mieszkaniowego nasilał się (Liszewski 1999, Wolaniuk 2003). Mieszkańcy reprezentujący tę kategorię społeczną przemieszczali się $\mathrm{w}$ kierunku peryferii - do wielkich osiedli mieszkaniowych oraz na niewielkie obszary szeregowej zabudowy jednorodzinnej powstającej na ich zapleczach (Koter 2009b). Na skutek tych procesów w końcu okresu socjalistycznego struktura społeczno-przestrzenna Łodzi, mimo pewnych cech mozaikowości, zbliżona była do modelu koncentryczno-sektorowego (Kaczmarek 1996, Marcińczak 2009). Miejsca zamieszkania przedstawicieli wyższych kategorii społecznych (biorąc pod uwagę kryterium wykształcenia i zamożności, ale przede wszystkim charakterystyczne dla ustroju socjalistycznego usytuowanie $\mathrm{w}$ hierarchii władzy) w większości pokrywały się $\mathrm{z}$ obszarami o najlepszych warunkach mieszkaniowych $\mathrm{w}$ mieście. Obejmowały one, podobnie jak $\mathrm{w}$ okresie przedwojennym, ścisłe centrum (w szczególności te jego fragmenty, które budowane dla ówczesnych elit charakteryzowały się dobrymi i bardzo dobrymi warunkami zamieszkania) oraz nowe wielkie osiedla mieszkaniowe, które tak jak w wielu innych miastach socjalistycznych, w postaci sektorów lokalizowano na obrzeżach, wzdłuż głównych arterii komunikacyjnych (ibid.). Tym samym struktura społeczno-przestrzenna socjalistycznej Łodzi reprezentowała model charakterystyczny dla tego typu miasta (por. Szelényi 1983, Smith 1996).

Okres transformacji ustrojowej $\mathrm{w}$ Łodzi przede wszystkim wiązał się $\mathrm{z}$ upadkiem dominującego tu przemysłu włókienniczego i z poważnym kryzysem ekonomicznym, głębszym niż $\mathrm{w}$ innych dużych miastach Polski. Gwałtowny wzrost bezrobocia, które po 1990 roku przybrało charakter strukturalny przekraczający 20\% (w „rekordowym” 1993 r. - 21,3\%), przy- 
czynił się do pauperyzacji dużej grupy mieszkańców. Zła sytuacja gospodarcza, szczególnie dotkliwa w początkowym okresie transformacji, po 2000 roku uległa pewnej poprawie, przy czym przez cały okres transformacji ustrojowej bezrobocie było tu najwyższe wśród innych dużych miast Polski. Od końca lat 80. Łódź zaczęła tracić mieszkańców (głównie z przyczyn naturalnych, ale także - choć w mniejszym stopniu - na skutek migracji) i rozpoczął się szybko postępujący proces jej demograficznego starzenia się. Te i inne procesy charakterystyczne dla drugiego przejścia demograficznego (czyli spadek liczby zawieranych małżeństw, zmniejszenie się liczby urodzeń, wzrost udziału jednoosobowych gospodarstw domowych) oraz dla transformacji miasta przemysłowego $\mathrm{w}$ poprzemysłowe ( $\mathrm{w}$ tym zmiana struktury zatrudnienia i ograniczenie roli przemysłu na rzecz usług) sprawiają, że Łódź, mimo swej specyfiki, od początku lat 90. wpisywała się w typowy model przemian charakterystyczny dla miasta po socjalizmie (por. Węcławowicz 2000, 2007, Zborowski 2000, Sýkora 2009).

Transformacja ustrojowa, tak jak $\mathrm{w}$ innych miastach postsocjalistycznych, spowodowała w Łodzi regres w budownictwie mieszkaniowym. O ile do połowy lat 90 . kończono jeszcze rozpoczęte wcześniej inwestycje, to w latach 1995-2004 w mieście oddano do użytku zaledwie 10,5 tys. nowych mieszkań, czyli tyle, ile w połowie lat 70. w jednym roku (Milewska, Ogrodowczyk 2006). Regres ten, co oczywiste, dotknął głównie sektor budownictwa uspołecznionego, które ze względów ustrojowych do końca lat 80 . koncentrowało niemal całą działalność budowlaną w mieście (rys. 25).

Kryzys budowlany nie spowodował całkowitej likwidacji budownictwa spółdzielczego, ponieważ z ogólnej niewielkiej liczby mieszkań oddanych w Łodzi do użytku w latach 1995-2004, wciąż ponad 40\% (4,1 tys.) stano-

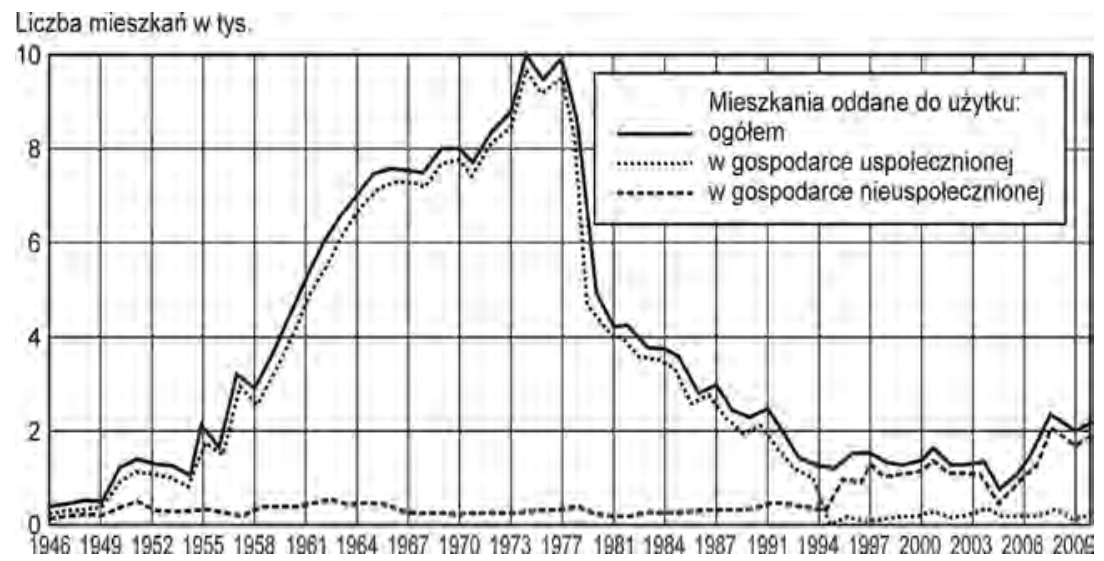

Rys. 25. Budownictwo mieszkaniowe w Łodzi w latach 1946-2010 Źródło: opracowanie własne na podstawie danych US w Łodzi 
wiły mieszkania wybudowane przez spółdzielnie154 (Milewska, Ogrodowczyk 2006). Zmieniło się jednak źródło ich finansowania, które w całości przerzucone zostało na członków spółdzielni, a także skala inwestycji. Działalność ta prowadzona po 1990 roku już na zasadzie działalności deweloperskiej była dość rozproszona w przestrzeni miasta i obejmowała pojedyncze budynki lub ich niewielkie zespoły. W znacznej części lokalizowano ją jednak $\mathrm{w}$ wybudowanych wcześniej wielkich osiedlach mieszkaniowych, ponieważ tereny te pozostawały $\mathrm{w}$ wieczystym użytkowaniu spółdzielni, a ponadto jako już uzbrojone stały się dla nich naturalnym i najtańszym obszarem inwestowania.

Liczba mieszkań w Łodzi w okresie ponad dwóch dekad po zmianie ustroju (w latach 1988-2013) wzrosła o blisko 35 tys., czyli o tyle ile przybyło $\mathrm{w}$ ciaggu trzech lat $\mathrm{w}$ rekordowej II połowie lat 70. XX wieku. Poprawa wskaźników mieszkaniowych, która nastąpiła w tym okresie (tab. 15) wynikała nie tylko z powstania nowych zasobów, ale także ze stopniowego wyłączania z użytkowania przedwojennej substancji o najniższym standardzie oraz ze zmniejszania się liczby ludności.

Odnotowany w ostatnich latach wzrost liczby mieszkań w Łodzi, mimo że mniejszy niż w innych dużych miastach Polski, częściowo zaspokoił odziedziczony po byłym ustroju głęboki deficyt mieszkaniowy charaktery-

Tab. 15. Wybrane wskaźniki demograficzne i mieszkaniowe w Łodzi w latach 1988-2013

\begin{tabular}{|l|c|c|c|}
\hline \multicolumn{1}{|c|}{ Wyszczególnienie } & \multicolumn{3}{c|}{ Rok } \\
\cline { 2 - 4 } & 1988 & 2002 & 2013 \\
\hline Liczba ludności w tys. & 854,3 & 789,3 & 711,3 \\
\hline Liczba gospodarstw domowych w tys. & 342,2 & 351,9 & 324,91 \\
\hline Liczba mieszkań zamieszkanych w tys. & 313,8 & 316,2 & 348,2 \\
\hline Przeciętna powierzchnia użytk. mieszkania w m ${ }^{2}$ & 45,7 & 52,1 & 53,7 \\
\hline Przeciętna powierzchnia użytk. mieszkania w m ${ }^{2}$ na osobę & 17,1 & 21,1 & 26,3 \\
\hline Przeciętna liczba izb w mieszkaniu & 2,85 & 3,06 & 3,10 \\
\hline Przeciętna liczba osób w mieszkaniu & 2,67 & 2,47 & 2,04 \\
\hline Udział mieszkań wyposażonych w: & & & \\
- wodociąg & 90,9 & 97,0 & 97,3 \\
- ustęp spłukiwany & 80,4 & 89,7 & 93,1 \\
- lazienkę & 75,6 & 85,3 & 89,0 \\
- centralne ogrzewanie & 70,7 & 78,6 & 80,2 \\
\hline
\end{tabular}

1 NSP 2011.

Źródło: opracowanie własne na podstawie danych NSP $(1988,2002)$ oraz Statystyki Łodzi (dla 2013 r.).

154 W 2005 r. w Łodzi działało 41 spółdzielni mieszkaniowych, spośród których 17 prowadziło działalność inwestycyjną, ale tylko cztery z nich (RSM Bawełna, SM Kielnia, SM Ogniwo oraz SM Piaski) prowadziła je na dużą skalę. Działalność pozostałych ograniczała się do budowy pojedynczych budynków (Milewska, Ogrodowczyk 2006). 
styczny dla niemal wszystkich miast krajów postsocjalistycznych (por. Stanilov 2007). Zaspokojenie to jednak ma wymiar głównie ilościowy (liczba mieszkań przekroczyła liczbę gospodarstw domowych), ale nie jakościowy, ponieważ specyfiką Łodzi jest wysoki udział zasobów komunalnych (najwyższy wśród innych miast, sięgający ponad $20 \%$ ogółu zasobów mieszkaniowych), które w znacznej części charakteryzują się złym stanem technicznym $^{155}$. Duży udział tych zasobów i ich zły stan utrzymania sprawia, że mimo poprawy w ostatnich dwóch dekadach wskaźników charakteryzujących warunki mieszkaniowe w Łodzi, są one wciąż gorsze niż w innych dużych miastach Polski (tab. 16). Dotyczy to zwłaszcza strefy centrum (tab. 17) oraz jej bezpośredniego otoczenia, gdzie dominuje substancja przedwojenna. Na tym tle $\mathrm{w}$ pełni wyposażone $\mathrm{w}$ infrastrukturę mieszkania $\mathrm{w}$ osiedlach blokowych reprezentują relatywnie dobre warunki mieszkaniowe.

Tab. 16. Wybrane wskaźniki demograficzne i mieszkaniowe Łodzi na tle największych miast Polski w 2013 roku

\begin{tabular}{|l|c|c|c|c|c|}
\hline \multicolumn{1}{|c|}{ Wyszczególnienie } & Łódź & Kraków & Poznań & Warszawa & Wrocław \\
\hline Liczba ludności w tys. & 711,3 & 758,9 & 548,0 & 1724,4 & 632,1 \\
\hline Liczba mieszkań zamieszkanych w tys. & 348,2 & 346,5 & 244,3 & 885,7 & 290,3 \\
\hline $\begin{array}{l}\text { Łączna powierzchnia użytkowa } \\
\text { mieszkań w tys. m }\end{array}$ & 18701 & 19986 & 15853 & 52046 & 20547 \\
\hline $\begin{array}{l}\text { Przeciętna powierzchnia użytkowa } \\
\text { mieszkania w m }{ }^{2}\end{array}$ & 53,7 & 57,7 & 64,91 & 58,8 & 70,8 \\
\hline $\begin{array}{l}\text { Przeciętna powierzchnia użytkowa } \\
\text { mieszkania w m² na osobę }\end{array}$ & 26,3 & 26,3 & 28,9 & 30,2 & 32,5 \\
\hline Przeciętna liczba izb w mieszkaniu & 3,1 & 3,2 & 3,5 & 3,2 & 3,9 \\
\hline Przeciętna liczba osób w mieszkaniu & 2,0 & 2,2 & 2,2 & 1,9 & 2,2 \\
\hline
\end{tabular}

Źródło: opracowanie własne na podstawie danych GUS.

Ważną konsekwencją przemian ustrojowych były zmiany struktury własnościowej mieszkań. Polegały one na zmniejszaniu się udziału zasobów mieszkaniowych pozostających $\mathrm{w}$ gestii podmiotów publicznych i spowodowane były sprzedażą mieszkań osobom fizycznym lub zwrotem ich dawnym właścicielom (bądź spadkobiercom), a także rozwojem prywatnego sektora budownictwa mieszkaniowego. Procesem prywatyzacji objęte zostały komunalne zasoby mieszkaniowe, które w Łodzi ze względów historycznych miały znacznie większy udział w strukturze zasobów niż w innych dużych miastach Polski. Ale także, co istotne z punktu widzenia niniej-

155 Jak podaje cytowany już raport Stan gospodarki mieszkaniowej w gminie Łódź, luka reprodukcyjna w zasobach mieszkaniowych będących w dyspozycji gminy Łódź oszacowana została w 2010 r. na poziomie $47 \%$, co oznacza, że niemal połowa tych zasobów powinna być wyeliminowana z użytkowania ze względu na zły stan techniczny. 
Tab. 17. Wyposażenie mieszkań w Łodzi na tle największych miast Polski i według dzielnic w 2009 roku

\begin{tabular}{|l|c|c|c|}
\hline \multirow{2}{*}{ Wyszczególnienie } & \multicolumn{3}{|c|}{ Udział mieszkań wyposażonych w: } \\
\cline { 2 - 4 } & wodociąg & lazienkę & centralne ogrzewanie \\
\hline $\begin{array}{l}\text { Miasta ogółem } \\
\text { - Łódź }\end{array}$ & 96,8 & & \\
\hline - Kraków & 98,8 & 85,3 & 78,9 \\
\hline - Poznań & 99,7 & 96,3 & 87,1 \\
\hline - Warszawa & 99,4 & 95,5 & 85,2 \\
\hline - Wrocław & 99,3 & 96,7 & 94,2 \\
\hline Dzielnice Łodzi & & 93,4 & 84,2 \\
- Bałuty & 97,2 & 88,8 & 86,2 \\
\hline - Górna & 94,5 & 82,6 & 77,9 \\
\hline - Polesie & 97,5 & 86,6 & 79,0 \\
\hline - Śródmieście & 98,1 & 74,4 & 54,2 \\
\hline - Widzew & 97,8 & 88,3 & 82,9 \\
\hline
\end{tabular}

Źródło: opracowanie własne na podstawie danych GUS.

szej pracy, zasoby spółdzielcze, których zasadniczą część stanowiły mieszkania w wielkich osiedlach. Podstawę prywatyzacji mieszkań spółdzielczych stanowią dwa akty prawne: Ustawa o wtasności lokali (z 24 czerwca 1994 r.), która wprowadziła m.in. pojęcie odrębnej własności lokalu mieszkaniowego, a w konsekwencji zróżnicowanie tytułów do zajmowanego lokalu w zasobie spółdzielni mieszkaniowych, oraz Ustawa o zmianie ustawy o spótdzielniach mieszkaniowych (z 14 czerwca 2007 r.). Obecnie funkcjonują cztery formy zasiedlenia mieszkania:

- z tytułu spółdzielczego lokatorskiego prawa do lokalu mieszkalnego (po wniesieniu wkładu mieszkaniowego; mieszkanie nie może być sprzedane przez lokatora ani nie podlega prawu dziedziczenia);

- z tytułu spółdzielczego własnościowego prawa do lokalu156, które jest zbywalne (w formie notarialnej), dziedziczne, podlega egzekucji

156 Tzw. spółdzielcze własnościowe prawo do lokalu jako ograniczone prawo rzeczowe tworzy szczególny rodzaj własności ustanowiony wyłącznie dla zasobów spółdzielczych. Prawo to zgodnie z cytowaną już Ustawa o spótdzielniach mieszkaniowych zostaje ustanowione na podstawie umowy pomiędzy spółdzielnią będącą właścicielem lub współwłaścicielem budynku a członkiem spółdzielni. Mieszkanie, na którym ustanowione jest spółdzielcze własnościowe prawo do lokalu, można oddawać $\mathrm{w}$ najem lub bezpłatne użytkowanie osobom trzecim, jednak jego właścicielem nadal pozostaje spółdzielnia. Ograniczenie spółdzielczego własnościowego prawa do lokalu wiąże się także z tym, że korzystanie z lokalu musi być zgodne z jego przeznaczeniem, tj. zaspokajaniem osobistych i rodzinnych potrzeb mieszkaniowych, a wykorzystywanie go do celów innych niż mieszkaniowe wymaga zawsze zgody spółdzielni mieszkaniowej. Od 31.12.2012 r. nie ma już możliwości ustanawiania spółdzielczego własnościowego prawa do lokalu, przysługuje ono jedynie osobom, na rzecz których zostało ustanowione przed tą datą. 
i może być przedmiotem hipoteki (pod warunkiem posiadania księgi wieczystej prowadzonej przez spółdzielnię);

- z tytułu prawa odrębnej własności lokalu (właściciele posiadają pełnię praw do lokalu oraz są zobowiązani uczestniczyć w wydatkach związanych z eksploatacją i utrzymaniem nieruchomości stanowiących mienie spółdzielni, które są przeznaczone do wspólnego korzystania przez osoby zamieszkujące $\mathrm{w}$ budynku i w osiedlu);

- z tytułu najmu (lokator nie musi być członkiem spółdzielni mieszkaniowej, nie wnosi wkładu mieszkaniowego, jedynie ustaloną kaucję oraz czynsz za użytkowanie mieszkania).

$Z$ danych pochodzących $z$ trzech ostatnich NSP wynika, że udział zasobów mieszkaniowych $\mathrm{w}$ budynkach będących własnością spółdzielni wynosił w Łodzi w 1988 roku 42,3\%, w 2002 roku - 44,8\%, a w $2011-42,0 \%$. Odsetek zasobów należących do osób fizycznych zwiększył się w tym czasie z 13,4\% do 27,7\%, a zasobów pozostających w gestii Skarbu Państwa (zarządzanych przez publiczne przedsiębiorstwa gospodarki mieszkaniowej, a na mocy Ustawy z 10 maja 1990 roku skomunalizowanych) spadł o ponad 20 punktów procentowych, do poziomu $21,7 \%$. Wysoki i wciąż utrzymujący się niemal na tym samym poziomie udział mieszkań w zasobach spółdzielczych nie pokazuje faktycznego stanu ich prywatyzacji, ponieważ dane gromadzone przez GUS dotyczą budynków. Te zaś, mimo postępującej prywatyzacji znajdujących się w nich mieszkań, poza nielicznymi wyjątkami157 wciąż stanowią własność spółdzielni mieszkaniowych. Dlatego też jedynym źródłem danych o procesie prywatyzacji lokali w zasobach spółdzielczych są informacje pozyskiwane bezpośrednio w spółdzielniach.

Z informacji takich uzyskanych w 2014 roku w sześciu łódzkich spółdzielniach mieszkaniowych ${ }^{158}$ wynika, że mniej niż $10 \%$ ich zasobów stanowią mieszkania lokatorskie (z tzw. spółdzielczym lokatorskim prawem do lokalu), od 45 do 60\% mieszkania spółdzielcze własnościowe (z tzw. spółdzielczym własnościowym prawem do lokalu), a od 30 do $45 \%$ mieszkania stanowiące własność odrębną ${ }^{159}$. O szybkości tempa tych przekształ-

157 Wyjątki takie dotyczą sytuacji, kiedy nastąpiło wyodrębnienie się wszystkich mieszkań $\mathrm{w}$ budynku i zawiązanie wspólnoty mieszkaniowej. Mówi o tym art. 26 ust. 1 Ustawy o zmianie ustawy o spótdzielniach mieszkaniowych z 14 czerwca 2007 r., zgodnie z którym: „Jeżeli w określonym budynku lub budynkach położonych w obrębie danej nieruchomości została wyodrębniona własność wszystkich lokali, po wyodrębnieniu własności ostatniego lokalu stosuje się przepisy Ustawy z 24 czerwca 1994 r. o własności lokali, niezależnie od pozostawania przez właścicieli członkami spółdzielni", co w praktyce oznacza, że w nieruchomości przestają obowiązywać przepisy ustawy o spółdzielniach mieszkaniowych.

158 SM Batory, SM Botanik, SM Chrobry, SM Dąbrowa, SM Piaski, SM Teofilów.

159 Dla porównania - w osiedlu Ursynów w Warszawie w 2010 r. 76\% stanowiły mieszkania spółdzielcze własnościowe, a co piąte mieszkanie miało wyodrębnioną własność (Górczyńska 2013, s. 173). 
ceń świadczy fakt, że w połowie lat 90. udział mieszkań lokatorskich w łódzkich osiedlach wynosił od 60 do $70 \%$, a spółdzielczych własnościowych od 30 do $40 \%$. Obecnie, mimo rozszerzenia prawnych możliwości wyodrębniania lokali (poprzez objęcie nimi także mieszkań lokatorskich), wciąż najbardziej popularną formą własności w wielkich osiedlach jest spóldzielcze własnościowe prawo do lokalu. Forma ta, mimo że ułomna i ograniczona, pozwala na obrót mieszkaniami na rynku wtórnym oraz ich dziedziczenie, toteż nie wszyscy właściciele przekształcają ją we własność odrębną. Nawet mimo tego, że nie podlega ona ograniczeniom charakterystycznym dla własności spółdzielczej ${ }^{160}$.

Podczas wywiadów przeprowadzonych $\mathrm{w}$ spółdzielniach ustalono również, że proces przekształcenia spółdzielczych własnościowych praw do lokalu we własność odrębną najszybciej dokonywał się w latach 2007-2009, a po 2009 roku jego tempo osłabło. Nieliczni zaś lokatorzy, którzy nie przekształcili dotychczas formy własności swoich mieszkan, nawet na wspomnianą już ułomną własność spółdzielczą (co było możliwe do końca 2012 r.), i wciąż zajmują mieszkania lokatorskie, to głównie osoby najstarsze, często samotne, które nie są zainteresowane posiadaniem mieszkania na własność. Dotyczy to także osób zadłużonych w spółdzielniach ${ }^{161}$ lub reprezentujących na tyle niski status ekonomiczny, że przekształcenie formy własności mieszkania, nawet na preferencyjnych warunkach, przekracza ich możliwości finansowe.

Właścicielami mieszkań blokowych najczęściej są ich obecni lokatorzy, dla których mieszkania te często są najcenniejszym posiadanym dobrem materialnym ${ }^{162}$. Wciąż także większość $\mathrm{z}$ nich stanowią ci, którzy otrzymali je przed 1990 rokiem w drodze przydziału, a w przypadku osiedli najstarszych także ich dzieci lub wnuki.

160 Odrębna własność lokalu daje m.in. prawo do wyjścia ze spółdzielni i zawiązania wspólnoty mieszkaniowej.

${ }_{161}$ W 2013 r. liczba mieszkań w zasobach spółdzielczych, których lokatorzy zalegają z opłatami za mieszkanie wynosiła w Łodzi 38,8 tys., z czego 8,1 tys. obciążone było zaległościami trwającymi dłużej niż trzy miesiące. Łączna kwota tego zadłużenia wynosiła 33,7 tys. zł (średnio 870 zł na mieszkanie). Dla porównania, w zasobach komunalnych miasta zadłużonych było 18,7 tys. mieszkań, ale przeciętna kwota ich zadłużenia była znacznie wyższa (2733 zł na mieszkanie) (Statystyka Łodzi 2014).

162 Masowa prywatyzacja mieszkań po zmianie ustroju spowodowała pojawienie się kategorii tzw. biednych właścicieli mieszkań. W Polsce dotyczy to przede wszystkim sprywatyzowanych mieszkań komunalnych i zakładowych (zob. Zaniewska, red. 2005), ale także spółdzielczych. Jest bowiem pewnym paradoksem, że odsetek właścicieli mieszkań w krajach postsocjalistycznych jest znacznie większy niż w krajach Europy Zachodniej, a nawet istnieje prawidłowość, że im kraj biedniejszy tym większy udział właścicieli mieszkań (wg Eurostatu w Słowacji, na Litwie i w Rumunii udział ten przekracza 90\%, w Polsce 80\%, podczas gdy średnia w krajach UE-15 nie przekracza 60\% - dane dla 2014 r.). 


\subsection{Wielkie osiedla mieszkaniowe Łodzi - rozwój przestrzenny i charakterystyka}

W 2013 roku w Łodzi było 348,2 tys. mieszkań. Ponad połowa z nich to mieszkania $\mathrm{w}$ budynkach wielorodzinnych wybudowanych $\mathrm{w}$ technologii prefabrykatów, z których nie wszystkie jednak wchodzą w skład wielkich osiedli mieszkaniowych. Część z nich, jak już powiedziano, to pojedyncze budynki lub niewielkie enklawy zabudowy blokowej wmieszanej w starszą zabudowę mieszkaniową, a część to budynki w osiedlach nieprzekraczających swoją skalą 5 tys. mieszkań, którą w niniejszej pracy przyjęto jako kryterium definicyjne wielkich osiedli.

Do jednostek, które spełniają to kryterium i stanowią zwarte, wyodrębnione przestrzennie formy urbanistyczne o jednorodnej zabudowie, należy dziewięć największych osiedli mieszkaniowych w mieście (rys. 26). Podzielono je na trzy grupy różniące się okresem w jakim powstawały, a w konsekwencji, na skutek obowiązujących wówczas normatywów mieszkaniowych i urbanistycznych, stosowanym systemem budownictwa, układem przestrzennym zabudowy oraz strukturą wielkościową oferowanych w nich mieszkań, a także składem społeczno-demograficznym mieszkańców ${ }^{163}$. Ich rozwój i zagospodarowanie omówiono w oparciu o najbardziej typowe przykłady osiedli (po dwa z każdej z grup).

Grupa 1 obejmuje osiedla najstarsze wybudowane w latach 60. i w pierwszej połowie lat 70. XX wieku, do których należą - w kolejności od największego biorąc pod uwagę liczbę mieszkańców w 2010 roku: Teofilów (39,4 tys.), Dąbrowa (35,6 tys.), Żubardź (25,2 tys.) i Zarzew (22,9 tys.). Budowa tych osiedli realizowana była według obowiązującego wówczas w całym kraju, tzw. normatywu oszczędnościowego, toteż współcześnie oferują one mniej korzystne warunki mieszkaniowe niż inne łódzkie osiedla o zabudowie blokowej, głównie ze względu na niewielkie powierzchnie użytkowe mieszkań i małą ich funkcjonalność.

Największe w tej grupie jest osiedle Teofilów wybudowane w latach 1964-1977164, zlokalizowane w północno-zachodniej części Łodzi. Osiedle to

163 Społeczno-demograficzną charakterystykę wielkich osiedli mieszkaniowych Łodzi przeprowadzono na podstawie danych z Urzędu Statystycznego w Łodzi dla tzw. jednostek osiedlowych przyjętych jako jeden z poziomów agregacji danych spisowych.

164 Wszystkie informacje dotyczące liczby budynków, mieszkań, systemów zabudowy oraz rozkładów wewnętrznych mieszkań uzyskano z materiałów spółdzielni mieszkaniowych, które budowały te osiedla lub obecnie zarządzają znajdującymi się w nich zasobami mieszkaniowymi. Spółdzielnie te to: RSM Bawełna, SM Dąbrowa, SM Zarzew (osiedla Dąbrowa, Zarzew, Widzew-Wschód, Olechów); SM Teofilów i SM Rogatka (osiedle Teofilów), SM Radogoszcz-Wschód i SM Radogoszcz-Zachód (osiedle Radogoszcz), SM Botanik, SM Zagrodniki (osiedle Retkinia). 
zostało zaprojektowane w myśl koncepcji miasta linearnego A. Sorii y Mata. W jego układzie przestrzennym wyznaczyć można cztery podstawowe strefy położone wzdłuż głównej osi komunikacyjnej, jaką jest dwupasmowa ulica Aleksandrowska: (1) przemysłową (tzw. Teofilów Przemysłowy), (2) komunikacyjną (komunikacja samochodowa i tramwajowa), (3) mieszkalną oraz (4) strefę zieleni i rekreacji, wyznaczającą południową granicę osiedla. Inwestorem osiedla była RSM Lokator, a obecny zarząd nad jego zasobami sprawują SM Teofilów oraz niewielka SM Rogatka ${ }^{165}$. W zasobach spółdzielni SM Teofilów ${ }^{166}$ znajdują się 203 budynki mieszkalne (obejmujące 15,3 tys. mieszkań), 38 pawilonów handlowych oraz 37 zespołów garażowych wybudowanych na gruncie o powierzchni 115 ha. Zabudowa osiedla

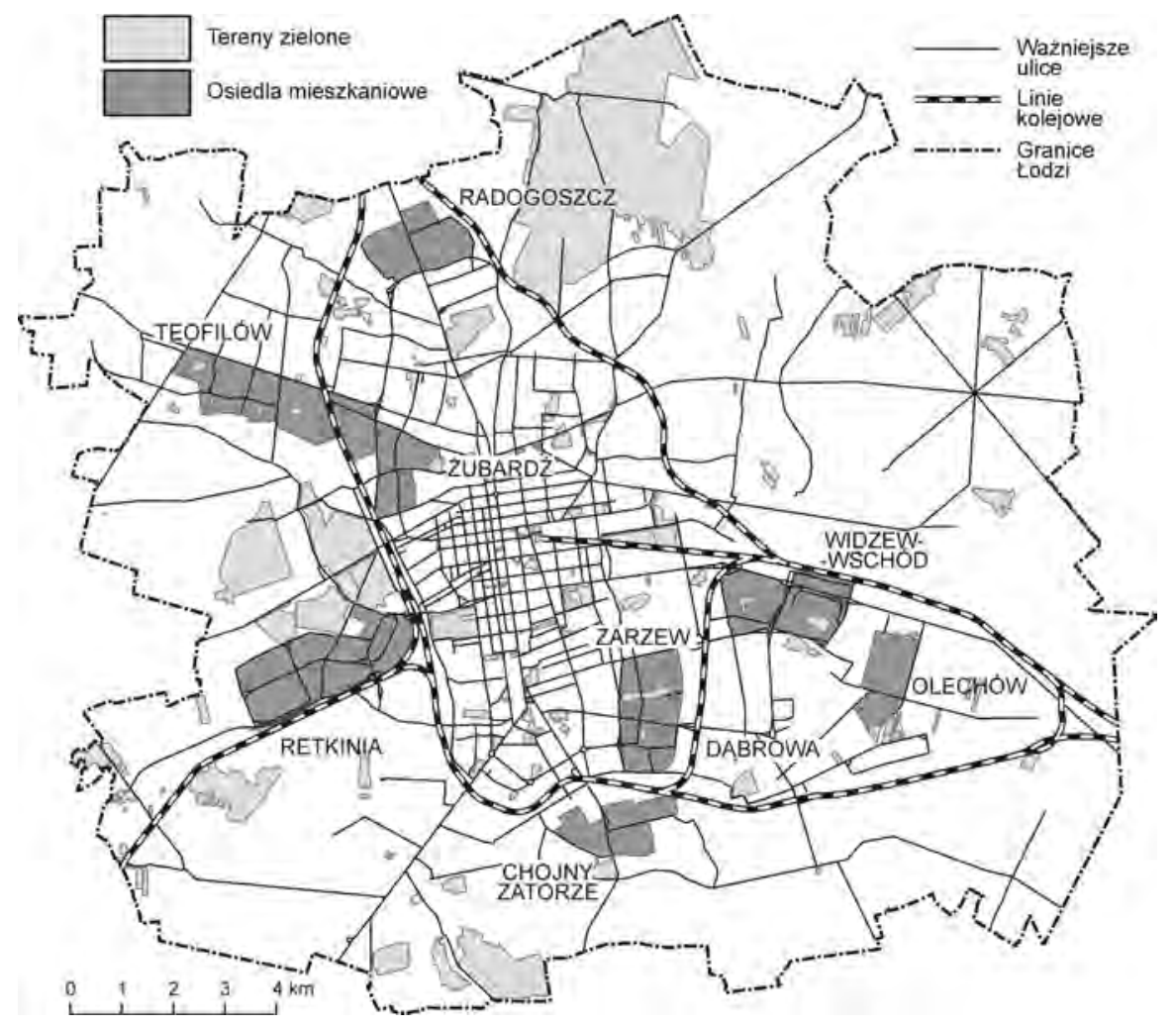

Rys. 26. Lokalizacja badanych osiedli mieszkaniowych w przestrzeni Łodzi Źródło: opracowanie własne

165 SM Rogatka w administracji ma tylko osiem budynków.

$166 \mathrm{~W}$ zasobach zarządzanych przez SM Teofilów wyodrębnia się trzy mniejsze zespoły, które powstawały na kolejnych etapach budowy osiedla i które obecnie mają odrębne administracje: Teofilów A (osiedle im. W. Reymonta), Teofilów B (osiedle im. S. Żeromskiego) i, najdalej wysunięty na zachód, Teofilów C (osiedle im. M. Konopnickiej). 


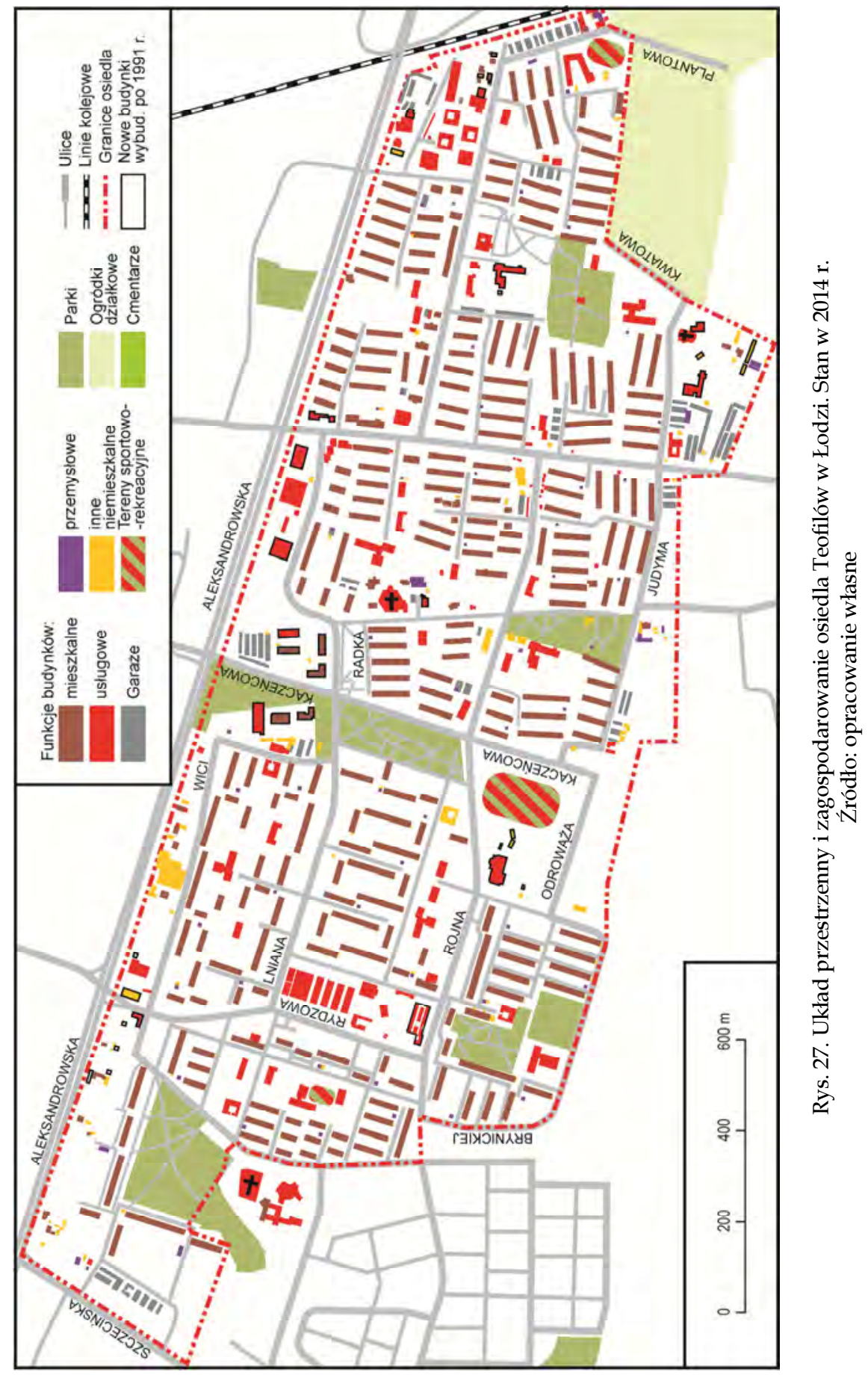


jest dość gęsta, a jej układ w starszej, wschodniej części ma charakter wyłącznie grzebieniowy, natomiast w nowszej, położonej dalej na zachód, blokowy, liniowy i grzebieniowy (rys. 27). Pierwotna zabudowa mieszkaniowa składa się z dwóch typów budynków: 5- i 11-kondygnacyjnych, przy czym większość $\mathrm{z}$ nich stanowią budynki niskie. Wzniesiono je w technologii wielkiej płyty, w systemie ŁSM (Łódzka Sekcja Mieszkaniowa), opracowanym i stosowanym tylko na terenie Łodzi. Ponad połowa mieszkań $\mathrm{w}$ osiedlu to lokale o powierzchni użytkowej do $39 \mathrm{~m}^{2}$, a blisko $90 \%$ do $49 \mathrm{~m}^{2}$. Dominują mieszkania typu M-3, a większość z nich to lokale nierozkładowe $\mathrm{z}$ amfiladowym układem pomieszczeń. Ich wielkość zgodna jest z obowiązującymi wówczas normatywami określającymi powierzchnię mieszkań (M-2 - do $30 \mathrm{~m}^{2}$, M-3 - do $38 \mathrm{~m}^{2}$, a M-4 - do $48 \mathrm{~m}^{2}$ ).

Kolejnym reprezentantem tej grupy jest osiedle Dąbrowa budowane w latach 1966-1975, zlokalizowane w południowo-wschodniej części miasta na terenach położonych w bezpośrednim sąsiedztwie linii kolei obwodowej, po jej wewnętrznej stronie. $W$ osiedlu tym do połowy lat 70. wzniesiono 208 budynków, w których mieściło się 16,3 tys. mieszkań. Powierzchnia osiedla wynosi 158 ha.

Zabudowa jest gęsta, a jej układ w większości ma charakter grzebieniowy (fot. 3, 4, rys. 28). Niemal wszystkie budynki wzniesione zostały w systemie wielkopłytowym „Dąbrowa” (w wersji D-64A), który był jedną z odmian systemu ŁSM. Zdecydowana większość z nich to budynki 5-kondygnacyjne, a około $20 \%$ stanowily wieżowce o 11 lub 12 kondygnacjach (fot. 3 i 4). Ponad połowa mieszkań, podobnie jak w osiedlu Teofilów, to mieszkania typu M-3, o powierzchni nieprzekraczającej normatywnej wielkości $38 \mathrm{~m}^{2}$, częściowo lub całkowicie nierozkładowych (rys. 29).

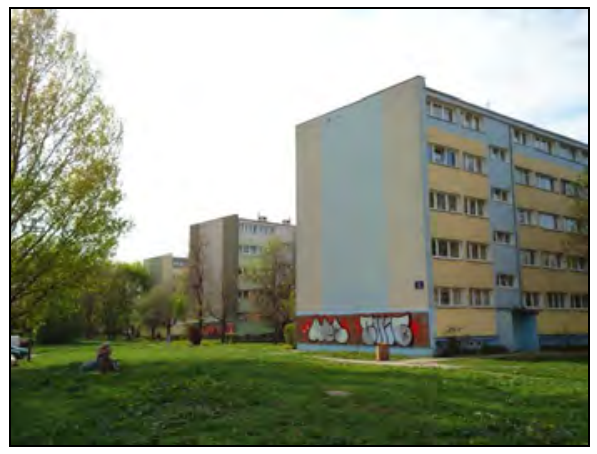

Fot. 3. Typowa zabudowa 5-kondygnacyjna w osiedlu Dąbrowa Źródło: archiwum autora

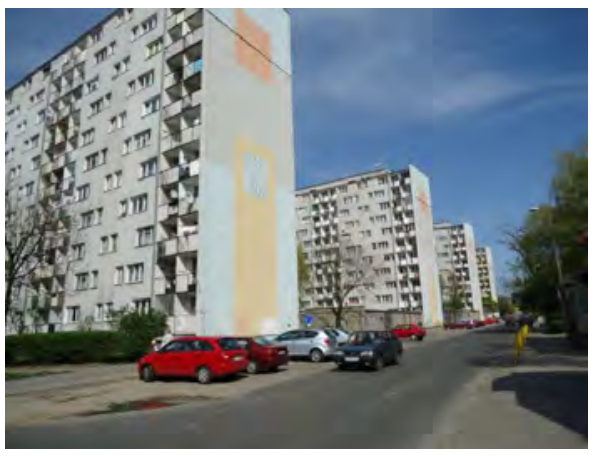

Fot. 4. Typowa zabudowa 11-kondygnacyjna w osiedlu Dąbrowa Źródło: archiwum autora 


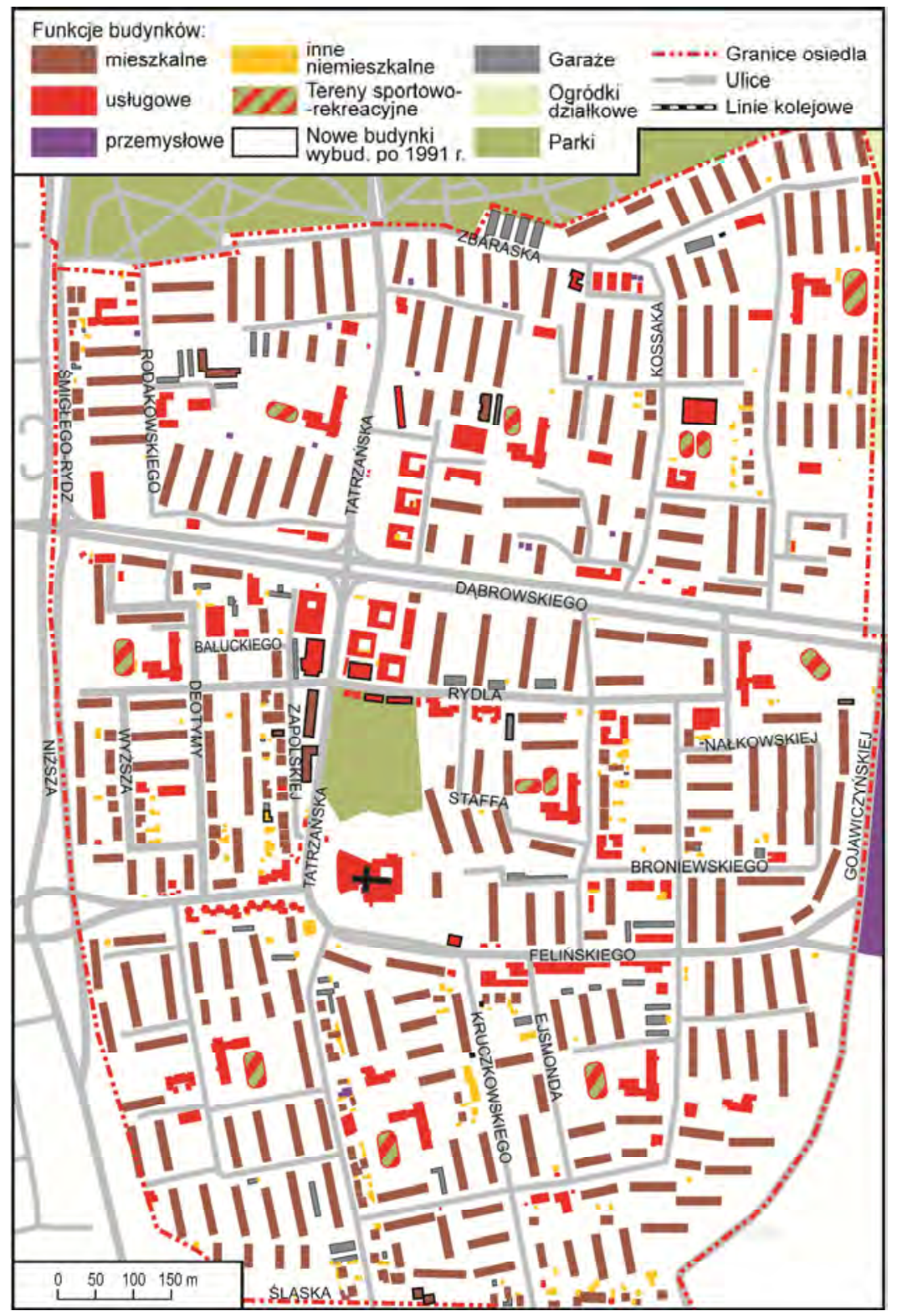

Rys. 28. Układ przestrzenny i zagospodarowanie osiedla Dąbrowa w Łodzi (stan w 2014 r.) Źródło: opracowanie własne 


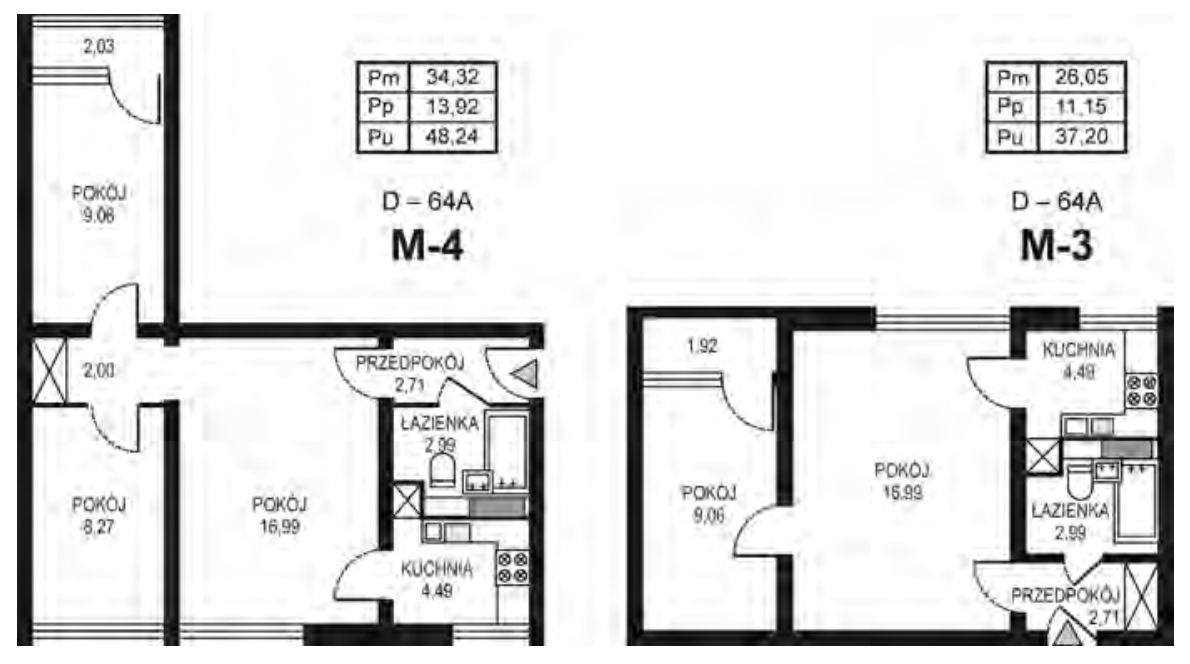

Rys. 29. Typowe rozkłady mieszkań M-3 i M-4 w systemie D-64 A stosowane w osiedlu Dąbrowa

Źródło: opracowanie własne na podstawie materiałów udostępnionych przez RSM Bawełna

Wyodrębniona $\mathrm{w}$ pracy druga grupa osiedli obejmuje znacznie większe obszarowo jednostki powstałe w latach 70. i w pierwszej połowie lat 80 . XX wieku. Należą do niej dwa największe osiedla Łodzi - Retkinia, która w 2010 r. koncentrowała blisko 10\% mieszkańców miasta (70,6 tys.), i Widzew-Wschód (42,9 tys.).

Największe z łódzkich osiedli Retkinia zlokalizowana została w retkińsko-smulskim paśmie osadniczym (Bald 2002), położonym wzdłuż łódzko-kaliskiej linii kolejowej, w zachodniej części miasta. Osiedle to zaplanowane zostało jako przedłużenie istniejącego już Karolewa, gdzie wcześniej powstało niewielkie osiedle im. M. Fornalskiej. Jego budowę zaplanowano na terenie kilku wsi i osad o wspólnej nazwie Retkinia (Koter 2009b). Rozpoczęto ją w 1972 roku i kontynuowano aż do połowy lat 80. W pierwszej fazie budowy (1972-1976) powstały osiedla Zagrodniki, Piaski oraz Hufcowa, określane później Retkinią-Wschód. W kolejnej (lata 1974-1979) osiedle Balonowa (zwane później Retkinią-Południe) oraz osiedle Retkinia-Północ. W ostatniej fazie (lata 1978-1985) zaczęto zagospodarowywać pod budownictwo mieszkaniowe pozostawione wcześniej tereny otwarte połżone w środkowej części osiedla, na których pierwotnie miały być zlokalizowane obiekty handlowo-usługowe i kulturalno-oświatowe obsługujące wszystkich mieszkańców Retkini. Tereny te, zlokalizowane wzdłuż głównych osi urbanistycznych osiedla - przebiegającej południkowo ulicy Armii Krajowej oraz prostopadłej do niej alei kard. S. Wyszyńskiego - sukcesywnie wypeł- 


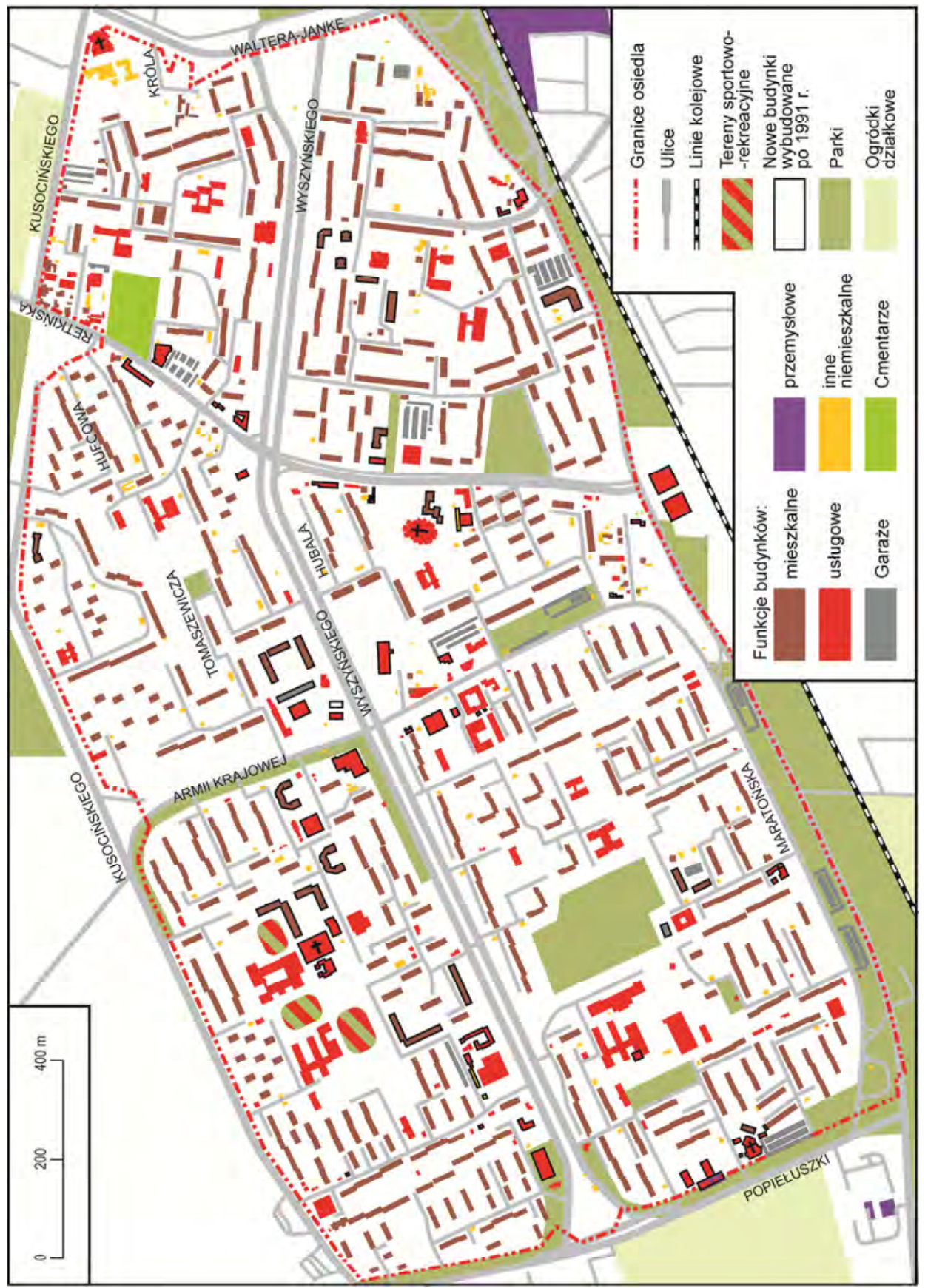

Rys. 30. Układ przestrzenny i zagospodarowanie osiedla Retkinia w Łodzi (stan w 2014 r.) Źródło: opracowanie własne 
niane pojedynczymi obiektami usługowymi i mieszkalnymi, do dziś tworzą najmniej zagospodarowany obszar Retkini, określany jako osiedle Sympatyczna. Powierzchnia osiedla wynosi ponad 350 ha, a zastosowane w nim układy zabudowy są zróżnicowane (rys. 30).

Trwający ponad dekadę wieloetapowy proces inwestowania w osiedlu sprawił, że jego zabudowa jest bardziej zróżnicowana wewnętrznie niż innych łódzkich osiedli. Większość stanowią 5- i 11-kondygnacyjne bloki najczęściej liczące od dwóch do sześciu klatek schodowych. Są jednak wśród nich wieżowce liczące po 10 klatek schodowych, w których mieści się ponad 200 mieszkań, a także niskie, kameralne, zatopione w zieleni budynki punktowe (z jedną klatką schodową) liczące po 20 mieszkań. Wszystkie bloki powstałe do 1985 roku wybudowane są z wielkiej płyty w systemie tzw. szczecińskim ${ }^{167}$, stosowanym $\mathrm{w}$ wielu innych polskich miastach. System ten pozwalał na budowę w pełni rozkładowych mieszkań, o nieco większych niż dotychczas powierzchniach użytkowych i z dużymi balkonami. Większość mieszkań w osiedlu to M-3 i M-4 o powierzchni odpowiednio 42 i $53 \mathrm{~m}^{2}$.

Kolejnym osiedlem $\mathrm{z}$ tej grupy jest powstały nieco później Widzew-Wschód zlokalizowany we wschodniej części miasta w tzw. koluszkowskim paśmie osadniczym, wzdłuż jednej z arterii komunikacyjnych miasta (trasy W-Z). Jego budowa trwała w latach 1976-1985. Osiedle składa się z trzech części, starszej położonej na wschód od ulicy Puszkina (im. B. Chrobrego), młodszej - na zachód od tej ulicy (im. S. Batorego), oraz najmniejszej obszarowo i najnowszej (z lat 1983-1985) części, zlokalizowanej na północ od ulicy Rokicińskiej (im. Mieszka I). Zabudowa osiedla Widzew-Wschód zajmuje teren o powierzchni 288 ha i jest dość luźna. Charakteryzuje ją duża ilość terenów otwartych, które podobnie jak na Retkini pozostawiono z przeznaczeniem na funkcje handlowo-usługowe oraz tereny rekreacyjne. Zabudowa ma charakter mieszany z elementami wszystkich układów stosowanych w osiedlach mieszkaniowych (grzebieniowego, liniowego, gniazdowego i blokowego) (rys. 31).

Nieco ponad połowę budynków stanowią 5-kondygnacyjne, pozostałe to 11- i 12-kondygnacyjne. Osiedle wznoszono w dość istotnie zmodyfikowanej wersji systemu zabudowy wielkopłytowej Dąbrowa (warianty D-70 i D-75) oraz w nowszych systemach W-70 i Wk-70 opartych na rozwiązaniach stosowanych w b. NRD. Były to tzw. systemy otwarte, które pozwalały na większą różnorodność w projektowaniu mieszkań i większą ich

167 System "szczeciński” oparty został na technologii importowanej z ZSRR. Pierwsze budynki w tym systemie zostały zbudowane w latach 1971-1972 w Szczecinie, skąd wzięła się jego nazwa. System umożliwiał konstrukcję budynków 5- i 11-kondygnacyjnych w układach klatkowych, korytarzowych i punktowych (Wojtkun 2008). 


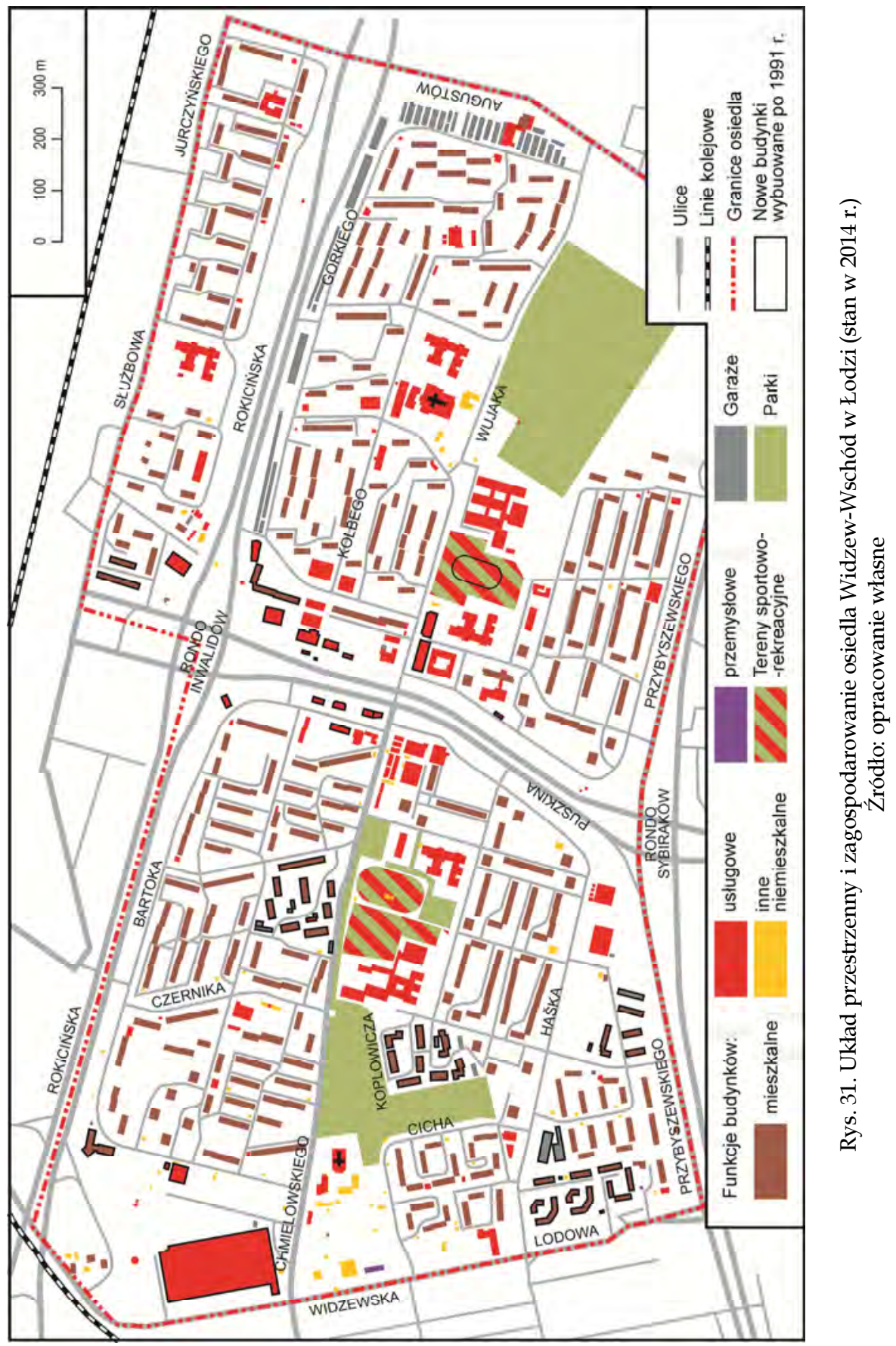


funkcjonalność (rys. 32). Wielkość lokali budowanych w tych systemach przekraczała ówczesne, $\mathrm{i}$ tak podniesione w 1974 roku normatywy mieszkaniowe. Dzięki temu zlokalizowane tu mieszkania miały znacznie większe powierzchnie użytkowe niż budowane $\mathrm{w}$ okresie wcześniejszym i nieco większe niż w osiedlu Retkinia. Część mieszkań typu M-3 miało powierzchnie przekraczające $50 \mathrm{~m}^{2}$, a M-4 $-60 \mathrm{~m}^{2}$, choć większość mieściła się w granicach $43-47 \mathrm{~m}^{2}(\mathrm{M}-3)$ oraz $54-57 \mathrm{~m}^{2}(\mathrm{M}-4)$.
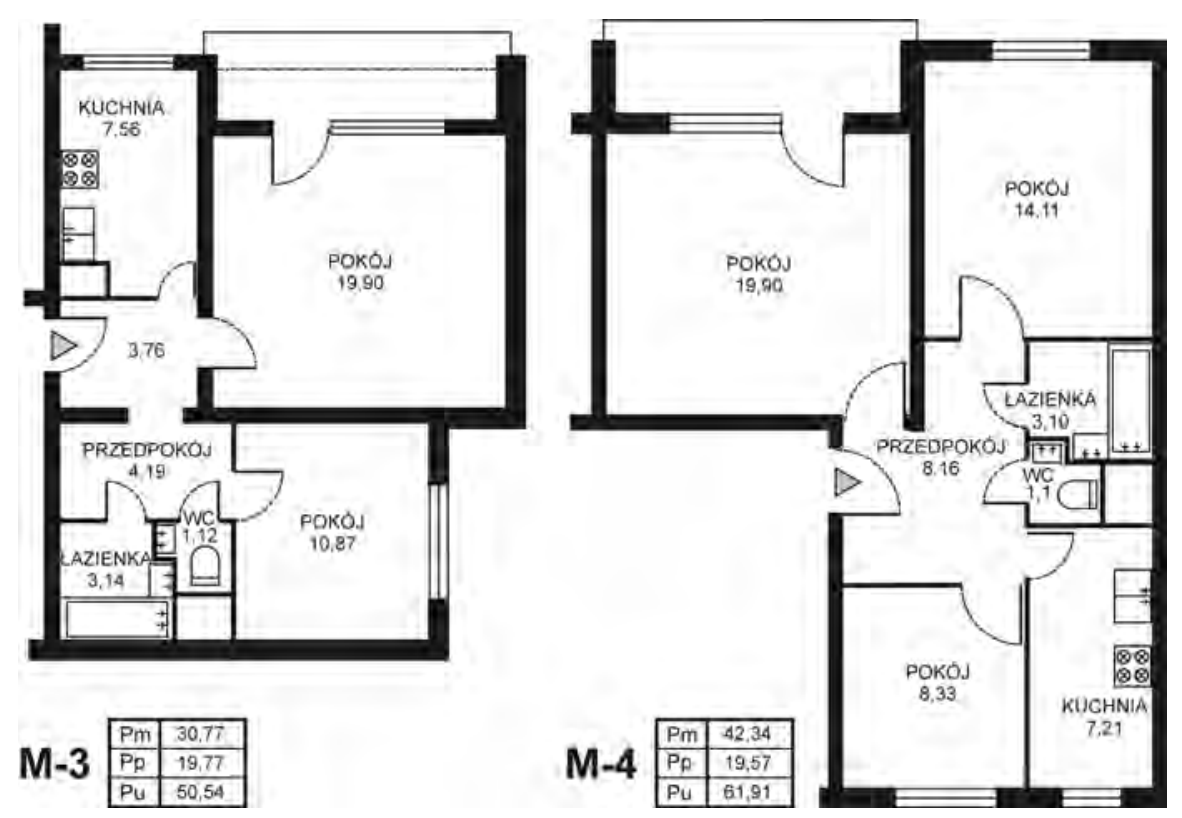

Rys. 32. Przykładowe rozkłady mieszkań w systemach Wk-70 stosowanych w osiedlu Widzew-Wschód

Źródło: opracowanie własne na podstawie materiałów udostępnionych przez RSM Bawełna

W grupie trzeciej znajdują się najmłodsze łódzkie osiedla blokowe, wzniesione w latach 80 . i w I połowie lat 90 . XX wieku. Do grupy tej należą: Radogoszcz (w 2010 r. - 44,0 tys. mieszkańców), Chojny-Zatorze (31,0 tys.) oraz najmłodszy ze wszystkich osiedli, rozbudowywany w latach 90 . Olechów (Olechów-Janów) - 19,6 tys. mieszkańców.

Największe wśród nich osiedle Radogoszcz położone jest w północnej części Łodzi po obu stronach jednej z głównych dróg wyjazdowych z miasta ulicy Zgierskiej. Składa się z dwóch części. Starszą z nich jest Radogoszcz-Zachód, która liczy 70 budynków powstałych w latach 1979-1982 przewidzianych dla około 10 tys. mieszkańców. W zasobach tej części osiedla 


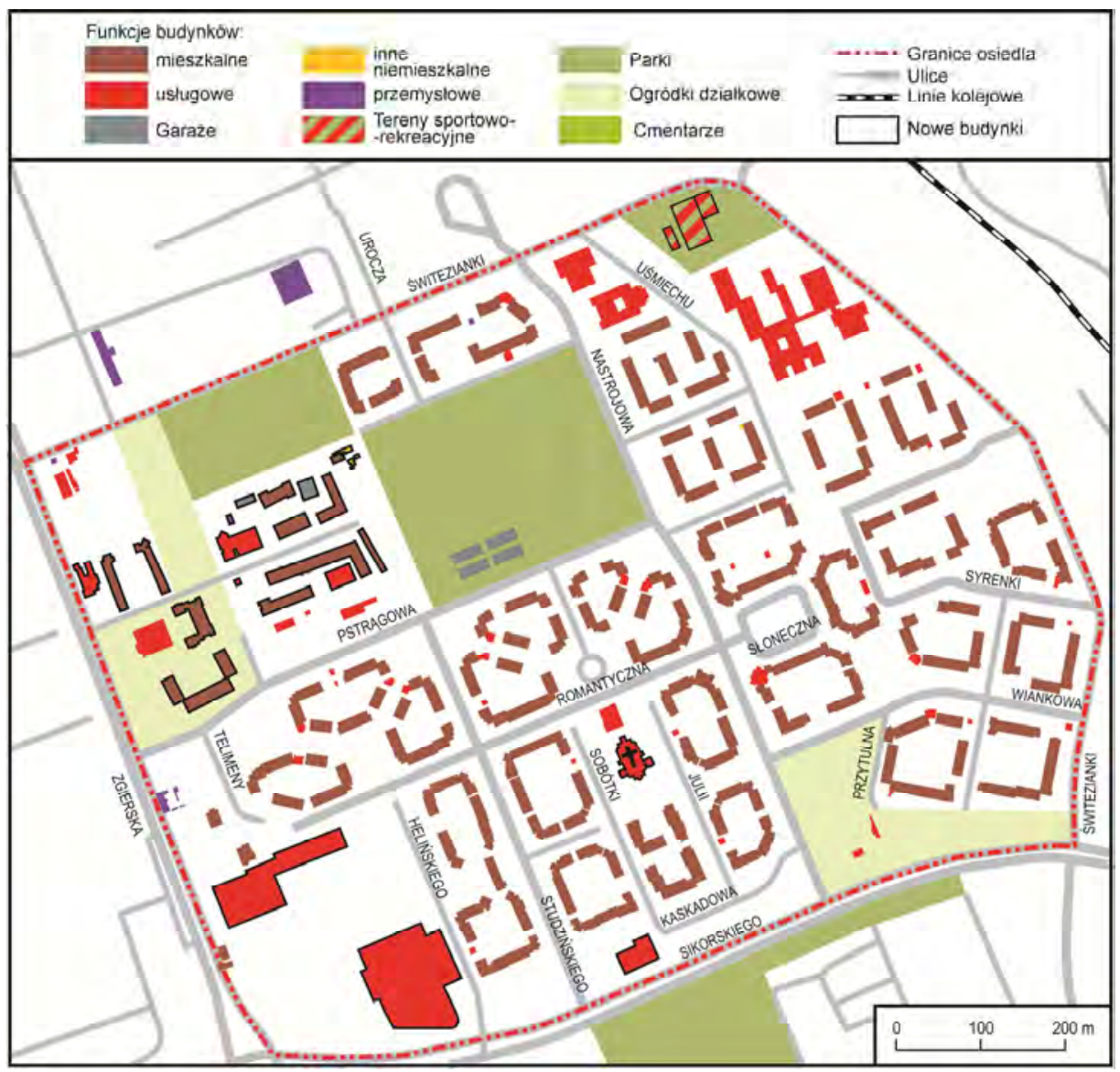

Rys. 33. Układ przestrzenny i zagospodarowanie osiedla Radogoszcz-Wschód w Łodzi (stan w 2014 r.)

Źródło: opracowanie własne

znajduje się 70 wielorodzinnych budynków mieszkalnych (z czego 60 to budynki 5-kondygnacyjne). Młodszą jest osiedle Radogoszcz-Wschód, które obejmuje 199 wielorodzinnych budynków mieszkalnych wzniesionych dwuetapowo w latach 1982-1992. Najpierw (1982-1987) wybudowano północną część składającą się z 29 budynków (tzw. Sitowie), a następnie (lata 19841992) znacznie większą południową, obejmującą 170 budynków. Mimo że obydwie części osiedla wybudowane zostały $\mathrm{w}$ technologii wielkiej płyty (w systemie "szczecińskim"), ich fizjonomia i układ zabudowy bardzo się różnią. Zachodnia część ma krajobraz charakterystyczny dla osiedli z lat 60. i 70., który tworzą jednakowe prostopadłościenne budynki usytuowane równolegle do siebie w układzie grzebieniowym i liniowym. Część wschod- 
nia natomiast zbudowana jest w układzie blokowym, a budynki tworzą półotwarte wewnętrzne dziedzińce, gdzie znajdują się place zabaw, miejsca odpoczynku i osiedlowa zieleń (rys. 33).

Układ przestrzenny tej części osiedla nawiązuje do tradycyjnych rozwiązań urbanistycznych. Jego centralny fragment zajmuje wypełniony zielenią, reprezentacyjny plac Słoneczny (fot. 5-7), wokół którego zlokalizowane są budynki mieszkalne $\mathrm{z}$ wbudowaną $\mathrm{w}$ parterach funkcją usługowo-handlową. Wysokość budynków oraz ich forma architektoniczna są zróżnicowane, co sprawia że osiedle Radogoszcz-Wschód ma oryginalną fizjonomię, czym wyróżnia się spośród innych łódzkich osiedli mieszkaniowych budowanych w okresie socjalistycznym.

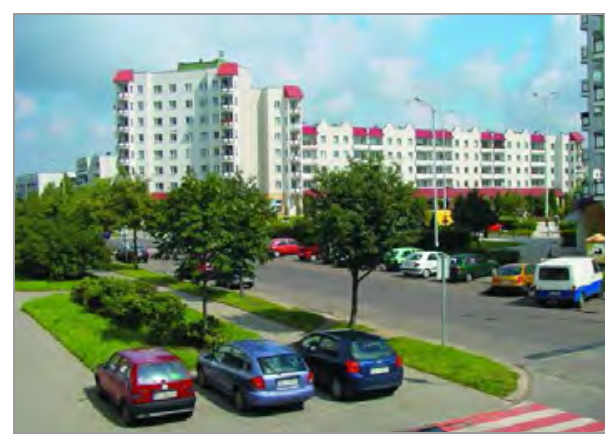

Fot. 5. Widok na zabudowę osiedla Radogoszcz-Wschód Źródło: archiwum autorki

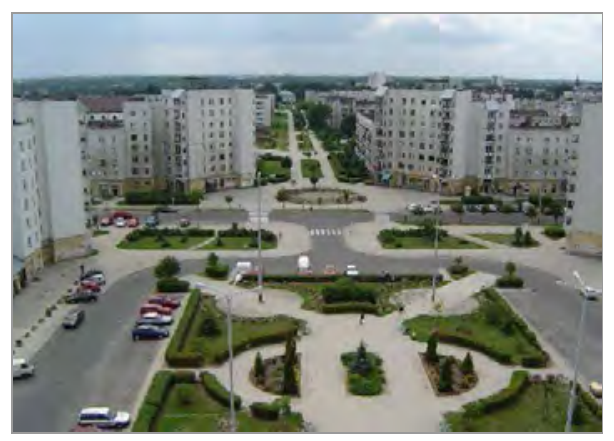

Fot. 6. Widok na plac Słoneczny w osiedlu Radogoszcz-Wschód Źródło: archiwum autorki

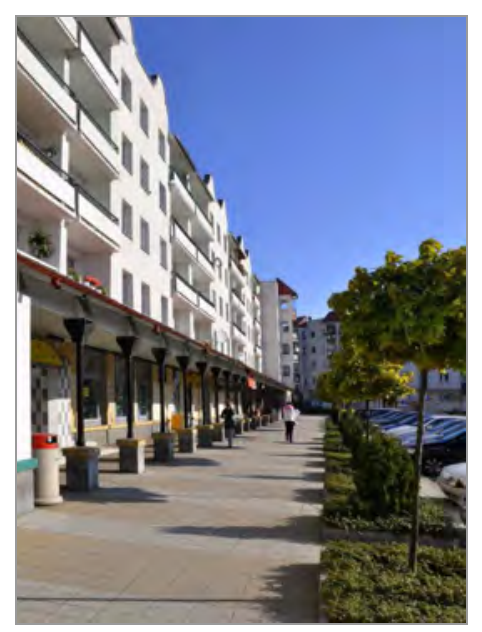

Fot. 7. Widok na pierzeję placu Słonecznego w osiedlu Radogoszcz-Wschód Źródło: archiwum autorki 


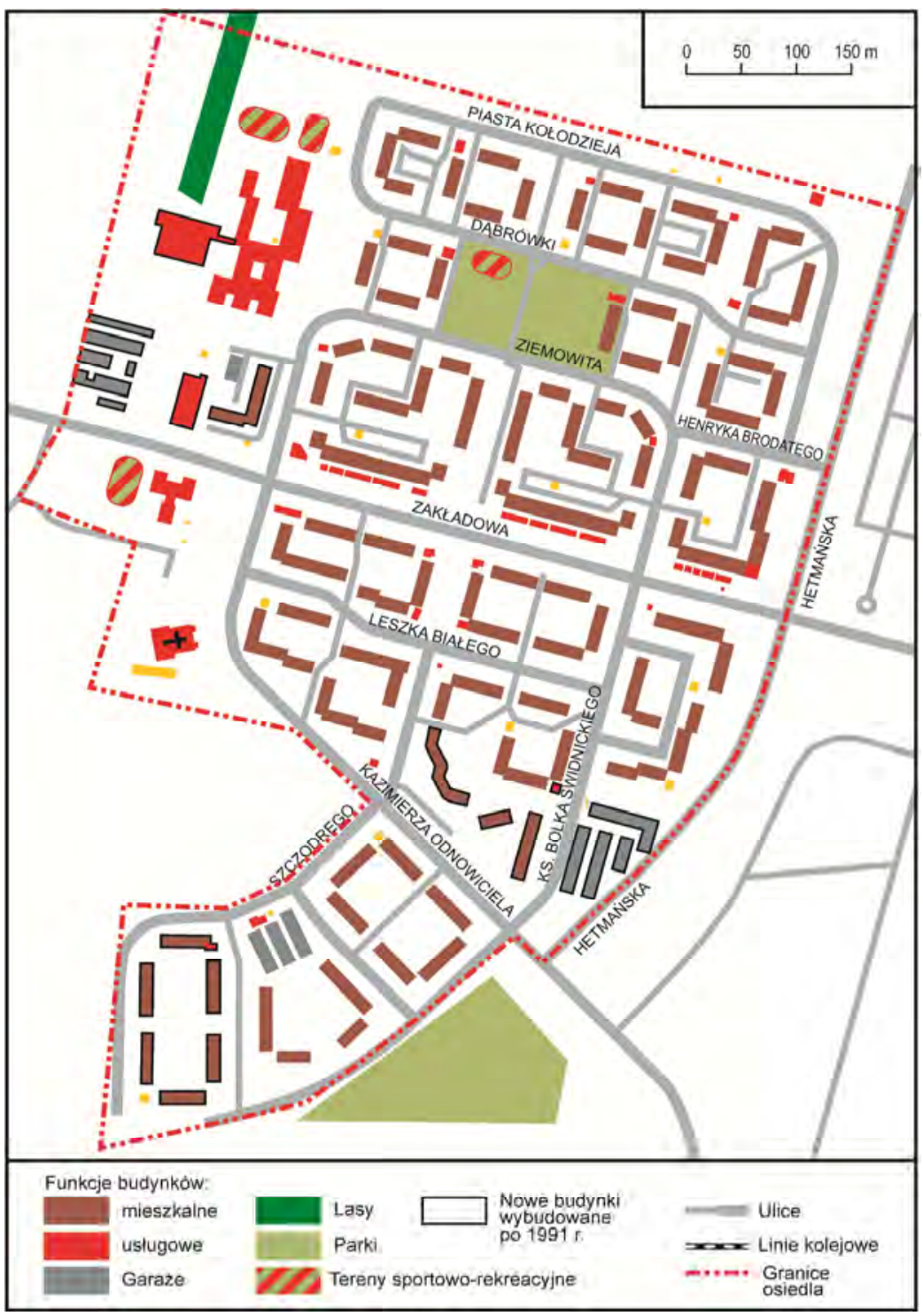

Rys. 34. Układ przestrzenny i zagospodarowanie starszej części osiedla Olechów w Łodzi (stan w 2014 r.) Źródło: opracowanie własne

Budowę najmłodszego $\mathrm{z}$ wielkich łódzkich osiedli mieszkaniowych Olechowa (rys. 34), zlokalizowanego na przedłużeniu osiedla WidzewWschód, rozpoczęto w 1987 roku i z przerwami kontynuowano do połowy lat 90. XX wieku. Według pierwotnych zamierzeń miało to być jedno z więk- 
szych łódzkich osiedli (zakładano, że zamieszka je około 90 tys. mieszkańców - Drogi rozwoju...), ale realizację tych planów przerwała zmiana ustroju.

Osiedle składa się z czterech części, z których tylko dwie starsze noszą nazwę Olechów, a nowsze - Olechów-Janów ${ }^{168}$. W świadomości potocznej jednak funkcjonuje nazwa Olechów obejmująca wszystkie jego części, także nowsze. Obecnie znajdują się tutaj 274 budynki mieszkalne, z czego 129 oddano do użytku w latach 1988-1991, a pozostałe w okresie późniejszym, co $\mathrm{w}$ związku ze zamianami $\mathrm{w}$ sposobie finansowania budownictwa mieszkaniowego znajduje odzwierciedlenie $\mathrm{w}$ fizjonomii i statusie społecznym mieszkańców. Zabudowa starszej części osiedla w większości jest niska i składa się z niewielkich 5-kondygnacyjnych bloków, wzniesionych w technologii wielkiej płyty, liczących od trzech do pięciu klatek schodowych. Tylko sześć z nich to budynki ośmiokondygnacyjne. Osiedle to, mimo że powstawało niemal równolegle z osiedlem Radogoszcz-Wschód, ma znacznie mniej zróżnicowaną zabudowę i znacznie skromniejszą formę architektoniczną budynków, na skutek czego jego fizjonomia bardziej przypomina osiedla blokowe z wcześniejszych dekad. Tym, co wyróżnia Olechów jest blokowy układ zabudowy $\mathrm{z}$ wewnętrznymi półotwartymi dziedzińcami, wypełnionymi zielenią i zagospodarowanymi placami zabaw.

Duży walor osiedla jeszcze przed 1990 rokiem stanowiły również atrakcyjne, funkcjonalne i relatywnie duże mieszkania (rys. 35). Inwestorem osiedla była spółdzielnia mieszkaniowa "Bawełna”, toteż budowano je w tym samym co Widzew-Wschód systemie wielkopłytowym W-70, ale o większych powierzchniach lokali. Średnia powierzchnia użytkowa mieszkań M-3 wynosiła tu $50 \mathrm{~m}^{2}$, podczas gdy w budowanych dwie dekady wcześniej osiedlach Teofilów i Dąbrowa nie przekraczała $38 \mathrm{~m}^{2}$.

Porównanie osiedli z poszczególnych okresów pozwoliło stwierdzić, że wraz ze stosowanymi $\mathrm{w}$ nich systemami zabudowy i strukturą wielkościową mieszkań, które ewoluowały w kolejnych dekadach, zmieniał się także poziom ich wyposażenia $\mathrm{w}$ infrastrukturę społeczną i usługową. Jakkolwiek bowiem dla wszystkich osiedli blokowych z okresu miasta socjalistycznego charakterystyczna była dominacja funkcji mieszkaniowej i opóźnienia $\mathrm{w}$ budowie infrastruktury towarzyszącej, która powstawała wówczas, gdy większość budynków była już zasiedlona, to osiedla wznoszone

168 Pierwszą najstarszą część Olechowa stanowi os. Słowiańskie, zlokalizowane na południe od ul. Piasta Kołodzieja, wybudowane w całości przez SM Bawełna do początku lat 90. XX w. Drugą os. Sienkiewiczowskie, zlokalizowane na północ od Słowiańskiego, budowane w latach 90. przez spółdzielnię oraz deweloperów. Trzecią tworzą budynki wybudowane przez TBS oraz gminę Łódź, czwartą natomiast budynki najnowsze, powstałe po 2000 r., budowane wyłącznie przez deweloperów. 
do połowy lat 60 . były lepiej wyposażone niż budowane w okresie późniejszym. Tempo ich wznoszenia nie było jeszcze tak szybkie, co pozwalało na realizację przyjętych wówczas normatywów urbanistycznych określających poziom tego wyposażenia.
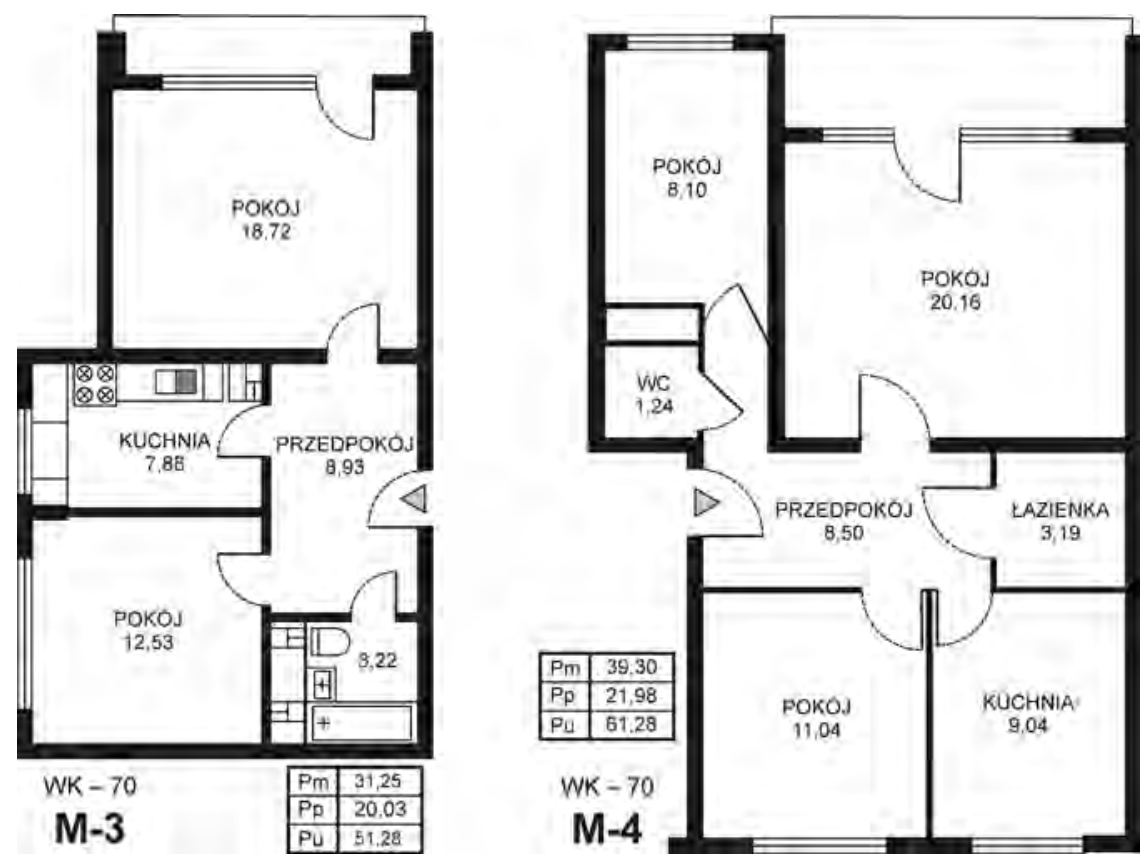

Rys. 35. Przykładowe rozkłady mieszkań typu M-3 oraz M-4 stosowane w osiedlu Olechów

Źródło: opracowanie własne na podstawie materiałów udostępnionych przez RSM Bawełna

Począwszy od połowy lat 60 . XX wieku, kiedy tempo budowy nowych mieszkań znacznie przyspieszyło, sytuacja ta zaczęła ulegać stopniowemu pogorszeniu, a w połowie lat 70. nastąpił już wyraźny regres budownictwa towarzyszącego, trwający do końca okresu wznoszenia wielkich osiedli. I tak, np. w ponad 45-tysięcznym osiedlu Widzew-Wschód do końca lat 80. wybudowano obiekty handlowo-usługowe o łącznej powierzchni użytkowej 13,1 tys. $\mathrm{m}^{2}$ (w tym m.in. sześć pawilonów oraz dwa budynki przychodni), zaś powierzchnia obiektów zaplanowanych, których nie udało się zrealizować, wynosiła prawie drugie tyle, bo około 12 tys. $\mathrm{m}^{2}$ (Drogi rozwoju...). Podobna sytuacja miała miejsce $\mathrm{w}$ budowanym $\mathrm{w}$ tym okresie osiedlu Retkinia. Charakterystyczne dla osiedli z lat 70 . było także przyjmowanie roz- 
wiązań tymczasowych, polegających na adaptacji parterowych mieszkań i przeznaczaniu ich na niezbędne usługi ${ }^{169}$. W osiedlu Widzew-Wschód np. zagospodarowano tak ponad 100 mieszkań zapewniając w ten sposób miejsce dla pięciu przedszkoli, trzech żłobków, trzech punktów pocztowych, dwóch bibliotek publicznych, dwóch komisariatów MO, apteki, przychodni zdrowia oraz kilkunastu innych placówek usługowych i handlowych. Ich łączna powierzchnia w osiedlu w końcu lat 80 . wynosiła 6,8 tys. $\mathrm{m}^{2}$ (Drogi rozwoju...). Niedostateczne wyposażenie $\mathrm{w}$ infrastrukturę towarzyszącą dotyczyło także osiedli z kolejnej dekady, z jednym jednakże wyjątkiem, jakim jest osiedle Radogoszcz-Wschód, które wyróżniało się nie tylko odmienną od pozostałych fizjonomią, ale również lepszym poziomem wyposażenia w usługi i handel. W osiedlach powstających od II połowy lat 70., charakterystyczne było także pozostawianie dużej rezerwy terenowej z założeniem sukcesywnego wypełniania jej programem usługowym oraz terenami sportu i rekreacji, co jednak nie zostało zrealizowane aż do końca trwania ustroju.

Okres budowy poszczególnych osiedli, jak już powiedziano, determinował nie tylko ich strukturę przestrzenną i fizjonomię, ale także skład społeczno-demograficzny mieszkańców. W końcu okresu socjalistycznego, osiedla z lat 60. i I połowy lat 70. charakteryzowały się najstarszą strukturą wieku, największym udziałem osób utrzymujących się z niezarobkowych źródeł i największym odsetkiem 1-osobowych gospodarstw domowych. Najnowsze natomiast (w tym także Olechów, który wówczas jeszcze rozbudowywano) najmłodszą strukturą wieku, największym udziałem osób utrzymujących się z pracy i najmniejszym odsetkiem gospodarstw 1-osobowych (tab. 18).

Status społeczny mieszkańców osiedli, mierzony poziomem wykształcenia, jakkolwiek heterogeniczny, na skutek omówionych już w pracy socjalistycznych zasad alokacji mieszkaniowej, niektóre z nich plasował dość wysoko w strukturze społeczno-przestrzennej Łodzi. Duża relatywna atrakcyjność oferowanych w nich warunków mieszkaniowych oraz silne ograniczenie alternatywnych sposobów zaspokojenia potrzeb mieszkaniowych przyciągały przedstawicieli wyższych kategorii społecznych, którzy - jak już powiedziano - począwszy od lat 60 . zaczęli opuszczać niedoinwestowane i niszczejące centrum miasta. Najniższa pozycja statusowa osiedla Dąbrowa, które do dziś ma nieformalny status osiedla robotniczego, wynikała głównie ze składu członków spółdzielni RSM Bawełna. Jak dowiadujemy się z publikacji wydanej z okazji 50-lecia tej spółdzielni (Drogi rozwoju...), w 1965 roku, kiedy rozpoczęto budowę tego osiedla, na skutek zmian w przepisach nastąpił gwałtowny napływ do grona kandydatów osób mniej zamożnych, które wcześniej oczekiwały na przydział mieszkania kwaterunkowego, a których pozbawiono tego prawa (ibid., s. 31).

${ }^{169}$ Jak podaje D. Jarosz (2010) praktyka ta była dość powszechna także w innych miastach. 


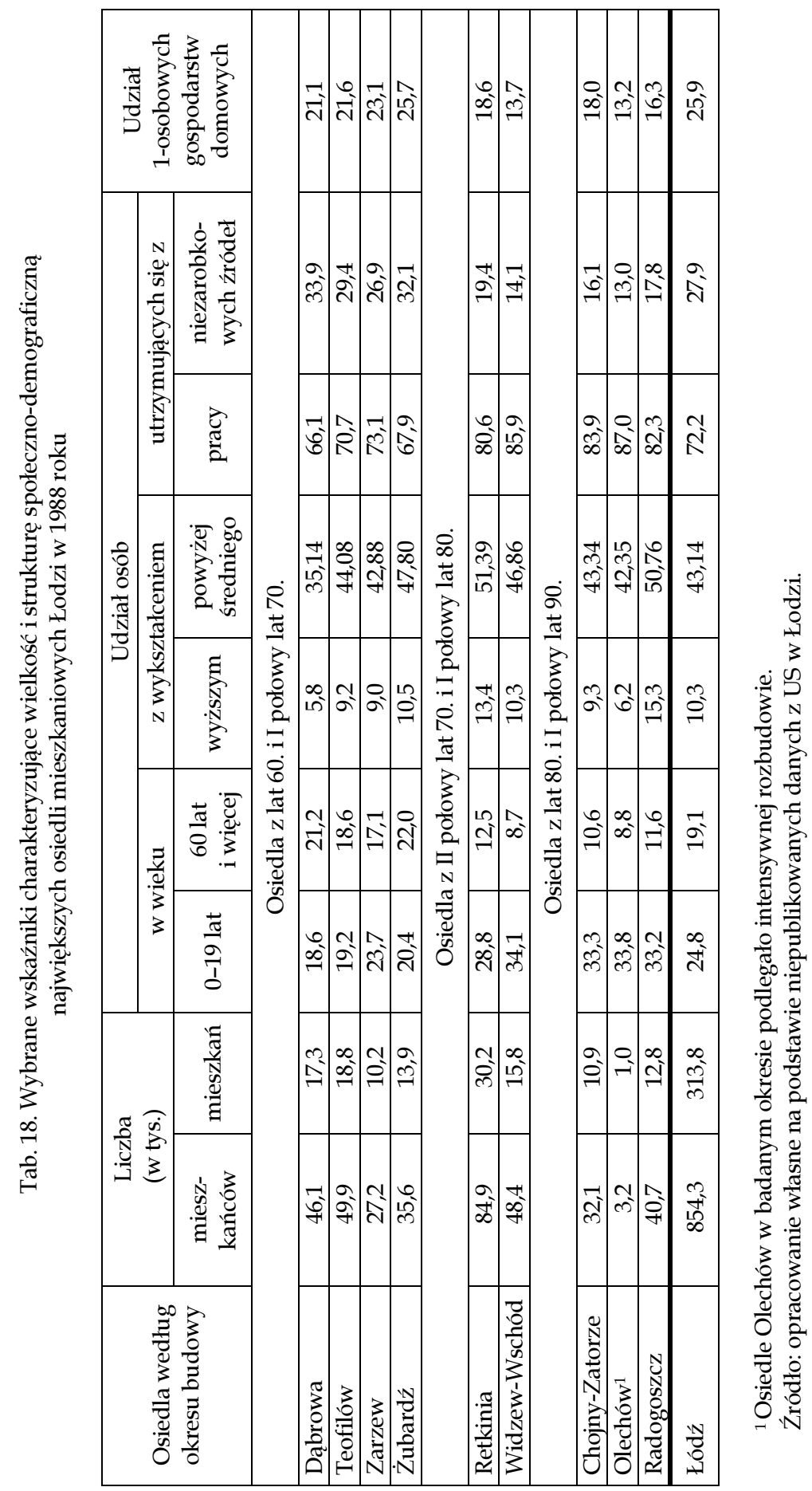




\subsection{Przemiany wielkich osiedli mieszkaniowych Łodzi po 1990 roku}

Przemiany wielkich osiedli mieszkaniowych Łodzi w okresie transformacji, podobnie jak $w$ rozdziale piątym pracy, zanalizowano $w$ odniesieniu do ich struktury społecznej (w ujęciu demograficznym i stratyfikacyjnym), morfologicznej, funkcjonalnej (funkcjonalno-przestrzennej) oraz fizjonomii. Osobna grupa zagadnień omówionych $\mathrm{w}$ niniejszym rozdziale dotyczy przemian osiedlowych przestrzeni publicznych, które dokonują się we wszystkich wymienionych wymiarach. Strukturę społeczno-demograficzną mieszkańców osiedli zanalizowano na podstawie źródeł zastanych, do których należą dane statystyczne pochodzące z NSP $(1988,2002)$, a także niepublikowane dane US w Łodzi opracowane na podstawie bilansu liczby i struktury ludności miasta (za rok 2010). Źródłem informacji o mieszkańcach wybranych osiedli były także wywiady przeprowadzone w spółdzielniach mieszkaniowych zarządzających zasobami w tych osiedlach oraz wywiady kwestionariuszowe i swobodne przeprowadzone wśród mieszkańców. Analizę przemian struktury przestrzennej oparto na danych pozyskanych w wyniku inwentaryzacji dokonanej na obszarze objętym badaniem, danych uzyskanych w spółdzielniach mieszkaniowych oraz literatury. Zgromadzony w ten sposób materiał ma charakter ilościowy i jakościowy, a jego analiza posłużyła przede wszystkim do identyfikacji procesów zachodzących $\mathrm{w}$ wielkich osiedlach i określenia ich kierunku, ponieważ ze względu na ograniczenia $\mathrm{w}$ dostępie do danych (lub też ich brak dla jednostek przestrzennych, jakimi są osiedla), nie zawsze możliwa była szczegółowa kwantyfikacja analizowanych zjawisk.

\subsubsection{Przemiany w strukturze demograficznej i statusie społecznym mieszkańców}

Biorąc pod uwagę wyodrębnione uprzednio trzy grupy wielkich osiedli mieszkaniowych, na podstawie analizy danych statystycznych pochodzących z NSP (1988 i 2002) sformułowano następujące wnioski odnoszące się do pierwszych kilkunastu lat transformacji:

- osiedla najstarsze budowane w latach 60. i na początku lat 70. oraz osiedla budowane w drugiej połowie lat 70 . i w pierwszej połowie lat 80. straciły mieszkańców, a osiedla najmłodsze ich zyskały;

- we wszystkich osiedlach (oprócz najstarszego Żubardzia) nastąpił wzrost liczby mieszkań związany z intensyfikacją po 1990 roku istniejącej tam dotychczasowej zabudowy mieszkaniowej; 


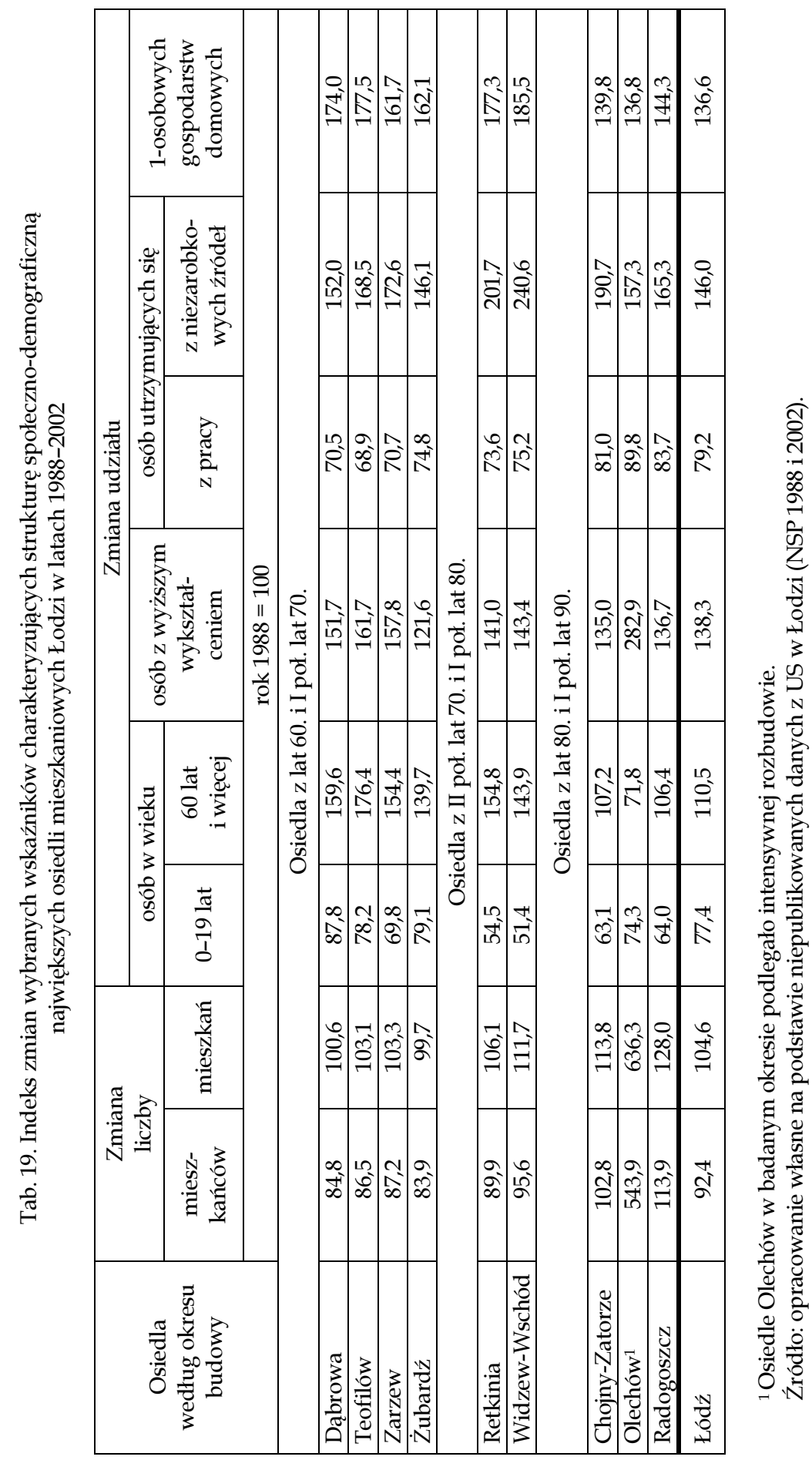


- we wszystkich osiedlach istotnie wzrósł udział jednoosobowych gospodarstw domowych (które, jak wynika z ich struktury wieku i poziomu feminizacji, są najczęściej gospodarstwami emeryckimi tworzonymi przez kobiety), przy czym największe tempo tego wzrostu odnotowano w osiedlach najstarszych i z lat 70. i I poł. lat 80.;

- we wszystkich grupach osiedli zmniejszył się udział osób najmłodszych, przy czym najsilniejszy jego spadek nastąpił w osiedlach $\mathrm{z}$ lat 70. i I pol. lat 80;

- w osiedlach najstarszych oraz z lat 70. i I poł. lat 80. znacząco wzrósł udział osób w wieku powyżej 60 lat, a w osiedlach najnowszych pozostał bez zmian lub nawet spadł (na Olechowie);

- we wszystkich grupach osiedli, nawet tych o najmłodszej strukturze wieku, spadł udział osób utrzymujących się z pracy i wzrósł odsetek utrzymujących się ze źródeł niezarobkowych;

- prawie we wszystkich osiedlach poprawiła się struktura wykształcenia mieszkańców, przy czym wzrost ten następował w takim samym tempie, a nawet szybciej niż poprawa struktury wykształcenia w całym mieście. Jedynie w osiedlach Chojny-Zatorze i Radogoszcz, których mieszkańcy w 1988 roku charakteryzowali się najlepszą strukturą wykształcenia wzrost ten był niższy niż średnio dla miasta (tab. 19).

W drugim badanym okresie, po 2002 roku, który obejmuje mniejszą liczbę dostępnych danych statystycznych i krótszy przedział czasowy (lata 2002-2010), w badanych osiedlach odnotowano następujące zmiany:

- ubytek mieszkańców, który dotknął niemal wszystkie jednostki, oprócz wciąż rozwijającego się przestrzennie i demograficznie osiedla Olechów;

- wzrost liczby mieszkań, który poza Olechowem wahał się od 3\% do nawet $12 \%$ (w osiedlu Zarzew);

- spadek liczby osób w wieku przedprodukcyjnym (najgłębszy w osiedlach Radogoszcz i Widzew-Wschód);

- wzrost liczby osób w wieku poprodukcyjnym, największy w osiedlach Zarzew, Widzew-Wschód i Olechów (tab. 20).

$\mathrm{W}$ efekcie tych zmian, w 2010 roku udział osób w wieku poprodukcyjnym w najstarszych osiedlach mieszkaniowych przekroczył 30\%, a w największym osiedlu z lat 70. Retkini, sięgnął prawie 25\% (rys. 36).

Porównanie dynamiki przemian zachodzących w obu badanych okresach (1988-2002 oraz 2002-2010) nie jest możliwe ze względu na różną długość ich trwania i różny zakres dostępnych danych. Stwierdzić można jednak, że przemiany społeczno-demograficzne odnotowane $\mathrm{w}$ wielkich osiedlach zarówno w pierwszym, jak i w drugim analizowanym okresie, do których należą depopulacja ( $\mathrm{z}$ wyjątkiem rozbudowywanego osiedla Ole- 
Tab. 20. Indeks zmian wybranych wskaźników charakteryzujących strukturę społeczno-demograficzną największych osiedli mieszkaniowych Łodzi w latach 2002-2010

\begin{tabular}{|l|c|c|c|c|}
\hline \multirow{2}{*}{$\begin{array}{l}\text { Osiedla według } \\
\text { okresu budowy }\end{array}$} & \multicolumn{3}{|c|}{ Zmiana liczby } & Zmiana udziału osób w wieku \\
\cline { 2 - 5 } & mieszkańców & mieszkań & $0-17$ lat & $60 / 65$ i więcej \\
\cline { 2 - 5 } & \multicolumn{5}{|c|}{ Osiedla z lat 60. i I połowy lat 70. } \\
\hline Dąbrowa & 86,5 & 103,6 & 87,9 & 105,4 \\
\hline Teofilów & 87,1 & 103,9 & 94,6 & 117,5 \\
\hline Zarzew & 92,2 & 111,8 & 85,5 & 144,5 \\
\hline Źubardź & 84,4 & 103,8 & 85,7 & 108,2 \\
\hline \multicolumn{5}{|c|}{ Osiedla z II połowy lat 70. i I połowy lat 80. } \\
\hline Retkinia & 86,8 & 104,5 & 86,1 & 112,1 \\
\hline Widzew-Wschód & 85,9 & 102,0 & 77,0 & 136,4 \\
\hline \multicolumn{5}{|c|}{ Osiedla z lat 80. i I połowy lat 90. } \\
\hline Chojny-Zatorze & 88,0 & 107,9 & 90,8 & 103,2 \\
\hline Olechów & 123,8 & 150,9 & 89,9 & 135,4 \\
\hline Radogoszcz & 91,8 & 110,9 & 74,1 & 124,6 \\
\hline Łódź & 90,1 & 110,1 & 87,0 & 130,6 \\
\hline
\end{tabular}

Źródło: opracowanie własne na podstawie niepublikowanych danych US w Łodzi.

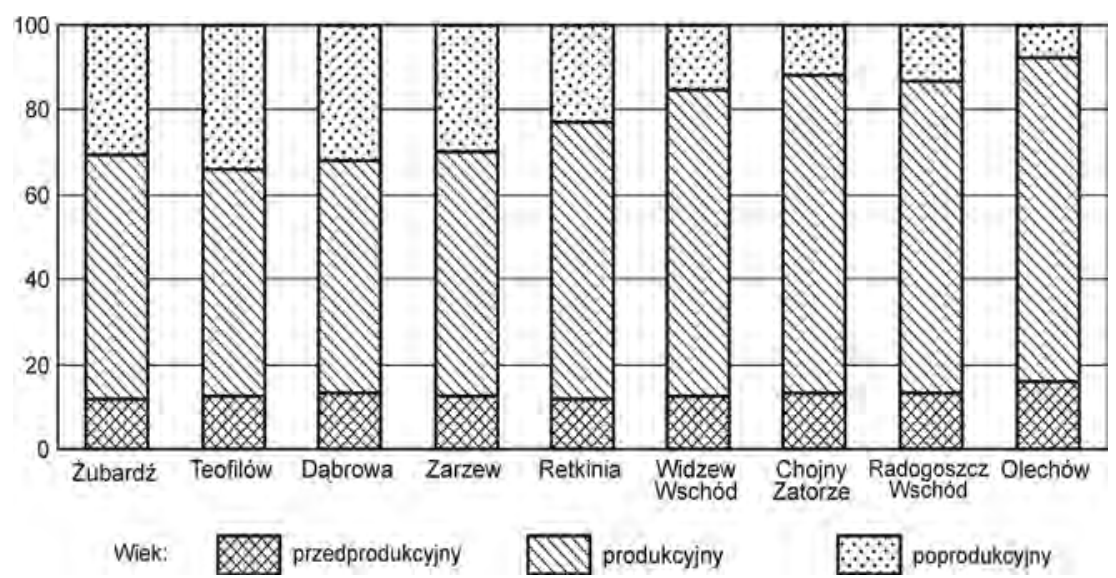

Rys. 36. Struktura wieku w największych osiedlach mieszkaniowych

Łodzi w 2010 r. (uporządkowana według wieku osiedla)

Źródło: opracowanie własne na podstawie niepublikowanych danych US w Łodzi

chów), starzenie się ludności, wzrost liczby jednoosobowych gospodarstw domowych i spadek udziału osób utrzymujących się z pracy, a także wzrost poziomu wykształcenia mieszkańców (we wszystkich osiedlach oprócz Olechowa) mają ten sam kierunek i zbieżne są z procesami zachodzącymi 
w całym mieście, a różne jest jedynie ich tempo. Warto także odnotować, że szybkie tempo starzenia się mieszkańców najstarszych osiedli w latach 1988-2002, po 2002 roku nieco spowolniło (rys. 37), a w osiedlach nowszych pozostało bez zmian lub nawet przyspieszyło, co wiąże się z cyklem życia zamieszkujących je gospodarstw domowych.

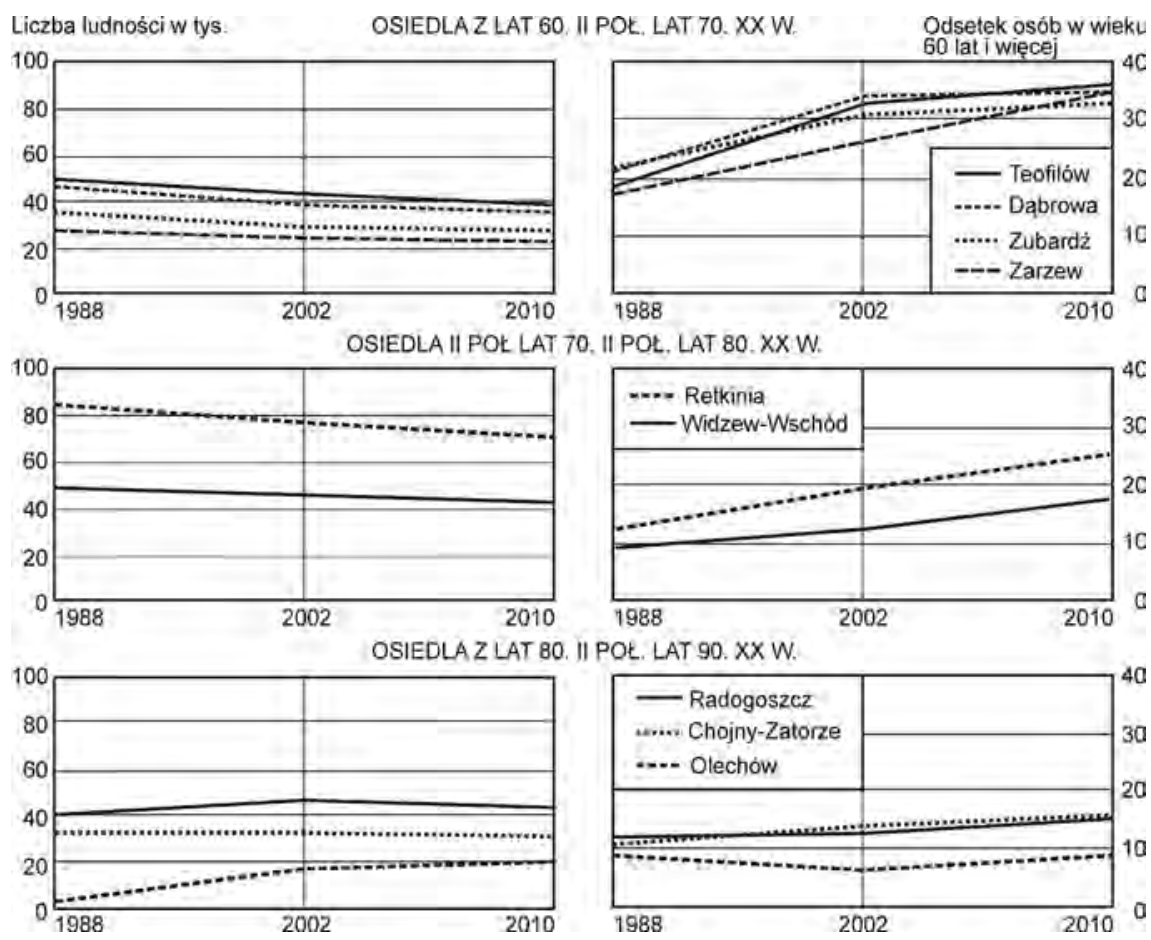

Rys. 37. Liczba ludności i udział osób w wieku powyżej 60 lat w największych osiedlach mieszkaniowych Łodzi w latach 1988-2010 Źródło: opracowanie własne

Analiza rozwoju demograficznego łódzkich osiedli pozwoliła wydzielić w ich cyklu życia następujące fazy:

- faza budowy, która w różnych osiedlach trwała od kilku do kilkunastu lat i w czasie której, nie czekając na ukończenie budowy całego osiedla, sukcesywnie zasiedlano oddawane do użytku budynki lub ich niewielkie grupy;

- faza wzrostu, która następowała po ukończeniu budowy osiedla i była związana z dodatnim przyrostem naturalnym (większość gospodarstw domowych była w fazie rozwoju rodziny) oraz nielicznymi uzupełnieniami zabudowy mieszkaniowej (w postaci pojedynczych budynków); 


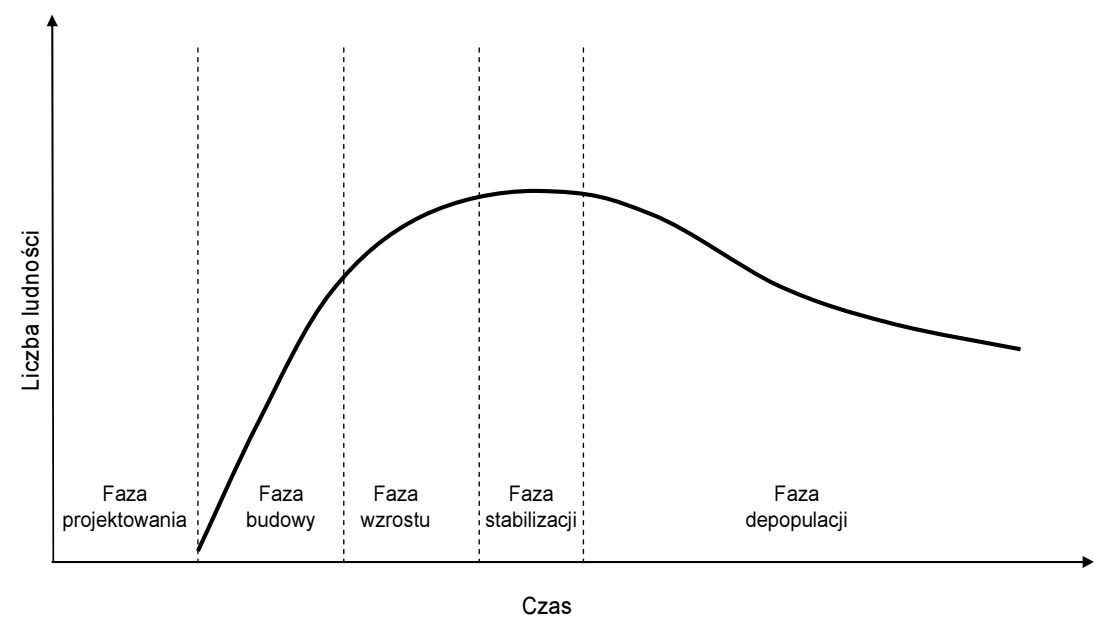

Rys. 38. Fazy rozwoju demograficznego wielkich osiedli mieszkaniowych budowanych w Łodzi w latach 1960-1990 Źródło: opracowanie własne

- faza stabilizacji, w której liczba urodzeń była we względnej równowadze z liczbą zgonów, a wymiana migracyjna na skutek warunków ustrojowych i małej skłonności do ruchliwości przestrzennej odbywała się na bardzo niewielką skalę;

- faza depopulacji, związana z naturalnym ubytkiem ludności oraz ujemnym bilansem migracyjnym (rys. 38).

Dwie pierwsze fazy, budowy i wzrostu, kiedy liczba ludności stale powiększała się, w starszych osiedlach trwały około 20 lat, faza stabilizacji 5-7 lat, po czym następowała trwająca aż do czasów obecnych faza depopulacji. W nowszych faza ubytku ludności rozpoczeła się wcześniej w związku z nakładaniem się na ten proces zmian demograficznych towarzyszących procesom transformacji ustrojowej. Obecnie, w drugiej dekadzie XXI wieku, wszystkie łódzkie osiedla oprócz wciąż rozwijającego się Olechowa, znajdują się $w$ fazie depopulacji.

Ważnym czynnikiem wpływającym na obraz przemian struktury społeczno-demograficznej omawianych osiedli mieszkaniowych są migracje. W Łodzi, w związku ze zmniejszeniem się od połowy lat 80. XX wieku napływu ludności, mają one charakter głównie wewnętrzny, a często także jak ustalono $\mathrm{w}$ badaniach kierunków wewnątrzmiejskich migracji stałych łodzian w latach 90. - nawet wewnątrzosiedlowy (Michalski, Szafrańska 2000).

Bliższe dane dotyczące wielkości migracji w roku $2013{ }^{170}$ pokazały, że we wszystkich badanych osiedlach odnotowano przewagę wyjazdów nad

170 Niepublikowane dane dotyczące migracji przedstawione przez M. Sztybel-Boberek (2015; poster Migracje wewnętrzne mieszkańców Łodzi w 2013 r., w ramach XXVI KWoM w Łodzi). 
przyjazdami, przy czym saldo migracji w poszczególnych jednostkach wynosiło od kilkudziesięciu do kilkuset osób, wahając się od $-1,7 \%$ o w osiedlu Teofilów do -15,2\%o w osiedlu Widzew-Wschód. Ogólem osiedla te liczące w 2013 roku 333,3 tys. mieszkańców straciły ich 12,8 tys., a zyskały 10,3 tys. Największy odpływ względny (powyżej 10\%o) odnotowano w osiedlach Zarzew, Widzew-Wschód i Chojny-Zatorze. Wskazuje to, że na wyjazdy nie ma wpływu wiek osiedla, ani jego wielkość. I mimo że jednoroczne dane o wielkości migracji nie uprawniają do dalej idących wniosków na temat pozycji osiedli w strukturze rezydencjalnej miasta, to interesujące wydają się proporcje wyjazdów w podziale na Łódź i obszary połżone poza Łodzią, które uznać można za względnie stałe. $Z$ cytowanych już danych dotyczących struktury migracji mieszkańców osiedli wynika, że liczba wyjazdów poza Łódź ogólem ze wszystkich badanych osiedli w 2013 roku była siedmiokrotnie, a w poszczególnych osiedlach od kilku do kilkunastokrotnie mniejsza niż ich liczba w obrębie Łodzi. To oznacza, że mieszkańcy osiedli blokowych, niekoniecznie - jak się powszechnie uważa - masowo migrują do strefy podmiejskiej. Nieco więcej (proporcjonalnie), choć wciąż niewiele migracji na tereny położone poza Łodzią odnotowano w osiedlach nowszych. Jak można sądzić, wynika to ze struktury demograficznej ich mieszkańców i większego udziału tych kategorii wiekowych (jeszcze względnie młodych, ale już ustabilizowanych zawodowo), które poszukują poprawy warunków życia wyjeżdżając z miasta.

Bliższe dane dotyczące struktury społeczno-demograficznej oraz statusu migrantów w całym badanym okresie nie są niestety dostępne w tak małych jednostkach przestrzennych jak osiedla mieszkaniowe. Jednak z systematycznych badań jakościowych i ilościowych prowadzonych $\mathrm{w}$ osiedlach (wywiady w spółdzielniach mieszkaniowych, wywiady z mieszkańcami, analiza danych US), a także z wcześniejszych badań wewnątrzmiejskich migracji stałych łodzian (Michalski, Szafrańska 2000) wynika, że do procesów migracyjnych, które wpływały po 1990 roku na skład społeczny omawianych osiedli należą:

- napływ mieszkańców o wyższym niż ludność dotychczasowa statusie społeczno-ekonomicznym i wysokiej aktywności zawodowej, którzy nabyli lokale na pierwotnym rynku mieszkaniowym (w nowych budynkach wmieszanych $\mathrm{w}$ istniejącą zabudowę osiedli lub lokalizowanych na ich obrzeżach);

- napływ mieszkańców o wyższym, ale nie tak wysokim jak grupa zasiedlająca nowe budynki, statusie społeczno-ekonomicznym i wysokiej aktywności zawodowej, którzy nabyli mieszkania na wtórnym rynku mieszkaniowym; 
- napływ osób młodych o różnym statusie ekonomicznym, które stały się właścicielami mieszkań w wyniku dziedziczenia - proces ten ma charakter wymiany pokoleniowej (pokolenie wnuków zastępuje pokolenie dziadków) zsynchronizowanej z okresem budowy osiedla i rozpoczynającej się po upływie około 40 lat od czasu oddania go do użytku, dlatego też obecnie zachodzi głównie w osiedlach z lat 60 . i początku lat 70.;

- odpływ mieszkańców o wysokim statusie społeczno-ekonomicznym i wysokich aspiracjach mieszkaniowych, głównie do zabudowy jednorodzinnej zlokalizowanej na peryferyjnie położonych terenach miasta, a w mniejszym stopniu do strefy podmiejskiej, ale też do rewitalizowanych kamienic czynszowych na obszarze śródmiejskim i do nowoczesnej zabudowy apartamentowej w różnych lokalizacjach. Odpływ ten motywowany jest nie tylko poszukiwaniem lepszych warunków życia, ale często także wyższego prestiżu mieszkaniowego;

- odpływ osób młodych o różnym statusie społeczno-ekonomicznym związany $\mathrm{z}$ wchodzeniem wielu gospodarstw domowych $\mathrm{w}$ fazę "opuszczonego gniazda" - obecnie głównie w osiedlach nowszych z II połowy lat 80 . i początków lat 90.;

- odpływ mieszkańców o bardzo niskim statusie społeczno-ekonomicznym, których sytuacja materialna nie pozwala na utrzymanie dotychczasowego mieszkania, zazwyczaj do mieszkań komunalnych w kamienicach czynszowych o niskim standardzie lub do mieszkań o mniejszej powierzchni użytkowej w różnych formach zabudowy wielorodzinnej i w różnych lokalizacjach. Głównie są to pierwotni mieszkańcy osiedla, którzy mieszkania otrzymali przed 1989 rokiem $\mathrm{w}$ ramach przydziałów i nie dokonali ich przekształcenia we własność (a niekiedy ich dzieci lub wnuki). Proces ten zachodził głównie w latach 90. w okresie silnego kryzysu strukturalnego w Łodzi, ale zachodzi także obecnie, lecz na znacznie mniejszą skalę 171 .

${ }^{171}$ W pacy dotyczącej wielkomiejskiej biedy w Polsce W. Warzywoda-Kruszyńska (2012) tak pisze o strategiach migracyjnych łodzian we wczesnych latach 90 . XX w.: "Ci, którym się udało, szybko decydowali się na poprawę swoich warunków mieszkaniowych. Wyprowadzali się więc z kamienic do bloków posiadających urządzenia sanitarne, których brakowało w starych przedwojennych czynszówkach. [...] Gdy utrata pracy spowodowała zadłużenie w spółdzielni mieszkaniowej, ci, którzy wcześniej mieli szczęście dostać mieszkanie w blokach, $\mathrm{w}$ obawie przed eksmisją poszukiwali chętnych do zamiany mieszkania w zamian za spłacenie zadłużenia i pewną sumę pieniędzy daną dotychczasowemu lokatorowi bloków "pod stołem", czyli za tzw. odstępne. Z procederu tego byli zadowoleni wszyscy: spółdzielnie mieszkaniowe, bo pozbywały się dłużników, nowi nabywcy, bo poprawiali swoje warunki mieszkaniowe, poprzedni lokatorzy, bo nie groziła im już eksmisja za długi. Ci ostatni dopiero z czasem zdawali sobie sprawę z zagrożeń, jakie wiązały się ze zmianą sąsiedztwa, ale najczęściej 
Jak już powiedziano, procesem, który w największym stopniu kreuje napływ do wielkich osiedli osób o wyższym statusie społecznym niż mieszkańcy dotychczasowi, jest pojawianie się $\mathrm{w}$ przestrzeni osiedli nowej zabudowy mieszkaniowej. W Łodzi, podobnie jak w innych miastach postsocjalistycznych, proces ten polega na wprowadzaniu w strukturę wewnętrzną osiedli ( $w$ ich obszarach centralnych, a także na obrzeżach) pojedynczych budynków wielorodzinnych lub ich zespołów, charakteryzujących się inną od otoczenia technologią budowy (nie jest to już wielka płyta), wyższym standardem wykończenia i odmienną fizjonomią (detale architektoniczne, elementy małej architektury, kolor, bryła budynku - fot. 8-17; z archiwum autorki).

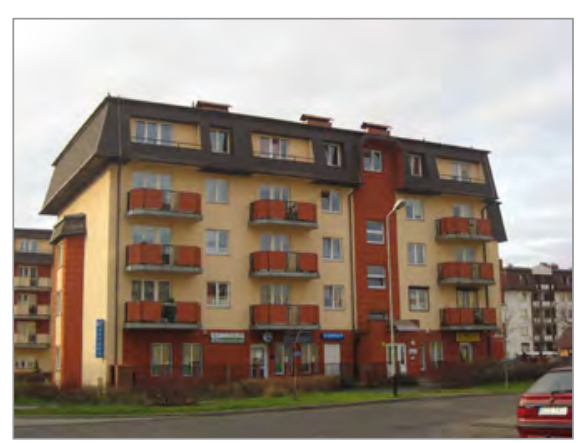

Fot. 8. Nowa zabudowa (z 1997 r.) w osiedlu Retkinia w Łodzi

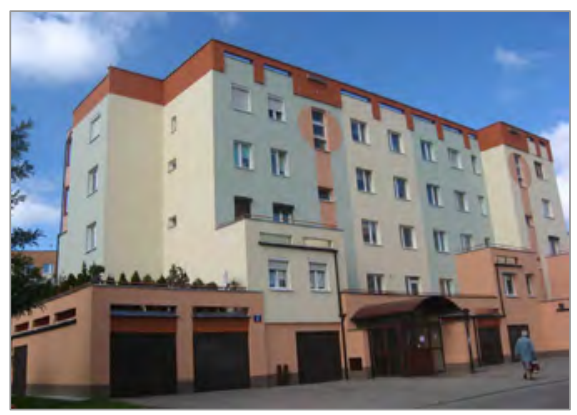

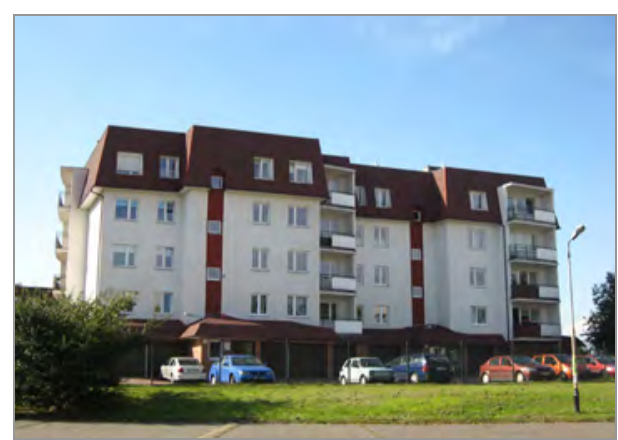

Fot. 9. Nowa zabudowa (z 2000 r.) w osiedlu Widzew-Wschód w Łodzi

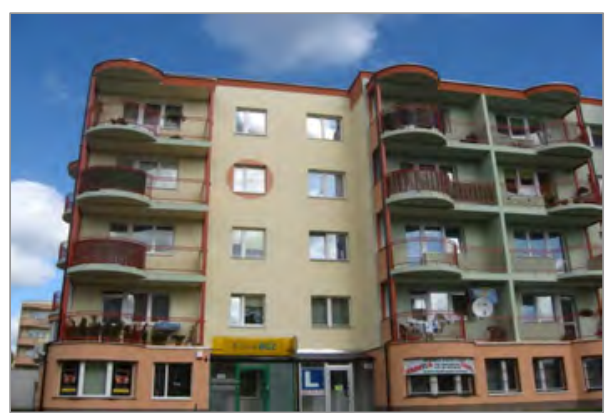

Fot. 10, 11. Nowa zabudowa mieszkaniowa z II poł. lat 90. XX wieku - w parterach usługi lub garaże (osiedle Widzew-Wschód)

było już za późno. Z terenu dzisiejszych enklaw [enklaw biedy zlokalizowanych $\mathrm{w}$ bezpośrednim otoczeniu strefy centrum Łodzi - przyp. E.S.] wyprowadzali się więc [do osiedli blokowych - przyp. E.S.], bardziej przedsiębiorczy i zamożniejsi, a wprowadzali biedniejsi i mniej zaradni (ibid., s. 153). 


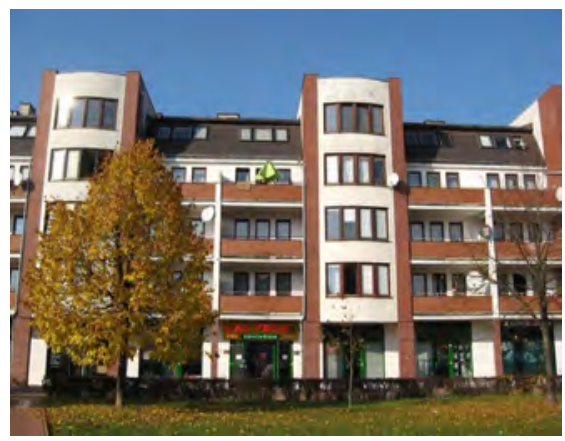

Fot. 12. Nowa zabudowa mieszkaniowa powstała po $2000 \mathrm{r}$. w osiedlu Retkinia

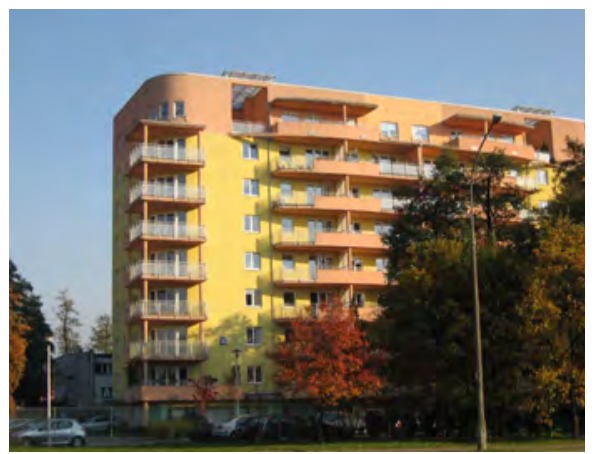

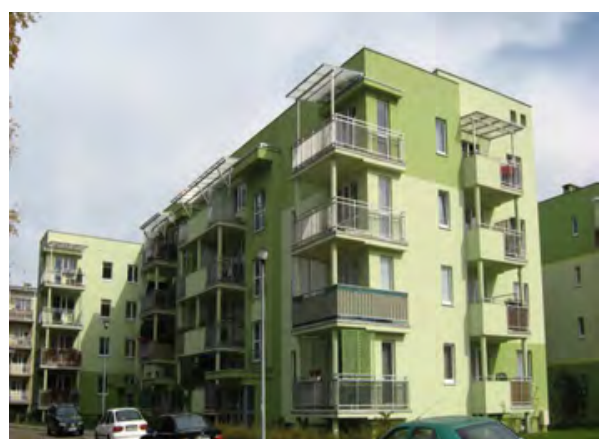

Fot. 13. Nowa zabudowa mieszkaniowa powstała po 2000 r. w osiedlu Olechów

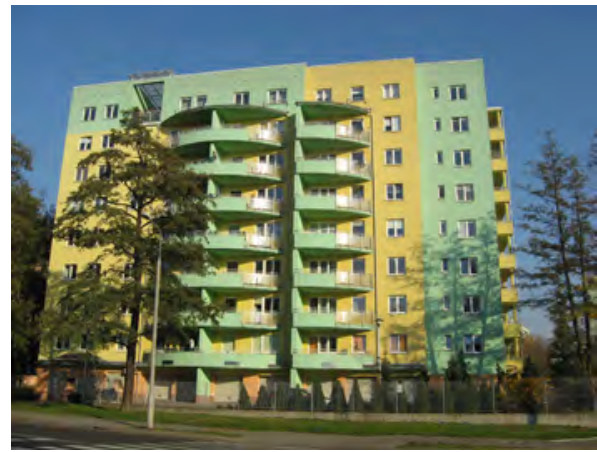

Fot. 14, 15. Nowa wielkoskalowa zabudowa mieszkaniowa powstała po $2000 \mathrm{r}$. w osiedlu Teofilów
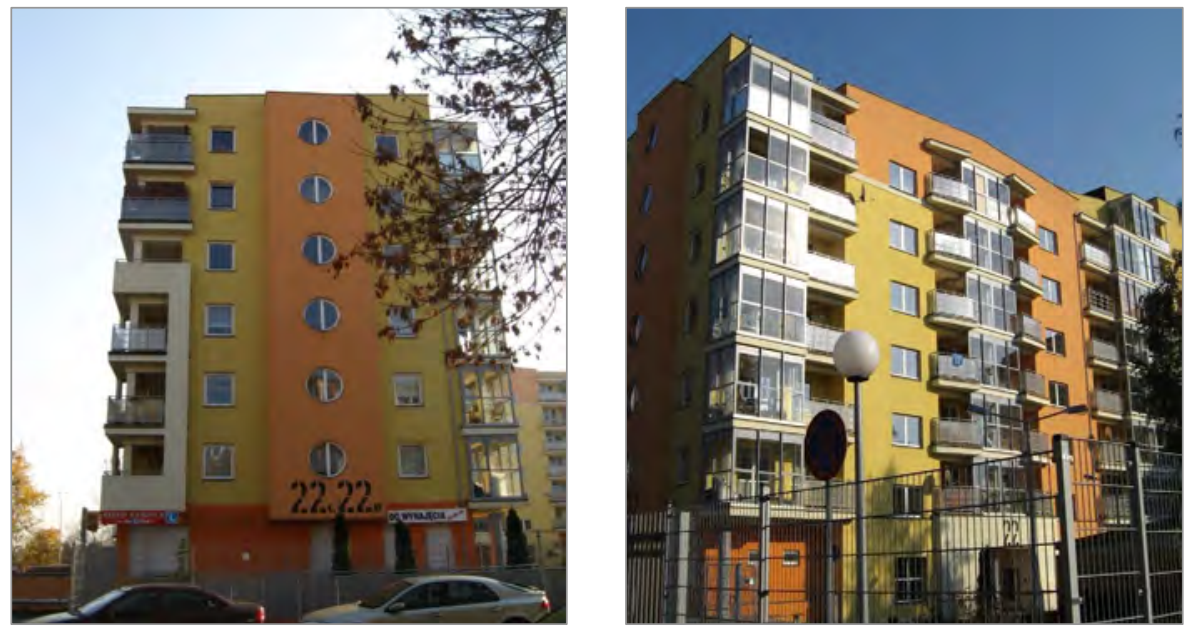

Fot. 16, 17. Nowa wielkoskalowa zabudowa mieszkaniowa powstała po 2000 r. w osiedlu Retkinia 
Badania pokazały, że rozwój przestrzenny osiedli i lokowanie w nich nowych inwestycji mieszkaniowych po 1990 roku uzależnione jest od okresu budowy osiedla. $W$ osiedlach najstarszych i z lat 70. rozwój ten odbywa się "do wewnątrz", w granicach tych osiedli z okresu ich budowy. Wynika to $\mathrm{z}$ tego, że $\mathrm{w}$ momencie zmiany ustrojowej, kiedy rozpoczął się okres inwestowania, osiedla te otoczone były terenami już zagospodarowanymi. Osiedla najnowsze natomiast, budowane były na obrzeżach miasta w otoczeniu terenów niezagospodarowanych, w związku z czym mogły rozwijać się "na zewnątrz”. W osiedlach najstarszych ze względu na gęstą zabudowę rozwój ten odbywał się także na znacznie mniejszą skalę niż w osiedlach z lat 70., w których pozostawiono duże rezerwy terenów wolnych pod przyszłą zabudowę usługową oraz funkcje rekreacyjno-sportowe. Świadczy o tym liczba nowych budynków mieszkaniowych powstałych po 1990 roku, która w osiedlu Olechów wynosi 146, w osiedlu Widzew-Wschód 53, a w najstarszym Teofilowie zaledwie 6.

Specyfiką Łodzi jest to, że tylko niektóre z nowych inwestycji mieszkaniowych powstają jako osiedla zamknięte (gated communities). Jak pokazały badania inwentaryzacyjne przeprowadzone na użytek niniejszej pracy, wśród blisko 300 nowych budynków powstałych po 1995 roku w badanych osiedlach 71 jest ogrodzonych. Powstawanie gated communities wśród istniejącej wcześniej pierwotnej zabudowy osiedli, jak już powiedziano, nie jest zjawiskiem pozytywnym, ponieważ nosi znamiona zawłaszczania przestrzeni publicznej i przerywa jej ciągłość oraz ogranicza dostępność dla pozostałych użytkowników (fot. 18-23; z archiwum autorki).

Proces tworzenia zamkniętych separowanych enklaw o wyższym statusie społecznym i lepszych warunkach zamieszkiwania prowadzi także do innych negatywnych zjawisk zachodzących w strukturze społeczno-przestrzennej osiedli, czyli separacji oraz segregacji.
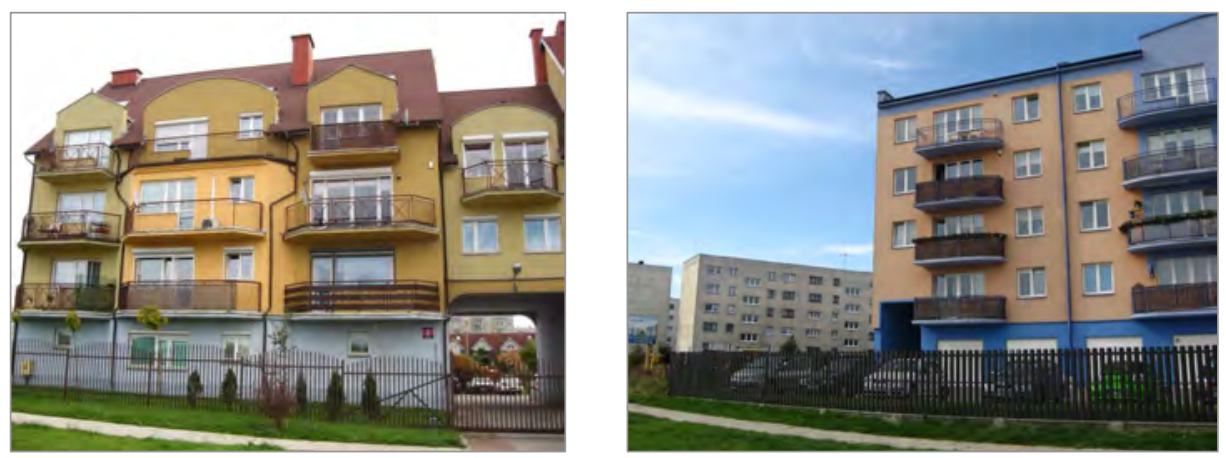

Fot. 18, 19. Nowa zabudowa grodzona powstała po 2000 r. w osiedlu Olechów 

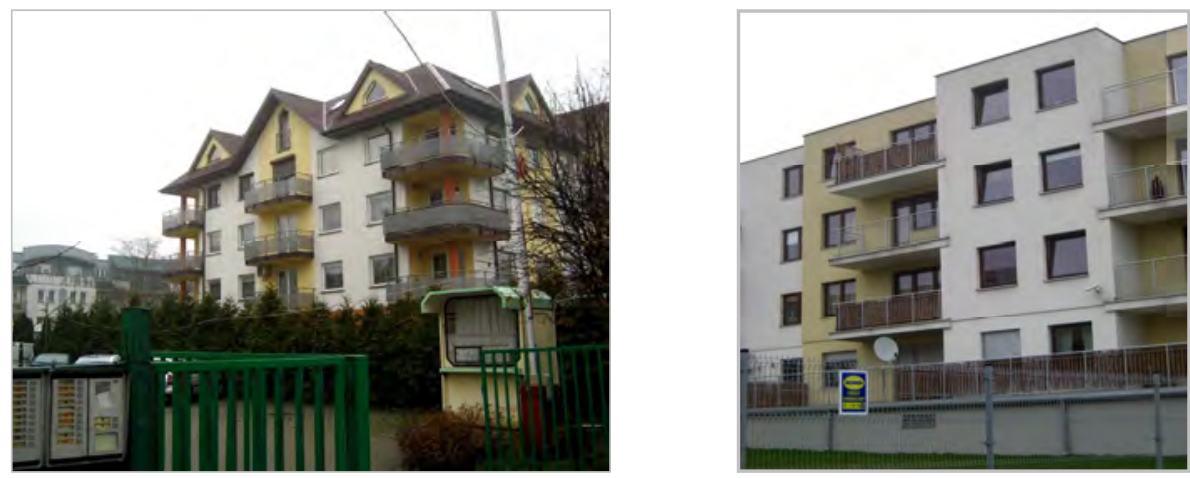

Fot. 20, 21. Nowa zabudowa grodzona powstała po 2000 r. osiedle Radogoszcz-Wschód i Zarzew
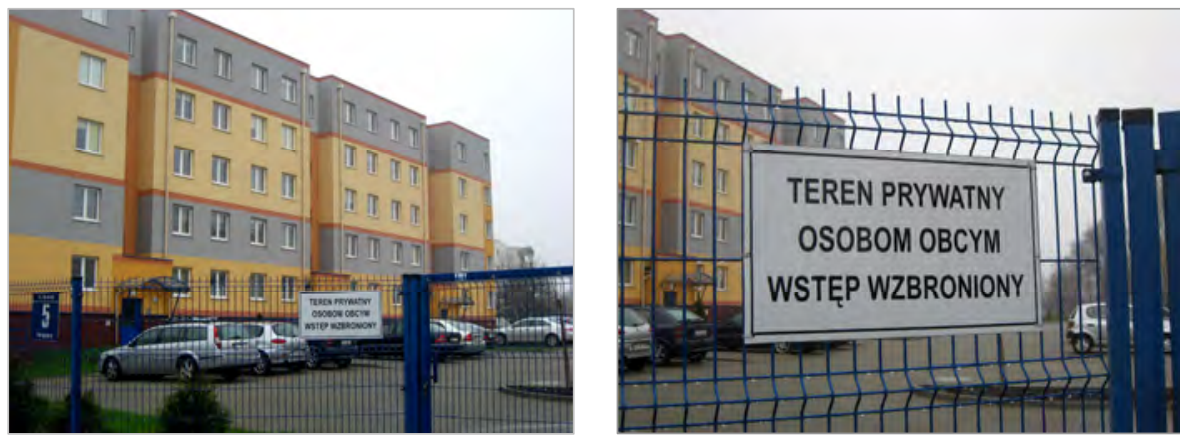

Fot. 22, 23. Nowa zabudowa grodzona powstałą w 2008 r. w osiedlu Radogoszcz-Wschód

I mimo że w Łodzi skala separowania się nie jest tak duża jak w innych wielkich miastach Polski (por. Jałowiecki, Łukowski 2007), to jednak jak wynika z badań ankietowych przeprowadzonych w osiedlu Retkinia w 2006 roku (Szafrańska 2009), przez pozostałych mieszkańców osiedla zjawisko to postrzegane jest bardzo negatywnie.

Aby zobrazować społeczny wymiar omawianego procesu należy odpowiedzieć na pytanie, kim są mieszkańcy nowych budynków? O ich wyższym statusie socjoekonomicznym niż przeciętnie $\mathrm{w}$ mieście świadczy siła nabywcza wyrażająca się tym, że dysponują zasobami finansowymi (lub zdolnością kredytową), które umożliwiają nabycie mieszkania na pierwotnym rynku. Ceny nowych mieszkań bowiem, mimo tego że w Łodzi należą do najniższych w kraju, to biorąc pod uwagę relatywnie niską na tle innych miast siłę nabywczą lodzian, stwarzają istotną barierę w nabyciu mieszkania na rynku pierwotnym. Z danych NBP172 wynika, że średnia transakcyjna

172 Raport o sytuacji na rynkach nieruchomości mieszkaniowych i komercyjnych w Polsce w 2014 r. (http://www.nbp.pl/publikacje/rynek_nieruchomosci/raport_2014.pdf). 
cena $1 \mathrm{~m}^{2}$ nowego mieszkania w Łodzi, jakkolwiek w ostatnich latach nieco spadła ${ }^{173}$, to nadal jest wysoka $\mathrm{w}$ stosunku do dochodów. W pierwszym kwartale 2014 roku wynosiła 4,8 tys. zl, czyli około 130\% średniego wynagrodzenia brutto w mieście (3,6 tys. zł).

Z wywiadów swobodnych przeprowadzonych wśród mieszkańców nowych budynków zlokalizowanych w dwóch największych osiedlach mieszkaniowych Łodzi - Widzew-Wschód oraz Retkinia ${ }^{174}$ wynika, że są to w zdecydowanej większości:

- specjaliści w zawodach wymagających wyższego wykształcenia ${ }^{175}$ (lekarze, nauczyciele, informatycy, farmaceuci, urzędnicy wyższego szczebla, pracownicy instytucji finansowych i ubezpieczeniowych) oraz przedsiębiorcy - właściciele niewielkich firm działających przede wszystkim w sferze usług (informatyczne, projektowe, remontowo-budowlane, prawne, ubezpieczeniowe); są to zatem kategorie społeczne (przedstawiciele grup zawodowych), które w obecnej stratyfikacji społecznej, krystalizującej się na nowo po okresie PRL i wciąż podlegającej rekompozycji, określić można jako klasę średnią;

- osoby o wysokiej aktywności zawodowej - niemal wszyscy respondenci niebędący emerytami zadeklarowali, że są aktywni zawodowo, a nieliczne osoby niepracujące to matki wychowujące małe dzieci;

- osoby, których wiek w momencie nabywania nowych mieszkań najczęściej mieścił się przedziale 30-40 lat (a obecnie 35-45 lat);

- rodziny z dziećmi (głównie jednym lub dwojgiem), rzadziej pary bez dzieci (młode lub w fazie "opuszczonego gniazda"), a także gospodarstwa 1-osobowe, częściej tworzone przez kobiety niż przez mężczyzn;

- właściciele zajmowanych mieszkań, deklarujący względne zaspokojenie swoich aktualnych potrzeb mieszkaniowych oraz zadowolenie z miejsca zamieszkania i niechęć do migracji;

- osoby, dla których obecne mieszkanie jest nie pierwszym, lecz kolejnym już etapem w samodzielnej biografii mieszkaniowej (wcześniej

173 Na koniec IV kwartału 2011 r. wynosiła 5,0 tys. zł.

174 Badania przeprowadzono $\mathrm{w}$ czterech nowych budynkach mieszkalnych ( $\mathrm{w}$ tym w dwóch ogrodzonych) wybudowanych w latach 1997, 2001, 2003 i 2005, zlokalizowanych w osiedlach Widzew-Wschód oraz Retkinia. Ze względu na zamieszkiwanie w grodzonych budynkach, do których dostęp był ograniczony fizycznie oraz z uwagi na relatywnie wysoki status społeczny badanych byli to tzw. trudni respondenci, którzy zazwyczaj odmawiają udziału w badaniach, dlatego też udało się przeprowadzić tylko 52 wywiady. Zastosowana technika badawcza w metodologii badań społecznych określana jest jako wywiad swobodny ze standaryzowaną listą poszukiwanych informacji (Przybyłowska 1978) i stosowana w przypadku poruszania kwestii trudnych, drażliwych lub badań wśród "trudnych respondentów".

175 Wśród badanych odnotowano także czterech respondentów ze stopniem naukowym doktora. 
w większości byli właścicielami lub najemcami mieszkań w starszych blokach, znacznie rzadziej mieszkali w kamienicach lub domach jednorodzinnych).

Skład społeczny lokatorów nowych budynków sprawia, że tworzą one obszary o charakterze enklaw o znacznie wyższym niż otoczenie statusie społeczno-zawodowym i ekonomicznym. Stwierdzono także, że budynki i zespoły grodzone charakteryzują się wyższym standardem od niegrodzonych i większą przeciętną powierzchnią użytkową mieszkań. Oferowane w nich mieszkania są także nieco droższe, co sprawia, że przyciągają zamożniejszych, którzy poza poprawą warunków mieszkaniowych zyskują również, nie mniej dla nich ważne, poczucie większego prestiżu mieszkaniowego, którego nie dostarczają nowe budynki powstałe bez ogrodzenia.

Innym procesem, który zapobiega obniżaniu się dotychczasowej pozycji społecznej wielkich osiedli mieszkaniowych w strukturze miasta jest, jak już powiedziano, napływ osób, które nabywają lokale na wtórnym rynku mieszkaniowym (w zabudowie powstałej w okresie budowy osiedli). Proces ten ma charakter rozproszony i nie jest widoczny w przestrzeni osiedli tak jak enklawy nowej zabudowy, a jego skala zależy od okresu budowy osiedla. Im osiedle jest starsze, tym silniejsza wymiana mieszkańców. Z wywiadów przeprowadzonych w spółdzielniach mieszkaniowych łódzkich osiedli wynika, że w osiedlach budowanych w latach 70. i 80. ubiegłego wieku około $30 \%$, a w osiedlach z lat 60 . w niektórych budynkach nawet do $50 \%$ mieszkańców to nowi właściciele (lub lokatorzy) mieszkań, którzy nabyli je na wtórnym rynku bądź odziedziczyli. Wśród nabywców mieszkań dominują osoby z pokolenia 30-latków, które zakładają pierwsze własne gospodarstwa domowe i poprzez zakup mieszkania w osiedlu blokowym (które jest relatywnie dostępne cenowo, a relacja jego ceny do standardu jest względnie korzystna) rozpoczynają swoją samodzielną biografię mieszkaniową, traktując takie mieszkanie (w zależności od kondycji ekonomicznej gospodarstwa domowego) jako przejściowe lub docelowe. Nie trzeba dodawać, że status socjoekonomiczny tych osób także jest wyższy niż przeciętny status dotychczasowych mieszkańców osiedli, choć nie tak znacząco jak lokatorów nowych budynków. Ma to związek ze strukturą ich cen. Z informacji pozyskanych w 2014 roku w trzech łódzkich biurach obrotu nieruchomościami ${ }^{176}$ wynika, że średnie ceny transakcyjne mieszkań blokowych na wtórnym rynku mieszkaniowym wynoszą około 3,7 tys. zł i wahają się od 3 do 4,5 tys. zł za m². Różnice te w dużym stopniu uzależnione są od okresu budowy poszczególnych osiedli, który determinuje standard mieszkań i budynków, a pośrednio również skład społeczny sąsiedztwa i prestiż zabudo-

176 Metrohouse SA, Domino, Home Broker Nieruchomości SA. 
wy, ale także od indywidualnych cech i stanu technicznego mieszkania177. Najniższe ceny mieszkań (przeciętnie około 3 tys. zł za $\mathrm{m}^{2}$ ) odnotowano w osiedlach Dąbrowa i Teofilów, natomiast najwyższe w osiedlu Radogoszcz-Wschód.

Jakkolwiek procesy migracyjne są ważnym elementem kształtującym strukturę społeczno-demograficzną badanych osiedli, to przeprowadzona analiza dowiodła, że obecnie $\mathrm{w}$ największym stopniu jest ona determinowana przez czas budowy i pierwotną strukturę mieszkańców. Wynika to, jak już powiedziano, po pierwsze z planowego zasiedlania mieszkań w okresie socjalistycznym ludnością zróżnicowaną społecznie, ale dość jednorodną pod względem cech demograficznych i struktury gospodarstw domowych. Po drugie natomiast $\mathrm{z}$ wciąż niewielkiej ruchliwości przestrzennej mieszkańców tych osiedli, nadal bowiem większość z nich to ci sami, którzy jako pierwsi zasiedlili lokale i mieszkają w nich do dziś, starzejąc się razem z nimi.

Wyniki przeprowadzonej analizy prowadzą także do wniosku, że wszystkie badane osiedla blokowe w Łodzi w okresie postsocjalistycznym, podobnie jak w okresie socjalistycznym, charakteryzują się relatywnie wysokim na tle miasta statusem społecznym. Świadczy o tym nie tylko omówiony już poziom wykształcenia mieszkańców osiedli, ale także inne mierniki tradycyjnie przyjmowane $\mathrm{w}$ geografii społecznej miast do pomiaru zróżnicowań społeczno-przestrzennych, do których należą: poziom bezrobocia, zagrożenie przestępczością, odsetek korzystających z pomocy społecznej, poziom aktywności społecznej i zawodowej mieszkańców oraz poziom kapitału ludzkiego i społecznego. Danych, które pozwalają ustalić obecną pozycję wielkich osiedli mieszkaniowych w strukturze społeczno-przestrzennej Łodzi dostarczyły między innymi badania obszarów słabości społecznej w mieście (Liszewski 2009), zmian w strukturze społeczno-przestrzennej Łodzi (Marcińczak 2009), przestrzennego zróżnicowania poziomu kapitału ludzkiego i społecznego w mieście (Szafrańska 2008) oraz badania z zakresu geografii przestępczości (Marcińczak, Siejkowska 2004, Mordwa 2013). Do najbardziej syntetycznych i ujmujących największą liczbę zmiennych należy badanie obszarów słabości społecznej w Łodzi (por. Liszewski 2009), z którego wynika, że niemal wszystkie z omawianych w pracy największych osiedli mieszkaniowych miasta reprezentują najlepszy w mieście typ jednostek wysokiej aktywności społecznej, charakteryzujący się najmniejszym natężeniem negatywnych zjawisk społecznych. Wyjątek od tej

177 Do cech determinujących ceny mieszkań w poszczególnych osiedlach należą typ budynku (za zdecydowanie mniej atrakcyjne uchodzą mieszkania w budynkach wysokich) oraz jego szczegółowa lokalizacja w osiedlu (odległość od ruchliwych ulic, ilość zieleni w najbliższej okolicy itp). Duże znaczenie ma także stan utrzymania mieszkania i jego standard związany z poziomem poczynionych w nim inwestycji (np. wymienione okna, nowe podłogi, wymieniona instalacja), a także kondygnacja, na której znajduje się mieszkanie. 
reguły stanowią osiedla Dąbrowa oraz Zarzew, które należą do obszarów określanych przez autorów tego badania jako przejściowe, plasujące się pomiędzy obszarami słabości społecznej i obszarami aktywności (ibid.). Osiedla te, stosując typologię zaproponowaną przez J. Temelovą i in. (2011), można zaliczyć do tzw. osiedli na rozdrożu, których dalsze przekształcenia przynieść mogą zarówno poprawę statusu społecznego, jak i jego degradację.

Reasumując dokonane analizy przemian struktury społeczno-demograficznej największych łódzkich osiedli mieszkaniowych i ich obecnej pozycji w strukturze ekologicznej miasta można stwierdzić, że w Łodzi (podobnie jak w wielu innych miastach postsocjalistycznych - por. rozdz. 5) status społeczny i prestiż wielkich osiedli determinowany jest przez okres budowy osiedla, a w pewnym uproszczeniu także, że jest on tym wyższy, im młodsze jest osiedle.

\subsubsection{Przemiany struktury funkcjonalno-przestrzennej i morfologii}

Wielkie osiedla mieszkaniowe Łodzi podlegają również zmianom funkcjonalnym. Jedną $\mathrm{z}$ najważniejszych przemian $\mathrm{w}$ ich strukturze funkcjonalnej, podobnie jak ma to miejsce $\mathrm{w}$ osiedlach innych miast postsocjalistycznych, jest komercjalizacja, czyli stopniowe powiększanie udziału obszarów komercyjnych (przede wszystkim handlu, ale też usług różnego rodzaju) kosztem innych niekomercyjnych funkcji (lub funkcji o niższym stopniu zysku ekonomicznego), takich jak kultura, szkolnictwo, mieszkalnictwo. Proces ten dokonuje się przede wszystkim poprzez wypełnianie się dotychczasowej zabudowy nowymi obiektami o funkcji usługowej i usługowo-handlowej oraz wznoszenie nowych budynków o funkcji mieszkaniowo-usługowej a także, choć w znacznie mniejszym stopniu, poprzez zmiany funkcji w zabudowie istniejącej (fot. 24-29; z archiwum autorki).
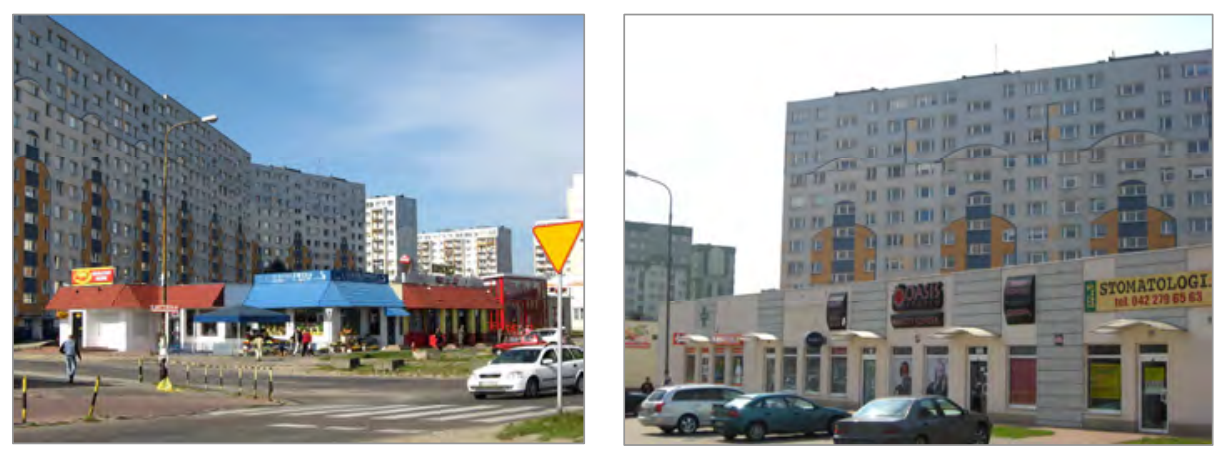

Fot. 24, 25. Nowa zabudowa handlowo-usługowa w osiedlu Widzew-Wschód powstała w latach 1995-2005 

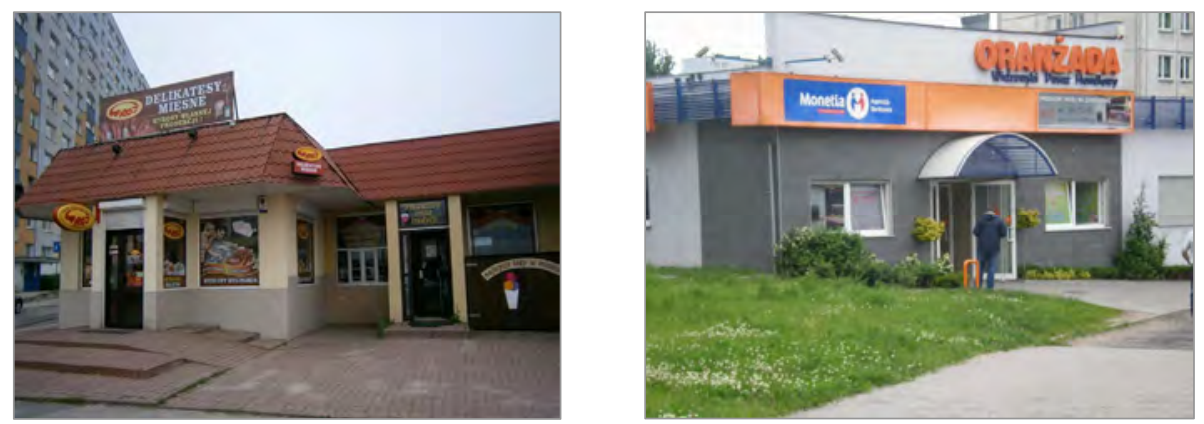

Fot. 26, 27. Nowa zabudowa handlowo-usługowa w osiedlu Widzew-Wschód powstała po 2005 roku
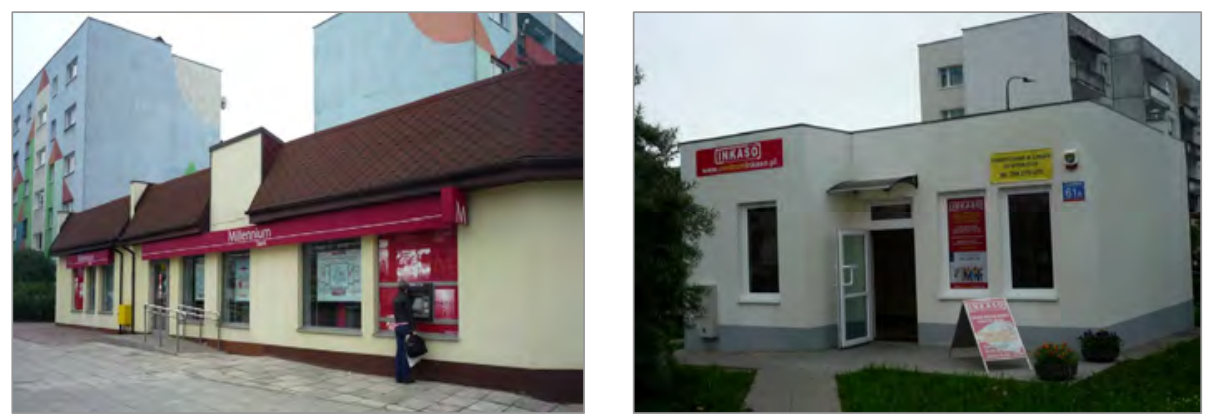

Fot. 28, 29. Nowa zabudowa handlowo-usługowa w osiedlu Olechów powstała po 2005 roku

Badania przeprowadzone na użytek niniejszej pracy pokazały, że w omawianych osiedlach w ciągu dwóch ostatnich dekad powstały bardzo liczne nowe placówki usługowe (najczęściej są to oddziały banków i firm ubezpieczeniowych, prywatne gabinety i przychodnie lekarskie oraz rehabilitacyjne, salony fryzjerskie i kosmetyczne, a także stacje obsługi pojazdów), wielkopowierzchniowe obiekty handlowe należące do wszystkich wielkich sieci handlowych (Biedronka, Carrefour, Tesco, Lidl i InterMarche) i lokalne galerie handlowe (np. nowoczesny, powstały w 2009 roku obiekt Galeria Retkińska na Retkini lub oddana do użytku w 2013 roku Galeria Widzewska w osiedlu Widzew-Wschód) oraz wiele mniejszych placówek handlowych (głównie sklepów spożywczych, odzieżowych i obuwniczych, a także aptek, ale też sklepów innych branż oferujących towary nienależące do podstawowych, jak np. sklepy jubilerskie, muzyczne, księgarskie i inne) - fot. 30, 31.

Do bardzo dynamicznie rozwijającego się sektora usług w osiedlach należą usługi z zakresu prywatnej opieki zdrowotnej. Wiąże się to zapewne, jak w całym kraju, z niewydolnością publicznej służby zdrowia, ale także - jak się wydaje - ze starzeniem się mieszkańców osiedli, których zapotrzebowanie na ten rodzaj usług i to zlokalizowanych w pobliżu miejsca zamiesz- 
kania stale się powiększa i będzie powiększał także w przyszłości. Jednym z przejawów tego procesu jest spektakularny wzrost liczby aptek, która np. w osiedlu Widzew-Wschód wzrosła z dwóch w 1988 roku do 20 w 2014. Podobnie było na Retkini, gdzie w 1988 roku było ich cztery, a w 2014 już 29. I mimo że liczba aptek $\mathrm{w}$ tym czasie zwiększyła się $\mathrm{w}$ całym mieście, to wzrost ten był sześcio-, a nie jak w osiedlu Widzew dziesięciokrotny.
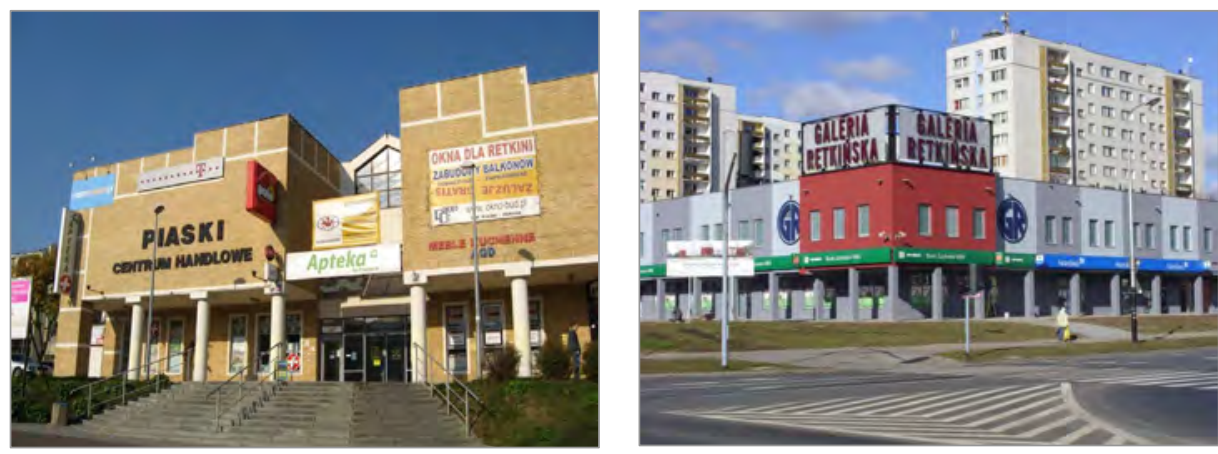

Fot. 30, 31. Lokalne galerie handlowo-usługowe w osiedlu Retkinia powstałe w II połowie lat 90. XX wieku Źródło: archiwum autora

Badania pokazały także, że na koniec 2014 roku w analizowanych osiedlach zlokalizowana była prawie połowa obecnych w Łodzi sklepów sieci Biedronka (17 spośród 37), niemal wszystkie sklepy sieci Carrefour (9 spośród 11), ponad połowa sklepów Tesco (10 spośród 16), połowa sklepów sieci Lidl (5 spośród 10) oraz wszystkie łódzkie sklepy sieci InterMarche (3) - tab. 21.

W okresie transformacji w osiedlach łódzkich powstały również liczne nowe lokale gastronomiczne - restauracje, pizzerie, puby i kawiarnie (tab. 22, fot. 32), niektóre o kontrowersyjnej architekturze (fot. 33) oraz inne komercyjne obiekty spędzania wolnego czasu (kluby fitness, siłownie, szkoły tańca itp) $)^{178}$.

Omówiony proces komercjalizacji w osiedlach łódzkich najintensywniej dokonywał się w latach 90. XX wieku oraz na początku XXI wieku. Dziś trwa nadal, ale jego tempo po upływie 25 lat od początku transformacji spadło, co wiąże się z pewnym nasyceniem rynku. Procesowi temu towarzyszy dekoncentracja przestrzenna działalności handlowej i usługowej, budując osiedla zakładano bowiem, że obiekty te powinny być skoncentro-

$178 \mathrm{Z}$ obserwacji wynika, że w ostatnich latach (po 2000 r.), kiedy większość podstawowych potrzeb mieszkańców osiedli zostało zaspokojonych, te które powstają zaspokajają potrzeby wyższego rzędu, np. otwarta w 2009 r. kawiarnia z galerią sztuki na Retkini (Friends Cafe). 
Tab. 21. Placówki handlowe należące do obecnych w Polsce dużych sieci handlowych, zlokalizowane w badanych osiedlach mieszkaniowych Łodzi na koniec 2014 roku

\begin{tabular}{|l|c|c|c|c|c|c|}
\hline $\begin{array}{c}\text { Osiedla } \\
\text { mieszkaniowe } \\
\text { w Łodzi }\end{array}$ & Biedronka & Carrefour & Tesco & Lidl & $\begin{array}{c}\text { Inter } \\
\text { Marche }\end{array}$ & Suma \\
\hline \multicolumn{7}{|c|}{ Osiedla z lat 60. i I poł. lat 70. } \\
\hline Dąbrowa & 2 & 1 & 0 & 1 & 0 & 4 \\
\hline Teofilów & 1 & 2 & 1 & 1 & 0 & 5 \\
\hline Zarzew & 1 & 2 & 1 & 1 & 0 & 5 \\
\hline Źubardź & 0 & 0 & 1 & 1 & 0 & 2 \\
\hline \multicolumn{7}{|c|}{ Osiedla z II pol. lat 70. i I pol. lat 80. } \\
\hline Retkinia & 3 & 1 & 2 & 1 & 1 & 8 \\
\hline Widzew-Wschód & 4 & 1 & 2 & 0 & 1 & 8 \\
\hline \multicolumn{7}{|c|}{ Osiedla z lat 80. i I poł. lat 90. } \\
\hline Chojny-Zatorze & 2 & 2 & 1 & 0 & 0 & 5 \\
\hline Olechów & 2 & 0 & 0 & 0 & 0 & 2 \\
\hline Radogoszcz & 2 & 0 & 2 & 0 & 1 & 5 \\
\hline Suma & 17 & 9 & 10 & 5 & 3 & 44 \\
\hline
\end{tabular}

Źródło: opracowanie własne na podstawie inwentaryzacji.

Tab. 22. Obiekty gastronomiczne w badanych osiedlach mieszkaniowych Łodzi w latach 2001 i 2014

\begin{tabular}{|l|c|c|c|c|c|}
\hline \multirow{7}{*}{$\begin{array}{l}\text { Osiedla według } \\
\text { okresu budowy }\end{array}$} & $\begin{array}{c}\text { restau- } \\
\text { racje }\end{array}$ & bary & $\begin{array}{c}\text { punkty } \\
\text { gastronomiczne }\end{array}$ & ogółem & $\begin{array}{c}\text { ogółem (restauracje, puby, } \\
\text { pizzerie, bary } \\
\text { i punkty gastronomiczne) }\end{array}$ \\
\hline \multicolumn{7}{|c|}{ Osiedla z lat 60. i I poł. lat 70. } \\
\hline Dąbrowa & 1 & 5 & 7 & 13 & 19 \\
\hline Teofilów & 2 & 5 & 6 & 13 & 18 \\
\hline Zarzew & 1 & 2 & 5 & 8 & 10 \\
\hline Żubardź & 3 & 7 & 7 & 17 & 21 \\
\hline \multicolumn{7}{|c|}{ Osiedla z II poł. lat 70. i I poł. lat 80. } \\
\hline Retkinia & 7 & 19 & 15 & 41 & 43 \\
\hline Widzew-Wschód & 6 & 12 & 12 & 30 & 31 \\
\hline \multicolumn{7}{|c|}{ Osiedla z lat 80. i I poł. lat 90. } \\
\hline Chojny-Zatorze & 4 & 15 & 14 & 33 & 33 \\
\hline Olechów & 2 & 6 & 2 & 10 & 19 \\
\hline Radogoszcz & 7 & 10 & 10 & 27 & 224 \\
\hline Suma & 33 & 81 & 78 & 192 & \\
\hline
\end{tabular}

Źródło: opracowanie własne na podstawie E. Klima, J. Bratkowski 2005 (dla 2001 r.) oraz inwentaryzacji (dla 2014 r.). 


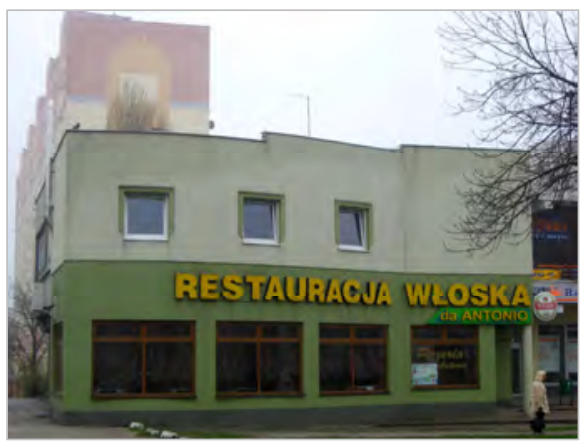

Fot. 32. Restauracja w osiedlu Dąbrowa powstała w II poł. lat 90 . XX w. Źródło: archiwum autorki

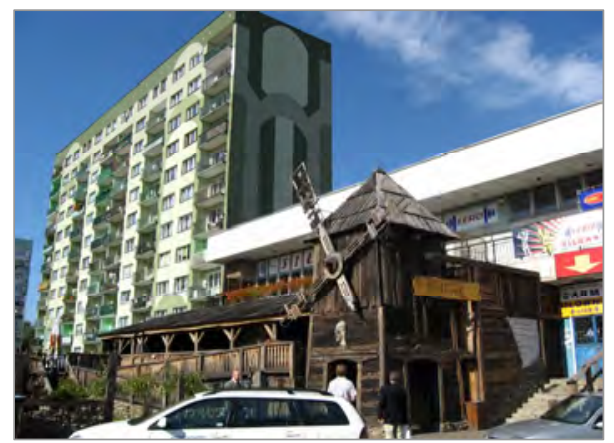

Fot. 33. Restauracja w osiedlu Widzew-Wchód powstała po $2000 \mathrm{r}$. Źródło: archiwum autorki

wane $\mathrm{w}$ środkowej ich części, na skutek czego znajdowały się one często w znacznej odległości (uwzględniając poruszanie się pieszo) od miejsc zamieszkania położonych na ich obrzeżach. Proces dokonujący się obecnie poprawia zatem nie tylko poziom wyposażenia w usługi, ale też zwiększa ich dostępność przestrzenną, co w istotny sposób poprawia warunki zamieszkania w osiedlach blokowych.

Szczegółowa inwentaryzacja zabudowy przeprowadzona w 2014 roku w osiedlach reprezentujących każdy z trzech okresów budowy: (1) Teofilów - lata 60. i początek lat 70., (2) Widzew-Wschód - lata 70. i I połowa lat 80., oraz (3) Olechów - II połowa lat 80. i później, pokazała, że liczba budynków o funkcji usługowej w każdym z nich znacząco wzrosła po 1989 roku (tab. 23). Największy przyrost ich liczby, niemal ośmiokrotny, nastąpił w najnowszym osiedlu Olechów, co wynika z okresu jego budowy, a najmniejszy w najstarszym Teofilowie. Biorąc jednak pod uwagę obecne proporcje liczby budynków usługowych do liczby budynków mieszkalnych można stwierdzić, że w osiedlu Olechów jest ona znacznie mniej korzystna niż w osiedlach starszych. Wynika to z faktu, że nowa część tego osiedla (Olechów-Janów), budowana od połowy lat 90. już niemal wyłącznie przez deweloperów (a jeśli przez spółdzielnie mieszkaniowe to również na zasadzie działalności deweloperskiej) i w mniejszej części przez TBS oraz gminę, jest znacznie słabiej wyposażona $\mathrm{w}$ infrastrukturę handlową i usługową niż część wznoszona w poprzednim ustroju. Tym samym starsza część osiedla ma charakter mieszkaniowo-usługowy, ponieważ koncentruje się $w$ niej zdecydowana większość zlokalizowanych w osiedlu budynków o funkcji usługowej, a nowsza niemal wyłącznie mieszkaniowy.

Analiza wielkości i fizjonomii budynków usługowych znajdujących się w łódzkich osiedlach pokazała, że nowsze z nich, powstałe po 2000 roku, są większe powierzchniowo i kubaturowo oraz staranniej zaprojektowane niż 
- powstające $\mathrm{w}$ latach 90. XX wieku, szczególnie w ich I połowie, czyli w okresie rodzącego się w Polsce kapitalizmu - liczne niewielkie obiekty, często wznoszone przy użyciu nietrwałych materiałów budowlanych i charakteryzujące się wątpliwą estetyką. Nowsze obiekty handlowo-usługowe są nie tylko większe, ale często także wielofunkcyjne - np. powstałe w niemal wszystkich łódzkich osiedlach lokalne galerie handlowe oraz sklepy wielkopowierzchniowe, którym często towarzyszy działalność usługowa.

Tab. 23. Budynki o funkcji mieszkaniowej, mieszkaniowo-usługowej i usługowej w osiedlach Teofilów, Widzew-Wschód i Olechów w latach 1989-2014

\begin{tabular}{|c|c|c|c|c|c|c|c|c|c|}
\hline \multirow[b]{3}{*}{ Rok } & \multicolumn{3}{|c|}{ Teofilów } & \multicolumn{3}{|c|}{ Widzew-Wschód } & \multicolumn{3}{|c|}{ Olechów a } \\
\hline & \multicolumn{9}{|c|}{ liczba budynków o funkcjach } \\
\hline & $\begin{array}{c}\text { miesz- } \\
\text { kanio- } \\
\text { wych }\end{array}$ & $\begin{array}{c}\text { miesz- } \\
\text { kanio- } \\
\text { wo- } \\
\text { usługo- } \\
\text { wych }\end{array}$ & $\begin{array}{l}\text { usłu- } \\
\text { gowych }\end{array}$ & $\begin{array}{l}\text { miesz- } \\
\text { kanio- } \\
\text { wych }\end{array}$ & $\begin{array}{l}\text { miesz- } \\
\text { kanio- } \\
\text { wo- } \\
\text { usługo- } \\
\text { wych }\end{array}$ & $\begin{array}{l}\text { usłu- } \\
\text { gowych }\end{array}$ & $\begin{array}{c}\text { miesz- } \\
\text { kanio- } \\
\text { wych }\end{array}$ & $\begin{array}{c}\text { miesz- } \\
\text { kanio- } \\
\text { wo- } \\
\text { usługo- } \\
\text { wych }\end{array}$ & $\begin{array}{l}\text { usłu- } \\
\text { gowych }\end{array}$ \\
\hline 1989 & 239 & 16 & 60 & 220 & 35 & 16 & 79 & 7 & 6 \\
\hline 1999 & 252 & 17 & 87 & 236 & 39 & 115 & 111 & 10 & 26 \\
\hline 2009 & 259 & 20 & 114 & 256 & 45 & 136 & 231 & 18 & 42 \\
\hline 2014 & 259 & 21 & 119 & 256 & 46 & 144 & 274 & 21 & 45 \\
\hline
\end{tabular}

a Wraz z osiedlem Olechów-Janów.

Źródło: opracowanie własne na podstawie inwentaryzacji (dla 2014 r.) oraz publikacji Drogi rozwoju... i materiałów SM Teofilów (dla lat wcześniejszych).

Szczegółowej inwentaryzacji poddano także wszystkie placówki handlowe i usługowe działające w sektorze usług rynkowych, jak i nierynkowych zlokalizowane w badanych osiedlach. $Z$ analizy ich struktury wynika, że najwięcej, bo około połowa, zajmuje się handlem detalicznym, w tym głównie handlem artykułami spożywczymi (tab. 24). Relatywnie dużo placówek świadczy też usługi związane z ochroną zdrowia. Większość z nich to podmioty komercyjne, do których należą prywatne gabinety lekarskie i stomatologiczne, a także niepubliczne przychodnie i spółki medyczne oferujące usługi lekarzy o różnych specjalnościach. Wiele podmiotów świadczy również usługi finansowe i ubezpieczeniowe - głównie są to oddziały i filie niemal wszystkich działających w Polsce banków komercyjnych. Dużą grupę stanowią także placówki edukacyjne. Najwięcej wśród nich jest publicznych przedszkoli i szkół wszystkich szczebli powstałych w okresie poprzedniego ustroju. Dość licznie reprezentowane są jednak także prywatne instytucje edukacyjne - niepubliczne przedszkola i punkty opieki nad dziećmi oraz oddziały i filie komercyjnych szkół językowych dla dzieci i dorosłych. 
Tab. 24. Placówki handlowe i usługowe (publiczne i niepubliczne) działające w osiedlach Teofilów, Widzew-Wschód i Olechów w 2014 r. według sekcji Polskiej Klasyfikacji Działalności (PKD 2007)

\begin{tabular}{|l|c|c|c|}
\hline \multirow{2}{*}{\multicolumn{1}{c|}{ Rodzaj działalności według sekcji PKD }} & \multicolumn{3}{c|}{ Liczba placówek w osiedlu } \\
\cline { 2 - 4 } & Teofilów & $\begin{array}{c}\text { Widzew- } \\
- \text {-Wschód }\end{array}$ & Olechów ${ }^{\mathrm{a}}$ \\
\hline Handel hurtowy i naprawa pojazdów (sekcja G.1) & 4 & 7 & 2 \\
\hline Handel detaliczny (sekcja G.2) & 221 & 292 & 115 \\
\hline Transport i gospodarka magazynowa & 12 & 15 & 10 \\
\hline Zakwaterowanie i usługi gastronomiczne & 18 & 31 & 19 \\
\hline Informacja i komunikacja & 6 & 8 & 1 \\
\hline Działalność finansowa i ubezpieczeniowa & 30 & 38 & 11 \\
\hline Działalność związana z obsługą rynku nieruchomości & 3 & 6 & 5 \\
\hline Działalność profesjonalna, naukowa i techniczna & 17 & 24 & 17 \\
\hline Działalność w zakresie usług administrowania & 7 & 8 & 3 \\
\hline Edukacja & 18 & 32 & 19 \\
\hline Opieka zdrowotna i pomoc społeczna & 43 & 51 & 31 \\
\hline Działalność związana z kulturą, rozrywką i rekreacją & 16 & 19 & 12 \\
\hline Pozostała działalność usługowa & 47 & 59 & 28 \\
\hline Suma & 442 & 590 & 273 \\
\hline
\end{tabular}

a Wraz z osiedlem Olechów-Janów.

Źródło: opracowanie własne na podstawie inwentaryzacji.

Tab. 25. Placówki handlowe i usługowe (publiczne i niepubliczne) działające w osiedlach Teofilów, Widzew-Wschód i Olechów w 2014 r. według okresu rozpoczęcia działalności

\begin{tabular}{|l|c|c|c|}
\hline \multirow{2}{*}{$\begin{array}{c}\text { Okres rozpoczęcia } \\
\text { działalności na terenie } \\
\text { osiedla }\end{array}$} & \multicolumn{3}{|c|}{ Liczba placówek w osiedlu } \\
\cline { 2 - 4 } & Teofilów & Widzew-Wschód & Olechów $^{\text {a }}$ \\
\hline Do 1979 r. & 87 & 25 & - \\
\hline $1980-1989$ & 56 & 45 & 12 \\
\hline $1990-1999$ & 119 & 210 & 88 \\
\hline $2000-2009$ & 138 & 236 & 122 \\
\hline $2010-2014$ & 42 & 74 & 273 \\
\hline Suma & 442 & 590 & 213 \\
\hline
\end{tabular}

a Wraz z osiedlem Olechów-Janów.

Źródło: opracowanie własne na podstawie inwentaryzacji.

Badania inwentaryzacyjne pokazały także, że największa liczba tych placówek rozpoczęła działalność w obecnej lokalizacji w pierwszej dekadzie XXI wieku, a zatem stosunkowo niedawno (tab. 25). Wynika to między innymi z dużej dynamiki zmian funkcjonalno-przestrzennych zachodzących w miastach postsocjalistycznych, ponieważ wiele podmiotów powstałych wcześniej było w międzyczasie likwidowanych lub relokowanych, a w ich 
miejsce powstawały nowe o tym samym lub innym profilu działalności. Do najdłużej funkcjonujących należą placówki publiczne, które często istnieją w tej samej lokalizacji od czasów budowy osiedla. Głównie dotyczy to szkół i przedszkoli, które ulokowane są w specjalnie powstałych w tym celu budynkach, ale także publicznych placówek służby zdrowia i urzędów pocztowych.

Największą liczbę placówek handlowych i usługowych działających w omawianych osiedlach w przeliczeniu na 1000 mieszkańców odnotowano w osiedlu Widzew-Wschód (14,9), nieco mniejszą w najstarszym Teofilowie $(12,6)$, a najmniejszą w osiedlu Olechów $(11,7)$. I mimo że miernik ten byłby bardziej precyzyjny, gdyby uwzględnić powierzchnię tych placówek, a nie tylko ich liczbęi79, to jednak i na tej podstawie można stwierdzić, że najsłabiej wyposażony w infrastrukturę handlowo-usługową jest Olechów. Biorąc pod uwagę wiek tego osiedla i młodą strukturę demograficzną mieszkańców, zapewne stan ten jest przejściowy i w niedługim czasie ulegnie zmianie. Generalnie przeprowadzone badania pokazały, że osiedla blokowe są dobrze wyposażone $\mathrm{w}$ infrastrukturę handlową i usługową oraz że wyposażenie to $\mathrm{w}$ kolejnych dekadach poprawia się.

Bardzo dobry poziom wyposażenia łódzkich osiedli w usługi potwierdzają także badania J. Dzieciuchowicza z zespołem (Dzieciuchowicz, red. 2005). Typologia przestrzenna rynkowych firm usługowych dokonana przez tego autora na podstawie ich rozmieszczenia w mieście w roku 2001 pokazała, że większość osiedli blokowych reprezentuje ten sam typ co centrum miasta. Typ ten charakteryzuje się wysokim potencjałem oraz bardzo dużą gęstością i dostępnością usług rynkowych. Monofunkcyjny charakter osiedli przestaje być zatem tym, co je definiuje i wyróżnia z przestrzeni miejskiej.

$\mathrm{Na}$ skutek omówionych przemian funkcjonalnych następują także zmiany $\mathrm{w}$ sferze społecznej. $\mathrm{W}$ wielkich osiedlach mieszkaniowych powstają liczne nowe miejsca pracy i pojawiają się nowe, nieobecne tam dotychczas miejsca spędzania wolnego czasu. Zmienia się także dzienna ścieżka życia mieszkańców, ponieważ zaspokojenie większości potrzeb (już nie tylko podstawowych) może odbywać się w ograniczonej przestrzeni osiedla i nie wymaga przemieszczania się do centrum.

Warto także odnotować, że zasięg przestrzenny wielu usług o charakterze komercyjnym i niekomercyjnym zlokalizowanych $w$ badanych osiedlach znacznie przekracza ich obszar. Niektóre świadczone $\mathrm{w}$ nich usługi przez swój unikatowy charakter lub wysoki poziom, przyciągają mieszkań-

179 Podczas badań terenowych często odmawiano odpowiedzi na pytanie o powierzchnię inwentaryzowanych placówek, często też zatrudnieni w nich pracownicy nie chcieli lub nie umieli jej określić, wobec czego zrezygnowano z tego pytania. 
ców z innych obszarów miasta. Przykładem mogą być szkoły gimnazjalne i ponadgimnazjalne zlokalizowane $\mathrm{w}$ osiedlach, które zajmują wysokie pozycje $\mathrm{w}$ rankingach oświatowych, unikatowa $\mathrm{w}$ skali Łodzi szkoła podstawowa $\mathrm{z}$ rozszerzonym programem tanecznym ${ }^{180}$, w której uczą się dzieci $z$ odległych rejonów oraz inne placówki, które oferując usługi na poziomie porównywalnym $\mathrm{z}$ centrum miasta, przy niższym poziomie czynszów, są bardziej konkurencyjne.

Zmiany w strukturze przestrzennej osiedli następują również na skutek przekształceń niezagospodarowanych dotychczas terenów w zieleń osiedlową i tereny rekreacyjne oraz rekreacyjno-sportowe (fot. 34, 35). Obszarów tych, jak już powiedziano, nie zagospodarowano wcześniej głównie na skutek zaniechań $\mathrm{w}$ realizacji pierwotnych założeń architektoniczno-urbanistycznych osiedli, które uwzględniały znacznie lepsze wyposażenie ich w infrastrukturę społeczną i usługową. Przeprowadzone badania pokazały, że począwszy od lat 90 . tereny te przekształcane są $w$ parki, boiska do gier zespołowych (głównie w sąsiedztwie szkół), place zabaw, skwery z zielenią. Przykładem takiej znaczącej obszarowo inwestycji, może być park Widzewska Górka181 (fot. 36, 37) o charakterze rekreacyjno-wypoczynkowym, liczący blisko 10 ha, zlokalizowany w osiedlu Widzew-Wschód, którego budowa finansowana była z budżetu miasta. Park powstał w latach 1999-2004 na leżącej w środkowej części osiedla niezagospodarowanej przestrzeni „niczyjej", a w 2004 roku uhonorowany został nagrodą Towarzystwa Urbanistów Polskich za najlepiej zagospodarowaną przestrzeń publiczną w województwie łódzkim.

Łódzkie osiedla zyskały również wiele nowych terenów rekreacyjno-sportowych, które powstały $\mathrm{w}$ ramach ogólnopolskiego programu Orlik 2012, współfinansowanego z budżetu państwa. W wyniku jego realizacji w badanych osiedlach pojawiło się 16 nowych wielofunkcyjnych boisk sportowych wraz z niezbędną infrastrukturą. Zmiany te w istotny sposób przyczyniają się do poprawy warunków zamieszkania w osiedlach blokowych, przy czym - jak pokazała analiza przestrzennego rozmieszczenia nowych terenów o charakterze rekreacyjnym i sportowo-rekreacyjnym - ich rozwój następuje głównie w osiedlach nowszych, budowanych od II połowy lat 70 .

180 Na przykład Gimnazjum Publiczne nr 22 (Retkinia), Gimnazjum Publiczne nr 29 i nr 34 (Widzew-Wschód), LO XXXI (Dąbrowa), SP nr 34 (Widzew-Wschód).

181 Budowa parku obejmowała dwa etapy. W latach 1999-2001 wykonano: promenadę, alejki, oświetlenie parku oraz odwodnienie terenu, założono trawniki, posadzono drzewa i krzewy ozdobne, zbudowano tor przeszkód dla rowerów górskich, mostek łączący dwa wzniesienia, urządzenia zabawowe, lawki itp. W latach 2002-2004 zrealizowano II etap budowy parku obejmujący place zabaw oraz tereny sportowe - boiska do gier zespołowych, do tenisa, urządzenia do ćwiczeń siłowych. Dzięki realizacji II etapu powstał „zielony klin”- korytarz napowietrzający osiedle. 
Jedną z przyczyn tego stanu jest znacznie większa gęstość zabudowy $\mathrm{w}$ osiedlach budowanych wcześniej, kiedy obowiązywały inne normatywy urbanistyczne i nie pozostawiano tak dużych rezerw terenowych pod przyszłe zagospodarowanie usługowe i rekreacyjne.

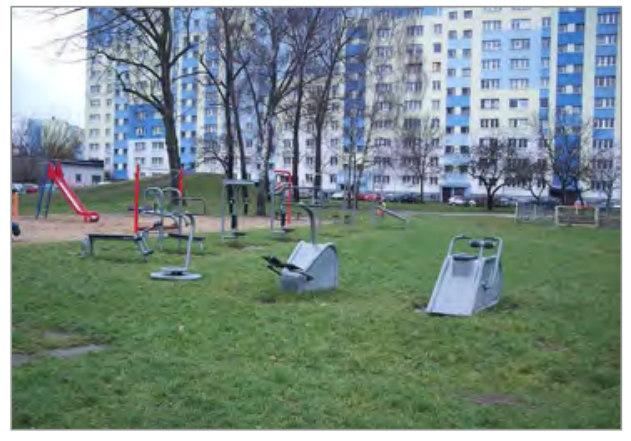

Fot. 34. Siłownia plenerowa w osiedlu Retkinia powstała po $2000 \mathrm{r}$.

Źródło: fot. 34-37 z archiwum autorki

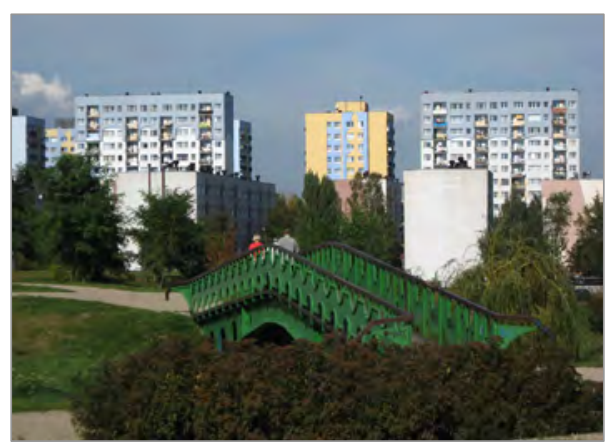

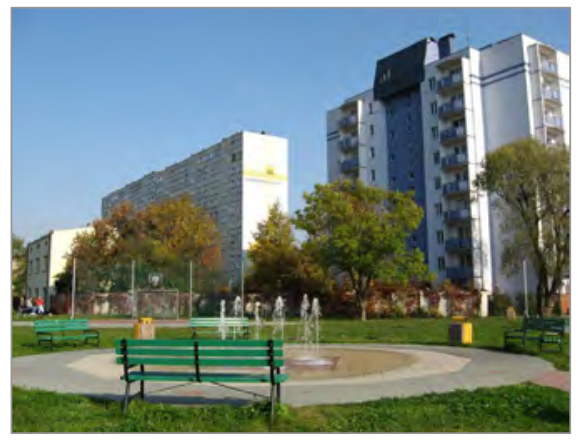

Fot. 35. Nowa przestrzeń wypoczynku w osiedlu Retkinia zagospodarowana po $2010 \mathrm{r}$.

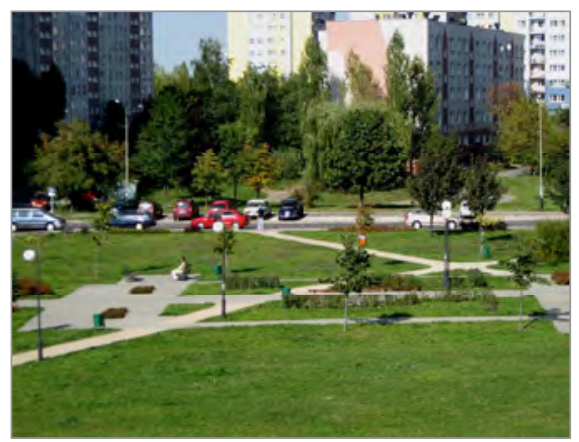

Fot. 36, 37. Park Widzewska Górka w osiedlu Widzew-Wschód założony w latach 1999-2004

Innym niekomercyjnym wymiarem przemian funkcjonalnych łódzkich osiedli blokowych w okresie transformacji jest wypełnianie ich dotychczasowej zabudowy nową zabudową sakralną, określane w literaturze jako sakralizacja przestrzeni (por. rozdz. 5). W Łodzi, podobnie jak w całej Polsce, proces ten obejmuje niemal wyłącznie świątynie rzymskokatolickie. Badania pokazały, że spośród 25 kościołów tego wyznania, których budowę rozpoczęto w Łodzi po 1989 roku, zdecydowana większość (18) zlokalizowanych jest w badanych osiedlach lub w ich bezpośrednim sąsiedztwie (rys. 39).

Spośród 22 nowych parafii erygowanych w mieście po 1989 roku (budowa kościoła nie zawsze równoznaczna jest z erygowaniem nowej parafii 


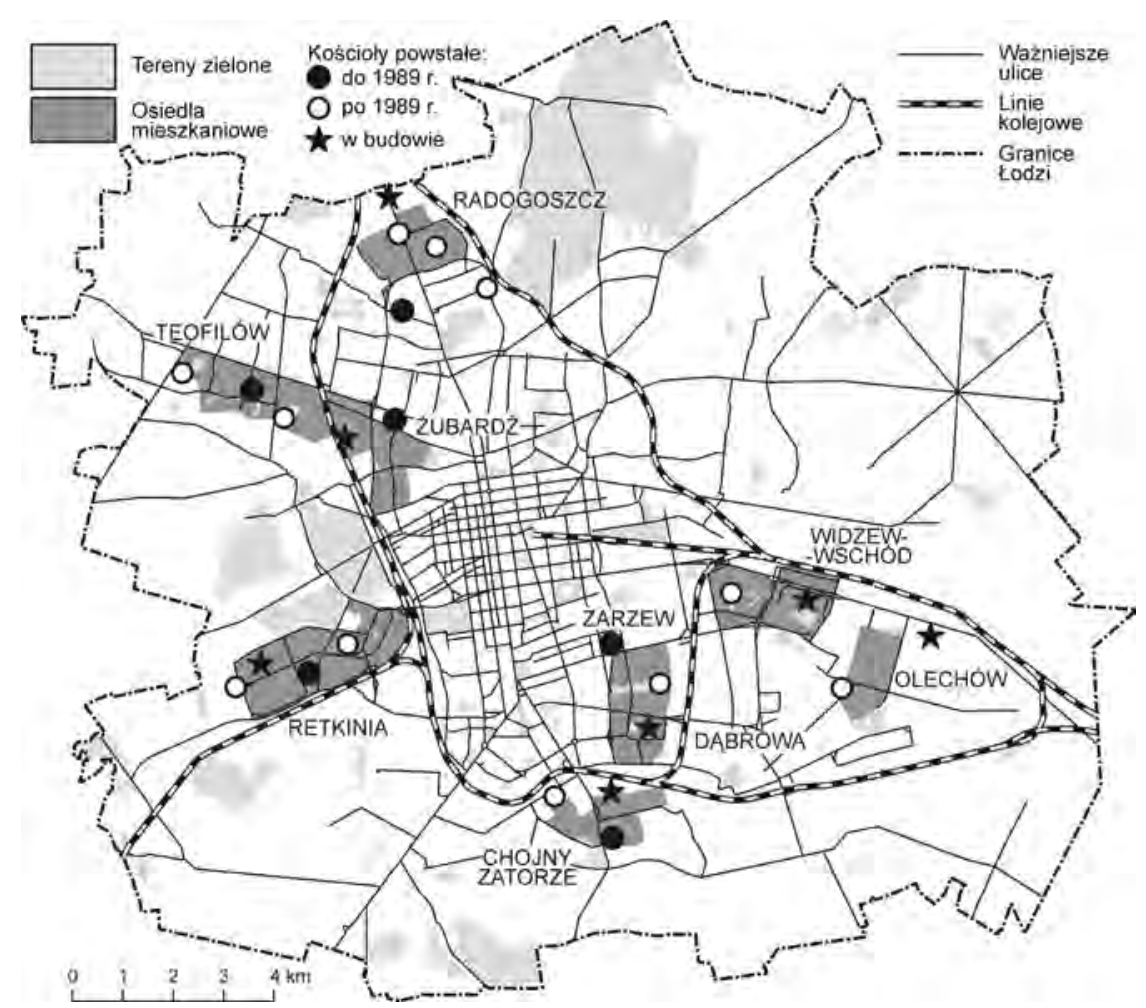

Rys. 39. Rozmieszczenie kościołów rzymskokatolickich zlokalizowanych w największych osiedlach mieszkaniowych Łodzi lub w ich bezpośrednim sąsiedztwie (stan w 2014 r.) Źródło: opracowanie własne na podstawie inwentaryzacji

i vice versa), aż 15 to parafie powstałe w badanych osiedlach (Klima 2009). W 2014 roku na badanym obszarze zlokalizowanych było 17 nowych kościołów, z których 11 powstało po 1989 roku oraz 7, które są obecnie w budowie. Obiekty te najczęściej budowane były na obszarach przeznaczonych $\mathrm{w}$ fazie projektowania osiedli na tereny zieleni lub usług, które przez lata pozostawały niezagospodarowane. Nowe kościoły powstawały również na obrzeżach osiedli.

Omówiony proces, w zależności od wielkości zajmowanego terenu, w lódzkich osiedlach ma charakter sensu stricto lub sensu largo. Częściej jednak sensu largo, ponieważ na większości działek zajmowanych przez budynki sakralne znajdują się też inne budynki, w których prowadzona jest działalność związana z funkcją religijną (np. przedszkola katolickie, biblioteki parafialne, sale spotkań). Część terenów będących we władaniu Kościoła zajmują także obiekty, w których prowadzona jest niereligijna działalność komercyjna. Przykłady terenów użytkowanych przez dwie parafie w osiedlu Widzew-Wschód (rys. 40) pokazują różne sposoby zagospodaro- 
wania działek, na których znajdują się kompleksy sakralne w łódzkich osiedlach. Pierwszym z nich jest kompleks budynków użytkowanych przez parafię pw. Matki Boskiej Jasnogórskiej182, wznoszonych w latach 19811996, drugi zaś to zespół obiektów należących do parafii pw. św. Brata Alberta Chmielowskiego ${ }^{183}$, które budowano w latach 1987-2000.

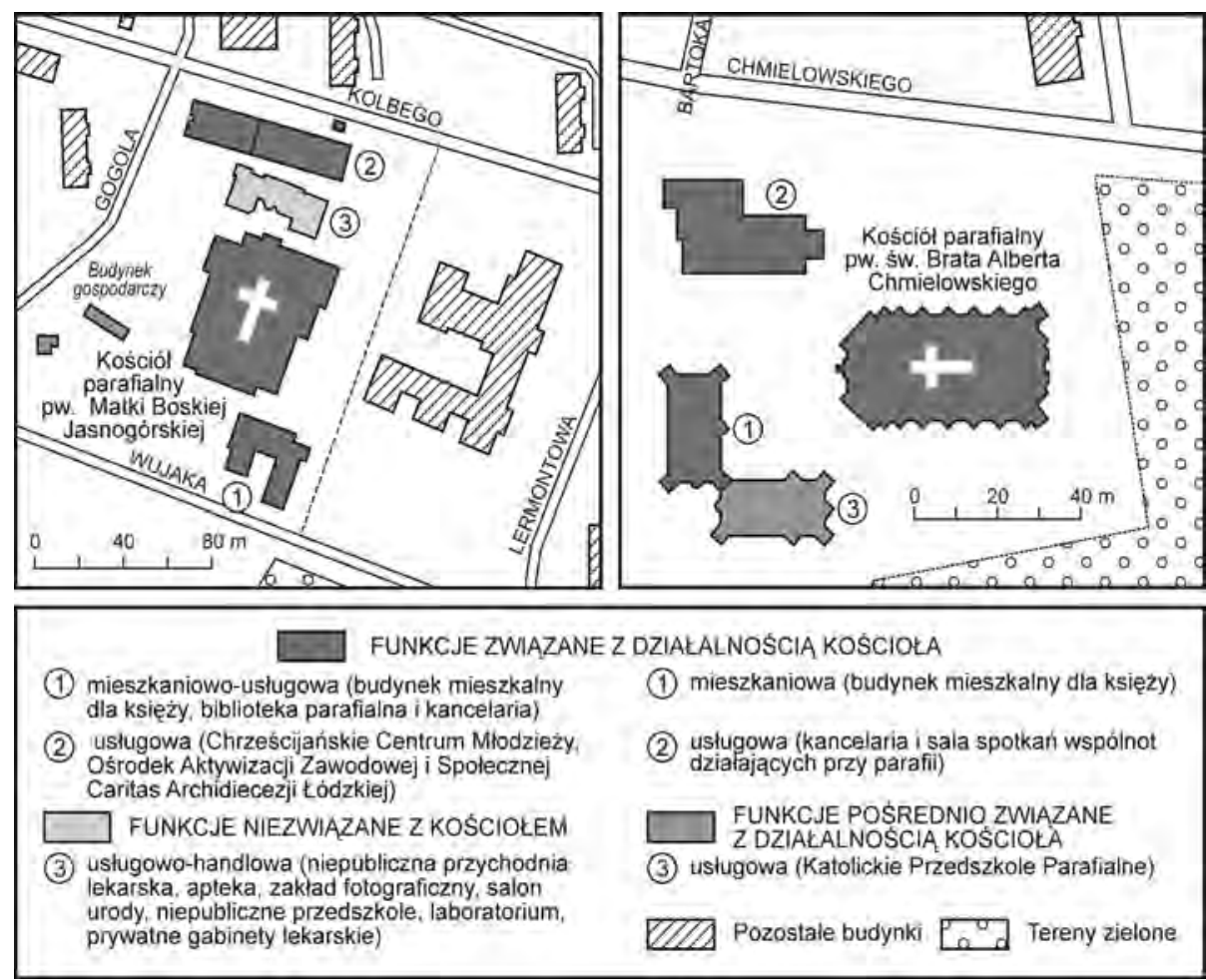

Rys. 40. Funkcje terenów znajdujących się we władaniu Kościoła użytkowanych przez parafie pw. Matki Boskiej Jasnogórskiej oraz pw. św. Brata Alberta Chmielowskiego

w osiedlu Widzew-Wschód (stan w 2014 r.)

Źródło: opracowanie własne na podstawie inwentaryzacji

182 Parafia pw. Matki Boskiej Jasnogórskiej erygowana została po kilkuletnich staraniach Kurii w 1981 r. Budowę kompleksu kościelnego rozpoczęto od budowy kaplicy oraz sal katechetycznych, które oddano do użytku już w końcu 1981 r. Budynek monumentalnej świątyni, w której jednorazowo mieści się ponad 6 tys. wiernych powstawał w latach 1983-1996. Jego cechą charakterystyczną jest modernistyczna nowoczesna bryła. Obecnie kompleks składa się $\mathrm{z}$ siedmiu budynków, które zajmują ponad 5 tys. $\mathrm{m}^{2}$ powierzchni użytkowej.

183 Parafia pw. św. Brata Alberta Chmielowskiego erygowana została w 1987 r. Wzniesienie kompleksu zaczęło się od budowy kaplicy oraz sal katechetycznych, które oddano do użytku już w końcu 1988 r. Budynek świątyni powstawał w latach 1991-2000. Jego cechą charakterystyczną jest modernistyczna nowoczesna trójnawowa bryła nawiązująca do tradycyjnej architektury sakralnej. Obecnie kompleks składa się z czterech budynków. 
Powstające w osiedlach obiekty sakralne charakteryzują się różną fizjonomią i różną wielkością, zawsze jednak stanowią ważną dominantę architektoniczną i wysokościową $\mathrm{w}$ ich mało zróżnicowanym krajobrazie. Niektóre z nich nawiązują w stylu do tradycyjnej architektury sakralnej, inne natomiast to budynki na wskroś nowoczesne (fot. 38-39).

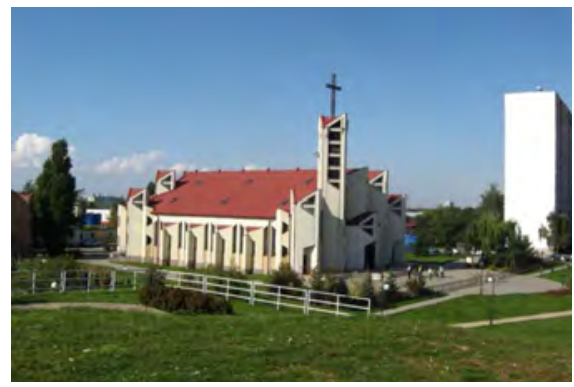

Fot. 38. Kościół parafialny pw. św. Brata Alberta Chmielowskiego budowany w latach 1991-2000 - osiedle Widzew-Wschód

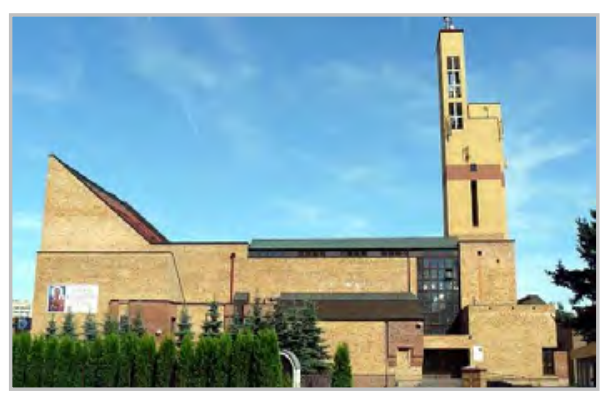

Fot. 39. Kościół parafialny pw. Matki Boskiej Jasnogórskiej ukończony w 1996 r. - osiedle Widzew-Wschód

Źródło: archiwum autorki

Osobną kwestią związaną z przekształceniami struktury przestrzennej wielkich osiedli jest wytyczanie i budowa nowych miejsc parkingowych. Problem ten $\mathrm{w}$ ostatnich latach wraz $\mathrm{z}$ rozwojem motoryzacji i wzrostem zamożności mieszkańców Łodzi, wśród których coraz częściej obserwuje się posiadanie więcej niż jednego auta $\mathrm{w}$ gospodarstwie domowym, nabiera coraz większego znaczenia. I choć liczba samochodów w przeliczeniu na 1000 mieszkańców jest $\mathrm{w}$ Łodzi najniższa wśród innych wielkich miast w Polsce (na koniec 2012 r. wynosiła 448; średnia dla wielkich miast przekraczała 500), to szybko rośnie. A duża koncentracja mieszkańców w osiedlach i wysoka intensywność zabudowy zwłaszcza w osiedlach starszych, sprawia, że ich niedostateczna liczba stanowi coraz poważniejszy problem. Wszechobecne auta zaparkowane w osiedlowych uliczkach, alejkach spacerowych, tuż przy wejściach do klatek schodowych, a nawet na skwerach i trawnikach, niszczą nawierzchnię, infrastrukturę, zieleń, utrudniają poruszanie się pieszych i zdecydowanie negatywnie wpływają na użytkowanie i percepcję osiedlowej przestrzeni. Nieliczne garaże budowane $\mathrm{w}$ łódzkich osiedlach do końca lat 60. zaspokajają znikomą część potrzeb, ponieważ nawet wówczas, gdy je budowano ich liczba nie była wystarczająca. Sytuacji tej nie poprawiła niewielka liczba garaży powstających w parterach nowych budynków.

$\mathrm{Z}$ obserwacji przeprowadzonych $\mathrm{w}$ badanych osiedlach wynika, że powstające $w$ nich nowe parkingi najczęściej lokalizowane są na obrzeżach, 
wzdłuż arterii komunikacyjnych wyznaczających ich granice lub wzdłuż większych ulic przecinających osiedla. Jednym z negatywnych skutków takiej lokalizacji jest zajmowanie przez parkingi pasów zieleni, które miały osłaniać zabudowę mieszkaniową przed hałasem ulicznym i spalinami, a obecnie zamiast drzew i krzewów znajdują się na nich parkujące samochody. Pozytywną stroną takiej lokalizacji jest jednakże, zgodne z zasadami Karty Ateńskiej, wyprowadzanie samochodów z uliczek osiedlowych i przestrzeni międzyblokowej. Z przeprowadzonej inwentaryzacji wynika, że większość parkingów $\mathrm{w}$ badanych osiedlach znajduje się $\mathrm{w}$ zarządach prywatnych podmiotów, które prowadzą tę działalność na zasadach komercyjnych ${ }^{184}$. Zwykle są to tereny o niskim stopniu zainwestowania (tylko ogrodzenie i szlaban), a tylko około $20 \%$ stanowią parkingi zadaszone wiatami. Tylko w jednym z badanych osiedli (Widzew-Wschód) wybudowano parking wielopoziomowy (w 2012 r.). Skromna w tym zakresie działalność spółdzielni i wspólnot mieszkaniowych polega głównie na cywilizowaniu „dzikich" parkingów przed wejściami do klatek schodowych poprzez wytyczanie i budowę nowych ogólnodostępnych miejsc parkingowych, często kosztem trawników i zieleni wokół bloków. Od kilku lat obserwuje się także "wyprowadzanie" samochodów z wąskich uliczek znajdujących się pomiędzy blokami stosując zmianę organizacji ruchu drogowego (liczne zakazy wjazdu i ulice jednokierunkowe), co niewątpliwie poprawia bezpieczeństwo mieszkańców, zmniejsza hałas i zanieczyszczenia spalinami, a tym samym przyczynia się do poprawy warunków zamieszkania.

\subsubsection{Przemiany fizjonomiczne}

Przemianom społecznym, morfologicznym i funkcjonalnym zachodzącym $\mathrm{w}$ wielkich osiedlach mieszkaniowych Łodzi towarzyszą zmiany w ich fizjonomii. Jeśli mają skoordynowany i planowy charakter oraz jednego inwestora (np. spółdzielnię mieszkaniową), zmieniając wygląd osiedli czynią z nich bardziej przyjazne środowisko mieszkaniowe i poprawiają ich społeczny odbiór, a wśród mieszkańców wzmacniają poczucie więzi z zamieszkiwanym obszarem. Niestety zdarza się, że są one chaotyczne i przypadkowe, co nie sprzyja ani estetyce otoczenia, ani wzmacnianiu więzi mieszkańców z osiedlem. Na zmiany te składają się:

- zmiana wyglądu elewacji budynków mieszkalnych (bogatsza kolorystyka i przełamanie szarości betonowej pustyni), głównie na skutek inwestycji termomodernizacyjnych, które do 2014 r. objęły około $90 \%$

184 Miesięczny koszt parkowania samochodu w badanych osiedlach w 2014 r. wynosił od $70 \mathrm{zl}$ (parkingi pod gołym niebem) do nawet $120 \mathrm{zł} \mathrm{w}$ parkingach zadaszonych wiatami. 
budynków zlokalizowanych w łódzkich osiedlach (fot. 40-43), niekiedy w sposób dość kontrowersyjny estetycznie (fot. 44-45);
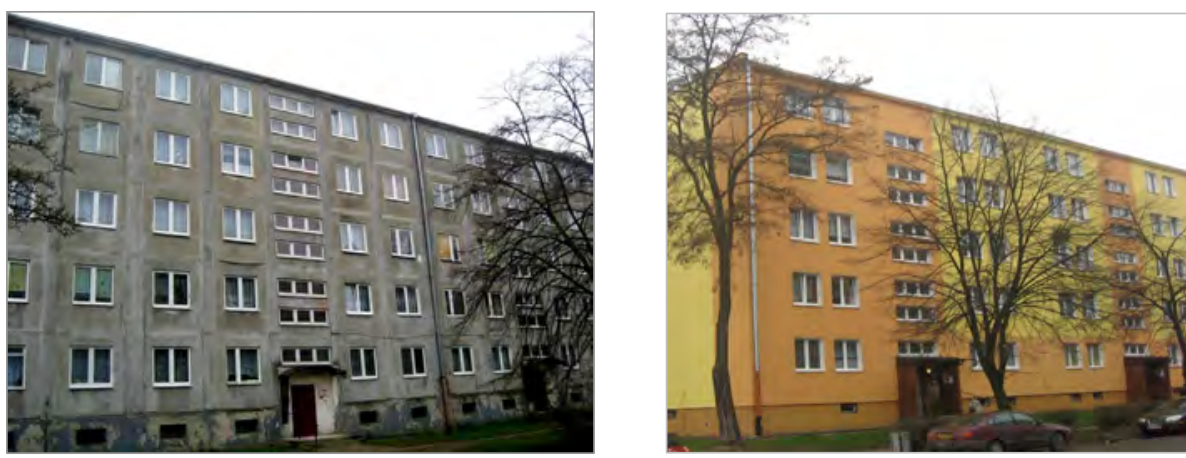

Fot. 40, 41. Budynek mieszkalny z lat 60 . XX wieku przed i po termomodernizacji oraz zmianie koloru elewacji (osiedle Dąbrowa) Źródło: fot. 40-45 z archiwum autora
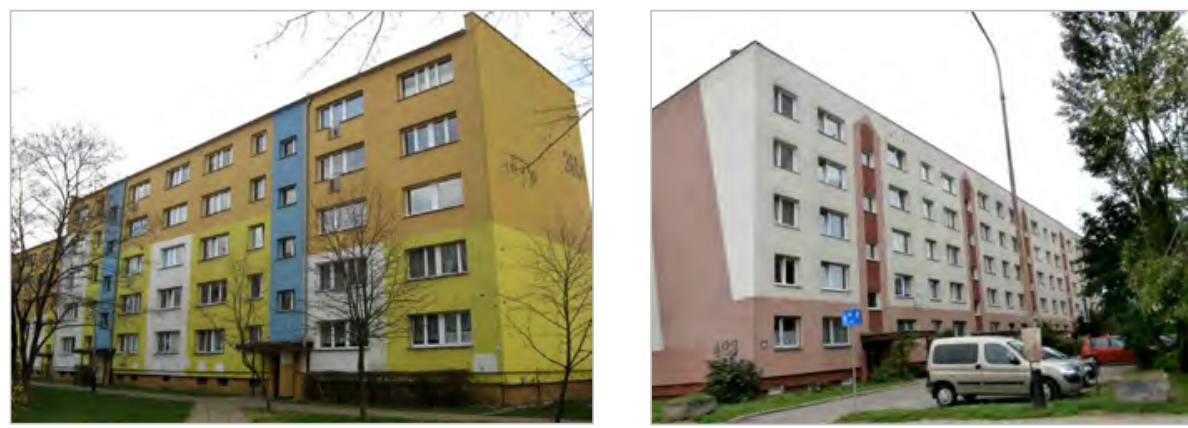

Fot. 42, 43. Pierwotna zabudowa mieszkaniowa z lat 70. po termomodernizacji oraz zmianie koloru elewacji (osiedla Retkinia i Widzew-Wschód)
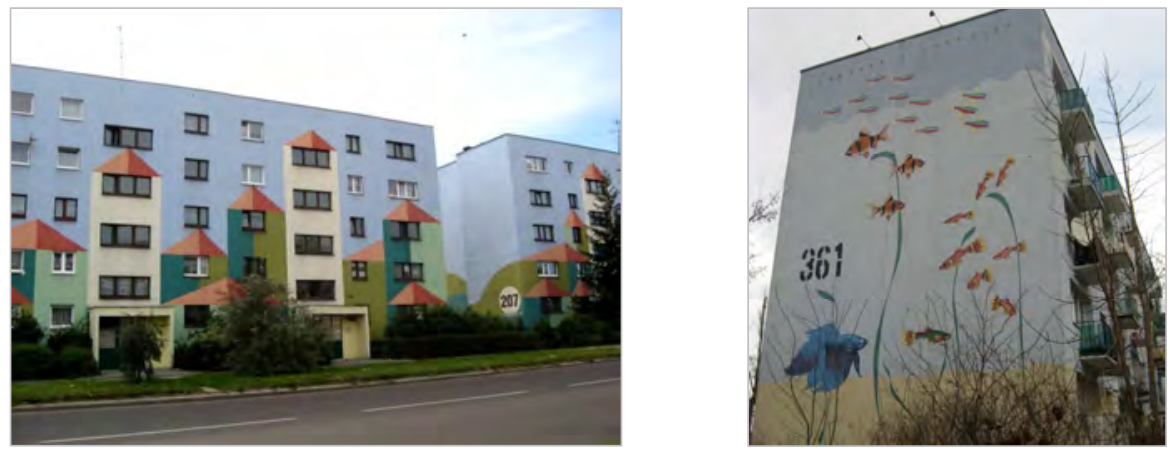

Fot. 44, 45. Pierwotna zabudowa mieszkaniowa z lat 70. i 80. po termomodernizacji oraz zmianie koloru elewacji (osiedle Olechów i Retkinia) 
- poprawa wizualnego stanu technicznego budynków obejmująca wymianę i remonty okien, parapetów zewnętrznych, balkonów, wymianę drzwi wejściowych do klatek schodowych oraz drzwi zsypów (w budynkach wysokich), budowę nowych schodów, podjazdów dla osób niepełnosprawnych, wymianę domofonów itp.;

- przełamanie monotonii krajobrazu i jednolitego wyglądu budynków poprzez wprowadzanie zróżnicowanej architektonicznie nowej zabudowy mieszkaniowej i usługowej o różnych funkcjach, w tym przede wszystkim zabudowy sakralnej, która stała się ważną dominantą $\mathrm{w}$ krajobrazie osiedli, a także pojawienie się w przestrzeni nieobecnych dotychczas elementów małej architektury i detali architektonicznych;

- wzrost wielkości powierzchni i poprawa zagospodarowania terenów pełniących funkcje rekreacyjne (place zabaw, parki, skwery, boiska);

- poprawa stanu osiedlowej zieleni (poprzez nowe nasadzenia oraz większą dbałość o zieleń), ale niekiedy także jej dewastacja na skutek bardzo dotkliwego braku miejsc parkingowych i zajmowania terenów zielonych przez „dzikie" parkingi;

- wprowadzanie elementów służących lepszej orientacji w przestrzeni (poprawa oznakowania budynków) (fot. 46, 47).
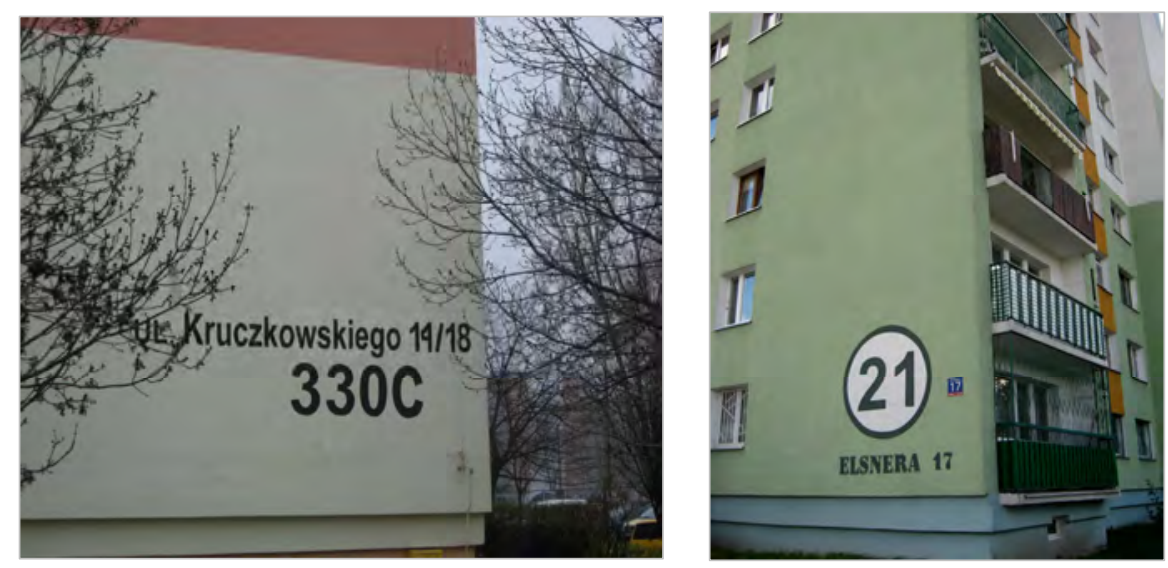

Fot. 46, 47. Nowe oznakowanie budynków mieszkalnych z lat 60. i 70. ułatwiające orientację w przestrzeni (osiedla Dąbrowa i Widzew-Wchód)

Źródło: archiwum autora

Odnotowane zmiany w strukturze przestrzennej wielkich osiedli mieszkaniowych Łodzi, na które składają się przemiany w ich strukturze morfologicznej, funkcjonalnej i fizjonomii, dokonały się zarówno w wyniku urucho- 
mienia procesów rynkowych (np. komercjalizacja, uzupełnianie zabudowy mieszkaniowej), jak i zmian politycznych (sakralizacja), ale także są efektem celowych działań określanych jako modernizacja, humanizacja lub reurbanizacja (por. rozdz. 2), zmierzających do poprawy jakości warunków zamieszkania w tych osiedlach (tab. 25). Te ostatnie są realizowane głównie przez podmioty zarządzające zasobami mieszkaniowymi, ale też władze miasta czy mieszkańców (np. poprzez budżet obywatelski czy różne ciała przedstawicielskie, takie jak rady osiedli).

Tab. 25. Przemiany przestrzenne wielkich osiedli mieszkaniowych Łodzi determinanty, aktorzy, efekty

\begin{tabular}{|c|c|c|}
\hline Determinanty & $\begin{array}{c}\text { Główni aktorzy } \\
\text { wytwarzania przestrzeni }\end{array}$ & Efekty \\
\hline $\begin{array}{l}\text { Procesy } \\
\text { wolnorynkowe }\end{array}$ & \begin{tabular}{|l} 
- przedsiębiorcy dzia- \\
łający na rynku miesz- \\
kaniowym (dewelo- \\
perzy) \\
- przedsiębiorcy działa- \\
jący na rynku usług \\
- gospodarstwa \\
domowe - nabywcy \\
nowych nieruchomości
\end{tabular} & $\begin{array}{l}\text { - pojawianie się nowej zróżnicowanej zabu- } \\
\text { dowy mieszkaniowej i towarzyszące im za- } \\
\text { właszczanie przestrzeni publicznej oraz pro- } \\
\text { cesy segregacji i separacji } \\
\text { - pojawianie się nowej zróżnicowanej zabu- } \\
\text { dowy usługowej i usługowo-handlowej } \\
\text { (komercjalizacja przestrzeni) } \\
\text { - wytyczanie i budowa nowych terenów } \\
\text { parkingowych o charakterze komercyjnym }\end{array}$ \\
\hline $\begin{array}{l}\text { Zmiany } \\
\text { polityczne }\end{array}$ & - Kościół & $\begin{array}{l}\text { - budowa nowych obiektów sakralnych } \\
\text { (sakralizacja przestrzeni) }\end{array}$ \\
\hline $\begin{array}{l}\text { Planowe dzia- } \\
\text { lania moderni- } \\
\text { zacyjne w celu } \\
\text { poprawy jakości } \\
\text { warunków } \\
\text { zamieszkania }\end{array}$ & $\begin{array}{l}\text { - } \text { spółdzielnie } \\
\text { mieszkaniowe } \\
\text { - wspólnoty } \\
\text { mieszkaniowe } \\
\text { - władze miasta } \\
\text { - } \text { mieszkańcy }\end{array}$ & $\begin{array}{l}\text { - poprawa estetyki i stanu technicznego } \\
\text { zabudowy } \\
\text { - kreacja nowych oraz poprawa jakości } \\
\text { istniejących terenów zielonych i sporto- } \\
\text { wo-rekreacyjnych } \\
\text { - wytyczanie i budowa nowych miejsc } \\
\text { parkingowych }\end{array}$ \\
\hline
\end{tabular}

Źródło: opracowanie własne.

Obserwacje dowodzą, że zakres tych zmian jest większy w osiedlach nowszych, budowanych od połowy lat 70., co wiąże się z mniejszą intensywnością poziomą ich zabudowy i większą rezerwą terenów wolnych, które podlegają przekształceniom morfologicznym i fizjonomicznym bez naruszania ich podstawowej tkanki urbanistycznej, jaką jest pierwotna zabudowa blokowa. Ich intensywność, jak można sądzić, różnicują także cechy zamieszkujących tam społeczności, takie jak struktura wieku, struktura gospodarstw domowych i status społeczno-ekonomiczny mieszkań- 
ców, które kreują określone potrzeby i stwarzają popyt na określone formy zagospodarowania przestrzeni i wyposażenia osiedla. Generalnie na dużą intensywność przemian we wszystkich grupach osiedli wpływa przede wszystkim znaczna koncentracja mieszkańców - potencjalnych użytkowników i klientów. Duże znaczenie miało również bardzo słabe wyposażenie tych osiedli w infrastrukturę społeczną i usługową przed 1990 rokiem, będące przez lata głównym kryterium definicyjnym tej formy zabudowy (syndrom "monofukcyjnych betonowych pustyni"), które w momencie zmiany ustroju stworzyło znakomite warunki do inwestowania.

Reasumując można stwierdzić, że omówione powyżej zmiany przestrzenno-funkcjonalne, morfologiczne oraz fizjonomiczne, jakie dokonały się w wielkich osiedlach mieszkaniowych Łodzi skutkują:

- ograniczeniem monofunkcyjnego charakteru tych osiedli (nowe obiekty usługowe, wielkopowierzchniowe obiekty handlowe, kościoły, tereny rekreacyjne, miejsca spędzania wolnego czasu);

- dekoncentracją przestrzenną działalności handlowej i usługowej na obszarze osiedli;

- pojawieniem się nowych miejsc pracy zlokalizowanych w osiedlach i nowych miejsc spędzania wolnego czasu;

- urozmaiceniem krajobrazu i poprawą estetyki przestrzeni.

Są to zatem zmiany, które niewątpliwie przyczyniają się do poprawy warunków zamieszkania w osiedlach. Niekiedy jednak, ze względu na swój chaotyczny i nieskoordynowany charakter oraz mnogość inwestorów, którzy wznoszą nowe budynki o różnej architekturze, nie zawsze uwzględniającej specyfikę otoczenia, przemiany te nie tylko nie zmierzają do poprawy estetyki, ale nawet powodują chaos przestrzenny i architektoniczny w osiedlach. W niektórych przypadkach prowadzą również do nadmiernego zagęszczenia zabudowy i zmniejszania powierzchni terenów zielonych, a także omówionych już procesów segregacji i separacji.

Te ostatnie procesy obecnie są jeszcze w Łodzi w fazie inicjalnej, ponieważ grupy mieszkańców, które oddzielają się przestrzennie od pozostałej większości, jakkolwiek mają wyższy status społeczno-ekonomiczny, to różnica ta we wciąż heterogenicznych i zróżnicowanych społecznie osiedlach nie jest tak wyraźna, jak w przypadku obszarów zdegradowanych społecznie i urbanistycznie, gdzie zachodzą klasyczne procesy separacji, związane z polaryzacją społeczną i kształtowaniem się miasta dualnego (por. Matlovič $\mathrm{i}$ in. 2001). W perspektywie jednak, jeśli otoczenie będzie podlegało regresji statusowej, odgradzanie się grup zajmujących wyższe pozycje może prowadzić do polaryzacji społecznej w przestrzeni osiedli. 


\subsection{Percepcja i waloryzacja wielkich osiedli mieszkaniowych Łodzi - wybrane aspekty}

Wielkie osiedla mieszkaniowe o zabudowie blokowej - jak już powiedziano są środowiskiem mieszkaniowym, wokół którego istnieje wiele stereotypów, wymagających weryfikacji w drodze badań empirycznych prowadzonych $\mathrm{w}$ różnej skali przestrzennej i przy użyciu różnych metod. Jednym $\mathrm{z}$ takich przedsięwzięć były wykonane na użytek niniejszej pracy badania percepcji i waloryzacji dziewięciu największych osiedli mieszkaniowych Łodzi przeprowadzone wśród ich mieszkańców w 2012 roku. Celem tych badań było określenie poziomu atrakcyjności mieszkaniowej osiedli w opiniach mieszkańców oraz dostarczenie wiedzy o zróżnicowaniu przestrzennym i determinantach tego zjawiska. Badania przeprowadzone zostały przy użyciu metody kwestionariuszowej $\mathrm{w}$ technice standaryzowanego wywiadu bezpośredniego (face to face) na reprezentatywnej próbie obejmującej 1002 dorosłych mieszkańców wybranych osiedli. Próba została dobrana przy użyciu metody random-route 185 .

W badaniu przyjęto pięć grup kryteriów wyodrębnionych na podstawie przeglądu literatury dotyczącej percepcji atrakcyjności przestrzeni mieszkaniowej (por. rozdz. 6). Należą do nich kryteria: (1) użytkowe - obejmujące poziom wyposażenia osiedli $\mathrm{w}$ wybrane elementy zagospodarowania przestrzeni oraz ich dostępność komunikacyjną, (2) estetyczne - uroda okolicy, czystość, zadbanie i wizualna atrakcyjność zabudowy, (3) bezpieczeństwa - poczucie bezpieczeństwa w osiedlu, (4) społeczne, czyli więzi sąsiedzkie, oraz (5) sentymentalne (emocjonalne), które obejmują takie zmienne, jak poziom więzi $\mathrm{z}$ osiedlem $\mathrm{i}$ satysfakcję $\mathrm{z}$ zamieszkiwania $\mathrm{w}$ nim. Pytania dotyczące ocen sformułowane były z użyciem pięciostopniowej skali Likerta oraz siedmiostopniowych skal dyferencjału semantycznego, tzw. skal Osgooda, wykorzystywanych w badaniach percepcji przestrzeni miejskiej (por. Libura 1988).

Analiza struktury respondentów uzyskanej w wyniku przeprowadzonych badań pozwoliła stwierdzić, że wśród badanych przeważały kobiety, które stanowily prawie 57\% ankietowanych. Biorąc pod uwagę ich wiek, największą grupę (ponad 1/5) stanowily osoby w wieku 20-29 lat, 60-69 lat (blisko $1 / 5$ ) oraz 30-39 lat (15\%). Uwzględniając wykształcenie, najliczniej reprezentowana była grupa osób z wykształceniem średnim (ponad 45\%),

185 Ankieterzy rozpoczynali realizację badania od wylosowanego punktu startowego, przeprowadzając wywiady w co piątym mieszkaniu, poczynając od tego punktu. Za punkt startowy przyjęto pierwszy blok/mieszkanie przy wylosowanej ulicy. Kolejne wywiady realizowano kierując się zawsze $\mathrm{w}$ prawo. $W$ jednym gospodarstwie domowym można było przeprowadzić wywiad tylko z jedną osobą. 
$\mathrm{w}$ drugiej kolejności z wykształceniem wyższym magisterskim (ponad 17\%), w trzeciej - z zasadniczym zawodowym (ponad 15\%). Większość respondentów to osoby aktywne zawodowo (ponad 40\%) oraz emeryci i renciści (blisko 1/3). Prawie $1 / 5$ ankietowanych stanowili uczniowie i studenci. Ponad $1 / 3$ respondentów oceniła swoją sytuację finansową jako przeciętną (na $4 \mathrm{w}$ siedmiopunktowej skali, gdzie 1 oznacza bardzo złą, a 7 - bardzo dobrą sytuację), a blisko $40 \%$ jako lepszą niż przeciętną (oceny od 5 do 7 ).

Ponad 90\% respondentów zadeklarowało, że mieszka w pierwotnej zabudowie osiedlowej powstałej przed 1990 rokiem, a wśród nich nieco ponad $60 \% \mathrm{w}$ zabudowie liczącej do pięciu kondygnacji i blisko 30\% w zabudowie wysokiej. Niemal wyłącznie są to bloki 4- i 11-piętrowe, co wynika ze struktury zabudowy $\mathrm{w}$ powojennych osiedlach mieszkaniowych w Łodzi. Wśród badanych jest także nieliczna grupa (7\%), mieszkających w zabudowie nowszej, powstałej po 1990 roku. Najwięcej respondentów stanowili mieszkańcy lokali typu M-3 (46\%) oraz M-4 (blisko $1 \frac{1}{3}$ badanych). Dla zdecydowanej większości z nich (ponad 84\%) badane osiedla nie były pierwszym miejscem zamieszkania. Najwięcej osób spośród tej grupy (ponad 2/3) zamieszkiwało wcześniej inną część Łodzi. Co czwarty respondent pochodził z innej miejscowości (w większości z aglomeracji łódzkiej). Blisko $1 / 3$ to osoby mieszkające $\mathrm{w}$ badanych osiedlach krócej niż 10 lat, co jest konsekwencją rosnącej w ostatnich latach rotacji mieszkańców w zabudowie osiedlowej i obrotu tymi mieszkaniami na rynku wtórnym. Ponad 1/3 respondentów mieszkała poprzednio również w zabudowie blokowej (dwukrotnie częściej $\mathrm{W}$ zabudowie niskiej niż $\mathrm{w}$ wysokiej), 1/5 W zabudowie kamienicznej, a mniej niż $1 / 5 \mathrm{~W}$ domach jednorodzinnych.

Wyniki przeprowadzonych badań pokazały, że w opinii zdecydowanej większości ankietowanych osiedla są wystarczająco dobrze wyposażone w placówki handlowe i usługowe, w tereny zieleni i place zabaw dla dzieci, nie wystarczająco natomiast w miejsca spędzania wolnego czasu, obiekty gastronomiczne i sportowo-rekreacyjne oraz w miejsca parkingowe. Najbardziej jednak respondentom brakuje w osiedlach obiektów kultury (rys. 42).

Oceny wyposażenia poszczególnych osiedli były zróżnicowane. We wszystkich osiedlach najwyżej oceniono wyposażenie w sklepy spożywcze (w każdym z nich ponad 90\% respondentów oceniło ich liczbę jako zdecydowanie lub raczej wystarczającą) oraz obecność terenów zieleni. Najniższy odsetek pozytywnych ocen wyposażenia w usługi był w osiedlu Olechów, a najwyższy odnotowano w osiedlu Widzew-Wschód. Podobnie było z oceną wyposażenia w sklepy innych branż, która także najniższa była na Olechowie $(53 \%)$ a najwyższa na Widzewie-Wschód (79\%). Obiektów sportowo-rekreacyjnych najbardziej brakuje mieszkańcom osiedla Zarzew (tylko $30 \%$ zadowolonych), a najmniej Widzewa-Wschód (80\%). Ci ostatni są również najbardziej zadowoleni z wyposażenia osiedla w obiekty gastronomicz- 


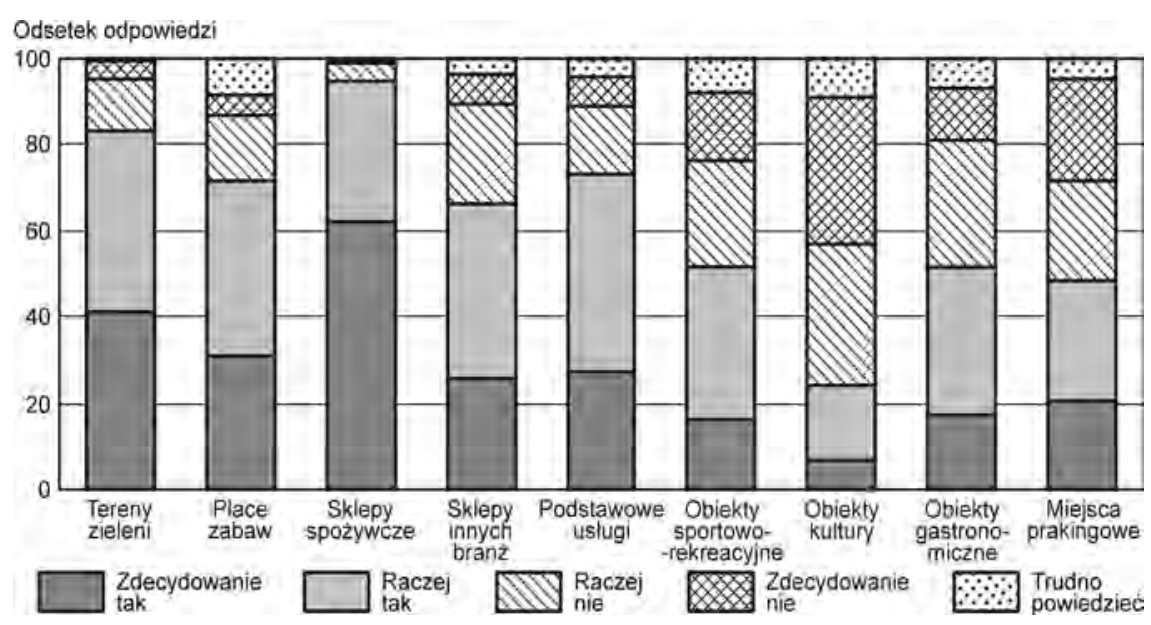

Rys. 42. Ocena wyposażenia osiedli w wybrane elementy zagospodarowania przestrzeni Źródło: opracowanie własne na podstawie badań ankietowych z 2012 r.

ne (66\% usatysfakcjonowanych). Najsłabiej we wszystkich osiedlach ocenione zostało ich wyposażenie w obiekty kultury i miejsca parkingowe. Brak tych ostatnich najbardziej dotyka mieszkańców Dąbrowy oraz Retkini, a najmniej Olechowa oraz Radogoszcza, charakteryzujących się najmniejszym zagęszczeniem zabudowy. Mieszkańcy osiedli najnowszych - Olechowa, Chojen-Zatorze i Radogoszcza-Wschód - najbardziej podkreślali natomiast niedostatek instytucji kultury (rys. 43).

Generalnie, najlepiej w opinii mieszkańców ocenione zostało wyposażenie i zagospodarowanie osiedla Widzew-Wschód (najwięcej odpowiedzi pozytywnych), a najsłabiej Żubardzia, Dąbrowy oraz Zarzewa, czyli osiedli najstarszych, jednak bez wybudowanego w latach 60 . i I połowie lat 70 . Teofilowa. Relatywnie wysoka ocena tego ostatniego pokazała zatem, że okres budowy osiedli jest ważnym lecz nie jedynym czynnikiem decydującym o percepcji ich wyposażenia.

Kolejnym badanym aspektem waloryzacji osiedli była ocena ich połączeń komunikacyjnych z centrum Łodzi oraz z innymi dzielnicami, które respondenci ocenili bardzo wysoko. Połączenia z centrum miasta uznało za dobre lub bardzo dobre blisko $90 \%$ respondentów, a z innymi dzielnicami ponad $95 \%$, przy czym $\mathrm{w}$ tym drugim przypadku mniejszy był udział ocen bardzo dobrych (rys. 44).

Połączenia komunikacyjne najlepiej ocenione zostały przez mieszkańców osiedli zlokalizowanych bliżej centrum, czyli Zarzew i Dąbrowa, a także zlokalizowanych dalej, ale położonych wzdłuż głównych arterii komunikacyjnych miasta, czyli Teofilów, Widzew-Wschód oraz daleki Olechów. Najmniej osób, które uznały, że ich osiedla mają dobre lub bardzo dobre 
połączenia komunikacyjne mieszka w osiedlach Chojny-Zatorze i Radogoszcz-Wschód, nie bardziej niż pozostałe oddalonych od centrum miasta, lecz zlokalizowanych w osi komunikacyjnej północ-południe, która stanowi fragment drogi krajowej nr 1 o bardzo dużym natężeniu ruchu.
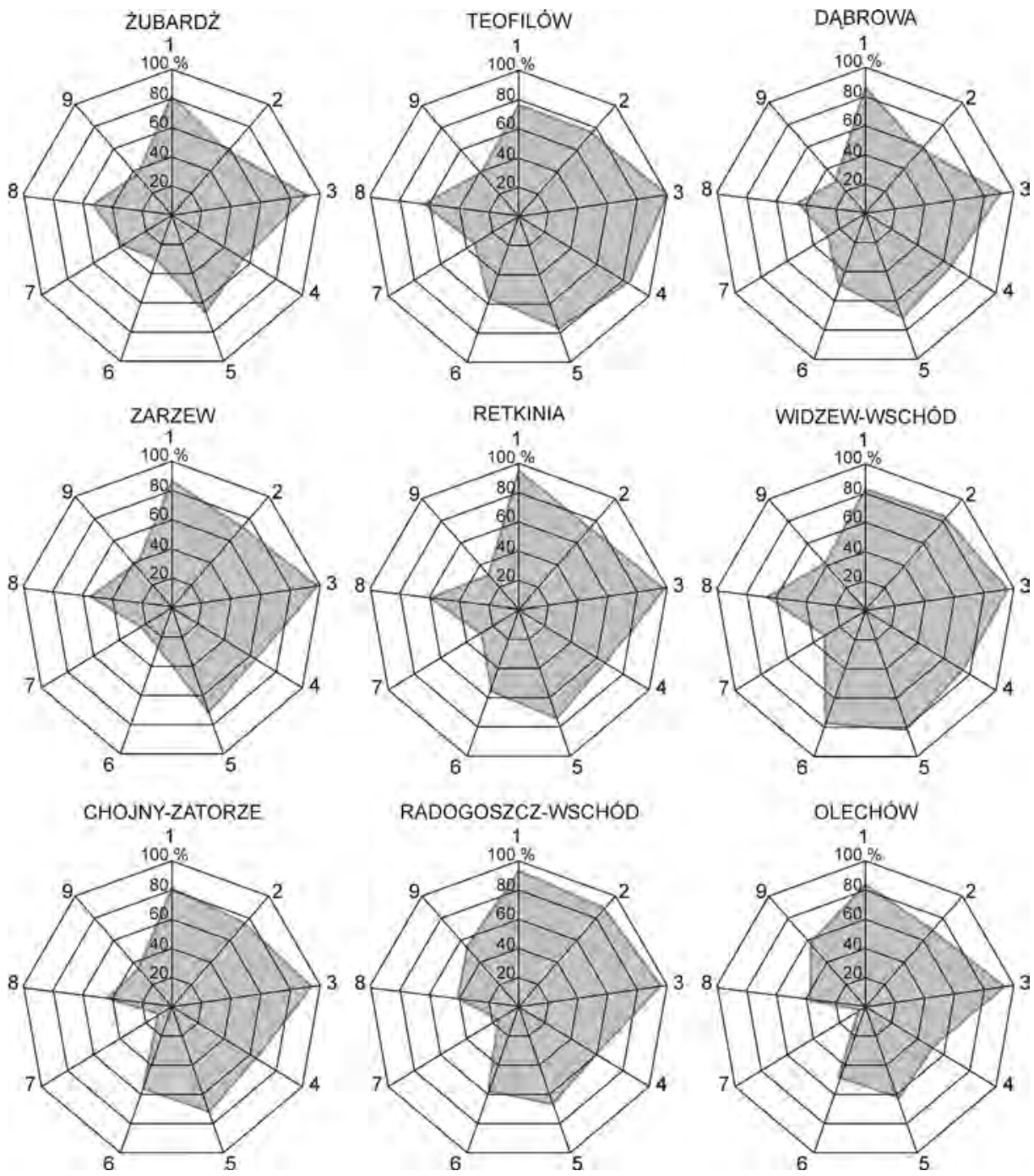

Rys. 43. Ocena wyposażenia poszczególnych osiedli w wybrane elementy zagospodarowania przestrzeni: 1 - tereny zieleni, 2 - place zabaw, 3 - sklepy spożywcze, 4 - sklepy innych branż, 5 - podstawowe usługi, 6 - obiekty sportowo-rekreacyjne,

7 - obiekty kultury, 8 - obiekty gastronomiczne, 9 - miejsca parkingowe.

Wartości na poszczególnych skalach przedstawiają sumę ocen pozytywnych.

Osiedla uporządkowane według okresu budowy

Źródło: opracowanie własne na podstawie badań ankietowych z 2012 r. 


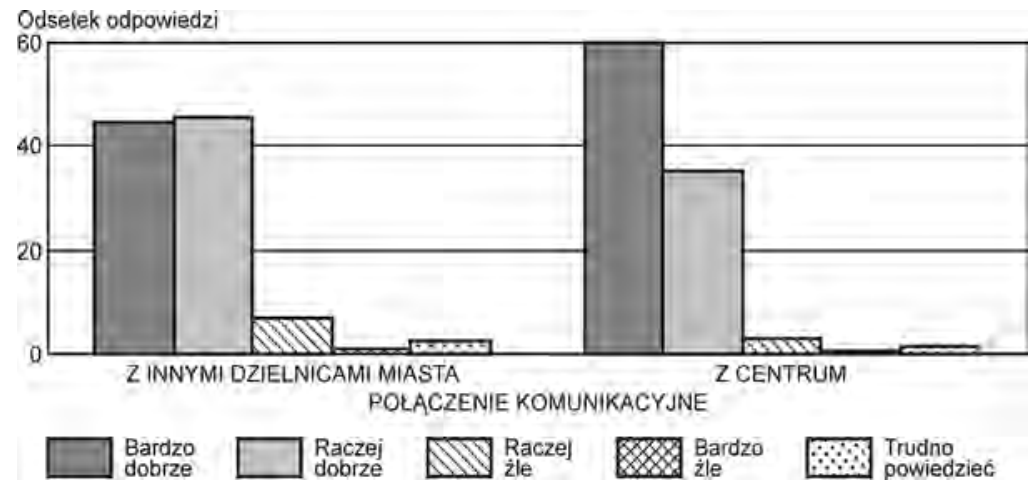

Rys. 44. Ocena połączeń komunikacyjnych osiedli w opinii mieszkańców Źródło: opracowanie własne na podstawie badań ankietowych z 2012 r.

Przeprowadzone badania pokazały również, że relatywnie wysoko, zwłaszcza w konfrontacji ze stereotypem osiedli jako formą zabudowy o niskich walorach wizualnych, ocenione zostały ich czystość, zadbanie, estetyka oraz atrakcyjność. Zmienne te mierzone były przy użyciu siedmiostopniowych skal dyferencjału semantycznego skonstruowanych dla następujących par: brudne - czyste, zaniedbane - zadbane, brzydkie - ładne oraz nieatrakcyjne - atrakcyjne. Uzyskane odpowiedzi potraktowane zostały jako składowe ogólnego stanu wizualnego osiedli, określanego w literaturze jako ład estetyczny. Wyniki pokazały, że zdecydowana większość respondentów wybierała wartości bliskie neutralnym (4) oraz wartości po prawej stronie skali (od 5 do 7), wskazujące na pozytywną ocenę osiedli pod badanymi względami. Średnie wartości uzyskane dla wszystkich osiedli wahają się od 4,73 w ocenie czystości do 4,96 w ocenie ich walorów estetycznych. Najwyżej w każdej ze skal ocenione zostało osiedle Radogoszcz-Wschód, a najniżej Dąbrowa (rys. 45).

Analiza zróżnicowania ocen poszczególnych osiedli w każdej z badanych skal pokazała ich relatywnie nieduże (poza dwoma skrajnie ocenionymi osiedlami) zróżnicowanie przestrzenne oraz wpływ okresu budowy na ocenę. Osiedla nowsze ocenione zostały lepiej niż starsze. Najniższe średnie oceny we wszystkich badanych aspektach uzyskała Dąbrowa, a trzy pozostałe osiedla z tej grupy: Zarzew, Teofilów i Żubardź, ocenione zostały nieco wyżej, lecz podobnie do siebie (z jednym jednakże wyjątkiem, jakim była relatywnie wysoka ocena estetyki osiedla Żubardź). Niemal jednakowo mieszkańcy ocenili także osiedla Retkinia, Widzew-Wschód, Chojny-Zatorze oraz Olechów, czyli z dekady lat 70. i późniejsze. Zdecydowanym liderem natomiast jest osiedle Radogoszcz-Wschód, które we wszystkich badanych aspektach uzyskało ocenę wyższą niż 5 (rys. 46). 


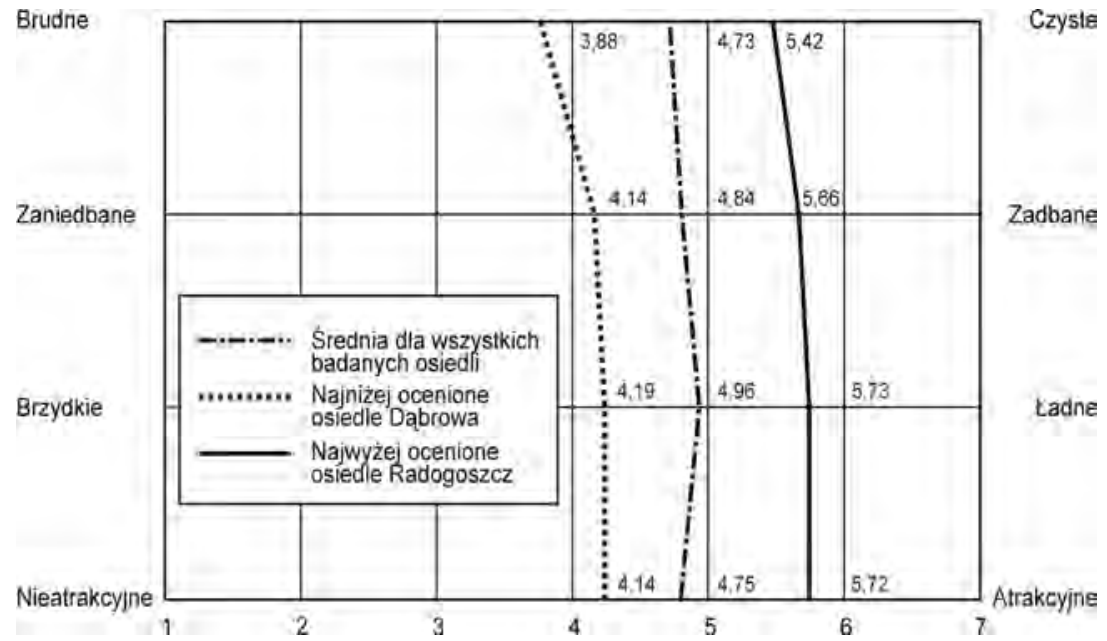

Rys. 45. Ocena osiedli na skalach dyferencjału semantycznego

Źródło: opracowanie własne na podstawie badań ankietowych z 2012 r.

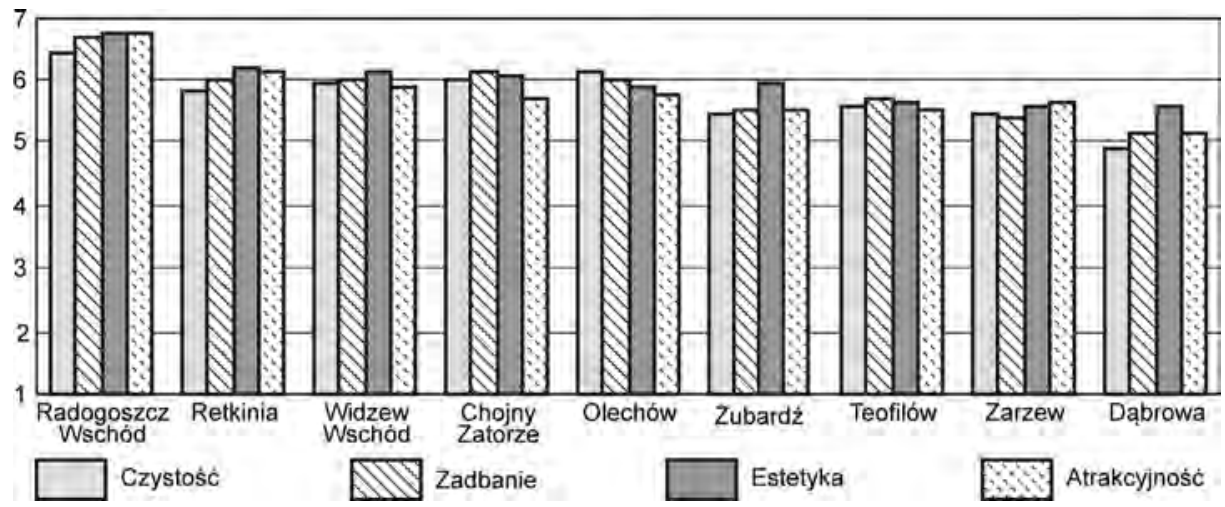

Rys. 46. Ocena ładu estetycznego poszczególnych osiedli mierzona

za pomocą skali dyferencjału semantycznego.

Osiedla uporządkowane według wartości ocen

Źródło: opracowanie własne na podstawie badań ankietowych z 2012 r.

Jednym z niezwykle ważnych aspektów relacji człowieka $\mathrm{z}$ miejscem zamieszkania, jak już powiedziano, jest poczucie bezpieczeństwa rozumiane jako brak zagrożenia przestępczością. Przeprowadzone badania pokazały, że łódzkie osiedla odbierane są jako bezpieczne, ponieważ średnio prawie $3 / 4$ respondentów na pytanie: czy czuje się w swoim osiedlu bezpiecznie? - odpowiedziała twierdząco. Niestety, tylko co czwarty respondent zadeklarował, że czuje się bardzo bezpiecznie, a ponad połowa, że raczej bezpiecznie. 
Analiza zróżnicowania przestrzennego pokazała, że poczucie bezpieczeństwa mieszkańców związane jest $\mathrm{z}$ wiekiem osiedla, ponieważ najwyższe jest w osiedlach najnowszych, Radogoszcz-Wschód i Olechów, gdzie prawie $40 \%$ ankietowanych czuje się bardzo, a ponad połowa raczej bezpiecznie (rys. 47). Najbardziej zagrożeni przestępczością czują się natomiast mieszkańcy Dąbrowy, Teofilowa, Zarzewa i Żubardzia, czyli osiedli z lat 60. i I polowy lat 70.

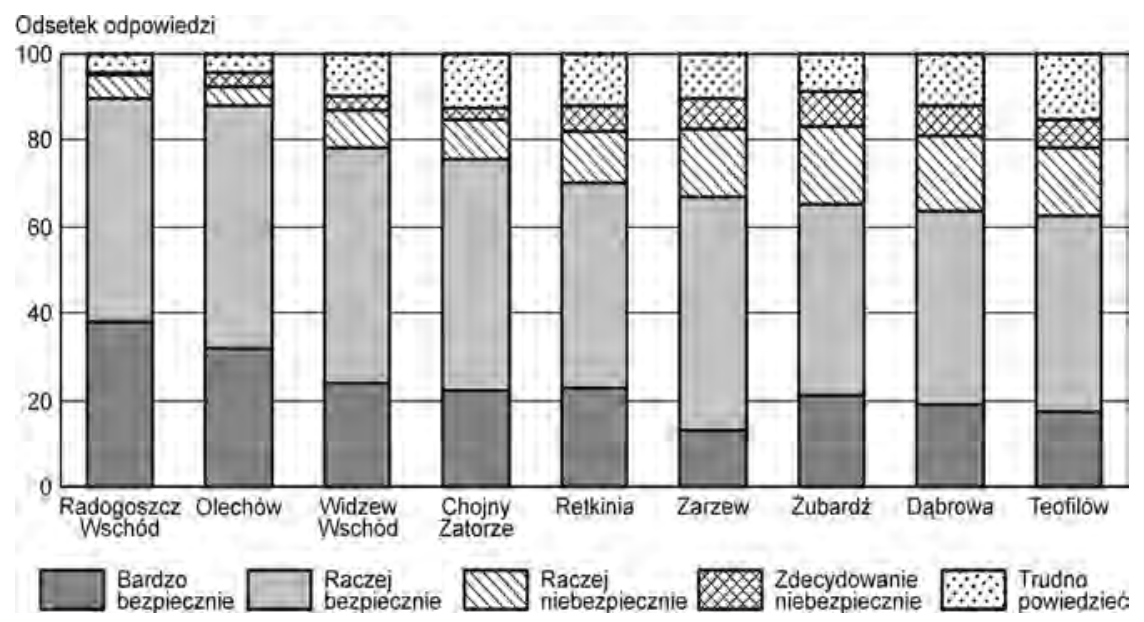

Rys. 47. Poczucie bezpieczeństwa w zamieszkiwanym osiedlu (uporządkowane według udziału deklarujących, że czują się bezpiecznie) Źródło: opracowanie własne na podstawie badań ankietowych z 2012 r.

Kolejna badana zmienna, czyli poziom satysfakcji mieszkaniowej wyrażony jako stopień zadowolenia $\mathrm{z}$ zamieszkiwania $\mathrm{w}$ osiedlu, jak pokazała analiza wyników badań, we wszystkich osiedlach jest bardzo wysoki. Średnio niemal $90 \%$ respondentów odpowiedziało, że są zadowoleni z zamieszkiwania $\mathrm{w}$ osiedlu, $\mathrm{w}$ tym prawie połowa $\mathrm{z}$ nich, że są bardzo zadowoleni. Najwyższą satysfakcję z zamieszkiwania odnotowano w osiedlach najnowszych, tj. Radogoszcz-Wschód i Olechów, gdzie ponad 90\% respondentów stwierdziło, że są bardzo lub raczej zadowoleni (rys. 48). Nieco niższa natomiast, choć również wysoka satysfakcja jest w starszych, z lat 70. - Widzew-Wschód i Retkinia. Zadowolenie z zamieszkiwania w obu tych osiedlach jest na podobnym poziomie, przy czym $w$ pierwszym więcej jest osób bardzo zadowolonych, a w drugim więcej "raczej” zadowolonych. Najmniej usatysfakcjonowani są respondenci z osiedli najstarszych, czyli Zarzewa, Żubardzia, Teofilowa i Dąbrowy.

Preferencje migracyjne badanych wyrażone przez chęć wyprowadzenia się z zamieszkiwanego osiedla wskazują, że średnio ponad $70 \% \mathrm{z}$ nich nie 


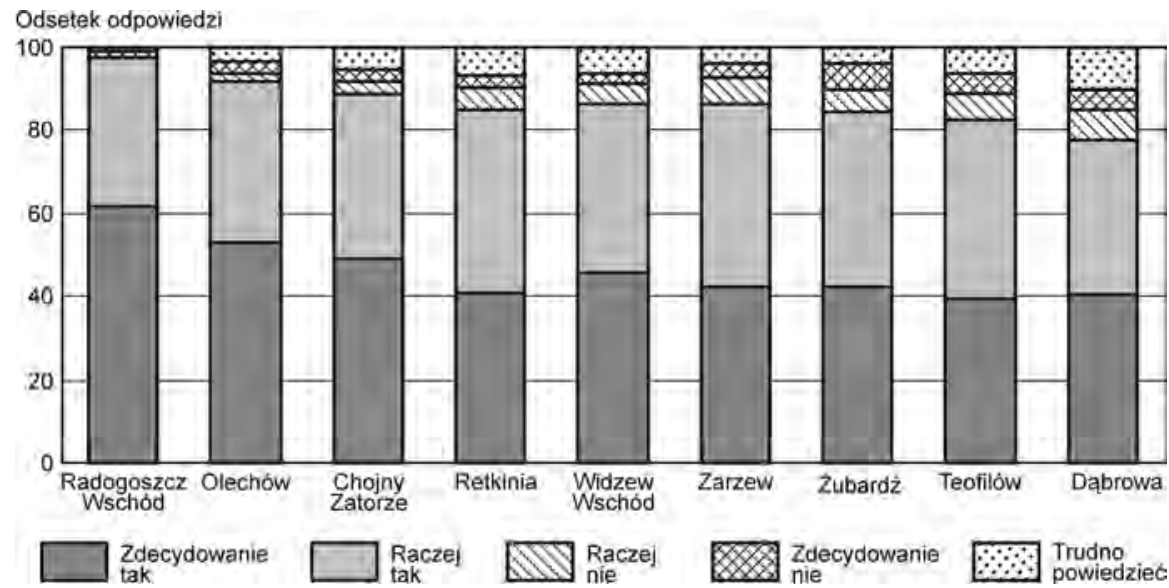

Rys. 48. Poziom satysfakcji z zamieszkiwania w osiedlach (uporządkowany według udziału zdecydowanie i raczej zadowolonych) Źródło: opracowanie własne na podstawie badań ankietowych z 2012 r.

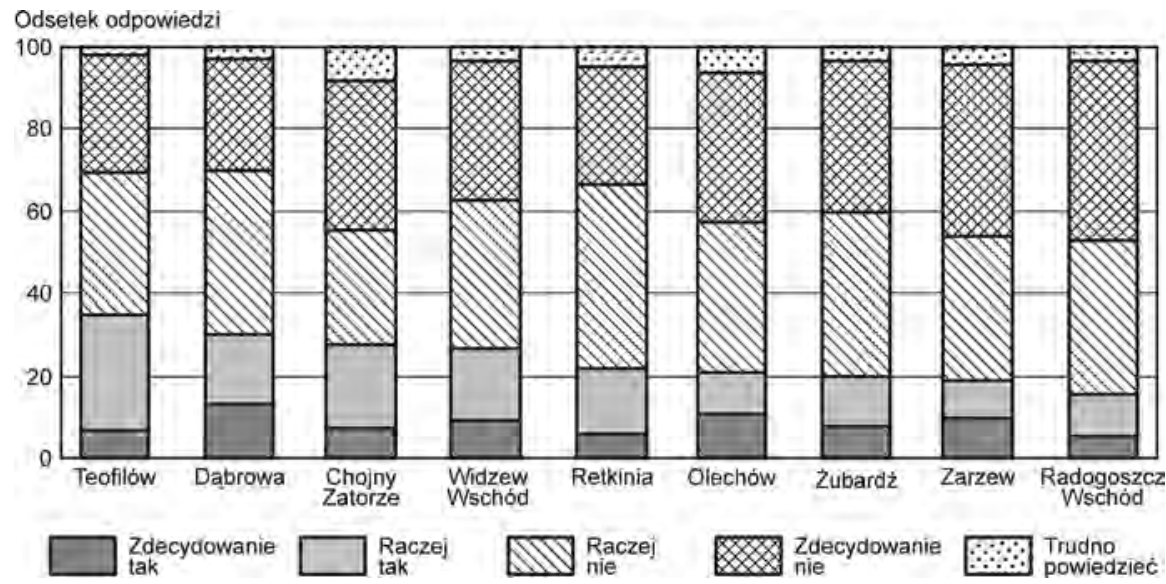

Rys. 49. Chęć wyprowadzenia się z osiedla (uporządkowana według udziału zdecydowanie i raczej chętnych do migracji) Źródło: opracowanie własne na podstawie badań ankietowych z 2012 r.

chciałaby się wyprowadzać (blisko połowa „zdecydowanie nie”, a połowa „raczej nie”). Z analizy zróżnicowania przestrzennego wynika, że największa chęć wyprowadzenia się z osiedla dotyczy mieszkańców Teofilowa oraz Dąbrowy, czyli osiedli z lat 60. i z I połowy lat 70., w których respondenci równocześnie zadeklarowali najniższy poziom satysfakcji mieszkaniowej. Najmniej respondentów natomiast wyraziło chęć wyprowadzenia się z osiedla Radogoszcz-Wschód, które jest jednym $\mathrm{z}$ najmłodszych wśród badanych (rys. 49). oraz ze znacznie starszych osiedli - Żubardź i Zarzew. W przy- 
padku osiedli starszych można to tłumaczyć strukturą wieku respondentów oraz ich długim zamieszkiwaniem i wysokim stopniem zasiedziałości, natomiast w przypadku nowego osiedla Radogoszcz-Wschód prawdopodobnie dużą satysfakcją z oferowanych przez to osiedle warunków zamieszkania.

Jako powody braku chęci wyprowadzenia się respondenci najczęściej podawali zadowolenie z zamieszkania, a także przyzwyczajenie do miejsca, dużą ilość zieleni i odpowiednie wyposażenie osiedla. Ankietowani często odpowiadali, że osiedle jest "przyjemne", „spokojne”, "zadbane”, że mają tu dużo znajomych i „wszystko w zasięgu ręki", oraz używali stwierdzeń typu: "odpowiada mi to osiedle", „lubię tu mieszkać”, ale również „nie lubię zmian”. Ta część respondentów, która wolałaby zmienić miejsce zamieszkania uzasadniała swoje zdanie głównie odmiennymi preferencjami co do rodzaju zabudowy (najczęściej chęcią zamieszkania we własnym domu), potrzebą poprawy warunków mieszkaniowych (kupno większego mieszkania) lub pragnieniem wyprowadzki do innego osiedla, które jest nowsze, ładniejsze, bardziej zadbane. Bardzo nieliczna grupa, około 5\% odpowiedzi, chciałaby wyprowadzić się z powodu „nieodpowiedniego sąsiedztwa".

Biorąc pod uwagę kombinację dwóch analizowanych wcześniej zmiennych, tj. satysfakcji mieszkaniowej oraz chęci wyprowadzenia się, wyodrębniono cztery typy postaw mieszkańców wobec osiedla. Pierwsza z nich obejmuje zadowolonych $\mathrm{z}$ zamieszkiwania $\mathrm{w}$ osiedlu i niechętnych do wyprowadzenia się z niego (usatysfakcjonowani stabilni), druga - niezadowolonych $\mathrm{z}$ zamieszkiwania $\mathrm{w}$ osiedlu, ale mimo to również niechętnych do opuszczenia go (nieusatysfakcjonowani stabilni), trzecia - zadowolonych $\mathrm{z}$ zamieszkiwania $\mathrm{w}$ osiedlu, ale równocześnie deklarujących chęć wyprowadzenia się (usatysfakcjonowani mobilni), a czwarta - niezadowolonych z zamieszkiwania i chcących się wyprowadzić (nieusatysfakcjonowani mobilni). Uzyskane wyniki pokazują, że najliczniejszą grupę tworzą usatysfakcjonowani stabilni, co wiąże się z ogólnym wysokim poziomem satysfakcji z zamieszkiwania i można to zinterpretować jako korzystne z punktu widzenia przyszłości osiedli. Ci natomiast, którzy chcą je opuścić także w większości należą do usatysfakcjonowanych. Na uwagę zasługuje znikomy odsetek osób określanych w pracy S. Musterda i R. van Kempena (2007) jako „uwięzionych”, czyli takich, którzy mimo dyssatysfakcji z zamieszkiwania równocześnie nie przejawiają chęci migracji (tab. 26).

Analiza odpowiedzi uzyskanych na kolejne pytanie - o poczucie emocjonalnego związku z osiedlem - pozwala stwierdzić, że deklarowany stopień przywiązania mieszkańców do osiedla jest wysoki, choć niższy niż stopień satysfakcji mieszkaniowej. Średnio blisko $2 / 3$ respondentów zadeklarowało mniejsze lub większe przywiązanie do swojego osiedla, niemała jednak grupa $(22,5 \%)$ stwierdziła, że nie czuje więzi emocjonalnej z tym 
obszarem. Najsilniejsze związki emocjonalne zadeklarowali mieszkańcy osiedli Radogoszcz-Wschód oraz Widzew-Wschód (rys. 50). Najsłabsze natomiast odnotowano wśród mieszkańców Retkini, będącej największym osiedlem mieszkaniowym w Łodzi, oraz Olechowa, które jest najnowszym $\mathrm{z}$ badanych osiedli, a więc respondenci mieszkają $\mathrm{w}$ nim relatywnie najkrócej.

Tab. 26. Postawy wobec osiedla uwzględniające poziom satysfakcji z zamieszkiwania oraz chęć wyprowadzenia się

\begin{tabular}{|l|c|c|}
\hline \multicolumn{1}{|c|}{ Typy postawa) } & Liczba & Udział w $\%$ \\
\hline Usatysfakcjonowani stabilni & 702 & 70,1 \\
\hline Nieusatysfakcjonowani stabilni & 6 & 0,6 \\
\hline Usatysfakcjonowani mobilni & 157 & 15,7 \\
\hline Nieusatysfakcjonowani mobilni & 54 & 5,4 \\
\hline Niezdecydowani & 83 & 8,3 \\
\hline Suma & 1002 & 100,0 \\
\hline
\end{tabular}

a) Typy skonstruowano w oparciu o sumę odpowiedzi „zdecydowanie” i „raczej” na każde z pytań.

Źródło: opracowanie własne na podstawie badań ankietowych z 2012 r.

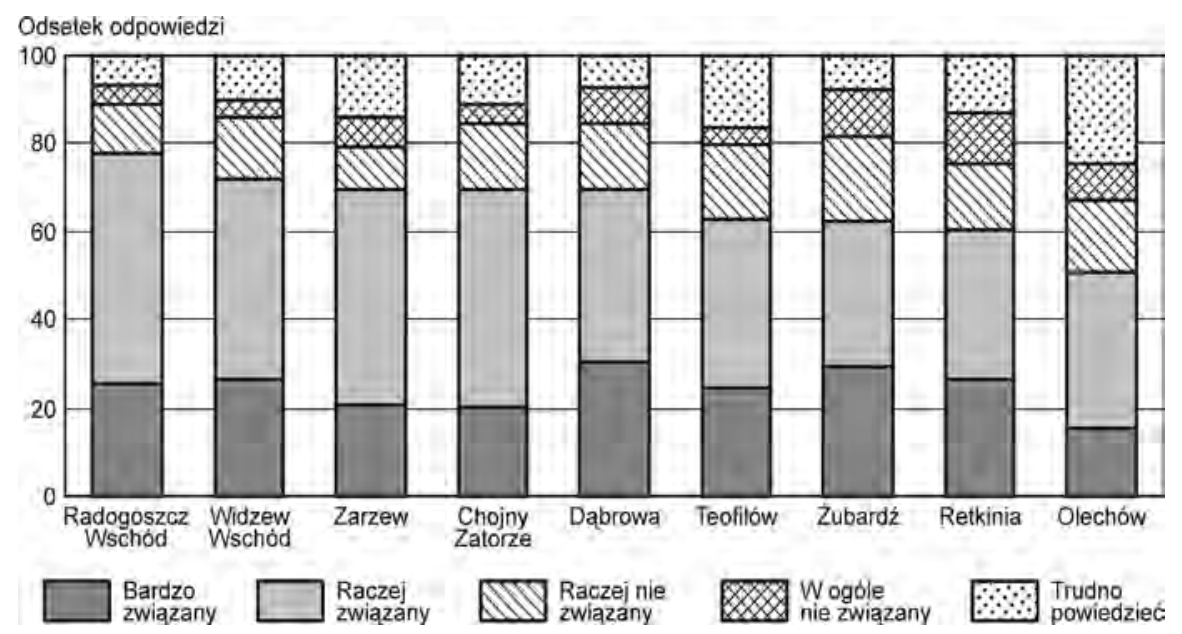

Rys. 50. Poczucie przywiązania emocjonalnego do zamieszkiwanego osiedla (uporządkowane według udziału deklarujących przywiązanie do osiedla) Źródło: opracowanie własne na podstawie badań ankietowych z 2012 r.

Ważnym aspektem więzi z miejscem zamieszkania są relacje społeczne, które tworzą się na bazie wspólnie zamieszkiwanego terytorium, czyli relacje sąsiedzkie. Analiza kontaktów sąsiedzkich w osiedlach dokonana została 
w oparciu o subiektywną ocenę tych kontaktów oraz określenie ich zakresu, czyli liczby sąsiadów, których obejmują, a także ich typu. Za J. Turowskim (1976) w badaniach wyróżniono cztery typy sąsiedztwa cechujące się różnym stopniem społecznego zaangażowania: sąsiedztwo towarzysko-świadczeniowe, które polega na częstych i bliskich kontaktach wkraczających w sferę życia prywatnego, sąsiedztwo znajomościowo-okazjonalne, oparte na okazjonalnych stosunkach społecznych związanych z doraźną pomocą, sąsiedztwo grzecznościowo-konwencjonalne ograniczone do konwencjonalnych gestów i wymiany ukłonów oraz dystansowanie się wobec środowiska sąsiedzkiego, zakładające izolację społeczną.

Analiza pierwszego z badanych aspektów sąsiedztwa, czyli subiektywnej oceny jego jakości, pokazała, że zdecydowana większość badanych (średnio ponad 80\%) oceniła je jako dobre lub bardzo dobre. Opinia ta jest mało zróżnicowana przestrzennie, ponieważ w osiedlu Dąbrowa, w którym relacje te oceniono najniżej i tak ponad $77 \%$ respondentów udzieliło odpowiedzi pozytywnej - „,bardzo” lub „raczej” dobrze (rys. 51).

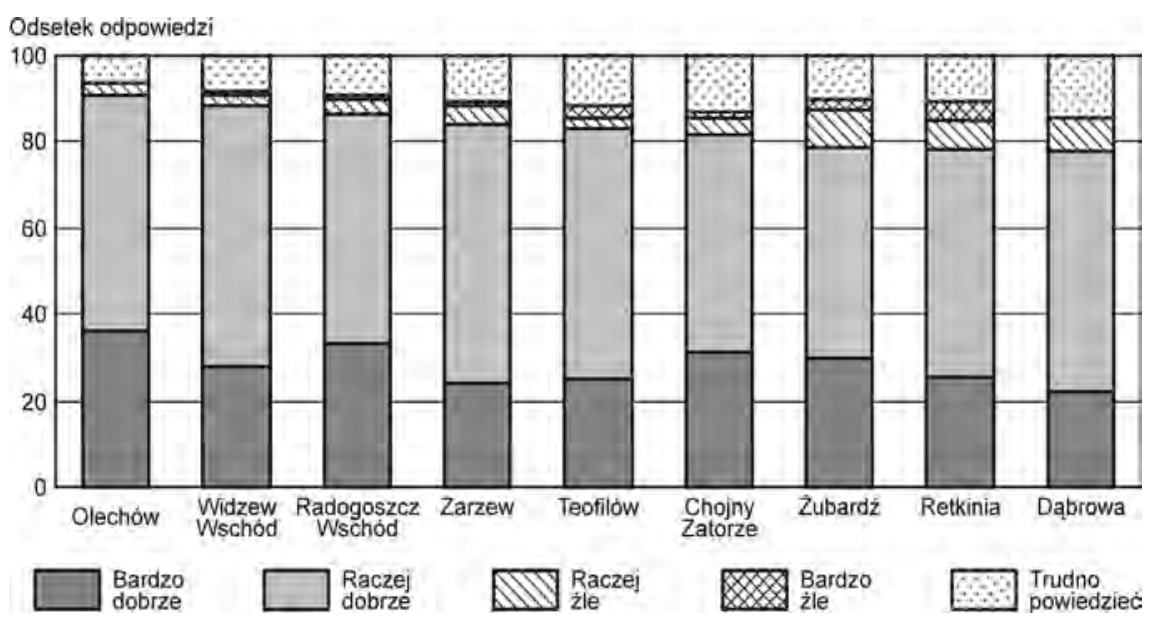

Rys. 51. Ocena stosunków sąsiedzkich w badanych osiedlach (uporządkowana według udziału ocen bardzo dobrych i dobrych) Źródło: opracowanie własne na podstawie badań ankietowych z 2012 r.

Z bliższej analizy więzi sąsiedzkich wynika, że ich forma i zakres w badanych osiedlach jest typowy dla wielkiego miasta (por. Kotus 2007, Bujwicka 2011). Najczęściej praktykowaną formą jest sąsiedztwo grzecznościowo-konwencjonalne ograniczające się do wymiany pozdrowień, w drugiej kolejności natomiast znajomościowo-okazjonalne związane z bliższymi kontaktami podejmowanymi okazjonalnie. Znacznie mniejsza grupa respondentów opisała swoje kontakty z sąsiadami jako zażyłe polegające na czę- 
stych spotkaniach towarzyskich. Najmniejsza grupa natomiast całkowicie dystansuje się od sąsiadów przyjmując postawę izolacji (rys. 52). Rezultaty te znajdują potwierdzenie $w$ innych badaniach prowadzonych zarówno w Łodzi (por. Janiszewska i in. 2011, Szafrańska 2009), jak i w innych miastach postsocjalistycznych, nie tylko w Polsce (por. rozdz. 6).

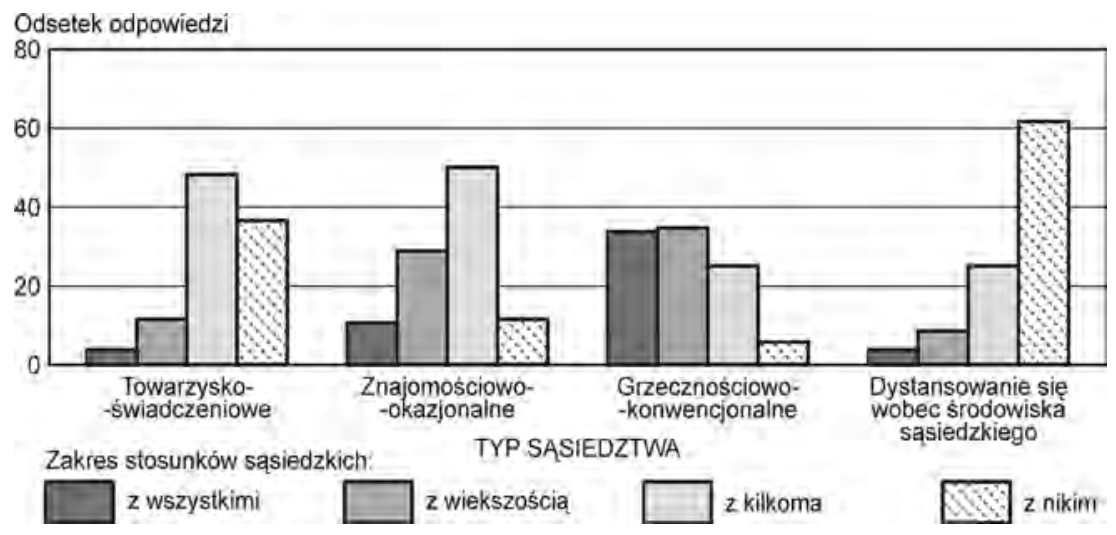

Rys. 52. Typy i zakres stosunków sąsiedzkich w badanych osiedlach Źródło: opracowanie własne na podstawie badań ankietowych z 2012 r.

Kolejnym etapem analizy było określenie determinant wybranych aspektów oceny zamieszkiwanych osiedli i więzi z nimi, które na użytek niniejszych badań podzielono na społeczne, określone przez profil społeczno-demograficzny respondentów i czas zamieszkiwania w osiedlu (hipoteza stratyfikacyjna i hipoteza zakorzenienia lokalnego) oraz mieszkaniowe, określone przez typ zajmowanego mieszkania, formę jego własności i rodzaj zabudowy, w podziale na wysoką i niską (hipoteza warunków mieszkaniowych). W związku z tym, że zmienne te wyrażone są w skali nominalnej i porządkowej, w celu zbadania zależności pomiędzy nimi użyto współczynnika kontyngencji $C$ Pearsona ${ }^{186} \mathrm{w}$ jego skorygowanej wersji $\left(C_{\text {skor }}\right)^{187}$.

Analiza zależności pokazała że cechy społeczno-demograficzne respondentów w większości pozostawały w statystycznie istotnym związku

186 Współczynnik Pearsona $C$ jest miarą opartą na statystyce $\chi^{2}$, która opisuje siłę zależności pomiędzy zmiennymi wyrażonymi w skali nominalnej i porządkowej. Wartości tego wskaźnika zawierają się w przedziale od 0 do 1 (Starzyńska 2000).

187 Współczynnik $C$ teoretycznie zawierający się w przedziale od 0 do 1 nigdy nie przekracza wartości maksymalnej $\left(C_{\max }\right)$, która uzależniona jest od wielkości tablicy kontyngencyjnej. Zatem w celu unormowania tej miary i możliwości porównywania współczynników obliczonych dla tablic o różnej wielkości, oblicza się jego wartość skorygowaną $\left(\mathrm{C}_{\text {skor }}\right)$, którą uwzględnia wielkość tablicy. Wartość $C_{\text {skor }}$ podobnie jak wartość $C$, zawiera się w przedziale od 0 do 1 (Starzyńska 2000). 
z udzielanymi przez nich odpowiedziami, przy czym siła tych zależności była różna (tab. 27). Na opinie respondentów prawie nie miała wpływu ich płeć, zamieszkiwanie $w$ osiedlu od urodzenia ani rodzaj zamieszkiwanej zabudowy (w podziale na wysoką i niską). W większym natomiast stopniu udzielane odpowiedzi modyfikował wiek ankietowanych, ich wykształcenie, status zawodowy i deklarowany stan zamożności, a także długość zamieszkiwania $\mathrm{w}$ osiedlu. Większą satysfakcję z zamieszkiwania w osiedlu i silniejsze do niego przywiązanie, a także lepszą jego ocenę wyrażali respondenci ze starszych grup wiekowych. Nie jest zatem zaskoczeniem, że zmienne te zależne są także od poziomu wykształcenia badanych, ponieważ mieszkańcy z niższym jego poziomem to często osoby starsze. Ocena wyposażenia i ładu estetycznego zamieszkiwanej przestrzeni natomiast w największym stopniu uzależniona była od sytuacji materialnej respondenta oraz długości zamieszkiwania w osiedlu. W tym przypadku im lepsza była sytuacja materialna ankietowanych, tym ocena była bardziej surowa.

Analizę zależności tych samych aspektów oceny zamieszkiwanych osiedli i więzi z nimi przeprowadzono również dla wybranych cech społecznych i urbanistycznych osiedli, wśród których znalazły się: wielkość osiedla mierzona liczbą mieszkań, status społeczny określony udziałem osób z wyższym wykształceniem, poziom starości demograficznej wyrażony udziałem osób po 60. roku życia, wielkość mieszkań w osiedlu mierzona udziałem mieszkań najmniejszych (do $39 \mathrm{~m}^{2}$ ) oraz odległość osiedla do centrum miasta (wyrażona liczbą kilometrów pomiędzy ich punktami centralnymi). Przyjęte do analizy zmienne wyrażone są w skali ilorazowej, toteż korelacje pomiędzy nimi oparto na współczynnik korelacji $r$ Perasona.

Dokonana analiza dowiodła, że cechą, która najsilniej różnicuje postawy mieszkańców wobec osiedli jest ich status społeczny, mierzony udziałem osób z wyższym wykształceniem, a najsłabiej ich wielkość (tab. 28). Status społeczny osiedli wpływa przede wszystkim na zadowolenie z zamieszkiwania w osiedlach i niechęć do migracji, a także na poczucie bezpieczeństwa. Starość demograficzna osiedli natomiast, która - jak pokazano wcześniej - związana jest $\mathrm{z}$ okresem ich budowy, największy wpływ ma na poczucie bezpieczeństwa mieszkańców oraz na ocenę kontaktów sąsiedzkich i zadowolenie z zamieszkiwania w osiedlu.

W świetle poprzednio omówionych wyników pokazujących zróżnicowanie przestrzenne uzyskanych odpowiedzi, wnioski te nie zaskakują. Interesujące jest natomiast to, że demograficzna starość osiedli i związany z nią duży udział małych mieszkań, czyli cechy charakterystyczne dla osiedli najstarszych, budowanych w latach 60 . i w I połowie lat 70., skorelowane są ujemnie z oceną kontaktów sąsiedzkich (wyrażoną odsetkiem bardzo i raczej zadowolonych $\mathrm{w}$ pięciostopniowej skali Likerta). Oznaczałoby to, że kontakty te, choć bardzo dobrze ocenione we wszystkich osiedlach, wcale 


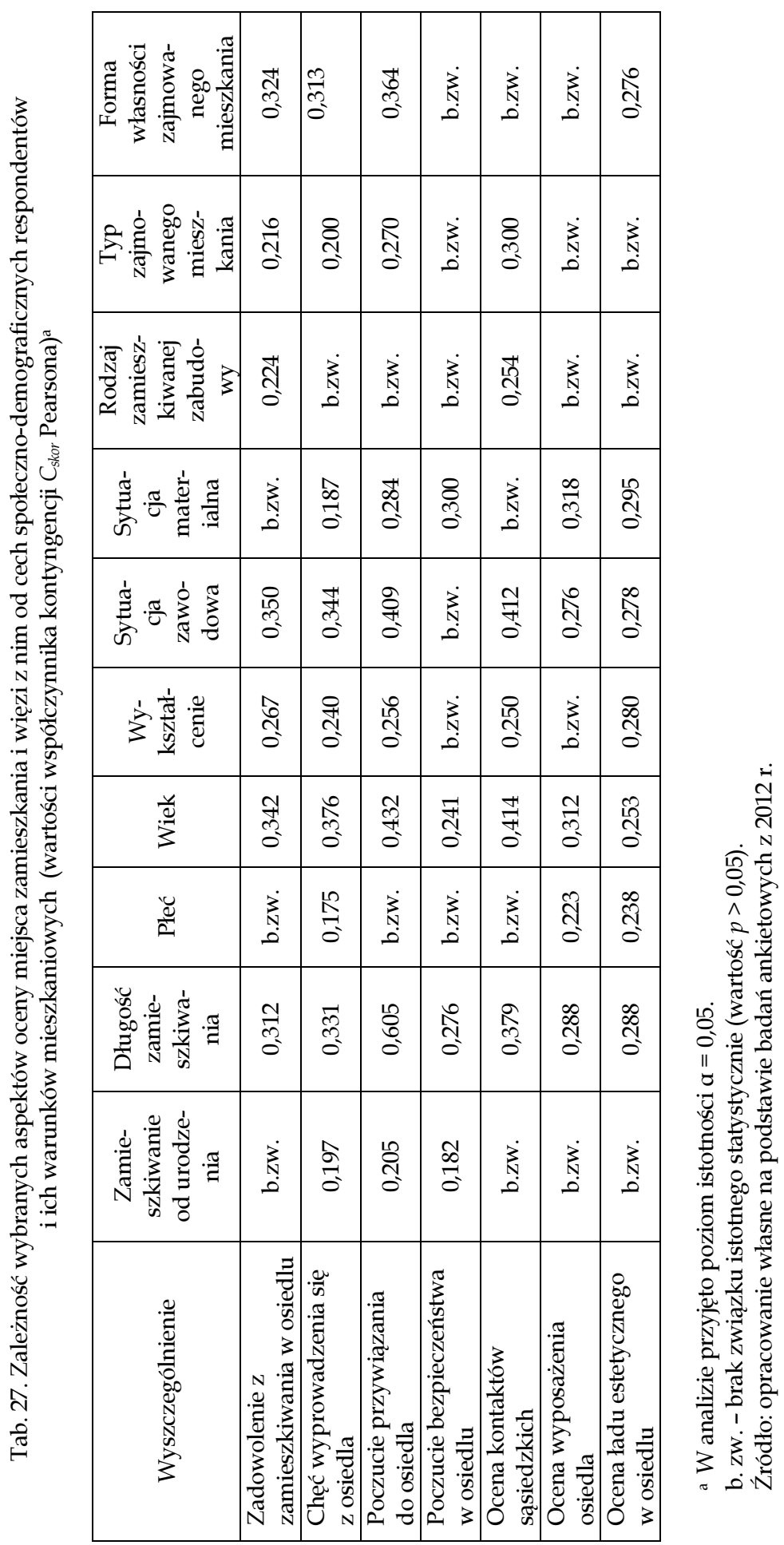


Tab. 28. Zależność wybranych aspektów oceny miejsca zamieszkania i więzi z nim od cech urbanistycznych i społecznych osiedli

(wartości współczynnika korelacji $r$ Pearsona)a

\begin{tabular}{|l|r|r|r|r|c|}
\hline \multirow{2}{*}{ Ocena miejsca zamieszkania } & \multicolumn{5}{|c|}{ Cechy urbanistyczne i społeczne osiedla } \\
\cline { 2 - 6 } & 1 & 2 & 3 & 4 & 5 \\
\hline Zadowolenie z zamieszkiwania w osiedlu & b.zw. & 0,831 & $-0,554$ & $-0,593$ & b.zw. \\
\hline Chęć wyprowadzenia się z osiedla & b.zw. & $-0,637$ & b.zw. & b.zw. & b.zw. \\
\hline Poczucie przywiązania do osiedla & b.zw. & b.zw. & b.zw. & b.zw. & b.zw. \\
\hline Poczucie bezpieczeństwa w osiedlu & b.zw. & 0,647 & $-0,878$ & $-0,839$ & 0,627 \\
\hline Ocena kontaktów sąsiedzkich & $-0,667$ & b.zw. & $-0,574$ & $-0,436$ & 0,506 \\
\hline Ocena wyposażenia osiedla & 0,444 & b.zw. & b.zw. & b.zw & b.zw. \\
\hline Ocena ładu estetycznego w osiedlu & b.zw. & 0,820 & $-0,766$ & $-0,863$ & 0,405 \\
\hline
\end{tabular}

Objaśnienia: 1 - Wielkość osiedla, 2 - Status społeczny osiedla, 3 - Starość demograficzna osiedla, 4 - Udział małych mieszkań w osiedlu, 5 - Odległość osiedla od centrum.

a $W$ analizie przyjęto poziom istotności $\alpha=0,05$.

b.zw. - brak związku istotnego statystycznie (wartość $p>0,05$ ).

Źródło: opracowanie własne na podstawie badań ankietowych z 2012 r.

nie są najlepsze $\mathrm{w}$ osiedlach najstarszych, co wiązać się może z zachodzącą $\mathrm{w}$ nich $\mathrm{w}$ ostatnich latach wyraźnie dostrzegalną wymianą pokoleniową i relatywnie dużym napływem nowych mieszkańców. Ocena tych kontaktów, jak pokazała analiza współczynnika kontyngencji $C, \mathrm{w}$ dużym stopniu jest uzależniona natomiast od indywidualnych cech respondentów, takich jak wiek i sytuacja zawodowa, przy czym najlepiej oceniają je osoby starsze oraz emeryci.

Analiza zależności pokazała także, że deklarowane przywiązanie do osiedli nie jest uwarunkowane ich cechami urbanistycznymi ani społecznymi przyjętymi w badaniu. Silnie natomiast jest $\mathrm{z}$ nimi skorelowane poczucie bezpieczeństwa respondentów. Dotyczy to w szczególności tych cech osiedli, które wynikają z ich wieku. Potwierdza to uzyskane wcześniej wyniki, zgodnie z którymi badani zamieszkujący $\mathrm{w}$ osiedlach najstarszych czuli się najmniej bezpieczni w miejscu zamieszkania.

Reasumując można stwierdzić, że wśród indywidualnych cech respondentów, które najsilniej różnicują postawy mieszkańców wobec zamieszkiwanych osiedli należą wiek i długość zamieszkiwania w osiedlu. Wśród cech społecznych i urbanistycznych charakteryzujących osiedla, największe znaczenie ma natomiast starość demograficzna osiedli, udział w nich małych mieszkań, a także ich status społeczny, czyli cechy związane z okresem ich budowy. Uzyskane w łódzkich osiedlach rezultaty pozwoliły zatem potwierdzić hipotezę zakorzenienia lokalnego, formułowaną $\mathrm{w}$ badaniach postaw wobec miejsca zamieszkania, a także zależność pomiędzy okresem budowy osiedla i jego oceną, generalnie tym lepszą, im nowsze jest osiedle. 


\subsection{Podsumowanie}

Celem rozdziału 7 było prześledzenie rozwoju oraz analiza przemian spolecznych, przestrzennych i funkcjonalnych wielkich osiedli mieszkaniowych w wybranym mieście postsocjalistycznym, jakim jest współczesna Łódź. Analizie poddano również wybrane aspekty percepcji i waloryzacji łódzkich osiedli, które z jednej strony pokazują, jaki jest subiektywny odbiór tych środowisk mieszkaniowych przez mieszkańców, z drugiej zaś stanowią źródło, na podstawie którego prognozować można ich perspektywy. Zaprezentowane $\mathrm{w}$ rozdziale analizy oparte zostały na źródłach zastanych oraz wynikach własnych badań terenowych przeprowadzonych $\mathrm{w}$ dziewięciu największych osiedlach mieszkaniowych Łodzi spełniających kryteria definicyjne przyjęte w pracy.

Przeprowadzona analiza przemian społeczno-demograficznych zachodzących w łódzkich osiedlach po 1990 roku pozwoliła stwierdzić, że do najważniejszych $z$ nich należą depopulacja ${ }^{188}$, starzenie się ludności, wzrost liczby jednoosobowych gospodarstw domowych i spadek udziału osób utrzymujących się z pracy, a zatem procesy charakterystyczne dla przemian ludnościowych zachodzących współcześnie niemal we wszystkich postsocjalistycznych osiedlach mieszkaniowych i większości obszarów zurbanizowanych. Tempo tych przemian $\mathrm{w}$ poszczególnych osiedlach jest zróżnicowane, a jego główną determinantą jest czas ich budowy. Zjawisko to, podobnie jak w innych miastach Europy Środkowo-Wschodniej, jest konsekwencją stosowania przed 1990 roku socjalistycznych regul alokacji mieszkaniowej i planowego zasiedlania nowo budowanych osiedli ludnością zróżnicowaną społecznie, ale dość jednorodną pod względem wieku i struktury gospodarstw domowych. Wpływ na to ma także wciąż niewielka ruchliwość przestrzenna mieszkańców (przed 1990 r. ograniczana przez brak rynku mieszkaniowego, a obecnie przez czynniki ekonomiczne), ponieważ większość $\mathrm{z}$ nich to ci, którzy jako pierwsi zasiedlili swoje mieszkania i mieszkają w nich do dziśs, starzejąc się razem z nimi.

W toku analizy stwierdzono także, że status społeczny łódzkich osiedli (uwzględniając wykształcenie mieszkańców) relatywnie wysoki na tle miasta w okresie socjalizmu nie uległ po 1990 roku znaczącemu obniżeniu. Wzrosło natomiast jego zróżnicowanie i to zarówno pomiędzy poszczególnymi osiedlami, jak i wewnątrz osiedli. A ich obecna pozycja statusowa, podobnie jak struktura demograficzna, uzależniona jest od czasu budowy i generalnie jest tym wyższa, im młodsze jest osiedle. Zróżnicowanie to jest konsekwencją po pierwsze ich struktury demograficznej (niższym pozio-

${ }^{188} \mathrm{Z}$ wyjątkiem intensywnie rozbudowywanego osiedla Olechów. 
mem wykształcenia starszych grup wiekowych), po drugie zaś różnic w warunkach mieszkaniowych jakie oferują te osiedla, szczególnie $\mathrm{w}$ zakresie wielkości i rozplanowania mieszkań, które w kolejnych dekadach okresu realnego socjalizmu ulegały stopniowej poprawie. Było to związane z ewolucją obwiązujących wówczas normatywów mieszkaniowych i urbanistycznych, dzięki którym mieszkania o tej samej strukturze budowane w latach 80. mają powierzchnie średnio o około $20-30 \%$ większe niż mieszkania z lat 60., są bardziej funkcjonalne i ulokowane w zabudowie o mniejszym zagęszczeniu i lepszym rozplanowaniu. Współcześnie decyduje to o wyższej pozycji nowszych osiedli na lokalnym rynku mieszkaniowym. Świadczy o tym zarówno zróżnicowanie cen mieszkań w zależności od okresu budowy osiedla, jak i percepcja oraz waloryzacja poszczególnych osiedli wśród ich mieszkańców - generalnie tym lepsza, im nowsze jest osiedle.

Wpływ na obecną strukturę społeczno-demograficzną i statusową łódzkich osiedli, która w dużej mierze ukształtowana została pod wpływem procesów socjalistycznej alokacji mieszkaniowej, mają także zachodzące po 1990 roku procesy rynkowe. Zainicjowały one uzupełnianie pierwotnej zabudowy mieszkaniowej nową zabudową o wyższym standardzie (wznoszoną głównie przez spółdzielnie mieszkaniowe i deweloperów), czyli proces określany jako redevelopment oraz umożliwiły obrót sprywatyzowanymi mieszkaniami na wtórnym rynku. W latach 90. odnotowano w lódzkich osiedlach również szczególną formę procesu gentryfikacji, związanej z odpływem do zasobów komunalnych grup ludności określanych jako „przegrani transformacji", których w nowych warunkach ustrojowych nie było stać na utrzymanie mieszkań blokowych uzyskanych $\mathrm{w}$ formie przydziału $\mathrm{w}$ okresie socjalizmu i napływem $\mathrm{w}$ ich miejsce ludności o wyższym statusie, która opuszczała tym samym zaniedbane i niszczejące wówczas centrum miasta. Na skutek wymienionych procesów do łódzkich osiedli napłynęła i wciąż napływa ludność młodsza, zamożniejsza i o wyższym poziomie wykształcenia niż dotychczasowi mieszkańcy, co istotnie przyczynia się do zachowania ich relatywnie wysokiego statusu na tle miasta. Dotyczy to, jak już stwierdzono, przede wszystkim osiedli nowszych, budowanych od połowy lat 70. XX wieku, w których proces uzupełniania zabudowy mieszkaniowej zachodzi na większą skalę i które charakteryzują się wyższą atrakcyjnością na wtórnym rynku mieszkaniowym.

Biorąc pod uwagę rynek mieszkaniowy Łodzi status ten w najbliższym czasie może ulec pogorszeniu, ponieważ po 1990 roku, podobnie jak w innych miastach postsocjalistycznych, rozwijają się obszary nowej zabudowy jedno- i wielorodzinnej, powiększają się suburbia oraz realizowane są działania służące rewitalizacji obszarów centralnych i zachodzą związane z nimi, bardzo jeszcze powolne, procesy gentryfikacji tych terenów. Jednak struk- 
tura własności zasobów w wielkich osiedlach, w zdecydowanej większości sprywatyzowanych i podlegających dziedziczeniu oraz obrotowi na wtórnym rynku mieszkaniowym, a także wciąż duży udział przedwojennej substancji mieszkaniowej o niskim standardzie i relatywnie mała zamożność łodzian stanowią czynniki, które - jak można sądzić - w najbliższej przyszłości będą spowalniać ewentualne procesy obniżania się ich statusu.

Analiza przekształceń struktury funkcjonalno-przestrzennej oraz morfologii największych łódzkich osiedli mieszkaniowych pozwoliła stwierdzić, że do najważniejszych i najpowszechniejszych $\mathrm{z}$ nich, podobnie jak $\mathrm{w}$ innych miastach postsocjalistycznych, należą komercjalizacja, sakralizacja oraz poprawa stanu zagospodarowania i pojawienie się nowych przestrzeni publicznych o różnych funkcjach. Procesy te prowadzą do ograniczenia monofunkcyjnego charakteru badanych osiedli przez budowę w nich licznych nowych obiektów handlowo-usługowych, kościołów i terenów rekreacyjnych oraz sportowo-rekreacyjnych, a w konsekwencji przestrzennej dekoncentracji handlu i usług na obszarze osiedli oraz pojawienia się w nich nowych miejsc pracy i miejsc spędzania wolnego czasu. Wymienione zmiany w strukturze przestrzennej wielkich osiedli zachodzą we wszystkich badanych jednostkach, jednak ich intensywność jest większa w osiedlach nowszych, powstałych od połowy lat 70. XX wieku. Wynika to głównie z dostępności terenów wolnych i z mniejszej niż w starszych osiedlach gęstości zabudowy, ale także z cech zamieszkującej tam społeczności: struktury wieku, gospodarstw domowych i statusu społeczno-ekonomicznego mieszkańców, które w osiedlach nowszych i młodszych demograficznie stwarzają większy popyt na bardziej zróżnicowane formy zagospodarowania i wyposażenia osiedla.

Inną ważną grupą przemian stwierdzonych w łódzkich osiedlach jest poprawa stanu i kolorystyki elewacji budynków oraz pojawienie się $\mathrm{w}$ ich przestrzeni nowych dominant wizualnych w postaci obiektów sakralnych, czy też nowych budynków mieszkaniowych i usługowych o zróżnicowanej architekturze. Przemiany te sprawiają, że krajobraz osiedli nie jest już tak monotonny, szary i jednolity jak w okresie socjalizmu. I choć niekiedy nowa kolorystyka budynków lub artystyczny wyraz tych przemian jest kontrowersyjny i pozostawia wiele do życzenia, nie ma wątpliwości, że uczytelniają one przestrzeń osiedlową i przyczyniają się do jej lepszej waloryzacji. Pośrednio zaś mogą przyczyniać się do podniesienia atrakcyjności mieszkaniowej i wzrostu poczucia przywiązania do osiedla oraz zapobiec migracji do innych obszarów miasta.

Integralną częścią przeprowadzonej analizy przemian struktury społecznej i przestrzennej łódzkich osiedli były badania percepcji i waloryzacji przeprowadzone wśród ich mieszkańców. Ich wyniki dowodzą, że atrakcyj- 
ność mieszkaniowa łódzkich osiedli w opinii mieszkańców oceniana jest wysoko. Ankietowani pozytywnie ocenili walory użytkowe i zagospodarowanie osiedli, poza dwoma tylko aspektami, które obejmują wyposażenie ich w miejsca spędzania wolnego czasu oraz miejsca parkingowe. Zaskakująco dobrze oceniona została estetyka osiedli. Mieszkańcy postrzegają je także jako względnie czyste i zadbane. Ważnym wnioskiem $z$ badań jest także deklarowane przez nich relatywnie duże poczucie bezpieczeństwa. Walory społeczne osiedli (biorąc pod uwagę relacje z sąsiadami) również ocenione zostały wysoko, a deklarowana przez nich względnie niewielka zażyłość sąsiedzka jest typowa także dla innych rodzajów zabudowy we współczesnych miastach (zob. rozdział 6). Zdecydowana większość mieszkańców osiedli zdeklarowała, że czuje się z nimi emocjonalnie związana. Respondenci w większości deklarowali też satysfakcję z zamieszkiwania w nich i niechęć do zmiany miejsca zamieszkania. Większość należy do grupy określonej jako "usatysfakcjonowani stabilni", tzn. zadowoleni z zamieszkiwania $\mathrm{w}$ osiedlu i niechętni do wyprowadzenia się z niego.

Badania pokazały również, że osiedla nowsze są lepiej postrzegane i waloryzowane przez mieszkańców niż osiedla starsze. Podłożem tego są, jak już powiedziano, różnice $\mathrm{w}$ ich strukturze społeczno-demograficznej i statusowej oraz warunkach mieszkaniowych będące dziedzictwem poprzedniego ustroju, ponieważ na podstawie analizy zależności stwierdzono, że takie cechy jak wielkość osiedla czy odległość od centrum nie mają wpływu na jego ocenę.

Tak dobra ogólna ocena wielkopłytowych osiedli mieszkaniowych w Łodzi jest jednak uwarunkowana nie tylko lokalnie. Jak można sądzić, głównym jej źródłem (tak jak w innych europejskich miastach postsocjalistycznych) jest szeroki kontekst społeczno-ekonomiczny i kulturowy oraz aktualna sytuacja na krajowym rynku nieruchomości. Te bowiem czynniki silnie determinują możliwości nabywcze gospodarstw domowych, a w konsekwencji wpływają na dobre postrzeganie osiedli blokowych i ich wysoką względną atrakcyjność. Wpływ na ich dobrą ocenę ma również rola i udział tych osiedli w zasobach mieszkaniowych miast, który w Łodzi sięga blisko połowy. $\mathrm{W}$ tej sytuacji, tak jak $\mathrm{w}$ innych miastach postsocjalistycznych, co podkreśla wielu autorów (zob. rozdział 6), zamieszkiwanie w nich wydaje się "mieszkaniową normą" i nie powoduje dysonansu ani poczucia deprywacji mieszkaniowej w świadomości społecznej.

Niewątpliwie jednak wpływ na pozytywną ocenę łódzkich osiedli mają ich rzeczywiste walory, do których należą przede wszystkim dobre wyposażenie $\mathrm{w}$ infrastrukturę społeczną i usługową, duża ilość zieleni, dobra dostępność komunikacyjna, a także relatywnie dobre w porównaniu z innymi obszarami miasta warunki mieszkaniowe. Ten ostatni argument jest 
szczególnie istotny w Łodzi - mieście o dużym udziale starej zdekapitalizowanej substancji mieszkaniowej o niskim standardzie i największym wśród innych wielkich miast polskich udziale zasobów komunalnych. Łódź jest także miastem o relatywnie niskiej, w porównaniu z innych miastami, zamożności mieszkańców, co istotnie może wpływać na poziom ich aspiracji mieszkaniowych i ewaluację aktualnego środowiska mieszkaniowego.

Reasumując należy stwierdzić, że przedstawione $\mathrm{w}$ rozdziale wyniki badań wielkich osiedli mieszkaniowych przeprowadzonych w Łodzi, mimo jej specyfiki, nie odbiegają od rezultatów badań prowadzonych $\mathrm{w}$ innych miastach postsocjalistycznych omówionych $\mathrm{w}$ poprzednich rozdziałach pracy. 



\section{ZAKOŃCZENIE}

Przedmiotem analizy w niniejszej pracy były geneza, rozwój, przemiany i percepcja wielkich osiedli mieszkaniowych o zabudowie blokowej powstałych w II połowie XX wieku, stanowiących najbardziej widoczne i rozległe przestrzennie dziedzictwo socjalizmu we współczesnych miastach postsocjalistycznych. Osiedli, których idea zrodziła się wiele lat przed II wojną światową, głównie w celu zapewnienia minimum egzystencjalnego dla najuboższych, a które na wiele powojennych dziesięcioleci stały się standardem mieszkaniowym dla milionów, niezależnie od ich statusu społecznego i zamożności.

Podjęcie refleksji zarówno teoretycznej, jak i empirycznej dotyczącej wielkich osiedli mieszkaniowych $\mathrm{w}$ mieście postsocjalistycznym uznano za ważne co najmniej z kilku powodów. Po pierwsze osiedla te stanowią bardzo istotny element struktury przestrzennej miast po socjaliźmie, zamieszkiwany przez blisko połowę ich mieszkańców. Po drugie są to obszary, w których po 1990 roku zachodzą daleko idące przemiany, zarówno społeczno-demograficzne, funkcjonalne, jak i morfologiczne. Zmienia się także ich fizjonomia i społeczna percepcja. Po trzecie obszary te są wciąż stosunkowo mało poznane, postrzegane przez pryzmat wielu stereotypów, które należy weryfikować $\mathrm{w}$ badaniach $\mathrm{w}$ różnych skalach przestrzennych i przy użyciu różnych metod. Po czwarte wreszcie, przemiany zachodzące $w$ wielkich osiedlach mieszkaniowych, ich społeczna percepcja oraz pozycja w strukturze społeczno-przestrzennej miast postsocjalistycznych są ważne nie tylko dla przyszłości tej formy zabudowy, ale ze względu na jej rozmiary i znaczący udział w zasobach mieszkaniowych, także dla przyszłości tych miast.

W pracy sformułowano tezę, że ścieżki rozwojowe wielkich osiedli mieszkaniowych oraz ich społeczna percepcja w miastach postsocjalistycznych wykazują daleko idącą specyfikę, która jest konsekwencją wytworzenia się w krajach Europy Centralnej i Wschodniej w II połowie XX wieku szczególnego typu miasta niemającego odpowiednika w innych warunkach ustrojowych. A obserwowane $\mathrm{w}$ nich obecnie, w XXI wieku, procesy nie tylko nie powielają procesów zachodzących $\mathrm{w}$ miastach zachodnioeuropejskich i amerykańskich, lecz przebiegają według własnego unikatowego wzorca, który uwarunkowany jest zarówno dziedzictwem okresu realnego 
socjalizmu, jak i przebiegiem procesów transformacyjnych, na które nakładają się zmiany zachodzące w skali europejskiej oraz globalnej.

Głównymi celami pracy $\mathrm{w}$ warstwie poznawczej, w wymiarze empirycznym, były identyfikacja i analiza przemian społecznych oraz przestrzennych zachodzacych $\mathrm{w}$ wielkich osiedlach mieszkaniowych i określenie poziomu ich społecznej akceptacji, a także rozpoznanie determinant tych procesów w kontekście przemian miasta socjalistycznego w postsocjalistyczne. W wymiarze teoretycznym za cel przyjęto ustalenie czy istnieje jeden wspólny (uniwersalny) wzorzec przekształceń wielkich osiedli mieszkaniowych $\mathrm{w}$ miastach postsocjalistycznych i w jakim stopniu powiela on ścieżki przekształceń wielkich osiedli w miastach zachodnioeuropejskich. W warstwie aplikacyjnej natomiast praca miała być głosem w toczącej się obecnie dyskusji na temat przyszłości wielkich osiedli w miastach po socjalizmie. Aby jednak zbadać i zrozumieć fenomen wielkich osiedli mieszkaniowych we współczesnych miastach, prześledzono genezę tej formy zabudowy oraz jej rozwój w okresie realnego socjalizmu, co znacznie rozszerzyło zakres czasowy pracy poza okres miasta postsocjalistycznego.

Analizy, które pozwoliły na zrealizowanie tak postawionych celów badawczych oparte były na źródłach zastanych oraz szerokich studiach literaturowych, a także na badaniach własnych przeprowadzonych na użytek niniejszej pracy w wybranym mieście postsocjalistycznym, jakim jest współczesna Łódź.

Ustalenia dotyczące genezy i rozwoju wielkich modernistycznych osiedli mieszkaniowych w krajach Europy Centralnej i Wschodniej w II połowie $X X$ wieku pozwoliły stwierdzić, że niespotykana nigdzie indziej masowa skala tej formy zabudowy $w$ miastach socjalistycznych wynikała przede wszystkim ze specyfiki ustroju. I mimo że budowa tych osiedli uwarunkowana była także przez czynniki niespecyficzne dla socjalizmu działające w skali całej Europy, takie jak duże zniszczenia wojenne i wzrost liczby ludności w miastach, który powodował potrzebę szybkiej budowy jak największej liczby mieszkań, to jednak najważniejszą rolę odegrały czynniki ideologiczne i polityczne. Kluczową wśród nich rolę odegrał brak rynku mieszkaniowego zastąpionego przez przyjętą $w$ tym systemie socjalistyczną politykę mieszkaniową. Realizatorzy tej polityki stosując swoisty paternalizm państwa opiekuńczego odgórnie określali najlepszy, ich zdaniem, sposób zaspokojenia potrzeb mieszkaniowych i decydowali o tym kto, jak i gdzie ma mieszkać. Wpisująca się $\mathrm{w}$ ten model budowa wielkich osiedli była rezultatem utopijnych, jak się okazało w praktyce, założeń o możliwości realizacji przyjętej w tym ustroju idei egalitaryzmu i wyrównywania warunków zamieszkania w przestrzeni miejskiej. Duże znaczenie miało również przekonanie, że dostarczony $w$ ten sposób standard jest w stanie zaspokoić potrzeby mieszkaniowe $\mathrm{w}$ miastach $\mathrm{w}$ wymiarze nie tylko ilościowym - cze- 
go w praktyce nigdy nie udało się zrealizować, ale też jakościowym. Nie uwzględniono bowiem ich ewolucji ani indywidualnego charakteru.

W pracy ustalono również, że trajektorie rozwoju wielkich osiedli mieszkaniowych $\mathrm{w}$ miastach socjalistycznych, mimo różnic pomiędzy poszczególnymi krajami, miały wiele cech wspólnych, charakterystycznych dla socjalistycznego modelu mieszkalnictwa, a równocześnie znacząco różniły się od trajektorii rozwoju tej formy zabudowy w miastach krajów zachodnioeuropejskich. Tam bowiem już w latach 70. XX wieku, po krótkim okresie fascynacji modernizmem i zaspokojeniu powojennego głodu mieszkaniowego, zaczęto wycofywać się z budowy wielkich osiedli. Wynikało to głównie z tego, że wraz ze wzrostem zamożności mieszkańców w osiedlach tych zaczęły następować procesy filtracji mieszkaniowej oraz inwazji na te obszary ludności słabszej ekonomicznie i społecznie, które doprowadziły do znacznego obniżenia ich prestiżu mieszkaniowego, a w wielu przypadkach do daleko idącej deterioracji społecznej i urbanistycznej. W miastach socjalistycznych natomiast, w gospodarce permanentnego niedoboru, gdzie proces alokacji mieszkaniowej miał charakter polityczny, a równocześnie nie istniała (lub istniała w niewielkim zakresie) realna perspektywa poprawy warunków mieszkaniowych poza systemem, budowa wielkich osiedli trwała aż do początku lat 90. i zdominowała niemal całe budownictwo mieszkaniowe. To sprawiło, że ich skala w zasobach mieszkaniowych miast oraz status społeczny i prestiż były znacznie wyższe od obserwowanego w krajach zachodnich.

Na podstawie analizy przemian społecznych oraz przestrzennych zachodzących $\mathrm{w}$ wielkich osiedlach mieszkaniowych $\mathrm{w}$ miastach postsocjalistycznych stwierdzono, że nie istnieje jeden wspólny (uniwersalny) ich wzorzec. Przemiany te zachodzą bowiem w różnym tempie w różnych krajach, miastach, a nawet w poszczególnych osiedlach. Różnią się też częstotliwością występowania. Niektóre z nich mają charakter powszechny, inne występują często, lecz nie we wszystkich osiedlach, a niektóre mają charakter incydentalny związany ze specyfiką poszczególnych osiedli lub miast, w których są zlokalizowane. Systematyzacja tych procesów wymaga zatem uwzględnienia różnic w częstotliwości ich występowania (tab. 29). Bliższa analiza tych procesów pozwoliła stwierdzić, że w większości osiedli mają one ten sam kierunek. Różni się jedynie ich tempo.

W toku analiz stwierdzono także, że głównymi determinantami zidentyfikowanych przemian zachodzących $\mathrm{w}$ wielkich osiedlach mieszkaniowych po 1990 roku są zmiany ustrojowe (w tym głównie uwolnienie procesów rynkowych) oraz szeroko rozumiane zmiany cywilizacyjne zachodzące we współczesnym świecie. $W$ znacznie mniejszym stopniu natomiast są one rezultatem działań planowych służących podnoszeniu jakości środowiska mieszkaniowego (określanych w literaturze najczęściej jako modernizacja lub humanizacja osiedli). Ważną zmienną, która wpływa na różnice 


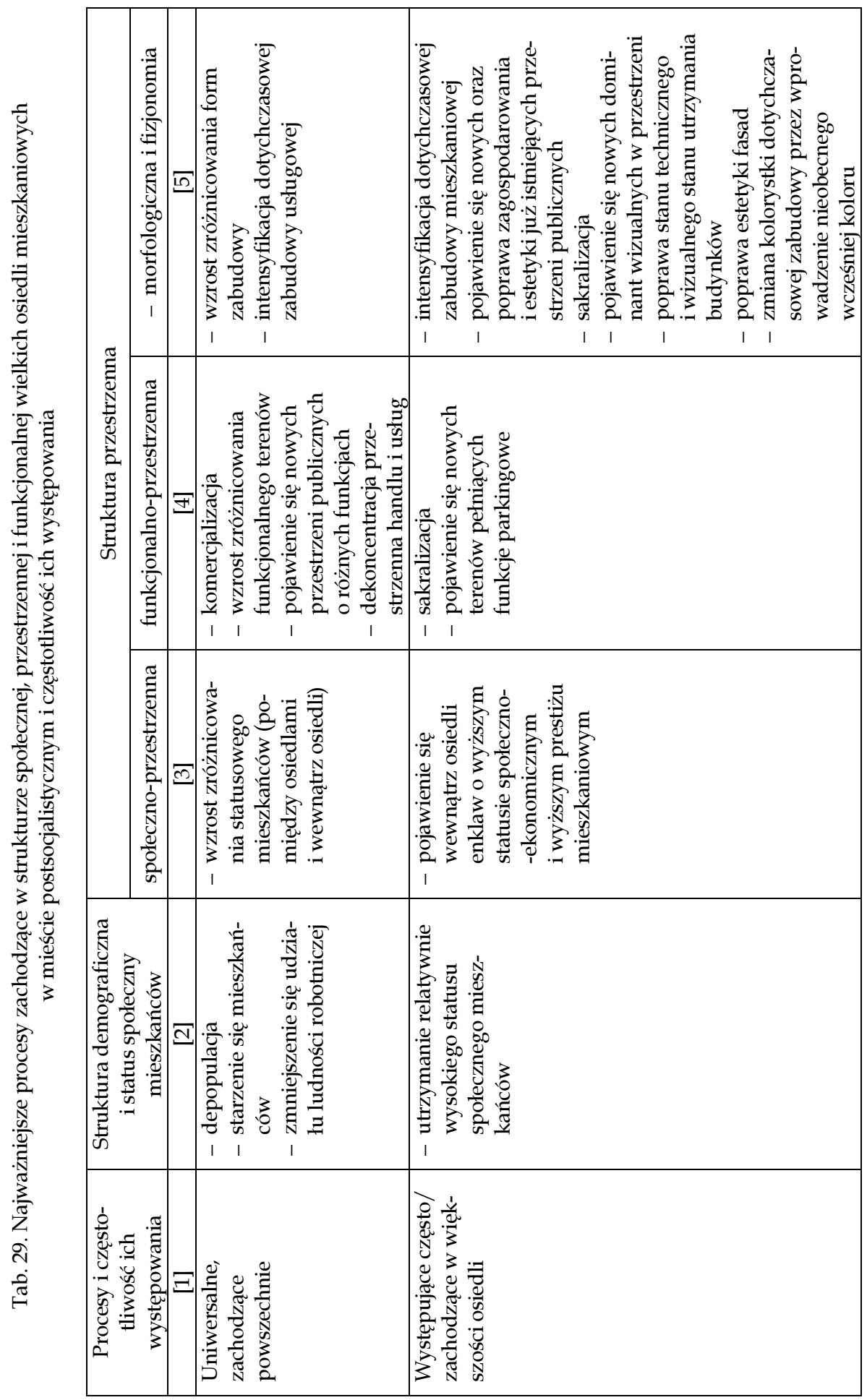




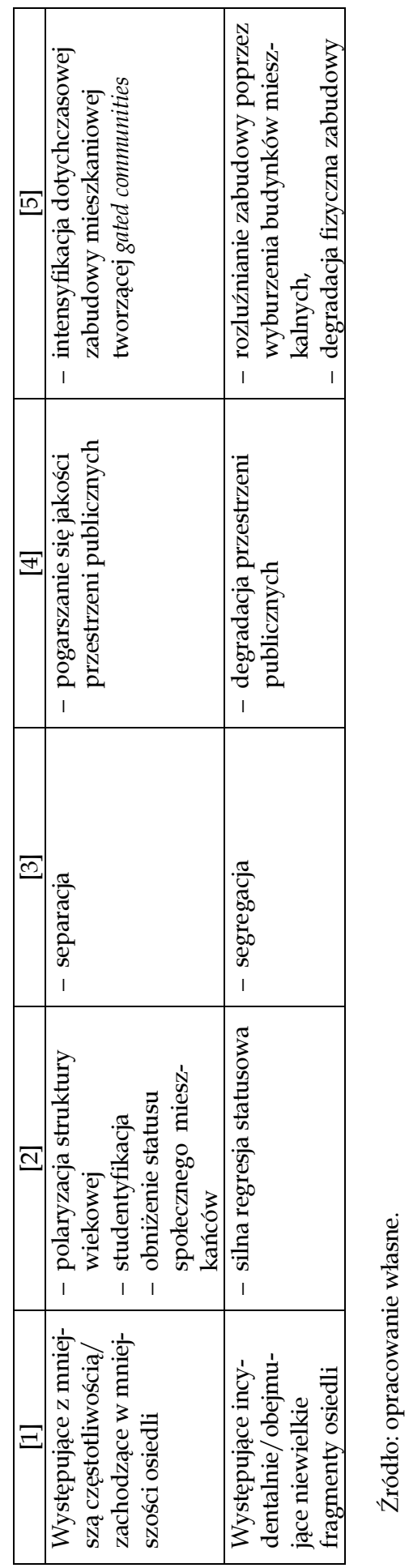


w tempie zachodzenia i kierunku omówionych przemian jest także okres budowy osiedli. To konsekwencja stosowania przed 1990 rokiem socjalistycznych reguł alokacji mieszkaniowej wpisujących się w charakterystyczny dla tego ustroju model mieszkalnictwa, który polegał na planowym zasiedlaniu nowopowstających osiedli ludnością zróżnicowaną społecznie, ale dość jednorodną pod względem wieku i struktury gospodarstw domowych. A w niektórych krajach także okresowym preferowaniu $\mathrm{w}$ dostępie do mieszkań określonych grup ludności, wyodrębnionych w oparciu o inne kryteria (np. ludność robotnicza, elity związane z ówczesną władzą itp.). Duże znaczenie ma także ewoluujący w kolejnych dekadach sposób zagospodarowania osiedli oraz standard oddawanych do użytku mieszkań, najczęściej tym lepszy im później budowane było osiedle.

Analiza przemian struktury społecznej mieszkańców pozwoliła na stwierdzenie, że wielkie osiedla mieszkaniowe w mieście postsocjalistycznym nie tylko nie uległy zapowiadanej w latach 90 . XX wieku degradacji społecznej, ale mimo pewnych symptomów filtracji mieszkaniowej, związanej z odpływem ludności zamożniejszej i o wyższych aspiracjach mieszkaniowych, wiele z nich utrzymało relatywnie wysoki status społeczny i dobrą pozycję $\mathrm{w}$ strukturze społeczno-przestrzennej tych miast. Proces ten, jak pokazały badania, uwarunkowany jest $\mathrm{z}$ jednej strony wciąż relatywnie małą, przeniesioną z poprzedniego ustroju, skłonnością do mobilności rezydencjalnej dotychczasowych mieszkańców osiedli, z drugiej zaś napływem nowych mieszkańców, którzy dziedziczą, wynajmują lub nabywają tu mieszkania i to zarówno na rynku wtórnym, jak i na rynku pierwotnym. Napływający do osiedli nabywcy mieszkań w większości charakteryzują się relatywnie wysokim poziomem wykształcenia i zamożności, a zatem należą do kategorii, którą można określić jako postsocjalistyczna klasa średnia. Jest to głównie tzw. klasa średnia niższa, ale w przypadku nowych aprtamentowców o podwyższonym standardzie i wewnętrznych osiedli grodzonych, także klasa średnia wyższa. W większości są to także osoby młodsze niż ludność dotychczasowa. Tworzą one małe, 1- lub 2-osobowe gospodarstwa domowe lub też niewielkie rodziny nuklearne. Napływ grup o niższym statusie, który w krajach zachodnioeuropejskich przyczyniał się do drastycznego niekiedy obniżenia pozycji osiedli blokowych w strukturze społeczno-przestrzennej miast, jest $\mathrm{w}$ miastach postsocjalistycznych ograniczony przez strukturę własności zasobów mieszkaniowych. Poza miastami b. NRD, w zdecydowanej większości stanowią one bowiem zasób prywatny, podlegający regułom gry rynkowej.

Ustalono także, że nieliczne osiedla lub ich fragmenty, w których zachodzą procesy degradacji społecznej, a w konsekwencji także fizycznej charakterystycznej dla spirali upadku, to głównie obszary, już w okresie powstawania przeznaczone dla uboższych kategorii społecznych, które dziś 
określić można jako „socjalistyczną underclass”. Obszary te, najczęściej stanowiące niewielkie wewnątrzosiedlowe enklawy liczące od kilku do kilkunastu budynków, zasiedlane były przez osoby o niskich kwalifikacjach zawodowych, korzystające $\mathrm{z}$ pomocy społecznej, popadające $\mathrm{w}$ konflikt z prawem, a w niektórych krajach (na Węgrzech i b. Czechosłowacji) ludność romską. To oznacza, że zachodzące $\mathrm{w}$ nich współcześnie negatywne procesy są przede wszystkim konsekwencją socjalistycznej alokacji mieszkaniowej i koncentracji osób pozostających na marginesie społeczeństwa już $\mathrm{w}$ okresie socjalizmu, a w mniejszej mierze przemian transformacyjnych, które jedynie zjawisko to pogłębiły i wydaje się, że także utrwaliły. Zjawiska te dotyczą niewielkiej grupy osiedli, ponieważ - jak już powiedziano - zdecydowana większość z nich charakteryzowała się heterogenicznym, lecz relatywnie dobrym na tle miast, statusem społecznym mieszkańców, który po 1990 roku w większości pozostał zachowany lub nieznacznie obniżył się.

Kolejny ważny wniosek, który pozwala stwierdzić, jak przekształcają się wielkie osiedla po socjaliźmie, wynika $\mathrm{z}$ analizy przemian ich struktury funkcjonalno-przestrzennej i związany jest z przełamaniem dotychczasowego monofunkcyjnego charakteru tych osiedli, określanego też jako stan niedorozwoju funkcji miejskich, który stanowił jedną z najważniejszych ułomności tej formy urbanistycznej. Proces ten określono w pracy jako umiastowienie, ponieważ jeśli jedną z głównych cech wyróżniających przestrzeń miejską jest jej wielofunkcyjność, to wypełnienie tych dotychczas monofunkcyjnych obszarów wieloma różnymi funkcjami sprawia, że stają się one pełnoprawnymi przestrzeniami miejskimi. $\mathrm{W}$ wyniku tego procesu wielkie osiedla mieszkaniowe stały się obszarami, w których zaspokojone mogą zostać wszystkie podstawowe, a nawet niektóre ponadpodstawowe potrzeby mieszkańców. Skala tego zjawiska sprawia, że niektóre osiedla zaczynają przyciągać swą ofertą także mieszkańców innych obszarów miasta. Na skutek tego procesu $\mathrm{w}$ wielkich osiedlach mieszkaniowych powstały liczne nowe miejsca pracy i pojawily się nowe, nieobecne tam dotychczas miejsca spędzania wolnego czasu. Wpływa to na zmianę dziennej ścieżki życia mieszkańców, ponieważ zaspokojenie większości potrzeb może odbywać się w ograniczonej przestrzeni osiedla i nie wymaga przemieszczania się do centrum. A wytworzone na skutek rozwoju nowych funkcji w osiedlach nowe przestrzenie publiczne oraz miejsca, w których mieszkańcy mogą spędzać czas wolny, mimo że nie mają rangi ogólnomiejskiej, to jednak w skali osiedli stanowią ważny element życia społecznego. Tworzą one bowiem, w myśl koncepcji R. Oldenburga (2000), tzw. miejsca trzecie, które po miejscach pracy i miejscach zamieszkania, są zasadniczym tworzywem miasta i ważnym elementem miejskiego stylu życia.

Można zatem stwierdzić, że te nie-miejskie dotychczas obszary, jakimi były socjalistyczne wielkie osiedla mieszkaniowe, w okresie miasta posocja- 
listycznego nabrały cech miejskości. Proces ten określany jako umiastowienie, jak pokazano $\mathrm{w}$ pracy, nie ma charakteru planowego i tylko $\mathrm{w}$ niewielkim stopniu jest wynikiem działań zamierzonych. Tym samym pokazuje sposób, w jaki gospodarka rynkowa weryfikuje modernistyczną zasadę ścisłego strefowania funkcjonalnego miasta zawartą w ideowym manifeście tej formy zabudowy, jakim była Karta Ateńska z 1933 roku. Proces ten przywracając równowagę funkcjonalną $\mathrm{w}$ przestrzeni miejskiej jest zgodny z postulatami tzw. nowego urbanizmu (por. Gzell 2010), który stanowi reakcję na modernizm i wpisuje się w zasady zrównoważonego rozwoju miast. I mimo że truktura przestrzenna tych osiedli jest wciąż daleka od tradycyjnej i taka w większości już pozostanie, jednak poprawa ich ładu funkcjonalnego jest niewątpliwie zmianą zmierzającą w pozytywnym kierunku.

Przeprowadzona $\mathrm{w}$ pracy analiza zmian $\mathrm{w}$ strukturze morfologicznej i fizjonomii osiedli pozwoliła ustalić również, że w wielkich osiedlach mieszkaniowych nastąpiła poprawa estetyki i stanu zagospodarowania publicznych i półpublicznych przestrzeni międzyblokowych. Nastąpiło to poprzez wprowadzenie nieobecnego tu wcześniej koloru, detalu architektonicznego i elementów małej architektury, a także dzięki zagospodarowaniu wolnych dotychczas terenów („przestrzeni niczyich”) i rozwojowi nowej zabudowy o różnych funkcjach oraz odmiennej od otoczenia architekturze. Proces ten anonimowej dotychczas przestrzeni osiedli blokowych nadaje wyrazistości, charakteru i znaczenia, czyli cech niezbędnych dla wytworzenia walorów Tuanowskiego "miejsca”. Poziom zaawansowania tego procesu jest zróżnicowany w poszczególnych osiedlach, ale jak pokazują badania empiryczne prowadzone wśród mieszkańców, jest przez nich dostrzegany. A zmieniając społeczny odbiór tego środowiska mieszkaniowego, wzmacnia identyfikację z nim oraz podnosi jego subiektywną atrakcyjność mieszkaniową, co w przyszłości zapobiec może odpływowi mieszkańców.

Kolejny ważny wniosek sformułowano w oparciu o analizę wyników badań percepcji wielkich osiedli mieszkaniowych, która pokazała, że ich mieszkańców charakteryzuje relatywnie wysoki poziom satysfakcji mieszkaniowej i więź z zamieszkiwanym obszarem oraz słaba skłonność do migracji. Większość $z$ nich wykazuje duże zadowolenie $z$ wyposażenia osiedli $\mathrm{w}$ infrastrukturę handlowo-usługową oraz tereny zielone, dobrze ocenia ich dostępność komunikacyjną, a także dostrzega zmiany zmierzające do poprawy ich zagospodarowania i estetyki. W toku analizy stwierdzono również, że zabudowa blokowa nie jest środowiskiem mieszkaniowym, które charakteryzuje się znacząco większą niż inne typy środowisk anonimowością stosunków w miejscu zamieszkania, ani niechęcią mieszkańców do kontaktów sąsiedzkich czy dążeniem do izolacji. Relacje sąsiedzkie w wielkich osiedlach są zróżnicowane, ale $\mathrm{w}$ wielu $\mathrm{z}$ nich dobre, a nawet bardzo dobre, także w porównaniu z innymi typami współczesnej zabudowy wielkomiej- 
skiej. W badaniach tych stwierdzono również, że mimo istnienia stereotypu niebezpiecznych blokowisk, większość mieszkańców czuje się w nich bezpiecznie.

Do nielicznych negatywnych aspektów tej formy zamieszkiwania, podnoszonych przez mieszkańców niemal wszystkich badanych osiedli, należą zbyt małe powierzchnie mieszkań, a także niedostatek miejsc spędzania wolnego czasu oraz niedobór parkingów. Mieszkańcy, którzy chcą się wyprowadzić najczęściej argumentują swoje zamiary potrzebą posiadania większego lokum lub realizacją marzeń o zamieszkaniu we własnym domu jednorodzinnym, często położonym poza miastem. Najczęściej deklarowane motywy migracji nie wiążą się zatem z działaniem czynników wypychających identyfikowanych $w$ osiedlach krajów zachodnioeuropejskich (np. niski prestiż osiedla, złe otoczenie społeczne, degradacja przestrzeni czy wzrost przestępczości), a raczej z czynnikami obiektywnymi, takimi jak zmiany w cyklu życia rodziny oraz wzrost zamożności, a także pojawienie się, po 1990 roku, nieistniejących wcześniej możliwości realizacji indywidualnych aspiracji mieszkaniowych, które tłumione były w okresie poprzedniego ustroju. Są zatem wynikiem procesów filtracji, ale nie mają skali masowego exodusu mieszkańców zapowiadanego w latach 90. ubiegłego wieku.

Wśród uwarunkowań relatywnie dobrej percepcji i waloryzacji wielkich osiedli największe znaczenie, jak się wydaje, ma szczególny kontekst historyczny oraz geograficzny, w jakim funkcjonują te osiedla, na który składają się społeczno-kulturowa, ekonomiczna i polityczna specyfika miast po socjalizmie. Kontekst ten na skutek urynkowienia mieszkalnictwa po 1990 roku oraz wciąż nie najlepszej kondycji ekonomicznej mieszkańców silnie determinuje możliwości nabywcze gospodarstw domowych, a w konsekwencji wpływa na relatywnie dobre postrzeganie tych obszarów i wysoką ocenę ich atrakcyjności. Duże znaczenie ma także rola i udział tej formy zabudowy w zasobach mieszkaniowych miast, które również mają istotny wpływ na ich percepcję. To co powszechne nie może bowiem stygmatyzować.

Odnosząc dokonane w pracy ustalenia do obecnych w literaturze światowej koncepcji przemian środowisk mieszkaniowych stwierdzić można, że $\mathrm{w}$ wielkich osiedlach miast postsocjalistycznych nie obserwuje się lub obserwuje $\mathrm{w}$ bardzo niewielkim zakresie ( $\mathrm{w}$ bardzo nielicznych osiedlach lub $\mathrm{w}$ ich fragmentach), zjawisko określane jako spirala upadku lub syndrom wielkiego osiedla, czyli procesy silnej i wielopłaszczyznowej degradacji społecznej, fizycznej oraz ekonomicznej typowe dla osiedli w miastach Europy Zachodniej. Nie znalazły w nich także potwierdzenia teorie o charakterze deterministycznym, które źródła problemów w wielkich osiedlach upatrują głównie w ich niskich walorach architektoniczno-urbanistycznych i wadliwym planie zabudowy (por. Newman 1972, Coleman 1985). Jak bowiem wynika z omówionych w pracy badań własnych i ustaleń innych autorów, 
układ przestrzenny osiedli sam $\mathrm{w}$ sobie nie generuje ani negatywnych ani pozytywnych zachowań społecznych (a jeśli tak, to w bardzo niewielkim zakresie), ponieważ występujące $\mathrm{w}$ wielkich osiedlach mieszkaniowych zjawiska patologii społecznej mają różnorodny charakter i wynikają z różnych przesłanek. Przede wszystkim jednak są konsekwencją koncentracji tanich mieszkań subsydiowanych ze środków publicznych i ludności reprezentującej niższe kategorie społeczne oraz dużej rotacji mieszkańców, czyli czynników, które nie występowały w mieście socjalistycznym i nie występują $\mathrm{w}$ postsocjalistycznym, gdzie osiedla te $\mathrm{w}$ zdecydowanej większości obejmują już prywatny zasób mieszkaniowy.

Tym samym można stwierdzić, że zarówno istniejące wcześniej uwarunkowania ustrojowe, które przy zachowaniu tej samej formy urbanistycznej decydowały o zupełnie innym składzie społecznym mieszkańców osiedli, jak i proces transformacji (w tym zwłaszcza szybkie tempo zachodzących zmian i równoczesne nakładanie się nań procesów o charakterze globalnym i europejskim), stanowią dziedzictwo, które ma charakter unikatowy i istotnie determinuje procesy zachodzące $\mathrm{w}$ osiedlach miast postsocjalistycznych, a tym samym odróżnia je od procesów zachodzących w miastach zachodnioeuropejskich.

Uzyskane w toku studiów i analiz wnioski pozwalają stwierdzić, że teza postawiona we wstępie do pracy została potwierdzona. Ścieżki przekształceń wielkich osiedli $\mathrm{w}$ miastach postsocjalistycznych nie tylko nie powielają ścieżek zidentyfikowanych w miastach zachodnioeuropejskich, lecz tworzą odrębny, zróżnicowany wewnętrznie, ale odmienny od zachodnioeuropejskiego, wzorzec przekształceń uwarunkowany zarówno dziedzictwem okresu realnego socjalizmu, jak i przebiegiem procesów transformacyjnych, na które nakładają się procesy zachodzące w skali europejskiej oraz globalnej.

Oryginalność procesów transformacji wielkich osiedli w miastach postocjalistycznych i ich odmienność od procesów zachodzących w krajach zachodnioeuropejskich, dzięki którym osiedla w krajach Europy Środkowo-Wschodniej nie degradują się tak jak osiedla krajów zachodnich, wydaje się być konsekwencją następujących czynników:

- ogromna skala tych osiedli i ich duży udział w zasobach mieszkaniowych miast postsocjalistycznych, sięgający $40 \%$, który decyduje o powszechności tej formy habitatu i traktowaniu jej jako „mieszkaniowej normy";

- przeniesiony z czasów poprzedniego ustroju oraz utrwalony po roku 1990 deficyt mieszkań, obecnie jednak nie o charakterze strukturalnym (jak w okresie miasta socjalistycznego), lecz ekonomicznym;

- zaawansowana prywatyzacja osiedlowych zasobów mieszkaniowych, w niektórych krajach sięgająca ponad 90\%, która jest czynni- 
kiem hamującym skłonności migracyjne i przyczynia się do silniejszej więzi zarówno z własnym mieszkaniem, jak i osiedlem, a w efekcie do większej stabilizacji mieszkaniowej;

- relatywnie wysokie ceny i koszty utrzymania mieszkań w osiedlach blokowych (wyższe niż w zasobach publicznych), często przekraczające możliwości ekonomiczne najuboższych gospodarstw domowych;

- struktura dochodów mieszkańców miast posocjalistycznych i niekorzystna relacja cen mieszkań do przeciętnego wynagrodzenia, które wciąż ograniczają możliwości pełnego zaspokojenia potrzeb mieszkaniowych większości przeciętnie uposażonych gospodarstw domowych i decydują o ich większej stabilizacji przestrzennej;

- wciąż relatywnie dobre warunki mieszkaniowe oferowane w tej formie zabudowy, zwłaszcza $\mathrm{w}$ porównaniu $\mathrm{z}$ istniejącą $\mathrm{w}$ wielu miastach starą substancją mieszkaniową o niskim standardzie;

- dobre i ulegające szybkiej poprawie w dwóch ostatnich dekadach wyposażenie osiedli $\mathrm{w}$ infrastrukturę handlowo-usługową oraz społeczną; duża ilość terenów zielonych, szczególnie w stosunku do często pozbawionych zieleni obszarów gęstej zabudowy śródmiejskiej oraz dobra dostępność komunikacyjna wielu osiedli;

- heterogeniczny, ale wciąż relatywnie dobry status społeczno-ekonomiczny mieszkańców;

- wytworzona w poprzednim ustroju relatywnie niewielka skłonność do ruchliwości przestrzennej, duża zasiedziałość i przyzwyczajenie do miejsca, a w efekcie duża stabilizacja mieszkaniowa,

- znacznie ograniczane w okresie realnego socjalizmu i wciąż niewygórowane aspiracje mieszkaniowe większości mieszkańców miast postsocjalistycznych.

Przedstawione opracowanie prezentuje stan wielkich osiedli mieszkaniowych w mieście postsocjalistycznym w końcu pierwszej dekady XXI wieku. Biorąc jednak pod uwagę, że badane zjawiska mają charakter dynamiczny, studia takie powinny być prowadzone cyklicznie i opierać się na stałym monitoringu zmian społeczno-demograficznych oraz przestrzennych i funkcjonalnych wielkich osiedli mieszkaniowych zarówno zachodzących spontanicznie, jak i będących efektem podejmowanych w nich planowych działań modernizacyjnych. Projektując badania osiedli należy uwzględnić całe dostępne spektrum metod i podejść badawczych, które wzajemnie się uzupełniają i pozwalają weryfikować. Należy także brać pod uwagę różne skale przestrzenne, od europejskiej i krajowej, poprzez miejską aż po skalę pojedynczego osiedla. Ważnym zadaniem wydaje się także stały monitoring postaw i preferencji mieszkańców miast postsocjalistycznych, który pozwoli 
określać ich indywidualne aspiracje mieszkaniowe, które pod wpływem nieustających zmian społeczno-ekonomicznych oraz kulturowych wciąż ewoluują i współcześnie znacznie wykraczają poza aspiracje mieszkańców miast z okresu socjalizmu.

Potrzeba takich badań ma w miastach postsocjalistycznych również wymiar aplikacyjny. Mało bowiem jeszcze zaawansowany proces odnowy wielkich osiedli mieszkaniowych, aby mógł osiągnąć większą skalę i przynieść oczekiwane efekty, wymaga kompleksowej diagnozy stanu tych zasobów w poszczególnych miastach i analizy zachodzących w nich przemian. Niestety częsty brak dostępu do szczegółowych danych statystycznych gromadzonych w skali wewnątrzmiejskiej (głównie w zakresie struktur społecznych) utrudnia takie badania i wymaga prowadzenia badań częściowych.

Przyszłość wielkich osiedli mieszkaniowych $\mathrm{w}$ miastach postsocjalistycznych determinowana będzie przez wiele współzależnych czynników. Należą do nich czynniki egzogeniczne - zewnętrzne w stosunku do osiedli, działające na poziomie globalnym (europejskim), krajowym i lokalnym (miejskim) oraz czynniki endogeniczne - kształtowane przez specyfikę poszczególnych osiedli i zamieszkującej je społeczności (tab. 30). Wymienione determinanty mogą stanowić zarówno szanse, jak i bariery w utrzymaniu dotychczasowej pozycji wielkich osiedli mieszkaniowych w strukturze społeczno-przestrzennej miast i decydować o scenariuszach ich rozwoju. Analiza wymienionych determinant pozwala sformułować trzy takie scenariusze: optymistyczny (utrzymanie dotychczasowej relatywnie dobrej pozycji), umiarkowanie optymistyczny (niewielki spadek ich pozycji) oraz pesymistyczny (rozwój procesów określonych jako spirala upadku). Ostatni scenariusz, w świetle przeprowadzonych badań, wydaje się jednak mało prawdopodobny w ciągu najbliższych 20-30 lat.

Tab. 30. Determinanty przyszłości wielkich osiedli mieszkaniowych w miastach postsocjalistycznych

\begin{tabular}{|l|l|}
\hline $\begin{array}{c}\text { Grupy } \\
\text { determinant }\end{array}$ & Determinanty \\
\hline \multicolumn{2}{|c|}{ Egzogeniczne, działające na poziomie globalnym (europejskim) oraz krajowym } \\
\hline Urbanistyczne & $\begin{array}{l}- \text { rola i udział wielkich osiedli w zasobach mieszkaniowych miast, } \\
\text { pozycja wielkich osiedli mieszkaniowych w strukturze ekologicznej } \\
\text { miast }\end{array}$ \\
\hline $\begin{array}{l}\text { Społeczno- } \\
\text {-demograficzne }\end{array}$ & $\begin{array}{l}\text { liczba i struktura demograficzna ludności w miastach, określająca } \\
\text { ilościowy i jakościowy popyt na zasoby mieszkaniowe, } \\
\text { atrakcyjność migracyjna miast dla migracji krajowych oraz między- } \\
\text { narodowych, a także potencjalna liczba oraz struktura migrantów } \\
\text { i ich presja na zasoby mieszkaniowe w miastach }\end{array}$ \\
\hline
\end{tabular}




\begin{tabular}{|c|c|}
\hline Ekonomiczne & $\begin{array}{l}\text { - po stronie popytowej - poziom zamożności i siła nabywcza i/lub } \\
\text { zdolność kredytowa gospodarstw domowych, } \\
\text { - po stronie podażowej - oferta krajowego rynku nieruchomości i do- } \\
\text { stępność kredytów inwestycyjnych }\end{array}$ \\
\hline Polityczne & $\begin{array}{l}\text { - } \text { krajowa/europejska polityka mieszkaniowa i jej priorytety, } \\
\text { - } \text { obecność i znaczenie w krajowej/europejskiej polityce, mieszkanio- } \\
\text { wej programów modernizacji/humanizacji wielkich osiedli miesz- } \\
\text { kaniowych, } \\
\text { - } \\
\text { - } \\
\text { uporządkowanie kwestii własnościowych w miastach, } \\
\text { mieszkańców w procesach modernizacji/humanizacji osiedli }\end{array}$ \\
\hline $\begin{array}{l}\text { Społeczno- } \\
\text {-kulturowe }\end{array}$ & $\begin{array}{l}\text { - preferencje w zakresie systemu wartości i wzorów rodziny oraz stylu } \\
\text { życia, } \\
\text { - poziom aspiracji mieszkaniowych i skłonność do ruchliwości rezy- } \\
\text { dencjalnej ludności, } \\
\text { - społeczna percepcja pozycji wielkich osiedli mieszkaniowych } \\
\text { w strukturze ekologicznej miast i prestiż tej formy zabudowy }\end{array}$ \\
\hline & Egzogeniczne, działające na poziomie miejskim \\
\hline Urbanistyczne & $\begin{array}{l}\text { - } \text { rola i udział wielkich osiedli w zasobach mieszkaniowych miasta, } \\
\text { - pozycja ośrodka miejskiego w strukturze osadniczej kraju, w tym } \\
\text { szczególna rola miast stołecznych oraz atrakcyjnych migracyjnie, } \\
\text { - warunki zamieszkania oferowane w wielkich osiedlach mieszka- } \\
\text { niowych w relacji do warunków oferowanych w innych formach } \\
\text { zabudowy w mieście }\end{array}$ \\
\hline $\begin{array}{l}\text { Społeczno- } \\
\text {-demograficzne }\end{array}$ & $\begin{array}{l}\text { - liczba i struktura demograficzna ludności w mieście określająca } \\
\text { ilościowy i jakościowy popyt na zasoby mieszkaniowe oferowane } \\
\text { w osiedlach, } \\
\text { - atrakcyjność migracyjna miasta dla migracji krajowych oraz mię- } \\
\text { dzynarodowych a także potencjalna liczba oraz struktura migran- } \\
\text { tów i ich presja na zasoby mieszkaniowe w mieście }\end{array}$ \\
\hline Ekonomiczne & $\begin{array}{l}\text { - po stronie popytowej - poziom zamożności i siła nabywcza i/lub } \\
\text { zdolność kredytowa gospodarstw domowych działających na } \\
\text { lokalnym rynku nieruchomości, } \\
\text { - po stronie podażowej - ilościowa, jakościowa oraz cenowa oferta } \\
\text { lokalnego rynku nieruchomości, a także poziom jej dostosowania do } \\
\text { możliwości nabywczych gospodarstw domowych działających na } \\
\text { lokalnym rynku, } \\
\text { - struktura własności zasobów mieszkaniowych w mieście, w tym } \\
\text { w szczególności struktura własności mieszkań w wielkich osiedlach, } \\
\text { - ceny i koszty utrzymania mieszkań w wielkich osiedlach w relacji do } \\
\text { cen i kosztów utrzymania w innych formach zabudowy }\end{array}$ \\
\hline Polityczne & $\begin{array}{l}\text { - lokalna polityka mieszkaniowa oraz obecność w niej programów } \\
\text { modernizacji/humanizacji wielkich osiedli mieszkaniowych, } \\
\text { - uporządkowanie kwestii własnościowych w mieście, } \\
\text { - wykorzystywanie przez władze lokalne istniejących możliwości } \\
\text { partycypacji mieszkańców w procesach modernizacji/humanizacji } \\
\text { osiedli, } \\
\text { - dostosowywanie wyposażenia osiedli w obiekty infrastruktury } \\
\text { społecznej do zmieniającej się struktury społeczno-demograficznej } \\
\text { mieszkańców (głównie dotyczy to szkół, przedszkoli, instytucji } \\
\text { kultury oraz instytucji adresowanych do osób starszych) }\end{array}$ \\
\hline
\end{tabular}




\begin{tabular}{|c|c|}
\hline $\begin{array}{l}\text { Społeczno- } \\
\text {-kulturowe }\end{array}$ & $\begin{array}{l}\text { - poziom aspiracji mieszkaniowych mieszkańców miasta i skłonność } \\
\text { do ruchliwości rezydencjalnej, } \\
\text { - prestiż tej formy zabudowy i społeczna percepcja jej pozycji struk- } \\
\text { turze ekologicznej miasta }\end{array}$ \\
\hline \multicolumn{2}{|r|}{ Endogeniczne } \\
\hline Urbanistyczne & $\begin{array}{l}\text { - położenie osiedla w przestrzeni miasta i jego dostępność komuni- } \\
\text { kacyjna (w szczególności odległość od linii szynowego transportu } \\
\text { zbiorowego), } \\
\text { - morfologia (wielkość, wysokość i gęstość) oraz obecny stan tech- } \\
\text { niczny zabudowy a także wielkość i struktura mieszkań (cechy te ze } \\
\text { względu na centralistyczne planowanie najczęściej uzależnione są od } \\
\text { okresu budowy osiedla), } \\
\text { - } \text { warunki zamieszkania oferowane w osiedlu, w szczególności } \\
\text { w relacji do warunków oferowanych w innych formach zabudowy } \\
\text { w mieście, } \\
\text { - zakres dotychczas przeprowadzonych i planowanych działań mo- } \\
\text { dernizacyjnych mających na celu odnowę fizyczną osiedla, } \\
\text { - wyposażenie w infrastrukturę handlowo-usługową i społeczną } \\
\text { (w tym dostosowanie jej do aktualnej struktury społeczno-demogra- } \\
\text { ficznej mieszkańców), } \\
\text { - zagospodarowanie i stan utrzymania przestrzeni publicznych oraz } \\
\text { innych przestrzeni wspólnych, } \\
\text { - ilość i stan utrzymania terenów zielonych, } \\
\text { - obecność i liczba pustostanów }\end{array}$ \\
\hline $\begin{array}{l}\text { Społeczno- } \\
\text {-demograficzne }\end{array}$ & $\begin{array}{l}\text { - struktura demograficzna i status społeczno-ekonomiczny miesz- } \\
\text { kańców osiedla }\end{array}$ \\
\hline Polityczne & $\begin{array}{l}\text { - sprawność podmiotów zarządzających osiedlem i ich efektywność } \\
\text { w pozyskiwaniu funduszy zewnętrznych na inwestycje przyczynia- } \\
\text { jące się do modernizacji/humanizacji wielkich osiedli, } \\
\text { - } \text { wykorzystywanie przez podmioty zarządzające osiedlem istnieją- } \\
\text { cych możliwości partycypacji mieszkańców w procesach moderni- } \\
\text { zacji/humanizacji osiedli, }\end{array}$ \\
\hline Ekonomiczne & $\begin{array}{l}\text { - struktura własności zasobów mieszkaniowych w osiedlu, } \\
\text { - ceny i koszty utrzymania mieszkań w osiedlu w relacji do możli- } \\
\text { wości ekonomicznych gospodarstw domowych oraz w relacji do cen } \\
\text { i kosztów utrzymania mieszkań w innych formach zabudowy } \\
\text { w mieście }\end{array}$ \\
\hline $\begin{array}{l}\text { Społeczno- } \\
\text {-kulturowe }\end{array}$ & $\begin{array}{l}\text { - prestiż osiedla i społeczna percepcja jego pozycji w strukturze ekolo- } \\
\text { gicznej miasta, } \\
\text { - poziom identyfikacji z miejscem zamieszkania, który decyduje } \\
\text { o ewentualnych preferencjach migracyjnych oraz określa aktywność } \\
\text { i chęć partycypacji mieszkańców w procesach modernizacji/huma- } \\
\text { nizacji osiedli. }\end{array}$ \\
\hline
\end{tabular}

Źródło: opracowanie własne.

Przyszłość wielkich osiedli mieszkaniowych w krajach postsocjalistycznych pozostaje więc kwestią otwartą. Odwieczny dylemat dotyczący zużytych technicznie lub moralnie zasobów mieszkaniowych - który w skrócie 
wyraża się pytaniem: burzyć czy modernizować? - w przypadku tej formy zabudowy wydaje się mieć oczywistą odpowiedź. O potrzebie modernizacji tych zasobów decyduje wiele czynników. Najważniejsza jak się wydaje jest jednak ich wielka skala oraz obecna sytuacja na rynku mieszkaniowym miast postsocjalistycznych, charakteryzująca się nieustannym niedoborem mieszkań w stosunku do potrzeb (nie tylko ilościowym, ale też jakościowym) oraz wciąż niekorzystną relacją cen mieszkań do dochodów gospodarstw domowych, która dla większości mieszkańców wiąże się z brakiem możliwości satysfakcjonującego zaspokojenia potrzeb mieszkaniowych.

Dalsze badania wielkich osiedli mieszkaniowych powinny uwzględniać zarówno indywidualne potrzeby obecnych oraz potencjalnych mieszkańców, jak i zmiany cywilizacyjne zachodzące we współczesnym świecie, do których należą między innymi starzenie się mieszkańców, wzrost liczby jednoosobowych gospodarstw domowych, malejąca liczba dzieci, wzrost indywidualizacji, zwiększanie się ilości czasu wolnego, wzrost potrzeby bezpieczeństwa, zmiany technologiczne, głównie w sposobie komunikowania się, a także wzrost mobilności przestrzennej.

Pole badawcze przyszłych studiów nad tym zagadnieniem wykracza zatem znacznie poza same osiedla, ale wydaje się to niezbędne, bowiem jak pisał ponad dekadę temu J. Musil (2003, s. 28), miasta postsocjalistyczne funkcjonują w warunkach dwóch jednoczesnych rewolucji: upadku systemu socjalistycznego oraz globalizacji. A proces ich przemian nie jest zwykłą „restauracją" i powrotem do przerwanej na pół wieku ścieżki rozwoju, ale niemającym odpowiednika w historii szczególnym okresem, kiedy najnowsze formy globalnej gospodarki zaszczepia się w społeczeństwach, które przez co najmniej pięć dekad żyły w warunkach odmiennych niż zachodnie. 


\section{Bibliografia}

Adamczewska-Wejchert H., 1985, Kształtowanie zespołów mieszkaniowych, Wyd. Arkady, Warszawa.

Adamus J., 2011, Przemiany przestrzeni publicznej na osiedlach mieszkaniowych w okresie po transformacji systemowej. Studium przypadku - Radogoszcz-Wschód, [w:] I. Jażdżewska (red.), Przestrzeń publiczna miast, XXIV „Konwersatorium Wiedzy o Mieście”, Wyd. Uniwersytetu Łódzkiego, Łódź, s. 201-211.

Adriaanse C., 2007, Measuring residential satisfaction: a residential environmental satisfaction scale (RESS), "Journal of Housing Built Environment", 22, s. 287-304.

Adriaanse C., 2011, On measuring and explaining neighbourhood success. A behavioural economic approach, IOS Press, Amsterdam.

Andersen H.S., 2002, Excluded places: the interaction between segregation, urban decay and deprived neighbourhoods, „Housing. Theory and Society”, 19, s. 153-169.

Andráško I., Lesová P., Kunc J., Tonev P., 2013, Perception of quality of life in Brno housing estates, „Hungarian Geographical Bulletin”, 62 (1), s. 90-101.

Andrusz G., Harloe M., Szelényi I., 1996 (eds.), Cities after Socialism: Urban and Regional Change and Conflict in Post-socialist Societies, Blackwell Publishers, Oxford, Cambridge.

Augé M., 2010, Nie-miejsca. Wprowadzenie do antropologii hipernowoczesności, Wyd. Naukowe PWN, Warszawa.

Bać Z., 1987, Habitat - środowisko mieszkaniowe człowieka, Wyd. Politechniki Wrocławskiej, Wrocław.

Bać Z., 1994, Humanizacja zespołów mieszkaniowych Habitat' 93, Wyd. Politechniki Wrocławskiej, Wrocław.

Baer W., Williamson Ch., 1988, The Filtering of Households and Housing Units, "Journal of Planning Literature", 3, s. 127-152.

Bald K., 2002, Planowanie Łodzi i zagospodarowania przestrzennego miasta w ujęciu historycznym, plansza XLII, [w:] S. Liszewski (red.), Atlas miasta Łodzi, Urząd Miasta Łodzi, Łódzkie Towarzystwo Naukowe, Łódź.

Bańka A., 2002, Społeczna psychologia środowiskowa, Wyd. Naukowe Scholar, Warszawa.

Baranowski K., 1996, Inteligencja łódzka w latach Drugiej Rzeczypospolitej, Wyd. Politechniki Łódzkiej, Łódź.

Bartnicka M., 1986, Percepcja przestrzeni miejskiej Warszawy na przykładzie dzielnicy Ochota, „Przegląd Geograficzny”, 58, 1-2, s. 165-189.

Bartnicka M., 1989, Wyobrażenia przestrzeni miejskiej, IGiPZ PAN, Warszawa.

Bartoszek A., Gruszczyński L., Szczepański M.S., 1997, Miasto i mieszkanie w społecznej świadomości, Wyd. Śląsk, Katowice.

Basista A., 1999, Dlaczego czeka nas odnowa osiedli zwanych blokowiskami?, [w:] Mieszkanie XXI wieku, Wyd. Wydziału Architektury Politechniki Białostockiej, Białystok, s. 196-202.

Basista A., 2001, Betonowe dziedzictwo, Wyd. Naukowe PWN, Warszawa-Kraków.

Bauman Z., 1997, Glokalizacja, czyli komu globalizacja, a komu lokalizacja?, „Studia Socjologiczne", 3, s. 53-60. 
Bauman Z., 2006, Płynna nowoczesność, Wyd. Literackie, Kraków.

Beck U., 2002, Społeczeństwo ryzyka. W drodze do innej nowoczesności, Wyd. Naukowe Scholar, Warszawa.

Beckhoven van E., Bolt G., van Kempen R., 2009, Theories of neighbourhood change and neighbourhood decline: Their signficance for post-WWII large housing estates, [w:] R. Rowlands, S. Musterd., R. van Kempen (eds.) Mass housing in Europe: Multiple faces of development, change and response, Palgrave MacMillan, Basingstoke, s. 20-50.

Benevolo L., 1995, Miasta w dziejach Europy, Oficyna Wydawnicza Volumen, Warszawa.

Berg van den L., Drewett R., Klaassen L.H., Rossi A., Vijverberg C.H.T., 1982, A Study of Growth and Decline, Pegasus, Oxford.

Bernt M., 2007, Neither normalisation, nor decay: Housing estates in Eastern Germany, [w:] B. Komar, B. Kucharczyk-Brus (eds.), Housing and environmental conditions in postcommunist countries, Wyd. Politechniki Śląskiej, Gliwice, s. 41-55.

Bierzyński A., Kozłowska A., 2005, Large housing estates in Poland. Territorial enclosure, privatization of the public space, RESATE, Conference for researchers and policy-makers 1921.05.2005, Ljubljana, Slovenia, http://restate.geo.uu.nl/conference/posterexhibition /Poland1.pdf (dostęp: 18.08.2013).

Blanc M., Stébé J., 2004, France. From dreams to disillusion, [w:] R. Turkington, R. van Kempen, F. Wassenberg (eds.), High-rise Housing in Europe. Current Trends and Future Prospects, Delft University Press, Delft, s. 187-202.

Blunt A., Dowling R., 2006, Home. Key ideas in geography, Routledge, London.

Blunt A., Wills J., 2000, Dissident Geographies: An Introduction to Radical Ideas and Practice, Prentice Hall, Harlow.

Bojar H., 1991, Rodzina i życie rodzinne, [w:] M. Marody (red.), Co nam zostało z tych lat... Społeczeństwo polskie u progu transformacji systemowej, Wyd. Aneks, Londyn, s. 8-37.

Borowik I., 2003, Blokowiska - miejski habitat w oglądzie socjologicznym, Arboretum, Wrocław.

Borowik I., 2007, Kierunki przemian wspótczesnego miasta - suburbanizacja oraz humanizacja blokowisk, [w:] I. Borowik, K. Sztalt (red.), Wspótczesna socjologia miasta. Wielość ogladów i kierunków badawczych dyscypliny, Wyd. Uniwersytetu Wrocławskiego, Wrocław, s. 97-104.

Brukalska B., 1948, Zasady społeczne projektowania osiedli mieszkaniowych, Wyd. Ministerstwa Odbudowy, Warszawa.

Brukalska B., 1962, O rozwoju warunków mieszkaniowych, „Architektura”, 4.

Buckley R., Tsenkova S., 2006, Urban Housing Markets in Transition: New Instruments to Assist the Poor, [w:] S. Tsenkova, Z. Nedovic-Budic (eds.), The Urban Mosaic of Postsocialist Europe, Springer-Verlag, Heidelberg, s. 173-192.

Bujwicka A., 2011, Typy wielkomiejskiego sąsiedztwa. Wyobrażone a praktykowane stosunki sąsiedzkie mieszkańców Łodzi, „Acta Universitatis Lodziensis. Folia Sociologica”, 36, s. 101-119.

Burgess E., 1925, The Growth of the City: An Introduction to a Research Project, [w:] R. Park, E. Burgess, R.D. Mc Kenzie (eds.), The City, University Of Chicago Press, Chicago, s. $47-62$.

Buttimer A., 1969, Social space in interdisciplinary perspective, [w:] E. Jones (ed.), Readings in social geography, Oxford University Press, Oxford, s. 128-138.

Castells M., 1977, The Urban Question. A Marxist Approach, Edward Arnold, London.

Castells M., 1982, Kwestia miejska, PWN, Warszawa.

Cesarski M., 2007, Sytuacja mieszkaniowa w Polsce w latach 1988-2005. Dziedzictwo i przemiany, Wyd. Szkoły Głównej Handlowej, Warszawa. 
Chądzyńska E., 2004, Czynniki wptywające na percepcje $i$ waloryzacje przestrzeni miejskiej przez mieszkańców, [w:] J. Słodczyk (red.), Przemiany struktury przestrzennej miast $w$ sferze funkcjonalnej i społecznej, Wyd. Uniwersytetu Opolskiego, Opole.

Chmielewski J. M., 2001, Teoria urbanistyki w projektowaniu $i$ planowaniu miast, Oficyna Wydawnicza Politechniki Warszawskiej, Warszawa.

Chmielewski J.M., Mirecka M., 2001, Modernizacja osiedli mieszkaniowych, Oficyna Wydawnicza Politechniki Warszawskiej, Warszawa.

Ciesiółka P., 2010, Rehabilitacja zabudowy blokowej na przykładzie osiedla Jana III Sobieskiego w Poznaniu, [w:] I. Jażdżewska (red.), Osiedla blokowe w strukturze przestrzennej miast, XXIII „Konwersatorium Wiedzy o Mieście”, Wyd. Uniwersytetu Łódzkiego, Łódź, s. $89-100$.

Clapham D., 2002, Housing Pathways: A Post Modern Analitical Framework, „Housing. Theory and Society", 19, 2, s. 57-68.

Clark E., 2010, Filtering, [w:] Encyclopedia of Geography, SAGE Publications.

Coleman A. M., 1985, Utopia on trial: Vision and reality in planned housing, Hillary Shipman, London.

Constantin D., 2007, Large housing estates rehabilitation in Central and East European countries in the post-socialist period: Institutional issues in the case of Romania. Asia - Pacific Economic and Business History Conference, University of Sydney, http://jaqm.ro/issues/ volume-1,issue-2/pdfs/constantin.pdf (dostęp: 15.10.2013).

Coudroy de Lille L., 2000, Jak dalece można porównywać miasta europejskie? Refleksje nad procesami i pojecciami na przykładzie osiedli mieszkaniowych we Francji w Polsce, [w:] I. Jażdżewska (red.), Miasto postsocjalistyczne - organizacja przestrzeni miejskiej jej przemian, XIII „Konwersatorium Wiedzy o Mieście”, Wyd. Uniwersytetu Łódzkiego, ŁTN, Łódź, s. 99-112.

Coudroy de Lille L., 2001, Przestrzeń rezydencjalna miasta postsocjalistycznego - próba diagnozy i kierunki rozwoju na przykładzie Warszawy, [w:] I. Jażdżewska (red.), Miasto postsocjalistyczne - organizacja przestrzeni miejskiej i jej przemiany, XIV „Konwersatorium Wiedzy o Mieście”, Wyd. Uniwersytetu Łódzkiego, Łódź, s. 199-208.

Coudroy de Lille L., 2010, Taniec i blokowiska w mieście (przykład Francji), [w:] I. Jażdżewska (red.), Osiedla blokowe w strukturze przestrzennej miast, XXIII „Konwersatorium Wiedzy o Mieście", Wyd. Uniwersytetu Łódzkiego, Łódź, s. 273-285.

Csaba T., 2006, How we really live in panel blocks. Case study on the conditions and potentials of Large Housing Estates in Budapest - for sustainable development, Roeleveld Sikkes Architects, Haga-Budapest.

Csizmady A., 2003, Poverty and Ethnicity in Six Post-socialist Countries, Forum, 19, Berliner Osteuropa Info, s. 3-10.

Czado J., 2012, Możliwości rehabilitacji wielkich zespotów mieszkaniowych na przykładzie wybranych państw zachodnich, „Czasopismo Techniczne. Architektura”, 29, s. 25-38.

Czapiński J., Panek T., 2011, (red.), Diagnoza społeczna 2011. Warunki i jakość życia Polaków, Rada Monitoringu Społecznego, Warszawa.

Czapska J., 2012, (red.), Zapobieganie przestępczości przez kształtowanie przestrzeni, Wyd. Uniwersytetu Jagiellońskiego, Kraków.

Czarnecki W., 2002, Podstawy urbanistyki, Wyższa Szkoła Finansów i Zarządzania w Białymstoku, Białystok.

Czarnek P., 2009, Zasada równości wobec prawa, [w:] D. Dudek (red.), Zasady ustroju III Rzeczypospolitej Polskiej, Wyd. Wolters Kluwer, Warszawa, s. 90-98.

Czekaj K., 2007, Socjologia Szkoty Chicagowskiej i jej recepcja w Polsce, Wyd. Górnośląskiej Wyższej Szkoły Handlowej, Katowice. 
Czepczyński M., 1999, Rozwój i upadek koncepcji osiedli blokowych, [w:] T. Marszał (red.), Budownictwo mieszkaniowe w latach 90. Zróżnicowanie przestrzenne i kierunki rozwoju, Biuletyn KPZK PAN, 190, s. 49-67.

Czepczyński M., 2006, Krajobrazy mieszkaniowe Trójmiasta, [w:] T. Marszał, D. Stawasz (red.), Przestrzeń rezydencjalna w miastach polskich, „Biuletyn KPZK PAN”, 227, s. 55-67.

Czyż T. (red.), 1991, Zróżnicowanie przestrzenne poziomu życia ludności, „Biuletyn KPZK PAN", 153.

Černič Mali B., Sendi R., Boškić R., Filipović M., Goršič N., 2005, Large Housing Estates in Ljubljana and Koper, Slovenia. Opinions of Residents on Recent Developments, Faculty of Geosciences, Utrecht University, Utrecht.

Davidson M., Lees L., 2005, New-bulid "gentrification" and London's riverside renaissance, „Environment and Planning A", 37 (7), s. 1165-1190.

Dekker K., van Kempen R., 2005, Large housing estates in Europe: a contemporary overview, [w:] R. van Kempen, K. Dekker, S. Hall, I. Tosics (eds.), Restructuring Large Housing Estates in European Cities, Policy Press, Bristol, s. 19-46.

Dekker K., van Kempen R., 2009, Resident Satisfaction in Post-WWII Housing Estates, [w:] R. Rowlands, S. Musterd, R. van Kempen (eds.), Mass Housing in Europe, Palgrave Macmillan, s. 53-76.

Dekker K., de Vos S., Musterd S., van Kempen R., 2011, Residential Satisfaction in Housing Estates in European Cities: A Multi-level Research Approach, „Housing Studies”, 26, 4, s. 479-499.

Demko G.J., Regulska J., 1987, Socialism and its impact on urban processes and the city, „Urban Geography", 8, s. 289-292.

Denzin N.K., 2006, Sociological Methods. A Sourcebook, Aldine Transaction.

Dimitrovska Andrews K., 2005, Mastering the post-socialist city: impacts on planning the built environment, [w:] F.E.I. Hamilton, K. Dimitrovska Andrews, N. Pichler-Milanović (eds.), Transformation of Cities in Central and Eastern Europe: Towards Globalization. United Nations University Press, Tokyo, New York, Paris, s. 153-186.

Dimitrovska Andrews K., Černič Mali B., 2004, Slovenia. Effects of privatisation, [w:] R. Turkington, R. van Kempen, F. Wassenberg (eds.), High-rise Housing in Europe. Current Trends and Future Prospects, Delft University Press, Delft, s. 249-264.

Divinský B., 2004, Slovakia. A continuing role for high-rise housing estates, [w:] R.Turkington, R. van Kempen, F. Wassenberg (eds.), High-rise Housing in Europe. Current Trends and Future Prospects, Delft University Press, Delft, s. 215-230.

Dolata M., Kotus J., 2004. Społeczne naznaczanie obszarów miasta, [w:] I. Jażdżewska (red.), Zróżnicowanie warunków życia ludności w mieście, XVII „Konwersatorium Wiedzy o Mieście", Wyd. Uniwersytetu Łódzkiego, Łódź, s. 245-256.

Domański B., Libura H., 1986, Geograficzne badania wyobrażeń, postaw i preferencji, „Przegląd Geograficzny", 58, s. 143-164.

Domański H., 1997, Elementy nowego ładu, Wyd. Instytutu Filozofii i Socjologii PAN, Warszawa.

Domański H., 2002, Główne kierunki zmian w strukturze społecznej, [w:] M. Marody (red.), Wymiary życia społecznego. Polska na przełomie XX i XXI wieku, Wyd. Naukowe Scholar, Warszawa, s. 69-96.

Domański H., 2004, Struktura społeczna, Wyd. Naukowe Scholar, Warszawa.

Downs R.M., 1970, Geographic space perception. Past approaches and future prospects, [w:] C. Board, R.J. Chorley, R. Hagget, D.R. Staddort (eds.), „Progress in Geography”, 2, Edward Arnold, London, s. 65-108. 
Drogi rozwoju. 50-lecie Robotniczej Spótdzielni Mieszkaniowej „Bawełna” w Łodzi, 2008, Robotnicza Spółdzielnia Mieszkaniowa „Bawełna”, Łódź.

Durmanov V., Dubbeling D., 2004, Ukraine. Inheritance of centralised planning, [w:] R. Turkington, R. van Kempen, F. Wassenberg (eds.), High-rise Housing in Europe. Current Trends and Future Prospects, Delft University Press, Delft, s. 203-214.

Dymnicka M., 2007, Osiedla za brama a ciagłość kulturowa i społeczna w kształtowaniu przestrzeni miejskiej, [w:] B. Jałowiecki, W. Łukowski (red.), Gettoizacja polskiej przestrzeni miejskiej, Warszawa, s. 53-72.

Dzieciuchowicz J., 2002, Zasoby mieszkaniowe Łodzi. Rozwój, struktura przedmiotowa i przestrzenna, „Acta Universitatis Lodzienzis. Folia Geographica Socio-Oeconomica” , 4.

Dzieciuchowicz J., 2005, Typologia przestrzenna ustug rynkowych, [w:] J. Dzieciuchowicz (red.), Ustugi rynkowe w Łodzi w dobie transformacji, Wyd. Uniwersytetu Łódzkiego, Łódź, s. 47-64.

Dzieciuchowicz J., 2011, Środowisko mieszkaniowe wielkiego miasta. Przykład Łodzi, Wyd. Uniwersytetu Łódzkiego, Łódź.

Dzeciuchowicz J., Suliborski A., Stolarczyk B., 1972, Warunki mieszkaniowe centrum Kielc w ujęciu przestrzennym, "Zeszyty Naukowe Uniwersytetu Łódzkiego”, 49, s. 37-65.

Dziewoński K., 1990, Koncepcje i metody badawcze z dziedziny osadnictwa, „Prace Geograficzne" IGPiPZ PAN, 154.

Egedy T., 2000, The situation of high-rise housing estates in Hungary, [w:] Z. Kovács (ed.), Hungary Towards the 21st Century - The Human Geography of Transition, Geographical Research Institute HAS, Budapest, s. 169-185.

Enyedi G., 1996, Urbanization under Socialism, [w:] G. Andrusz, M. Harloe, I. Szelényi (eds.), Cities after Socialism. Urban and Regional Change and Conflict in Post-socialist Societies, Blackwell Publishers, Oxford, s. 100-118.

Enyedi G., 1998, Transformation in Central European Postsocialist Cities, [w:] G. Enyedi (ed.) Social Change and Urban Restructuring in Central Europe, Akademiai Kiadó, Budapest, s. 9-34.

Erőss A., 2013, Past and present of large housing estates in Visegrad Countries and Armenia, „Hungarian Geographical Bulletin”, 62 (1), s. 77-82.

French R.A., Hamilton F.E.I., 1979, The Socialist City: Spatial Structure and Urban Policy, John Wiley \& Sons, Chichester.

Frieske K., 2007, Przestępczość w Polsce na przełomie stuleci. Stereotypy i realia, [w:] M. Marody (red.), Wymiary życia społecznego. Polska na przełomie XX $i$ XXI wieku, Wyd. Naukowe Scholar, Warszawa, s. 212-240.

Fuhrmann M., 2008, Człowiek w wielkim osiedlu mieszkaniowym - zjawisko sąsiedztwa czy obojętność?, [w:] Człowiek w mieście. Symbioza, adaptacja, konflikt, Wyd. Elipsa, Warszawa, s. 54-59.

Fuhrmann M., 2009a, Relacje społeczne mieszkańców i ich zwiąki z terytorium a zagospodarowanie przestrzenne osiedli mieszkaniowych, „Prace Geograficzne”, 121, IGiGP Uniwersytetu Jagiellońskiego, Kraków, s. 107-112.

Fuhrman M., 2009b, Związki mieszkańców z terytorium a zagospodarowanie przestrzenne osiedla mieszkaniowego, [w:] I. Jażdżewska (red.), Duże i średnie miasta polskie w okresie transformacji, XXII „Konwersatorium Wiedzy o Mieście”, Wyd. Uniwersytetu Łódzkiego, Łódź, s. 117-125.

Fuhrman M., 2010, Residents' relationship with the territory and the spatial planning of residential housing developments, "Miscellanea Geographica”, 14, s. 265-272.

Gaczek W., 1979, Struktura przestrzeni rezydencjonalnej Poznania. Studium analizy czynnikowej, PWN, Warszawa-Poznań. 
Gaczek W., Rykiel Z., 1999, Nowe lokalizacje mieszkaniowe w przestrzeni miasta, [w:] T. Marszał (red.), Budownictwo mieszkaniowe w latach 90. - zróżnicowanie przestrzenne i kierunki rozwoju, "Biuletyn KPZK PAN”, 190, s. 29-47.

Gądecki J., 2007, Za murami - krytyczna analiza dyskursu na temat osiedli typu gated communities w Polsce, [w:] B. Jałowiecki, W. Łukowski (red.), Gettoizacja polskiej przestrzeni miejskie, Wyd. Naukowe Scholar, Warszawa, s. 87-103.

Gądecki J., 2012, Gentryfikacja starej części Nowej Huty, Wyd. IFIS PAN, Warszawa.

Gehl J., 2009, Życie między budynkami. Użytkowanie przestrzeni publicznych, Wyd. RAM, Kraków.

Geróházi E., Szemző H., 2005, How to improve the inherited bad reputation of a housing Estate: the story of Havanna in Budapest, RESATE, Conference for researchers and policymakers 19-21.05.2005, Ljubljana, http://restate.geo.uu.nl/conference/posterexhibition/Hun gary1.pdf (dostęp: 20.09.2013).

Giddens A., 1990, The Consequences of Modernity, Stanford University Press, Stanford.

Ginsbert A., 1962, Łódź, Studium monograficzne, Wyd. Łódzkie, Łódź.

Gold J.R., 1980, An Introduction to Behavioural Geography, Oxford University Press, London.

Goldzamt E., 1971, Urbanistyka krajów socjalistycznych - problemy społeczne, Arkady, Warszawa.

Gołdyka L., 1976, W sprawie pojęcia przestrzeni społecznej, „Kultura i Społeczeństwo”, 2, s. 193-202.

Gorczyca K., 2009, Wielkie osiedla mieszkaniowe - diagnoza stanu obecnego, podejmowane dziatania rewitalizacyjne, [w:] W. Jarczewski (red.), Przestrzenne aspekty rewitalizacji - śródmieścia, blokowiska, tereny poprzemysłowe, pokolejowe i powojskowe, Rewitalizacja Miast Polskich, t. 4, Instytut Rozwoju Miast, Kraków, s. 89-123.

Gorczyca K., 2010, Przemiany społeczno-przestrzenne na terenie osiedla pracowników Zakładów Azotowych w Tarnowie, [w:] I. Jażdżewska (red.), Osiedla blokowe w strukturze przestrzennej miast, XXIII „Konwersatorium Wiedzy o Mieście”, Wyd. Uniwersytetu Łódzkiego, Łódź, s. 309-319.

Goryński J., 1973, Mieszkanie wczoraj, dziś i jutro, Wyd. Wiedza Powszechna, Warszawa.

Goryński J., 1974, Rozwój budownictwa mieszkaniowego w Łodzi w okresie Polski Ludowej, Materiaty na sesję naukowa: „Wczoraj, dziś i jutro Łodzi”, Łódź.

Gould P.R., 1966, On mental maps, „Discussion Paper", 9, Michigan University.

Górczyńska M., 2008, Percepcja i waloryzacja osiedla mieszkaniowego (na podstawie badań prowadzonych w Warszawie w ramach projektu RESTATE), „Przegląd Geograficzny”, 80, 2, s. 267-287.

Górczyńska M., 2014, Zmiany zróżnicowań społecznych i przestrzennych w wybranych dzielnicach Warszawy $i$ aglomeracji paryskiej: dynamika i aktorzy, „Prace Geograficzne”, 246, IGiPZ PAN, Warszawa.

Grigsby W., 1963, Housing Market and Public Policy, University of Philadelphia Press, Philadelphia.

Grigsby W., Baratz M., Galster G., Maclennan D., 1987, The dynamics of neighborhood change and decline, "Progress in Planning”, 28, s. 1-76.

Groeger L., 2004, Waloryzacja przestrzeni mieszkaniowej w opiniach klientów tódzkich biur obrotu nieruchomościami, Wyd. Uniwersytetu Łódzkiego, Łódź.

Groeger L., 2013, Zróżnicowanie i wartościowanie przestrzeni mieszkaniowej na przykładzie miast województwa tódzkiego, Wyd. Uniwersytetu Łódzkiego, Łódź.

Gronostajska B., 2010a, Zespoły mieszkaniowe z wielkiej płyty w XXI wieku - problemy i perspektywy, "Architecturae et Artibus”, 2, s. 19-26. 
Gronostajska B., 2010b, Oszczędność w ksztattowaniu środowiska mieszkaniowego - modernizacja osiedli z wielkiej ptyty, "Czasopismo Techniczne. Architektura”, 14, s. 127-135.

Grudziński A.,1999, Standard mieszkaniowy w retrospekcji, „Sprawy Mieszkaniowe”, 2-3, IGM, Warszawa.

Grzeszczak J., 2010, Gentryfikacja osadnictwa: charakterystyka, rozwój koncepcji badawczej i przegląd wyjaśnień, IGiPZ PAN, Warszawa.

Guzik R., 2000a, Przestępczość w przestrzeni miejskiej Krakowa w wyobrażeniach jego mieszkańców, [w:] I. Jażdżewska (red.), Miasto postsocjalistyczne - organizacja przestrzeni miejskiej i jej przemiany, XIII „Konwersatorium Wiedzy o Mieście”, Wyd. Uniwersytetu Łódzkiego, Łódzkie Towarzystwo Naukowe, Łódź, s. 201-204.

Guzik R., 2000b, Przestrzenny obraz przestępczości w prasie krakowskiej, „Prace Geograficzne", 106, Instytut Geografii Uniwersytetu Jagiellońskiego, s. 197-216.

Gzell S., 2010, Reurbanizacja: uwarunkowania, „Międzyuczelniane Zeszyty Naukowe. Urbanistyka", Urbanista, Warszawa.

Gzell S., Gruszecka K., Rembarz G., 2009, Osiedle: Reurbanizacja, „Międzyuczelniane Zeszyty Naukowe. Urbanistyka", Urbanista, Warszawa.

Hall E., 1976, Ukryty wymiar, PIW, Warszawa.

Hamilton F.E.I., 1979, Spatial structure of East European cities, [w:] R.A. French, F.E.I. Hamilton (eds.), The Socialist City, Spatial Structure and Urban Policy, John Wiley \& Sons, Chichester, s. 195-262.

Hamilton F.E.I., Dimitrovska Andrews K., Pichler-Milanović N. (eds.), 2005, Transformation of Cities in Central and Eastern Europe: Towards Globalization, UN University Press, New York.

Hamilton M., Hirszowicz M., 1995, Klasy i nierówności społeczne w perspektywie porównawczej, Instytut Studiów Politycznych Polskiej Akademii Nauk, Warszawa.

Harloe M., 1996, Cities in the Transition, [w:] G. Andrusz, M. Harloe, I. Szelényi (eds.), Cities after Socialism. Urban and Regional Change and Conflict in Post-socialist Societies, Blackwell Publishers, Oxford, s. 1-29.

Harris Ch.D., Ullman E.L., 1945, The Nature of Cities, „The Annals of the American Academy of Political and Social Science", 242, 1, s. 7-17.

Harvey D., 1973, Social Justice and the City, Edward Arnold, London.

Harvey D., 1975, Class structure in a capitalist society and the theory of residential differentiation, [w:] M. Chisholm, R. Peel, P. Haggett (eds.), Processes in Physical and Human Geography, Heinemann, Edinburgh, s. 354-372.

Hegedús J., Tosics I., 1996, The Disintegration of the East European Housing Model, [w:] D. Clapham, J. Hegedús, K. Kintrea, I. Tosics (eds.), Housing Privatization in Eastern Europe, Greenwood Press, Westport, s. 15-40.

Hegedús J., Tosics I., 1998, Towards new models of the housing system, [w:] G. Enyedi (ed.) Social Change and Urban Restructuring in Central Europe, Akadémiai Kiadó, Budapest, s. 137-168.

Heidegger M., 1977, Budować, mieszkać, myśleć, Czytelnik, Warszawa.

Hidalgo M.C., Hernández B., 2001, Place Atachment: Conceptual and Empirical Questions, "Journal of Environmental Psychology", 21, s. 273-281.

Howard E., 1902, Garden Cities of Tomorrow, (reprint z 1985 r.), Attic Books, Eastbourne.

Hoyt H., 1939, The Structure and Growth of Residential Neighbourhoods in American Cities, Federal Housing Administration, Washington.

Ilnicki D., 2001, Inwestycje mieszkaniowe w przestrzeni Wrocławia, [w:] I. Jażdżewska (red.), Miasto postsocjalistyczne - organizacja przestrzeni miejskiej i jej przemiany, XIV „Konwersatorium Wiedzy o Mieście”, Wyd. Uniwersytetu Łódzkiego, Łódź, s. 221-235. 
Ilnicki D., 2003, Zmiany i przestrzenne zróżnicowanie budownictwa mieszkaniowego w Polsce w latach dziewięćdziesiątych, [w:] T. Marszał (red.), Budownictwo w przestrzeni lokalnej, Wyd. Uniwersytetu Łódzkiego, Łódź s. 7-22.

Ilnicki D., 2006, Rozwój przestrzeni rezydencjalnej Wrocławia, [w:] T. Marszał, D. Stawasz (red.), Przestrzeń rezydencjalna w miastach polskich, „Biuletyn KPZK PAN”, z. 227, s. 36-54.

Jacobs J., 1961, The Death and Life of Great American Cities, Random House, New York.

Jadach-Sepioło A., 2009, Gentryfikacja w kontekście rewitalizacji, [w:] A. Zborowski (red.), Demograficzne i spoteczne uwarunkowania rewitalizacji miast w Polsce, Instytut Rozwoju Miast, Kraków, s. 125-135.

Jakóbczyk-Gryszkiewicz J. (red.), 2012, Procesy gentryfikacji w mieście, cz. I, XXV „Konwersatorium Wiedzy o Mieście", Wyd. Uniwersytetu Łódzkiego, Łódź.

Jakóbczyk-Gryszkiewicz J. (red.), 2013, Procesy gentryfikacji, cz. II, XXVI „Konwersatorium Wiedzy o Mieście", Wyd. Uniwersytetu Łódzkiego, Łódź.

Jakóbczyk-Gryszkiewicz J., 2013, Procesy studentyfikacji w Łodzi, [w:] J. Jakóbczyk-Gryszkiewicz (red.), Procesy gentryfikacji, cz. II, XXVI „Konwersatorium Wiedzy o Mieście", Wyd. Uniwersytetu Łódzkiego, Łódź, s. 95-107.

Jakóbczyk-Gryszkiewicz J., Marcińczak Sz., Wolaniuk A., 2014, Gentrification processes in the city, [w:] Society and space in contemporary Poland in Eódz University geographical research, praca zbiorowa, Wyd. Uniwersytetu Łódzkiego, Łódź, s. 83-111.

Jałowiecki B., 1968, Osiedle i miasto, Wyd. Arkady, Warszawa.

Jałowiecki B., 1980, Człowiek w przestrzeni miasta, Śląski Instytut Naukowy, Katowice.

Jałowiecki B., 1991, Lekcja blokowisk (przedmowa), [w:] Miasto socjalistyczne i świat społeczny jego mieszkańców, „Rozwój Regionalny - Rozwój Lokalny - Samorząd Terytorialny”, 32, Wyd. EIRRiL Uniwersytetu Warszawskiego, Warszawa, s. 5-11.

Jałowiecki B., 1994, Miasto socjalistyczne jako skansen urbanistyki XX wieku, [w:] E. Kaltenberg-Kwiatkowska (red.), Miasta polskie w dwusetlecie prawa o miastach, Polskie Towarzystwo Socjologiczne, Warszawa, s. 39-45.

Jałowiecki B., 1995, Miasto polskie - między utopia a rzeczywistością, [w:] P. Starosta (red.), Zbiorowości terytorialne i więzi społeczne, Wyd. Uniwersytetu Łódzkiego, Łódź, s. 36-43.

Jałowiecki B., 2010, Społeczne wytwarzanie przestrzeni, Wyd. Naukowe Scholar, Warszawa.

Jałowiecki B., Łukowski W. (red.), 2007, Gettoizacja polskiej przestrzeni miejskiej, Wyd. Naukowe Scholar, Warszawa.

Jałowiecki B., Sekuła E., Smętkowski M., Tucholska A. (red.), 2009, Warszawa. Czyje jest miasto?, Wyd. Naukowe Scholar, Warszawa.

Jałowiecki B., Szczepański M.S., 2006, Miasto i przestrzeń w perspektywie socjologicznej, Wyd. Naukowe Scholar, Warszawa.

Janiszewska A., Klima E., Rochmińska A., 2010, Sąsiedztwo w „blokowisku” w Łodzi, [w:] I. Jażdżewska (red.), Osiedla blokowe w strukturze przestrzennej miast, XXIII „Konwersatorium Wiedzy o Mieście”, Wyd. Uniwersytetu Łódzkiego, Łódź, s. 299-308.

Janiszewska A., Klima E., Rochmińska A., 2011, Jakość życia na łódzkich osiedlach, [w:] J. Dzieciuchowicz (red.), Wspótczesne przemiany środowiska mieszkaniowego - wybrane problemy, "Space - Society - Economy", 10, Wyd. Uniwersytetu Łódzkiego, Łódź, s. $145-179$.

Jarczewski W., 2010, Skala degradacji miast w Polsce, [w:] Z. Ziobrowski, W. Jarczewski (red.), Rewitalizacja miast polskich - diagnoza, Instytut Rozwoju Miast, Kraków, s. 57-64.

Jarosz D., 2010, Mieszkanie się należy... Studium z peerelowskich praktyk społecznych, Oficyna Wydawnicza Aspra JR, Warszawa. 
Jaroszewska-Brudnicka R., 2004, Zróżnicowanie przestrzeni społecznej Torunia, Wyd. Naukowe UMK, Torun.

Jasiński A., 2013, Architektura w czasach terroryzmu: miasto - przestrzeń publiczna - budynek, Wyd. Wolters Kluwer Polska, Warszawa.

Jażdżewska I. (red.), 2000, Miasto postsocjalistyczne - organizacja przestrzeni miejskiej i jej przemiany, cz. I, XIII „Konwersatorium Wiedzy o Mieście”, Wyd. Uniwersytetu Łódzkiego, Łódzkie Towarzystwo Naukowe, Łódź.

Jażdżewska I. (red.), 2001, Miasto postsocjalistyczne - organizacja przestrzeni miejskiej i jej przemiany, cz. II, XIV „Konwersatorium Wiedzy o Mieście”, Polskie Towarzystwo Geograficzne, Łódzkie Towarzystwo Naukowe, Łódź.

Jażdżewska I. (red.), 2004, Zróżnicowanie warunków życia ludności w mieście, XVII „Konwersatorium Wiedzy o Mieście", Wyd. Uniwersytetu Łódzkiego, Łódź.

Jażdżewska I. (red.), 2010, Osiedla blokowe w strukturze przestrzennej miast, XXIII „Konwersatorium Wiedzy o Mieście", Wyd. Uniwersytetu Łódzkiego, Łódź.

Jażdżewska I., 2010, Sakralizacja przestrzeni osiedli blokowych. Przykład Łodzi i Sankt Petersburga, [w:] I. Jażdżewska (red.), Osiedla blokowe w strukturze przestrzennej miast, XXIII „Konwersatorium Wiedzy o Mieście”, Wyd. Uniwersytetu Łódzkiego, Łódź, s. 151169.

Jencks Ch., 1982, Le Corbusier - tragizm wspótczesnej architektury, Wydawnictwa Artystyczne i Filmowe, Warszawa.

Jencks Ch., 1987, Ruch nowoczesny w architekturze, Wydawnictwa Artystyczne i Filmowe, Warszawa.

Jerschina J., Lesińska E., Pytliński Ł., Siwek H., 2012, Badania poczucia bezpieczeństwa mieszkańców Prądnika Czerwonego w Krakowie ze szczególnym uwzględnieniem wpływu zmian architektonicznych i technicznych na poziom lęku przed przestępczościa, [w:] J. Czapska (red.), Zapobieganie przestępczości przez kształtowanie przestrzeni, Wyd. Uniwersytetu Jagiellońskiego, Kraków, s. 201-247.

Jewdokimow M., 2011, Zmiany społecznych praktyk zamieszkiwania, Wyd. Uniwersytetu Kardynała Stefana Wyszyńskiego, Warszawa.

Jędrzejczyk D., 2004, Geografia humanistyczna miasta, Dialog, Warszawa.

Kabisch S., Grossmann K., 2013, Challenges for large housing estates in light of population decline and ageing. Results of a long-term survey in East Germany, "Habitat International", 39, s. 232-239.

Kaczmarek J., 2005, Podejście geobiograficzne w geografii społecznej. Zarys teorii i podstawy metodyczne, Wyd. Uniwersytetu Łódzkiego, Łódź.

Kaczmarek S., 1996, Struktura przestrzenna warunków zamieszkania w Łodzi, „Szlakami Nauki", 23, Łódzkie Towarzystwo Naukowe, Łódź.

Kährik A., Tammaru T., 2010, Soviet Prefabricated Panel Housing Estates: Areas of Continued Social Mix or Decline? The Case of Tallinn, „Housing Studies”, 25 (2), s. 201-219.

Kallabova E., 2000, Selected Conections of the Prefab Housing Estates Development in the Cities and Towns of the Czech Republic, [w:] I. Jażdżewska (red.), Miasto postsocjalistyczne organizacja przestrzeni miejskiej i jej przemiany, XIII „Konwersatorium Wiedzy o Mieście”, Wyd. Uniwersytetu Łódzkiego, Łódzkie Towarzystwo Naukowe, Łódź, s. 113120.

Kaltenberg-Kwiatkowska E., 1982, Koncepcje ekologii społecznej w socjologii polskiej, [w:] Z. Pióro (red.), Przestrzeń i społeczeństwo. Z badań ekologii społecznej, KiW, Warszawa.

Kaltenberg-Kwiatkowska E. (red.), 1982, Mieszkanie. Analiza socjologiczna, PWE, Warszawa.

Kaltenberg-Kwiatkowska E., 1996, Neighbourhood in Contemporary Poland: Stereotypes and Reality, [w:] J. Allen, I. Ambrose, E. Kaltenberg-Kwiatkowska (eds.), Housing Socio- 
logy and Societal Change. New Challenges and Direction, University of Technology, Warsaw, s. 123-139.

Kaltenberg-Kwiatkowska E., 2002, Sąsiedztwo we wspótczesnym świecie. Stereotypy i rzeczywistość, [w:] W. Misztal, J. Styk (red.), Stare i nowe struktury społeczne w Polsce. Czynniki miastotwórcze w okresach wielkich zmian społecznych, Wyd. Uniwersytetu Marii Curie-Skłodowskiej, Lublin, s. 255-280.

Kaltenberg-Kwiatkowska E., 2005, Warunki mieszkaniowe w świadomości społecznej, [w:] L. Frąckiewicz (red.), Przeszłość i przyszłość polskiej polityki mieszkaniowej, Wyd. IPISC, Warszawa, s. 153-169.

Kaltenberg-Kwiatkowska E., 2007, Biografie mieszkaniowe: domy dzieciństwa babek wnukom opowiedziane, [w:] G. Woroniecka (red.), Co znaczy mieszkać: szkice antropologiczne, Wyd. Trio, Warszawa, s. 136-172.

Kania P., 2010, Od Charlesa Fouriera do Paolo Soleriego - przemiany w sposobie kształtowania struktur osiedli mieszkaniowych na przestrzeni wieków, "Architecturae et Artibus", 2, s. 27-33.

Kelling G.L., Coles C.M., 2000, Wybite szyby. Jak zwalczyć przestępczość i przywrócić ład w najbliższym otoczeniu, Media Rodzina, Poznań.

Kempen van R., Dekker K., Hall S., Tosics I., 2005, Restructuring Large Housing Estates in Europe. The Policy Press, University of Bristol, Bristol.

Kiciński A., 2004, Poland. A future for the 'blokowisko'?, [w:] R. Turkington, R. van Kempen, F. Wassenberg (eds.), High-rise Housing in Europe. Current Trends and Future Prospects, Delft University Press, Delft, s. 187-202.

Klima E., Bratkowski J., 2005, Usługi gastronomiczne, [w:] J. Dzieciuchowicz (red.), Ustugi rynkowe w Łodzi w dobie transformacji, Wyd. Uniwersytetu Łódzkiego, s. 147-183.

Klima E., 2009, Łódzkie kościoty katolickie po 1989 roku, [w:] I. Jażdżewska (red.), Duże i średnie miasta polskie w okresie transformacji, XXII „Konwersatorium Wiedzy o Mieście”, Wyd. Uniwersytetu Łódzkiego, Łódzkie Towarzystwo Naukowe, Łódź, s. 267-279.

Klima E., 2012, Geografia domu - mieszkanie w bloku, „Acta Universitatis Lodziensis. Folia Geographica Socio-Oeconomica", 12, s. 19-36.

Klima E., 2013, Dwelling or living in a block of flats. Towards the Polish geography of home, "Quaestiones Geographicae", 32, 2, s. 81-90.

Knorr-Siedow T., 1996, Present and future outlook for large housing estates, European Academy of the Urban Environment, Institute for Regional Development and Structural Planning, http:/ / www.eaue.de/Housing/housfut/htm (dostęp: 20.02.2012).

Knorr-Siedow T., 1997, Facts about the history and context of the large prefabricated housing estates in Europe, the paper for the conference "A future for the large housing estates", Sofia, Bulgaria, 19-21 October.

Knorr-Siedow T., 2004, Germany. Common legacy from a divided past, [w:] R. Turkington, R. van Kempen, F. Wassenberg (eds.), High-rise Housing in Europe. Current Trends and Future Prospects, Delft University Press, Delft, s. 165-186.

Knorr-Siedow T., Droste C., 2005, Large Housing Estates in Berlin, Germany: Opinions of Residents on Recent Developments, Faculty of Geosciences, Utrecht University, Utrecht.

Knox P., Pinch S., 2010, Urban Social Geography. An Introduction, Pearson Education Ltd, England.

Komar B., 2012, Analiza historyczna rozwoju osiedli mieszkaniowych na podstawie wybranych przykładów: Grünau w Lipsku i im. Tysiaclecia w Katowicach na tle wzorcowych koncepcji mieszkalnictwa XX wieku, "Architecturae et Artibus”, 2, s. 13-25.

Komar B., 2014, Wspótczesna jakość spółdzielczej przestrzeni osiedlowej w świetle zasad rozwoju zrównoważonego na wybranych przykładach, Wyd. Politechniki Śląskiej, Gliwice. 
Konrad G., Szelényi I., 1974, Social conflicts of underurbanization, [w:] A.A. Brown, J.A. Licari, E. Neuberger (eds.), Urban and Social Economics in Market and Planned Economies, Praeger, New York, s. 206-226.

Kostinskiy G., 2001, Post-Socialist Cities in Flux, [w:] R. Paddison (ed.), Handbook of Urban Studies, Sage London, s. 451-465.

Kotarbiński A., 1967, Rozwój urbanistyki i architektury polskiej w latach 1944-1964, PWN, Warszawa.

Koter M., 2009a, Kształtowanie się tkanki miejskiej Łodzi do 1918 roku, [w:] S. Liszewski (red.), Łódź. Monografia miasta, Łódzkie Towarzystwo Naukowe, Łódź, s. 62-112.

Koter M., 2009b, Tkanka miejska Łodzi w latach 1918 - 1989, [w:] S. Liszewski (red.), Łódź. Monografia miasta, Łódzkie Towarzystwo Naukowe, Łódź, s. 218-264.

Kotus J., 2006, Changes in the spatial structure of a large Polish city - the case of Poznan, "Cities", 23, 5, s. 364-381.

Kotus J., 2007, Natura wielkomiejskich sąsiedztw, Wyd. UAM, Poznań.

Kovács Z., 1999, Cities from state-socialism to global capitalism: an introduction, "GeoJournal”, 49, s. 1-6.

Kovács Z., Douglas M., 2004, Hungary. From socialist ideology to market reality, [w:] R. Turkington, R. van Kempen, F. Wassenberg (eds.), High-rise Housing in Europe. Current Trends and Future Prospects, Delft University Press, Delft, s. 231-248.

Kovács Z., Herfert G., 2012, Development Pathways of Large Housing Estates in Post-socialist Cities: An International Comparison, „Housing Studies”, 27, 3, s. 324-342.

Kozłowski S., 2005, Pozytywne przykłady modernizacji osiedli mieszkaniowych, [w:] I. Jażdżewska (red.), Wspótczesne procesy urbanizacji $i$ ich skutki, XVIII „Konwersatorium Wiedzy o Mieście", Wyd. Uniwersytetu Łódzkiego, Łódź, s. 341-350.

Kozłowski S., 2006, Niektóre wyniki badań osiedli Wrzeciono i Ursynów w Warszawie (w ramach programu RESTATE), [w:] T. Marszał, D. Stawasz (red.), Przestrzeń rezydencjalna w miastach polskich, "Biuletyn KPZK PAN”, 227, s. 151-165.

Kozłowski S., 2010, Przeszkody i bariery na drodze humanizacji osiedli, [w:] I. Jażdżewska (red.), Osiedla blokowe w strukturze przestrzennej miast, XXIII „Konwersatorium Wiedzy o Mieście”, Wyd. Uniwersytetu Łódzkiego, Łódź, s. 73-87.

Krajewski K., 2012, Obiektywny stan bezpieczeństwa w Krakowie i w dzielnicy Prądnik Czerwony na tle sytuacji w pozostatych miastach oraz badanych dzielnicach, [w:] J. Czapska (red.), Zapobieganie przestępczości przez kształtowanie przestrzeni, Wyd. UJ, Kraków, s. $183-200$.

Kryczka P., 1981, Społeczność osiedla mieszkaniowego w wielkim mieście. Ideologie i rzeczywistość, PWN, Warszawa.

Kwiatkowski K., Racoń-Leja K., 2005, Mieszkać bezpiecznie po holendersku. Społeczność wobec przestępczości, „Autoportret", 4 (13), s. 24-27.

Le Corbusier, 1973, The Athens Charter, 1943, Grossman Publishers, New York.

Lefebvre H., 1991, The Production of Space, Blackwell, Oxford.

Lewicka M., 2004, Identyfikacja z miejscem zamieszkania mieszkańców Warszawy: determinanty $i$ konsekwencje, [w:] J. Grzelak, T. Zarycki (red.), Społeczna mapa Warszawy, Wyd. Naukowe Scholar, Warszawa, s. 273-315.

Lewicka M., 2012, Psychologia miejsca, Wyd. Naukowe Scholar, Warszawa.

Libura H., 1988, Badania wyobrażeń geograficznych na przykładzie mieszkańców Sanoka, „Dokumentacja Geograficzna", 1, IGiPZ PAN, Warszawa.

Lisowski A., 1990, Wstęp do geografii społecznej, Wyd. Uniwersytetu Warszawskiego, Warszawa. 
Lisowski A., 1998, Postmodernistyczna dekonstrukcja geografii miast, [w:] J. Kaczmarek (red.), Metodologia geografii osadnictwa na przełomie wieków, X „Konwersatorium Wiedzy o Mieście", Wyd. Uniwersytetu Łódzkiego, Łódź, s. 31-38.

Lisowski A., 2003, Koncepcje przestrzeni w geografii człowieka, Wydział Geografii i Studiów Regionalnych Uniwersytetu Warszawskiego, Warszawa.

Lisowski A., 2004, Zmiany warunków życia w aglomeracji warszawskiej, [w:] I. Jażdżewska (red.), Zróżnicowanie warunków życia ludności w mieście, XVII „Konwersatorium Wiedzy o Mieście", Wyd. Uniwersytetu Łódzkiego, Łódź, s. 67-76.

Lisowski A., 2007, "Przestrzeñ" $i$ "percepcja” w transdyscyplinarnych badaniach miast - spojrzenie geografa, [w:] M. Madurowicz (red.), Percepcja wspótczesnej przestrzeni miejskiej, Wydział Geografii i Studiów Regionalnych Uniwersytetu Warszawskiego, Warszawa, s. 17-30.

Lisowski A., 2008, Geografia społeczna, [w:] A. Jackowski, S. Liszewski, A. Richling (red.), Historia geografii polskiej, Wyd. Naukowe PWN, Warszawa, s. 195-205.

Liszewski S., 1988, Geograficzno-ekonomiczne i społeczne problemy badania miast w Polsce, seria "Geografia", 42, Uniwersytet Adama Mickiewicza, Poznań, s. 153-163.

Liszewski S., 1995, Zróżnicowanie przestrzenne poziomu i jakości warunków życia w aglomeracjach miejskich, "Acta Universitatis Lodziensis. Folia Geographica Socio-Oeconomica", 20, s. 207-219.

Liszewski S., 1999, Elity intelektualne w przestrzeni miasta. Przykład Łodzi, [w:] J. Kaczmarek (red.), Wspótczesne przemiany struktur przestrzennych dużych miast, XI „Konwersatorium Wiedzy o Mieście”, Katedra Geografii Miast i Turyzmu Uniwersytetu Łódzkiego, Łódzkie Towarzystwo Naukowe, Łódź, s. 9-21.

Liszewski S., 2001a, Ewolucja funkcjonalna Łodzi, [w:] S. Liszewski (red.), Zarys monografii województwa łódzkiego, Łódzkie Towarzystwo Naukowe, Łódź, s. 29-46.

Liszewski S., 2001b, Model przemian przestrzeni miejskiej miasta postsocjalistycznego, [w:] I. Jażdżewska (red.), Miasto postsocjalistyczne - organizacja przestrzeni miejskiej $i$ jej przemiany, XIV „Konwersatorium Wiedzy o Mieście”, Wyd. Uniwersytetu Łódzkiego, Łódź, s. 303-310.

Liszewski S., 2004, Rola i zadania geografii w badaniach zróżnicowania przestrzennego warunków życia mieszkańców miast. Założenia teoretyczne i program badań, [w:] I. Jażdżewska (red.), Zróżnicowanie warunków życia ludności w mieście, XVII „Konwersatorium Wiedzy o Mieście", Wyd. Uniwersytetu Łódzkiego, Łódź, s. 7-17.

Liszewski S., 2008a, Formy i struktury przestrzenne wielkich skupisk miejskich, [w:] S. Liszewski (red.), Geografia urbanistyczna, Wyd. Uniwersytetu Łódzkiego, Łódź, s. 187-233.

Liszewski S., 2008b, Geografia osadnictwa, [w:] A. Jackowski, S. Liszewski, A. Richling (red.), Historia geografii polskiej, Wyd. Naukowe PWN, Warszawa, s. 161-176.

Liszewski S., 2009, Warunki życia mieszkańców Łodzi w latach 1918-1989, [w:] S. Liszewski (red.), Łódź. Monografia miasta, Łódzkie Towarzystwo Naukowe, Łódź, s. 343-363.

Lowe G.S., 1994, Towards a Social Theory of Housing in Eastern Europe, [w:] T. Tanninen, I. Ambrose, O. Siksiö (eds.), Transitional Housing Systems. East-West Dialogue on the New Roles of Actors in Changing Housing Policies, Bauhaus, Dessau, s. 32-44.

Lowry I.S., 1960, Filtering and housing standards, „Land Economics”, 36, s. 362-370.

Lynch K., 1960, The Image of the City, MIT Press, Cambridge.

Łodziński P., 2009, Wybrane problemy modernizacji budynków mieszkalnych z wielkiej płyty na przyktadzie osiedla Hellersdorf w Berlinie, "Architecturae et Artibus", 2, s. 39-43.

Madurowicz M. (red.), 2007, Percepcja wspótczesnej przestrzeni miejskiej, Wydział Geografii i Studiów Regionalnych Uniwersytetu Warszawskiego, Warszawa. 
Madurowicz M. (red.), 2010, Wartościowanie wspótczesnej przestrzeni miejskiej, Wydział Geografii i Studiów Regionalnych Uniwersytetu Warszawskiego, Warszawa.

Maier K., 2005, Czech Housing Estates: Recent Changes and New Challenges, "Geographia Polonica", 78, 1, s. 39-52.

Maik W., Stachowski J., 1995, Preteoretyczne modele pojęciowe w geografii społecznej $i$ ich rola w budowie teorii $i$ wyjaśnianiu zjawisk społeczno-przestrzennych, "Acta Universitatis Lodzienzis. Folia Geographica", 19, s. 5-20.

Maik W., 2006, Problematyka człowieka w geografii w świetle tradycji i rozwoju myśli geograficznej, [w:] W. Maik, K. Rembowska, A. Suliborski (red.), Człowiek w badaniach geograficznych, Podstawowe idee i koncepcje w geografii, 2, Wyd. Wyższej Szkoły Gospodarki, Bydgoszcz, s. 11-26.

Maik W., 2011, Przestrzeń publiczna w mieście: pojęcie, ujęcia badawcze, funkcje i ewolucja zjawiska, [w:] I. Jażdżewska (red.), Przestrzeń publiczna miast, XXIV „Konwersatorium Wiedzy o Mieście", Wyd. Uniwersytetu Łódzkiego, Łódź, s. 9-14.

Maik W., 2012, Podstawy teoretyczno-metodologiczne studiów geograficzno-miejskich, Wyd. WSG, Bydgoszcz.

Majer A., 2010, Socjologia i przestrzeń miejska, PWN, Warszawa.

Marcińczak S., 2004, Ocena warunków zamieszkania w opinii mieszkańców osiedla im. Montwiłła-Mireckiego w Łodzi, [w:] I. Jażdżewska (red.), Zróżnicowanie warunków życia ludności w mieście, XVII „Konwersatorium Wiedzy o Mieście”, Wyd. Uniwersytetu Łódzkiego, Łódź, s. 199-208.

Marcińczak S., 2006, Struktura społeczna i warunki życia - przykład dwóch łódzkich enklaw mieszkaniowych wybudowanych w latach 1930-1944, [w:] M. Czepczyński (red.), Przestrzenie miast postsocjalistycznych. Studia społecznych przemian przestrzeni zurbanizowanej, Bogucki Wyd. Naukowe, Gdańsk-Poznań, s. 177-193.

Marcińczak S., 2009, Przemiany struktury społeczno-przestrzennej Łodzi w latach 1988-2005, Wyd. Uniwersytetu Łódzkiego, Łódź.

Marcińczak S., 2013, Segregacja społeczna w mieście postsocjalistycznym. Bukareszt, Warszawa $i$ Tallin na początku XXI wieku, Wyd. Uniwersytetu Łódzkiego, Łódź.

Marcińczak S., Siejkowska A., 2004, Zróżnicowanie przestrzenne w Łodzi w latach 1988-2001 a percepcja obszarów niebezpiecznych, [w:] J. Słodczyk (red.), Przemiany struktury przestrzennej miast w sferze funkcjonalnej $i$ społecznej, Wyd. Uniwersytetu Opolskiego, Opole, s. 363-375.

Marody M. (red.), 1991, Co nam zostało $z$ tych lat... Społeczeństwo polskie u progu transformacji systemowej, Wyd. Aneks, Londyn.

Marszał T., 1999a, Zróżnicowanie i kierunki rozwoju budownictwa mieszkaniowego w Polsce, [w:] T. Marszał (red.), Budownictwo mieszkaniowe w latach 90. Zróżnicowanie przestrzenne i kierunki rozwoju, „Biuletyn KPZK PAN”, 190, Warszawa, s. 7-27.

Marszał T., 1999b, Struktura przestrzenna wielorodzinnego budownictwa mieszkaniowego w Łodzi w latach 90., [w:] T. Marszał (red.), Budownictwo mieszkaniowe w latach 90. - zróżnicowanie przestrzenne i kierunki rozwoju, „Biuletyn KPZK PAN”, 190, Warszawa, s. 69-90.

Marszał T. (red.), 1999, Budownictwo mieszkaniowe w latach 90. - zróżnicowanie przestrzenne i kierunki rozwoju, „Biuletyn KPZK PAN”, 190, Warszawa.

Marszał T. (red.), 2003, Budownictwo w przestrzeni lokalnej, Wyd. Uniwersytetu Łódzkiego, Łódź.

Marszał T., Stawasz D., 2006, Budownictwo mieszkaniowe w polskich miastach po 1990 roku stan i trendy rozwoju, [w:] T. Marszał, D. Stawasz (red.), Przestrzeń rezydencjalna w miastach polskich, „Biuletyn KPZK PAN”, 227, s. 8-19. 
Marullo S.,1983, Racial Differencies in Housing Consumption and Filtering, [w:] J. Pipkin, M. La Gory, J. Blau (eds.), Remaking the City, State University of New York Press, Albany, s. 229-253.

Masica R., Milewska K., 2003, Zmiany w zagospodarowaniu zespotu osiedli mieszkaniowych: przykład Widzewa-Wschodu w Łodzi, [w:] T. Marszał (red.), Zagospodarowanie przestrzeni miejskiej Łodzi, Biuletyn KPZK PAN, 203, s. 29-44.

Matlovič R., 2000, Sakralizacja - czastkowy proces transformacji przestrzeni miejskiej miasta postkomunistycznego na przykładzie Preszowa, [w:] I. Jażdżewska (red.), Miasto postsocjalistyczne - organizacja przestrzeni miejskiej i jej przemiany, XIII „Konwersatorium Wiedzy o Mieście", Wyd. Uniwersytetu Łódzkiego, Łódzkie Towarzystwo Naukowe, Łódź, s. 121-128.

Matlovič R., Ira V., Sykora L., Szczyrba Z., 2001, Procesy transformacyjne struktury przestrzennej miast postkomunistycznych (na przykładzie Pragi, Bratystawy, Ołomuńca oraz Preszowa, [w:] I. Jażdżewska (red.), Miasto postsocjalistyczne - organizacja przestrzeni miejskiej i jej przemiany, cz. II, XIV „Konwersatorium Wiedzy o Mieście”, Wyd. Uniwersytetu Łódzkiego, Łódzkie Towarzystwo Naukowe, Łódź, s. 243-252.

Matlovič R., Sedlakova A., 2007, Transformation processes of the urban space in post-communist cities, [w:] M. Malikowski, S. Solecki (red.), Przemiany przestrzenne $w$ dużych miastach Polski i Europy Środkowo-Wschodniej, Nomos, Kraków, 32-46.

Michalska-Żyła A., 2010, Psychospołeczne więzi mieszkańców z miastem, Wyd. Uniwersytetu Łódzkiego, Łódź.

Michalski W., Szafrańska E., 2000, Wewnątrzmiejskie migracje stałe mieszkańców Łodzi, [w:] D. Szymańska (red.), Procesy i formy ruchliwości przestrzennej ludności w okresie przemian ustrojowych, Wyd. Uniwersytetu Mikołaja Kopernika, Toruń, s. 201-216.

Milewska K., 2003, Zagospodarowanie dzielnicy - przykład Olechowa w Łodzi, [w:] T. Marszał (red.), Zagospodarowanie przestrzeni miejskiej Łodzi, „Biuletyn KPZK PAN”, 203, Warszawa, s. 79-89.

Milewska-Osiecka K., 2010, Budownictwo mieszkaniowe aglomeracji łódzkiej (zróżnicowanie i struktura przestrzenna po 1994 r.), Wyd. Uniwersytetu Łódzkiego, Łódź.

Milewska K., Ogrodowczyk A., 2006, Struktura budownictwa wielorodzinnego na obszarze Łodzi, [w:] T. Marszal, D. Stawasz (red.), Przestrzeń rezydencjalna w miastach polskich, „Biuletyn KPZK PAN”, 227, s. 90-113.

Mirecka M.A., 1995, Rehabilitacja osiedli mieszkaniowych z lat 1945-1970, „Międzyuczelniane Zeszyty Naukowe. Urbanistyka", Urbanista, Gdańsk.

Misiak W., 1988, Wielkie zespoły mieszkaniowe jako przestrzeń społeczna, [w:] B. Jałowiecki, E. Kaltenberg-Kwiatkowska (red.), Procesy urbanizacji i przeksztatcania miast w Polsce, Ossolineum, Wrocław, s. 123-138.

Misiak W., 1993, Jakość życia w osiedlach miejskich, Wyd. Uniwersytetu Wrocławskiego, Wrocław.

Misiak W., 2005, Nowe procesy i zjawiska po przełomie 1989 roku w miastach polskich [w:] B. Jałowiecki, M.S. Szczepański, A. Majer (red.), Przemiany miasta, Wyd. Naukowe Scholar, Warszawa, s. 267-284.

Miszewska B., 2000, Wybrane elementy zmian morfologiczno-funkcjonalnych w osiedlach willowych Wrocaławia, „Urbánne a krajinné tnie”, 3, Filozofická Fakulta Prešovskiej Univerzity, Prešov, s. 64-81.

Miszewska B., 2001, Osiedla rezydencjalne wrocławian - kontynuacja procesu, zmienność formy, [w:] I. Jażdżewska (red.), Miasto postsocjalistyczne - organizacja przestrzeni miejskiej $i$ jej przemiany, XIV „Konwersatorium Wiedzy o Mieście”, Wyd. Uniwersytetu Łódzkiego, Łódź, s. 187-197. 
Miszewska B., 2006, Osiedla rezydencjalne Wroctawia, [w:] T. Marszal, D. Stawasz (red.), Przestrzeń rezydencjalna w miastach polskich, „Biuletyn KPZK PAN”, 227, s. 114-131.

Miszewska B., Sikorski D., 2010, Blokowiska a dewaloryzacja przestrzeni miejskiej na przykładzie południowej dzielnicy Wroctawia, [w:] I. Jażdżewska (red.), Osiedla blokowe w strukturze przestrzennej miast, XXII „Konwersatorium Wiedzy o Mieście”, Wyd. Uniwersytetu Łódzkiego, Łódź, s. 127-140.

Miszewska B., Szmytkie R., 2010, Staromiejskie blokowiska w strukturze przestrzennej miast Dolnego Śląska, [w:] I. Jażdżewska (red.), Osiedla blokowe w strukturze przestrzennej miast, XXII „Konwersatorium Wiedzy o Mieście”, Wyd. Uniwersytetu Łódzkiego, Łódź, s. 27-36.

Mordwa S., 2003, Wyobrażenia miast Polski Środkowej, Wyd. Uniwersytetu Łódzkiego, Łódź.

Mordwa S., 2010, Poczucie bezpieczeństwa wybranych osiedli w Łodzi, [w:] M. Madurowicz (red.), Wartościowanie wspótczesnej przestrzeni miejskiej, Wyd. WGiSR Uniwersytetu Warszawskiego, Warszawa, s. 307-316.

Mordwa S., 2013, Przestępczość i poczucie bezpieczeństwa w przestrzeni miasta. Przykład Łodzi, Wyd. Uniwersytetu Łódzkiego, Łódź.

Moss von S., 2009, Le Corbusier. Elements of the Synthesis, 010 Publishers, Rotterdam.

Motak M., 2003, Skąd się wzięty blokowiska?, "Czas Kultury”, 4 (115), s. 2-10.

Motak M., 2012, Wielkie osiedla mieszkaniowe jako fenomen architektoniczny $i$ urbanistyczny XX wieku. Geneza, rozwój, zmierzch, [w:] J. Czapska (red.), Zapobieganie przestępczości przez kształtowanie przestrzeni, Wyd. Uniwersytetu Jagiellońskiego, Kraków, s. 165-182.

Murie A., Knorr-Siedow T., van Kempen R., 2003, Large Housing Estates In Europe: General Development And Theoretical Backgrounds, RESTATE, report 1, Utrecht University, Utrecht.

Musil J., 1993, Changing urban systems in post-communist societies in Central Europe: analysis and prediction, "Urban Studies", 30 (6), s. 899-905.

Musil J., 2003, Pięćdziesiąt lat socjologii miasta, "Studia Regionalne i Lokalne”, 1(11), s. 5-38.

Musil J., 2005, City development in Central and Eastern Europe before 1990. Historical context and socialist legacies, [w:] I. Hamilton, K. Dimitrowska Andrews, N. Pichler-Milanović (eds.), Transformation of Cities in Central and Eastern Europe: towards golobalization, United Nations University, Tokyo, New York, Paris, s. 22-43.

Musterd S., van Kempen R., 2005, Large-scale Housing Estates in European Cities: Opinions of Residents on Recent Developments. RESTATE, report 4k, Utrecht University, Utrecht.

Musterd, S., van Kempen, R., 2007, Trapped or on the springboard? Housing careers in large housing estates, "Journal of Urban Affairs", 29, s. 311-329.

Mysłek P., 2007, Wartościowanie przestrzeni zamieszkania na przykładzie Łodzi, [w:] A. Majer (red.), Socjologia miasta. Nowe dziedziny badań, Wyd. Uniwersytetu Łódzkiego, Łódź, s. 81-99.

Nagy E., 2001, Winners and losers in the transformation of city centre retailing in East Central Europe, „European Urban and Regional Studies”, 8 (4), s. 340-348.

Newman O., 1972, Defensible space. Crime prevention through urban design, Macmillan, New York.

Niezabitowski M., 2010, Ludzie starsi w starzejącym się blokowisku. Przypadek osiedla Superjednostka w Katowicach, [w:] I. Jażdżewska (red.), Osiedla blokowe w strukturze przestrzennej miast, XXIII „Konwersatorium Wiedzy o Mieście”, Wyd. Uniwersytetu Łódzkiego, Łódź, s. 285-297.

Nowak S., 1973, Teorie postaw, PWN, Warszawa. 
Nowakowski M., 2013, Sto lat planowania przestrzeni polskich miast (1910-2010), Oficyna Naukowa, Warszawa.

Nurek S., 1982, Waloryzacja przestrzeni osiedli mieszkaniowych, Uniwersytet Śląski, Katowice.

Okólski M., 2000, Zmiany demograficzne w Polsce w latach 90., [w:] Czy kryzys demograficzny w Polsce?, Instytut Problemów Współczesnej Cywilizacji, Warszawa, s. 5-26.

Okólski M., 2005, Demografia. Podstawowe pojęcia, procesy $i$ teorie w encyklopedycznym zarysie, Wyd. Naukowe Scholar, Warszawa.

Oldenburg R., 2000, Celebrating the third place: Inspiring stories about the "Great good places" at the heart of our communities, Marlowe \& Company, New York.

Ossowski S., 1962, O osobliwościach nauk społecznych, PWN, Warszawa.

Ostańska A., 2009, Problemy rewitalizacji zespotów prefabrykowanej zabudowy mieszkaniowej na przykładzie osiedla im. S. Moniuszki w Lublinie, „Budownictwo i Architektura”, 4 (1), s. 85-104.

Ostrowska M., 1991, Człowiek a rzeczywistość przestrzenna, Autorska Oficyna Wydawnicza Nauka i Życie, Szczecin.

Ostrowski W., 1975, Urbanistyka wspótczesna, Wyd. Arkady, Warszawa.

Ostrowski W., 2001, Wprowadzenie do historii budowy miast. Ludzie i środowisko, Oficyna Wydawnicza Politechniki Warszawskiej, Warszawa.

Ouredniček M., Temelová J., 2009, Twenty years after socialism: the transformation of Prague's inner structure, „Studia Universitatis Babes-Bolyai. Sociologia”, 1, s. 9-30.

Pacione M., 2001, Urban geography: a global perspective, Routledge, London.

Park R.E., Burgess E., McKenzie R.D., 1925, The City, University of Chicago Press, Chicago.

Parysek J., 1998, Efekty procesu transformacji społeczno-gospodarczej w Polsce. Bilans okresu 1989-1996, [w:] J. Parysek i H. Rogacki (red.), Przemiany społeczno-gospodarcze Polski lat dziewięćdziesiątych, Bogucki Wyd. Naukowe, Poznań, s. 25-46.

Parysek J., 2004, Warunki życia w miastach polskich w okresie transformacji, [w:] I. Jażdżewska (red.), Zróżnicowanie warunków życia ludności w mieście, XVII „Konwersatorium Wiedzy o Mieście”, Wyd. Uniwersytetu Łódzkiego, Łódź, s. 55-66.

Parysek J., 2005, Miasta polskie na przełomie XX i XXI. Rozwój i przekształcenia strukturalne, Bogucki Wyd. Naukowe, Poznań.

Pasztor G., Peter L., 2009, Urban Housing Problem in Romania: The Legacy of Communist Block of Flats, „Studia Universitatis Babes-Bolyai. Socjologia”, 1, s. 79-100.

Pawłowska K., 1996, Idea swojskości w urbanistyce i architekturze miejskiej, "Monografia” 203, Wyd. Politechniki Krakowskiej, Kraków.

Pawłowski K., 1972, Tony Garnier - pionier urbanistyki nowoczesnej, PWN, Warszawa.

Pazder D., 2008, Społeczne zagadnienia kreacji i odnowy przestrzeni miejskiej, „Teka Komisji Architektury Urbanistyki Studiów Krajobrazowych PAN", 4, s. 164-171.

Peisert A., 2009, Spótdzielnie mieszkaniowe: pomiędzy wspólnotą obywatelską a alienacją, Wyd. Uniwersytetu Warszawskiego, Warszawa.

Perry C.A., 1939, Housing for the machine age, Russell Sage Foundation, New York.

Pieniążek M., 2010, The Peripheral Housing Estate as a form of Urban Spatial Development. The Status Quo and Perspectives, "Miscellanea Geographica”, 14, s. 1-10.

Pirvelli M., 2000, Podstawy teoretyczne urbanistyki socrealizmu, [w:] I. Jażdżewska (red.), Miasto postsocjalistyczne - organizacja przestrzeni miejskiej i jej przemiany, XIII „Konwersatorium Wiedzy o Mieście”, Wyd. Uniwersytetu Łódzkiego, Łódzkie Towarzystwo Naukowe, Łódź, s. 17-23.

Pocock D., Hudson R., 1978, Images of the Urban Environment, Macmillan, London.

Power A., 1997, Estates on the Edge: The Social Consequences of Mass Housing in Northern Europe, Macmillan, London. 
Prak N.L., Priemus H., 1986, A model for the analysis of the decline of postwar housing, "International Journal of Urban and Regional Research", 10 (1), s. 1-7.

Prawelska-Skrzypek G., 1989, Miasta o niezharmonizowanym rozwoju w świadomości mieszkańców (na przykładzie miast polskich), „Rozprawy Habilitacyjne”, 204, Wyd. Uniwersytetu Łódzkiego, Kraków.

Przybyłowska I., 1978, Wywiad swobodny ze standaryzowana lista poszukiwanych informacji i możliwości jego zastosowania w badaniach socjologicznych, "Przegląd Socjologiczny", 30, s. 53-68.

Racoń-Leja K., 2010, Bariery w ksztattowaniu przestrzeni publicznej w zespołach mieszkaniowych, "Czasopismo Techniczne. Architektura”, 6, s. 165-170.

Radwańska M., 2007, Percepcja przestrzeni miejskiej - przykład miasta Torunia, [w:] M. Madurowicz (red.), Percepcja współczesnej przestrzeni miejskiej, Wydział Geografii i Studiów Regionalnych Uniwersytetu Warszawskiego, Warszawa, s. 371-381.

Radwańska M., 2010, Wewnątrzmiejskie migracje state jako czynnik ksztattujący struktury społeczno-demograficzne wielkiego zespołu mieszkaniowego Torunia, [w:] I. Jażdżewska (red.), Osiedla blokowe w strukturze przestrzennej miast, XXIII „Konwersatorium Wiedzy o Mieście”, Wyd. Uniwersytetu Łódzkiego, Łódź, s. 237-249.

Rapley M., 2003, Quality of life. A critical introduction, Sage Publications, London.

Relph E., 1976, Place and Placelessness, Pion, London.

Rembarz G., 2005, Jakość przestrzeni publicznej w procesie reurbanizacji wielkich osiedli mieszkaniowych, [w:] M. Kochanowski (red.), Przestrzeń publiczna miasta postindustrialnego, „Biblioteka Urbanisty”, 5, Urbanista, Warszawa, s. 146-165.

Rembarz G., 2007, Przyszłość osiedli wielkopłytowych, „Giełda Nieruchomości”, 7.

Rembarz G., 2010, Rola przestrzeni publicznej w odnowie i kształtowaniu miejskiego środowiska mieszkaniowego, [w:] P. Lorens, J. Martyniuk-Pęczek (red.), Zarządzanie rozwojem przestrzennym miast, Urbanista, Gdańsk, s. 138-156.

Rewers E., 2007, Post-polis. Wstęp do filozofii ponowoczesnego miasta, Universitas, Kraków.

Rębowska A., 1999, Rehabilitacja wielkoblokowych zespołów mieszkaniowych w Polsce, [w:] Gospodarka przestrzenna gmin i odnowa miast, IV Krakowska Konferencja Międzynarodowa, Kraków.

Rębowska A., 2000, Rehabilitacja blokowisk, [w:] Z. Ziobrowski, D. Ptaszycka-Jackowska, A. Rębowska, A. Geissler (red.), Rewitalizacja, rehabilitacja, restrukturyzacja. Odnowa miast, IGPiK, Kraków, s. 85-105.

Rębowska A., Jeżak J., Rydzik W., Węglowski M., 2006, Strategie rehabilitacji „blokowisk”, Instytut Rozwoju Miast, Kraków.

Robertson R., 1995, Glocalization: Time-space and Homogeneity-Heterogeneity, [w:] M. Featherstone, S. Lash, R. Robertson (eds.), Global Modernities, Sage Publications, London, s. $25-44$.

Rodzoś J., Flaga M., 2010, Nowa sytuacja społeczna starych osiedli mieszkaniowych na przykładzie osiedla im. A. Mickiewicza w Lublinie, [w:] I. Jażdżewska (red.), Osiedla blokowe w strukturze przestrzennej miast, XXIII „Konwersatorium Wiedzy o Mieście”, Wyd. Uniwersytetu Łódzkiego, Łódź, s. 101-118.

Rowlands R., Musterd S., van Kempen R. (eds.), 2010, Mass Housing in Europe, Multiple Faces of Development, Change and Response, Palgrave Macmillan.

Ruoppila S., Kährik, A., 2003, Socio-economic residential differentiation in post-socialist Tallinn, "Journal of Housing and the Built Environment", 18, s. 49-73.

Rydz E., Szymańska W., 2007, Waloryzacja przestrzeni miejskiej pod względem atrakcyjności mieszkaniowej i poczucia bezpieczeństwa średnich miast Pomorza, [w:] M. Madurowicz 
(red.), Percepcja wspótczesnej przestrzeni miejskiej, Wydział Geografii i Studiów Regionalnych Uniwersytetu Warszawskiego, Warszawa, s. 331-341.

Rykiel Z., 1999, Przemiany struktury społeczno-przestrzennej miasta polskiego a świadomość terytorialna jego mieszkańców, „Prace Geograficzne”, 170, IGiPZ PAN, Wrocław.

Rykiel Z., 2000, Przemiany przestrzeni społecznej polskiego miasta postsocjalistycznego, [w:] I. Jażdżewska (red.), Miasto postsocjalistyczne - organizacja przestrzeni miejskiej i jej przemiany, XIII „Konwersatorium Wiedzy o Mieście”, Wyd. Uniwersytetu Łódzkiego, Łódzkie Towarzystwo Naukowe, Łódź, s. 31-39.

Rykiel Z. (red.), 2008, Nowa przestrzeń społeczna w badaniach socjologicznych, Wyd. Uniwersytetu Rzeszowskiego, Rzeszów.

Rzyski S., Mędrzycka K., 2010, Osiedla blokowe versus inne formy zabudowy mieszkaniowej w Gdańsku - percepcja i waloryzacja warunków zamieszkania, [w:] I. Jażdżewska (red.), Osiedla blokowe w strukturze przestrzennej miast, XXIII „Konwersatorium Wiedzy o Mieście", Wyd. Uniwersytetu Łódzkiego, Łódzkie Towarzystwo Naukowe, Łódź, s. 251-259.

Sagan I., 1997, Wielkie zespoty mieszkaniowe - niczyja przestrzeń czy niczyje miejsce? „Kwartalnik Geograficzny", 2-3, s. 15-21.

Sagan I., 2008, Miasto jako przedmiot badań geografii, [w:] B. Jałowiecki (red.), Miasto jako przedmiot badań naukowych w początkach XXI wieku, Wyd. Naukowe Scholar, Warszawa, s. 105-119.

Sagan I., 2000a, Miasto. Scena konfliktów i wspótpracy, Wyd. Uniwersytetu Gdańskiego, Gdańsk.

Sagan I., 2000b, Społeczny i rynkowy wymiar miejsca w mieście socjalistycznym i postsocjalistycznym, [w:] I. Jażdżewska (red.), Miasto postsocjalistyczne - organizacja przestrzeni miejskiej i jej przemiany, XIII „Konwersatorium Wiedzy o Mieście”, Wyd. Uniwersytetu Łódzkiego, Łódzkie Towarzystwo Naukowe, Łódź, s. 67-71.

Sailer-Fliege U., 1999, Characteristics of post-socialist urban transformation in East Central Europe, "Geo Journal", 49, s. 7-16.

Schneider-Skalska G., 2004, Kształtowanie zdrowego środowiska mieszkaniowego. Wybrane zagadnienia, „Monografia” 307, Wyd. Politechniki Krakowskiej, Kraków.

Shaftoe H., 2007, Crime in High-Rise - Is It the Biult Environment's Fault, [w:] T. Lukas (ed.), Crime Prevention in High Rise Housing, Duncker \& Humblot, Berlin, s.19-40.

Shevky E., Williams M., 1949, The Social Areas of Los Angeles. Analysis and Typology. University of California Press, Berkeley and Los Angeles.

Shevky E., Bell W., 1955, Social Area Analysis, Stanford University Press, Stanford.

Siemiński W., 1980, Cele społeczne w kształtowaniu społeczności osiedlowych w Polsce, [w:] S. Nowakowski, W. Mirowski (red.), Planowanie społecznego rozwoju miast i społeczności terytorialnych a badania socjologiczne, Ossolineum, Wrocław, s. 133-144.

Siemiński W., 1982a, Budynek i osiedle jako przedłużenie funkcji mieszkania, [w:] E. Kaltenberg-Kwiatkowska (red.), Mieszkanie. Analiza socjologiczna, PWE, Warszawa, s. 245-266.

Siemiński W., 1982b, Egalitaryzm i dostępność przestrzenna jako cel postulatowy i realizowany. Analiza na przykładzie osiedli mieszkaniowych, [w:] Z. Pióro (red.), Przestrzeń i społeczeństwo. Z badań ekologii społecznej, KiW, Warszawa, s. 339-359.

Skowroński W., 2008, Ilustrowany leksykon architektoniczno-budowlany, Arkady, Warszawa.

Słodczyk J., 2001, Przestrzeń miasta i jej przeobrażenia, Wyd. Uniwersytetu Opolskiego, Opole.

Słodczyk J., 2010, Geneza i rozwój osiedli blokowych, [w:] I. Jażdżewska (red.), Osiedla blokowe w strukturze przestrzennej miast, XXIII „Konwersatorium Wiedzy o Mieście”, Wyd. Uniwersytetu Łódzkiego, Łódź, s. 11-25. 
Słodczyk J., 2012, Historia planowania i budowy miast, Wyd. Uniwersytetu Opolskiego, Opole.

Słomczyński K.M., Janicka K., 2005, Pęknięta struktura społeczeństwa polskiego, [w:] M. Jarosz (red.), Polska, ale jaka?, Oficyna Naukowa, Warszawa, s. 162-184.

Smith D.M., 1996, The socialist city, [w:] G. Andrusz, M. Harloe, I. Szelényi (eds.), Cities after Socialism. Urban and Regional Change and Conflict in Post-Socialist Societies, Blackwell Publishers, Oxford, s. 70-99.

Smith-Heimer M., 1985, The Potential of Filtering as Public Policy, „Berkeley Planning Journal", 5(1), s. 94-104.

Sokołowski D., 1999, Zróżnicowanie zbioru małych miast większych osiedli wiejskich w Polsce w ujęciu koncepcji kontinuum miejsko-wiejskiego, Wyd. Naukowe Uniwersytetu Mikołaja Kopernika, Torun.

Sołoducha K., 2007, Krótka historia blokowisk, www.sztuka-architektury.pl. (dostęp: 20.04.2013).

Somerville P., van Beckhoven E., van Kempen R., 2009, The decline and rise of neighbourhoods: the importance of neighbourhood governance, "European Journal of Housing Policy", 9 (1), s. 25-44.

Stanilov K., 2007, Housing trends in Central and Eastern European cities during and after the period of transition, [w:] K. Stanilov (ed.), The Post- Socislist City. Urban Form and Space Transformations in Central and Eastern Europe after Socialism, "GeoJournal Library", 92, Springer, Dorgdrecht, s. 173-190.

Starosta P., 2000, Globalizacja i nowy komunitaryzm, „Kultura i Społeczeństwo”, 3, s. 47-68. Starzyńska W., 2000, Statystyka praktyczna, PWN, Warszawa.

Statystyka Łodzi 2014, Urząd Statystyczny w Łodzi, Łódź.

Stedman R., 2002, Toward a social psychology of place: Predicting behavior from place-based cognitions, attitude, and identity, "Environment and Behavior", 34, s. 561-581.

Stenning A., 2005, Transformation of Life, Work and Community in Post-socialist Europe: A Westerner Studies Nowa Huta, Poland, "Geographia Polonica”, 78(1), s. 9-22.

Stenning A., Świątek D., Smith A., Rochovská A., 2007, Poverty and Household Economic Practices in Nowa Huta, Poland, "Geographia Polonica", 80 (1), s. 7-24.

Stenning A., Smith A., Rochovská A., Świątek D., 2010, Domesticating Neo-liberalism: Spaces of Economic Practice and Social Reproduction in Post-Socialist Cities, Wiley-Blackwell, West Sussex.

Stępniak M., 2014, Przekształcenia przestrzennego rozmieszczenia zasobów mieszkaniowych w Warszawie w latach 1945-2008, „Prace Geograficzne”, 245, IGiPZ PAN, Warszawa.

Stępniak M., Węcławowicz G., Górczyńska M., Bierzyński A., 2009, Atlas Warszawwy, 11, IGiPZ PAN Warszawa.

Struyk R. J., 1996, Housing privatization in the former Soviet bloc to 1995, [w:] G. Andrusz, M. Harloe, I. Szelényi (eds.), Cities after Socialism. Urban and Regional Change and Conflict in Post-Socialist Societies, Blackwell Publishers, Oxford, s. 192-213.

Suliborski A., 1976, Środowisko mieszkaniowe miasta jako przedmiot badań geografii osadnictwa, "Acta Universitatis Lodziensis. Zeszyty Naukowe Uniwersytetu Łódzkiego", 7, s. 123-135.

Sulima M, 2010, Miejsce zamieszkania a przestrzeń publiczna albo swojskość i obcość, „Czasopismo Techniczne. Architektura", 6, s. 223-228.

Sýkora L., 1999, Changes in the internal spatial structure of post-communist Prague, "GeoJournal", 49, s. 79-89

Sýkora L., 2000, Post-communist City, [w:] I. Jażdżewska (red.), Miasto postsocjalistyczne organizacja przestrzeni miejskiej i jej przemiany, cz. I, XIII „Konwersatorium Wiedzy o Mieście”, Wyd. Uniwersytetu Łódzkiego, Łódź, s. 41-45. 
Sýkora L., 2009, Post-Socialist Cities, [w:] R. Kitchin, N. Thrift (eds.), International Encyclopedia of Human Geography, 8, Elsevier, Oxford, s. 387-395.

Syrkus H., 1976, Ku idei osiedla społecznego 1925-1975, PWN, Warszawa.

Szafrańska E., 2008, Kapitał ludzki i społeczny w przestrzeni miasta. Przykład Łodzi, [w:] J. Słodczyk, E. Szafranek (red.), Mechanizmy i uwarunkowania budowania konkurencyjności miast, Wyd. Uniwersytetu Opolskiego, Opole, s. 63-78.

Szafrańska E., 2009, Atrakcyjność mieszkaniowa blokowiska w opinii mieszkańców na przykładzie zespołu mieszkaniowego Retkinia-Pótnoc w Łodzi, [w:] I. Jażdżewska (red.), Duże i średnie miasta polskie w okresie transformacji, XXII „Konwersatorium Wiedzy o Mieście", Wyd. Uniwersytetu Łódzkiego, Łódź, s. 197-210.

Szafrańska E., 2010, Wielkie osiedla mieszkaniowe w okresie transformacji - próba diagnozy i kierunki przemian na przykładzie w Łodzi, [w:] I. Jażdżewska (red.), Osiedla blokowe w strukturze przestrzennej miast, XXIII „Konwersatorium Wiedzy o Mieście”, Wyd. Uniwersytetu Łódzkiego, Łódź, s. 219-236.

Szafrańska E., 2012, Gentryfikacja wielkich osiedli mieszkaniowych w mieście postsocjalistycznym - nowe zjawisko czy nadużycie terminologiczne, [w:] J. Jakóbczyk-Gryszkiewicz (red.), Procesy gentryfikacji w mieście, cz. I, XXVI „Konwersatorium Wiedzy o Mieście", Wyd. Uniwersytetu Łódzkiego, Łódź, s. 153-167.

Szafrańska E., 2013, Large Housing Estates in Post-socialist Poland as a Housing Policy Challenge, "European Spatial Research and Policy”, 20 (1), s. 119-129.

Szafrańska E., 2014, Transformations of large housing estates in post-socialist city: The case of Łódź, Poland, „Geographia Polonica”, 87 (1), s. 77-94.

Szczepański M.S, 1991, „Miasto socjalistyczne” i świat społeczny jego mieszkańców, Europejski Instytut Rozwoju Lokalnego i Regionalnego, Warszawa.

Szczepański M.S., 1999, Modernizacja, [w:] Encyklopedia socjologii, t. 2, Oficyna Naukowa, Warszawa, s. 268-274.

Szczepański M.S., 2005, Miasta realnego socjalizmu - miasta realnego kapitalizmu, [w:] B. Jałowiecki, A. Majer, M.S. Szczepański, Przemiany miasta. Wokót socjologii Aleksandra Wallisa, Wyd. Naukowe Scholar, s. 235-251.

Szelényi I., 1983, Urban Inequalities under State Socialism, Oxfrod University Press.

Szelényi I., 1996, Cities under Socialism and After, [w:] G. Andrusz, M. Harloe, I. Szelényi (eds.), Cities after Socialism. Urban and Regional Change and Conflict in Post-socialist Societies, Blackwell Publishers, Oxford, s. 286-317.

Szelényi I., 2001, Poverty, Ethnicity and Gender in Transitional Societies. Introduction, „Review of Sociology", 2, s. 5-10.

Szkurłat E., 2004, Więzi terytorialne młodzieży z miastem. Uwarunkowania i przemiany, Wyd. Uniwersytetu Łódzkiego, Łódź.

Szkurłat E., 2007, Psychologiczne $i$ kulturowe uwarunkowania percepcji środowiska, [w:] M. Madurowicz (red.), Percepcja wspótczesnej przestrzeni miejskiej, WGiSR Uniwersytetu Warszawskiego, Warszawa, s. 63-72.

Szmytkie R., 2010, Przemiany funkcjonalno-przestrzenne osiedla w Jelczu-Laskowicach, [w:] I. Jażdżewska (red.), Osiedla blokowe w strukturze przestrzennej miast, XXIII „Konwersatorium Wiedzy o Mieście", Wyd. Uniwersytetu Łódzkiego, Łódź, s. 207-216.

Szmytkowska M., 2004, Warunki mieszkaniowe jako istotny wyznacznik społeczno-przestrzennej polaryzacji miast. Przypadek Gdyni, [w:] I. Jażdżewska (red.), Zróżnicowanie warunków życia w mieście, XVII „Konwersatorium Wiedzy o Mieście”, Wyd. Uniwersytetu Łódzkiego, Łódź, s. 215-226.

Szmytkowska M., 2008, Przestrzeń społeczna miasta w okresie transformacji. Przypadek Gdyni, Wyd. Naukowe Scholar, Warszawa. 
Szolginia W., 1982, Architektura i budownictwo. Ilustrowana encyklopedia dla wszystkich, Wyd. Naukowo-Techniczne, Warszawa.

Szolginia W., 1987, Ład przestrzenny w zespole mieszkaniowym, IGPiK, Warszawa.

Szymańska W., 2010, Struktury społeczne osiedli blokowych w średnich miastach Pomorza na przykładzie Stupska, [w:] I. Jażdżewska (red.), Osiedla blokowe w strukturze przestrzennej miast, XXII „Konwersatorium Wiedzy o Mieście”, Wyd. Uniwersytetu Łódzkiego, Łódź, s. 261-271.

Śleszyński P., 2004a, Demograficzne przesłanki rozwoju rynku mieszkaniowego w aglomeracji warszawskiej, „Przegląd Geograficzny”, 76, 4, s. 493-514.

Śleszyński P., 2004b, Warunki życia w Warszawie w świetle dostępności przestrzennej mieszkańców do wybranych ustug na początku XXI wieku, [w:] I. Jażdżewska (red.), Zróżnicowanie przestrzenne warunków życia ludności w mieście (aglomeracji miejskiej), XVI „Konwersatorium Wiedzy o Mieście", Katedra Geografii Miast i Turyzmu Uniwersytetu Łódzkiego, Łódź, s. 77-86.

Śleszyński P., 2005, Perspektywy rozwoju rynku mieszkaniowego w Polsce w świetle sytuacji demograficznej, ekonomicznej i stanu zaspokojenia potrzeb mieszkaniowych, „Studia Regionalne i Lokalne", 1(19), s. 45-64.

Śleszyński P., 2007, Możliwości szacowania popytu na mieszkania w świetle dostępnych danych demograficznych, społecznych i ekonomicznych, „Problemy Rozwoju Miast”, 3, s. 19-34.

Taylor M., 1998, Combating the social exclusion of housing estates, "Housing Studies”, 13, s. 819-832.

Temelová J., Novák J., Ouředníček M., Puldová P., 2011, Housing Estates in the Czech Republic after Socialism: Various Trajectories and Inner Differentiation, „Urban Studies”, 48 (9), s. 1811-1834.

Temkin K., Rohe W. M., 1996, Neighbourhood change and urban policy, "Journal of Planning Education and Research", 15 (3), s. 159-170.

Tobiasz-Lis P., 2013, Zmiany wyobrażeń mieszkańców Łodzi o przestrzeni miasta, Wyd. Uniwersytetu Łódzkiego, Łódź.

Tokajuk A., 2007, Zespoty mieszkaniowe z lat 1945-1970, Wyd. Politechniki Białostockiej, Białystok.

Tokajuk A., 2010, Idea $i$ forma: unikaty $i$ uniformy $w$ polskiej architekturze mieszkaniowej II potowy XX wieku, „Czasopismo Techniczne. Architektura”, 7, s. 387-392.

Tosics I., 2004, European urban development: sustainability and the role of housing, "Journal of Housing and the Built Environment", 19, s. 67-90.

Tosics I., 2005, City development in Central and Eastern Europe since 1990, [w:] F.E.I. Hamilton, K. Dimitrovska Andrews, N. Pichler-Milanović (eds.), Transformation of Cities in Central and Eastern Europe: towards globalization, United Nations University, Tokyo, New York, Paris, s. 44-78.

Tosics I., Gerőházi E., Szemző H., 2005, Large Housing Estates in Budapest and Nyíregyháza, Hungary: Opinions of Residents on Recent Developments, Faculty of Geosciences, Utrecht University, Utrecht.

Treija S., 2010, Quality of open space in large scale housing area in Riga, 22nd International Housing Research Conference Urban Dynamics \& Housing Change, ENHR, 4-7 July 2010, Istanbul, http://www.soc.cas.cz/sites/default/files/soubory//090609094307 a27bfc844008f57893f.pdf (dostęp: 18.08.2013).

Trybuś J., 2011, Przewodnik po warszawskich blokowiskach, Wyd. Muzeum Powstania Warszawskiego, Warszawa.

Tsenkova S., 1996, Bulgarian Housing Reform and Forms of Housing Provision, „Urban Studies", 33 (7), s. 1205-1219. 
Tsenkova S., 2003, Post-socialist cities in a Globalizing World, University of Calgary, Calgary. Tsenkova S., 2006, Beyond Transitions: Understanding Urban Change in Post-socialist Cities, [w:] S. Tsenkova, Z. Nedovic-Budic (eds.), The Urban Mosaic of Post-socialist Europe, Springer-Verlag, Heidelberg, s. 21-51.

Tuan Y.F., 1971, Geography, phenomenology and the study of human nature, "The Canadian Geographer", 15, s. 181-192.

Tuan Y.F, 1987, Przestrzeń i miejsce, PIW, Warszawa.

Turkington R., van Kempen R., Wassenberg F. (eds.), 2004, High-rise Housing in Europe, Current Trends and Future Prospects, Delft University Press, Delft.

Turowski J., 1969, Spótdzielcze osiedle mieszkaniowe: monografia socjologiczna osiedla im. A. Mickiewicza Lubelskiej Spótdzielni Mieszkaniowej, Zakład Wydawnictw CRS, Warszawa.

Turowski J., 1973, Socjologiczne aspekty społeczności osiedlowej, "Studia Socjologiczne”, 3, s. 217.

Turowski J., 1976, Kształtowanie się zbiorowości osiedlowych w wielkich miastach, „Studia Socjologiczne", 1 .

Turowski J. (red.), 1976, Nowe osiedla mieszkaniowe. Ludność - środowisko mieszkalne - życie społeczne, "Materiały i Studia”, 13, Zakład Wydawnictw CZSR, Warszawa.

Turowski J., 1979, Środowisko mieszkalne w świadomości ludności miejskiej, Ossolineum, Wrocław.

Tyszka Z., 1982, Rodziny wspótczesne w Polsce, IWZZ, Warszawa.

Wallis A., 1977, Miasto i przestrzeń, PWN, Warszawa.

Wallis A., 1990, Socjologia przestrzeni, Wyd. Nowa, Warszawa.

Walmsley D.J., Lewis G.J., 1997, Geografia człowieka podejścia behawioralne, PWN, Warszawa.

Warchalska-Troll A., 2012, How to Measure Susceptibility to Degradation in Large Post-socialist Housing Estates?, „Prace Geograficzne”, 130, IGiGP Uniwersytetu Jagiellońskiego, s. 55-71.

Warzywoda-Kruszyńska W., 2012, Wielkomiejska bieda w Polsce, [w:] H. Kubiak (red.), Polska bieda, Krakowska Akademia im. Andrzeja Frycza Modrzewskiego, Kraków, s. $141-162$.

Wassenberg F., 2013, Large Housing Estates: Ideas, Rise, Fall and Recovery. The Bijlmermeer and beyond, Serie: Sustainable Urban Areas, 48, Delft University Press, Delft.

Wassenberg F., Turkington R., van Kempen R., 2004, Prospects for high-rise housing estates, [w:] R. Turkington, R. van Kempen, F. Wassenberg (eds.), High-rise Housing in Europe: Current Trends and Future Prospects, Delft University Press, Delft, s. 265-280.

Wassenberg F., van Kempen R., 2004, The Nethrlands. Modernist housing in a developed welfare state, [w:] R. Turkington, R. van Kempen, F. Wassenberg (eds.), High-rise Housing in Europe: Current Trends and Future Prospects, Delft University Press, Delft, s. 129-146.

Weidemann S., Anderson J.R., 1985, A Conceptual Framework for Residential Satisfaction, [w:] I. Altman, C.H. Werner (eds.), Home environment, Plenum Press, New York, s. 153-182.

Węcławowicz G., 1988, Struktury społeczno-przestrzenne w miastach Polski, „Prace Habilitacyjne IGIPZ PAN", Ossolineum, Wrocław.

Węclawowicz G., 1998, Social Polarisation in Postsocialist Cities: Budapest, Prague and Warsaw, [w:] G. Enyedi (ed.), Social Change and Urban Restructuring in Central Europe, Akadémiai Kiadó, Budapest, s. 55-66.

Węcławowicz G., 1999, Miasto polskie w transformacji - Ksztattowanie się miasta postsocjalistycznego [w:] J. Kaczmarek (red.), Zróżnicowanie przestrzenne struktur społecznych $w$ duzych miastach, XI „Konwersatorium Wiedzy o Mieście”, Wyd. Uniwersytetu Łódzkiego, Łódzkie Towarzystwo Naukowe, Łódź, s. 33-44. 
Węcławowicz G., 2000, Kształtowanie się nowego modelu zróżnicowań społeczno-przestrzennych miasta w Europie Środkowej - wybrane elementy przejścia od miasta socjalistycznego do miasta postsocjalistycznego, [w:] I. Jażdżewska (red.), Miasto postsocjalistyczne - organizacja przestrzeni miejskiej i jej przemiany, XIII „Konwersatorium Wiedzy o Mieście”, Wyd. Uniwersytetu Łódzkiego, Łódzkie Towarzystwo Naukowe, Łódź, s. 25-30.

Węcławowicz G., 2002, Przestrzeń i społeczeństwo współczesnej Polski, PWN, Warszawa.

Węcławowicz G., 2003, Restrukturyzacja wielkich osiedli mieszkaniowych w miastach europejskich. Opis projektu badawczego, „Przegląd Geograficzny”, 75, 2, s. 469-477.

Węcławowicz G., 2007, Geografia społeczna miast, Wyd. Naukowe PWN, Warszawa.

Węcławowicz G., 2013, Transnational Development Strategy for the Post-socialist Cities of Central Europe, IGIPZ PAN, Warszawa.

Węcławowicz G., Guszcza A., Kozłowski S., 2004, Large Housing Estates in Poland: Polices and Practices, RESTATE report, Utrecht University, Utrecht.

Węcławowicz G., Guszcza A., Kozłowski S., Bielawska A., Adamiak A., Krasowska M., Fader A., Bierzyński A., 2005, Large Housing Estates in Poland: Opinions of Residents on Recent Developments, RESTATE report, Utrecht University, Utrecht.

Węcławowicz G., Kozłowski S., Bajek R., 2003, Large Housing Estates in Poland. Overview of Developments and Problems in Warsaw, RESTATE report, Utrecht University, Utrecht.

Wiebenson D., 1969, Tony Garnier. The Cite Industrielle. Planning and Cities Series, George Braziller, New York.

Wiechmann T., 2009, What are the problems of shrinking cities? Lessons learned from an international comparison, [w:] K. Pallagst (ed.), The Future of Shrinking Cities: Problems, Patterns and Strategies of Urban Transformation in a Global Context, Institute of Urban and Regional Development, UC Berkeley, s. 5-16.

Wiest K., 2011, Large-scale housing estates in Central and East European cities: between residential preferences and local housing market differences, "Housing. Theory and Society”, 28, 4, s. $410-431$.

Wilczek M., 2010, Rozwój standardu mieszkaniowego w Polsce na tle krajów europejskich, Wyd. Akademii Ekonomicznej, Katowice.

Wilson J.Q., Kelling G.L., 1982, Broken windows: The police and neighborhood safety, "Atlantic Monthly", 249 (3), s. 29-38.

Winiarczyk-Raźniak A., 2004, Zróżnicowanie przestrzenne warunków życia w Krakowie, [w:] I. Jażdżewska (red.), Zróżnicowanie warunków życia ludności w mieście, XVII „Konwersatorium Wiedzy o Mieście", Wyd. Uniwersytetu Łódzkiego, Łódź, s. 97-106.

Wisłocka I., 1971, Dom i miasto jutra, Arkady, Warszawa.

Włodarczyk J.A., 2004, Żyć znaczy mieszkać, Śląskie Wyd. Naukowe Wyższej Szkoły Zarządzania i Nauk Społecznych, Tychy.

Wnuk-Lipiński E., 2003, Granice wolności. Pamiętnik polskiej transformacji, Wyd. Naukowe Scholar, Warszawa.

Wojtkiewicz J., 2010, Morfologia osiedla mieszkaniowego na przykładzie jednostki mieszkaniowej Zarzew w Łodzi, [w:] I. Jażdżewska (red.), Osiedla blokowe w strukturze przestrzennej miast, XXII „Konwersatorium Wiedzy o Mieście”, Wyd. Uniwersytetu Łódzkiego, Łódź, s. 171-184.

Wojtkun G., 2004, Osiedle mieszkaniowe w strukturze miasta XX wieku, Wyd. Politechniki Szczecińskiej, Szczecin.

Wojtkun G., 2008, Wielorodzinne budownictwo mieszkaniowe w Polsce. W cieniu wielkiej płyty, „Przestrzeń i Forma”, 10, s. 175-194.

Wojtkun G., 2012a, Blokowiska - (nie)wdzięczna spuścizna, "Czasopismo Techniczne. Architektura", 108, s. 477-482. 
Wojtkun G., 2012b, Standardy wspótczesnego mieszkalnictwa, „Przestrzeń i Forma”, 17, s. 301-322.

Wolaniuk A., 2003, Elity naukowe Łodzi na tle przestrzeni społecznej, [w:] I. Sagan, M. Czepczyński (red.), Wymiar i wspótczesne interpretacje regionu, Uniwersytet Gdański, Gdańsk-Poznań, s. 189-196.

Woroniecka G., 2007, Wstęp, [w:] G. Woroniecka (red.), Co znaczy mieszkać. Szkice antropologiczne, Wyd. Trio, Warszawa, s. 13-27.

Zaniewska H. (red.), 2005, Mieszkania dla ubogich w zrównoważonym rozwoju miast, Instytut Rozwoju Miast, Kraków.

Zborowski A., 2000, Przemiany przestrzeni miasta postsocjalistycznego. Teoria i praktyka, [w:] I. Jażdżewska (red.), Miasto postsocjalistyczne - organizacja przestrzeni miejskiej i jej przemiany, XIII Konwersatorium Wiedzy o Mieście, Wyd. Uniwersytetu Łódzkiego, Łódzkie Towarzystwo Naukowe, Łódź, s. 61-66.

Zborowski A., 2001, Procesy globalizacji w mieście postsocjalistycznym, [w:] I. Jażdżewska (red.), Miasto postsocjalistyczne - organizacja przestrzeni miejskiej i jej przemiany, cz. II, XIV „Konwersatorium Wiedzy o Mieście”, Polskie Towarzystwo Geograficzne, Łódzkie Towarzystwo Naukowe, Łódź, s. 94-106.

Zborowski A., 2004, Wybrane aspekty badań poziomu i jakości życia w dużym mieście, [w:] I. Jażdżewska (red.), Zróżnicowanie warunków życia ludności w mieście, XVII „Konwersatorium Wiedzy o Mieście”, Wyd. Uniwersytetu Łódzkiego, Łódź, s. 19-30.

Zborowski A., 2005, Przemiany struktury społeczno-przestrzennej regionu miejskiego w okresie realnego socjalizmu i transformacji ustrojowej (na przykładzie Krakowa), IGiGP, Uniwersytet Jagielloński, Kraków.

Zimbardo P., 1999, Psychologia i życie, Wyd. PWN, Warszawa.

Ziobrowski Z., 1998, Bariery modernizacji i rozwoju miast - identyfikacja i pokonywanie, Urząd Mieszkalnictwa i Rozwoju Miast, IGPiK, Kraków.

Ziółkowski J., 1965, Urbanizacja miasto osiedle, PWN, Warszawa.

Ziółkowski M., 1999, O imitacyjnej modernizacji społeczeństwa polskiego, [w:] P. Sztompka (red.), Imponderabilia wielkiej zmiany. Mentalność, wartości i więzi społeczne czasów transformacji, Wyd. Naukowe PWN, Warszawa, s. 38-64.

Znaniecki F., 1938, Socjologiczne podstawy ekologii ludzkiej, „Ruch Prawniczy, Ekonomiczny i Socjologiczny", 18 (1), s. 89-119.

\section{Artykuły prasowe}

Frustraci z wielkiej ptyty, „Wprost”, 37/2000.

Skocz do góry, „Polityka”, 10/2001.

\section{Akty prawne}

Ustawa o uporządkowaniu stosunków kredytowych z 28.12.1989 r. (Dz. U. Nr 74/1989, poz. 440). Ustawa o wtasności lokali z 24.06.1994 r. (Dz. U. Nr 85/1994, poz. 388).

Ustawa o wspieraniu przedsięwzięć termomodernizacyjnych z 18.12.1998 r. (Dz. U. Nr 162/1998, poz. 1121, z późn. zm.).

Ustawa o spótdzielniach mieszkaniowych z 15.12.2000 r. (Dz. U. Nr 4/2001, poz. 27).

Ustawa o zmianie ustawy o spótdzielniach mieszkaniowych oraz o zmianie niektórych innych ustaw z 14 czerwca 2007 r. (Dz. U. Nr 125/2007, poz. 873).

Ustawa o wspieraniu termomodernizacji i remontów z 21.11.2008 r. (Dz. U. Nr 223/2008, poz. 1459). 


\section{Materiały niepublikowane}

Stan gospodarki mieszkaniowej w gminie Łódź, opracowanie przygotowane na zlecenie Urzędu Miasta Łodzi, przez zespół autorski w składzie E. Kucharska-Stasiak, M. Załęczna, K. Żelazowski, Łódź 2011.

\section{Materiały internetowe}

Raport o sytuacji na rynkach nieruchomości mieszkaniowych i komercyjnych w Polsce w 2014 r. http://www.nbp.pl/publikacje/rynek_nieruchomosci/raport_2014.pdf (dostęp: 20.05.2015).

Rynek nieruchomości w Polsce w 2011 r., https:// www.multibank.pl/ (dostęp: 20.05.2015). 


\section{LARGE HOUSING ESTATES IN POST-SOCIALIST CITIES: ORIGIN, DEVELOPMENT, CHANGES, PERCEPTION Summary}

Keywords: large housing estates, CEE countries, post-socialist city.

\section{Introduction}

Large-scale prefabricated housing estates are present in the urban landscapes of nearly all European countries. The idea according to which these estates were built, i.e., that of improving the living conditions of the working class through the construction of modern housing estates, emerged in the early 20th century. However, the principal period of construction of the large housing estates followed on from the devastation wrought by the Second World War. Then, a severe shortage of dwellings combined with the rapid post-War growth in population and the increasing pace of urbanisation made housing estates a viable and widespread solution that could offer homes to a very large of people in need, for a relatively cheap price (Dekker et al. 2005, p. 2). The result was the construction of large apartment blocks separated by extensive, landscaped green areas, as well as a separation of functions (Musterd \& van Kempen 2007). Nowadays, these estates very often are recognized as problem areas in many European cities, especially in Western Europe (Turkington et al. 2004, Dekker at al. 2005, Wassenberg 2013).

Although modernist large housing estates were erected all over Europe on both sides of the Iron Curtain; the systemic and political factors decided that they developed on the largest scale in socialist countries. In socialist cities, they were seen as instruments of social transformation and an improvement in living conditions, especially for the working class (Węclawowicz et al. 2005). Moreover, the idea of collective and uniform housing was perfectly fitted to state-socialist politics and made it possible to achieve the ideological goal which was a mix of different social groups, in accordance with the idea of egalitarianism (Kovács \& Herfert 2012). Hence the era of the construction of large housing estates in CEE countries lasted until the end of the $80^{\prime}$ s, i.e., to the collapse of socialism, while in most Western European countries it ended almost two decades earlier. Today they constitute a significant part of the housing market in former socialist countries.

During the socialist era, these residential complexes were built hastily and negligently in order to satisfy growing residential needs caused by accelerating urbanization. The designers of these estates, whose architectural form was determined only by functional requirements, did not think of any particular group of users, nor did they consider their housing needs or aspirations. The only group whose needs were taken into consideration were families with children (Temelova et al. 2011). Despite the numerous drawbacks of these estates, such as monotonous architecture, poor quality of construction and relatively small dwelling areas, as well as the insufficient social infrastructure and the shortage of basic services, moving to a block of flats in a new housing estate was 
usually the only chance to improve one's living conditions during the socialist period (Węcławowicz 2007). The structural deficit on the housing market resulting from dynamic urbanization, the progressing degradation of pre-war housing resources, limitations put on private construction, as well as low incomes and relatively modest residential aspirations, created a reality in which dwelling in a block of flats was a dream for the majority of socialist cities' inhabitants, regardless of their social status (Lewicka 2004).

Despite their similar physiognomy, the large housing estates built in socialist countries were different from those found in Western Europe. They differed primarily in terms of the urban planning scale and the role played in the local housing market, the time of construction, and the socio-economic profile of inhabitants - and consequently their position in the ecological structure of the city in which they were located (Coudroy de Lille 2000; Turkington et al. 2004; Musterd \& van Kempen 2005; Dekker et al. 2005, 2007; Sykora 2009; Kovács, Herfert 2012).

As noted by numerous authors (Czepczyński 1999; Rykiel 1999; Kiciński 2004; Turkington at al. 2004, Węclawowicz 2007), most of the large-block housing estates originating in the socialist period (especially those built in the 1970s, i.e., during the era of their fullest development), were characterised by:

- a large urban-planning and demographic scale, frequently exceeding the threshold of 2000 dwellings acknowledged in the literature as the defining criterion,

- construction using industrial prefabricated (large-panel) technology,

- monotonous architecture and a uniform appearance of buildings,

- a peripheral location in an urban space,

- an illegible spatial configuration and spatial anonymity,

- an absence of functional diversification - the housing function was prevalent, while other urban functions were underdeveloped, especially the service function and social infrastructure,

- low workmanship standards and progressing physical (technical) degradation,

- small sizes of dwellings,

- a heterogeneous, mixed community, with a predominance of families with children.

Nevertheless, as has been stated already, these estates were seen as an attractive place to live in socialist cities.

The collapse of socialism brought significant socio-economic changes, and consequently an alteration in the position of large housing estates on the local housing market. In line with the political and economic transformation from socialism to postsocialism, housing supply and demand changed substantially. The appearance of new forms of housing, such as gated communities and residential parks, as well as the processes of suburbanisation and revitalisation of the inner city created a great challenge for large housing estates, and started to endanger their position (Kovács, Herfert 2012). As a result of an increase in socio-economic disparities and the changes in the housing aspirations of many inhabitants along with growth in their purchasing power, the residential prestige of such estates rapidly decreased. In the 1990s some authors predicted that prefabricated socialist housing estates, by the same token as in West European countries, would soon become problem areas and turn into post-socialist slums (see Jałowiecki 1995; Szelény 1996; Enyedi 1998; Czepczyński 1999; Rykiel 1999). As suggested by Enyedi (1998, p. 33) "the rapid decline of housing estates into slums represents the 'time bomb' of urban development, a possible source of a grave urban crisis". Recently 
the discussion of physical decay and the outflow of better-off inhabitants has slowed down (Wiest 2011), but the future development of large housing estates still remains a great challenge in many former socialist countries, primarily due to the fact that they constitute the dominant form of urban residential environment.

\section{Objective and methods}

This study had cognitive and explanatory objectives, and its results complement the debate on similarities and differences between development trajectories of large housing estates in Western Europe and post-socialist cities.

The first purpose of this study was to identify ongoing changes in post-socialist large housing estates and to clarify the crucial factors underpinning them. These transformations in question were analysed in two dimensions: a social dimension encompassing changes in socio-demographic and socio-economic structure of inhabitants and spatial dimension relating to socio-spatial, functional and physical (morphological and physiognomic) changes. The key question was:

- how have large housing estates built during the socialist period have changed under the new socio-demographic, political and economic conditions after the collapse of communism?

- whether the processes occurring in large housing estates in post-socialist cities reproduce now, and will reproduce in the future, the negative phenomena of social and physical degradation, in the literature referred as the 'large housing estate syndrome' (Rembarz 2010) or 'spiral of decline' (Prak, Priemus 1986).

The 'large housing estate syndrome' was a phenomenon recognized in Western Europe in the 1980s and defined as a complex of spatial-social conditions, producing a negative image of an estate and accelerating the downward spiral and the replacement of the culturally stronger inhabitants by weaker ones. It leads to an increase in the number of vacant flats and structural social problems, intensifying the spatial degradation. This in turn causes the economic potential of the estate (such as the purchasing power or the market value of the housing resources) to disappear (Rembarz 2010). The 'spiral of decline' may be increased because more stable and affluent households move away or because there are no opportunities for deprived households to move away (Prak, Premius 1986).

The second objective of this study was to get knowledge of selected aspects of the perception of large housing estates among the inhabitants and to identify their determinants. In order to precisely illustrate the studied phenomenon, the respondents were asked to evaluate the quality of their closest living environment taking into consideration the following criteria: utilitarian, which include the location of the studied area within the city, the amount of greenery, the availability of services of all kinds, accessibility to social infrastructure facilities and transportation accessibility; aesthetic the appearance of the surroundings, cleanliness, maintenance and architecture quality; safety - the sense of security in the area; social, which involve neighborhood bonds and finally, emotional criteria, which include the level of attachment to the area and satisfaction with it (see Mysłek 2007).

The first part of the study was based on a review of the available literature in selected post-socialist cities. The selection criterion of cities was limited by the availability of data. The second part was based on case study research conducted in nine largest housing estates within one of the largest Polish cities - the city of Łódź. Analysis of 
changes in the social structure of inhabitants was based on statistical data collected during the National Censuses in 1988 and 2002, on unpublished data from the Statistical Office as well as on information obtained during interviews with employees of the housing cooperatives which administer the estates. The changes which took place in the spatial and functional structure of examined areas and in their physiognomy were identified by field research (observation and inventory).

The study also presents the results of a questionnaire survey carried out in 2012 in the nine largest housing estates in Lodz. The research was realized using standardized direct interviews with a representative sample of 1002 inhabitants of housing estates.

\section{Results and conclusions}

The research has provided evidence that the main social and spatial transformations that have been taking place within large housing estates since 1990, as discussed in this study, include:

- the ageing of the population, which is accompanied by other processes, not specific to this form of urban development and observed in all large European cities, such as a decrease in the birth rate, reduction in household size and increase in the number of 1-person households, as related to the second demographic transition;

- the intensification of housing development, which takes the form of individual multi-family buildings or complexes, characterized by a higher standard and distinctive physiognomy (architectural detail, the colour and shape of the buildings), which results in an inflow of new residents and the formation of enclaves of a higher socio-economic status within the estate space. These processes lead to an increase in the socio-spatial diversification of these estates;

- the "studentification" - an inflow of students, who, for the time of their studies, rent and sometimes even buy such flats. This process, primarily spreads through academic cities, and within them the housing estates with favourable locations in relation to the universities;

- privatization which took place at different rates in different countries. However in most of them the percentage of flat owners increased sharply, and in some, e.g. the Baltic states and Bulgaria, it reached values of over 90\% (Tsenkova 2003);

- commercialization caused primarily by supplementing existing commercial buildings with new ones, as well as by changing the functions of others. These processes improve access to shopping and services and reduce their spatial concentration, as well as help overcome the mono-functional nature of the estates. As a result, the social sphere of the housing estates is changing, new jobs appear, and new places and new forms of spending leisure time. The daily routine of the inhabitants changes as well, because satisfying the majority of needs (not only basic ones) may take place within the estate space and does not require commuting to the city centre. In consequence of these changes, the inhabitants' living conditions have improved;

- the sacralisation of space, which takes place by emergence of new sacred buildings, the construction of which was severely restricted in socialist times;

- the improvement in the physiognomy of buildings (by modernization of their facades), and the improvement in quality of public and semi-public spaces 
among blocks of flats. These spaces undeveloped during the socialist period, after 1990 were turned into new parks, playgrounds, sports fields, and other greenery and recreation areas. These processes on the one hand, if planned and coordinated, improve the appearance of buildings and entire estates, but on the other hand, if chaotic and uncoordinated, not only do not help to beautify the space, but rather bring architectural and spatial disorder.

These transformations varied between countries, cities, and individual housing estates, too. Also, they differ in terms of frequency of occurrence. Some are found to have occurred universally, other frequently, but not in all housing estates, and some incidentally, which is relative to the specific characteristics of individual housing estates and the cities in which they are located (Table 1).

Table 1. The main transformation processes ongoing as regards the social and spatial structure of large housing estates in post-communist cities, as well as their frequencies of occurrence

\begin{tabular}{|c|c|c|c|c|}
\hline \multirow{3}{*}{$\begin{array}{l}\text { Frequency of } \\
\text { occurrence }\end{array}$} & \multicolumn{4}{|c|}{ Processes in particular intra-urban structures } \\
\hline & \multirow{2}{*}{$\begin{array}{c}\text { socio-demographic } \\
\text { and socio-economic } \\
\text { structure of } \\
\text { inhabitants } \\
\end{array}$} & \multicolumn{3}{|c|}{ spatial structure and physical layout } \\
\hline & & $\begin{array}{l}\text { socio-spatial } \\
\text { structure }\end{array}$ & $\begin{array}{l}\text { functional } \\
\text { structure }\end{array}$ & $\begin{array}{l}\text { morphology and } \\
\text { physiognomy }\end{array}$ \\
\hline $\begin{array}{l}\text { Common } \\
\text { processes }\end{array}$ & $\begin{array}{l}\text { depopulation, } \\
\text { ageing of } \\
\text { population, } \\
\text { reduced share } \\
\text { accounted for by } \\
\text { the working } \\
\text { population }\end{array}$ & $\begin{array}{l}\text { increased } \\
\text { disparities as } \\
\text { regards economic } \\
\text { status among } \\
\text { inhabitants } \\
\text { (between and } \\
\text { within estates) }\end{array}$ & $\begin{array}{l}\text { commercialisation, } \\
\text { increased func- } \\
\text { tional diversity, } \\
\text { spatial, } \\
\text { emergence of new } \\
\text { public spaces, } \\
\text { deconcentration of } \\
\text { trade and services, }\end{array}$ & $\begin{array}{l}\text { increased diversity of } \\
\text { building forms, } \\
\text { intensification of } \\
\text { commercial building, }\end{array}$ \\
\hline $\begin{array}{l}\text { Processes occurr- } \\
\text { ing frequently/ } \\
\text { taking place on } \\
\text { a majority of } \\
\text { housing estates }\end{array}$ & $\begin{array}{l}\text { maintenance of } \\
\text { relatively high } \\
\text { social status } \\
\text { residents }\end{array}$ & $\begin{array}{l}\text { emergence of } \\
\text { enclaves with } \\
\text { higher than } \\
\text { average socio- } \\
\text { economic status } \\
\text { and higher } \\
\text { residential } \\
\text { prestige }\end{array}$ & \begin{tabular}{|l|} 
sacralisation, \\
appearance of \\
large areas of \\
car parking
\end{tabular} & $\begin{array}{l}\text { intensification of } \\
\text { residential building, } \\
\text { sacralisation, } \\
\text { emergence of new } \\
\text { public spaces, } \\
\text { emergence of new } \\
\text { architectural symbols, } \\
\text { improved development } \\
\text { of existing public spaces, } \\
\text { improved visual state of } \\
\text { buildings, } \\
\text { introduction of new } \\
\text { colour to existing } \\
\text { building facades, }\end{array}$ \\
\hline $\begin{array}{l}\text { Processes occurr- } \\
\text { ing on a minority } \\
\text { of housing estates }\end{array}$ & $\begin{array}{l}\text { polarisation of age } \\
\text { structure, student- } \\
\text { ification, deteriora- } \\
\text { tion in socio- } \\
\text { economic status }\end{array}$ & separation & $\begin{array}{l}\text { deterioration of } \\
\text { public spaces }\end{array}$ & $\begin{array}{l}\text { emergence of gated } \\
\text { communities }\end{array}$ \\
\hline $\begin{array}{l}\text { Processes occurr- } \\
\text { ing incidentally } \\
\text { or in small parts } \\
\text { of estates (into } \\
\text { individual } \\
\text { neighbourhoods) }\end{array}$ & $\begin{array}{l}\text { significant } \\
\text { deterioration in } \\
\text { socioeconomic } \\
\text { status }\end{array}$ & segregation & $\begin{array}{l}\text { significant } \\
\text { deterioration of } \\
\text { public spaces }\end{array}$ & $\begin{array}{l}\text { demolition of residential } \\
\text { buildings, } \\
\text { degradation of } \\
\text { buildings }\end{array}$ \\
\hline
\end{tabular}

Source: own work. 
The most important of the ongoing changes include the following:

- maintaining a relatively high social status of the inhabitants, because after several years of transformation, despite the fact that better-off population with higher expectations as regards their place of residence are leaving the estates, the large housing estates still enjoy a relatively high social status, mainly as a result of the inflow of new residents. The latter purchase flats on the secondary market and settle down in the flats in new buildings, bought on the primary market. This contradicts the social degradation of these estates predicted in the 1990s, which is very important if we consider their future;

- changing the mono-functional character of the large housing estates, described by other authors as the state of urban functions underdevelopment, which was one of the main drawbacks of this particular urban form. As a result, large housing estates became areas where the inhabitants' basic (or even higher order) needs can be satisfied, and which attract the inhabitants of other parts of the city as well;

- aestheticizing buildings and improving the state of development of public and half-public spaces among blocks of flats by introducing colour, architectonic detail and elements of small architecture. The process gives distinctiveness and significance to the space of block housing estates (so far anonymous), i.e. qualities which are necessary to create place advantages. It is not advanced enough, but as numerous empirical studies conducted among the inhabitants of estates show, it is acknowledged by them and due to the changed social perception of this housing environment, the inhabitants identify themselves with it stronger and its residential attractiveness increases, which may prevent the outflow of residents.

Referencing the findings of the present study to the concepts of housing environment transformations described in world literature and used to investigate the transformations of large housing estates in West European cities, it can be stated that in the case of housing estates in post-socialist cities no, or very few, observations (in very few housing estates or their fragments) have been made of the phenomenon referred to as "spiral of decline" or "large housing estate syndrome" typical for this urban form in Western Europe.

Also, compared with many West European cities, the scale of filtration processes resulting from the outflow of high-status residents is much smaller. Actually, migrations out of housing estates are informed not so much by degradation of large housing estates, as by the arrival of new and more attractive residential areas that were not present in socialist cities, as well as the opportunity to satisfy individual housing needs outside the housing construction system subsidised by the state, as mortgage credits only became available after the system transformation. Hence, an important role in this process was played by the rather obvious, given the situation, growth of housing aspirations, strongly suppressed under the previous regime, and the natural technical and moral wear and tear of housing estate housing facilities resulting from their life cycle. Therefore, filtration processes within large housing estates are evolutionary in nature and fully governed by the natural process of certain housing resources becoming worn-out and obsolete, not by mass exodus of residents, as was predicted.

The processes of transformation of large housing estates in post-socialist cities are genuine and different from those taking place in many West European countries. The fact that housing estates in CEE countries do not degrade as much as they do in Western Europe and still are attractive as a place to residents above all results from the following: 
- enormous scale of those housing estates and their share in the housing resources of post-socialist cities reaching 30-40\%, which makes them common and considered as the "typical housing standard";

- housing deficiency carried over from the times of the former political system and preserved after 1990, though today its nature is not structural (as was under the previous regime) but economic;

- far-reaching privatisation of housing resources within housing estates, in some countries in excess of $90 \%$ of housing units, which factor reduces migration mobility and increases attachment to both the flat and the housing estate, and consequently improves public perception of them and enhances residential stability;

- structure of the incomes of post-socialist cities' residents and unfavourable ratio of the prices of new flats to the average income, which still prevents most average-income households from fulfilling their housing aspirations, in as much as it increases their residential stability;

- still relatively good living conditions offered by this residential form, especially in comparison with the old, low standard housing substance found in many cities (mainly as a result of underinvestment and lack of renovation works in the central areas of cities during the socialist period);

- relatively good and continuously improving furnishing of estates with shopping, service and social infrastructure; a large amount of greenery, especially as regards the densely built-up areas, often devoid of greenery, as well as good transport accessibility of many estates;

- relatively weak spatial mobility, established in the previous political system; considerable lack of migration and a sense of belonging; in effect - considerable residential stabilization;

- strongly limited during the socialist period and still modest aspirations of postsocialist cities' residents as regards their place of living in comparison with the inhabitants of other countries, as well as international standards;

- a sense of the lack of choice, caused by the socio-economic situation of the postsocialist cities inhabitants and the situation on the real estate market and the unfavorable relation between salaries and the prices of flats, which create a financial barrier, making it impossible for many households to satisfy their housing needs.

The future of large housing estates in post-socialist cities will be determined by a number of mutually dependent factors, including both, exogenous - external in relation to the estates, operating on the global (European), national and local (urban) level, and endogenous factors, resulting from the specific character of individual estates and their inhabitants (Table 2). The abovementioned determinants may be both chances for and barriers to maintaining the present position of large housing estates in the socio-spatial structure of cities, as well as they may decide about further development scenarios. An analysis of the determinants allows us to formulate three scenarios: optimistic (maintaining the present, relatively good position), fairly optimistic (a slight decline of status) and pessimistic (a development of processes referred to as a spiral of decline). The research shows, however, that the latter seems to be unlikely within the next 20 to 30 years. Moreover, numerous processes found in post-socialist large housing estates, contribute to the prevention of the negative phenomena leading to the degradation of these areas, identified in many estates in Western Europe. 
Table 2. Factors determining the future of large housing estates in post-socialist cities

\begin{tabular}{|c|c|}
\hline $\begin{array}{l}\text { Group } \\
\text { of factors }\end{array}$ & Particular factors \\
\hline \multicolumn{2}{|r|}{ Exogenous, operating on the global (European) and national level } \\
\hline $\begin{array}{l}\text { Urbanistic } \\
\text { (morphological, } \\
\text { functional and } \\
\text { socio-spatial) }\end{array}$ & $\begin{array}{l}\text { role and share of large estates in the housing resources of cities, } \\
\text { position of large housing estates in the ecological structure of cities }\end{array}$ \\
\hline $\begin{array}{l}\text { Socio- } \\
\text { demographic }\end{array}$ & $\begin{array}{l}\text { number and demographic structure of urban population, } \\
\text { migration attractiveness of cities in domestic and international migrations, as well } \\
\text { as the potential number and structure of migrants and their need for housing } \\
\text { estates in cities }\end{array}$ \\
\hline Economic & $\begin{array}{l}\text { on the demand side - the level of affluence and the purchasing power and/or } \\
\text { household creditworthiness, } \\
\text { on the supply side - the domestic real estate market offer and the accessibility of } \\
\text { investment loans }\end{array}$ \\
\hline Political & $\begin{array}{l}\text { national/European housing policy, } \\
\text { the existence and significance of modernization / humanization programs } \\
\text { regarding large housing estates in the national / European housing policy, } \\
\text { sorting out ownership issues in cities, } \\
\text { creating or developing the already existing possibilities for the inhabitants to } \\
\text { participate in the modernization/humanization of estates }\end{array}$ \\
\hline Socio-cultural & $\begin{array}{l}\text { preferences as regards the family patterns, values and lifestyles system, } \\
\text { level of housing aspirations and the residential mobility inclinations among the } \\
\text { population, } \\
\text { social perception of the position of large housing estates in the ecological structure } \\
\text { of cities; the prestige of estates }\end{array}$ \\
\hline \multicolumn{2}{|r|}{ Exogenous, operating at the urban level } \\
\hline $\begin{array}{l}\text { Urbanistic } \\
\text { (morphological, } \\
\text { functional and } \\
\text { socio-spatial) }\end{array}$ & $\begin{array}{l}\text { role and share of large estates in the housing resources of city, } \\
\text { position of an urban centre in the settlement hierarchy of the country, } \\
\text { living conditions offered in large housing estates in relation to the conditions } \\
\text { offered in other forms of building in the city }\end{array}$ \\
\hline $\begin{array}{l}\text { Socio- } \\
\text { demographic }\end{array}$ & $\begin{array}{l}\text { number and demographic structure of the population, defining the quantitative } \\
\text { and qualitative demand for the housing resources offered in estates, } \\
\text { migration attractiveness of the city in domestic and international migrations }\end{array}$ \\
\hline Economic & $\begin{array}{l}\text { on the demand side - the level of affluence and the purchasing power and/or the } \\
\text { creditworthiness of the households present on the local real estate market, } \\
\text { on the supply side - quantitative, qualitative and price offer of the local real estate } \\
\text { market, as well as the level of its adjustment to the purchasing capabilities of the } \\
\text { households present on the local real estate market, } \\
\text { ownership structure in the large housing estates in the city, } \\
\text { price and cost of apartment maintenance in block housing estates compared to the } \\
\text { price and cost of maintenance in other forms of building }\end{array}$ \\
\hline Political & $\begin{array}{l}\text { local housing policy and the existence of programs of modernization/ humaniza- } \\
\text { tion of large housing estates, } \\
\text { sorting out ownership issues in city, } \\
\text { local authorities making use of the fact that the inhabitants can participate in the } \\
\text { modernization and humanization of estates, } \\
\text { adjusting the number of social infrastructure facilities in the estates to the chang- } \\
\text { ing socio-demographic structure of the inhabitants (it mainly regards schools, } \\
\text { kindergartens, cultural institutions and institutions associated with elderly } \\
\text { people) }\end{array}$ \\
\hline Socio-cultural: & $\begin{array}{l}\text { level of housing aspirations and the residential mobility inclinations among the } \\
\text { population, } \\
\text { prestige of housing estates and the social perception of their position in the } \\
\text { ecological structure of the city }\end{array}$ \\
\hline
\end{tabular}




\begin{tabular}{|c|c|}
\hline \multicolumn{2}{|r|}{ Endogenous } \\
\hline $\begin{array}{l}\text { Urbanistic } \\
\text { (morphological, } \\
\text { functional and } \\
\text { socio-spatial) }\end{array}$ & $\begin{array}{l}\text { location of an estate within urban space and its accessibility by transport } \\
\text { (particularly the distance from the lines of rail public transport), } \\
\text { morphology (size, height and density) and the present condition of the buildings, } \\
\text { as well as the size and structure of flats (due to central planning, these features } \\
\text { usually depend on the period in which the estate was built), } \\
\text { living conditions offered in a housing estate, particularly in comparison to the } \\
\text { conditions offered in other forms of building in the city, } \\
\text { scope of modernization activities carried out so far, as well as planned, aiming at } \\
\text { the physical renovation of the estate, } \\
\text { providing shopping-service and social infrastructure, adjusted to the current } \\
\text { socio-demographic structure of the inhabitants, } \\
\text { developing and maintenance of public spaces and other common areas, } \\
\text { number and maintenance of green areas, } \\
\text { occurrence and number of vacant flats }\end{array}$ \\
\hline $\begin{array}{l}\text { Socio- } \\
\text { demographic }\end{array}$ & demographic structure and the socio-economic status of the inhabitants \\
\hline Political & $\begin{array}{l}\text { efficiency of estate management, } \\
\text { the effectiveness of estate management entities as regards gaining external funds } \\
\text { for investments contributing to the modernization / humanization of large } \\
\text { housing estates, } \\
\text { estate managements entities taking advantage of the fact that the inhabitants can } \\
\text { participate in the modernization / humanization of estates }\end{array}$ \\
\hline Economic & $\begin{array}{l}\text { ownership structure of the housing resources in an estate, } \\
\text { the price and cost of apartment maintenance in an estate in relation to the } \\
\text { economic capabilities of households and compared to the price and cost of } \\
\text { maintenance in other forms of building in the city }\end{array}$ \\
\hline Socio-cultural & $\begin{array}{l}\text { prestige of a housing estate and the social perception of its position in the } \\
\text { ecological structure of the city, } \\
\text { level of identification with the place of residence, which determines possible } \\
\text { migration preferences and defines the inhabitants' activeness and willingness to } \\
\text { participate in the modernization/humanization of estates. }\end{array}$ \\
\hline
\end{tabular}

Source: own work.

It appears, therefore, that the conditions prevailing under the previous political and economic system (which shaped a totally different social composition of housing estate residents within the same urban form) have combined with the transformation process itself (of fast pace and overlapping with global processes) to represent a unique legacy that determines the transformations taking place on the large housing estates of cities in formerly-communist countries, and thus distinguishes these from the processes that have been ongoing in Western European cities. 